\section{Sumario}

\section{Estudios}

El accidente de trabajo en el mar: génesis y evolución de su protección en el ordenamiento jurídico español

Francisco Javier Arrieta Idiakez

La prueba del Derecho extranjero ante los tribunales españoles

Alfonso-Luis Calvo

Caravaca y Javier

Carrascosa González

La Bioética entre la conciencia, la norma y la religión

Arturo Calvo Espiga
Derecho aplicable a los contratos celebrados a través de Internet

Luís de Lima Pinheiro

\section{Notas y \\ Jurisprudencia}

Recorrido por la jurisprudencia sobre los denominados

"Alardes": una fiesta plagada de conflictos María Burzaco Samper

Fibromialgia y/o

Síndrome de la Fatiga Crónica. Una propuesta para la aproximación a su doble dimensión jurídica y médica Javier León Iglesias

\section{Congresos}

Transporte marítimo de mercancías de corta distancia

Carlos Llorente Gómez de Segura

Repercusiones del hecho del consumo en las vicisitudes del Derecho social Manuel María Zorrilla Ruiz

Universidad de Deusto 



\section{Estudios de Deusto}





\section{Estudios de Deusto}

Revista de la Universidad de Deusto Incluida en el catálogo LATINDEX Indexada en la base de datos ISOC

Fundada en 1904

Segunda época. Vol. 54/2

Desde su fundación vol. 77

(Fasc. 117)

Julio-Diciembre 2006

Bilbao

Universidad de Deusto 2006 


\section{Director:}

Ignacio María Beobide

Secretario:

Luis Ignacio Gordillo

\section{Consejo de Redacción:}

Ricardo de Ángel Luis Ignacio Gordillo

Iciar Basterretxea Gema Tomás

Ignacio María Beobide Demetrio Velasco

María Pilar Canedo

\section{Consejo Asesor:}

Rosario Besné

Javier Caño

Jorge Caramés

Juan Echano

Víctor Fernando Manrique

Ramón Múgica

Fernando Renedo

Aitziber Emaldi

Javier San Juan

Marta Enciso

Manuel María Zorrilla

\section{Administración:}

Publicaciones

Universidad de Deusto - Apartado 1 - E48080 Bilbao

Tfno.: $944139000 \quad$ Fax: 944456817

\section{Distribución:}

Ediciones Mensajero

Sancho Azpeitia, 2 - E48014 Bilbao

Tfno.: 944470358 Fax: 944472630

\section{Precios de suscripción:}

Europa ............. $26 €$

Otros países ......... $50 \$$

Número suelto $\ldots \ldots \ldots . \quad 14,50 €$

Revista incluida en el catálogo LATINDEX. Indexada en la base de datos ISOC.

Ninguna parte de esta publicación, incluido el diseño de la cubierta, puede ser reproducida, almacenada o transmitida en manera alguna ni por ningún medio, ya sea eléctrico, químico, mecánico, óptico, de grabación, o de fotocopia, sin permiso previo del editor.

Publicación impresa en papel ecológico.

(c) Publicaciones de la Universidad de Deusto

Apartado 1 - E48080 Bilbao

e-mail: publicaciones@deusto.es

ISSN: $0423-4847$

Depósito legal: BI - 2.350-93

Impreso en España/Printed in Spain

Fotocomposición: IKUR, S. A. - Bilbao

Impresión: Baster, S. L. L. 


\section{Sumario}

\section{Estudios}

Francisco Javier ARRIETA IDIAKEZ, El accidente de trabajo en el mar: génesis y evolución de su protección en el ordenamiento jurídico español

Alfonso-Luis Calvo Caravaca y Javier CarRascosa González, La prueba del Derecho extranjero ante los tribunales españoles

Arturo CALVo ESPIGA, La Bioética entre la conciencia, la norma y la religión

Luís De Lima PINHeIRo, Derecho aplicable a los contratos celebrados a través de Internet

\section{Notas y Jurisprudencia}

María BuRZACo SAMPER, Recorrido por la jurisprudencia sobre los denominados "Alardes": una fiesta plagada de conflictos

Javier LEÓN IGLESIAS, Fibromialgia y/o Síndrome de la Fatiga Crónica. Una propuesta para la aproximación a su doble dimensión jurídica y médica

\section{Congresos}

Carlos Llorente Gómez de Segura, Transporte marítimo de mercancías de corta distancia

Manuel María ZorRilla Ruiz, Repercusiones del hecho del consumo en las vicisitudes del Derecho social 


\section{๑) Universidad de Deusto - ISSN 0423-4847}




\section{ESTUDIOS}




\section{๑) Universidad de Deusto - ISSN 0423-4847}




\title{
El accidente de trabajo en el mar: génesis y evolución de su protección en el ordenamiento jurídico español
}

\author{
Francisco Javier Arrieta Idiakez \\ Profesor de Derecho del Trabajo \\ Universidad de Deusto
}

\begin{abstract}
Resumen: En el presente trabajo se estudia la génesis y evolución del accidente de trabajo en el mar. Se parte de los antecedentes remotos de su protección, en la medida en que dichos antecedentes constituyen el fondo histórico de la regulación del accidente de trabajo en el actual Sistema de la Seguridad Social. Precisamente, el fondo histórico justifica las peculiaridades del accidente de trabajo en el ámbito marítimo. En ese sentido, se analizan las ideas, interpretaciones y soluciones jurídicas desarrolladas en distintos períodos, en torno a la regulación del accidente de trabajo, con el objetivo de proteger a la gente de mar. Especialmente, se muestra la evolución desde la Ley de Accidentes de Trabajo de 1900 hasta el Régimen Especial de los Trabajadores del Mar de nuestros días.
\end{abstract}

Palabras clave: Accidente de trabajo, protección, evolución, Seguridad Social, Régimen Especial de los Trabajadores del Mar.

Abstract: The present study caters for the origins and development of the occupational accident at sea. The starting point is set to the background surrounding its protection, standing as the historical foundation of its current regulation under the Social Security System, and where such historical background serves to justify the very peculiarities of the occupational accident at sea, itself. To this end, the study inquires into the ideas, interpretations, and legal answers provided to the legal regulation of the occupational accident, formulated during different periods of time, in the interest of the protection of sea workers'. Under such circumstances, great care has been taken when observing the changes occurred under the Spanish legislation, with a special emphasis being given to those happened between the "Occupational Accidents Act" of 1900, and today's "Sea Workers' Special Regime".

Key words: Occupational accident, protection, evolution, Social Security, Sea Workers' Special Regime.

Sumario: Introducción. - I. Antecedentes remotos de la protección del accidente de trabajo en el mar: 1. Las Cofradías de mareantes. 2. Las compilaciones mercantiles del ámbito marítimo. 3. Los modernos códigos de Derecho Mercantil. - II. La Ley de Accidentes de Trabajo de 30 de enero de 1900 y su repercusión en los trabajadores del mar: 1. La Ley de Accidentes de Trabajo de 30 de enero de 1900. 2. Los problemas de aplicación de la Ley de Accidentes de Trabajo de 30 de enero de 1900 a los trabajadores del mar. 2.1. La eventual inclusión de los trabajadores del 
mar en el concepto de operario. 2.2. Las especificidades del trabajo en el mar en relación con la regulación del accidente de trabajo. 3. Hacia una regulación específica de los accidentes de mar. - III. La difícil disyuntiva: accidentes de mar o accidentes de trabajo: 1. La regulación de los accidentes de mar. 2. Las aportaciones de la jurisprudencia ante la difícil disyuntiva existente. - IV. La lenta pero progresiva equiparación de los accidentes de mar con los accidentes de trabajo: 1. La dictadura del General Primo de Rivera. 2. La II República. 3. El período franquista.V. Los accidentes de trabajo en el mar, en el sistema de Seguridad Social: 1. Los accidentes de trabajo respecto a los trabajadores por cuenta ajena. 2. Los accidentes de trabajo respecto a los trabajadores por cuenta propia.

\section{Introducción}

1. En el ordenamiento jurídico español, el accidente de trabajo, entendido como riesgo social cuyas resultas constituyen situaciones de necesidad protegibles por el actual Sistema de Seguridad Social, cuenta con un importante fondo histórico en el ámbito marítimo.

2. Quizás, a simple vista, este fondo histórico pueda entenderse como un mero conjunto de datos y hechos estáticos, pertenecientes a tiempos pasados $\mathrm{y}$, por ende, sin valor alguno en la actualidad.

Nada más lejos de la realidad, puesto que en el interior de dicho fondo histórico fluyen con dinamismo multitud de ideas, interpretaciones y soluciones jurídicas que, además de mostrar el sentir y el quehacer existente en distintos períodos por proteger a la gente de mar de los accidentes de trabajo, también informan e inspiran muchos de los elementos que en la actualidad son inherentes a la figura del accidente de trabajo, conforme al artículo 115 del Real Decreto Legislativo 1/1994, de 20 de junio, por el que se aprueba el Texto Refundido de la Ley General de la Seguridad Social (TRLGSS) ${ }^{1}$.

3. Ciertamente, este estudio, a través del análisis de la génesis y de la evolución del accidente de trabajo en el mar, pretende exteriorizar el enorme valor que dicho fondo histórico posee para comprender la actual regulación del accidente de trabajo, así como las peculiaridades que dicha regulación presenta en el ámbito marítimo pesquero.

\section{Antecedentes remotos de la protección del accidente de trabajo en el mar}

4. Desde muy antiguo, la gente de mar se valió de diversas técnicas de protección para enfrentarse a las situaciones de infortunio o necesidad deri-

${ }^{1}$ BOE de 29 de junio de 1994, núm. 154. 
vadas del acaecimiento de diversos riesgos, entre los que se encontraban los accidentes de trabajo.

En tal sentido, RUMEU DE ARMAS señaló, con palabras crudas, pero sin faltar a la verdad, que «los marineros se mostraron mucho más preocupados que los hombres de tierra adentro. A mayor riesgo, mayor es el espíritu de previsión, y aquellos hombres, avezados a las luchas del mar, sabían bien que en muchas ocasiones partían pletóricos de vida, unas veces para no volver más, dejando desamparados a su mujer y a sus hijos; y otras, para regresar inválidos, y sumirse en la más negra y miserable indigencia» ${ }^{2}$. Esa preocupación de la gente de mar la plasma, también con acierto, CASARIEGO, al afirmar que «es muy distinta la situación del marinero de una lancha a la del obrero de una fábrica» ${ }^{3}$.

En verdad, los pescadores y comerciantes marítimos no dudaron en hacer suyas, en amoldar a sus específicas necesidades, las técnicas de protección surgidas en tierra.

5. De este modo, a partir de la Edad Media, la técnica de protección mutualista se desarrolló en las Cofradías de mareantes y en las compilaciones mercantiles del ámbito marítimo.

\section{Las Cofradías de mareantes}

6. Las Cofradías de mareantes, que a partir de la segunda mitad del siglo XIV se encontraban consolidadas como una institución perfectamente organizada en toda la costa cantábrica, obedecían, básicamente, a un objeto o finalidad: la ordenación de la actividad marítimo-pesquera ${ }^{4}$.

En este sentido, las cofradías de mareantes regularon a través de sus correspondientes ordenanzas diversas cuestiones relacionadas con los mareantes-cofrades, entre las que destacaba la asistencia social otorgada ante situaciones de necesidad originadas por distintas causas, tales como la inactividad, la vejez, la enfermedad, el cautiverio o los accidentes ${ }^{5}$.

En lo que se refiere a los accidentes, las ordenanzas dedicaban especial atención a la protección de sus resultas, a saber, la muerte y la invalidez.

${ }^{2}$ Rumeu De Armas, A. Historia de la Previsión Social en España. Madrid: Editorial Revista de Derecho Privado, 1944, p. 149.

${ }^{3}$ CASARIEGo, J. E. Historia del Derecho y de las Instituciones Marítimas del Mundo Hispánico. Madrid: José Ruiz Alonso, Impresor, 1947, p. 170.

${ }^{4}$ Respecto a la ordenación de la actividad marítimo-pesquera llevada a cabo por las cofradías de mareantes véase ERKoreKa GERVASIO, J. I. Análisis Histórico-Institucional de las Cofradías de Mareantes del País Vasco. Vitoria-Gasteiz: Servicio Central de Publicaciones del Gobierno Vasco. Colección Itsaso, núm. 8, 1991.

${ }^{5}$ Parece que los auxilios al trabajador o a su familia no eran devengados sino cuando el interesado carecía de medios para subvenir sus necesidades, y no por el solo hecho de hallarse en una situación de paro, enfermedad, incapacidad, etcétera. LeIZAOLA, J. M. ${ }^{a}$ Obras Completas. Donostia-San Sebastián: Sendoa, 1981, tomo III, p. 948. 
7. La protección ante la muerte de algún cofrade solía consistir en los auxilios destinados, por una parte, a sufragar los gastos de entierro y, por otra parte, a paliar el infortunio de viudas y huérfanos.

En relación con la viudedad y la orfandad, la mayoría de las ordenanzas regulaban una serie de auxilios, si bien éstos variaban de una cofradía a otra. Así, en algunos lugares, el auxilio consistía en limosnas u otras prestaciones de carácter pecuniario ${ }^{6}$. En otros lugares, se pretendía que fueran las viudas y los huérfanos quienes fuesen capaces de obtener su sustento, para lo que se atribuía a las viudas la tarea de instruir y cuidar a los huérfanos ${ }^{7}$, o se obligaba a los maestres a completar sus tripulaciones con los huérfanos ${ }^{8}$. Con frecuencia, los mayordomos o capitanes de las cofradías actuaban como tutores de los huérfanos, cuidando de la alimentación, educación y vestimenta de los más jóvenes? 9

En torno al riesgo de invalidez, fueron muchas las ordenanzas que regularon conjuntamente la invalidez y la vejez, al entender que ambas imposibilitaban definitivamente la prestación de servicios en cualquier embarcación. De hecho, la vejez se especificaba como causa inevitable de invalidez. No obstante, al margen de la vejez, se reconocía que la invalidez podía derivar de cualquier circunstancia relacionada con el trabajo en el mar, y más concretamente de los accidentes y las guerras.

Ante la situación de invalidez, las cofradías concedían un auxilio diario, cuya función era sostener al inválido y a su familia. A cambio, los inválidos quedaban obligados a instruir en las cosas del mar y de la navegación a los huérfanos de las cofradías ${ }^{10}$.

8. Junto a la protección de las resultas de los accidentes de trabajo, las Ordenanzas regulaban también la protección ante la posibilidad de que los mareantes cayeran enfermos. Así, algunas cofradías, como las sevillanas, tenían sus propios hospitales, en los que se auxiliaba a los cofrades ${ }^{11}$. Pero, en la mayoría de las cofradías, se auxiliaba a los enfermos con prestaciones dinerarias, equivalentes o no a la parte que adquiriría de haberse incorporado a la embarcación, dependiendo siempre de la situación económica de la cofradía, y, también, con prestaciones no dinerarias ${ }^{12}$. Entre estas últimas, destacaban el suministro de las medicinas necesarias para su restablecimiento, la propia asistencia médica o la compañía y las visitas, a turnos, por parte de los demás cofrades ${ }^{13}$.

${ }^{6}$ ERkoreka Gervasio, J. I. ob. cit., p. 325.

${ }^{7}$ Al respecto, vid. Rumeu De ARmas, ob. cit., p. 382.

${ }^{8}$ Ejemplos de todo ello en Rumeu De Armas, ob. cit., pp. 152-153.

${ }^{9}$ Al respecto, vid. Rumeu De Armas, ob. cit., p. 382.

${ }^{10}$ Respecto al auxilio de invalidez, las Ordenanzas de la Cofradía de Portugalete, de 1638, son consideraras modélicas por RuMEU De ARMAS, A. ob. cit., p. 381.

${ }^{11}$ Rumeu De Armas, A. ob. cit., p. 149.

${ }^{12} \mathrm{Al}$ respecto, véase CASARIEGO, J. E. ob. cit., p. 176.

${ }^{13}$ ERkoreka Gervasio, J. I. ob. cit., 323. 
No obstante, no se indemnizaban todas las enfermedades. Parece ser que se exceptuaban aquéllas en las que su causa se debiera a la conducta del afectado. Así ocurre, por ejemplo, con los males o enfermedades venéreas ${ }^{14} \mathrm{o}$ con las enfermedades provenientes de crimen ${ }^{15}$.

9. Esta importante labor de protección social desarrollada por las cofradías de mareantes debe completarse con las medidas contenidas en las compilaciones mercantiles del ámbito marítimo.

\section{Las compilaciones mercantiles del ámbito marítimo}

10. La práctica del comercio marítimo resurge durante la Edad Media, y con ello la necesidad de regular todos sus aspectos. Esta necesidad se cubrirá con una serie de compilaciones de antiguas costumbres y usos marítimos, realizadas por hombres expertos de mar, y teniendo en cuenta la importante y rica actividad de los tribunales consulares existentes en los puertos más importantes, derivada del intenso tráfico marítimo.

En España destaca la aplicación de los Rooles o Juicios de Olerón, en los puertos de Poniente, y la aplicación del Libro del Consulado del Mar, en los puertos de Levante ${ }^{16}$.

11. La importancia de la aplicación de estas dos compilaciones se refleja, igualmente, en los mecanismos que éstas regulan para proteger a la gente de mar de determinadas situaciones de infortunio o necesidad, entre las que se encuentran las derivadas de accidentes de trabajo.

12. Los Rooles o Juicios de Olerón, de origen francés, según la opinión sostenida por la casi unanimidad de los escritores ${ }^{17}$, parece que se aplican en el Reino de Castilla junto a las Siete Partidas, pues «nada más natural que los españoles de la costa cantábrica adoptaran los usos marítimos de los puertos de Occidente de la Francia, con los cuales tenían relaciones frecuentes» ${ }^{18}$.

${ }^{14}$ Rumeu De Armas, A. ob. cit., p. 149.

${ }^{15}$ Erkoreka Gervasio, J. I. ob. cit., p. 324.

${ }^{16}$ Conforme a GARCíA SANZ, en las costas españolas «puede hablarse con cierta propiedad de dos tradiciones marítimas medievales, la mediterránea o de Levante y la atlántica o de Poniente, que suponen también hasta cierto punto, dos concepciones distintas de la cultura naval en general, desde el derecho marítimo y las costumbres náuticas hasta la arquitectura naval» (GARCía SANZ, A. «Estudios sobre los orígines del Derecho Marítimo Hispano-Mediterráneo». In AHDE, 1969, tomo XXXIX, p. 215).

${ }^{17}$ Vid. Font Rius, J. M. ${ }^{\mathrm{a}}$ «Prólogo» al Libro del Consulado del Mar. Edición del texto original catalán y traducción castellana de Antonio Capmany. Barcelona: Cámara Oficial de Comercio y Navegación de Barcelona, 1965, p. 51. En el mismo sentido, véase Blanco, F. Estudios Elementales de Derecho Mercantil. Madrid: Hijos De Reus Editores, 1910, tomo I, p. 197.

18 Martí De Eixala, R. Instituciones de Derecho Mercantil de España. Barcelona: Librería de Álvaro Verdaguer, 1879, 8. a edición, p. 84. 
Pero, además de cualquier hipótesis, prueba que así sucedió un códice de la biblioteca de El Escorial, que contenía una versión castellana de dichos jui$\operatorname{cios}^{19}$.

En efecto, la legislación oficial castellana resultaba paupérrima para regular una vida náutica tan activa como la que se hacía en el Cantábrico ${ }^{20}$. Aunque las Partidas regularon ciertos aspectos del Derecho marítimo, resultaban insuficientes ${ }^{21}$. Un claro ejemplo de esta insuficiencia es la ausencia de reglas en torno a la protección de la gente de mar en situación de infortunio.

Por el contrario, los Rooles o Juicios de Olerón, centrados exclusivamente en los problemas derivados del tráfico marítimo, dan solución a los diversos problemas que surgen en el ámbito marítimo-mercantil, incluso para proteger a aquellos marinos que se encuentran en situación de infortunio.

Precisamente, respecto a la protección social otorgada a los marinos, el juicio séptimo se refiere a la protección existente cuando un marino enferma o muere en acto de servicio. Además, las heridas, y, por tanto, los accidentes sufridos, se asimilan a las enfermedades.

De este modo, en cuanto a la enfermedad, se diferencian dos situaciones. Mientras que en los casos en que el marino enferma, pero no está muy grave,

«el maestre lo debe poner fuera en una casa, E le deve dar gasete ardente o candelas e un moço de la nao quelo sirva o a logar una muger que lo sirva [al tiempo que] el maestre lo deve proveer de tal vianda como dara a otro en la nao. Esto es a saber que le deve dar tanto como despenderia en la nao sy sano fuesse en non mas» ${ }^{22}$,

en los casos en que el marino está muy grave, por lo que

«quiere aver vjandas mas delicadas $\mathrm{E}$ de mayor coste $\mathrm{El}$ maestre non es tenudo de gelas dar E la nao non deve de morar por el ante deve yr e seguir su vijae E si dicho marinero guareciere deve aver su soldada toda ${ }^{23}$.

Pero, conforme al juicio sexto, el maestre o patrón queda liberado cuando las heridas se sufren en los supuestos en que

«ay algunos que salen fuera de la nao syn licencia del maestre o Renjegan o dicen palabras malas o fazen peleas o contiendas» ${ }^{24}$.

${ }^{19}$ Ibidem.

${ }^{20}$ Casariego, J. E. ob. cit., p. 140.

${ }^{21}$ En torno al contenido de las Partidas, véase Martí De EiXALA, R. ob. cit., p. 83.

${ }^{22}$ Casariego, J. E. ob. cit., p. 265.

${ }^{23}$ Ibidem.

${ }^{24}$ Ibidem. 
Por su parte, al fallecer algún marino según el último inciso del juicio séptimo, el maestre

«devela [la soldada toda] aver su muger o sus legitimos herederos» ${ }^{25}$.

13. Estos juicios, tan valiosos para la protección de la gente de mar en el ámbito marítimo de Poniente, se irán difuminando con el paso del tiempo, hasta llegar a su completa desaparición, debido, sobre todo, a la gran influencia que ejercerá el Libro del Consulado del Mar a nivel internacional.

14. El Libro del Consulado del Mar, además de ser el primer código escrito de los usos y costumbres con que los principales Estados marítimos del Levante dirigieron su navegación y comercio, desde los primeros siglos de la Baja Edad Media, se convertirá en el único que, por consentimiento de todas las naciones comerciantes, lleve el sello de Derecho náutico de las gentes $^{26}$. Fue tal la importancia de esta compilación, que estuvo en vigor hasta principios del siglo XIX, cuando la corriente codificadora originó la aparición de modernos códigos de comercio.

Corresponde a la ciudad de Barcelona el honor de haber creado esta compilación, pero, ya con anterioridad, durante el reinado de Jaime I, en pleno siglo XIII, el despliegue rotundo de la actividad mercantil catalana se traduce en las primeras elaboraciones del Derecho marítimo mediterráneo, apoyándose, principalmente, en las relaciones que los puertos de Barcelona, Valencia, Mallorca y Tortosa mantienen con los puertos italianos y de otros países mediterráneos.

15. Surge así el embrión del futuro Libro del Consulado del Mar, cuando el Rey Jaime I aprueba en 1258 las Ordenanzas para la policía y gobierno de las embarcaciones mercantes de Barcelona, hechas por los Prohombres del mar de dicha Ciudad, comúnmente denominadas Ordinations Ripariae.

Destaca en estas Ordinations Ripariae el espíritu de amplia hermandad y mutualidad existente entre los mercaderes y gente de mar de su ámbito de aplicación. Este espíritu se manifiesta, asimismo, en la protección de los marineros ante las situaciones de muerte y enfermedad ${ }^{27}$.

${ }^{25}$ Ibidem.

${ }^{26}$ Capmany y MonPalau, A. «Discurso del Editor» al Libro de las Costumbres Marítimas de Barcelona, hasta aquí llamado vulgarmente Libro del Consulado. Madrid: Imprenta de Don Antonio de Sancha, 1791, pp. 9-10. En Libro del Consulado del Mar. Edición del texto original catalán y traducción castellana de Antonio Capmany, Barcelona: Cámara Oficial de Comercio y Navegación de Barcelona, 1965.

${ }^{27}$ Rumeu De Armas considera a las Ordinatios Ripariae y al Libro del Consulado del Mar «como los primeros cuerpos legales españoles en los que la reparación económica de los accidentes de trabajo queda garantizada de un modo orgánico» (RUMEU DE ARMAS, A. ob. cit., p. 156). 
A estas dos situaciones se refiere, concretamente, el capítulo $\mathrm{XXI}^{28}$. En primer lugar dispone

«que si algún marinero muriese sirviendo una nave o leño desde el punto en que el buque salga de la grada, o del fondeadero, o de algún puerto; tendrá derecho a todo su salario, conforme a lo que estuviese escrito en el libro de asientos de la misma embarcación».

En segundo lugar, en torno a la posible enfermedad de los marineros, establece varios principios. Así,

«si un marinero, enfermase o se estropeare en sus miembros desde el punto de haberse botado al agua la nave o el leño; el patrón abonará al dicho marinero, su comida precisa para todo el viage, si el tal fuese en el susodicho viage, y el marinero habrá toda su soldada. Pero si dicho marinero no quisiere ir al referido viage, no cobrará soldada alguna».

Pero

«si el marinero hubiese recibido tal estropeamiento haciendo el servicio de dicha nave o leño, que no pueda ir al viage al juicio de dos prohombres de la ribera, cobrará tan sólo la media soldada. Y si el patrón hubiese pagado el salario entero al sobredicho marinero, no tendrá obligación de poner otro marinero en lugar del que quedare en tierra; mas si sólo le hubiese pagado la mitad del salario, deberá poner otro marinero en lugar del que se quedó, y dar la restante mitad del susodicho salario que no pagó, al nuevo marinero: y sus mercaderes estarán obligados a rehacer a éste, puesto en lugar del otro, la otra mitad».

16. A pesar de la perfección técnica con la que se redactaron la Ordinations Ripariae, muy pronto, el impresionante desarrollo del tráfico marítimo provocó la superación de dicha regulación y la elaboración de la compilación más importante de cuantas han existido en el ámbito marítimo: el Libro del Consulado del Mar.

La brillantez del Libro del Consulado del Mar, justificada por su extensa vigencia, se aprecia también en la regulación realizada en torno a las relaciones laborales de los sujetos embarcados, dentro del título III, bajo la rúbrica «De las obligaciones entre el patrón y los marineros de la tripulación». En dicho título se recoge, además, una serie de capítulos dedicados a la protección de los marineros ante dos situaciones de necesidad o infortunio en concreto: la muerte y el cautiverio. A los efectos de esta exposición, resulta del máximo interés la regulación de la protección ante la muerte, como resulta del accidente de trabajo.

${ }^{28}$ Capmany y Monpalau, A. «Apéndice a las Costumbres Marítimas» del Libro del Consulado. Madrid: Imprenta de Don Antonio De Sancha, 1791, pp. 555-556. En Libro del Consulado del Mar. Edición del texto original catalán y traducción castellana de Antonio Capmany, Barcelona: Cámara Oficial de Comercio y Navegación de Barcelona, 1965. 
La técnica utilizada para llevar a cabo la protección de los marineros, frente a la actualización de un riesgo que les produzca la muerte, adquiere matices propios, en comparación con el mutualismo practicado por las cofradías de mareantes.

Concretamente, cuando el marinero fallecía en los casos tipificados por el propio Libro del Consulado del Mar, el patrón estaba obligado a abonar una serie de auxilios, a fin de que los afectados superasen la situación de infortunio en la que se hallaban.

En realidad, en relación con la muerte de alguno de los marineros, se regulan varias situaciones de las que derivan obligaciones para los patrones.

a) Cuando un marinero cae enfermo y muere en la nave (capítulo CXXVIII $^{29}$ : si un marinero cae enfermo y muere en la nave, el patrón «debe pagarle por entero su salario. Y si se hallase algún pariente del difunto allí, se le deben dar sus cosas. Pero, háyalo declarado antes el difunto o no, se han de dar a los hijos o a la mujer, si ésta hacía actualmente vida con el marido. Mas si la mujer no le era fiel o estaba separada de él quando partió de su tierra, o después de partido hubiese huido, el patrón con el escribano, y con aprobación de la justicia, debe darlas a los parientes más cercanos» ${ }^{30}$.

b) Cuando el marinero alistado muere antes «de haber dado a la vela» (capítulo CXXVIII ${ }^{31}$ : «el marinero ajustado ya para viaje que, por voluntad de Dios, muere antes que la nave haya dado a la vela, debe haber la quarta parte del salario, y éste se asignará y dará a sus herederos».

c) Cuando el marinero alistado muere después «de haber dado ya la vela $\mathrm{y}$ antes que la nave llegue a donde ha de tomar puerto» (capítulo CXXVIII $^{32}$ : en este supuesto, «la mitad del salario debe ser del difunto y darse a sus herederos. Y si hubiese recibido ya todo el salario antes de morir, todo debe ser suyo y dado a sus herederos. Y el patrón nada puede sobre esto disputar ni pedir».

d) Cuando el marino es contratado por meses y muere (capítulo CXXIX) ${ }^{33}$ : «debe ser pagado y dado todo a sus herederos, por lo que haya servido».

e) Cuando el patrón lleva consigo un sirviente por tiempo fijo, y éste muere «antes del tiempo que ajustó servir» (capítulo CCLXXII) ${ }^{34}$ : el patrón «estará obligado a pagar y a dar a los parientes de dicho sirviente a prorrata de lo que haya servido, sin contradicción alguna».

${ }^{29}$ CAPmany y Monpalau, ob. cit., p. 118.

${ }^{30}$ Como puede apreciarse, en este capítulo se establecen las prestaciones de muerte y supervivencia, con la intención de proteger, en la medida de lo posible, a los huérfanos, a las viudas y a los parientes más allegados. Al mismo tiempo, este capítulo es la norma general en cuanto a los auxilios por muerte, pues, como se observará a continuación, existen otros capítulos dedicados a situaciones específicas.

${ }^{31}$ Capmany y Monpalau, A. ob. cit., p. 119.

32 Ibidem.

${ }^{33}$ Ibidem.

${ }^{34}$ Capmany y Monpalau, A. ob. cit., p. 167. 
Por tanto, resulta evidente la responsabilidad de los patronos respecto a sus marineros, con lo que el Derecho marítimo se adelanta a las distintas teorías sobre la responsabilidad desarrolladas a partir del siglo XIX con el objetivo de declarar a los empresarios responsables de los accidentes de trabajo, ocurridos en sus fábricas, y sufridos por sus trabajadores.

17. Posteriormente, a todos estos capítulos contenidos en el Libro del Consulado del Mar, se les incorporarán los capítulos del rey Pedro IV de Aragón, sobre los actos y hechos marítimos, promulgados en Barcelona en 1340, y de aplicación a los patrones, tripulaciones y cargadores de naves de comercio catalanas, valencianas, sardas y corsas, por hallarse todas ellas bajo el dominio marítimo de la Corona de Aragón.

Nuevamente, la preocupación por los riesgos que amenazan la seguridad de la gente de mar, y que de actualizarse pueden crear graves situaciones de necesidad o infortunio, resulta patente en estos capítulos.

En la misma línea de los capítulos ya existentes en el Libro del Consulado del Mar, el capítulo séptimo, de los treinta y ocho que incorpora el rey Pedro IV de Aragón, se refiere a una situación no prevista hasta el momento, a saber, la enfermedad.

A tenor del capítulo séptimo, pueden diferenciarse dos situaciones, con las correspondientes obligaciones del patrón. Así, por una parte, se establece que

«si el marinero u otro alistado se lastima algún miembro, o toma enfermedad haciendo el servicio de la nave, devengará su sueldo mientras esté a bordo, como si estuviese sano; y el patrón deberá satisfacerle los salarios, y cumplirle qualquiera otra cosa, según el tenor y forma de su alistamiento» ${ }^{35}$.

Por otra parte, se dispone que si el marinero

«estaba en viage de Ultramar, el patrón deberá en todo caso volverle con aquella nave, hasta que le dexe en el lugar, en donde le alistó» ${ }^{36}$.

18. Todos estos capítulos contenidos en el Libro del Consulado del Mar se mantendrán vigentes hasta el siglo XIX, cuando por influjo de la filosofía liberal las compilaciones comiencen a ser sustituidas por los modernos códigos de Derecho mercantil.

\section{Los modernos códigos de Derecho Mercantil}

Con todo, la magnífica experiencia de la protección otorgada a la gente de mar por el Libro del Consulado del Mar influyó de manera importante en

\footnotetext{
${ }^{35}$ Capmany y Monpalau, A. ob. cit., p. 575.

${ }^{36}$ Ibidem.
} 
los redactores del primer Código de Comercio español (1829) ${ }^{37}$. Inspirados claramente por la compilación medieval, los legisladores decimonónicos mantendrán el espíritu de aquélla en las disposiciones contenidas en la Sección III, Título II, del Libro III, bajo la rúbrica «de los oficiales y equipaje de la nave».

Por consiguiente, en lo que respecta a los accidentes de trabajo, se regula la protección concedida en situaciones de enfermedad y muerte, en la forma que a continuación se expone:

a) Enfermedad: «no cesa de devengar salario el hombre de mar que enfermare durante la navegación, á menos que no haya emanado la enfermedad de un hecho culpable. En cualquier caso se sufragarán del fondo comun de la nave los gastos de asistencia y curación, quedando obligado el enfermo al reintegro con sus salarios, y no siendo estos suficientes, con sus bienes» (artículo 718).

Igualmente, se asimilarán a la enfermedad las dolencias que procedan de «herida recibida en el servicio o defensa de la nave», con lo que el concepto de enfermedad parece englobar a los accidentes de trabajo. En estos casos, «será el hombre de mar asistido y curado á espensas de todos los que interesen en el producto de esta» (artículo 719).

b) Muerte: primero, se establece la protección ante la situación de muerte natural, aunque teniendo en cuenta varias circunstancias, y, después, ante la muerte en defensa de la nave.

Así, conforme al primer supuesto, «muriendo el hombre de mar durante el viaje, se abonará a sus herederos el salario que corresponda al tiempo que haya estado embarcado, si el ajuste estuviere hecho por mesadas. Si hubiere sido ajustado por viaje, se considerará que ha ganado la mitad de su ajuste falleciendo en el viaje de ida, y la totalidad si muriese en el regreso. Cuando el hombre de mar haya ido á la parte, se abonará a sus herederos toda la que corresponda si murió despues de comenzado el viaje; pero aquellos no tendrán derecho alguno si falleciera antes de comenzarse» (artículo 720).

En el segundo supuesto, «cualquiera que sea el ajuste de hombre de mar, muerto en defensa de la nave, se le considerará vivo para devengar los salarios y participar de las utilidades que correspondan á los demás de su clase, concluido que sea el viaje» (artículo 721).

19. Más de un siglo después de haberse aprobado el Código de Comercio de 1829, estas medidas protectoras de la gente de mar se introdujeron, prácticamente en iguales términos, en el Cogido de Comercio de 1885, vigente en la actualidad ${ }^{38}$.

${ }^{37}$ Articulado y comentarios en Gómez de la Serna, P. y Reus y García, J. Código de Comercio, concordado y anotado. Madrid: Imprenta de la Revista de Legislación, 1863, 4. ${ }^{\text {a }}$ edición.

${ }^{38}$ Gaceta de Madrid de 16 de octubre a 24 de noviembre de 1885, núms. 289 a 328. 
En ese sentido, mientras que el artículo 644 se ocupa de regular la protección en situación de enfermedad, a la que se siguen asimilando los accidentes de trabajo, mediante la referencia a las dolencias procedentes de las heridas recibidas en servicio o defensa del buque, el artículo 645 se refiere a la situación de muerte.

\section{La Ley de Accidentes de Trabajo de 30 de enero de 1900 y su reper- cusión en los trabajadores del mar}

20. Las postrimerías del siglo XIX, así como los inicios del siglo XX, se caracterizan por la incertidumbre en la protección de toda clase de trabajadores. Es el período de la cuestión social. Período en el que comienzan a ceder los postulados liberales, a favor del intervencionismo estatal en materia social.

En el ámbito marítimo pesquero, la incertidumbre en la protección de la gente de mar se fundamenta, básicamente, en dos aspectos.

Por un lado, las cofradías de mareantes, al igual que sucede con el resto de los gremios, chocan de lleno con uno de los principios básicos del liberalismo, según el cual debía eliminarse cualquier cuerpo intermedio existente entre la sociedad y el Estado.

El hecho de que la supresión de las cofradías de mareantes se retrase en el tiempo, en comparación con el resto de los gremios, hasta la promulgación del Real Decreto de 10 de julio de $1864^{39}$, y de que, en la práctica, algunas cofradías, de un modo u otro, bajo distintos ropajes, consigan mantener su identidad, evidencia la importancia de esta institución, y la dificultad existente para eliminarla. Ello no obstante, la inseguridad que esta situación provocaba suscitaba muchas dudas en cuanto a la protección que debía concederse a los trabajadores del mar en situación de infortunio.

Por otro lado, la extensión al ámbito marítimo de los riesgos sociales, fruto de la industrialización, y de la ideología liberal, en sus tres vertientes, económica, política y jurídica, aumentaron la sensación de desprotección de la gente de mar.

Ciertamente, a medida que avanza la tecnología en las embarcaciones, y la pesca de altura adquiere tintes capitalistas, también en el ámbito marítimo-pesquero cobra sentido el concepto de riesgos sociales, y surgen, por tanto, los mismos problemas que en tierra respecto a la forma de enfrentarse a dichos riesgos.

21. Cuando, durante el último cuarto del siglo XIX, el Estado decide intervenir en los aspectos sociales, lo hace, inicialmente, con una preocupación filantrópica, inspirado más en vagas razones de caridad que de estricta

${ }^{39}$ Gaceta de Madrid de 13 de julio de 1864, núm. 1965. 
justicia; caridad a través de la cual se pretende mantener la paz social ante las gravísimas consecuencias individuales y sociales de los accidentes de trabajo y enfermedades profesionales ${ }^{40}$.

El reflejo del intervencionismo estatal en materia social también se deja sentir en la protección de la gente de mar. Por ese motivo, el legislador, en un primer momento, se decanta por establecer ciertas medidas de carácter preventivo para los trabajadores del mar.

Un claro ejemplo de la plasmación del binomio caridad-prevención en el ámbito marítimo lo constituye la Real Orden de 1 de mayo de $1878^{41}$, consecuencia de un siniestro ocurrido en las aguas del Cantábrico. Preocupado por las graves consecuencias que de las tempestades pueden derivarse para los trabajadores del mar, el legislador reacciona en dicha norma «con la adopción de medidas que tienden á evitar desgracias parecidas, hasta donde pueda alcanzar la previsión humana» (Exposición). Estas medidas consisten en:

a) La transmisión sin la menor demora, por parte del Observatorio Astronómico de Madrid, de «los partes meteorológicos diarios del centro de París y demás de donde los reciba a los Capitanes de los puertos de Palamós, Barcelona, Tarragona, Valencia, Alicante, Cartagena, Almería, Málaga, Algeciras, Cádiz, Sevilla, Huelva, Vigo, Villagarcía, Muros, Corcubión, Coruña, Santa Marta de Ortigueira, Rivadeo, Gijón, Santander, Bilbao y San Sebastián» (regla primera).

b) La obligación de los Capitanes de los puertos consistente en exponer al público los partes meteorológicos y de trasmitirlos por el telégrafo a los Ayudantes de los distritos, para que también los expongan al conocimiento del público, «cuando [se] anuncien temporales en las costas ó mares de la misma provincia marítima ó limítrofes» (regla segunda).

c) El aviso a los pescadores y buques de cabotaje sobre la llegada de temporales a las costas o mares de la misma provincia o limítrofes «por medio de una señal conocida de antemano, puesta en un asta en el punto más culminante y visible de la localidad» (regla tercera).

d) La obligación de los Capitanes de los puertos de San Sebastián, Bilbao, Santander, Gijón, Rivadeo, Santa Marta de Ortigueira, Ferrol, Coruña, Corcubión, Muros, Villagarcía y Vigo e, igualmente, de los Capitanes de los puertos de Palamós, Barcelona, Tarragona, Vinaroz, Valencia, Alicante, Cartagena, Almería, Málaga, Algeciras, Cádiz, Sevilla y Huelva de comunicarse diaria y recíprocamente por telégrafo, a las seis de la tarde, el tiempo que reine en las costas respectivas, con las alturas barométricas y la probabilidad de que continúe o amaine, tomando el parecer de los prácticos (regla quinta).

${ }^{40}$ Respecto a la Seguridad Social en la etapa denominada filantrópica, vid. MonToyA Melgar, A. «La Seguridad Social española: aproximación histórica». En RT, 1976, núms. 54 y 55 , p. $10-13$.

${ }^{41}$ Gaceta de Madrid de 5 de mayo de 1878, núm. 125. 
e) La recomendación para que se inicie «una reforma beneficiosa en la construcción de las embarcaciones de pesca y de tráfico de puerto á puerto... procurando que además de ser con cubierta abierta al centro para servicio de los remeros, pero que pueda cerrarse en caso de necesidad con cuarteles de correderas, reúnan una combinación de espacios vacíos herméticamente cerrados, que sirvan de flotadores y las hagan insumergibles, y que el lastre que usen sea de agua en barriles, que además de la cualidad de flotar llenos pueden fácilmente vaciarse y cuyo peso nunca ofrece peligros» (regla sexta).

22. Sin embargo, el binomio caridad-prevención resultó insatisfactorio para proteger de los riesgos sociales a los trabajadores asalariados, entre los que se hallaban los trabajadores del mar. En definitiva, el binomio caridadprevención no solventaba la incertidumbre existente, y cada vez resultaba más evidente la necesidad de apostar por una técnica específica de protección de los riesgos sociales.

\section{La Ley de Accidentes de Trabajo de 30 de enero de 1900}

23. Con la llegada del siglo Xx, irrumpe la Ley de Accidentes de Trabajo de 30 de enero de $1900^{42}$, y con ella se abren nuevos derroteros en el campo de la protección.

La Ley de Accidentes de Trabajo se convierte en el primer mecanismo que el legislador español establece en el intento por equilibrar los diferentes intereses entre patronos y trabajadores, y apaciguar los efectos de la cuestión social. Además, su carácter específico supone el inicio de un nuevo período que pone fin a la incertidumbre existente ante la insuficiencia de las técnicas de protección existentes hasta el momento para enfrentarse a los riesgos sociales, y, especialmente, a los accidentes de trabajo, de los que derivaban las peores consecuencias para los trabajadores, y de los que, al mismo tiempo, traían causa las principales reivindicaciones obreras.

24. La vía expeditiva abierta por la Ley de Accidentes de Trabajo de 1900 se inspira en la idea del riesgo profesional, atribuyendo al patrono la responsabilidad

«de los accidentes ocurridos á sus operarios con motivo y en el ejercicio de la profesión ó trabajo que realicen, á menos que el accidente sea debido a fuerza mayor extraña al trabajo en que se produzca el accidente» (artículo 2).

Acaecidos los accidentes, se indemniza a los obreros en las situaciones de incapacidad de trabajo absoluta o parcial, temporal o perpetua, en la forma y cuantía que establece la propia Ley (artículo 4).

${ }^{42}$ Gaceta de Madrid de 31 de enero de 1900, núm. 31. 
En los supuestos en que el accidente

«produjese la muerte del obrero, el [patrono] queda obligado á sufragar los gastos de sepelio, no excediendo éstos de 100 pesetas, y además á indemnizar á la viuda, descendientes legítimos menores de diez y seis años y ascendientes...» (artículo 5).

Además, en los establecimientos industriales comprendidos por la propia Ley (artículo 3) se faculta a los propietarios para sustituir las indemnizaciones por pensiones vitalicias,

«siempre que las garanticen á satisfacción de la víctima ó sus derecho habientes...» (artículo 10).

Pero si importantes eran todas estas prescripciones, la más importante radicó en la introducción del seguro como elemento que posibilitaba a los patronos transmitir las obligaciones o responsabilidades derivadas de los riesgos sociales a una sociedad de seguros debidamente constituida (artículo 12). Con ello, se establece el carácter voluntario del seguro de accidentes de trabajo para los empresarios, con lo que ya no se pretende que sean los trabajadores mismos los que suscriban las correspondientes pólizas, tal y como ocurría años atrás, con los primeros seguros privados.

Por consiguiente, la conjunción de la responsabilidad empresarial por el riesgo profesional y de la técnica del seguro, aunque voluntario, sitúa en la esfera del empresario la solución del problema de la protección de los trabajadores en situación de infortunio.

25. Los innegables avances en protección social se vieron confirmados con la promulgación del Real Decreto de 28 de julio de $1900^{43}$, aprobatorio del Reglamento para la aplicación de la Ley de Accidentes de Trabajo de 30 de enero de 1900.

Por el contrario, en lo que respecta a los trabajadores del mar, tales avances suscitaban muchas dudas, puesto que la Ley de Accidentes de Trabajo no mencionaba las actividades marítimo-pesqueras entre las industrias o trabajos que daban lugar a responsabilidad del patrono (artículo 3).

Desde el primer momento, el silencio de la Ley en torno a las actividades marítimo-pesqueras planteó diversas interpretaciones por parte de los interesados, que no tardaron en llegar a los tribunales.

\section{Los problemas de aplicación de la Ley de Accidentes de Trabajo de 30 de} enero de 1900 a los trabajadores del mar

26. La gente de mar tuvo que enfrentarse a una serie de problemas para conseguir la aplicación de la Ley y del Reglamento de Accidentes de Traba-

${ }^{43}$ Gaceta de Madrid de 30 de julio de 1900, núm. 211. 
jo en las actividades marítimo pesqueras. Los problemas se debían, a veces, al silencio mantenido, tanto por la Ley como por el Reglamento, en cuanto a las actividades marítimo-pesqueras y, otras veces, a las especificidades que presenta el trabajo en el mar y que no casaban con la regulación de los accidentes de trabajo.

\subsection{LA EVENTUAL INCLUSIÓN DE LOS TRABAJADORES DEL MAR EN EL CONCEP- TO DE OPERARIO}

27. La primera de las cuestiones planteadas giraba en torno a la posibilidad de que los trabajadores del mar quedaran incorporados en el concepto de operario mantenido por la Ley y el Reglamento de Accidentes de Trabajo.

En términos de la Ley, es operario

«todo el que ejecuta habitualmente un trabajo manual fuera de su domicilio por cuenta ajena» (artículo 1)

$\mathrm{y}$, en el mismo sentido, el Reglamento considera operarios a

«todos los que ejecutan habitualmente trabajo manual fuera de su domicilio por cuenta ajena, con remuneración ó sin ella, á salario ó á destajo, en virtud de contrato verbal ó escrito» (artículo 2).

La denominación genérica de «operario» permite a los tribunales extraer tempranamente conclusiones acerca de la aplicación de la Ley y del Reglamento de Accidentes de Trabajo a la gente de mar.

Así, conforme a la sentencia de 27 de febrero de $1903^{44}$, en primer lugar,

«aun cuando la Ley de $1 .^{\circ}$ de enero de 1900 (sic.), sobre accidentes del trabajo, sea una Ley cuyos beneficios alcanzan más general y principalmente a los obreros y dependientes sujetos al simple jornal o salario con que se les remunera en las empresas o industrias que se refiere el art. 3 . $^{\circ}$ de la misma, comprendiendo a todos bajo la denominación genérica de operarios, en ninguno de sus preceptos existe base cierta para establecer entre aquéllos distinción alguna por razón de su mayor o menor categoría, conocimientos que les sean exigidos y sueldo o salario que disfruten, al objeto de excluir de la Ley a ninguno, si concurren en él las circunstancias de desempeñar las funciones que le están asignadas, ejecutando habitualmente un trabajo manual fuera de su domicilio, por cuenta ajena, aun cuando sea con carácter técnico, pues ni la concurrencia en el operario de estudios o título profesional constituye razón alguna para prescindir de la índole del trabajo que ejecute, ni sería tal distinción conforme al alcance fundamental de la Ley, cual es el de asegurar en la forma que prevé los

${ }^{44}$ García Ormaechea, R. Jurisprudencia del Tribunal Supremo y de la Comisión Superior de Previsión sobre Accidentes de Trabajo, 1902-1934. Madrid: Imprenta y Encuadernación de los Sobrinos de la Sucesora de M. Minuesa de los Ríos, 1935, pp. 175-176. 
accidentes a que están expuestos, por la índole de sus trabajos, los que se hallan al servicio de empresas o industrias a que aquélla se refiere, que no tiene el carácter de meramente benéfica para los más menesterosos, y sí el de aseguradora de los accidentes o siniestros que puedan sobrevenir a cuantos emplean su actividad física en los trabajos de las respectivas empresas, con mayor exposición acaso para los que en ellas intervienen directa o inmediatamente con la responsabilidad de sus conocimientos y técnicas».

Atendiendo a ese hecho, se afirma en la sentencia que

«la circunstancia de que el lesionado fuese primer maquinista del vapor donde ocurrió el siniestro que produjo su muerte, la de que tuviese la consideración de oficial del buque, con personal colocado a sus órdenes, la de que, como tal maquinista, hubiera tenido que acreditar la pericia y adquirir título que las disposiciones legales vigentes exigen, y la de que cobrase sueldo y no jornal o salario, en nada, absolutamente en nada, desvirtúan el hecho culminante de tener que intervenir, dirigir y manejar, materialmente y manualmente, la máquina de vapor donde se produjo la explosión, y de que esta función la desempeñaba habitualmente, fuera de su domicilio, por cuenta ajena, porque por esto, y no por mero accidente o casualidad, fue la primera víctima de la explosión, hallándose tan expuesto o más que otro alguno a siniestros de semejante naturaleza; porque, aun cuando la Ley habla de salarios o jornales para la determinación de las indemnizaciones, esto no debe entenderse en sentido restrictivo, ya que la misma Ley comprende entre sus disposiciones a personas que tienen asignados, por sus funciones, verdaderos sueldos, cuales son los dependientes de comercio, y los que no tienen ninguna clase de emolumentos, y porque cuando la razón de la Ley es igual en uno y otro caso, nada sería más fácil que burlarla dándola otra interpretación respecto de este extremo».

28. Estas conclusiones a las que había llegado la jurisprudencia influyeron rápidamente en la labor del legislador, pues la Real Orden de 12 de mayo de $1903^{45}$, considerando las «instancias de la Junta Central de la Liga marítima y la de las Asociaciones de Capitanes y Pilotos de la Marina Mercante de Bilbao y Gijón», dispone

a) primero, «que en el artículo 3 de la Ley de Accidentes de Trabajo se consideren incluidos los operarios por cuenta ajena que se dediquen á cualquiera especie de navegación, pesca y demás industrias marítimas similares, ya trabajen con remuneración, ya sin ella, á salario ó á destajo, en virtud de contrato verbal ó escrito»;

${ }^{45}$ Gaceta de Madrid de 14 de mayo de 1903, núm. 134. En ese sentido, véase Del Peso Y CALVO, P. La protección legal del accidente de trabajo y de la enfermedad profesional, 1900-1967. Madrid: Impreso en Hijos de E. Minuesa, 1971, p. 30. 
b) segundo, «que el plazo de veinticuatro horas que se consigna en el artículo 8 del Reglamento de dicha Ley, empiece á contarse, cuando el accidente haya ocurrido en el mar, desde el momento en que el buque llegue á puerto español ó extranjero en que haya cónsul de la Nación»;

c) tercero, «que se invite á los patronos y empresas marítimas á que en los contratos que hagan con Capitanes y Pilotos consignen que para los efectos de la indemnización por accidentes se les considere incluidos en la Ley de Accidentes de Trabajo ${ }^{46}$; que se recomiende á las Autoridades de Marina que procuren persuadir á las partes para que se establezca esta condición en los contratos en que intervengan; y por fin, que se tengan presentes las razones expuestas en las instancias mencionadas para cuando se trate de la modificación de la ley»

29. Con posterioridad a esta Real Orden, también el Tribunal Supremo se pronuncia a favor de la inclusión de la gente de mar, en su sentencia de 20 de febrero de $1908^{47}$, al señalar que

«por el hecho de ser el causante de la actora, cuando perdió su vida, en el naufragio de una lancha, patrón de cabotaje, y exigir este cargo u oficio conocimiento de mayor pericia para dirigirla, vigilar el trabajo de otros y corregirlos, no por ello carecía del carácter de operario, puesto que antes y en el momento del suceso dedicaba habitualmente su actividad física, fuera de su domicilio, por cuenta ajena y con salario fijo, a desempeñar, según las necesidades del servicio lo exigían, operaciones manuales, unas veces; trabajos prácticos y de mayor pericia, otras, particularmente en los momentos precursores a su muerte en que, falto de personal auxiliar, sólo contaba con el maquinista».

30. Finalmente, la jurisprudencia acabará extendiendo el concepto de operario a los trabajadores del mar retribuidos a la parte. Así, lo confirma, por ejemplo, la sentencia del Tribunal Supremo de 9 de noviembre de $1909^{48}$. Los argumentos empleados por esta sentencia para considerar operarios a los trabajadores a la parte resultan interesantes, ya que constituirán el punto de partida de sentencias posteriores.

Conforme a los argumentos del caso concreto tratado en la sentencia

«dándose por probado que los dueños del vapor, para las operaciones de la industria pesquera..., industria no exceptuada por la Ley de Accidentes de Trabajo, admitían y despedían a su voluntad a los marineros que formaban la tripulación del barco, retribuyéndoles, mientras servían, con una par-

${ }^{46}$ El primer considerando de la Real Orden señalaba que «siendo de indudable aplicación las disposiciones de la Ley de Accidentes del Trabajo á los marineros y demás obreros manuales de la navegación, en cambio el carácter técnico de las profesiones de Capitán y Piloto de la Marina Mercante impide incluir á los que las siguen, conforme al artículo 2 del Reglamento, que define lo que se entiende por obrero para los efectos de la Ley».

${ }^{47}$ García Ormaechea, R. ob. cit., p. 177.

${ }^{48}$ García Ormaechea, R. ob. cit., pp. 212-213. 
te mínima determinada de los productos de la pesca, así como que los propios marineros dejaban el servicio del barco cuando lo tenían por conveniente, sin contraer entre sí, ni con terceras personas, ninguna clase de responsabilidad civil, no cabe sostener fundadamente que esos marineros constituyeran, juntamente con los dueños del barco, ninguna sociedad. Esto sentado, las relaciones de los marineros con los dueños del barco, en cuanto a la industria pesquera a que se dedicaba, no son otras que las del obrero con el patrono, pues no es esencial que la retribución afecte la forma de salario».

Ahondando en la misma idea, la sentencia del Tribunal Supremo de 10 de diciembre de $1918^{49}$ determina que los trabajadores a la parte considerados operarios son, en realidad trabajadores por cuenta ajena, claramente diferenciados de la figura del socio. Así, son trabajadores y no socios

«los tripulantes de un barco pesquero a quienes el dueño retribuye con una parte del producto de la pesca, y, como mínimo, con el importe de su manutención, porque no hay sociedad, ya que, en este contrato, las obligaciones son comunes, y jamás un socio trabaja por cuenta y cargo de otro, ni los socios están remunerados por sus servicios, teniendo únicamente participación en las ganancias, apareciendo, por el contrario, perfectamente definido el contrato de arrendamiento de servicios, porque existe la obligación de una persona de prestarlo a otra por su cuenta y cargo y un precio cierto, lo que no quiere decir precio fijo, pues el legislador lo que ha declarado es la certeza de la concurrencia de precio, no sus contingencias y modalidades de pago».

En conclusión, los trabajadores del mar retribuidos a la parte son considerados operarios, siempre y cuando no constituyan una sociedad junto a los dueños del barco.

\subsection{LAS ESPECIFICIDADES DEL TRABAJO EN EL MAR EN RELACIÓN CON LA REGU- LACIÓN DEL ACCIDENTE DE TRABAJO}

31. Solventada la cuestión acerca de la inclusión de los trabajadores del mar en el concepto de «operario» fijado por la Ley y el Reglamento de Accidentes de Trabajo, los problemas de interpretación comenzaron a plantearse en torno a las especificidades del trabajo en el mar. Efectivamente, con el paso del tiempo, la realidad de los hechos se encargó de demostrar que el trabajo en el mar presenta ciertas peculiaridades no previstas por el legislador.

32. Una de las más arduas polémicas se suscitó respecto al concepto de fuerza mayor. La Ley de Accidentes de Trabajo liberaba a los patronos de la obligación de pagar las correspondientes indemnizaciones a los trabajadores accidentados con motivo y en el ejercicio de la profesión o trabajo realizado

\footnotetext{
${ }^{49}$ García OrmaecheA, R. ob. cit., p. 213.
} 
cuando el accidente se debía a fuerza mayor extraña al trabajo (artículo 2). Teniendo en cuenta que muchos de los accidentes producidos en el mar se deben precisamente a los riesgos originados por éste, la polémica se centró en la conveniencia de incluir en el concepto de fuerza mayor los riesgos que el mar depara.

Una vez más, los trabajadores del mar tuvieron que acudir a los tribunales para hallar la solución. De esta suerte, la jurisprudencia completó la legislación de accidentes de trabajo, pronunciándose sobre el carácter de accidente de trabajo de naufragios, abordajes o cualquier otro riesgo que el mar produce, independientemente de los que a bordo suceden.

33. En relación con los naufragios, la sentencia del Tribunal Supremo de 28 de diciembre de $1906^{50}$ declara en el asunto tratado por ésta que

«la niebla y estado del mar fueron las causas determinantes del naufragio y muerte del obrero... [y] aquéllas causas... constituyen notoriamente un accidente de trabajo o profesión...».

Por tanto, no sólo el naufragio, sino también las inclemencias del tiempo que lo originan son considerados accidentes de trabajo en el ámbito marítimo-pesquero. Igualmente, la sentencia del Tribunal Supremo de 20 de febrero de $1908^{51}$ consideró que

«el naufragio de una lancha, por rotura del cable que la remolcaba, suceso en el cual perecieron sus tripulantes, no es debido a fuerza mayor extraña a las ocupaciones que desempeñaban en aquel momento, sino a uno de los accidentes que frecuentemente ocurren en la vida del mar».

34. En la misma línea, pero con un análisis más profundo, la sentencia del Tribunal Supremo de 23 de abril de $1908^{52}$, establece, en primer lugar, que

«el artículo 2 de la Ley de Accidentes de Trabajo, comprende todos aquellos que, con ocasión de éste, sobrevienen aun cuando procedan de causas fortuitas, siempre que tengan relación con los riesgos propios de cada una de las profesiones o industrias que dicha Ley abarca, mientras no sean producidos por fuerza mayor extraña al trabajo, debiendo entenderse que existe fuerza extraña cuando ésta es de tal naturaleza, que ninguna relación ni conexión guarde con el ejercicio de la profesión de que se trate y salvo también el caso de la culpa, sólo imputable a la persona que sufrió el accidente».

En segundo lugar, partiendo de esa definición de fuerza mayor extraña al trabajo, la sentencia indica que

${ }^{50}$ García Ormaechea, R. ob. cit., p. 202.

${ }^{51}$ García Ormaechea, R. ob. cit., pp. 144 y 202.

${ }^{52}$ García Ormaechea, R. ob. cit., pp. 202-203. 
«entre los accidentes que pueden ocurrir con ocasión de una navegación hay que comprender, según dicho criterio, no solamente los que ocurran a bordo, independientemente de los riesgos que el mar ofrece, sino éstos mismos, por ser propios e inherentes a la profesión del navegante, toda vez que, dentro del sentido y finalidad de la Ley, sería contradictorio de la misma excluir aquellos que son los que más comúnmente se producen en las condiciones ordinarias de toda navegación, que en este aspecto difieren del ejercicio de aquellas industrias a que especialmente se refiere el artículo 3 de la Ley».

Por consiguiente, se deja constancia de las particularidades que presenta el trabajo en el mar.

Así, en relación con el choque de un barco con otro, la sentencia llega a la conclusión de que como este supuesto

«es uno de tantos accidentes fortuitos a que se hallan expuestos los que navegan, y éstos son, en tal caso, debidos, no a fuerza alguna extraña desligada de los riesgos del mar, sino a causa proveniente de estos mismos riesgos, previstos, aunque, a veces, inevitables, es manifiesto que la embestida del barco que produjo el siniestro no es fuerza mayor extraña, que excluya las responsabilidades de la Ley de Accidentes de Trabajo, y que la diligencia y pericia del barco abordado no desvirtúa la verdadera índole del accidente ocurrido...».

Refuerzan el mismo criterio la sentencia del Tribunal Supremo de 11 de junio de $1908^{53}$, que declara que

«el siniestro marítimo (abordaje) no cae dentro de la excepción de fuerza mayor extraña como excluyente de responsabilidad»,

así como la sentencia del Tribunal Supremo de 25 de abril de $1913^{54}$, que recuerda que

«es doctrina establecida que sólo debe entenderse como fuerza extraña la que, por su naturaleza, no puede tener relación ni conexión con el ejercicio de la industria u oficio de que se trate, criterio según el cual los riesgos que el mar ofrece, por ser propios e inherentes a la profesión del navegante, han de considerarse comprendidos en el concepto de accidente de trabajo, a los efectos de indemnización establecidos en la Ley»,

\section{y concluye señalando cómo}

«el naufragio de la barca pesquera, producido por el temporal, que sorprendió a sus tripulantes cuando se hallaban dedicados al ejercicio de su industria, constituye un accidente, debido no a fuerza extraña de los riesgos del mar, sino a causa propia y peculiar de los mismos, por su naturaleza, siempre prevista, aunque muchas veces inevitable».

\footnotetext{
${ }^{53}$ García Ormaechea, R. ob. cit., p. 203.

${ }^{54}$ García Ormaechea, R. ob. cit., pp.144 y 203.
} 
35. Asimismo, junto al problema de determinar si los riesgos del mar son considerados accidentes de trabajo a los efectos de la Ley de Accidentes de Trabajo, los tribunales tuvieron que hacerse cargo de otras cuestiones. Todo ello se traduce a la postre en la extensión del concepto de accidente de trabajo.

36. Los accidentes acaecidos antes o después del trabajo supusieron una de las primeras causas de la extensión del concepto. Las especiales circunstancias que rodean al trabajo en el mar evidenciaron tempranamente este problema.

Así, la sentencia del Tribunal Supremo de 11 de junio de $1908^{55}$ realizó la siguiente interpretación:

«se entiende que es con ocasión del trabajo el accidente que ocurre a un obrero, contratado para prestar servicio en un barco, y que perece en abordaje del que le conducía, por cuenta de la empresa, al puerto donde estaba aquél, pues no es posible desconocer que desde el embarque empezó el cumplimiento de la obligación, quedando sometido a las determinaciones impuestas por el patrono, que no podían ser contrariadas sin romper el pacto celebrado. En tales condiciones es preciso reconocer que, al ocurrir el abordaje, productor de la muerte del obrero, lo fue por consecuencia y con ocasión del trabajo concertado con la Compañía demandada, teniendo en cuenta la conexión o necesario enlace que existe entre aquél y los medios que le fueron impuestos para cumplir el compromiso, ajenos de todo punto a su voluntad, no siendo admisible decomponerlos o separarlos en distintos períodos, estableciendo diferencias de tiempo que puedan conducir a conclusiones diversas, ya que todos ellos forman un conjunto necesario e indispensable para realizar el fin propuesto».

La importancia de esta interpretación consiste en que en ella se encuentra el origen de lo que posteriormente se denominarán «accidentes in itinere» ${ }^{56}$.

37. Otra de las especificidades del trabajo en el mar, a saber, la que deriva del hecho de que los mareantes alternan, en un mismo espacio físico y temporal, el trabajo y la vida ordinaria, requirió, igualmente, el pronunciamiento de los tribunales en aquellos supuestos en los que el accidente sucedía en los intervalos del trabajo.

Sobre este aspecto se pronunció de la siguiente forma la sentencia del Tribunal Supremo de 9 de noviembre de $1909^{57}$, en el caso concreto del que conocía:

${ }^{55}$ García Ormaechea, R. ob. cit., p. 119.

${ }^{56}$ Del Peso y Calvo, C. «Pasado, presente y futuro del accidente in-itinere». En RISS, 1968, núm. 2.

${ }^{57}$ García Ormaechea, R. ob. cit., pp. 121-122. 
«ocurrido el accidente, al marinero de una barca, al separarse de las operaciones de pesca para satisfacer una necesidad perentoria, que fue a realizar en la proa del barco, por falta en el mismo de otro lugar más adecuado, cayéndose entonces al mar y ahogándose, es manifiesto que tal accidente se halla íntimamente relacionado con las funciones que dentro del barco tenían que desempeñar los marineros, y, por todo ello, comprendido entre las que determinan, en cada caso, la responsabilidad de los patronos».

38. Por último, dentro de la tendencia de extender la protección por accidentes de trabajo, la jurisprudencia comenzó a incluir en el concepto «por consecuencia del trabajo» ciertas enfermedades, dando lugar a una fecunda casuística, en la que se diferencian las enfermedades profesionales de las que no lo son, con una amplia repercusión de cara a la futura distinción entre accidentes de trabajo y enfermedades profesionales.

Entre la abundante jurisprudencia, pueden citarse, como botón de muestra, tanto en un sentido como en otro, la sentencia del Tribunal Supremo de 29 de noviembre de $1913^{58}$, según la cual

«declarado que la bronconeumonía productora de la muerte del obrero fue ocasionada con motivo y a consecuencia del trabajo que efectuaba en la cámara frigorífica de un vapor dedicado a la pesca, y en la que prestaba sus servicios, es manifiesto que debe calificarse de accidente comprendido en la Ley, porque dicha enfermedad fue inherente al trabajo realizado por cuenta y en interés del patrono, relacionándose de manera absoluta e inmediata con el ejercicio de la ocupación de la víctima»,

y la sentencia del Tribunal Supremo de 11 de junio de $1907^{59}$, que ante un diagnóstico de apoplejía cerebral, no concede ninguna indemnización

«porque se declaró que la enfermedad fue independiente del trabajo».

\section{Hacia una regulación específica de los accidentes de mar}

39. La jurisprudencia puso de manifiesto los problemas que suscitaban en el ámbito marítimo-pesquero los conceptos de «operario» y «fuerza mayor» establecidos en la Ley de Accidentes de Trabajo de 1900, al igual que otras circunstancias, como la posible extensión de la protección por accidente de trabajo.

Debido a ello, la Real Orden de 20 de septiembre de $1919^{60}$ quiso hacerse eco de que

${ }^{58}$ García Ormaechea, R. ob. cit., p. 71.

${ }^{59}$ García Ormaechea, R. ob. cit., pp. 94-95.

${ }^{60}$ Gaceta de Madrid de 24 de noviembre de 1919, núm. 267. 
«el riesgo de mar y, por consiguiente, los accidentes de él derivados son de especial naturaleza y comprende a todas las clases competentes de las dotaciones de los buques, y procede, por tanto, que se colme de una manera expeditiva y práctica esta deficiencia de nuestra legislación en lo que al personal de nuestra Marina Mercante concierne, por cuyo bienestar moral está en la obligación de velar» (Exposición).

Para ello, encomendó al Comité Oficial de Seguros

«la redacción urgente de un sistema de indemnizaciones por accidentes de mar a bordo de los buques que abarcase los casos no comprendidos en la Ley de Accidentes de Trabajo con aplicación a todas las clases componentes de las dotaciones de los buques» (artículo 1).

Con ello, se abrían las puertas a un nuevo horizonte en el que las particularidades del mar podrían ser contempladas desde el punto de vista de una regulación específica.

\section{La difícil disyuntiva: accidentes de mar o accidentes de trabajo}

\section{La regulación de los accidentes de mar}

40. Toda la evolución jurisprudencial en torno a la posible aplicación de la Ley de Accidentes de Trabajo en el ámbito marítimo-pesquero y, sobre todo, el encargo realizado por la Real Orden de 20 de septiembre de 1919 al Comité Oficial de Seguros, justificaron una regulación específica de los accidentes de mar.

Esta regulación se llevó a cabo mediante el Real Decreto de 15 de octubre de $1919^{61}$. La importancia de esta norma no resulta solamente por la protección específica de los accidentes de mar, sino que se debe, fundamentalmente, a que establece en España el primer seguro obligatorio, al declarar que

«las Compañías de navegación y toda entidad individual o colectiva, propietaria de buques, están obligadas a asegurar a las dotaciones de éstos contra los accidentes de mar» (artículo 1).

Curiosamente, la particularidad y la espectacularidad de los riesgos del mar, riesgos como los naufragios, los temporales, las colisiones o abordajes, inexistentes en otros sectores, facilitaron, de alguna manera, adelantarse en el tiempo a otros sectores, tan apegados a la idea del riesgo social, en lo que respecta a la instauración de los seguros sociales obligatorios.

${ }^{61}$ Gaceta de Madrid de 15 de octubre de 1919, núm. 294. 
La técnica del seguro desarrollada en tierra como forma de protección de las personas había adquirido su punto álgido en la Alemania del Canciller Bismarck, en la forma de seguros sociales obligatorios. El éxito de esta técnica de protección específica supuso su rápida importación por parte de otros Estados. En España se manifestó por primera vez en el ámbito marítimo-pesquero.

41. La regulación de los accidentes de mar, por el Real Decreto de 15 de octubre de 1919, además de la instauración del primer seguro social obligatorio en España, supuso superar el concepto de «operario» fijado por la Ley y el Reglamento de Accidentes de Trabajo y, por ende, extender el ámbito de protección a los trabajadores por cuenta ajena, en general, sin atender al carácter manual del trabajo realizado.

Así se desprendía de la obligación de asegurar a las «dotaciones» de los buques, ya que a efectos del Real Decreto

«se entiende por dotación de un barco la que señala el artículo 648 del Código de Comercio y la que de un modo especial determina la póliza» (artículo 2).

\section{De forma que esta remisión significa considerar dotación al}

«conjunto de todos los individuos embarcados, de Capitán a paje, necesarios para su dirección, maniobras y servicio y, por tanto, estarán comprendidos en la dotación la tripulación, los Pilotos, Maquinistas, Fogoneros y demás cargos de a bordo no especificados...» (artículo 648 del Código de Comercio).

No obstante, el seguro obligatorio de los accidentes de mar cuenta con una excepción de importancia, ya que de forma contraria a lo que la jurisprudencia del Tribunal Supremo había venido considerando acerca de los trabajadores del mar contratados a la parte, incluyéndolos en el concepto de operarios, a efectos de cobrar las indemnizaciones previstas por la Ley de Accidentes de 1900, ahora, se dispone que

«quedan exentos de la obligación del seguro los propietarios de barcos que tengan convenido con sus tripulantes un sistema de remuneración en el cual vayan a la parte en los rendimientos que aquéllos obtengan, siempre que dicho extremo se haga constar en documento otorgado ante la Autoridad de Marina correspondiente o ante Notario público, y suscrito por todos los interesados, en el cual además, la tripulación renunciará al seguro» (artículo 10).

42. En cuanto al concepto de accidente de mar, el Real Decreto entiende por tal

«todo el que sobrevenga con ocasión del manejo y navegación del buque en puerto y en la mar, de sus máquinas principales y auxiliares y ejecución de servicios a flote y en dique o varadero... con la sola exclusión de los casos que caen bajo la acción directa de la Ley de Accidentes de Trabajo» (artículo 3). 
El propio legislador diferenciaba, en consecuencia, dos tipos de accidentes: los específicos de mar y los genéricos de la Ley de Accidentes de Trabajo. Por ello, a partir de ese momento, la protección de los mareantes ante los accidentes se subordinará a esta diferenciación. Esta dicotomía en ocasiones planteó dudas sobre la conexión de ambas regulaciones, e incluso sobre la legislación aplicable, y, por ello, los tribunales tuvieron que pronunciarse sobre este extremo. Bien merece traer a colación la jurisprudencia de la época, pues marca el límite existente entre los accidentes de mar y los que no lo son.

\section{Las aportaciones de la jurisprudencia ante la dificil disyuntiva existente}

43. Una correcta definición de la relación entre ambos tipos de accidentes se establece por la sentencia del Tribunal Supremo de 27 de octubre de $1922^{62}$, para lo que se lleva a cabo la siguiente argumentación:

«para la recta aplicación de las disposiciones del Real Decreto de 15 de octubre de 1919 precisa tener en cuenta que en su artículo 3, después de consignar lo que entiende por accidente de mar, a los efectos de las indemnizaciones que más adelante establece y de estatuir que el abono de las mismas comprende a todo el personal que forma la dotación del buque, excluye expresamente de su disfrute los casos que caen bajo la acción directa de la Ley de Accidentes de Trabajo, con lo cual quedó determinada la existencia de dos disposiciones orígenes de derecho a la indemnización que, lejos de contrariarse, se armonizan y completan».

Partiendo de dicha armonización y complementariedad, en primer lugar se determina que

«la Ley de 30 de enero de 1900 [de Accidentes de Trabajo], en sus artículos 1 y 2 , en relación con el 2 del Reglamento de 28 de julio del mismo año, y con la Real Orden de 12 de mayo de 1903, reconoce el derecho a ser indemnizados por los accidentes que sufran con motivo y en el ejercicio de la profesión o trabajo que ejecuten, por cuenta ajena, los operarios que se dediquen a cualquiera especie de navegación, pesca y demás industrias similares, declarando dicha Real Orden que el carácter técnico de las profesiones de Capitán y Piloto de la Marina Mercante impedían incluir a los que las siguen en la Ley de Accidentes de Trabajo, conforme al artículo 2 del Reglamento, que define lo que se entiende por obrero, a los efectos de la Ley».

En segundo lugar, se recuerda como

«con el fin de obviar la dificultad que antes se indica, y habida cuenta de que el riesgo de mar y, por consecuencia, los accidentes de él derivados, son de especial naturaleza y distintos éstos de los que dimanan

${ }^{62}$ García Ormaechea, R. ob. cit., pp. 203-204. 
directamente del oficio que se practica o de los útiles que se emplean, se dictó el Real Decreto ya relacionado».

A modo de conclusión, y aplicando todas estas argumentaciones al caso concreto, se señala que

«ocurrido el accidente cuando el obrero prestaba servicio de vigilancia en un buque fondeado en un puerto, se halla comprendido el caso en la excepción que establece el último inciso del párrafo 3 de la citada disposición, por no haber influido en la realización del suceso causa alguna proveniente de riesgo o accidente de mar, y debe ser aplicada la Ley de Accidentes».

A iguales conclusiones llegó la sentencia del Tribunal Supremo de 7 de febrero de $1923^{63}$, sobre un accidente sufrido como consecuencia de un incendio a bordo, «hallándose el buque atracado y no ejecutándose en él servicio alguno».

Por su parte, la sentencia del Tribunal Supremo de 12 de mayo de $1925^{64}$ indica que

«el Real Decreto de 15 de octubre de 1919 constituye tan sólo una disposición supletoria de la Ley de 30 de enero de 1900, encaminada a que no quedaran sin indemnización por la redacción del artículo 2 de la Ley los accidentes debidos a fuerza mayor extraña al trabajo que constituyen los mayores y más corrientes riesgos de los obreros dedicados al servicio de la navegación».

44. Por el contrario, declararon el carácter de accidente de mar respecto a los naufragios las sentencias del Tribunal Supremo de 15 de abril de $1924^{65}$ — «siniestro en que pereció un marinero, a bordo de un balandro, víctima de naufragio»—-, de 18 de abril de $1924^{66}$ — «la muerte por naufragio del barco»—, y de 8 de agosto de $1924^{67}$ — «naufragio de un vapor»-

45. Mayores dudas suscitaron, sin embargo, los accidentes producidos a bordo, como consecuencia de la aplicación de los vapores y de los motores de explosión a las embarcaciones, motivo por el que incrementaron los accidentes y las correspondientes alegaciones.

En estos supuestos, según se deduce de la jurisprudencia del Tribunal Supremo, para que los accidentes producidos como consecuencia de la aplicación de los vapores y de los motores de explosión fuesen considerados accidentes de mar, se requería que éstos fuesen causa de un siniestro calificado como accidente de mar, como lo eran los naufragios o los abordajes.

${ }^{63}$ García Ormaechea, R. ob. cit., p. 204.

${ }^{64}$ García Ormaechea, R. ob. cit., p. 208.

${ }^{65}$ García Ormaechea, R. ob. cit., p. 205.

${ }^{66}$ García Ormaechea, R. ob. cit., p. 206.

${ }^{67}$ Ibidem. 
Así, la sentencia del Tribunal Supremo de 8 de enero de $1926^{68}$ considera que existe un accidente de mar en el supuesto de un

«maquinista de barco que fallece a consecuencia de asfixia por sumersión, por haber naufragado el vapor en que prestaba sus servicios a causa de la explosión de una caldera».

No obstante, cuando los accidentes producidos como consecuencia de la aplicación de los vapores y de los motores de explosión no mantienen relación alguna con siniestros considerados accidentes de mar, la jurisprudencia se decanta por aplicar la Ley y el Reglamento de Accidentes de Trabajo.

En ese sentido, la sentencia del Tribunal Supremo de 31 de noviembre de $1931^{69}$ declara la inexistencia de accidente de mar en un caso relativo a la muerte de «un maquinista de vapor... por explosión de grisú del carbón almacenado».

\section{La lenta pero progresiva equiparación de los accidentes de mar con los accidentes de trabajo}

46. El acierto de la regulación del seguro obligatorio en materia de accidentes de mar permitió su rápida extensión más allá de la dotación de los buques, como lo demuestra el Real Decreto de 18 de mayo de $1921^{70}$, que

«hace extensivo y obligatorio para el personal de Prácticos de puertos de España en el ejercicio de sus funciones, en cuanto no se oponga a las bases que [en la propia norma]... se señalan, el seguro sobre accidentes de mar...» (artículo 1).

No obstante, el paso del tiempo demostrará la necesidad de tender hacia la equiparación de los accidentes de mar con los accidentes de trabajo. Esta necesidad se prolongará a lo largo de los diversos regímenes existentes en España, si bien en el horizonte permanecerá siempre la idea de avanzar hacia la equiparación.

\section{La dictadura del General Primo de Rivera}

47. Durante la dictadura del General Primo de Rivera, se adoptó la importante decisión de promulgar un Código del Trabajo que pusiera fin a la enorme dispersión que sufrían las normas laborales y que abogase por la unificación, garantía siempre de la seguridad jurídica.

\footnotetext{
${ }^{68}$ Ibidem.

${ }^{69}$ García Ormaechea, R. ob. cit., pp. 206-207.

${ }^{70}$ Gaceta de Madrid de 25 de mayo de 1921, núm. 145.
} 
A este fin, la Real Orden de 23 de agosto de $1926^{71}$ autorizó al Ministerio de Trabajo, Comercio e Industria para publicar una edición del Código del Trabajo, lo que dio lugar al primer intento real de codificación del Derecho del Trabajo en España ${ }^{72}$.

El Código del Trabajo se estructuró en cuatro libros y, en concreto, el tercero se refirió a los accidentes de trabajo. En lo que respecta a los trabajadores del mar, se mantiene la línea seguida desde la aprobación del Real Decreto de 15 de octubre de 1919, es decir, la diferenciación entre los accidentes de mar, objeto de aseguramiento obligatorio, y los accidentes de trabajo, objeto de aseguramiento voluntario.

De este modo, en el Título II, relativo a las «disposiciones reglamentarias generales en materia de accidentes de trabajo», el Capítulo IX, bajo la rúbrica «del seguro de accidentes de mar», recoge en su integridad el contenido del Real Decreto de 15 de octubre de $1919^{73}$.

Por tanto, una de las carencias en materia de protección de los accidentes de mar se mantiene de cara a los trabajadores remunerados a la parte, pues

«quedan exentos de la obligación del seguro los propietarios de barcos que tengan convenido con sus tripulantes un sistema de remuneración en el cual vayan a la parte en los rendimientos que aquéllos obtengan, siempre que dicho extremo se haga constar en documento otorgado ante la Autoridad de Marina correspondiente o ante Notario público, y suscrito por todos los interesados, en el cual, además, la tripulación renunciará al seguro» (artículo 301).

La gravedad que suponía esa exclusión se plasmó adecuadamente en la Exposición del Real Decreto de 5 de abril de $1929^{74}$. En ella se recalca como

«cuando ocurre un siniestro en que los tripulantes perecen o sufren lesiones de importancia, aun en el caso más favorable de no perderse la embarcación, el armador modesto no dispone de medios suficientes para pagar las indemnizaciones, aun vendiendo aquélla y quedándose en la miseria».

${ }^{71}$ Gaceta de Madrid de 30 de agosto de 1926, núm. 242.

72 Del Peso y Calvo, C. «De la protección gremial al vigente Sistema de Seguridad Social». En RFDUM, 1966, vol. x, núm. 25, p. 22.

${ }^{73}$ Como señala Del Peso y Calvo, «obedeciendo al mismo criterio de unidad, se insertan aquí, formando el debido apartado, los preceptos concernientes a los seguros de accidentes de mar, favoreciendo así, no solo su estudio, sino, y especialmente, su aplicación» (DEL Peso y Calvo, C. La protección legal del accidente de trabajo y de la enfermedad profesional, 1900-1967. Madrid: Impreso en Hijos de E. Minuesa, 1971, p. 78).

${ }^{74}$ Gaceta de Madrid de 9 de abril de 1929, núm. 99. 
Teniendo en cuenta esa situación, el articulado de este Real Decreto dispuso una serie de medidas para poner fin a la exclusión. Así, a partir de ese momento,

«las obligaciones y derechos establecidos en el Libro III del Código del Trabajo en caso de accidentes de trabajo y en previsión de los accidentes de mar alcanzan a los dueños o armadores de embarcaciones pesqueras, cualquiera que sea su tonelaje y el personal empleado en éstas, aun mediante el contrato a la parte en los rendimientos» (artículo 1).

\section{La II República}

48. Durante la II República, se produjo un gran avance en materia de accidentes de trabajo, pues aunque no se consiguió la unificación en la regulación de los accidentes de trabajo, manteniéndose normas diferentes para la agricultura, la industria y el mar, en el ámbito de los accidentes de trabajo en la industria se declaró la obligatoriedad del aseguramiento para los casos de incapacidades permanentes y de muerte; por su parte, el aseguramiento seguía siendo voluntario para los casos de incapacidad temporal y asistencia médica.

49. La ratificación por parte de España del Convenio núm. 17 de la OIT, sobre la indemnización por accidente de mar, de 10 de junio de $1925^{75}$, y del Convenio núm. 19 de la OIT, sobre la igualdad de trato (accidentes de trabajo), de 5 de junio de $1925^{76}$, hizo que durante la II República se procediese a modificar el sistema de reparación de los accidentes de trabajo.

Así, el 4 de julio de 1932, se aprobó la Ley de Bases con arreglo a las cuales debía estructurarse una nueva Ley reparadora de los accidentes de trabajo en la industria ${ }^{77}$. En virtud de ésta, se dictaron, posteriormente, primero, la Orden de 8 de octubre de 1932, mediante la cual se decretaba el Texto Refundido de la legislación de Accidentes de Trabajo en la Industria ${ }^{78}$, y, después, el Decreto de 31 de enero de 1933, por el que se aprobaba el Reglamento de la Ley de Accidentes de Trabajo en la Industria ${ }^{79}$.

50. Por lo que respecta a la gente de mar, a pesar de que el Convenio núm. 17 de la OIT, sobre la indemnización por accidentes de trabajo, no se aplicase «a la gente de mar ni a los pescadores» (artículo 3.1), tanto el Texto Refundido de la legislación de Accidentes de Trabajo de la Industria, como el Reglamento de la Ley de Accidentes de Trabajo en la Industria se refirieron al ámbito marítimo-pesquero.

${ }^{75}$ Gaceta de Madrid de 26 de mayo de 1928, núm. 147.

${ }^{76}$ Gaceta de Madrid de 26 de mayo de 1928, núm. 147.

${ }_{77}$ Gaceta de Madrid de 7 de julio de 1932, núm. 189.

${ }^{78}$ Gaceta de Madrid de 12 de octubre de 1932, núm. 286.

${ }^{79}$ Gaceta de Madrid de 2 de febrero de 1933, núm. 33. 
Efectivamente, el Texto Refundido incluye entre las industrias o trabajos que dan lugar a responsabilidad del patrono

«el acarreo y transporte de personas y mercancías por vía terrestre, marítima y de navegación interior y la pesca. En el transporte marítimo se entenderán comprendidas las personas que formen parte de la dotación de los buques. Para los tripulantes de las embarcaciones pesqueras se aplicará el Real Decreto-ley [sic.] de 5 de abril de 1929 y sus disposiciones complementarias» (artículo 7.6).

Por su parte, el Reglamento confirma la distinción entre accidentes de trabajo y accidentes de mar, al afirmar que

«la protección de las víctimas, de los accidentes de mar y el seguro obligatorio contra este riesgo que han de hacer las Compañías de navegación y demás entidades propietarias de buques seguirán rigiéndose por las disposiciones contenidas en los artículos 292 a 311 del Código del Trabajo y sus complementarias» (Disposición Transitoria cuarta).

Como concluyó Lledó MARTí, una de las consecuencias de la nueva regulación en materia de accidentes de trabajo consistió en la siguiente diferenciación: mientras que los accidentes de mar se indemnizaban «mediante entregas de capital», los accidentes de trabajo «mediante la constitución de renta» ${ }^{80}$, en los supuestos en que produjesen la muerte o la incapacidad permanente del trabajador ${ }^{81}$.

51. Ahora bien, los cambios más significantes se producen con la entrada en vigor del Decreto de 26 de julio de $1935^{82}$, mediante el cual se deroga la Disposición Transitoria cuarta del Reglamento de la Ley de Accidentes de Trabajo en la Industria de 1933 o, lo que es lo mismo, se produce la inaplicación del Capítulo IX del Título II del Libro III del Código del Trabajo.

${ }^{80}$ Lledó Martí, J. La Pesca Nacional. Madrid: Ediciones Pegaso, 1943, p. 222.

${ }^{81}$ Esta diferenciación, en cuanto a las indemnizaciones existentes entre los accidentes de mar y los accidentes de trabajo se debe a que la Ley de Bases de 4 de julio de 1932 (Base primera) modifica el artículo 168 del Código del Trabajo, dándole la siguiente redacción:

«las indemnizaciones debidas en caso de accidente [de trabajo] seguido de muerte o de incapacidad permanente de la víctima, serán abonadas a ésta o a sus derechohabientes en forma de renta. Por excepción de esta regla, las indemnizaciones podrán ser abonadas en totalidad o en parte en forma de capital cuando, a juicio de la autoridad competente, se ofrezca la garantía de empleo juicioso de dicha suma».

Esta regulación se mantiene por el Texto Refundido de la legislación de Accidentes de Trabajo en la Industria (artículo 21) y por el Reglamento de Accidentes de Trabajo en la Industria (artículo 26).

${ }^{82}$ Gaceta de Madrid de 27 de julio de 1935, núm. 208. 
Además, conforme a la Orden de 2 de mayo de $1936^{83}$, aclaratoria del Decreto de 26 de julio de 1935, el Capítulo IX del Título II del Libro III del Código del Trabajo solamente sería aplicable

«a los tripulantes de embarcaciones pesqueras contratados con remuneración a la parte, sin que por razón de analogía o similitud [pudieran]... aplicarse tales disposiciones al personal empleado en cualquiera otra clase de embarcaciones, para el que [regirían] en toda su integridad los beneficios del Reglamento de 31 de enero de 1933».

En consecuencia, a partir de ese momento debían distinguirse los accidentes de mar

«según que afectase al personal contratado a la parte o con retribución fija: los primeros se seguirían indemnizando mediante entregas de capital, pero los segundos se equiparaban a los de trabajo» ${ }^{84}$.

Con otras palabras, en adelante, los accidentes de mar sufridos por los trabajadores contratados a la parte seguirían protegiéndose como accidentes de mar, pero los sufridos por los trabajadores contratados con retribución fija se equipararían a los accidentes de trabajo en la industria.

Lógicamente, esta distinción suponía una evidente desigualdad en cuanto a las indemnizaciones concedidas para hacer frente a las situaciones de infortunio derivadas de uno u otro supuesto.

Así, los accidentes de trabajo resultaban indemnizados en la siguiente forma y cuantía: a) incapacidad temporal, 75 por 100 del salario; b) incapacidad permanente parcial, renta del 25 por 100 del salario; c) incapacidad permanente total, 37,5 por 100 del salario; d) incapacidad permanente absoluta, renta del 50 por 100 del salario; e) muerte, renta del 20 al 50 por 100 del salario (artículos 27 y 29 del Reglamento de la Ley de Accidentes de Trabajo en la Industria).

Por el contrario, los accidentes de mar se indemnizaban en la siguiente forma y cuantía: a) incapacidad temporal, 50 por 100 del salario; b) incapacidad permanente absoluta, salario de dos años; c) incapacidad permanente parcial, salario de un año; d) muerte, salario de dos años (artículo 4 del Real Decreto de 15 de octubre de 1919).

52. Realmente, el legislador republicano no consiguió unificar la regulación de los accidentes de trabajo y de los accidentes de mar, pues la regulación de estos últimos seguía siendo de aplicación a los trabajadores contratados a la parte ${ }^{85}$. Por lo demás, hubiera sido deseable acabar con esa des-

${ }^{83}$ BOE de 6 de mayo de 1936, núm. 127.

${ }^{84}$ Lledó MarTí, J. ob. cit., p. 222.

${ }^{85}$ Debe reconocerse que no fue fácil la equiparación en la protección de los accidentes de mar a los accidentes de trabajo, pues 
igualdad residual que generaba una discriminación injusta entre la gente de mar, pero para ello habrá que esperar al fin de la II República.

\section{El período franquista}

53. Una vez finalizada la Guerra Civil, con la caída de la II República y la instauración de un nuevo régimen político, en los prolegómenos de la Segunda Guerra Mundial, el Decreto de 23 de febrero de $1940^{86}$ se ocupó de una situación especialmente delicada.

Ciertamente, el alcance y desarrollo de la Segunda Guerra Mundial repercutió en alto grado en el transporte marítimo, poniendo en grave riesgo la vida de los tripulantes españoles, en condiciones tanto más graves cuanto que esos riesgos no se encontraban cubiertos por el seguro de accidentes de trabajo ordinario (Exposición del Decreto de 23 de febrero de 1940).

En consecuencia, el conflicto bélico se convirtió en fuente de un nuevo riesgo específico, que requería una previa tipificación para poder ser incorporada a la legislación vigente sobre protección de accidentes de trabajo. De lo contrario, los accidentes derivados del riesgo de guerra quedarían subsumidos en el concepto de fuerza mayor extraña al trabajo establecido por los artículos 6 del Texto Refundido de Accidentes de Trabajo en la Industria, de 8 de octubre de 1932, y del Reglamento de la Ley de Accidentes de Trabajo en la Industria, de 31 de enero de 1933, y, por ende, excluidos de la protección concedida por el seguro social de accidentes de trabajo.

54. Se estableció, así, que los siniestros ocurridos en el tráfico marítimo que afectasen a la tripulación de buques españoles, como consecuencia de riesgo de guerra, no comprendidos en la Ley de Accidentes de Trabajo en la Industria, debían asegurarse mediante el concierto de pólizas especiales por cada viaje (artículo 1 del Decreto de 23 de febrero de 1940).

Además, los armadores de buques mercantes o pesqueros españoles quedaron obligados a contratar el seguro de vida e incapacidad permanente de

«contra esta equiparación se levantó la voz del elemento patronal, alegando la distinta naturaleza del siniestro, ya que jurídicamente, caracteriza al accidente de trabajo la relación directa entre la labor que se realiza, el siniestro que se produce y la víctima del mismo, y, en cambio, el accidente de mar deriva de la navegación y de la fuerza mayor inevitable e imprevisible. Mientras los accidentes de trabajo derivan del riesgo profesional, que cada vez aumenta el progreso técnico, los accidentes de mar no se deben al riesgo profesional, y es la naturaleza la única que influye en su producción» (LLEDó MARTí, J. ob. cit., p. 222).

${ }^{86}$ BOE de 3 de marzo de 1940, núm. 63. Con el objeto de complementar este Decreto, ejecutándolo y haciéndolo eficaz, se aprobaron una serie de órdenes: Orden de 16 de abril de 1940 (BOE de 22 de abril de 1940, núm. 113), Orden de 17 de mayo de 1940 (BOE de 22 de mayo de 1940, núm. 143), Orden de 29 de noviembre de 1940 (BOE de 11 de diciembre de 1940, núm. 63). 
todos sus tripulantes contra los riesgos derivados directa o indirectamente de la guerra, cuando el tráfico hubiera de efectuarse por zonas posiblemente afectadas por ella (artículo 1 del Decreto de 23 de febrero de 1940).

En último término, una vez reguladas las especificidades del riesgo de guerra, se procedió a equipararlo al accidente de trabajo. Así se deducía, tanto de la posibilidad de concertar el seguro marítimo obligatorio de guerra en cualquiera de las compañías autorizadas para contratar los riesgos de accidentes del trabajo en general (artículo 5 del Decreto de 23 de febrero de 1940), como del mismo hecho de que las indemnizaciones en caso de siniestro debían ajustarse a las normas y cuantía establecidas para los accidentes del trabajo en la industria en el Reglamento de 31 de enero de 1933 (artículo 6 del Decreto de 23 de febrero de 1940).

55. No obstante, el carácter temporal del seguro marítimo de guerra quedó patente una vez finalizada la Gran Guerra. El Decreto de 22 de febrero de $1946^{87}$ se refirió a este extremo, señalando que «el período transcurrido desde la terminación de la pasada contienda aconseja[ba] la desaparición de dicho seguro» (Exposición). Acto seguido, derogó «en todas sus partes el Decreto de 23 de febrero de 1940» (artículo 1).

Ahora bien, para proteger a los trabajadores del mar de los siniestros que todavía podían producirse como consecuencia de la explosión de minas u otros artefactos de guerra, se facultó al Ministro de Trabajo para dictar las normas que estimase oportunas (artículo 2).

56. De este modo, la Orden de 4 de marzo de $1946^{88}$ dispuso que los siniestros que se produjesen en las embarcaciones españolas, tanto pesqueras como de transporte, a consecuencia de la explosión de minas u otros artefactos de guerra, debían considerarse como accidentes de trabajo e indemnizarse en armonía con los preceptos del Reglamento de 31 de enero de 1933 (artículo 1).

57. Finalmente, la Orden de 26 de junio de $1946^{89}$ declaró la no obligatoriedad del seguro por riesgos de minas u otros artefactos de guerra. No obstante, se permitió seguir considerando como accidentes de trabajo indemnizables, en las condiciones que la legislación del ramo establecía, los que podía sufrir el personal de las embarcaciones de todo orden, a consecuencia de las explosiones de minas u otros artefactos de guerra. Además, a los armadores o a sus representantes, que así lo desearan, se les concedió la posibilidad de cubrir este riesgo en la entidad aseguradora de accidentes que considerasen oportuno o mediante concierto especial.

${ }^{87}$ BOE de 4 de marzo de 1940, núm. 63.

${ }^{88}$ BOE de 11 de marzo de 1946, núm. 70.

${ }^{89}$ BOE de 12 de noviembre de 1946, núm. 316. 
58. En verdad, con la experiencia de la regulación del seguro marítimo de guerra, se avanzó de cara a la supresión de la diferencia existente entre la regulación de los accidentes de trabajo y de los accidentes de mar. Así, fruto de esa experiencia, el Decreto de 4 de junio de $1940^{90}$ reguló los accidentes de trabajo en el mar, equiparando, definitivamente, los accidentes de mar y los accidentes de trabajo en la industria, y poniendo fin a la discriminación que venían sufriendo los trabajadores contratados a la parte.

De este modo, el Decreto, en primer lugar, definió los accidentes de trabajo en el mar como los que producían una lesión corporal o la muerte del siniestrado, cualquiera que fuese la causa de origen, estando a bordo o en tierra con ocasión de las labores complementarias de la navegación o pesca, realizadas por cuenta ajena (artículo 1).

Definidos los accidentes de trabajo en el mar, se hizo hincapié en la equiparación de éstos y los accidentes de trabajo en la industria, al indicar que los accidentes del trabajo que sufriesen las tripulaciones de los barcos españoles dedicados a la pesca, transporte o cualquier otra actividad serían indemnizados en la forma y cuantía establecida por el Reglamento de 31 de enero de 1933, para los Accidentes del Trabajo en la Industria (artículo 2).

Por fin, la equiparación resultaba total, pues era obligatorio el seguro de incapacidad permanente y muerte para todas las personas que formasen parte, de un modo fijo o eventual, de la tripulación (artículo 3, párrafo primero). Se subrayó, en ese sentido, que en las embarcaciones dedicadas a la pesca era obligatorio el seguro, cualquiera que fuese su tonelaje y el personal empleado en ellas, aun mediando contrato a la parte en los rendimientos (artículo 3, párrafo segundo).

59. Igualmente, la tendencia expansiva de la regulación de accidentes de trabajo supuso el desarrollo de esta legislación en el ámbito de los trabajadores ocupados en las operaciones de carga y descarga en los puertos ${ }^{91}$.

${ }^{90}$ BOE de 20 de junio de 1940, núm. 172. Este Decreto fue cumplimentado por la Orden de 4 de abril de 1941 (BOE de 8 de abril de 1941, núm. 98), mediante la cual se fijaron las normas adecuadas para la determinación del salario base, a efectos de seguro de accidentes de trabajo de los pescadores con remuneración a la parte.

${ }^{91}$ En ese sentido, por medio del Decreto-ley de 9 de julio de 1954 (BOE de 25 de julio de 1954, núm. 206), se encomendó a las Secciones de Trabajos Portuarios, que habían sido creadas para que los estibadores portuarios disfrutasen de los beneficios laborales y de previsión, la garantía de la asistencia sanitaria y el pago de las indemnizaciones que debían satisfacerse a los trabajadores portuarios en caso de incapacidad temporal por accidente de trabajo. Entre las medidas adoptadas, destacaba la extensión de la protección a los accidentes in itinere, es decir, a los producidos cuando el trabajador se dirige al lugar de su contratación laboral, o al regreso a su domicilio. Por su parte, la Orden de 28 de octubre de 1954 (BOE de 11 de noviembre de 1954, núm. 315) dictó las disposiciones complementarias «indispensables para la efectividad de lo dispuesto en el citado Decreto-ley y en orden al más exacto cumplimiento del mismo» (Exposición). 
60. En definitiva, el afán de hacer efectiva la extensión de la aplicación de la legislación sobre accidentes de trabajo en la industria, desembocó en el Decreto de 22 de junio de 1956, por el que se aprobó el nuevo Texto Refundido regulador de la Ley y el Reglamento de Accidentes de Trabajo ${ }^{92}$.

La unificación conseguida con el nuevo Texto Refundido en materia de accidentes de trabajo consolidó de cara al futuro los conceptos básicos a tener en cuenta para la aplicación del seguro obligatorio de accidentes de trabajo.

\section{Los accidentes de trabajo en el mar en el Sistema de Seguridad Social}

61. El proceso de cambio iniciado por la Ley 193/1963, de 28 de diciembre, de Bases de la Seguridad Social ${ }^{93}$, que suponía el paso de los seguros sociales, dispersos y heterogéneos, hacia un verdadero Sistema de Seguridad Social, trajo consigo la diferenciación, por una parte, de un Régimen General, y, por otra parte, de una serie de Regímenes Especiales, entre los que se encontraba el Régimen Especial de los Trabajadores del Mar.

El desarrollo de la Ley de Bases, materializado por el Decreto de 21 de abril de 1966, que aprobó el Texto Articulado primero de la Ley de Bases de la Seguridad Social ${ }^{94}$, confirmó la apuesta inicial por encuadrar a los trabajadores del mar en un Régimen Especial. Además, dicho régimen debía regularse por ley.

62. El resultado fue la Ley 116/1969, de 30 de diciembre, por la que se regulaba el Régimen Especial de Seguridad Social de los Trabajadores del $\mathrm{Mar}^{95}$. Constituida mediante esta ley la columna vertebral de la protección de la gente de mar en el Sistema de Seguridad Social, el Decreto 1867/1970, de 9 de julio, aprobó el Reglamento General del Régimen Especial de la Seguridad Social de los Trabajadores del Mar (RGRETM) ${ }^{96}$.

63. La evolución normativa del Sistema de Seguridad Social supuso la aprobación de la Ley 24/1972, de 21 de junio, de Financiación y Perfeccionamiento de la Seguridad Social ${ }^{97}$. Entre las novedades que introdujo esta ley destacó el principio de cotización sobre salarios reales en lugar de los tarifados, de gran trascendencia a efectos de sanear financieramente el Sistema y de elevar sus prestaciones. Pero, además, de cara al futuro, en su Disposición Final tercera se autorizó al Gobierno para aprobar el Texto o Textos Refun-

\footnotetext{
${ }^{92}$ BOE de 15 de julio de 1956, núm. 197.

${ }^{93}$ BOE de 30 de diciembre de 1963, núm. 312.

${ }^{94}$ BOE de 22 de abril de 1966, núm. 96.

${ }^{95}$ BOE de 31 de diciembre de 1969, núm. 313.

${ }^{96}$ BOE de 11 de julio de 1970, núm. 165.

${ }^{97}$ BOE de 22 de junio de 1972, núm. 149.
} 
didos de la Ley de Seguridad Social, de 21 de abril de 1966, de la propia Ley 24/1972 y de las que regulaban los Regímenes Agrario y de Trabajadores del Mar, así como de los preceptos que en materia de Seguridad Social figuraban en otras disposiciones de igual rango, debiendo establecerse en la refundición la concordancia debida y la sistematización y depuración técnica adecuadas para lograr regularizar, aclarar y armonizar las leyes citadas mediante los preceptos del nuevo o nuevos textos.

64. Pese a todo, razones de urgencia y prioridad aconsejaron que se aprobase en primer lugar el Texto Refundido de la Ley de Seguridad Social, de 21 de abril de 1966, y de la Ley de 24/1972, de 21 de junio, de Financiación y Perfeccionamiento de la Seguridad Social, al que se incorporaron preceptos, en materia de Seguridad Social, contenidos en otras disposiciones de igual rango. Así, el Decreto 2065/1974, de 30 de mayo ${ }^{98}$, aprobó el citado Texto Refundido, bajo la denominación de Texto Refundido de la Ley General de la Seguridad Social.

Por su parte, el Decreto 2864/1974, de 30 de agosto, aprobó el Texto Refundido de las Leyes 116/1969, de 30 de diciembre, reguladora del Régimen Especial de la Seguridad Social de los Trabajadores del Mar, y 24/1972, de 21 de junio, de Financiación y Perfeccionamiento de la Seguridad Social $(\text { TRRETM })^{99}$.

65. Por tanto, en materia de accidentes de trabajo en el mar debe partirse de lo establecido en la normativa relativa al Régimen Especial de los Trabajadores del Mar, a saber, de lo preceptuado en el TRRETM y en el RGRETM.

Lo que sucede es que dicha normativa remite en ocasiones al Régimen General, regulado en la actualidad por el Real Decreto Legislativo 1/1994, de 20 de junio, por el que se aprueba el Texto Refundido de la Ley General de la Seguridad Social (TRLGSS).

Por todo ello, el estudio de los accidentes de trabajo en el mar, en el Sistema de Seguridad Social, debe obedecer, necesariamente, a la conjunción de las normas mencionadas.

66. Ello no obstante, teniendo en cuenta que una de las particularidades que presenta el Régimen Especial de los Trabajadores del Mar consiste en la inclusión de trabajadores por cuenta ajena y de trabajadores por cuenta propia o autónomos, conviene diferenciar el estudio de los accidentes de trabajo en el mar según afecten a unos u otros.

${ }^{98}$ BOE de 20 y 22 de julio, núms. 173 y 174.

${ }^{99}$ BOE de 10 de octubre de 1974, núm. 243. 


\section{Los accidentes de trabajo respecto a los trabajadores por cuenta ajena}

67. Si bien es cierto que los accidentes de trabajo sufridos por los trabajadores por cuenta ajena del Régimen Especial del Mar presentan algunas peculiaridades derivadas de las circunstancias en las que deben prestarse los servicios laborales, desde el punto de vista conceptual del que debe partirse, existe una coincidencia absoluta respecto al Régimen General de la Seguridad Social.

68. Por ende, respecto a los trabajadores por cuenta ajena del Régimen Especial del Mar, al igual que en el Régimen General, «se entiende por accidente de trabajo toda lesión corporal que el trabajador sufra con ocasión o por consecuencia del trabajo que ejecute por cuenta ajena» (artículo 115.1 del TRLGSS).

Igualmente, tienen la consideración de accidentes de trabajo (artículo 115.2 del TRLGSS):

a) los que sufra el trabajador al ir o volver del lugar de trabajo (accidentes denominados in itinere); b) los que sufra el trabajador con ocasión o como consecuencia del desempeño de cargos electivos de carácter sindical, así como los ocurridos al ir o volver del lugar en que se ejerciten las funciones propias de dichos cargos; c) los ocurridos con ocasión o por consecuencia de las tareas que, aun siendo distintas a las de su categoría profesional, ejecute el trabajador en cumplimiento de las órdenes del empresario o espontáneamente en interés del buen funcionamiento de la empresa; d) los acaecidos en actos de salvamento y en otros de naturaleza análoga, cuando unos y otros tengan conexión con el trabajo; e) las enfermedades no consideradas profesionales, que contraiga el trabajador con motivo de la realización de su trabajo, siempre que se pruebe que la enfermedad tuvo por causa exclusiva la ejecución del mismo; f) las enfermedades o defectos, padecidos con anterioridad por el trabajador, que se agraven como consecuencia de la lesión constitutiva del accidente; g) las consecuencias del accidente que resulten modificadas en su naturaleza, duración, gravedad o terminación, por enfermedades intercurrentes, que constituyan complicaciones derivadas del proceso patológico determinado por el accidente mismo o tengan su origen en afecciones adquiridas en el nuevo medio en que se haya situado al paciente para su curación.

Por último, también respecto a los trabajadores incluidos en el campo de aplicación del Régimen Especial de los Trabajadores del Mar «se presumirá, salvo prueba en contrario, que son constitutivas de accidente de trabajo las lesiones que sufra el trabajador durante el tiempo y en el lugar del trabajo» (artículo 115.3 del TRLGSS).

69. A pesar de la amplitud del concepto de accidente de trabajo, debe tenerse en cuenta que algunos supuestos se excluyen de éste. Así, por una parte, se excluyen los accidentes 
«debidos a fuerza mayor extraña al trabajo, entendiéndose por ésta la que sea de tal naturaleza que ninguna relación guarde con el trabajo que se ejecutaba al ocurrir el accidente. [Ahora bien,] en ningún caso se considerará fuerza mayor extraña al trabajo la insolación, el rayo y otros fenómenos análogos de la naturaleza» (artículo 115.4.a del TRLGSS).

\section{Por otra parte, se excluyen los accidentes}

«debidos a dolo o a imprudencia temeraria del trabajador accidentado» (artículo 115.4.b del TRLGSS) ${ }^{100}$.

No obstante, la calificación de un accidente como de trabajo no depende de «la imprudencia profesional que es consecuencia del ejercicio habitual de un trabajo y se deriva de la confianza que éste inspira» (artículo 115.5.a del TRLGSS), ni de «la concurrencia de culpabilidad civil o criminal del empresario, de un compañero de trabajo del accidentado o de un tercero, salvo que no guarde relación alguna con el trabajo» (artículo 115.5.b del TRLGSS).

70. Una vez señaladas las características que, en plena sintonía con el Régimen General de la Seguridad Social, presenta el concepto de accidente de trabajo respecto a los trabajadores por cuenta ajena del Régimen Especial del Mar, resulta oportuno centrarse en las peculiaridades que presentan los accidentes de trabajo sufridos por los trabajadores por cuenta ajena del Régimen Especial del Mar.

En concreto, estas peculiaridades se refieren a los trabajadores embarcados, ya que el trabajo a bordo presenta de por sí características especiales que condicionan también la regulación del accidente de trabajo: las embarcaciones, mientras permanecen faenando o navegando, son, al mismo tiempo, el centro de trabajo y la residencia de los trabajadores, de forma y manera que se confunden los tiempos de trabajo y de descanso; además, los servicios laborales deben prestarse en circunstancias de gran dureza y peligrosidad, no sólo por las condiciones del mar y debido a que las embarcaciones son cen-

${ }^{100}$ En este sentido, ante un caso en el que al realizar en cubierta, en la zona de popa, la operación de virar el arte de pesca, para lo cual se realiza una maniobra de giro o cambio de dirección del barco de forma un tanto enérgica con el propósito de lograr el desplazamiento de las pastecas que cuando alcanzan la posición correcta son fijadas con pasadores para limitar sus movimientos, un marinero intentó colocar el pasador sin esperar a que el barco recuperara razonablemente el equilibrio tras la maniobra de cambio de dirección, motivo por el cual la pasteca que no se había aún detenido, golpeó en su movimiento al trabajador que cayó al mar; su rescate no fue posible, la STSJ de Andalucía (Sevilla), de 19 de septiembre de 2003 (AS 2003\1036), considera en su 5. ${ }^{\circ}$ Fundamento de Derecho que «la actuación del trabajador con la realización precipitada de la maniobra respecto a la forma normal de llevarla a cabo, distorsiona la causalidad entre el daño y el juicio de reprochabilidad a la empresa, tanto en el ámbito contractual, al no estar acreditado el incumplimiento trascendente de una obligación a la que viniese vinculada, ni en el extracontractual al no evidenciarse la existencia de un acto culpable grave y esencial que motivase el desgraciado accidente...». 
tros de trabajo móviles, expuestos a posibles abordajes, sino también porque los trabajadores permanecen alejados del entorno familiar durante largos períodos de tiempo.

Así, las principales peculiaridades se producen en los accidentes denominados in itinere, es decir, en los que «sufra el trabajador al ir o al volver del lugar de trabajo» y en la presunción conforme a la cual «son constitutivas de accidente de trabajo las lesiones que sufra el trabajador durante el tiempo y en el lugar del trabajo».

71. Comenzando por las peculiaridades que presentan los accidentes in itinere, en el ámbito marítimo-pesquero, respecto a los trabajadores embarcados, conviene recordar que los primeros pasos para configurar este tipo de accidentes de trabajo se produjeron, curiosamente, en el ámbito marítimopesquero, a partir de la Sentencia del Tribunal Supremo de 11 de junio de 1908 [supra, II, 36].

Tal y como indicase Del Peso y CAlvo, «el Tribunal Supremo partió de la idea de una prolongación de jornada» ${ }^{101}$, movido, en términos de una sentencia del propio Tribunal Supremo, de 25 de marzo de 1960, por «razones de equidad y justicia», que permitiesen conceder al trabajador una protección de la que sin esa extensión carecía ${ }^{102}$.

72. No obstante, también hay que reconocer que ha sido en el ámbito marítimo-pesquero donde mayores problemas ha suscitado el accidente de trabajo in itinere, debido, una vez más, a las especiales circunstancias que concurren en él. Más allá del supuesto clásico del accidente de trabajo in itinere ${ }^{103}$, la casuística resulta riquísima en este campo y, por ello, la interpretación de cada caso debe realizarse cuidadosamente, sin que puedan establecerse de antemano parámetros fijos y definitivos. Por lo demás, la jurisprudencia así lo evidencia, partiendo siempre de la condición de que el accidente tenga alguna clase de relación, directa o indirecta, con el trabajo marítimo-pesquero realizado ${ }^{104}$.

${ }^{101}$ Del Peso y Calvo, C. «Pasado, presente y futuro del accidente in-itinere». En RISS, 1968, núm. 2, p. 247.

102 Ibidem.

${ }^{103}$ Por todas, la STS de 14 de diciembre de 1973 (Ar. 4758) y la STSJ de la Comunidad Autónoma del País Vasco, de 17 de enero de 1991 (AS 1991\261).

${ }^{104}$ Por ejemplo, ante un supuesto en el que un buque atracó en el puerto de Las Palmas de Gran Canaria, para el inicio de la parada biológica, quedando la tripulación libre de servicio, y en el que uno de los marineros, al regresar al buque a dormir, ya que al día siguiente debía regresar a su domicilio, falleció como consecuencia de su caída al agua desde la rampa de acceso al buque, la STSJ de Galicia, de 10 de diciembre de 1996 (AS 1996/4571) estimó la falta de relación de causalidad entre el accidente y el trabajo realizado, resultando determinante para ello los resultados de la autopsia, pues ésta confirmó que el fallecido presentaba una tasa de alcoholemia de 1,29 g por litro de sangre. 
73. Antes de realizar un breve resumen de la jurisprudencia existente sobre la materia, debe advertirse, además, que, en determinadas ocasiones, incluso puede confundirse el tipo del accidente de trabajo in itinere con algún otro tipo de accidente de trabajo.

De este modo, debe quedar claro que los accidentes en misión no son propiamente accidentes de trabajo in itinere, sino accidentes de trabajo puros y simples. Se consideran accidentes en misión «los que ocurren en el trayecto que el trabajador tiene que recorrer por consecuencia de su trabajo, bien habitualmente en el desempeño mismo de sus funciones..., bien en cumplimiento de órdenes o indicaciones ocasionales del empresario (por ejemplo, incorporación a su destino de capitán de buque)...» ${ }^{105}$.

74. Ya desde el punto de vista jurisprudencial, y partiendo siempre de la existencia de algún tipo de vínculo entre el accidente y el trabajo marítimopesquero realizado, una de las cuestiones más debatidas ha girado en torno a la consideración de accidente de trabajo in itinere de los «accidentes acaecidos cuando el trabajador en uso de permiso se traslada a tierra» ${ }^{106}$.

En el 3. ${ }^{\text {er }}$ Fundamento de Derecho se recogen, con ocasión del supuesto descrito, las principales causas que pueden dar lugar a la ruptura del nexo de causalidad entre el accidente y el trabajo. De este modo, se afirma como

«la previsión normativa contenida en el... [artículo 115.2.a del TRLGS], que recoge la reiterada doctrina del Tribunal Supremo configuradora del accidente in itinere, como aquel que sufre el trabajador durante el camino que ha de seguir desde su domicilio al trabajo o viceversa, exige para su actuación que no se rompa el nexo causal por algún acto personal del trabajador, bien por un acto temerario o imprudente o ya por un acto que interrumpa el ir o venir del domicilio al trabajo; y si bien la jurisprudencia ha seguido un criterio amplio y flexible en cuanto a la interrupción del nexo causal, sin embargo, la extensión interpretativa que ha hecho no es extensible al supuesto litigioso, habida cuenta de las circunstancias concurrentes y configuradoras del mismo; así el hecho de que el buque, de cuya tripulación formaba parte el trabajador fallecido, había atracado para el inicio de una parada biológica y la tripulación quedó libre de servicio, por lo que el regreso del accidentado al barco no era para prestar servicio y al día siguiente regresaba a su domicilio; por otro lado, el estado de intoxicación etílica en que se encontraba cuando pretendía subir al buque por la rampa de acceso, muy probablemente ha sido la causa de su caída al agua, lo que constituye, al menos, una actuación imprudente en su comportamiento, al haber actuado con total olvido de las más elementales normas de diligencia y colocarse en una situación de grave riesgo, fatalmente acaecido y de graves consecuencias; y estas circunstancias concurrentes habrán de conducir a estimar destruida la presunción legalmente establecida de que el trayecto es considerado lugar de trabajo y el tiempo de recorrido empleado en el iter lo es de trabajo y, en definitiva, apreciar la rotura del obligado nexo causal para la conceptuación de accidente de trabajo...».

105 Alonso Olea, M. y Tortuero Plaza, J. L. Instituciones de Seguridad Social. Madrid: Editorial Civitas, 2000, 17. ${ }^{\text {a edición, p. } 75 .}$

${ }^{106}$ Del Peso y Calvo, C. ob. cit., p. 262. 
Ante este problema, tras unos primeros momentos dubitativos ${ }^{107}$, la jurisprudencia ha sabido conectar las peculiaridades que presenta el trabajo marítimo-pesquero con la razón de ser del tipo de accidente de trabajo in itinere, puesto que como se extrae de la STS de 16 de abril de 1961 (4. ${ }^{\circ}$ Considerando $)^{108}$, los accidentes de trabajo, acaecidos cuando el trabajador embarcado se traslada a tierra en uso de permiso, no guardan relación alguna con el supuesto básico de accidente in itinere, entendido como el sobrevenido cuando el obrero se encamina al lugar de trabajo, desde su domicilio, o al regresar a éste, cumplido su cometido laboral. La diferencia estriba en que, en los supuestos de los trabajadores marítimo-pesqueros, el trabajo derivado del contrato de embarque es de tracto sucesivo, debido a que el lugar del trabajo y el domicilio coinciden en la embarcación.

Por tanto, partiendo de la idea de que la embarcación es, al mismo tiempo, lugar de trabajo y residencia de los trabajadores que prestan servicios a bordo, parece lógico calificar de accidente de trabajo in itinere al acaecido en el recorrido del trabajador que, estando su embarcación en puerto, desciende a tierra en uso de permiso para, transcurrido éste, reincorporarse de nuevo a sus labores a bordo ${ }^{109}$.

A esta conclusión se llega, igualmente, en la STCT de 12 de diciembre de 1978 (Considerando único) ${ }^{110}$, que tras afirmar que «la distinción e independencia de los conceptos domicilio y centro de trabajo no se da cuando por la profesión y larga temporada de la campaña se confunden ambos conceptos», refuerza esta argumentación al señalar como «ha de entenderse con un sentido lógico, humano y real» el hecho de que el trabajador que debido al trabajo está prolongadamente ausente y desligado de su familia, aproveche, dentro de la vigencia del contrato y atendidas las obligaciones de la profesión, el breve fondeado del buque en puerto, para trasladarse a la provincia a la que corresponde el puerto, pues ello «responde a una exigencia personal, familiar y social, en el que el ir y volver del trabajo queda reemplazado por volver e ir al trabajo, es decir, el ir al trabajo y volver a la familia se sustituye por el ir a la familia y volver al trabajo».

${ }^{107}$ Tal es así, que incluso algunas sentencias no consideraron a estos supuestos accidentes de trabajo in itinere. En este sentido, la STS de 25 de mayo de 1951 (Ar. 1554), en su 1. ${ }^{\text {er }}$ Considerando, entendía «que ocurrido el siniestro fuera de las horas de trabajo, libre el marinero de obligación alguna y cuando marchaba por su voluntad exclusiva hasta el barco donde servía,... [faltaba] nexo suficiente para ligar la desgracia a la faena». Por su parte, la STS de 23 de octubre de 1953 (Ar. 2649), en su 1. ${ }^{\text {er }}$ Considerando, negaba la existencia del accidente in itinere, basándose en una interpretación inflexible, según la cual «el siniestro no se produjo a bordo del... vapor ni con ocasión de labores complementarias de la navegación realizadas en tierra... sino cuando el... tripulante regresaba, al parecer, a bordo...».

108 Ar. 2096.

${ }^{109}$ Así lo confirman, por ejemplo, las SSTS de 22 de marzo de 1962 (1. er $^{\text {Considerando) }}$ y 11 de junio de 1966 (Considerando único), Ar. 1377 y 2801.

${ }^{110}$ Ar. 7022. 
75. En cuanto se refiere a la presunción conforme a la cual «son constitutivas de accidente de trabajo las lesiones que sufra el trabajador durante el tiempo y en el lugar del trabajo», las peculiaridades respecto a los trabajadores embarcados se relacionan, una vez más, con el hecho de que la embarcación es, para estos trabajadores, mientras prestan sus servicios laborales, al mismo tiempo, centro de trabajo y residencia.

76. El supuesto típico de esta presunción se extrae, por ejemplo, del $2 .^{\circ}$ Considerando de la STS de 3 de febrero de $1959^{111}$, ante un supuesto en el que un marinero, estando el buque en el que trabajaba de arribada, cayó al mar por la borda y pereció ahogado, pues se reputa «riesgo que por aquella circunstancia, lugar y forma en que se desarrolló debe estimarse accidente de trabajo, mientras no se justifique que obedecía a acto voluntario o a imprudencia extraprofesional».

En torno al supuesto típico en que juega la presunción, con ocasión de un caso de muerte repentina de marinero a bordo, la STS de 28 de febrero de $1966^{112}$, en su $2 .^{\circ}$ Considerando, establece la filosofía en la que debe inspirarse el juzgador, al indicar

«que si bien la presunción de la existencia de relación de causalidad entre el trabajo y siniestro implica de ordinario la concurrencia de un trauma, normalmente ostensible, puede suceder la indisposición seguida de muerte o la muerte fulminante de un trabajador en el lugar y durante la jornada laboral, sin causa aparente que lo explique, y en tal supuesto, debe conceptuarse accidente indemnizable si no consta que murió por fuerza mayor extraña, dolo, culpa o imprudencia extraprofesional y en general por causa que ninguna relación guarde con el trabajo, ya que la obligación de indemnizar a la víctima, o su aseguradora, es consecuencia del riesgo que en sí misma lleva la empresa de proteger al trabajador; prueba que en tal caso corresponde al patrono...» ${ }^{113}$.

Las directrices fijadas por esta sentencia son confirmadas, igualmente, en la STS de 6 de octubre de $1983^{114}$. Así, en su $2{ }^{\circ}$ Considerando, tras justificar la aplicación de la presunción iuris tantum, basándose en la inexistencia de prueba en contrario, se remite a la STS de 26 de mayo de $1976^{115}$ para afirmar que

«la circunstancia de que el accidente sobreviniera durante las horas en que los obreros pernoctaban, por la tarde en que cesaron en sus trabajos, en el lugar en que los efectuaban, no desposee al siniestro de su condición de laboral ni rompe el nexo causal entre el trabajo y el evento dañoso, pues

${ }^{111}$ Ar. 228.

112 Ar. 1354.

${ }^{113}$ Se citan, al respecto, las SSTS de 17 de octubre de 1962 (Ar. 3515) y de 27 de junio de 1963 (Ar. 2666).

114 Ar. 5053.

115 Ar. 3377. 
la amplia definición del accidente de trabajo que se contiene en el... [artículo 115.1 del TRLGSS] es tan extensa que comprende no sólo a las que sean consecuencia de la actividad laboral sino también a todos aquellos a los que el trabajo haya dado ocasión».

77. A pesar de todo, la viabilidad de la presunción sobre la existencia de accidente de trabajo puede complicarse debido a la interferencia de enfermedades comunes. En efecto, cuando se producen tales interferencias resulta decisivo, para que la presunción se confirme, probar que la enfermedad común no rompe la conexión trabajo-lesión.

Por lo demás, así lo ha confirmado la jurisprudencia. En este sentido, la STS de 22 de enero de $1955^{116}$, en un caso en el que el fogonero de un barco de pesca se sintió súbitamente enfermo y al de pocos minutos falleció, considera que la muerte fue debida a accidente de trabajo, a pesar de que dicho fogonero padecía asma bronquial. Efectivamente, pese a las suposiciones de que la muerte podía haber sido provocada por el asma bronquial que padecía o por una inhibición cardiaca, el Tribunal se decanta por la presunción favorable a la existencia de un accidente de trabajo, basándose en que en ningún momento se declararon las causas de la defunción, ni que éstas fueran extrañas, totalmente ajenas al trabajo que el fogonero realizaba, «como hubiera sido necesario para negar al accidente su carácter laboral...» (2. ${ }^{\circ}$ Considerando).

Se recoge esta misma doctrina, de manera clarividente, en la STS de 22 de septiembre de $1986^{117}$, al afirmarse, en el 1. ${ }^{\text {er }}$ Fundamento de Derecho,

«que ha de calificarse como accidente laboral aquél en el que de alguna manera concurra una conexión con la ejecución de un trabajo, bastando con que el nexo causal, indispensable siempre en algún grado, se dé sin necesidad de precisar su significación, mayor o menor, próxima o remota, concausal o coadyuvante, debiendo otorgarse dicha calificación cuando no aparezca acreditada la ruptura de la relación de causalidad entre actividad profesional y fallecimiento, excepto cuando hayan ocurrido hechos de tal relieve que sea evidente a todas luces la absoluta carencia de aquella relación» ${ }^{118}$.

Se recuerda, del mismo modo, como

«a través de [esta] uniforme y reiterada doctrina con criterio amplio y flexible, no restrictivo... [se] ha permitido configurar como accidentes de trabajo un gran número de enfermedades...».

Partiendo de esa misma doctrina o planteamiento, la STSJ de Galicia, de 16 de septiembre de $1991^{119}$, en su $2 .^{\circ}$ Fundamento de Derecho, realiza una serie de matizaciones importantes.

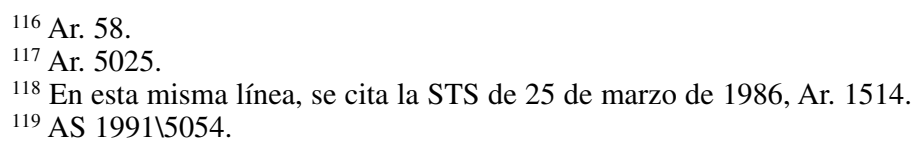




\section{La primera de las matizaciones se centra en que}

«el indicado planteamiento no solamente alcanza a los accidentes en sentido estricto, puesto que con arreglo al Diccionario de la Real Academia de la Lengua lesión no sólo es el daño o detrimento corporal causado por herida o golpe, sino también el que proviene de enfermedades ${ }^{120}$; si bien tratándose de éstas se requiere que por su propia naturaleza no sean susceptibles de una etiología laboral o que dicha etiología pueda ser excluida mediante prueba en contrario ${ }^{121}{ }$.

La segunda de las matizaciones viene a concretar la primera, al señalar que

«tal posibilidad ha sido reiteradamente admitida por la jurisprudencia en los supuestos de infarto de miocardio acaecidos en el lugar de trabajo y durante la jornada laboral, así como también en los asimilados que se producen in itinere, considerando que a todos ellos les resulta plenamente aplicable la presunción del... [artículo 115.3 del TRLGSS] ${ }^{122} \ldots$ y teniendo en cuenta que tales patologías cardiocirculatorias son de etiología y origen inciertos $^{123} \ldots$, y que la conexión trabajo-lesión no surge necesariamente de la realización de un esfuerzo físico excesivo, sino que puede derivar de otras circunstancias del medio laboral, como el estrés o las tensiones emocionales surgidas con ocasión del trabajo ${ }^{124}$..., por lo que incluso las manifestaciones anteriores de la enfermedad no son elemento decisivo para excluir el accidente de trabajo, al poder ser éste un factor agravante o desencadenante de la crisis ${ }^{125} \ldots$, primando en todo caso la laboralidad del evento cuando no es deducible con plena certeza que el óbito ocurrido en el lugar de trabajo y durante la jornada de trabajo (con la jurisprudencial extensión al ocurrido in itinere) no tiene conexión alguna con la actividad laboral $^{126} \ldots$, en el bien entendido de que tal prueba corresponde a la Entidad aseguradora ${ }^{127} \ldots$ y de que la presunción establecida por el artículo... [115.3 del TRLGSS] no es destruible por meras conjeturas e hipóte$\operatorname{sis}^{128} \ldots »$.

${ }^{120}$ Se cita, igualmente, la STS de 27 de enero de 1986, Ar. 285.

${ }^{121}$ Incidiendo en este planteamiento, véanse las SSTS de 30 de septiembre de 1986, 10 de octubre de 1987 y 22 de noviembre de 1988, Ar. 5219, 7842 y 8860.

122 Se citan en el mismo sentido las SSTS de 17 de noviembre de 1973, 8 de abril de 1974, 26 de enero de 1976, 17 de marzo de 1976 y 10 de diciembre de 1984, Ar. 4522, 2379, 376,1490 y 6358.

${ }^{123}$ Vid. las SSTS de 6 de octubre de 1986 y de 27 de diciembre de 1987, Ar. 5400 y 9046.

${ }^{124}$ Se cita, al respecto, la STS de 10 de octubre de 1987, Ar. 7842.

${ }^{125}$ Así lo establecen las SSTS de 30 de septiembre de 1986, 16 de noviembre de 1986 y 7 de marzo de 1987, Ar. 5219, 6465 y 1350.

${ }^{126}$ Vid. STS de 25 de marzo de 1986, Ar. 1414.

${ }^{127}$ Con apoyo en la STS de 8 de abril de 1987, Ar. 2379.

${ }^{128}$ En el mismo sentido se pronuncia la STS de 28 de septiembre de 1987, Ar. 6410. 
Por su parte, la STSJ de Galicia, de 29 de abril de $2000^{129}$, va más lejos, y considera accidente de trabajo el infarto de miocardio sufrido por un marinero que se encontraba descansando, a bordo de un buque, que faenaba en alta mar. Para ello, esta sentencia tiene en cuenta

«las especiales condiciones de trabajo a que se encuentran sometidos los marineros cuando se hayan a bordo de un buque de pesca que está faenando en alta mar que hace que, incluso cuando se encuentren en sus respectivos camarotes descansando, estén en situación de guardia permanente y en disposición de ser requeridos y llamados por la dirección del barco, como ocurre por ejemplo en el caso de producirse capturas de pescado o de cualquiera otra incidencia, de las múltiples que pueden surgir en un buque que se encuentra faenando en alta mar, que exija la presencia de los trabajadores en la cubierta del barco para realizar faenas de diversa índole o en otras dependencias. Y esta permanente disponibilidad que hace que no tengan un horario preestablecido dependiendo siempre de las contingencias, a veces imprevisibles, que puedan surgir en un barco en alta mar y que obliga a los trabajadores que se hayan a bordo a acudir a la llamada de su patrón de pesca para la realización de la tareas propias de su cometido, incluso cuando aquéllos se encuentren en sus camarotes descansando, permite extender la consideración de tiempo de trabajo a todo el tiempo de permanencia en el barco cuando éste se encuentra faenando, desde la salida de puerto hasta su regreso» $\left(2 .^{\circ}\right.$ Fundamento de Derecho).

Así lo entiende, igualmente, la STSJ de Galicia, de 19 de noviembre de $2001^{130}$, en un caso en el que el patrón de un barco pesquero falleció, según la autopsia, como consecuencia de una rotura de aneurisma abdominal, que le provocó un shock hemorrágico después de cenar y mientras tomaba una manzanilla, porque se encontraba indispuesto debido a un dolor que había padecido sobre las 16 horas del día anterior. La calificación de accidente de trabajo se basa en esta sentencia en que

«aunque la rotura de aneurisma abdominal... no se produce en el momento de la realización de una actividad concreta (tiempo de trabajo), sí ocurre en el lugar de trabajo (barco) y si [además] tenemos en cuenta... que el proceso se inicia sobre las 16 horas del día anterior la relación de causalidad entre trabajo y lesión parece indiscutible, por lo que debe aplicarse la presunción (iuris tantum), que la ley prevé» (2..$^{\circ}$ Fundamento de Derecho).

${ }^{129}$ AS $2000 \backslash 1095$.

${ }^{130}$ AS 2002\10985. 


\section{Los accidentes de trabajo respecto a los trabajadores por cuenta propia}

78. La principal particularidad que presentan los accidentes de trabajo en el Régimen Especial del Mar respecto a los trabajadores por cuenta propia o autónomos, de la que derivan el resto de las particularidades existentes en este ámbito, consiste en el concepto de accidente de trabajo aplicable a éstos.

De este modo, se entiende por accidente de trabajo de los trabajadores autónomos o por cuenta propia «el ocurrido como consecuencia directa e inmediata del trabajo que realizan por su propia cuenta y que determina su inclusión en... [el] Régimen Especial [del Mar]» (artículo 100 del RGRETM, en relación con el artículo 41.2 del TRRETM). Además, hay que tener en cuenta que este concepto comprende también a los armadores asimilados a trabajadores por cuenta ajena (artículo 98 del RGRETM, en relación con el artículo 40.6 del TRRETM), es decir, a aquellos «armadores que prestan servicio a bordo de la correspondiente embarcación y perciban, como retribución por su trabajo, una participación en el montón menor, o un salario, como tripulantes» (artículo 4, párrafo primero del TRRETM), siempre y cuando la embarcación en la que prestan sus servicios «exceda de diez TRB» y el número de técnicos y tripulantes enrolados, incluido el propio armador, «exceda de cinco» (artículos 7 y 3.1, número 1 y 3, del RGRETM).

79. Este concepto, en comparación con el concepto de accidente de trabajo de los trabajadores por cuenta ajena, es sustancialmente más estricto, puesto que respecto a los trabajadores por cuenta propia y a los armadores asimilados a trabajadores por cuenta ajena, la lesión corporal debe hallar su causa inmediata en el trabajo ejecutado, el cual, además, debe ser el que dé lugar a la inclusión en el campo de aplicación del Régimen Especial de la Seguridad Social del Mar ${ }^{131}$.

80. Como consecuencia del carácter estricto del concepto de accidente de trabajo, se reduce no sólo el juego de la causalidad, que debe necesariamente anudar el hecho dañoso a la lesión corporal, sino también su ámbito material ${ }^{132}$. Dicho con otras palabras, el carácter estricto del concepto de accidente supone una excepción a algunas de las ampliaciones que del concepto de accidente de trabajo realiza el artículo 115 del TRLGSS, en sus apartados 2 y 3 , de forma y manera que se «impide la interpretación extensiva o amplia» ${ }^{133}$.

${ }^{131}$ Vicente Palacio, M. ${ }^{\text {a }}$ A. «Acción protectora en el Régimen Especial de la Seguridad Social de los Trabajadores del Mar». En TS, 1995, núm. 49, p. 98.

132 Ibidem.

${ }^{133}$ El Sistema Español de Seguridad Social (y el de la Comunidad Económica Europea). Madrid: Editorial Revista de Derecho Privado. Editoriales de Derecho Reunidas, 1993, 5. ${ }^{\text {a }}$ edición, p. 518. 
81. En efecto, no cabe duda de que, ateniéndose al concepto de accidente de trabajo de los trabajadores por cuenta propia, no pueden considerarse accidentes de trabajo los sufridos «con ocasión o como consecuencia del desempeño de cargos electivos de carácter sindical, así como los ocurridos al ir o volver del lugar en que se ejerciten las funciones propias de dichos cargos» (artículo 115.2.b del TRLGSS), ni «los ocurridos con ocasión o por consecuencia de las tareas que, aun siendo distintas a las de su categoría profesional, ejecute el trabajador en cumplimiento de las órdenes del empresario o espontáneamente en interés del buen funcionamiento de la empresa» (artículo 115.2.c del TRLGSS).

82. Por el contrario, en determinados supuestos, deben realizarse matizaciones acerca de la aplicación del concepto de accidente de trabajo de los trabajadores por cuenta propia.

Así, los accidentes «acaecidos en actos de salvamento y en otros de naturaleza análoga» (artículo 115.2.d del TRLGSS) sólo pueden incluirse en el concepto de accidente de trabajo de trabajadores por cuenta propia cuando esos actos son precisos tras un accidente producido como consecuencia del desempeño de una actividad que da lugar a la inclusión en el campo de aplicación del Régimen Especial del Mar ${ }^{134}$.

Por su parte, la presunción de que «son constitutivas de accidentes de trabajo las lesiones que sufra el trabajador durante el tiempo y en el lugar del trabajo (artículo 115.3 del TRLGSS), en principio, no debe incluirse en el concepto de accidente de trabajo de los trabajadores por cuenta propia. El hecho de que el accidente ocurra «durante el tiempo y en lugar del trabajo» no es suficiente para la inclusión de la presunción en el concepto de accidente de trabajo de los trabajadores por cuenta propia, puesto que se requiere, igualmente, que el accidente se haya producido en el desempeño de alguna de las actividades que dan lugar a la aplicación del Régimen Especial del Mar, y como consecuencia de éste. En definitiva, para que, en estos casos, el accidente se considere como de trabajo, el trabajador por cuenta propia accidentado deberá probar todas esas circunstancias ${ }^{135}$.

Del mismo modo, la exigencia de que el accidente de trabajo sea «consecuencia directa o inmediata del trabajo que realizan» los trabajadores por cuenta propia, excluye, en principio, la posibilidad de incorporar al concepto de accidente de trabajo de estos trabajadores los accidentes denominados in itinere, a saber, los sufridos «al ir o volver del lugar de trabajo» (artículo 115.2.a del TRLGSS). Sin embargo, tal y como ha señalado la doctrina, el accidente que ocurra fuera del buque o del lugar de actividad normal, si no fuera un buque, puede considerarse accidente de trabajo normal, no in itine-

${ }^{134}$ En este sentido, vid. Vicente Palacio, M. ${ }^{a}$ A. ob. cit., p. 98.

135 Ibidem. 
$r e$, si ocurre «como consecuencia directa e inmediata del trabajo», ya que este trabajo puede y necesita a veces ser realizado fuera del buque o lugar de prestación del servicio ordinario marítimo-pesquero, como acarreo de útiles, de la pesca obtenida, etcétera. Así pues, respecto a los trabajadores del mar por cuenta propia o autónomos cabe la posibilidad del accidente de trabajo extra navem ${ }^{136}$.

83. En cambio, el carácter estricto, que presenta el concepto de accidente de trabajo de los trabajadores por cuenta propia, no afecta a:

a) las enfermedades, no consideradas profesionales, «que contraiga el trabajador con motivo de la realización de su trabajo, siempre que se pruebe que la enfermedad tuvo por causa exclusiva la ejecución del mismo» (artículo 115.2.e del TRLGSS); b) «las enfermedades o defectos, padecidos con anterioridad por el trabajador, que se agraven como consecuencia de la lesión constitutiva del accidente» (artículo 115.2.f del TRLGSS), siempre y cuando ese accidente se produzca «como consecuencia directa e inmediata del trabajo» realizado; c) «las consecuencias del accidente que resulten modificadas en su naturaleza, duración, gravedad o terminación, por enfermedades intercurrentes, que constituyan complicaciones derivadas del proceso patológico determinado por el accidente mismo o tengan su origen en afecciones adquiridas en el nuevo medio en que se haya situado el paciente para su curación» (artículo 115.2.g del TRLGSS), siempre y cuando, también en este último caso, el accidente se haya producido «como consecuencia directa e inmediata del trabajo».

${ }^{136}$ Ordeig Fos, J. M. ${ }^{\text {a }}$ ob. cit., pp. 518-519. 


\section{๑) Universidad de Deusto - ISSN 0423-4847}




\title{
La prueba del Derecho extranjero ante los tribunales españoles
}

\author{
Alfonso-Luis Calvo Caravaca \\ Catedrático de Derecho internacional privado \\ (Universidad Carlos III de Madrid, España) \\ $\mathrm{y}$ \\ Javier Carrascosa González \\ Profesor titular de Derecho internacional privado \\ (Universidad de Murcia, España)
}

\begin{abstract}
Resumen: El cambio de escenario social del Derecho internacional, el correlativo y espectacular desarrollo del Derecho internacional privado (que ha pasado a ser, gracias fundamentalmente al impulso del Derecho comunitario, uno de los sectores con mayor dinamismo del Ordenamiento Jurídico español) y el nuevo tratamiento procesal del Derecho extranjero que la LEC 1/2000 dispone hacen de la aplicación del Derecho extranjero por los tribunales españoles un debate de la máxima actualidad e importancia. El presente estudio abordará los «problemas generales» de la aplicación de un Derecho extranjero (y su tratamiento procesal) por los tribunales españoles desde la perspectiva de la prueba del Derecho foráneo ante dichos órganos judiciales.
\end{abstract}

Palabras clave: Derecho Internacional Privado, Derecho extranjero, prueba, LEC $1 / 2000$.

Abstract: The change of the International Law social scene, the correlative and spectacular development of the Private International Law (which has became one of the most dynamic areas of the Spanish Legal Order, because of the EU Law boost) and the new procedural treatment of the Foreign Law given by the LEC 1/2000 have made the implementation of the Foreign Law by Spanish Courts a major actuality debate. The present article deals with the general problems of the implementation of a Foreign Law (and its procedural treatment) by Spanish Courts from the point of view of the proof of the Foreign Law before those Courts. $1 / 2000$.

Key words: Private International Law, Foreign Law, proof, evidence, LEC

Sumario: I. Introducción. - II. Modelos teóricos de prueba del Derecho extranjero. 1. Los dos grandes modelos básicos. 2. La irresistible tendencia hacia un modelo de «prueba de oficio» del Derecho extranjero. - III. Antecedentes históricos. La Sala Civil del Tribunal Supremo y la prueba del Derecho extranjero. - IV. La LEC 1/2000 y la prueba del Derecho extranjero ante los tribunales españoles. 1. La prueba del Derecho extranjero: un sistema de «textura abierta». 2. Alegación del Derecho extranjero 3. Necesaria prueba del Derecho extranjero. 4. Momento procesal oportuno para probar el Derecho extranjero. 
5. Medios técnicos apropiados para probar el Derecho extranjero. A) Prueba del Derecho extranjero por las partes. B) Prueba del Derecho extranjero por el tribunal. 6. Objeto de la prueba del Derecho extranjero. 7. Carga de la prueba del Derecho extranjero. 8. Consecuencias jurídicas en el caso de falta de alegación y/o prueba del Derecho extranjero: las diferentes tesis. A) Tesis de la inadmisión de la demanda. B) Tesis de la «retroacción de actuaciones» procesales. C) Tesis de la aplicación de oficio del Derecho extranjero. D) Tesis de la aplicación sustitutiva del Derecho material español. E) Tesis de la desestimación de la demanda. a) Exposición y fundamentos de la tesis. b) La tesis de desestimación de la demanda y la tutela judicial efectiva. c) La tesis de la desestimación de la demanda y el art. 218.1.II LEC. F) La Constitución y la falta de alegación y prueba del Derecho extranjero. 9. Prueba imposible del Derecho extranjero.

\section{Introducción}

1. En presencia de una situación privada internacional, las «normas de conflicto» españolas indican al tribunal español qué concreto Derecho estatal es aplicable para resolver el fondo del litigio. Como es lógico, son numerosas las ocasiones en las que tales normas de conflicto conducen a la aplicación de un Derecho extranjero. El tribunal español debe aplicar Derecho extranjero para resolver el litigio surgido entre las partes. Pues bien, en tales supuestos, surge la cuestión del «tratamiento procesal de tal Derecho extranjero» en el contexto del proceso que se sigue en España: ¿debe alegarse el Derecho extranjero?; ¿debe probarse?; ¿quién debe o puede probar el Derecho extranjero?; ¿qué ocurre si el Derecho extranjero no se prueba en el proceso que se sigue en España? ¿Qué medios de prueba pueden emplearse para probar el Derecho extranjero? ¿Debe probarse siempre el Derecho extranjero? Todas estas cuestiones han preocupado a la doctrina española y extranjera especializada en el Derecho internacional privado (= DIPr.) desde hace muchos años. Pero lo cierto es que dichas cuestiones están hoy en día de rabiosa y plena actualidad debido a varios factores. Primero: el cambio de escenario social del Derecho internacional privado (las «situaciones privadas internacionales» son más numerosas y variadas que nunca antes). Segundo: el correlativo y espectacular desarrollo del Derecho internacional privado (que ha pasado a ser, gracias fundamentalmente al impulso del Derecho Comunitario, uno de los sectores con mayor dinamismo del Ordenamiento Jurídico español). Tercero: España cuenta con una nueva Ley de enjuiciamiento civil (= LEC 1/2000) que se ha ocupado de los problemas de «tratamiento procesal del Derecho extranjero», antes contemplados en el Código Civil (art. 12.6) tras la reforma de su Título Preliminar en 1974. No es de extrañar, pues, que la doctrina española más reciente haya dedicado esfuerzos de envergadura a aclarar cuál es el régimen jurídico de la prueba del 
Derecho extranjero ante los tribunales españoles que rige desde el 7 enero $2001^{1}$.

2. El presente estudio abordará los «problemas generales» de la aplicación, por tribunales españoles, de un Derecho extranjero. Por consiguiente, quedan al margen de este ensayo las cuestiones relativas a la aplicación extrajudicial del Derecho extranjero, esto es, la aplicación del Derecho extranjero por parte de Encargados del Registro civil, Notarios, Agentes Diplomáticos y Consulares de España en el extranjero y Registradores de la Propiedad. Igualmente, ciertos problemas concretos relacionados con la aplicación del Derecho extranjero por tribunales españoles quedarán también excluidos del presente análisis, problemas tales como la llamada «aplicación integral» del Derecho extranjero, el reenvío (aplicación de las normas de DIPr. extranjero que conducen a la aplicación de normas materiales de otro Derecho estatal), la aplicación de las normas de Derecho Público pertene-

${ }^{1}$ A. L. Calvo Caravaca / J. Carrascosa González, Derecho internacional privado, vol. I, 7. ed., Ed. Comares, Granada, 2006, pp. 241-280; ID., «Aplicación del Derecho extranjero en España y la nueva LEC», Tribunales de Justicia, nov. 2000, n. 11, pp. 1155-1170; ID., «Normas de conflicto, aplicación del Derecho extranjero en España y nueva LEC», AEDIP, núm. 1, 2001, pp. 215-237; ID., «El Derecho extranjero y el TS: la Sala de lo Social contraataca», AEDIP, 2002, pp. 103-114; ID., «La prueba del derecho extranjero en la nueva Ley española de Enjuiciamiento Civil 1/2000», Diario La Ley, 2005, núm. 6178 de 28 enero 2005, pp. 1-7; ID., «The Proof of Foreign Law in the New Spanish Civil Procedure Code 1/2000», IPRax, 2005-2, pp. 170-174; ID., «El Tribunal Constitucional y el Tribunal Supremo ante la falta de alegación y prueba del Derecho extranjero (en torno a la STS, Social, de 4 noviembre de 2004)», Diario La Ley, núm. 6238 de 25 abril 2005, pp. 1-11; P. ABARCA JunCo / M. Gómez Jene, «Alegación y prueba del Dcho. Extranjero en el procedimiento laboral», Rev. Esp. Der. Trabajo, sept.-oct. 2003 núm. 119, pp. 713-737; ID., «De nuevo sobre la alegación y prueba del Derecho extranjero en el procedimento laboral: A propósito de la STS (Social) de 4 noviembre 2004)», Rev. Esp. Der. Trabajo, abril-junio 2005, n. 126, pp. 119130; S. ÁlVAREZ GoNZÁLEZ, «La aplicación judicial del Derecho extranjero bajo la lupa constitucional», REDI, 2002-I, pp. 205-223; F. CALVO BABío, «Problemas para probar Derecho extranjero en procedimientos judiciales españoles», Iuris, n. 93, 2005, pp. 85-61; L. CARBALLO PIÑEIRO, «El carácter imperativo de la norma de conflicto y la prueba del Derecho extranjero: Una relectura en clave procesal y constitucional», AEDIP, núm. 1, 2001, pp. 483-503; L. CARRILlo Pozo, «Alegación y prueba del Derecho extranjero en el ámbito laboral y tutela judicial efectiva», Rev. Esp. Dcho. Trabajo, núm. 111, mayo-junio 2002, pp. 451-473; ID., «Una doctrina constitucional sobre alegación y prueba de la Ley extranjera», Ar. Social, 2003, núms.7-8, pp. 53-84; F. J. GARCimartín AlfÉrez, Sobre la norma de conflicto y su aplicación procesal (cinco cuestiones clásicas), Madrid, Tecnos, 1994; ID., «Nota a STS 17 diciembre 1991», REDI, 1992, vol. XLIV, pp. 239-243; F. GARAU SoBRINO, «La prueba del Derecho extranjero en la nueva LEC», $R G D$, n. 678-679, marzo-abril 2001, pp. 2343-2366; A. MARín LóPEZ, «La prueba de la Ley extranjera en la nueva LEC», AEDIP, núm.1, 2001, pp. 305-423; V. CuARTERo Rubio, «Prueba del Derecho extranjero y tutela judicial efectiva», Derecho Privado y Constitución, n. 14, 2000, pp. 21-71; J. MASEDA RODRíGUEZ, «La aplicación judicial del Derecho extranjero: el nuevo régimen de la LEC y la reciente jurisprudencia del Tribunal Constitucional», Actualidad Civil, n. 12, 2002, pp. 413-446. 
cientes al Derecho extranjero, la «segunda calificación», el «conflicto internacional transitorio» (ausländisches intertemporales Sachrecht), la cuestión de la aplicación en España de normas de Derecho extranjero contrarias a la Constitución extranjera del país cuyo Derecho se trata de aplicar, la interpretación del Derecho extranjero, los conocidos como «problemas de adaptación» (Angleichung), la aplicación de Leyes de Estados no reconocidos por España, el recurso de casación por infracción del Derecho extranjero, y la excepción del «orden público internacional» (ordre public / Public Policy / Voberhaltsklausel).

\section{Modelos teóricos de prueba del Derecho extranjero}

\section{Los dos grandes modelos básicos}

3. Dos «modelos teóricos» básicos se han propuesto como respuestas globales para regular satisfactoriamente la cuestión de la aplicación y prueba del Derecho extranjero. Con variantes y matices importantes, los distintos Estados siguen las líneas básicas de uno u otro «modelo» ${ }^{2}$. Se trata de los siguientes.

4. a) Modelo de aplicación del Derecho extranjero a instancia de parte. El Derecho extranjero lo deben probar las partes. Este modelo descansa en varios argumentos: 1) El Derecho extranjero es un mero «hecho procesal» y no es «Derecho». Como explica H. MuIR-WATT, el Derecho extranjero no se puede considerar como «Derecho», ya que si así fuera, se estarían aplicando, en un país, los «mandatos soberanos» dictados por otro país, lo que comportaría una lesión intolerable de la Soberanía estatal del país cuyos tribunales conocen del asunto ${ }^{3}$. Como el Derecho extranjero es un «hecho proce-

${ }^{2}$ A. L. Calvo Caravaca / J. Carrascosa González, Derecho internacional privado, vol.

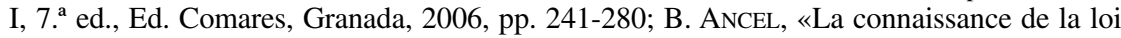
étrangere applicable», Droit international et droit communautaire, París, Centre culturel portugais, 1991, pp. 87-95; D. BuREAU, «L'accord procédural à l'epreuve», RCDIP, 1996, pp. 587-620; S. M. CARBONE, «Il diritto straniero ed il giudice italiano: presente e prospettive di sviluppo», RDI, 1991, vol. LXXIV, pp. 838-849; M. JÄNTERÄ-JAREBORG, «Foreign law in national courts: a comparative perspective», $R C A D I$, vol. 304, 2003, pp. 181-385; W. KRAUSE, Auslandisches Rechts und deutscher Zivilprozess, Constanza, 1990; U. KüSTER, Die Ermittlung ausländischen Rechts im deutschen Zivilprozess und ihre Kostenfragen. Eine rechtsvergleichende Untersuchung, Hannover, Diss. 1995; Y. LEQUETTE, «L'abandon de la jurisprudence Bisbal (a propos des arrets de la Premiere Chambre Civile des 11 et 18 octobre 1988)», RCDIP, 1989, pp. 277-339; H. LEWALD, «Le contrôle des cours suprêmes sur l'application des lois étrangeres», $R C A D I, 1936$, vol. 57, pp. 201-324; P. MAYER, «Le juge et la loi étrangère», RSDIDE, 1991, pp. 481-501; M. RUBINO-SAMMARTANO, «Il giudice nazionale di fronte alla legge straniera», RDIPP, 1991, pp. 315-344; I. ZAJTAY, «The Application of Foreign Law», IECL, vol. 2, Chapter 14, Tübingen, Den Haag, Paris, New York, 1972.

${ }^{3}$ H. Muir-WATt, «Loi étrangère», Dalloz Droit international, 2. ${ }^{a}$ ed. , 1998, p. 2. 
sal», lo deben probar las partes interesadas: los tribunales permanecen al margen de la prueba de los «hechos». Este primer argumento es, hoy en día, totalmente insostenible. En efecto, aplicar un Derecho extranjero en otro país en calidad de «Derecho», no lesiona en absoluto la Soberanía de ese otro país, pues el Derecho extranjero no es Derecho «vigente» en otro país, sino que sólo «se aplica» en otro país. Y de ello deriva que las legislaciones más modernas abandonen de modo radical la ecuación «Derecho extranjero $=$ hecho procesal». Dicha ecuación es falsa, por dos motivos. Primero, porque al comprobarse que la aplicación de un Derecho extranjero no daña la Soberanía del Estado cuyos tribunales conocen del asunto, no existe ninguna necesidad de concebir el Derecho extranjero como un mero y simple «hecho procesal». Segundo, porque el Derecho extranjero no desarrolla las funciones que despliegan los hechos procesales. El Derecho extranjero resuelve el litigio (al igual que hace el Derecho nacional cuando es aplicable al fondo del asunto). Desarrolla, por tanto, una función estrictamente jurídica. Los hechos procesales no resuelven el fondo del litigio, no resuelven la controversia. 2) El Derecho «extranjero» es «extranjero». Por ello no se puede tratar «igual» que el Derecho del país cuyos tribunales conocen del asunto. Consecuencia: el principio jura novit curia sólo debe alcanzar al Derecho nacional y nunca al Derecho extranjero. 3) La aplicación del Derecho extranjero, en la mayor parte de los supuestos, beneficia exclusivamente «intereses particulares» y no «intereses generales», razón por la que deben ser las partes interesadas las que prueben el Derecho extranjero. Son países que siguen este primer modelo, si bien con matices importantes, entre otros, Francia, España, Reino Unido, EE.UU., Argentina, Brasil, Quebec, etc.

5. b) Modelo de aplicación del Derecho extranjero de oficio por el tribunal. El Derecho extranjero lo debe probar el tribunal que conoce del asunto. Este modelo se construye sobre un argumento clave: el Derecho extranjero es «Derecho» (no por aplicarse en otro país, el Derecho extranjero deja de ser «Derecho»), y desarrolla una «función estrictamente jurídica» (el Derecho extranjero «resuelve el caso», zanja la controversia). Por ello, el Derecho extranjero debe ser tratado igual que el Derecho del país cuyos tribunales conocen del asunto. Es decir: el tribunal debe probar o acreditar el contenido del Derecho extranjero (jura novit curia). Son países que siguen este segundo modelo la inmensa mayoría de los que disponen de Leyes especiales de DIPr. promulgadas recientemente (Austria, Turquía, Suiza, Italia, Venezuela, Bélgica, etc.), así como Alemania, Japón, y muchos Estados de América del Sur.

6. El enfrentamiento entre ambos modelos es difícil de resolver. La razón es que el Derecho extranjero es «Derecho», pero también es «extranjero». Si se considera que el carácter «extranjero» del Derecho extranjero es determinante, entonces el primer modelo es preferible; si por el contrario se entiende que lo determinante es que el Derecho extranjero es «Derecho», el segundo modelo debe imponerse. Pero tras esta «batalla jurídica», late otra batalla 
social y económica, a menudo injustamente olvidada y postergada. Probar el Derecho extranjero es caro, lleva tiempo y es complicado. Pues bien, los Estados que prefieren un modelo de prueba del Derecho extranjero «a instancia de parte» estiman que, como los casos regidos por el Derecho extranjero son escasos en la práctica judicial, el coste de su prueba lo deben soportar, por regla general, las partes afectadas, ya que la sociedad no tiene por qué pagar con tiempo y dinero lo que afecta a un «sector reducido de sujetos». Por el contrario, los Estados que optan por la aplicación de oficio del Derecho extranjero estiman que los casos internacionales son numerosos y por tanto es justo distribuir el coste de la prueba del Derecho extranjero entre toda la sociedad, ya que toda la sociedad está implicada, de modo que es oportuno crear «estructuras públicas de prueba del Derecho extranjero» y ordenar a los tribunales que prueben, de oficio, el Derecho extranjero.

\section{La irresistible tendencia hacia un modelo de «prueba de oficio» del Dere- cho extranjero}

7. En la actualidad existen datos poderosos que inducen a pensar que la tendencia hacia una sistema de «prueba de oficio» de la Ley extranjera es inevitable e irreversible. Todo arranca de un postulado elemental: la creciente internacionalización de la sociedad en los países occidentales provoca un aumento espectacular de las situaciones jurídicas reguladas por un Derecho extranjero. Este «nuevo escenario» comporta varias consecuencias.

Primera. En los primeros años de este siglo XXI, la aplicación del Derecho extranjero es una cuestión que afecta ya a toda la sociedad y no una cuestión que implica a unos pocos sujetos. El porcentaje de litigios en los que se aplica un Derecho extranjero en Europa y también en España crece a ritmo exponencial. Llegará un momento en el que la mayor parte de los sujetos que habitan en España tendrán que litigar, alguna vez, con arreglo a un Derecho extranjero. Por ello, resulta conveniente establecer una «estructura pública de prueba del Derecho extranjero», en la que los tribunales prueban de oficio el Derecho extranjero a un coste mucho menor que el que implica probar el Derecho extranjero mediante «estructuras privadas» por los particulares implicados en situaciones privadas internacionales. Ello explica por qué las nuevas Leyes especiales de DIPr. en los diferentes Estados (Italia, Suiza, Rumanía, etc.), han apostado decididamente por un modelo de «prueba de oficio» del Derecho extranjero.

Segundo. El DIPr. español se está llenando de normas de conflicto «comunitarizadas», elaboradas por las instituciones comunitarias sobre la base de los arts. 61 y $65 \mathrm{TCE}^{4}$. Pues bien, estas nuevas normas de DIPr.

${ }^{4}$ S. BARIATTI, «Prime considerazioni sugli effetti dei principi generali e delle norme materiali del trattato CE sul diritto internazionale privato comunitario», RDIPP, 2003, pp. 671-706; J. BASEDOW, «The communitarisation of the conflict of laws under the treaty of 
«comunitarizadas» sólo son efectivas si se garantiza al máximo nivel la prueba del Derecho extranjero, pues en caso contrario, la «armonía internacional de soluciones» buscada con dichas normas, se desvanece (sin una garantía elevada de que el Derecho extranjero designado por estas normas de conflicto comunitarizadas se va a aplicar, renace el Forum Shopping y las soluciones distintas de Estado miembro a Estado miembro). Por ello, como recuerda M. JÄNTERÄ-JAREBORG, el art. 65.c) TCE permite que la UE elabore normas uniformes que impongan la prueba de oficio del Derecho extranjero en todos los Estados miembros, algo que sucederá con toda probabilidad en un futuro no lejano ${ }^{5}$.

Las consecuencias del nuevo escenario de los litigios internacionales entre particulares conduce inevitablemente a una conclusión: la tendencia hacia un sistema de prueba de oficio del Derecho extranjero parece irreversible.

Amsterdam», CMLR, 2000, p. 687-ss. ; ID. , «European Conflict of Laws Under the Treaty of Amsterdam», en P. J. Borchers / J. Zekoll (EDS. ), Essays F. K. Juenger, Nueva York, 2001, pp. 175-192; K. BoELE-WoElKI, «Unification and Harmonisation of Private International Law in Europe», Liber Amicorum K. Siehr, TMC Asser Press, The Hague, 2000, pp. 61-77; TH. M. DE BoER, «Prospects for European Conflicts Law in the Twenty-First Century», Essays F. K. Juenger, Nueva York, 2001, pp. 193-214; S. BRUINIER, Der Einflusss der Grundfreiheiten auf das internationale Privatrecht, Frankfurt am Main, Lang, 2003; A. L. CAlvo CARAVACA, «El DIPr. de la Comunidad Europea», International Law. Revista colombiana de Derecho internacional, núm. 2, diciembre 2003, pp. 277-300; H. GAUdEMETTALLON, «De l'utilité d'une unification du droit international privé de la famille dans l'Union Européenne», Estudos Magalhães Collaço, vol. I, Almedina, Portugal, 2002, pp. 159-185; H. U. Jessurun D'OliveirA, «The EU and a metamorphosis of Private International Law», Essays P. North, Oxford UP, 2002, pp. 111-136; СH. KoHLER, «Interrogations sur les sources du droit international privé européen après le traité d'Amsterdam», RCDIP, 1999, pp. 130; P. LAGARDE, «Développements futurs du droit international privé dans une Europe en voie d'unification: quelques conjetures», RabelsZ, 2004, pp. 225-243; S. LeIBLE / A. STAUDINGER, «El art. 65 TCE: ¿carta blanca de la Comunidad Europea para la unificación del DIPr. y procesal?», AEDIP, vol. I, 2001, pp. 89-115; PH. -E. PARTSCH, Le droit international privé européen de Rome a Nice, Bruxelles, Lacier, 2003; P. PICONE (a cura di), Diritto internazionale privato e Diritto comunitario, Cedam, Padova, 2004; F. POCAR, «La comunitarizzazione del DIPrivato: una european conflict of laws revolution», RDIPP, 2000, pp. 873884; F. Viangalli, La théorie des conflits de lois et le droit communautaire, Aix-en Provence, 2004; R. WAGNER, «EG-Kompetenz für das Internationale Privatrecht in Ehesachen?», RabelsZ, 2004, pp. 119-153; K. WANNEMACHER, Die Aussenkompetenzen der EG im Bereich des Internationalen Zivilverfahrensrechts: des räumliche Andwendungsbereich des Art. 65 EGV am Beispel der EuGVO und der EheVO, Frankfurt am Main, Lang, 2003; M. WILDERSPIN / A. -M. RouCHAUD-JOËT, «La compétence externe de la Communauté européenne en droit international privé», RCDIP, 2004, pp. 1-48.

${ }^{5}$ M. JÄNTERÄ-JAREBORG, «Foreign law in national courts: a comparative perspective», $R C A D I$, vol. 304, 2003, pp. 181-385. 


\section{Antecedentes históricos. La Sala Civil del Tribunal Supremo y la prueba del Derecho extranjero}

8. El tratamiento procesal del Derecho extranjero en España quedó sujeto a una serie de reglas elaboradas por la Sala Primera del TS en el siglo XIX antes de la promulgación del Código Civil en 1889. Ello fue así porque el citado Código Civil de 1889, en su redacción originaria, guardó un total silencio sobre el «tratamiento procesal del Derecho extranjero». Las reglas creadas por el TS pueden resumirse en tres grandes proposiciones.

1) Proposición uno: el Derecho extranjero no se trata procesalmente como Derecho, pues ello supondría un atentado contra la Soberanía española, ya que supondría aceptar en España «mandatos de Soberanos extranjeros». Por ello, para el TS, el Derecho extranjero se comporta como un «hecho procesal». Como tal, el Derecho extranjero debe alegarse y probarse «a instancia de parte» (STS 21 junio 1864, STS 20 marzo 1877, STS 13 enero 1885, STS 26 mayo 1887, STS 28 enero 1896, STS 7 noviembre 1896, STS 19 noviembre 1904, STS 1 febrero 1934, STS 9 enero 1936, STS 17 julio 1937, STS 29 septiembre 1956, STS 16 diciembre 1960, STS 30 junio 1962, STS 6 junio 1969, STS 5 noviembre 1971).

2) Proposición dos: el juzgador tiene la facultad, pero no la obligación, de «intervenir» en la prueba del Derecho extranjero. Pero mucho cuidado: nunca jamás el TS indicó cuándo el juez «podía intervenir» en la prueba del Derecho extranjero, por lo que ello resultaba discrecional (se hablaba de «discrecionalidad técnica»), pero lo cierto es que, más que discrecional, la intervención del tribunal al efecto resultaba verdaderamente arbitraria (STS 26 mayo 1887, STS 13 enero 1885, STS 30 enero 1930, STS 21 febrero 1935, STS 16 junio 1935, STS 16 octubre 1940, STS 14 diciembre 1940, etc.).

3) Proposición tres: si el Derecho extranjero no se prueba por la parte interesada, el tribunal español debía fallar con arreglo al Derecho material español (Back To Lex Fori Rule).

9. Las reglas elaboradas por la Sala Primera del TS en el siglo XIX siguieron observándose por los tribunales españoles de un modo prácticamente unánime durante todo el siglo Xx. Los cambios legislativos no tuvieron la más mínima incidencia en ello. Primero, porque el Código Civil de 1889 carecía de regulación sobre la cuestión. Segundo, porque aunque a partir de 1974, el art. 12.6.II Cc. se ocupó de la cuestión, su texto era confuso, ambiguo, impreciso y nebuloso. Algunas sentencias trataron de realizar una «lectura peculiar» del art. 12.6.II Cc. orientada a admitir una «obligación del juez» de probar el Derecho extranjero en defecto de prueba por las partes (SAT Valencia 3 abril 1982, SAP Oviedo, Sec. 4. ${ }^{\mathrm{a}}, 13$ marzo 1990; SAP Granada, Sec. 3. ${ }^{\text {a }}, 12$ febrero 1992). Pero es cierto que, en la práctica, la inmensa mayoría de los tribunales españoles con la Sala Civil del TS a la cabeza, siguió aferrada con cadenas irrompibles a las «tres proposiciones» que la 
Sala Primera del TS había elaborado en el siglo XIX (STS 12 enero 1989, STS 11 mayo 1989, STS 7 septiembre 1990, STS 10 diciembre 1990, STS 16 julio 1991, STS, 17 diciembre 1991, STS 23 octubre 1992, STS 31 diciembre 1994, STS 15 noviembre 1996, STS 25 enero 1999, STS 9 febrero 1999 , STS 5 junio 2000, STS 13 diciembre 2000, STS 17 julio 2001; también SAP Castellón 25 abril 2000, SAP Madrid 23 noviembre 2000). En resumen: para el TS, el art. 12.6.II Cc. y la Constitución española de 1978 no tuvieron la más mínima incidencia en la cuestión del tratamiento procesal del Derecho extranjero. Todo cambia para que todo siga igual, parecía pensar y decir la Sala Primera del Tribunal Supremo.

\section{La LEC 1/2000 y la prueba del Derecho extranjero ante los tribuna- les españoles}

\section{La prueba del Derecho extranjero: un sistema de «textura abierta»}

10. La regulación actual de la aplicación y prueba del Derecho extranjero se encuentra en el art. 281.2 LEC. El precepto indica: «También serán objeto de prueba la costumbre y el derecho extranjero. (...) El derecho extranjero deberá ser probado en lo que respecta a su contenido y vigencia, pudiendo valerse el tribunal de cuantos medios de averiguación estime necesarios para su aplicación».

11. La regulación de la prueba del Derecho extranjero en la LEC es sólo «parcial» (no exhaustiva). Esta afirmación debe ser entendida en dos sentidos.

12. En primer lugar, lo que la LEC regula en relación con la alegación y prueba del Derecho extranjero es una regulación «de líneas generales». En palabras más elegantes, puede afirmarse que el art. 281.2 LEC contiene un sistema de «textura abierta» en relación con la prueba del Derecho extranjero (F. J. GARCIMARTín AlFÉREZ ${ }^{6}$ ). Ello significa que el legislador español ha renunciado a elaborar en la LEC una regulación exhaustiva y minuciosa de la prueba del Derecho extranjero. Pudo hacerlo y no lo hizo. Pudo haber concretado cuáles son los medios de prueba del Derecho extranjero, el momento procesal oportuno al efecto, pudo fijar rígidamente la obligación del tribunal y/o de las partes de probar el Derecho extranjero en todos o en algunos procesos... Y no lo hizo. El legislador eligió otro camino: proporcionar las «líneas maestras» del régimen jurídico de la prueba del Derecho extranjero, y dejó intencionadamente a los tribunales la tarea de elaborar respuestas con-

${ }^{6}$ F. J. Garcimartín AlfÉreZ, «Nota a STS 17 diciembre 1991», REDI, 1992, vol. XLIV, pp. 239-243. 
cretas a las cuestiones no reguladas en la LEC. Por ello, la regulación española sobre la prueba del Derecho extranjero es una combinación de «regulación legal básica» y de «regulación jurisprudencial de desarrollo». Esta opción en favor de un «sistema flexible» debe ser valorada de modo muy positivo. En efecto, ello permite que la tradicional rigidez de las normas de Derecho internacional privado deje paso a un régimen jurídico «inteligente», capaz de adaptarse a las situaciones privadas internacionales en el contexto cambiante de la globalización propio del siglo $\mathrm{XXI}^{7}$. Sistemas rígidos y regulaciones reglamentistas de la prueba del Derecho extranjero son inconvenientes, aunque ciertos autores, como por ejemplo S. ÁlvAREZ GONZÁlEZ, defiendan tales regulaciones en nombre de una presunta «seguridad jurídica», prinicipio que nada tiene que ver con la cuestión ${ }^{8}$. Valga al efecto recordar las palabras de V. ITURRALDE SESMA, vertidas, a su vez, sobre el clásico trabajo de E. ZITELMANN: «nunca se conseguirá comprender en los limitados artículos de un código la abundancia inagotable de la vida real con todas las cuestiones jurídicas que ofrece; siempre surgen en la vida casos nuevos que ningún legislador hubiera podido prever $»^{9}$. O como escribe A. $\mathrm{NIETO}^{10}$, «el ordenamiento jurídico positivo no regula - y salvo excepciones, no puede regular-, casos individuales. La casuística es tan amplia que no se puede detallar». Las reglas para llevar a cabo la prueba del Derecho extranjero deben ser, necesariamente, «reglas generales y flexibles» y no reglas puntillosas y excesivamente particulares, singulares y por tanto, rígidas. Serían unas reglas inútiles. Ello es así porque sólo las normas jurídicas que contienen «enunciados generales» son «justas» (proporcionan una «igualdad de tratamiento legal») y «útiles» (una norma formulada para casos singulares es «poco efectiva»: sólo se aplicaría en contadas ocasiones) ${ }^{11}$. Y como nihil nuovo sub sole, ya decía el mismísimo ARISTÓTELES que por el hecho de que «la ley necesariamente es siempre general», eso no quiere decir que la ley sea «menos buena». La generalidad no es un «defecto» de las normas jurídicas, como impropiamente opinan algunos: es una característica consustancial a ellas. Pues bien, al presentarse como «reglas generales», las normas que rigen la prueba del Derecho extranjero escogen como «centro de su regulación» un «caso-tipo», el «caso general», el «caso más frecuente» (el «caso

7 J. Carrascosa González, Desarrollo judicial y Derecho internacional privado, Ed. Comares, Granada, 2004, pp. 205-211.

${ }^{8}$ S. Álvarez GonZÁLEZ, «Aplicación judicial del Derecho extranjero: la desconcertante práctica judicial, los estériles esfuerzos doctrinales y la necesaria reforma legislativa», Diario La Ley, núm. 6287 de 4 julio 2005.

${ }^{9}$ V. ITURRALDE SESMA, Lenguaje legal y sistema jurídico (cuestiones relativas a la aplicación de la Ley), Tecnos, Madrid, 1989, p. 181; E. Zitelmann, «Las lagunas del Derecho», $R G L J$, vol. 140,1922 , pp. 544-547.

${ }^{10}$ A. NiETo, El arbitrio judicial, Ariel Derecho, Barcelona, 2000, p. 228.

${ }^{11}$ S. C. SymeOnides, «The American Choice-of-Law Revolution in the Courts: Today and Tomorrow», RCADI, 2002, vol, 298, pp. 9-448, esp. p. 406. 
normal» o «caso ordinario» en terminología aristotélica) ${ }^{12}$. Por ello, no es apropiado aplicar la norma general de DIPr. relativa a la prueba del Derecho extranjero a ciertos «casos particulares». La ley no disimula «los vacíos que deja»: el legislador y la ley son conscientes de la «finitud de la ley», de su carácter «necesariamente incompleto». Por tanto, la «norma general» de DIPr. relativa a la prueba del Derecho extranjero no se puede aplicar literalmente a los «casos con perfiles específicos». Ello causaría «injusticias» y «resultados absurdos», ya que la norma general no fue diseñada para tales «casos con perfiles específicos». Solución: las «normas generales» deben ser objeto de las oportunas «reducciones teleológicas» por parte del intérprete. El tribunal debe llevar a cabo un «desarrollo judicial del DIPr.». El legislador es consciente de que la «Ley general» necesita un «desarrollo particular» por parte de los jueces. El legislador pudo establecer en la LEC 1/2000 un régimen de prueba del Derecho extranjero mucho más particularizado, más rígido, con la intención de cubrir hipótesis más concretas y singulares. Pero como antes se dijo, el legislador, pudiendo perfectamente haberlo hecho, no lo hizo. Esta «dejación del legislador» es deliberada y no tiene nada que ver con su falta de respeto por la «seguridad jurídica», como equivocadamente se ha escrito por algún autor ${ }^{13}$. Por eso, puede afirmarse, sin riesgo, que el legislador otorga con frecuencia, en el contexto del DIPr., una «habilitación legal» al juez y al operador jurídico para que éstos encuentren la solución más apropiada en los casos de «lagunas ocultas» de DIPr., en palabras de K. KREUZER $^{14}$.

Descendiendo a detalles, la LEC se limita a afirmar que 1) el Derecho extranjero debe ser probado (pero no indica si debe probarse el Derecho extranjero «proceso por proceso», es decir, cada vez que un Derecho extranjero sea aplicable); 2) debe probarse el «contenido» y la «vigencia» del Derecho extranjero (nada dice de «otros extremos» relativos al Derecho extranjero cuya prueba había venido siendo exigida por la tradicional jurisprudencia del TS, como la «aplicabilidad al caso del Derecho extranjero», su «interpretación», etc.); 3) como regla general, la prueba del Derecho extran-

\footnotetext{
12 Aristóteles, Moral a Nicómaco, Libro V, teoría de la Justicia, Capítulo X (De la equidad), colección Austral, Madrid, 2000, p. 234: «la ley necesariamente es siempre general (....) y así, en todas las cuestiones respecto de las que es absolutamente inevitable decidir de una manera puramente general, sin que sea posible hacerlo bien, la ley se limita a los casos más ordinarios, sin que disimule los vacíos que deja».

${ }^{13}$ S. Álvarez GonZÁLEZ, «Aplicación judicial del Derecho extranjero: la desconcertante práctica judicial, los estériles esfuerzos doctrinales y la necesaria reforma legislativa», Diario La Ley, núm. 6287 de 4 julio 2005.

${ }^{14}$ K. KREUZER, «Zur funktion von kollisionsrechtlichen Berichtigugsnormen», Z.f.Rvgl, 1992/3, p. 183: ID., «Berichtigungsklauseln im Internationalen Privatrecht», en Mélanges Imre Zajtay, Tübingen, 1982, pp. 295-331; J. D. GonZÁLEZ CAMPOS, «Diversification, spécialisation, flexibilisation et materialisation des règles de droit international privé», RCADI, 2000, vol. 287, pp. 9-426, esp. p. 187.
} 
jero se practica «a instancia de parte» (art. 282 LEC, todas las pruebas se practicarán a instancia de parte, no sólo la prueba de los «hechos»), pero es cierto que caben «excepciones» a dicha regla (art. 281.2 LEC, aunque también es verdad que la LEC no indica «en qué casos» puede y/o debe intervenir el tribunal en la prueba del Derecho extranjero); 4) el «Derecho extranjero» es algo totalmente diferente de los «hechos procesales»: los hechos procesales están sujetos a unas reglas determinadas de prueba que no son aplicables tout court al Derecho extranjero.

13. En segundo lugar, existe toda una pléyade de aspectos relativos a la alegación y prueba del Derecho extranjero que la LEC no regula ni tangencialmente, ni nuclearmente, ni mediante «líneas generales». Como destaca con su agudeza habitual F. F. GARAU SOBRINO, son muy numerosos los «silencios» de la LEC sobre la prueba del Derecho extranjero ${ }^{15}$. En efecto, la LEC guarda silencio, al menos, sobre los siguientes aspectos: 1) $i$ debe alegarse el Derecho extranjero?, ¿qué ocurre si ello no se hace?; 2) ¿debe probarse siempre, en cada proceso, el Derecho extranjero?; 3) ¿cuál es el momento procesal oportuno para probar el Derecho extranjero?; 4) ¿cuáles son los medios de prueba del Derecho extranjero?; 5) ¿quién debe o puede probar el Derecho extranjero?; 6) ¿qué ocurre si no se prueba el Derecho extranjero?; 7) ¿qué ocurre si resulta imposible probar el Derecho extranjero?

\section{Alegación del Derecho extranjero}

14. Los «hechos» deben alegarse al proceso en los términos del art. 399 LEC. Pero el Derecho extranjero no es un «hecho procesal»: el art. 281.2 LEC separa, con toda claridad, los «hechos» y el «Derecho extranjero». Esta distinción comporta varias consecuencias:

1) El Derecho extranjero no debe ser alegado por las partes como si fuera un «hecho procesal» más. La aplicación del Derecho extranjero a un caso concreto no depende de que las partes lo aleguen o no lo aleguen: deriva directamente de la norma de conflicto española.

2) Si una parte no alega un «hecho», éste no se toma en cuenta por el tribunal para fallar el caso, el hecho «desaparece del proceso», el hecho no existe (quod non est actis non est in mundo). Pero si una parte no alega el Derecho extranjero, éste no «desaparece» del proceso, porque sigue siendo el Derecho aplicable al caso, lo quieran o no lo quieran las partes, lo digan o no las partes, lo aleguen o no lo aleguen las partes.

3) La fundamentación jurídica de las pretensiones de las partes es siempre «objetiva». A cada pretensión corresponde una fundamentación jurídica

15 F. Garau Sobrino, «La prueba del Derecho extranjero en la nueva LEC», $R G D$, n. 678-679, marzo-abril 2001, pp. 2343-2366. 
correcta. Es ésa y ninguna otra. Por ello, si un supuesto se rige por un Derecho extranjero, las partes deben fundar sus pretensiones en tal Derecho extranjero, y si no lo hacen y basan sus pretensiones, por el contrario, en el Derecho español, la pretensión debe ser desestimada. Y debe ser desestimada porque en tal caso, la fundamentación jurídica de la pretensión de las partes es incorrecta. El tribunal no tiene por qué hacer el trabajo de unos abogados que son profesionales de la defensa técnica de las partes. Si la fundamentación jurídica es incorrecta, la demanda, o la contestación a la demanda, se desestima, la pretensión jurídica se rechaza. No está correctamente fundada.

15. Y a todo esto, ¿qué afirma al respecto el Tribunal Supremo? Desde el siglo XIX hasta fechas muy recientes, el TS sostuvo lo siguiente en relación con la alegación del Derecho extranjero (STS 16 diciembre 1960, STS 10 diciembre 1966, STS 9 mayo 1988): a) el Derecho extranjero debe ser alegado siempre por las partes interesadas; b) la falta de alegación del Derecho extranjero por las partes conduce a la «no aplicación» del Derecho extranjero al supuesto; c) el momento procesal oportuno para la alegación del Derecho extranjero es la primera instancia y no la apelación ni la casación; d) el Derecho extranjero debe alegarse en las fases del proceso aptas para la aportación al proceso de «elementos de hecho»: hoy, en la demanda y contestación a la demanda.

Pues bien, la diferencia radical entre «hechos» $\mathrm{y}$ «Derecho extranjero», diferencia que se extrae del art. 281 LEC, aconseja rechazar la posición tradicional del TS sobre esta cuestión. Y efectivamente, parece claro que el Tribunal Supremo ha girado al compás de los nuevos tiempos procesales y ha abandonado su más que centenaria jurisprudencia. En efecto, la STS 10 junio 2005 abandona claramente la línea anterior del TS. Dice el TS en la referida sentencia: «En efecto, los hechos están regidos por la regla de aportación de parte (quod non est in actis non est in mundo), mientras que, en nuestro ordenamiento, el Tribunal está facultado para valerse de cuantos medios de averiguación estime necesarios para la aplicación del Derecho extranjero (artículo 12.6.2 CC, redacción anterior a la Ley 1/2000, de 7 de enero, LEC que era la vigente al interponerse la demanda, y artículo 281.2 de esta última Ley), lo que significa tanto como que debe aplicarlo si es que lo conoce $y$, al fin, que de hecho la aportación de parte sólo sea necesaria para suplir aquella información. Por otro lado, la norma jurídica extranjera viene designada por la de conflicto del foro, que pertenece al ordenamiento que el Tribunal debe aplicar de oficio (artículo 12.6 CC). Como consecuencia el derecho extranjero no tiene que ser alegado en el proceso por las partes para que el Juez deba tener en cuenta la designación que de él efectúa la norma de conflicto, por más que ello sea para darle el tratamiento procesal que corresponda. Lo que han de alegar las partes son hechos que, por la concurrencia de elementos extranjeros, se subsuman bajo la previsión de la norma de conflicto. Basta con tal alegación para 
que, como efecto de dicha norma, se considere que el litigio debe resolverse según el Derecho extranjero en ella designado». Es suficiente ahora subrayar las palabras clave de esta resolución, por lo que hace a la cuestión de la alegación del Derecho extranjero: «el derecho extranjero no tiene que ser alegado en el proceso por las partes para que el Juez deba tener en cuenta la designación que de él efectúa la norma de conflicto, por más que ello sea para darle el tratamiento procesal que corresponda». Esta sentencia de la Sala Primera del TS de 10 junio 2005 representa un giro de 180 grados respecto de la precedente y más que centenaria jurisprudencia del TS relativa a la «alegación del Derecho extranjero». Y aunque esta sentencia no es perfecta (perfection is not for this world), sí representa un avance espectacular en la doctrina de la Sala Primera del TS respecto a obsoletas posiciones anteriores.

\section{Necesaria prueba del Derecho extranjero}

16. El Derecho extranjero debe probarse. Así lo exige expresamente el art. 281.2 LEC. El TS ya había sostenido, desde antiguo, que el Derecho extranjero debía ser probado: STS 7 noviembre 1896, STS 9 enero 1936, STS 6 junio 1969, STS 12 noviembre 1976, STS 19 diciembre 1977, STS 23 octubre 1992, STS 18 febrero 1993, STS 10 marzo 1993, etc. El Derecho extranjero debe probarse porque el tribunal y las partes están obligados a conocer las normas jurídicas españolas escritas (art. 1.6 Cc.: jura novit curia), pero ni el tribunal ni las partes están obligados a conocer las normas jurídicas extranjeras (I. ZAJTAY ${ }^{16}$ ). Por tanto, el Derecho extranjero se sitúa en un plano de «inferioridad procesal» respecto del Derecho escrito español, que nunca hay que probar (F. MÉLIN ${ }^{17}$ ).

17. No obstante, el art. 281.2 LEC no indica si la prueba del Derecho extranjero debe realizarse en cada litigio regulado por un Derecho extranjero, «proceso por proceso» y si debe probarse siempre. Para afrontar el problema cabe formular una regla general y una excepción.

${ }^{16}$ I. ZAJTAY, «L'application du droit étranger, science et fiction», RIDC, 1971, pp. 49-59; ID., «L'applicazione del diritto straniero, scienza e fictio», RDIPP, 1972, pp. 755-767; ID., «The application of foreign Law», IECL, vol. III, chapter 14, 1972; ID., «La reception des droits étrangeres et le droit comparé», RIDC, 1957, pp. 686-713; ID., Contribution à l'étude de la condition de la loi étrangère en droit international privé français, París, 1958; ID., «Le traitement du droit étranger dans le procés civil. Étude de droit comparé», RDIPP, 1962, pp. 233-253; ID., «Grundfragen der Anwendung ausländischen Rechts im Zivilprozess», Zeitschrift für Rechtsvergleichung, 12, 1971, pp. 271-280.

${ }^{17}$ F. MÉLIn, Droit international privé, 2. a ed., Gualino éditeur, Paris, 2005, pp. 125-1138; ID., La connaissance de la loi étrangère par les juges du fond (Recherches sur l'inferiorité procédurale de la loi étrangère dans le procès civil), PUAM, 2002, pp. 55-69. 
a) Regla general: cada vez que debe aplicarse un Derecho extranjero, éste debe probarse en el concreto proceso. El Derecho extranjero se debe probar porque se parte del principio siguiente: las partes y el tribunal no conocen el Derecho extranjero ni tienen el deber de conocerlo.

b) Excepción: cuando el Derecho extranjero es conocido por el tribunal no parece necesario exigir que se pruebe «otra vez». La antes citada STS 10 junio 2005 lo dice obiter dictum: la prueba del Derecho extranjero y la aportación de las partes al respecto sólo es precisa si se desconoce el Derecho extranjero. En efecto: la prueba es necesaria cuando el contenido de la prueba (en este caso, el Derecho extranjero) se desconoce. Pero no en caso contrario. Cuando el juez y presumiblemente también las partes conocen a la perfección el Derecho extranjero no tiene sentido exigir la prueba de lo que se conoce. Así, en los casos en los que resulta muy frecuente la aplicación del Derecho extranjero y éste ha sido probado anteriormente de modo indubitado ante tribunales españoles, dicha prueba no será necesaria. Exigir la prueba de un Derecho extranjero cuando el juez y las partes lo conocen de modo exacto porque ya ha sido probado en otro proceso, es costoso y no es necesario. Esta «eximente de prueba» puede resultar muy útil en el caso de tribunales que ejercen sus funciones en poblaciones con un número elevado de extranjeros de una determinada nacionalidad y que aplican con mucha frecuencia un determinado Derecho extranjero. Un ejemplo será útil: la SAP Baleares 26 abril 2005 estima suficientemente probado el Derecho inglés relativo al régimen económico matrimonial porque su aplicación en Eivissa por los tribunales españoles es muy frecuente. Sería supérfluo y provocaría dilaciones inútiles volver a probar un Derecho extranjero cuyo contenido es conocido.

\section{Momento procesal oportuno para probar el Derecho extranjero}

18. Probar el «Derecho extranjero» no es probar «hechos procesales». El régimen de prueba del Derecho extranjero es sui generis. El Derecho extranjero debe poder probarse en primera instancia, en apelación y en casación.

19. Desde el siglo XIX, el TS sostiene que la prueba del Derecho extranjero debe realizarse, exclusivamente, en primera instancia. No cabe realizarla ni en apelación ni en casación. La explicación, para el TS, es lógica. El Derecho extranjero debe ser tratado, sin piedad, como un mero «hecho procesal»: por tanto, si el Derecho extranjero no se prueba en primera instancia, dicha posibilidad precluye, de modo que no cabe probarlo ni en apelación ni en casación. Sin embargo, la diferencia entre «hechos procesales» y «Derecho extranjero» es clarísima en la LEC (vid. el texto entero del art. 281 LEC). Por ello, la posición centenaria del TS debe revisarse drásticamente: debe aceptarse la prueba del Derecho extranjero en primera instancia, en apelación y en casación. 


\section{Medios técnicos apropiados para probar el Derecho extranjero.}

\section{A) Prueba del Derecho extranjero por las Partes}

20. La prueba del Derecho extranjero es una cuestión procesal. Por tanto, los medios de prueba a emplear deben ser los recogidos en la Ley que regula el proceso que se sigue ante los tribunales españoles (art. 3 LEC: Lex fori Regit Processum). Conclusión: sólo cabe utilizar los medios de prueba admitidos en la Ley española cuando se trata de probar el Derecho extranjero ante los tribunales españoles. La cuestión es muy relevante pues numerosos pleitos se deciden en un sentido u otro porque las partes prueban «correctamente» o «no correctamente» el contenido del Derecho extranjero aplicable al fondo del asunto. Varios apartados pueden distinguirse.

21. a) Medios de prueba apropiados para probar el Derecho extranjero. El art. 281.2 LEC no especifica qué concretos medios de prueba deben emplearse para probar el Derecho extranjero. Ante el silencio legal, distintas precisiones parecen oportunas.

Primera. El art. 281.2 LEC se refiere a la «prueba» del Derecho extranjero. Sin embargo, el Derecho extranjero, más que «probarlo», hay que «acreditarlo» (STS 3 marzo 1997). La prueba es una actividad diseñada para los «hechos procesales». El Derecho extranjero no es un mero «hecho procesal». Por ello, su acreditación no sigue estrictamente las reglas sobre la prueba rigurosa de los hechos procesales.

Segunda. El sistema de acreditación del Derecho extranjero es un sistema flexible, vertebrado en torno a la «libertad de medios probatorios»o «prueba libre» (SAP Huesca 14 diciembre 2005). De tal modo, se facilita la acreditación del Derecho extranjero y se potencia su correcta aplicación.

Tercera. No existe una «lista cerrada» de medios apropiados para acreditar el Derecho extranjero. El legislador no ha querido formular esa «lista cerrada», precisamente para facilitar la acreditación del Derecho extranjero. Por tanto, pueden emplearse todos los medios, instrumentos y herramientas técnicas que, por su propia naturaleza, sean adecuadas para acreditar el contenido del Derecho extranjero, ya sean o no «medios probatorios» de los admitidos en la LEC (art. 299.3 LEC por analogía). Ejemplos: el interrogatorio o dictamen de un «experto en Derecho extranjero» (Expert Witness), es apropiado para acreditar el Derecho extranjero, aunque el art. 299 LEC no lo incluye como «medio de prueba». La SAP Huesca 14 diciembre 2005 admitió un dictamen elaborado por la profesora de Derecho internacional privado Dra. Dña. Pilar Diago Diago en torno al Derecho matrimonial marroquí aplicable al régimen económico matrimonial.

Cuarta. En el caso de emplearse auténticos medios probatorios, como la prueba pericial o documental, éstos no tienen por qué ajustarse «de modo riguroso» a las exigencias que la LEC requiere a tales medios. 
Quinta. No todos los medios de prueba previstos en la Ley española para probar «hechos procesales» (art. 299.1 y 2 LEC) son apropiados para acreditar el Derecho extranjero. Para probar el Derecho extranjero sólo pueden utilizarse los medios de prueba que permitan constatar con certeza el contenido del Derecho extranjero. Así, por ejemplo, el «reconocimiento judicial» no es un «medio idóneo» para probar el Derecho extranjero. Sin embargo, la interrogación de un «experto en Derecho extranjero» (Expert Witness) sí que lo es, como también los «documentos públicos»o el «dictamen pericial».

Sexta. El objetivo de la acreditación del Derecho extranjero es convencer al tribunal del contenido de tal Derecho extranjero. Una vez conseguido dicho objetivo, el tribunal puede aplicar el Derecho extranjero y dar una solución al litigio. En general, todos los medios de acreditación del Derecho extranjero son de libre apreciación por el tribunal. Es decir, el tribunal valorará la fuerza probatoria de los diferentes medios de prueba con arreglo a las «reglas de la sana crítica» y no está vinculado por las pruebas y datos proporcionados por las partes. Sin embargo, los documentos públicos a través de los que se acredita el Derecho extranjero hacen «prueba plena» del «estado de cosas» que se contiene en tales documentos en torno al Derecho extranjero (arts. 317, 319 y 323 LEC).

23. b) Un solo medio de prueba es suficiente. Es perfectamente admisible que las partes, cuando prueban el Derecho extranjero, utilicen al efecto, exclusivamente, «un solo medio de prueba». Por ejemplo: prueba del Derecho extranjero, exclusivamente, mediante documentos públicos, o mediante dictamen pericial. En la prueba del Derecho extranjero las partes no están obligadas a utilizar varios medios de prueba cumulativamente, ni a emplear determinados medios de prueba. En la práctica, es frecuente la prueba de un Derecho extranjero, exclusivamente, mediante documentos públicos: STS 6 abril 1979, STS 12 enero 1989, STS 17 diciembre 1991, STS 16 julio 1991, STS 17 marzo 1992, STS 15 noviembre 1996, SAP Asturias 14 enero 2002, SAP Alicante 27 febrero 2004, SAP Guadalajara 14 enero 2004, SAP Baleares 31 marzo 2004.

24. c) Prueba mediante documentos públicos. El medio de prueba más utilizado por los particulares para probar el Derecho extranjero es la prueba mediante documentos públicos (art. 317 LEC). Son documentos públicos, por ejemplo, las certificaciones expedidas por la Subdirección General de Cooperación Jurídica Internacional del Ministerio de Justicia español sobre el contenido del Derecho extranjero. Estas certificaciones sólo pueden ser solicitadas por los tribunales, no por las partes. En 1998 se cursaron más de 600 peticiones de información sobre contenido de Leyes extranjeras. También son documentos públicos las certificaciones expedidas por funcionarios diplomáticos o consulares extranjeros acreditados en España, que deben presentarse legalizados y traducidos a idioma oficial español (arts. 323.3 y 144 LEC), así como las certificaciones expedidas por funcionarios diplomáticos 
o consulares españoles acreditados en el Estado cuyo ordenamiento jurídico se trata de probar.

25. d) Las «fotocopias». En los tribunales españoles, es frecuente que las partes aporten «simples fotocopias de diversas normas aisladas» (SAP Madrid 23 noviembre 2000, SAP Tenerife 13 abril 2004, SAP Alicante 12 mayo 2004, SAP Baleares 26 abril 2005). Tales documentos no son documentos públicos. Además, tales «fotocopias» no permiten probar con certeza el Derecho extranjero, por lo que no deben ser admitidas a tal efecto.

26. e) Documentos privados. Otros documentos no públicos, como son las «colecciones privadas» de Leyes o las obras doctrinales de autores extranjeros, poseen mayor peso probatorio que unas «simples fotocopias». Aunque la jurisprudencia del TS ha sido reacia durante años a admitir estos documentos para probar el Derecho extranjero, no hay por qué eliminarlos radicalmente como «medios de acreditación del Derecho extranjero». Habrá que decidir en cada caso concreto si un determinado documento privado, como por ejemplo un autorizado texto doctrinal extranjero, puede servir para acreditar el Derecho extranjero «con certeza».

27. f) Prueba pericial. También cabe utilizar para probar el Derecho extranjero, exclusivamente, la «prueba pericial» (art. 335 LEC). Tal peritaje puede consistir en un informe elaborado por «expertos en el Derecho extranjero» solicitado por las partes. No es necesario que tales «expertos» sean sujetos de la nacionalidad extranjera del país cuyo Derecho se trata de probar. Sin embargo, no es un medio de prueba admisible el llamado «informe de parte», un informe redactado por expertos legales a instancia de una parte, en el que el experto «toma partido» en favor de las pretensiones concretas de la parte (SAP Alicante 28 abril 2005).

28. g) Expert Witness. Como antes se ha avanzado sobre las palabras de la STS 3 marzo 1997, el Derecho extranjero, más que «probarlo», hay que «acreditarlo». Ello supone que pueden emplearse «medios de acreditación del Derecho extranjero que no sean, técnicamente hablando, "medios de prueba" admitidos como tales en las leyes procesales. Por ello, puede admitirse como «medio de acreditación del Derecho extranjero», el interrogatorio de «testigos expertos en Derecho extranjero» (Expert Witness), mecanismo muy difundido en otros países, pero poco utilizado hasta ahora en España.

29. h) Los «hechos admitidos» no son operativos. No cabe aceptar la prueba del Derecho extranjero mediante la «doctrina de los hechos admitidos». En general, como es sabido, en el proceso civil, los hechos admitidos por ambas partes no deben probarse. Pues bien, no es admisible que las partes «acuerden» que el Derecho extranjero no debe probarse, de forma que el contenido del Derecho extranjero sea fijado «por acuerdo entre las partes». El art. 281.3 LEC sólo es aplicable a los «hechos» no al «Derecho extranje- 
ro». Aunque en tiempos pasados alguna jurisprudencia admitió esta tesis en relación con el Derecho extranjero (STS 9 julio 1885, STS 9 enero 1936, STS 1 febrero 1934, STS 27 abril 1978 y STS 4 octubre 1982, SAT Baleares 17 julio 1984), tras la STS 5 noviembre 1971 debe estimarse que esta tesis no puede eximir de prueba al Derecho extranjero. El tenor del art. 281.2 LEC es muy claro al respecto.

30. Y de nuevo, a todo esto, ¿cuál es la posición de la Sala Primera del Tribunal Supremo al respecto? En un primer momento, el TS adoptó una postura muy liberal sobre los medios de prueba del Derecho extranjero (vid. STS 21 junio 1864, STS 22 octubre 1867, STS 18 marzo 1875, STS 20 marzo 1877 y STS 27 mayo 1913): parecía incluso admitir el conocimiento privado que el tribunal tenía del Derecho extranjero. Pero a partir de la STS 13 enero 1885, quién sabe por qué, la postura de la Sala Primera del TS sobre los medios de prueba del Derecho extranjero se concreta en esta rígida afirmación: el Derecho extranjero debe ser probado a través de «documentos públicos»y, además, a través de «prueba pericial», un informe conjunto, legalizado y traducido, realizado por dos jurisconsultos del país extranjero cuya Ley debe probarse (STS 13 enero 1885, STS 19 noviembre 1904, STS 25 febrero 1926, STS 30 marzo 1928, STS 12 diciembre 1935, STS 6 diciembre 1961, STS 29 septiembre 1961, STS 30 junio 1962, STS 28 octubre 1968, STS 6 junio 1969, STS 5 noviembre 1971, STS 12 marzo 1973, STS 3 febrero 1975, STS 12 noviembre 1976, STS 27 abril 1978, STS 9 noviembre 1984, STS 23 octubre 1992, etc.). Pues bien, esta jurisprudencia debe hoy revisarse muy profundamente, pues en la actualidad, y tras la LEC $1 / 2000$ puede afirmarse que a) no es precisa una «prueba cumulativa» del Derecho extranjero mediante prueba documental y prueba pericial; b) cabe admitir la prueba del Derecho extranjero mediante documentos públicos y privados, o mediante otros medios de prueba, como el interrogatorio de un Expert Witness, siempre que tales medios permitan acreditar «con certeza» el Derecho extranjero.

\section{B) Prueba del Derecho eXtranjero POR el tribunal}

31. El art. 281.2 LEC indica que el tribunal podrá valerse «de cuantos medios de averiguación estime necesarios» para la aplicación del Derecho extranjero. Es una «norma abierta». En particular, el tribunal puede utilizar para «averiguar» el Derecho extranjero los siguientes mecanismos:

1) Todos los medios de prueba previstos en la LEC siempre que sean adecuados para probar un Derecho extranjero. Ejemplo: documentos públicos como las certificaciones o informes consulares sobre el contenido del Derecho extranjero, o un dictamen pericial.

2) Otros «medios de averiguación» del Derecho extranjero, aunque no sean, estrictamente hablando, «medios de prueba». Entre estos otros «medios de averiguación» cabe citar los siguientes. 
Primero. El propio conocimiento que el tribunal tenga del Derecho extranjero (private Wissen). A tal efecto debe subrayarse lo siguiente: a) cuando el tribunal emplea su propio conocimiento del Derecho extranjero, el tribunal debe respetar el «principio de contradicción», para que las partes puedan debatir, en su caso, sobre el verdadero contenido del Derecho extranjero; b) el tribunal debe también hacer constar en la sentencia, con toda claridad, la norma extranjera y su contenido, a efectos de un posible recurso (STS 10 junio 2005, STSJ Com.Valenciana Sala Civil y Penal 22 septiembre 2005); c) Los medios o instrumentos a través de los cuales el tribunal adquiere conocimiento del Derecho extranjero son en sí mismos irrelevantes, siempre que permitan al tribunal un completo y profundo conocimiento del Derecho extranjero.

Segundo. Los mecanismos previstos en determinados convenios internacionales para la acreditación del Derecho extranjero. Ejemplos no faltan: Convenio europeo de Londres de 7 junio 1968 sobre información del Derecho extranjero, Convención interamericana sobre prueba e información del Derecho extranjero, hecha en Montevideo el 8 mayo 1979, y ciertos Convenios bilaterales firmados por España con países como Méjico (1 diciembre 1984), Brasil (13 abril 1989), República Checa y Eslovaquia (4 mayo 1987), China (2 mayo 1992), Bulgaria (23 mayo 1993), Marruecos (30 mayo 1997), ex-URSS (26 octubre 1990), Uruguay (4 noviembre 1987). El citado Convenio europeo de Londres de 7 junio 1968 sobre información del Derecho extranjero, completado por el Protocolo adicional hecho en Estrasburgo el 15 marzo 1978, establece un sistema de información de los ordenamientos jurídicos de los Estados partes. Cubre la información relativa al Derecho civil y mercantil, Derecho procesal civil y mercantil y Derecho sobre la organización judicial de los Estados partes. Cada Estado designa un órgano único, denominado «órgano de recepción», encargado de recibir las peticiones de datos de información jurídica y de dar curso a dichas peticiones. Cada Estado puede designar uno o varios «órganos de transmisión» encargados de recibir las peticiones de datos procedentes de sus Autoridades judiciales, y de transmitirlas al órgano de recepción extranjero competente. El convenio especifica el necesario contenido de la petición de datos (art. 4). El «órgano de recepción» formulará por sí mismo la respuesta a la solicitud de información. Debe proporcionarse una respuesta objetiva e imparcial sobre el Derecho del Estado requerido, incluyendo, en su caso, los textos legislativos y reglamentarios y de decisiones jurisprudenciales. Los datos contenidos en una respuesta no vinculan a la Autoridad judicial de la cual emanare la petición (art. 8). El órgano de recepción está obligado a dar curso a la petición de información (art. 10.1), salvo excepciones muy limitadas. La petición de datos jurídicos se redacta en la lengua oficial o en una de las lenguas oficiales del Estado requerido, o se acompañarán de una traducción en dicha lengua. La respuesta será redactada en la lengua del Estado requerido (art.14). El Convenio de Londres es generalmente ignorado por los tribunales de los 
Estados parte, España incluida, naturalmente. Aunque hay gloriosas excepciones que resplandecen en el firmamento jurisprudencial: la SAP Navarra 29 diciembre 2004 es un ejemplo evidente de un juzgador que maneja de modo escrupulosamente correcto el citado Convenio de Londres sobre información del Derecho extranjero.

Tercero. La Red Judicial Europea en materia civil y mercantil. Dicha Red Judicial fue creada por Decisión del Consejo 2001/470/CE, de 28 mayo 2001. Cada Estado miembro designa un «punto de contacto» al que los órganos judiciales de ese Estado miembro y de los demás Estados miembros puede dirigirse para solicitar información sobre el Derecho extranjero. Dichos «puntos de contacto» canalizan la solicitud para asegurar su buen fin: responden a la solicitud o la envían a las autoridades competentes o a las mejor situadas para dar satisfacción a la petición. También pueden ayudar directamente a los ciudadanos interesados.

Cuarto. Mucho más dudosos son algunos mecanismos propuestos recientemente, pero que actualmente no están previstos en las leyes: a) «Consulta a tribunal extranjero» (Preliminary Reference Procedure): un tribunal podría acreditar el contenido de un Derecho extranjero mediante «consulta directa» a un tribunal de dicho Estado. Ello podría ser especialmente útil en la UE para garantizar la correcta aplicación de las normas de DIPr. «comunitarizadas» $\left(\mathrm{O} . \mathrm{REMIEN}^{18}\right)$. El informe del tribunal extranjero podría ser vinculante (legally biding) o no (only with persuasive authority). El mecanismo es ingenioso, pero presenta inconvenientes: si el informe es vinculante, el tribunal que emite el informe condicionaría la labor del tribunal consultante, y si no es vinculante, el tribunal consultado tendrá poca motivación y además las partes no podrían tener acceso al tribunal consultado; b) «Transmisión del caso» (Forum Non Conveniens decided on the basis of the Applicable Law): el tribunal que debe aplicar Derecho extranjero podría «transmitir» la resolución del caso a un tribunal extranjero del país cuyo Derecho se trata de aplicar y tal tribunal resolvería el litigio. Es un Forum Non Conveniens oculto (M. JÄNTERÄ-JAREBORG, D. MC.CLEAN ${ }^{19}$ ). El mecanismo no tiene, hoy en día, cabida en el DIPr. europeo, que no lo ha previsto en ningún instrumento legal. Por ahora.

${ }^{18}$ O. Remien, «Jura Novit Curia und die Ermittlung fremden Rechts im europäischen Rechtsraum der Artt. 61 ff EGV - für ein neues Vorabentscheidungsverfahren bei mitgliedstaatlichen Gerichten», en J. BASEDOw y OTROS, Aufbruch nach Europa- 74 Jahre MaxPlanck-Institut für Privatrecht, Mohr-Siebeck, Tübingen, 2001, pp. 617-631.

${ }^{19}$ M. JÄNTERÄ-JAREBORG, «Foreign law in national courts: a comparative perspective», RCADI, vol. 304, 2003, pp. 181-385; D. MCCLEAN, «A Common Inheritance? An Examination of the Private International Law Tradition of the Commonwealth», RCADI, vol. 260, 1996, pp. 11-98. 


\section{Objeto de la prueba del Derecho extranjero}

32. Debe probarse el «Derecho extranjero». Por «Derecho extranjero» hay que entender el entero ordenamiento jurídico extranjero, comprendiendo todo tipo de normas jurídicas que lo integren y que sean aplicables al caso concreto: normas escritas, costumbre y demás reglas que sean Derecho objetivo —ad ex. jurisprudencia, principios generales del Derecho, equidad, etc.- (SAP Barcelona 12 noviembre 1999).

33. El art. 281.2 LEC sólo indica que hay que probar el contenido y la vigencia del Derecho extranjero. La pregunta surge espontánea: ¿es suficiente probar sólo ambos extremos, o es preciso probar, además, «otros aspectos» del Derecho extranjero?

La primera tesis (se debe probar, exclusivamente, el «contenido y vigencia» del Derecho extranjero), ha sido defendida por la SJS Comunidad Madrid 29 octubre 2003: inclusio unius exclusio alterius.

La segunda tesis es la preferida por el TS y parece más correcta (STS 13 enero 1887, STS 12 mayo 1887, STS 10 julio 1900, STS 12 julio 1904, STS 19 noviembre 1904, STS 30 junio 1962, STS 12 enero 1989, STS 7 septiembre 1990, STS 16 julio 1991, STS 25 enero 1999, STS 11 mayo 1989, STS 12 diciembre 1935, STS 23 octubre 1992, SAP Madrid 23 noviembre 2000, SAP Castellón 22 noviembre 2002, SAP Girona 31 marzo 2003). En efecto: se deben probar todos aquellos aspectos del Derecho extranjero que sean necesarios para que el tribunal español falle del modo más aproximado a como lo haría un tribunal de dicho Estado extranjero (STS 30 junio 1962, STS 5 noviembre 1971). Por ello, debe probarse a) el contenido del Derecho extranjero: el tenor literal de las normas extranjeras; b) la vigencia y existencia del Derecho extranjero, lo que es importante en relación con países de reciente creación y en casos de posible contradicción entre las Leyes de un país concreto y la Constitución de dicho país; c) la interpretación concreta de las normas del Derecho extranjero: ello incluye, en su caso, la prueba de la jurisprudencia extranjera que aplica e interpreta el Derecho extranjero; d) la aplicabilidad del Derecho extranjero al caso concreto. Resultado: si se prueba el Derecho extranjero de modo detallado, dicho Derecho extranjero no suscitará «la menor duda razonable a los tribunales españoles», como indica el TS (STS 11 mayo 1989, STS 25 enero 1999, STS 17 julio 2001, SAP Girona 27 mayo 2002). Una vez acreditado satisfactoriamente el Derecho extranjero aplicable al fondo del asunto, el tribunal español debe dar respuesta a las peticiones de las partes, necesariamente, de manera motivada y sobre la base del Derecho extranjero aplicable. Si resuelve el litigio mediante la aplicación del Derecho sustantivo español, la sentencia está viciada de «nulidad» (SAP Málaga 29 julio 2004).

\section{Carga de la prueba del Derecho extranjero}

34. La LEC establece que, como regla general, la prueba del Derecho extranjero se practica a instancia de parte (art. 282 LEC). Pero también afir- 
ma que caben excepciones a dicha regla, porque el tribunal puede intervenir en la «aplicación» del Derecho extranjero (art. 281.2 LEC). Sin embargo, la LEC no precisa «en qué casos» y «con qué intensidad» puede intervenir el tribunal en la prueba del Derecho extranjero. Para resolver el problema, cabe distinguir varios grupos de casos.

35. a) Prueba del Derecho extranjero por las partes: «normas de conflicto meramente localizadoras». Cuando las normas de conflicto designan el Derecho extranjero con independencia, a priori, de su «contenido material», las partes deben probar el Derecho extranjero. Es cierto que la LEC $1 / 2000$ no indica «qué parte» debe hacerlo, demandante o demandado. En tal caso puede presumirse, como punto de partida, que ante la falta de indicación legal, valen las «reglas generales». De este modo, la parte interesada en la aplicación del Derecho extranjero deberá probarlo. Puede ser, por tanto, el demandante o el demandado. Dependerá del caso. Esta regla se justifica porque, visto que la aplicación del Derecho extranjero afecta a un «interés particular» y no a «intereses de la comunidad social», es justo que sean las partes las que asuman los costes de la prueba del Derecho extranjero (STSJ Andalucía Social 1 junio 2004). Así, la «parte interesada» en un «reenvío de retorno» (art. $12.2 \mathrm{Cc}$.), debe probar la norma de conflicto extranjera - que es también una norma de Derecho extranjero- (STS 15 noviembre 1996, SAP Tarragona 13 mayo 2004). El demandante debe probar el Derecho extranjero si basa en él su demanda; el demandado debe probar el Derecho extranjero si basa en él su contestación a la demanda (SAP Baleares 31 marzo 2004). El hecho de que el Derecho extranjero sea aplicable en virtud de una norma de conflicto contenida en un convenio internacional o Reglamento comunitario, no debe incidir en la aplicación del Derecho extranjero a instancia de parte, al menos si la norma de conflicto es «meramente localizadora» (SAP Alicante 18 noviembre 2003), pues las cuestiones de «prueba del Derecho extranjero» suelen quedar al margen de tales Convenios internacionales (T. C. HARTLEY ${ }^{20}$ ).

36. b) Prueba del Derecho extranjero por el tribunal: normas de conflicto que exigen la aplicación de oficio del Derecho extranjero. En ciertos casos, el legislador manifiesta un interés claro en que se aplique el Derecho extranjero. Ese interés debe prevalecer. Por ello, si las partes no prueban el Derecho extranjero, el tribunal está obligado a probar, de oficio, el Derecho extranjero. El coste de probar el Derecho extranjero lo asume el tribunal y el Estado porque se haya implicado un «interés sensible y general» que afecta a la «comunidad social». Los casos más relevantes en los que procede la

${ }^{20}$ T. C. HARTLEY, «Pleading and Proof of Foreign Law: The Major European Systems Compared», ICLQ, 1996, pp. 271-292. 
prueba de oficio del Derecho extranjero son los siguientes: (a) Derecho extranjero designado por normas de conflicto materialmente orientadas. Estas normas ordenan aplicar un concreto Derecho extranjero, precisamente, debido al contenido material de dicho Derecho extranjero. Con estas normas de conflicto, se defienden «intereses sensibles» — protección del menor, defensa del consumidor, del trabajador o del acreedor de alimentos, etc.-—; (b) Normas internacionalmente imperativas del Derecho extranjero (Eingriffsnormen). Defienden intereses estatales de primer orden, por lo que deben ser aplicadas de oficio por el tribunal español: ad ex. normas antitrust extranjeras.

37. c) Prueba del Derecho extranjero por el tribunal: imposibilidad de las partes de probar el Derecho extranjero. En ocasiones, las partes intentan probar el Derecho extranjero de buena fe y hacen todo lo posible al efecto, pero no consiguen probarlo. En tales casos, el tribunal está obligado a probar, de oficio, el Derecho extranjero, lo que puede hacer bien mediante una «ayuda» prestada a las partes para probar el Derecho extranjero, o incluso, mediante la realización de la «entera prueba» del Derecho extranjero (STC 10/2000 de 17 enero 2000, SAP Girona 7 junio 2004). Ejemplo: una mujer armenia solicitó el divorcio de su marido armenio, pero vista la situación bélica de su país, no pudo probar el Derecho extranjero. El TC indicó que el juez no debió desestimar la demanda de divorcio, sino que debía haber ayudado a la demandante a probar el Derecho extranjero (STC 10/2000 de 17 enero 2000, caso de los armenios). Si el tribunal no interviniera en estos casos, se vulneraría la tutela judicial efectiva (art. $24 \mathrm{CE}$ ). Pero mucho cuidado: para que esta «necesaria intervención del tribunal» se verifique, deben quedar claros estos extremos. Primero: la «necesaria intervención del tribunal» en estos casos no procede si la parte se encuentra en «en óptima disposición» para probar la Ley extranjera, pues en dicho supuesto, la parte, y sólo la parte, debe probar el Derecho extranjero (STSJ Madrid 26 febrero 2004), y si no lo hace, la pretensión de la parte debe ser desestimada. Segundo: debe quedar plenamente acreditado en el proceso, sin dudas razonables, que efectivamente, la prueba del Derecho extranjero resulta «imposible de facto» para la parte.

Los casos más frecuentes de «imposibilidad de prueba del Derecho extranjero por las partes» son los siguientes: (a) el país cuya Ley debe ser probada es un país muy lejano y/o está envuelto en conflictos bélicos u otras turbulencias sociales, lo que hace que, de hecho, los particulares tengan muchas dificultades para recabar información jurídica procedente de dichos países; (b) la parte no dispone de «recursos económicos suficientes» para costear una exitosa prueba del Derecho extranjero, por lo que, de hecho, la prueba del Derecho extranjero resulta imposible para dicha parte. Téngase en cuenta que el beneficio de justicia gratuita no cubre el pago a dos jurisconsultos extranjeros que acrediten el contenido del Derecho extranjero ni la traducción a lengua oficial española del texto legal extranjero (F. CALvo 
BABíO $\left.{ }^{21}\right)$. Por ello, la «justicia gratuita» no garantiza que la parte obtenga «gratis» la prueba del Derecho. Pues bien, cuando la parte no dispone de recursos económicos suficientes, el tribunal debe probar el Derecho extranjero. Ello evita que el DIPr. opere como un «Derecho para ricos» que sólo funciona correctamente cuando la parte dispone de recursos económicos suficientes para probar el Derecho extranjero, discriminando de facto al litigante económicamente menos favorecido (SAP Girona 7 junio 2004).

\section{Consecuencias jurídicas en el caso de falta de alegación y/o prueba del Derecho extranjero: las diferentes tesis}

38. La LEC 1/2000 no ofrece respuestas a la cuestión que se plantea cuando un Derecho extranjero rige un litigio por mandato de las normas de conflicto españolas, pero las partes argumentan sus posiciones sobre el Derecho español y no invocan y/o no prueban el Derecho extranjero. Tampoco ofrece respuesta a un caso muy frecuente: siendo aplicable un Derecho extranjero, el demandante presenta su demanda fundada en el Derecho español, y el demandado se limita a contestar que el Derecho español no es aplicable, sino que lo es el Derecho extranjero, Derecho que el demandado no prueba (ya que estima que debe ser el demandante el que lo debe probar y no lo hizo). La doctrina española y la jurisprudencia española han ofrecido distintas tesis al respecto. Al menos cinco tesis se han vertido (tesis de la inadmisión de la demanda, tesis de la retroacción de actuaciones procesales, tesis de la aplicación de oficio del Derecho extranjero, tesis de la aplicación sustitutiva del Derecho material español y tesis de la desestimación de la demanda).

Algún autor ha escrito que la «solución» es acometer una reforma legislativa del sistema vigente ${ }^{22}$. Pero esta propuesta presenta diversos puntos débiles. En primer lugar, esta propuesta ignora que un «sistema de textura abierta» como el actualmente vigente en España proporciona soluciones más saludables para los particulares que un futurible «sistema rígido». En efecto: el primer sistema, bien encauzado, se puede adaptar sin problemas a la cambiante realidad social actual. Sin embargo, el segundo sistema exige que la realidad social se adapte a la Ley, lo que, como es evidente, no suele suceder. Afirmar que sólo un «sistema rígido y definido» de prueba del Derecho extranjero cumple con el principio de «seguridad jurídica» es una afirmación con soporte débil. Explicación: el principio de «seguridad jurídica» no impli-

${ }^{21}$ F. Calvo Babío, «Problemas para probar Derecho extranjero en procedimientos judiciales españoles», Iuris, n. 93, 2005, pp. 85-61.

${ }^{22}$ S. Álvarez GonZÁLEZ, «Aplicación judicial del Derecho extranjero: la desconcertante práctica judicial, los estériles esfuerzos doctrinales y la necesaria reforma legislativa», Diario La Ley, núm. 6287 de 4 julio 2005; ID., «Nota a STS, Sala 4. a, de 4 de noviembre de 2004», en REDI, vol. 57, 2005-I, pp. 357-359. 
ca «normas rígidas» (un sistema de textura abierta que evoluciona «por casos» gracias a la creación de soluciones por los tribunales está en perfecta sintonía con la seguridad jurídica). Además, ello revela la intención de pretender poner puertas al campo, lo que no es fácil, ni realista ni conveniente. Encapsular en normas «definidas» o «rígidas» la inmensa riqueza de matices que pueden presentar todos los casos en los que un Derecho extranjero debe ser aplicado por tribunales españoles es un esfuerzo más vano que el destino que, según el Capítulo XI de la Odisea de Homero, sufría Sísifo, condenado a empujar una enorme piedra a la cima de una altísima montaña para ver, instantes antes de alcanzar dicho punto, cómo la piedra caía y debía comenzar de nuevo el inútil trabajo. Es, sencillamente, imposible. Además, ello impediría avanzar a la jurisprudencia en la creación de «grupos de casos» y de «grupos de reglas» válidos para regular un problema tan complejo como la prueba del Derecho extranjero. En segundo lugar, esta postura es poco eficiente y poco práctica: el juez que tiene que aplicar Derecho extranjero debe resolver el caso y dictar una sentencia (art. 1.6 Cc.), por lo que le interesa saber qué intepretación debe dar al art. 281.2 LEC, y no si el precepto debe reformarse o no. Al juez español que debe aplicar un Derecho extranjero, las consideraciones de lege ferenda le pueden resultar sugerentes, pero seguro que le serán completamente inútiles. Por otro lado, confiar en las intenciones de reforma del legislador es como confiar en la lotería: puede ser que toque, pero lo más probable es que no toque y que la reforma no se lleve a cabo. Por ello, estas propuestas de lege ferenda relativas a la posible reforma del sistema vigente se quedan en estériles sugerencias doctrinales, vox clamantis in deserto que el legislador no parece propicio, afortunadamente, a escuchar. En tercer lugar, porque esta presunta «propuesta» es una falacia. En efecto: ante las posibles soluciones al problema de «qué hacer» si el Derecho extranjero no se prueba en el proceso, se opta por no dar ninguna solución. ¿Qué debe hacer el juez español que tiene que aplicar un Derecho extranjero si las partes no prueban el contenido del Derecho? Respuesta: pedir que se cambie la LEC (?). Pues bien, eso no es una respuesta. Eso es «eludir la cuestión», la famosa falacia a la que ARISTÓTELES dio el nombre de Ignoratio Elenchi («elusión del asunto») en su célebre obra Refutaciones Sofísticas. Se trata de la falacia preferida de los sujetos que desean evitar toda crítica, ya que al «no resolver la cuestión», su propuesta no puede ser analizada para ver si ofrece soluciones satisfactorias o no satisfactorias. Esta falacia consiste, por tanto, en evitar dar «respuestas directas» a «preguntas directas» y está conectada con otras falacias no menos profundas, como por ejemplo, con la célebre «falacia de los peces rojos» (se introducen elementos que distraen la atención del problema central: la reforma legal es «muy importante» y eso evita dar una respuesta directa al problema del quid juris en caso de falta de prueba del Derecho extranjero).

En fin, refutada la falacia, puede dirigirse la mirada a las propuestas realistas y auténticas que ofrecen soluciones útiles al problema que se suscita 
cuando el Derecho extranjero no ha sido alegado y/o probado; resulta preciso analizar las cinco tesis principales al respecto.

\section{A) TeSis DE LA INADMISIÓN DE LA DEMANDA}

39. Algunos autores indican que si las partes no alegan ni prueban el Derecho extranjero, la demanda debe ser inadmitida. Pero la inadmisión de la demanda sólo es posible en los casos previstos por las leyes procesales (STC 33/2002 de 11 febrero 2002). Y las leyes procesales españolas no contemplan como causa de rechazo de la demanda, la «falta de alegación y/o prueba del Derecho extranjero» (art. 403 LEC). Por tanto, esta primera tesis debe ser rechazada.

\section{B) TESIS DE LA «RETROACCIÓN DE ACTUACIONES» PROCESALES}

40. Esta tesis fue acogida por la SAP Baleares 9 octubre 2002. Consiste en que, cuando la parte no prueba el Derecho extranjero, procede, con arreglo al art. 429 LEC 2000, «retrotraer las actuaciones procesales» de modo que la parte presente su demanda con sujeción al Derecho extranjero aplicable, se practique prueba contradictoria sobre el Derecho extranjero y finalmente, se dicte nueva sentencia con arreglo al Derecho extranjero. La tesis es ingeniosa, pero también rechazable, porque el art. 429.1.II LEC está diseñado para casos en los que la prueba propuesta es insuficiente, y en este supuesto, la cuestión problemática es que la parte ha fundamentado jurídicamente su pretensión de modo incorrecto, no que la «prueba» presentada sea «insuficiente». El tribunal no tiene por qué hacer el trabajo de los abogados, que es fundamentar correctamente una pretensión desde el punto de vista jurídico y que son profesionales que cobran por su trabajo. Por ello, la tesis debe ser rechazada.

\section{C) Tesis de la aplicación de oficio del Derecho eXtranjero}

41. Algunos autores indican que si las partes no alegan ni prueban el Derecho extranjero, el tribunal debe aplicar de oficio el Derecho extranjero designado por la norma de conflicto española, y luego dicho tribunal debe «imputar el coste» de la prueba practicada, a la parte que debió probar el Derecho extranjero (S. Álvarez GonzÁlez, J. C. Fernández Rozas / S. SÁnCHEZ LoRenZo, L. CARballo PiÑEIRO ${ }^{23}$ ).

${ }^{23}$ S. Álvarez GonZÁlez, «La aplicación judicial del Derecho extranjero bajo la lupa constitucional», REDI, 2002, pp. 205-223; J. C. FERnÁNDEZ RoZAS / S. SÁNCHEZ LoRENZO,

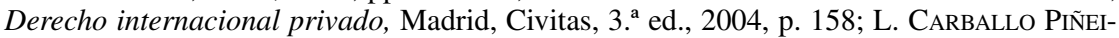
RO, «El carácter imperativo de la norma de conflicto y la prueba del Derecho extranjero, Una relectura en clave procesal y constitucional», AEDIP, núm.1, 2001, pp. 483-503, esp. p. 496. 
42. La tesis encaja a la perfección con el carácter imperativo de las normas de conflicto españolas (art. 12.6 Cc.). En efecto, con esta tesis, el Derecho aplicable al fondo del asunto no será, nunca, distinto de aquel designado por la norma de conflicto española. Algún autor ha afirmado que la tesis de «la aplicación de oficio de la ley extranjera, (...) optimiza los valores constitucionales y, precisamente por esa mayor potenciación, debe ser generalizada» (A. ESPINIELla MENÉNDEZ ${ }^{24}$ ). Y ¿qué argumentos se ofrecen para avalar tal afirmación? Pues ninguno. Simplemente se dice que las otras tesis rivales (la «aplicación sustitutiva de la Lex Fori» y la «desestimación de la demanda») son opciones que, como posibilidades en el marco legislativo (al margen de la Constitución) deben rechazarse porque la tesis de la aplicación de oficio del Derecho extranjero «optimiza los valores constitucionales». Pero cuidado: no se dice por qué optimiza los valores constitucionales, ni qué valores son ésos, ni por qué las otras tesis no optimizan dichos valores. Por ello, la afirmación de A. EsPinIELla MENÉNDEZ constituye una falacia: es la falacia de la «afirmación gratuita», también llamada falacia de «Ipsedixtismo» o «falacia de la aseveración». En efecto: toda persona que afirma algo contrae dos compromisos. Debe probar lo que afirma sin irse por las ramas y debe, a tal fin, aportar pruebas suficientes, argumentos convincentes al efecto. Pues bien, el autor citado ni prueba nada ni aporta argumento alguno que respalde su afirmación. Se limita a decir que la tesis que defiende es «la mejor» porque «optimiza los valores constitucionales». Esta afirmación revela una opinión personal. Pero dicha opinión no se acompaña de fundamentos. Y, por supuesto, aunque se ponga mucha vehemencia en la afirmación, el entusiasmo no convierte algo en verdadero. Y por más que se repita, tampoco ese algo, por muy repetido que sea, resulta ser más verdadero. No está de más recordar que el mismísmo Tribunal Constitucional (ATC 422/2004 de 4 noviembre 2004) indica que la tesis de la desestimación de la demanda es una solución perfectamente adaptada a la Constitución Española, «razonada y razonable». Claro que el autor citado en ningún momento cita el ATC 422/2004 de 4 noviembre 2004 (quizás porque el TC dice lo que algunos no quieren escuchar). Ahora bien: los hechos son tozudos. El ATC 422/2004 de 4 noviembre 2004 existe, está ahí (puede consultarse en $<$ www.tribunalconstitucional.es $>$ ). El aparato verbal de retórica utilizado por el autor citado no es más que un vestido de «pseudoprofundidad». Se realizan afirmaciones aparentemente grandilocuentes relacionadas con la «optimización de los valores constitucionales» y con el rechazo de «disquisiciones entre la naturaleza procesal o sustantiva del problema» y se emplean guarismos matemáticos en la argumentación jurídica. La utilización de toda esta parafernalia pseudoprofunda es una «cortina de humo» cuyos obje-

${ }^{24}$ A. ESPINIELla MENÉndeZ, «Nota a STC Sala 2. a núm. 172/2004 de 18 octubre 2004», REDI, 2005, vol. 57, pp. 344-349, esp. p. 346. 
tivos son bien claros: esconder al lector interesado en el tema datos muy relevantes (el ATC 422/2004 de 4 noviembre 2004 no existe para este autor), atacar la constitucionalidad de una tesis (tesis de la desestimación de la demanda), cuyo ajuste con la CE 1978 ha sido expresamente declarado por el TC en dicho Auto, y atacar la posición de los autores que, como los que firman este trabajo, defienden una solución al problema que es perfectamente legítima tanto en términos de legalidad ordinaria como en términos de «optimización de los valores constitucionales». Todo ello sin olvidar que «el Derecho no es aritmética» (M. VIRGós SORIANO ${ }^{25}$ ), por lo que «traducir a números» las argumentaciones jurídicas resulta profundamente inadecuado.

En el estadio actual del DIPr. español, la tesis de la aplicación de oficio del Derecho extranjero es una tesis equivocada. Y ello por varios motivos.

43. Primero. La tesis no respeta el «reparto de la carga de la prueba» realizado por el art. 282 LEC. En España, en el marco del proceso civil, las pruebas se practican «a instancia de parte». Lo dice el art. 282 LEC. Y este precepto se aplica, sin duda alguna, a la prueba del «Derecho extranjero». Es cierto que tal regla general experimenta ciertas inflexiones relativas a la prueba del Derecho extranjero, inflexiones a las que alude el art. 281.2 LEC («pudiendo valerse el tribunal de cuantos medios de averiguación estime necesarios para su aplicación [se refiere a la aplicación del Derecho extranjero]»). Pero la intervención del tribunal en este sentido, aunque puede ser «amplia» o «expansiva» no puede alterar el principio de base, en los «casos normales». De este modo, las pruebas (también la del Derecho extranjero) se practican cuando las proponen las partes, y no en caso contrario. El tribunal no puede ni debe relevar a las partes de lo que a éstas incumbe. Pero es que, además, esta tesis confunde las posibilidades del tribunal en cuanto a la «prueba del Derecho extranjero» y en cuanto a la «alegación del Derecho extranjero». Efectivamente: incluso aunque se interpretara el art. 281.2 LEC en un sentido de «máxima expansión» que permitiera al tribunal proceder a la prueba, no solicitada por las partes, del Derecho extranjero (interpretación que no parece compartible), ello no resuelve el problema, porque si una parte ha basado sus posiciones jurídicas en el Derecho sustantivo español cuando debía hacerlo con arreglo a un Derecho extranjero, el tribunal estaría «alterando» las posiciones jurídicas de las partes, estaría «corrigiendo los defectos jurídicos» de la demanda, y no simplemente supliendo problemas prácticos de «prueba» del Derecho extranjero. Es decir, el tribunal estaría alterando los «fundamentos jurídicos» presentados por la parte que debía haber fundado su pretensión en el Derecho extranjero (operación no permitida por el art. 281.2 LEC), algo sobre lo que se volverá más adelante.

${ }^{25}$ M. Virgós Soriano, «Las cosas y los derechos reales», en J. D. GonZález CAMpos Y OTROS, Derecho internacional privado parte especial, 6. ${ }^{\text {a }}$ ed. revisada, 1995, p. 270. 
El reparto de la carga de la prueba que lleva a cabo el art. 282 LEC diferencia al sistema español de DIPr. de otros sistemas extranjeros de Derecho internacional privado que parten del principio opuesto, esto es, que indican que la prueba del Derecho extranjero se llevará a cabo de oficio por el tribunal. En tal sentido, vid. art. 16 Ley federal suiza de Derecho internacional privado de 1987; art. 14 Ley italiana de Derecho internacional privado de 1995; arts. 3 y 4 Ley austríaca de Derecho internacional privado de 1978; art. 15.1 Código belga de Derecho internacional privado de 2004. Se puede discutir, por supuesto, si el «principio básico» seguido en Derecho internacional privado español es más o menos conveniente que el principio básico seguido en estos países. Pero no parece muy correcto discutir cuál ese principio básico en Derecho internacional privado español. En suma, en Derecho internacional privado español, el tribunal no tiene por qué hacer el trabajo de las partes asumiendo el coste económico, de recursos y de tiempo, que comporta la prueba de un Derecho extranjero, especialmente cuando los intereses en juego son «intereses particulares» (SAP Guipúzcoa 28 septiembre 2004).

44. Segundo. La tesis vulnera el art. 218.1.II LEC, y con ello, el principio de congruencia de la sentencia, el principio dispositivo, el principio de justicia rogada y la conformación del «objeto del proceso». En efecto, el tribunal no puede decidir el caso sobre «fundamentos de Derecho» distintos a los que las partes hayan hecho valer. Si las partes no invocan ni posteriormente prueban el Derecho extranjero cuando les corresponde hacerlo, el caso no puede fallarse con arreglo al Derecho extranjero, porque si así se hiciera, se vulneraría flagrantemente el art. 218.1.II LEC. En efecto, ¿por qué tiene el tribunal que decidir el caso sobre «fundamentos jurídicos» que no han sido esgrimidos por unas partes procesalmente «poco diligentes» asesoradas, por lo visto, por abogados que no saben fundamentar correctamente las pretensiones de sus clientes? Si las partes argumentan incorrectamente - lo que sucede cuando argumentan sobre el Derecho sustantivo español y no sobre el Derecho extranjero que debe regir el caso-, el tribunal no tiene por qué «hacer el trabajo» de una parte cuyos abogados no quieren o no saben fundamentar correctamente una pretensión jurídica. El art. 218.1.II LEC prohíbe expresamente una actuación del tribunal en dicho sentido. Y como se ha dicho antes, el art. 281.2 LEC puede servir de plataforma legal para potenciar una actitud más intervencionista del tribunal en orden a la «prueba procesal del Derecho extranjero», pero no puede servir de argumento para que el tribunal «rehaga» los planteamientos jurídicos de las partes.

45. Tercero. Es una tesis poco práctica, porque si el tribunal prueba el Derecho extranjero con la intención de «imputar su coste a las partes», nada impide al actor la «renuncia a la acción ejercitada» o al «derecho en que funde su pretensión» (art. 20.1 LEC), y nada impide tampoco al actor el «desistimiento» (art. 20.2 y 3 LEC), con lo que el tribunal habrá probado un Derecho extranjero pero no podrá imputar su «coste» a ninguna de las partes. 
46. Cuarto. Es una tesis que puede provocar indefensión y que, por tanto, puede vulnerar el art. $24 \mathrm{CE}$ y el derecho constitucional a la «tutela judicial efectiva». En efecto: si ambas partes argumentan sobre el Derecho español y el tribunal, sin embargo, falla con arreglo al Derecho extranjero, las partes pueden quedar jurídicamente «sorprendidas». Como escribe L. CARRILlo POZO, «la intempestiva aplicación de un ordenamiento que no es español puede provocar sorpresa y por ende indefensión en la otra parte» ${ }^{26}$. Las partes deben saber en qué términos se mueve el debate procesal. Y cuidado: el debate procesal lo fijan las partes, el demandante en su demanda y el demandado en su contestación a la demanda. El tribunal, por supuesto, debe fallar el caso sólo con arreglo a las normas jurídicas que sean «objetivamente aplicables». Pero no puede «dar la razón» al demandante o al demandado mediante la aplicación de «argumentos jurídicos» que las partes no hayan hecho valer en el proceso.

47. En suma, esta tesis no respeta el reparto de la carga de la prueba fijado en la LEC, vulnera el principio de congruencia de la sentencia, violenta indebidamente el principio dispositivo y el principio de Justicia rogada que rigen y vertebran el proceso civil, no respeta el principio de congruencia de la sentencia ni tampoco la conformación del objeto del proceso, raya en la indefensión de las partes y además, es una tesis es tan poco práctica, que los litigantes «avispados», que no son pocos, pueden burlarla con pasmosa facilidad.

\section{D) Tesis de la aplicación sustitutiva del Derecho material español}

48. La «tesis de la aplicación sustitutiva del Derecho material español» sostiene que si la parte argumenta, exclusivamente, basándose en el Derecho español, y no alega ni prueba el Derecho extranjero al que remite la norma de conflicto, es aplicable, entonces, el Derecho material español (Back To Lex Fori Rule).

49. La tesis se edifica sobre varios fundamentos, que son insistentemente remarcados por los muchos seguidores de esta tesis.

Primero. La Lex Fori presenta una «competencia general y residual» para regular «todo supuesto de Derecho privado». El argumento fue ya esgrimido hace más de cien años por el gran jurista francés E. BARTIN y fue seguido por el maestro galo H. BATIFFOL y por otros ilustres autores del vecino país transpirenaico ${ }^{27}$. Por ello, según esta tesis, ante la falta de la «regla espe-

${ }^{26}$ L. CARrillo Pozo, «Alegación y prueba del Derecho extranjero en el ámbito laboral y tutela judicial efectiva», Rev. Esp. Dcho. Trabajo, núm. 111, mayo-junio 2002, pp. 451473, esp. p. 467.

${ }^{27}$ E. BARTin, Principes de Droit international privé, París, Domat Montchrestien, 19301932-1935, p. 409 ; P. MAYER / V. Heuzé, Droit international privé, París, Montchrestien, 8. a ed., 2004, pp. 135-136 y 144-145 ; H. BATIFFol / P. LAGARDE, Droit international privé, vol. I, 8. a ed., París, LGDJ, 1993, pp. 563-567; Y. LoussouARn / P. Bourel / P. DE VAREI-

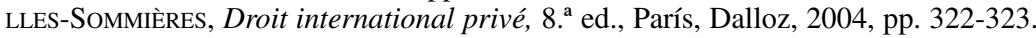


cial», —aplicación del Derecho extranjero-, se vuelve a la «regla general», que es la aplicación del Derecho del país cuyos tribunales conocen del asunto (Lex Fori).

Segundo. Si el Derecho extranjero no se alega ni prueba, debe aplicarse el Derecho sustantivo español porque sólo así se evita la «denegación de Justicia» y se proporciona una «respuesta sobre el fondo» al litigio. Por tanto, esta tesis respeta escrupulosamente el derecho a la «tutela judicial efectiva» (art. $24 \mathrm{CE}$ ).

Tercero. El Derecho extranjero es un «hecho procesal». No es «Derecho». Y no se puede considerar como «Derecho», porque si así fuera, se estarían aplicando, en España, los «mandatos soberanos» dictados por un legislador extranjero, lo que comportaría una lesión intolerable de la Soberanía española. Como el Derecho extranjero es un «hecho procesal», lo deben probar las partes interesadas. Y si no se alega ni se prueba el Derecho extranjero, éste «desaparece» del proceso: simplemente no existe. Por ello, el tribunal fallará el caso prescindiendo del «Derecho extranjero» (que se considera un «hecho no alegado al proceso»), es decir, fallará con arreglo al Derecho sustantivo español (Back To Lex Fori Rule).

50. Esta tesis es la más extendida en la práctica jurídica española. Al respecto pueden subrayarse varios datos.

En primer lugar, esta tesis es la preferida por la Sala Primera del TS. Esta Sala acogió la tesis que se comenta, ya antes de la promulgación del Código Civil en 1889. Y después de la promulgación del Código Civil en 1889, la Sala Primera del TS siguió sosteniendo la misma tesis. Y después de 1974, fecha en la que se introdujo en el Código Civil el art. 12.6.II, precepto que abordaba parcialmente el asunto, también siguió la Sala Primera del TS aferrada a su tesis tradicional. Aunque todavía la Sala Primera del TS no ha tenido ocasión de pronunciarse sobre la aplicación del hoy vigente art. 281.2 LEC 1/2000, dicha Sala Primera del TS ya ha dejado caer, obiter dicta, que el régimen recogido en el dicho precepto no altera para nada la solución que dicha Sala viene aplicando desde mediados del siglo XIX. Los pronunciamientos jurisprudenciales que siguen esta tesis son innumerables: vid. ad ex. STS 21 junio 1864, STS 20 marzo 1877, STS 13 enero 1885, STS 26 mayo 1887, STS 28 enero 1896, STS 7 noviembre 1896, STS 19 noviembre 1904, STS 1 febrero 1934, STS 9 enero 1936, STS 17 julio 1937, STS 29 septiembre 1956, STS 16 diciembre 1960, STS 30 junio 1962, STS 6 junio 1969, STS 5 noviembre 1971, STS 12 enero 1989, STS 11 mayo 1989, STS 21 junio 1989; STS 23 marzo 1994; STS 7 septiembre 1990; STS 25 enero 1999, STS 7 septiembre 1990, STS 10 diciembre 1990, STS 16 julio 1991, STS, 17 diciembre 1991, STS 23 octubre 1992, STS 31 diciembre 1994, STS 15 noviembre 1996, STS 25 enero 1999, STS 9 febrero 1999, STS 5 junio 2000, STS 13 diciembre 2000, STS 17 julio 2001, STS 5 marzo 2002, STS 29 diciembre 2003, STS 2 julio 2004, STS 10 junio 2005. Más de cien años con la misma tesis: bad habits die hard. 
En segundo lugar, esta tesis es seguida, en la actualidad, por muchas Audiencias Provinciales españolas. La razón radica en que, de este modo, las Audiencias evitan recursos de casación ante el TS. Los ejemplos son muy numerosos. Entre los más recientes, cabe citar: SAP Madrid 23 noviembre 2000, SAP Girona 19 mayo 2000, SAP Sevilla 9 enero 2002, SAP Castellón 22 noviembre 2002, SAP Girona 27 mayo 2002, SAP Barcelona 30 abril 2002, SAP Alicante 22 noviembre 2002, SAP Málaga 11 septiembre 2002, SAP Alicante 18 noviembre 2003, SAP Las Palmas 30 julio 2003, SAP SC Tenerife, Sec. 3. ${ }^{\text {, }} 28$ junio 2004, SAP Almería 28 junio 2004, SAP Tenerife 13 abril 2004, SAP Alicante 2 marzo 2004, SAP Barcelona 19 enero 2004, SAP Almería 28 junio 2004, Auto AP Vizcaya 25 junio 2004, SAP Vizcaya 13 mayo 2004, SAP Almería 9 noviembre 2004, SAP Barcelona 15 junio 2005, SAP Lleida 15 junio 2005, SAP Asturias 1 septiembre 2005, SAP Alicante 12 mayo 2005, STSJ Com. Valencia 16 mayo 2005, etc.

En tercer lugar, esta tesis es apoyada por ciertos autores, que defienden que el sistema español de Derecho internacional privado debe operar como un Fakultatives Kollisionsrecht o Facultative Choice-Of-Law System (M. Virgós Soriano / F. J. Garcimartín Alférez ${ }^{28}$ ): el Derecho extranjero al que remiten las normas de conflicto sólo se aplica si las partes lo hacen valer, lo alegan y lo prueban. Por tanto, tales partes son libres de «prescindir» de las normas de conflicto españolas (y consiguientemente son libres de «prescindir del Derecho extranjero»). Las partes pueden indicar al tribunal que desean que el litigio se rija por el Derecho sustantivo español. En el fondo, estos autores «flexibilizan» el sistema de Derecho internacional privado, porque la tesis del Facultative Choice-of-Law System resulta un «escape» muy oportuno para los casos en los que el punto de conexión de la norma de conflicto ofrece un resultado poco adaptado a las necesidades de los particulares. Ejemplo: el art. 107.2 Cc. indica que el divorcio contencioso entre dos cónyuges turcos debe regirse por la Ley turca. Pero si ninguno de los cónyuges está mínimamente interesado en la aplicación de la Ley turca, ¿qué sentido tiene obligar a las partes a alegar y probar el Derecho turco para obtener su divorcio en España? Ninguno. Con un Facultative Choice-of-Law System, las partes quedan «liberadas» de una norma de conflicto torpe y poco eficiente: las partes alegan el Derecho español y fundan en él sus pretensiones y nadie se acuerda del Derecho turco. Ello sucede en relación con normas de conflicto mal redactadas, normas de conflicto que siguen criterios erróneos de política legislativa, y que no prestan atención a los problemas reales de los particulares en el contexto internacional. El «ejemplo estrella» es el citado art. 107.2 Cc. (en su redacción dada por la Ley orgánica 11/2003, de 29 de septiembre, de medidas concretas en materia de seguridad ciudadana, violen-

${ }^{28}$ M. Virgós Soriano / F. J. Garcimartín AlfÉrez, Derecho procesal civil internacional. Litigación internacional, Civitas, Madrid, 2000, pp. 368-371. 
cia doméstica e integración social de los extranjeros, en BOE núm. 234 de 30 septiembre 2003), precepto que señala la Ley aplicable al divorcio y la separación judicial, un artículo que revela los muy escasos conocimientos del legislador sobre el Derecho internacional privado ${ }^{29}$.

51. Sin embargo, la «tesis de la aplicación sustitutiva del Derecho material español» es rechazable por varios motivos.

52. Primero. La tesis vulnera el «carácter imperativo» de las normas de conflicto recogido en el art. 12.6 Cc.: cuando un Derecho extranjero debe regular una controversia, tal Derecho es el «único Derecho aplicable», y el Derecho español nunca puede regular tal controversia.

53. Segundo. La tesis comporta una altísima inseguridad jurídica. Vulnera el art. 9 CE. Con esta tesis no se puede saber, a priori, cuál es el Derecho aplicable a una situación privada internacional (L. F. CARRILLO POZO ${ }^{30}$ ).

54. Tercero. La tesis favorece conductas estratégicas y antijurídicas de las partes, que, sabiendo que una situación se rige por un Derecho extranjero, invocan el Derecho español como aplicable. Ello es inaceptable, porque el «fundamento jurídico» de una pretensión es «objetivo», lo quieran o no las partes y digan lo que digan las partes en sus demandas o contestaciones, de modo que tal «fundamento jurídico» no puede ser «alterado» por mera conveniencia de las partes. Ejemplo: si procede la adquisición de propiedad por usucapión es porque así lo prevé un determinado precepto del Código Civil alemán, al que remite el art. 10. Cc. Pues bien: ese concreto precepto del Derecho alemán, y ninguno otro, es el «fundamento objetivo de la pretensión». Por tanto, no puede acogerse la pretensión de un sujeto que indica al tribunal, en su favor, la aplicación de otro precepto del Código civil español en vez del concreto precepto del Código civil alemán, que es el único precepto objetivamente aplicable al litigio.

55. Cuarto. No es cierto que el «Derecho Privado material interno español» presente una «vocación general» para regular todos los casos de Dere-

${ }^{29}$ A. L. Calvo Caravaca / J. Carrascosa González, Derecho internacional privado, vol. II, 6. ${ }^{\text {a }}$ ed., Ed. Comares, Granada, 2005, pp. 85-112; ID., «El divorcio internacional y el nuevo art. 107.2 del Código Civil», La Ley, 24 mayo 2004, pp. 1-9 y La Ley, 25 mayo 2004, pp. 1-7.; B. CAMPUZANo DíAZ, «Consideraciones acerca de la reforma del art. $107 \mathrm{Cc} . »$, en AA.VV., El Derecho de familia ante el siglo XXI: aspectos internacionales, Colex, Madrid, 2004, pp. 177-193; M. ${ }^{a}$ P. DiAgo DiAGo, «La nueva regulación española de las crisis matrimoniales ante el impacto de la multiculturalidad», en AA.VV., El Derecho de familia ante el siglo XXI: aspectos internacionales, Colex, Madrid, 2004, pp. 271-294.

${ }^{30}$ L. CARriLlo Pozo, «Alegación y prueba del Derecho extranjero en el ámbito laboral y tutela judicial efectiva», Rev. Esp. Dcho. Trabajo, núm. 111, mayo-junio 2002, pp. 451473; ID., «Una doctrina constitucional sobre alegación y prueba de la Ley extranjera», Aranzadi Social, 2003, núms.7-8, pp. 53-84. 
cho Privado. El Derecho Privado material español —el Derecho civil, mercantil y laboral español-, fue diseñado por el legislador para ser aplicado sólo en casos «internos» (Purely Internal Situations), no para ser aplicado en casos «internacionales» (Cases with Cross-Border Implications), por lo que el Derecho material interno español no constituye una «regla general» aplicable a «todo supuesto de Derecho Privado» ${ }^{31}$.

56. Quinto. No es cierto que, cuando el Derecho extranjero aplicable no ha sido alegado ni probado, la «única manera» de garantizar una «respuesta sobre el fondo del asunto» sea aplicar el Derecho sustantivo español. Esta afirmación es totalmente falsa. Como es evidente, la desestimación de una pretensión cuando ésta contiene un fundamento jurídico erróneo o inexistente, es una «auténtica respuesta sobre el fondo» que garantiza perfectamente la «tutela judicial efectiva» (art. $24 \mathrm{CE}$ ). $\mathrm{O}$ en otras palabras, tomadas de la doctrina del TC: una sentencia que desestima las pretensiones del actor, por estar erróneamente fundamentadas en Derecho, es una sentencia perfectamente «fundada en Derecho». Como expresa la STC 10/2000, de 17 de enero de 2000, «...lo relevante no es que las pretensiones de la parte se hayan desestimado, pues en multitud de ocasiones ha dicho este Tribunal que el derecho fundamental a la tutela judicial efectiva no garantiza un pronunciamiento acorde con las pretensiones de la parte, sino una resolución fundada en Derecho (...) Lo decisivo es que la desestimación de la pretensión de la parte sea la consecuencia de la previa conculcación por el propio órgano judicial de un derecho fundamental del perjudicado, encubriéndose tras una aparente resolución judicial fundada en Derecho una efectiva denegación de Justicia». En tal sentido, vid. también STC 55/1993, de 15 de febrero 1993, ATC 148/1999, de 14 de junio 1999, SSTC 1/1996, de 15 de enero 1996, STC 217/1998, de 16 de noviembre 1998, STC 183/1999, de 11 de octubre 1999. El ATC 422/2004 de 4 noviembre 2004 demuestra que esta tesis no es la única «constitucionalmente ajustada».

57. Sexto. No es cierto que la aplicación de un Derecho extranjero en España comporte un «atentado contra la Soberanía española». Este argumento es, hoy en día, como explica magistralmente H. MUIR-WATT ${ }^{32}$, totalmente insostenible: aplicar un Derecho extranjero en otro país en calidad de «Derecho», no lesiona en absoluto la Soberanía de ese otro país, pues el Derecho extranjero no es Derecho «vigente» en otro país, pues tal Derecho extranjero sólo «se aplica» en otro país. Este argumento, hoy, no convence, especial-

${ }^{31}$ A. L. Calvo Caravaca / J. Carrascosa González, Derecho internacional privado, vol. I, Ed. Comares, Granada, 7. ${ }^{\text {a }}$ ed., 2006, pp. 3-7.

${ }^{32}$ H. Muir-WatT, «Loi étrangère», Dalloz Droit international, 2. ${ }^{a}$ ed., 1998; A. L. CALvo Caravaca / J. Carrascosa González, Derecho internacional privado, volumen I, 7. ${ }^{a}$ ed., Comares, Granada, 2006, pp. 241-280. 
mente, cuando en la actualidad se admite que el Derecho internacional privado resuelve problemas atinentes al interés de los «particulares», no al interés de los «Estados».

58. En conclusión, esta tesis decimonónica genera inseguridad jurídica, no tiene soporte constitucional, es contraria al principio dispositivo que inspira el proceso civil y laboral, propicia las maniobras antijurídicas, desconoce el carácter y función de las normas de conflicto, y sus presuntos «argumentos de fondo» son falsos, vacíos, caducos, trasnochados, obsoletos y en muchas ocasiones, constituyen puros sofismas y dogmáticas declaraciones de principios que no se corresponden con la realidad.

\section{E) TESIS DE LA DESESTIMACIÓN DE LA DEMANDA}

a) Exposición y fundamentos de la tesis

59. Esta tesis indica que, en el caso de un litigio que debe regirse por un Derecho extranjero, si una parte argumenta, exclusivamente, sobre el Derecho español y no invoca ni prueba el Derecho extranjero, el tribunal debe dictar una sentencia que desestime la pretensión de dicha parte. Esta tesis es la más correcta, por varios motivos.

60. Primero. Porque en circunstancias normales (especialmente en presencia de normas de conflicto tradicionales «meramente localizadoras»), el tribunal no puede aplicar de oficio el Derecho extranjero (vid. art. 282 y 218.1.II LEC), pero tampoco puede aplicar el Derecho sustantivo español (se lo prohibe el art. 12.6 Cc., precepto que, debe recordarse, sigue plenamente vigente).

61. Segundo. Porque el art. 218.1.II LEC indica que el tribunal no puede resolver el caso acudiendo a «fundamentos de Derecho distintos a los que las partes han querido hacer valer»: si una parte argumenta su pretensión sobre el Derecho español y el Derecho aplicable era un Derecho extranjero, el tribunal no debe hacer el trabajo que corresponde al abogado de dicha parte (trabajo que dicho abogado no hizo correctamente). Este aspecto merece un análisis más detallado que se lleva a cabo más adelante.

62. Tercero. Porque de este modo se evita la «maniobra antijurídica» de permitir que las partes hagan aplicable el Derecho español «a voluntad» cuando el caso debe regirse por un Derecho extranjero (STSJ Canarias 19 septiembre 2003, STSJ Madrid Social 31 mayo 2004). Ello debe ser evitado, porque el fundamento jurídico de toda pretensión es «objetivo»: las partes no lo pueden «alterar». Ejemplo: si un divorcio contencioso entre cónyuges armenios se rige por el Derecho armenio (art. 107.2 Cc.), el fundamento jurídico de la demanda de divorcio debe encontrarse en el Derecho armenio, y nunca podrá sustentarse dicha demanda de divorcio en el Derecho español, 
aunque lo quieran las partes o exclusivamente el demandante, y se lo supliquen al tribunal y aunque resulte «más cómodo» tanto para las partes como para el tribunal. Las partes no pueden «alterar el fundamento objetivo» de la demanda de divorcio. Y el tribunal tampoco. Como muy correctamente expresó la STS, Social, 19 febrero 1990, la «falta de alegación y prueba [de la Ley extranjera] no puede conducir (...) a la aplicación de la ley española, pues ello equivaldría al absurdo de sancionar la omisión de prueba deliberadamente querida de la norma extranjera, con la aplicación de la ley española, cuando se considerase que ésta era más beneficiosa». También abunda en esta idea, con corrección extrema, la STS, Social, 22 mayo 2001: «lo que sucede es que, si el Derecho aplicable es el extranjero, la parte que formula la pretensión tiene que alegar y probar ese Derecho para que su pretensión sea acogida».

63. Cuarto. Porque esta tesis refuerza la seguridad jurídica (art. 9.3 CE): el Derecho aplicable nunca será un Derecho distinto al Derecho designado por la norma de conflicto. Ejemplo: si un contrato de trabajo a desarrollar en Inglaterra se rige por el Derecho inglés, conforme al cual se han pagado los salarios y se han prestado los servicios, resulta obvio, lógico, congruente y justo que si se plantea ante los tribunales españoles un pleito por presunto «despido improcedente» del trabajador, la cuestión litigiosa se decida con arreglo al Derecho inglés y no con arreglo a ningún otro ordenamiento jurídico estatal. Aplicar el Derecho español a este pleito rompería toda la seguridad jurídica que las normas de conflicto proporcionan.

64. Quinto. Porque esta tesis no supone ninguna «denegación de Justicia» ni por tanto, tampoco supone ninguna vulneración de la «tutela judicial efectiva» recogida en el art. 24 CE. En efecto: la desestimación de la demanda (Dismissal of the Case) es, en estos casos, una «respuesta motivada» a la pretensión de las partes. Únicamente significa que la demanda no ha sido correctamente planteada desde un punto de vista jurídico: las partes debían fundamentar sus posiciones en el Derecho extranjero y no en el Derecho español. Por tanto, la desestimación de la demanda es, en estos casos, una respuesta plenamente fundada y motivada, pues toda demanda cuyo fundamento jurídico sea irreal, inexistente o incorrecto, debe ser desestimada (ATC 422/2004 de 4 noviembre 2004 y Voto Particular STS, Social, 4 noviembre 2004). El TC indica, expresamente, que la «desestimación de una pretensión» cuando ésta se construye sobre un fundamento jurídico equivocado, irreal, erróneo o inexistente, es una «respuesta sobre el fondo» que encaja de modo perfecto con la «tutela judicial efectiva» exigida por el art. 24 CE. Es decir: una sentencia que desestima las pretensiones de las partes, por estar tales pretensiones erróneamente construidas en Derecho, es una sentencia «fundada en Derecho» (vid. STC 10//2000, de 17 de enero de 2000, STC 55/1993, de 15 de febrero 1993, ATC 148/1999, de 14 de junio 1999, SSTC 1/1996, de 15 de enero 1996, STC 217/1998, de 16 de noviem- 
bre 1998, STC 183/1999, de 11 de octubre 1999). Este aspecto será tratado más adelante con mayor detalle.

65. Una vez desestimada la demanda, se abre un profundo interrogante: ¿debe permitirse que el actor reitere su misma pretensión pero con una fundamentación jurídica basada ahora en un Derecho extranjero? La cuestión es muy dudosa porque el art. 400 LEC se presta a diversas interpretaciones. Parece aconsejable no «cerrar la puerta» totalmente a un nuevo proceso, de modo que, una vez desestimada la demanda incorrectamente fundamentada (se alegó y se fundamentó en Derecho español, Derecho que no puede aplicarse al caso), el actor puede volver a instar su pretensión fundándose en el Derecho extranjero aplicable según las normas de conflicto españolas. El art. 400 LEC no debería impedir «volver a plantear la cuestión» en este caso, porque al cambiar los «fundamentos jurídicos» de la demanda, se altera la «causa de pedir» y el «objeto del proceso». Por ello, la «cosa juzgada» del primer pleito no debería impedir volver a plantear un segundo pleito con un objeto diferente, como indica la STC 177/1985 de 18 diciembre 1985, pues en dicho caso, se altera el fundamento jurídico que sustenta la acción ejercitada, de modo que la causa petendi es ahora distinta. Así lo admite expresamente, con fundados argumentos, la SAP Castellón 7 abril 2005.

66. Esta tesis de la «desestimación de la demanda» cuenta con varios apoyos en la práctica española de Derecho internacional privado.

En primer lugar, ha sido una tesis defendida por numerosos tribunales inferiores, antes y después del vigente art. 281.2 LEC: SAP Bilbao 31 junio 1991, SAP Alicante, Sec. 4. ${ }^{\text {a }} 4$ octubre 1995, SAP Murcia 11 diciembre 1995, SAP Málaga 17 mayo 1995, STSJ Madrid Social 7 julio 1997, SAP Barcelona 15 septiembre 1998, SAP Alicante 27 noviembre 1998, SAP Madrid 28 septiembre 2000, SAP Valencia 3 febrero 1999, SAP Guadalajara 13 mayo 2000, SAP Castellón 23 abril 2002, STSJ Madrid Social 11 diciembre 2002, STSJ Galicia Social 31 octubre 2002, STSJ Madrid Social 31 mayo 2002, SJSocial Com. Madrid 11 noviembre 2002, STSJ Madrid 27 mayo 2002, SAP Madrid 26 marzo 2003, STSJ Canarias 19 septiembre 2003, SJS Com. Madrid 29 octubre 2003; SAP Barcelona 10 mayo 2004, SAP SC Tenerife, Sec. 4. ${ }^{\text {a }}, 28$ junio 2004, SAP Vizcaya 6 abril 2004, SAP Castellón 7 abril 2005.

En segundo lugar, es la tesis que defendió la Sala de lo Social del TS desde 2001 (STS, Social, 22 mayo 2001 y STS, Social, 25 mayo 2001). Este dato reviste una importancia crucial, porque, por primera vez en la Historia del Derecho internacional privado en España, una Sección del TS se alejó radicalmente de la caduca y decimonónica tesis centenaria seguida con ojos cerrados por la Sala Primera del TS («aplicación sustitutiva del Derecho material español»). Por desgracia, la STS, Social, 4 noviembre 2004, vuelve atrás y abandona dicha jurisprudencia, inclinándose, erróneamente, a favor de la tesis de la «aplicación subsidiaria del Derecho español», debido a una 
equivocada y sesgada lectura de la jurisprudencia del TC. La mencionada sentencia cuenta con dos votos particulares, ambos muy acertados, cuya lectura constituye un deleite para todo jurista y que ponen en cuarentena el fallo de la citada STS, Social, 4 noviembre 2004. Tales votos particulares demuestran, con meridiana claridad, que el fallo de la STS, Social, 4 noviembre 2004, carece de todo sustento legal, ya que se apoya en meros «argumentos de autoridad» (la solución correcta es la aplicación sustitutiva del Derecho español, pero no porque sea la «más ajustada a Derecho», sino simplemente, «porque lo dice el TC»), argumentos de autoridad que, además, son totalmente falsos (el TC no afirma lo que la STS, Social, 4 noviembre 2004, dice que el TC afirma: donde hay molinos de viento, la Sala de lo Social del TS ve gigantes). Esta actitud de «marcha atrás» en la jurisprudencia de la Sala de lo Social del TS se explica por el temor de dicha Sala a ser censurada por un futuro pronunciamiento del TC (la Sala de lo Social del TS «corrige» su anterior y acertada doctrina por temor a ser «desautorizada» en el futuro por el TC). Es un argumentum ad baculum «preventivo», otro sofisma tan falaz como el «argumento de autoridad».

En tercer lugar, esta tesis fue apoyada por el Ministerio Fiscal en el caso resuelto por la STC 172/2004 de 18 octubre 2004 y por el ATC 422/2004 de 4 noviembre 2004, que expresamente defendió el ajuste constitucional de esta tesis.

En cuarto lugar, es una tesis defendida, desde 2000, por A. L. Calvo CARAVACA / J. Carrascosa GonZÁlez ${ }^{33}$ y posteriormente por P. AbarCa JUNCO / M. GÓMEZ JENE ${ }^{34}$.

En quinto lugar, ha sido una tesis defendida en EE.UU. desde hace años: Crosby vs. Cuba Railroad Co. (1912), Walton vs. Arabian American Oil Company (1956), y fue también seguida en el pasado, en ciertos litigios, en Francia (regla Latour-Thinet), Suecia y Japón.

b) La tesis de desestimación de la demanda y la tutela judicial efectiva

67. La tesis de la «desestimación de la demanda» ha sido acusada de vulnerar el art. 24 CE y la «tutela judicial efectiva». Dicha acusación es total-

${ }^{33}$ A. L. Calvo Caravaca / J. Carrascosa González, «Aplicación del Derecho extranjero en España y la nueva LEC», Tribunales de Justicia, nov. 2000, n. 11, pp. 1155-1170; ID., «Normas de conflicto, aplicación del Derecho extranjero en España y nueva LEC», Anuario Español DIP, núm. 1, 2001, pp. 215-237; ID., «El Derecho extranjero y el TS: la Sala de lo Social contraataca», Anuario Español DIP, 2002, pp. 103-114; ID., Derecho internacional privado, volumen I, 5. ${ }^{\text {a }}$ ed. Comares, Granada, 2004, p. 277; ID., «La prueba del derecho extranjero en la nueva Ley española de Enjuiciamiento Civil 1/2000», La Ley, 2005, núm. 6178 de 28 enero 2005, pp. 1-7; ID., «The Proof of Foreign Law in the New Spanish Civil Procedure Code 1/2000», IPRax, 2005-2, pp. 170 ss.

${ }^{34}$ P. AbARCa Junco / M. Gómez JenE, «Alegación y prueba del Derecho extranjero en el procedimiento laboral», Rev. Esp. Der. Trabajo, sept.-oct. 2003, núm.119, pp. 713-737. 
mente infundada e injusta. En efecto: una sentencia que indica que la demanda o la pretensión jurídica debe ser «desestimada» constituye, sin duda ninguna, una «respuesta de fondo» al litigio (exigencia derivada del art. $24 \mathrm{CE}$ ). «Denegar la pretensión» es un modo plenamente correcto de «responder sobre el fondo», de «resolver el litigio» en Derecho. Optar por la «desestimación de la demanda» es una «respuesta de fondo» que respeta la «tutela judicial efectiva». Y aún hay más: es absolutamente necesario optar por la desestimación de la demanda cuando ésta no ha sido correctamente fundada, es decir, cuando los fundamentos jurídicos de la demanda son equivocados. Y cuando una parte alega y funda su demanda en el Derecho español cuando es claro, evidente, aceptado e indiscutido que el litigio se rige por un Derecho extranjero, dicha parte ha fundamentado incorrectamente su demanda: el tribunal está obligado a desestimar su pretensión porque ésta no ha sido correctamente argumentada desde un punto de vista jurídico. En tal caso, la «desestimación de la demanda» es una solución en perfecta «sintonía constitucional»: es una respuesta motivada y razonada, no arbitraria, y fundada en Derecho, y precisamente por ello, es una respuesta que satisface la «tutela judicial efectiva». Estos aspectos han sido tratados con todo rigor y gran brillantez por L. CARRILLO POZO. Este autor indica, con pleno acierto, que esta tesis «resulta impecable bajo el prisma de la constitucionali$d a d »^{35}$, porque si la parte ha planteado incorrectamente su pretensión, no puede esperar que, en tal caso, el tribunal dicte «una sentencia que le dé la razón» ${ }^{36}$. Por otro lado, la necesidad de fundar la pretensión en un Derecho extranjero no constituye ningún «presupuesto procesal» ni ningún «presupuesto de la acción». Fundar la pretensión en un Derecho extranjero cuando tal Derecho extranjero es el Derecho que objetivamente rige la controversia, es sólo «condición necesaria» para poder obtener una sentencia favorable. En los casos regidos por un Derecho extranjero, una pretensión no construida sobre tal Derecho extranjero conduce irremediablemente a la desestimación de la pretensión. E igualmente la falta de prueba de la legislación extranjera aplicable al fondo de litigio impide pronunciarse a los tribunales españoles y conduce inexorablemente a la desestimación de la pretensión.

El ATC 422/2004 de 4 noviembre 2004 bendice la constitucionalidad de la tesis de la desestimación de la demanda y deja muy clara su plena, total y perfecta sintonía con la «tutela judicial efectiva». Resulta útil y necesario recordar el caso que dio lugar al ATC 422/2004 de 4 noviembre 2004: el

${ }^{35}$ L. CARrillo Pozo, «Alegación y prueba del Derecho extranjero en el ámbito laboral y tutela judicial efectiva», Rev. Esp. Dcho. Trabajo, núm. 111, mayo-junio 2002, pp. 451473, esp. p. 455.

${ }^{36}$ L. CARRILlo Pozo, «Alegación y prueba del Derecho extranjero en el ámbito laboral y tutela judicial efectiva», Rev. Esp. Dcho. Trabajo, núm. 111, mayo-junio 2002, pp. 451473, esp. p. 471. 
demandante, de nacionalidad italiana, trabajó para la Embajada de España en Turquía desde 1952 como auxiliar, oficial, Vicecanciller y Canciller, hasta que dejó de prestar sus servicios al cumplir los setenta años. Fue entonces cuando reclamó su derecho a percibir una pensión de jubilación de la Seguridad Social española. El Derecho turco regía la cuestión como Ley del país de prestación habitual de los servicios. Pues bien, el Derecho turco no fue alegado ni probado por el demandante. Por ello, las sentencias de instancia desestimaron la pretensión y no aplicaron el Derecho español como «sustituto de la Ley extranjera» (Ley turca). El demandante, que pretendía la aplicación de la Ley sustantiva española ante la falta de prueba de la Ley turca, interpuso recurso de amparo ante el TC por presunta vulneración de la tutela judicial efectiva (art. $24 \mathrm{CE}$ ). Pues bien: el TC indica, con apoyo en el Ministerio Fiscal, que la desestimación de la demanda, solución acordada por los tribunales ordinarios, fue una respuesta constitucionalmente impecable: «aplicando la anterior doctrina al caso de autos, resulta inadmisible la lesión del derecho a la tutela judicial efectiva (art. 24.1 CE) alegado, toda vez que las resoluciones recurridas contienen un razonamiento que constituye, lógica y jurídicamente, suficiente motivación de la decisión adoptada, al permitir conocer que su ratio decidendi ha sido la falta de acreditación por la parte demandante del contenido de la legislación extranjera, aplicable al caso conforme al art. 10.6 Cc. por ser el lugar de la prestación de servicios del demandante, y en la que, además, se había fundado jurídicamente la pretensión esgrimida. Tal y como mantiene el Ministerio Fiscal, el rechazo de las resoluciones judiciales discutidas a aplicar la legislación española ante la falta de prueba por el demandante del Derecho extranjero, no constituye una denegación injustificada del derecho a la tutela judicial efectiva, sino una aplicación razonada y razonable de la legalidad ordinaria aplicable al caso. De modo que la simple disconformidad del recurrente con el razonamiento judicial, con su corrección o acierto, o el hecho de que la decisión a la que el mismo conduzca sea contraria a las pretensiones del recurrente, no implica lesión alguna del derecho fundamental que protege el art. 24.1 CE, ni, como tantas veces se ha dicho, permite a este Tribunal su revisión cual si de una nueva y superior instancia judicial se tratase (por todas, entre las más recientes, STC 76/2004, de 26 de abril de 2004 F. 3) .... No cabe, por tanto, apreciar la lesión del derecho a la igualdad ante la Ley, al constituir su queja, también en este caso, una mera disconformidad con la decisión judicial, razonada y razonable, de no aplicar subsidiariamente la legislación laboral española ante la falta de prueba del Derecho extranjero».

c) La tesis de la desestimación de la demanda y el art. 218.1.II LEC.

68. La incidencia del art. 218.1.II LEC en la alegación y prueba del Derecho extranjero es crucial. El texto de esta disposición indica que «[e]l tribunal, sin apartarse de la causa de pedir acudiendo a fundamentos de 
hecho o de Derecho distintos de los que las partes hayan querido hacer valer, resolverá conforme a las normas aplicables al caso, aunque no hayan sido acertadamente citadas o alegadas por los litigantes». Como explica I. TAPIA FERNÁNDEZ ${ }^{37}$, el tribunal no puede, a la hora de dictar sentencia, apartarse de la «causa de pedir» o causa petendi. En la LEC 1/2000, la «causa de pedir» está compuesta por dos elementos: a) el «elemento fáctico» (los «hechos»); b) el «elemento jurídico (los «fundamentos de derecho» realizados por los litigantes). La doctrina entiende que el «elemento jurídico» de la causa de pedir está compuesto, a su vez, por dos «factores»: a) el «fundamento jurídico de la pretensión» (es el «razonamiento jurídico» realizado por la parte); b) la «fundamentación jurídica» esgrimida por el litigante (el «soporte normativo» o conjunto de concretas normas jurídicas que, en opinión del litigante, son aplicables al caso y que apoyan su «razonamiento jurídico»). El tribunal está vinculado, sin duda, por el «fundamento jurídico de la pretensión» (por el «razonamiento jurídico») esgrimido por el actor. Si éste comete un error y esgrime un «fundamento jurídico» o «razonamiento jurídico» incorrecto, el tribunal no puede ni debe remediar dicho error. El tribunal está obligado, en tal caso, a dictar sentencia desestimatoria de la pretensión. El tribunal ni puede ni debe «corregir» a las partes si éstas aciertan en el «fundamento jurídico de la pretensión» pero se equivocan totalmente en lo que respecta al «soporte normativo» de tal fundamento. Por supuesto, tampoco el tribunal puede ni debe «corregir» a las partes si el «fundamento jurídico» de la pretensión es incorrecto y el «soporte jurídico» esgrimido también es incorrecto. El lugar que el principio jura novit curia ocupa en esta segunda tesis es diferente: el tribunal puede y debe corregir meros «errores materiales de las partes», tales como haber citado incorrectamente el tenor literal de un precepto, haber alegado un precepto cuando resulta claro que se quería alegar otro, cuando se cita un principio general del Derecho con un nombre equivocado, cuando se alegan normas de pertinente aplicación junto con normas inaplicables al caso, todas juntas y revueltas, siempre que se pueda extraer el «soporte jurídico principal» en el que se basa la parte, etc. El poder del tribunal para corregir «errores meramente materiales» cometidos por las partes se extrae de la letra del art. 218.1.II LEC, que sólo autoriza la intervención del tribunal cuando las partes han alegado las correctas «normas aplicables al caso», pero no lo han hecho «acertadamente». Es decir, no citar o alegar «acertadamente» las normas aplicables significa que se han citado y alegado las normas verdaderamente aplicables al supuesto, pero ello no se ha hecho «con exhaustividad y completa precisión» (A. DE la Oliva SANTos / I. DíEZ-PiCAZo GimÉnEZ ${ }^{38}$ ).

${ }^{37}$ I. TAPIA FERnÁNDEZ, El objeto del proceso. Alegaciones, sentencia cosa juzgada, Ed. La Ley, Madrid, 2000, pp. 116-118.

38 A. De la Oliva Santos / I. Díez-Picazo Giménez, Derecho procesal civil. El proceso

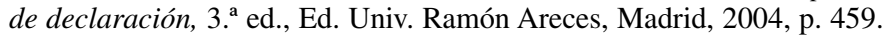


Este es el alcance justo y cabal del principio jura novit curia: el Derecho español no debe ser probado por las partes ni por el tribunal y el tribunal debe aplicar el Derecho objetivamente aplicable al supuesto, pero sin apartarse de la «causa de pedir» esgrimida por las partes. Por tanto, el tribunal no puede «sustituir la norma o conjunto de normas positivas en que, por lo que el litigante ha expuesto y pedido, se basa explícita o implícitamente la pretensión de obtener una concreta tutela jurisdiccional, por norma o normas distintas, no alegadas por ninguna de las partes» (A. DE LA OLIVA SANTOS / I. DíEZ-PicAzo GimÉnEz ${ }^{39}$ ). Por ello, se equivocan gravemente los autores, como A. EsPINIELla MENÉNDEZ, que afirman que «las normas jurídicas no aportan nada a la identificación del objeto procesal» y que «el cambio de la ley aplicable no altera la causa» ${ }^{40}$. Naturalmente que un cambio de la ley aplicable supone un cambio radical en la causa petendi. Basta comprender, como explica la doctrina procesalista citada, que el «elemento jurídico (los «fundamentos de derecho» realizados por los litigantes) de la causa petendi está compuesto por dos factores: el «razonamiento jurídico» realizado por las partes y el «soporte normativo» o conjunto de concretas normas jurídicas en las que las partes se apoyan. Es evidente que si se cambia el «soporte normativo» esgrimido a través de un cambio de Ley aplicable, la causa petendi cambia. Sostener lo contrario denota carencias jurídicas preocupantes.

69. La proyección del art. 218.1.II LEC en los litigios regidos por un Derecho extranjero produce consecuencias poderosas e interesantes.

Primera consecuencia. Si una parte fundamenta jurídicamente su pretensión en el Derecho sustantivo español y no en el Derecho extranjero que debe, según las normas de conflicto españolas, regir el supuesto, el art. 218.1.II LEC entra en acción. En la inmensa mayoría de estos casos, el «fundamento jurídico» será equivocado y el «soporte jurídico» alegado será erróneo. Por tanto, el tribunal español debe desestimar su pretensión. Equivocarse en el «Derecho estatal aplicable» al supuesto no es un mero «error material» que el tribunal puede o debe «corregir» en virtud del principio jura novit curia. Un error flagrante en el «razonamiento jurídico»y en el «soporte jurídico» conduce inexorablemente a la desestimación de la pretensión. O en las palabras utilizadas por L. CARRILlo Pozo, cuando un pleito se rige por un Derecho extranjero, «la alegación del Derecho extranjero aplicable según la norma de conflicto española es imperativa, condición para la acogida de las pretensiones del demandante» y además, «sin alega-

${ }^{39}$ A. De la Oliva Santos / I. Díez-Picazo Giménez, Derecho procesal civil. El proceso de declaración, 3. a ed., Ed. Univ. Ramón Areces, Madrid, 2004, pp. 456-459, esp, p. 459.

${ }^{40}$ A. EsPiniella MenÉndeZ, «Nota a STC, Sala Segunda, núm. 172/2004, de 18 de octubre», en REDI, 2005-I, vol. 57, pp. 344-349. 
ción del Derecho extranjero aplicable las pretensiones del demandante se desestimarán siempre» ${ }^{41}$.

Segunda consecuencia. Los supuestos en los que el «razonamiento jurídico» sea «correcto» y el «soporte jurídico» sea «incorrecto» (porque la pretensión se fundamentó en Derecho español cuando debía haberse fundamentado en un Derecho extranjero) son rarísimos. En la práctica puede decirse que estos casos serán inexistentes. En efecto: para que el «razonamiento jurídico» sea correcto, éste tendría que ser la consecuencia jurídica que el Derecho extranjero, aplicable al caso, anuda a unos determinados hechos, lo que no se producirá si se fundamenta la pretensión en el Derecho español cuando es aplicable el Derecho extranjero. Además, si la parte fundamenta su pretensión en el Derecho español es porque sabe que el Derecho extranjero no ampara su «fundamento jurídico». Pero incluso aun cuando se produjera este extrañísimo supuesto («razonamiento jurídico» correcto, pero «soporte jurídico» incorrecto), lo más ajustado a la letra y espíritu del art. 218.1.II LEC es desestimar la pretensión. El principio jura novit curia no debe activarse en estos casos, porque equivocarse en el «Derecho estatal aplicable» no es un «mero error material» padecido por la parte, de modo que el tribunal no debe ni puede «corregirlo».

Tercera consecuencia. Con la desestimación de la demanda se evita beneficiar a partes y abogados que no realizan correctamente su trabajo (el abogado redacta una demanda horrenda: no puede esperar que el tribunal haga valer argumentos jurídicos y preceptos legales que el mismo abogado no ha sabido ni ha querido introducir en el proceso), se protege la imperatividad de la norma de conflicto (evitando el zapping legal al que ciertos individuos son tan aficionados, de modo que un pleito regido por un Derecho extranjero nunca será resuelto con arreglo al Derecho español) y se salvaguarda la tutela judicial efectiva de la otra parte (que sólo estará obligada a defenderse contra los «soportes jurídicos» que han sido efectivamente esgrimidos contra ella por la parte contraria, pues el tribunal debe operar en el marco de los términos del debate procesal suscitado por las partes).

\section{F) La Constitución y la falta de ALEgación y PRUEBa DEL DeRecho EXTRANJERO}

70. La Constitución española no contiene ninguna regla, norma o principio que indique cuál es la solución jurídica al caso en el que un Derecho extranjero que rige el fondo del asunto, no ha sido alegado y probado por las

${ }^{41}$ L. CARrillo Pozo, «Alegación y prueba del Derecho extranjero en el ámbito laboral y tutela judicial efectiva», Rev. Esp. Dcho. Trabajo, núm. 111, mayo-junio 2002, pp. 451473, esp. p. 473; ID., «Una doctrina constitucional sobre alegación y prueba de la Ley extranjera», Ar. Social, 2003, núms.7-8, pp. 53-84. 
partes. Ni expresa ni implícita (L. CARRILlo PozO ${ }^{42}$ ). La Constitución española sí contiene, por supuesto, determinados preceptos que presentan un «alcance general» para todo el Derecho privado, lo que engloba, naturalmente, al Derecho internacional privado, que como es sabido, es Derecho privado. Entre tales principios, algunos pueden ser utilizados para averiguar qué tesis de entre las tesis antes vertidas supera el «test de ajuste constitucional». En concreto, el principio de «seguridad jurídica», la «interdicción de la arbitrariedad de los poderes públicos» y el derecho a la «tutela judicial efectiva» conforman los «parámetros constitucionales relevantes» para dilucidar la adecuación constitucional de las tesis en conflicto.

71. Haciendo escala en el derecho a la «tutela judicial efectiva», de tal derecho deriva la exigencia siguiente: toda persona tiene derecho a una «respuesta de fondo», razonada en Derecho, sobre su pretensión ejercitada ante los tribunales españoles. Por tanto, la tesis que se prefiera sobre la cuestión de qué hacer ante un caso en el que el demandante funda su pretensión en el Derecho español cuando el caso debe regularse por un Derecho extranjero, debe satisfacer las exigencias derivadas del derecho de «tutela judicial efectiva» recogido en el art. $24 \mathrm{CE}$. Cualquier solución que se ofrezca a la cuestión debatida debe estar, en todo caso, jurídicamente fundada, motivada y ser razonable y «no arbitraria» (STC 10/2000, de 17 de enero de 2000). Pero el derecho fundamental a la tutela judicial efectiva no implica el derecho de la parte a obtener un "pronunciamiento acorde con las pretensiones de la parte», sino el derecho a obtener «una resolución fundada en Derecho» (STC 55/1993, de 15 de febrero 1993, ATC 148/1999, de 14 de junio 1999, STC 10/2000, de 17 de enero de 2000, STC 1/1996, de 15 de enero 1996, STC 217/1998, de 16 de noviembre 1998, STC 183/1999, de 11 de octubre 1999).

72. Pues bien: examinadas detenidamente, la tesis de la «aplicación sustitutiva del Derecho sustantivo español», la tesis de la «aplicación de oficio del Derecho extranjero» y la tesis de la «desestimación de la demanda» cumplen, las tres, con el derecho a la «tutela judicial efectiva». Las tres tesis proporcionan una respuesta «fundada en Derecho» a los casos en los que el Derecho extranjero aplicable al litigio no ha sido alegado ni probado. Las tres tesis superan el «test de ajuste constitucional». Por tanto, resulta que el debate entre las tres tesis antes citadas y la preferencia por una de las tres tesis en conflicto son cuestiones situadas «más allá del ajuste constitucional» (no «al margen del ajuste constitucional»). En otras palabras: visto que las tres tesis encajan con el art. $24 \mathrm{CE}$ (el ajuste constitucional es necesario

${ }^{42}$ L. CARrillo Pozo, «Alegación y prueba del Derecho extranjero en el ámbito laboral y tutela judicial efectiva», Rev. Esp. Dcho. Trabajo, núm. 111, mayo-junio 2002, pp. 451473, esp. p. 465; ID., «Una doctrina constitucional sobre alegación y prueba de la Ley extranjera», Ar. Social, 2003, núms.7-8, pp. 53-84. 
siempre, pero se cumple en relación con las tres tesis enfrentadas), la preferencia por una de las tres tesis resulta ser una cuestión de «legalidad ordinaria» (L. CARRILlo POZO ${ }^{43}$ ). Es, así, el legislador, y en su caso, también los tribunales, los que tienen que decidir qué tesis es preferible. En consecuencia, el TC nada tiene que decir sobre el tema. Y si el TC se pronuncia al respecto - cosa que no ha hecho, pese a lo que erróneamente sostienen algunos autores y ciertas sentencias-, ello no vinculará a los tribunales, porque en tal caso, el TC no está operando como «intérprete supremo de la Constitución» (Voto particular a STS, Social, 4 noviembre 2004).

73. Y a todo esto, ¿qué ha afirmado el TC sobre la cuestión? En general, cabe afirmar que el TC se mueve con enorme dificultad ante este problema clave para el Derecho internacional privado: el TC no maneja con claridad las relaciones peligrosas entre «prueba del Derecho extranjero» y «tutela judicial efectiva $»^{44}$. Varios pronunciamientos del TC han abordado el problema. Entre ellos, los más destacables son los siguientes: a) STC 10/2000 de 17 enero 2000; b) STC 155/2001 de 2 julio 2001; c) STC 33/2002 de 11 febrero 2002; d) STC 172/2004 de 18 octubre 2004.

En la STC 10/2000 de 17 enero 2000, el TC indicó, únicamente, que cuando una parte intenta probar con todos sus recursos y medios a su alcance el Derecho extranjero y no le es ello posible, el tribunal debe ayudar a probar tal Derecho mediante los mecanismos jurídicos de los que disponen los órganos jurisdiccionales, que suelen ser más extensos y eficaces de los que disponen las partes. Pero sobre la cuestión de «qué Derecho debe aplicarse en el supuesto de que el Derecho extranjero aplicable al fondo del asunto no sea probado», el TC no indica nada en absoluto desde una «perspectiva constitucional».

En la STC 155/2001 de 2 julio 2001, el TC indicó que cuando es aplicable un Derecho extranjero y éste no se prueba por la parte, si el tribunal desestima la demanda, debe fundamentar o justificar dicha decisión para cumplir

${ }^{43}$ L. CARrillo Pozo, «Alegación y prueba del Derecho extranjero en el ámbito laboral y tutela judicial efectiva», Rev. Esp. Dcho. Trabajo, núm. 111, mayo-junio 2002, pp. 451473, esp. p. 465; ID., «Una doctrina constitucional sobre alegación y prueba de la Ley extranjera», Ar. Social, 2003, núms.7-8, pp. 53-84.

${ }^{44}$ L. CARBALlo PIÑEIRO, «El carácter imperativo de la norma de conflicto y la prueba del Derecho extranjero: Una relectura en clave procesal y constitucional», AEDIP, núm. 1, 2001, pp. 483-503; L. CARRILlo Pozo, «Alegación y prueba del Derecho extranjero en el ámbito laboral y tutela judicial efectiva», Rev. Esp. Dcho. Trabajo, núm. 111, mayo-junio 2002, pp. 451-473; ID., «Una doctrina constitucional sobre alegación y prueba de la Ley extranjera», Ar. Social, 2003, núms.7-8, pp. 53-84; V. CuArtero Rubio, «Prueba del Derecho extranjero y tutela judicial efectiva», Derecho Privado y Constitución, n. 14, 2000, pp. 21-71; J. MASEDA RoDRíGUEZ, «La aplicación judicial del Derecho extranjero: el nuevo régimen de la LEC y la reciente jurisprudencia del Tribunal Constitucional», Actualidad Civil, n. 12,2002 , pp. 413-446. 
con el principio de «tutela judicial efectiva» (arts. 24 y $120.3 \mathrm{CE}$ ). A pesar de las apariencias, que como es frecuente, engañan y mucho, el TC nada indica sobre la cuestión de «qué concreto Derecho debe aplicarse en el supuesto de que el Derecho extranjero aplicable al fondo del asunto no sea probado». El TC sólo precisa que si se opta por «desestimar la demanda», tal solución jurídica debe «fundarse en Derecho», razonarse, motivarse, y además, visto que el TS mantiene una determinada postura sobre la cuestión en una copiosa y centenaria jurisprudencia (aplicación sustitutiva del Derecho español), si el tribunal opta por otra solución (desestimación de la demanda), ello debe justificarse con un «plus de motivación» (del que, por cierto, el TC no señala en qué consiste y qué grado de profundidad debe presentar). La «simple desestimación» (desestimación «no motivada»o «no razonada»o «no justificada jurídicamente») no es constitucionalmente aceptable como respuesta al problema de «cuál es la respuesta jurídica en caso de falta de alegación y prueba del Derecho extranjero».

En la STC 33/2002 de 11 febrero 2002, el TC declaró que no se puede «inadmitir la demanda» ni dejar de pronunciarse sobre el fondo cuando la parte demandante debe fundar dicha demanda en un Derecho extranjero y no lo hace. Sobre la cuestión de «qué Derecho concreto debe aplicarse en el supuesto de que el Derecho extranjero aplicable al fondo del asunto no sea alegado ni probado», el TC no indica nada. Debe recordarse que la sentencia fue objeto de un «voto particular», de calidad muy notable, en el que el magistrado disidente, Excmo. Sr. D. Vicente Conde Martín de Hijas, insiste en que la solución al problema de cuál es la postura jurídica a adoptar en caso de que el Derecho extranjero no sea alegado ni probado es una cuestión de mera «legalidad ordinaria», sobre la que el TC puede expresar lo que tenga por conveniente, pero sin que ello pueda ser estimado como «doctrina constitucional del TC» que vincule a todos los órganos jurisdiccionales españoles. Posición que se ha visto refrendada por el importantísimo Auto TC 422/2004 de 4 noviembre 2004: "el rechazo de las resoluciones judiciales discutidas a aplicar la legislación española ante la falta de prueba por el demandante del Derecho extranjero, no constituye una denegación injustificada del derecho a la tutela judicial efectiva, sino una aplicación razonada y razonable de la legalidad ordinaria aplicable al caso. De modo que la simple disconformidad del recurrente con el razonamiento judicial, con su corrección o acierto, o el hecho de que la decisión a la que el mismo conduzca sea contraria a las pretensiones del recurrente, no implica lesión alguna del derecho fundamental que protege el art. 24.1 CE, ni, como tantas veces se ha dicho, permite a este Tribunal su revisión cual si de una nueva y superior instancia judicial se tratase».

En la STC 172/2004, de 18 de octubre de 2004, el TC acredita que lo aducido por el demandante de amparo no fue realmente así, sino que los Juzgados y tribunales españoles del orden de lo Social que decidieron el caso en distintas instancias siempre aplicaron el Derecho uruguayo. Por tanto, ni 
«desestimaron la demanda», ni «aplicaron subsidiariamente el Derecho sustantivo español». Y nada indica el TC sobre la cuestión de cuál es la respuesta jurídica que debe ofrecerse en el caso de que el Derecho extranjero aplicable al caso concreto no se haya alegado ni probado.

En el ATC 422/2004 de 4 noviembre 2004, el TC deja claro que la Constitución no impone una determinada tesis para dar solución al problema y que muy especialmente la tesis de la «desestimación de la demanda» puede utilizarse por los tribunales españoles, siempre que el tribunal motive y razone su decisión.

Por tanto, el TC no ha tomado partido por la tesis de la «aplicación sustitutiva del Derecho material español», pese a lo afirmado erróneamente por ciertos autores. El TC ha rechazado sólo una de las tesis en conflicto: la tesis de la «inadmisión de la demanda» no es constitucionalmente ajustada. El TC, finalmente, no ha tomado partido por ninguna de las tesis que se han propuesto.

Para cerrar este debate debe recordarse que la decisión de cuál de las tesis vertidas sobre el problema de la falta de alegación y prueba del Derecho extranjero por las partes es una decisión situada «más allá del debate constitucional»: es una cuestión de «legalidad ordinaria». Así lo dice expresamente el muy relevante ATC 422/2004 de 4 noviembre 2004: "el rechazo de las resoluciones judiciales discutidas a aplicar la legislación española ante la falta de prueba por el demandante del Derecho extranjero, no constituye una denegación injustificada del derecho a la tutela judicial efectiva, sino una aplicación razonada y razonable de la legalidad ordinaria aplicable al caso. De modo que la simple disconformidad del recurrente con el razonamiento judicial, con su corrección o acierto, o el hecho de que la decisión a la que el mismo conduzca sea contraria a las pretensiones del recurrente, no implica lesión alguna del derecho fundamental que protege el art. 24.1 CE, ni, como tantas veces se ha dicho, permite a este Tribunal su revisión cual si de una nueva y superior instancia judicial se tratase».

\section{Prueba imposible del Derecho extranjero}

74. En ciertos casos la prueba del Derecho extranjero puede resultar imposible: países de reciente creación, países en guerra, información insuficiente, etc. En dichos supuestos, el art. 281.2 LEC guarda silencio. Deben diferenciarse dos hipótesis.

Primera. Algunos preceptos del Derecho extranjero se han probado adecuadamente, pero otros preceptos no han sido probados, y resulta muy dificultoso recabar una información más profunda. En tal caso, los preceptos del Derecho extranjero que se hayan probado con éxito, se aplicarán. Los aspectos regidos por un Derecho extranjero cuya prueba ha resultado imposible se regirán por el Derecho designado por el siguiente punto de conexión de la norma de conflicto, si existe, y en última instancia, se regirán por el Derecho 
material español. Así operó la SAP Navarra 29 diciembre 2004: se solicitó prueba del Derecho suizo sobre seguros a través del antes citado Convenio de Londres de 1968, pero las autoridades suizas suministraron una prueba incompleta del mismo. El tribunal navarro aplicó todo el Derecho suizo que había sido probado, y en la parte que no se consiguió probar, aplicó el Derecho material español (SAP Navarra 29 diciembre 2004).

Segunda. En casos de prueba imposible total del Derecho extranjero, dos soluciones son posibles: a) se puede presumir la voluntad del legislador de, en tal caso, acudir al Derecho designado por el siguiente punto de conexión de la norma de conflicto, si existe (SAP Madrid 28 septiembre 2000); b) si la norma de conflicto sólo dispone de un único punto de conexión, se aplicará el Derecho material español como ultima ratio. Otras soluciones, apuntadas por la doctrina, no parecen adecuadas: rechazar la demanda, aplicar el Derecho que más se aproxime al Derecho extranjero inaplicable (Mutterrecht), aplicar un «Derecho uniforme» (Ersatzrecht) surgido de una síntesis entre los ordenamientos jurídicos en presencia o la «resolución judicial» del caso. 


\section{๑) Universidad de Deusto - ISSN 0423-4847}




\title{
La Bioética entre la conciencia, la norma y la religión (Acercamiento a un supuesto ético de proyección jurídica de la conciencia personal)
}

\author{
Arturo Calvo Espiga \\ Abogado del Tribunal de la Rota de Roma \\ Catedrático Habilitado de Derecho Eclesiástico del Estado \\ Universidad de Málaga
}

\begin{abstract}
Resumen: Se intenta, en principio, clarificar el concepto de bioética desde los parámetros de las denominadas éticas laicas y éticas religiosas. A continuación, se ofrece, partiendo de la incidencia que los problemas planteados desde la bioética tienen en los ámbitos jurídicos, una posible vía de solución capaz de superar las discrepancias en las soluciones aportadas desde las construcciones teóricas de las bioéticas al uso. Más allá de la ideología que subyace a las distintas opciones en bioética, se prima la asunción de la conciencia personal no sólo como límite negativo (objeciones) de situaciones límite, sino como fuente de derecho, lo que constituye a la persona y a su conciencia en instancia legitimadora de toda decisión que afecte a su vida, salud o integridad.
\end{abstract}

Palabras clave: Bioética, Conciencia, Derecho, Persona, Religión.

Abstract: To start, I try to clarify the concept of bioethics from the parameter of the so-called lay ethics and religious ethics. To continue, I offer, starting from incidence that the problems posed from the bioethics have in juridical fields, a possible way of solution capable of surpass the discrepancies in the solutions showed up from the theoretic constructions of the ordinary bioethics. Further away of the ideology that underlies to the different options in bioethics, we give priority to the assumption of the personal conscience not only as a negative limit (objections) of the extreme situations, but also as a law source, constituting to the person and to his conscience in which legitimizes all the decisions that affect to his life, health or integrity.

Key words: Bioethics, Conscience, Law, Person, Religion.

Sumario: 1. Sobre el significado de Bioética: 1) Los inicios. 2) Dificultades de sistematización. - 2. Para una razón jurídica del concepto de conciencia. - 3. Breve acercamiento a algunos planteamientos confesionales: 1) El pionero magisterio de la Iglesia Católica. 2) Fundamentos 'bio-teológicos' de las religiones monoteístas. 3) El trasunto práctico de los principios teológicos. - 4. Ante la vida y la muerte: ¿obstinación o diálogo?: 1) Las posturas y sus perfiles. 2) ¿Hacia una superación de las diferencias? 3) Horizontes de entendimiento. - 5. El ordenamiento jurídico desde la ética a la sociedad: 1) La conciencia personal, sujeto y fuente de derecho. 2) Viejos esquemas ante nuevos problemas. 3) Persona, norma, conciencia. 
Dadas las características de esta reflexión y el contexto en que se desarrolla, estimamos que el esfuerzo fundamental que estamos llamados a realizar ha de ser metodológico, introductorio, hermenéutico, como se denomina hoy a esa parte introductoria de los distintos saberes científicos en la que se establecen los criterios, pautas y modos que han de seguirse en el estudio y presentación de los problemas sobre los que las distintas ciencias versan y sobre los resultados o intentos de solución a que ellas conducen ${ }^{1}$. Quizás por ello seremos muy parcos en la presentación de soluciones. En el terreno en que nos movemos, sobre todo tal y como se están presentando en la sociedad española ciertas cuestiones relacionadas con la dimensión o patrimonio más importante y exquisito de la persona, cual es la propia vida, las soluciones rápidas y fáciles son patente segura de error o de manipulación.

También hemos de evitar la supeditación o utilización de importantes y profundos interrogantes del hombre actual, que afectan radicalmente a lo más profundo de la persona y de su propia continuidad y supervivencia como ser único y libre, a o para fines que, al margen de las auténticas necesidades y proyectos de mejora y progreso del ser humano, sólo buscan el triunfo de una determinada ideología, la cínica perpetuación en el poder e incluso la inadecuada satisfacción de inconfesados intereses económicos y comerciales.

\section{Sobre el significado de Bioética}

Bioética es una de las palabras más utilizadas y socorridas en los últimos años $^{2}$. Desde la reflexión científica, filosófica, jurídica y social en torno a la genética hasta la problemática que en su momento plantearon, por ejemplo, los trasplantes de órganos o las polémicas que hoy existen en torno a la muerte buscada, querida y procurada, el recurso o referencia a la bioética es moneda de cambio habitual para filósofos, moralistas, periodistas, articulistas, divulgadores, conferenciantes, tertulianos, editorialistas, etc. Pero ¿qué significa bioética?, ¿por qué esta palabra y no otra?, ¿por qué no thanatoéti$c a$, puesto que la gran mayoría de las veces que se recurre a este vocablo es para abrir vías a la muerte comprendida en otro eufemismo que no viene al caso $^{3}$ ?

${ }^{1}$ El presente artículo reproduce, casi en su totalidad, la exposición de una sesión de trabajo realizada en el mes de enero de 2006 dentro de los Cursos que la Universidad de Málaga organiza todos los años para la formación y promoción de personas mayores.

${ }^{2}$ Sobre el origen, historia y evolución de este término, puede verse W. T. REICH, «The Word 'Bioethics': Its Origins and the Legacies of Those Who Shaped It», Kennedy Institute of Ethics Journal, 1994, 319-333; IDEM, «Il termine 'Bioética'. Nascita, provenienza, forza», Itinerarium 2-3, 1994, 33-71.

${ }^{3}$ Cf. G. Fornero, Bioetica cattolica e bioetica laica (Milán 2005), 1-21. 


\section{1) Los inicios}

Sólo hay que remontarse al año 1970 para descubrir el inicio y consagración de este vocablo en el sentido significativo supuesto que arbitrariamente ha sido aceptado como tópica moneda de cambio que, con mucha frecuencia, encubre, en su uso, más que lo que explica o aclara. En este año, el cancerólogo estadounidense VAN RENSSELER POTTER publicó dos artículos que fueron completados con una posterior monografía en el año 1971, en que explica que con este término intentaba unir o relacionar las ciencias de la vida, las denominadas life sciences, con una comprensión axiológica (ética) de la vida que, al menos, facilitase los fundamentos o los medios para elaborar una especie de ciencia de la supervivencia (science of survival) ${ }^{4}$. El propio POTTER explicaba en un trabajo posterior que había elegido el prefijo a la raíz bio- para significar el saber biológico o, lo que es lo mismo, la ciencia de los seres vivientes; y que había optado por -ética para indicar el saber o la ciencia acerca de los sistemas de valores humanos ${ }^{5}$.

POTTER intentó, sobre todo, facilitar o diseñar un puente o sistema de relaciones capaz de garantizar la supervivencia y conservar el bienestar del hombre como consecuencia de la situación, auténtico cáncer para la naturaleza, creada por el incontrolado desarrollismo generado como consecuencia de la revolución científica y técnica. Sin embargo, en los años que siguieron a la formulación de Potter, prevaleció el significado que dieron al término tanto ANDRÉ HELlEGERS ${ }^{6}$, físiólogo de origen holandés especializado en embriología humana, fundador en el año 1971 en la Universidad jesuítica de Georgetown (Washington) del Kennedy Institute of Ethics, como un relevante miembro de éste, WARREN T. REICH, que, en la introducción a la Encyclopedia of Bioethics, propone la definición de bioética que hoy ya se considera clásica: «el estudio sistemático de la conducta humana en el ámbito de las ciencias de la vida y del cuidado de la salud, en cuanto examinada y juzga-

\footnotetext{
${ }^{4}$ Cf. V. R. Potter, «Bioethics. The Science of Survival», Perspectives in Biology and Medicine 14, 1970, 127-153; IDEM, «Biocybernetics and survival», Zygon, Journal of Religion and Sciences 5, 1970, 229-246; IDEM, Bioethics. A Bridge to the Future (1971). Aun cuando Potter explica que el término le vino de repente, como por una inspiración, al final de los años sesenta, no lo hizo público hasta los trabajos citados. Posteriormente, el propio Potter escribió una nueva obra conceptualmente muy crítica con el desarrollo de la bioética: Global Bioethics. Building on the Leopold Legacy (1988).

${ }^{5}$ Cf. V. R. PotTeR, «Humility and Responsibility - A Bioethic for Oncologist: Presidential Address», Cancer Research 35, 1975, 2297-2306, de forma especial las páginas 2298-2300.

${ }^{6}$ Cabe señalar que Hellegers no sólo ha sido la primera persona en dirigir un Instituto dedicado específicamente a la Bioética, sino que la propia palabra aparecía en su título originario establecido por el propio Hellegers y que, precisamente por ello, se denominó Joseph and Rose Kennedy Institute for the Study of Human Reproduction and Bioethics. El propio Reich considera a Potter y Hellegers como padrinos simultáneos del término bioética: cf. W. T. ReICH, «The Word 'Bioethics'. The Struggle Over its Earliest Meanings», Kennedy Institute of Ethics Journal 5/1, 1995, 19-34.
} 
da a la luz de valores y principios morales» ${ }^{7}$. Es de notar que el mismo PoTTER, ante la evidencia del poco éxito de su pionera aportación a la conceptualización del término bioética y el indiscutible predominio de la de HELLEGERS-REICH, acabará reconociendo que «la especial atención a los problemas suscitados en el ámbito de la ética médica hizo olvidar la idea originaria de bioética tal como yo la había concebido en referencia al marco global de las ciencias de la vida».

Es muy importante, a la hora de situar e intentar comprender las divergencias en torno al propio concepto y contenido de este término, no olvidar la ambigüedad significativa que arrastra desde sus orígenes. Mientras POTTER, en su perspectiva pionera, pretendía que la bioética se situase dentro de parámetros científicos de matriz biológica, encuadrándola, por tanto, en el marco de la biological science, para los estudiosos del entorno del Kennedy Institute la bioética habría de situarse más en el campo de la ética aplicada (applied ethics) orientada primariamente al estudio de las cuestiones y problemas derivados de la investigación biomédica, de la curación de las enfermedades y de la mejora de la calidad de vida y de la salud. Según esta perspectiva, la bioética ha de situarse en el plano más general y básico de lo que podríamos considerar como una antropología ética, entendida fundamental y básicamente como la infraestructura humana que da sentido a términos como salud y bioética. En definitiva, se trataría de defender y a la vez profundizar en la dignidad del ser humano, y en todo aquello que lo humaniza, de cara a los grandes avances biomédicos, en su más amplio sentido significativo, del mundo actual: desde la genética hasta todo lo referido a la patología de la muerte o del dolor ${ }^{9}$.

La recepción del término bioética, importado de los Estados Unidos, se realizó con más facilidad en aquellos países europeos, como, por ejemplo, Inglaterra, donde se estaba más familiarizado con la filosofía analítica. En Alemania y Francia, el proceso de recepción del término ha sido más dificultoso y problemático y se circunscribió su uso significativo mediante el recurso a fórmulas del tipo éthique bio-medical, medizinische Ethik, Ethik des Lebens, etc. En Italia, si bien tanto su implantación como su inmediato desarrollo encontraron dificultades tanto en el mundo médico como en el académico, ha acabado siendo muy bien acogido tanto en los ambientes laicos como católicos ${ }^{10}$. A semejanza de las circunstancias académicas que ro-

${ }^{7}$ W. T. REICH (ed.), Encyclopedia of Bioethics, vol. 1 (Nueva York 1978) XIX.

${ }^{8}$ V. R. POTTER, La prima idea di bioetica, en G. Russo (ed.), Bioetica generale e fondamentale (Turín 1995) 5-18, por lo que se refiere a la cita, página 11.

${ }^{9}$ Cf. J. Masiá Clavel, Bioética y antropología (Madrid 1998), 11-32.

${ }^{10}$ En Italia fue Menico Torchio, profesor de Biología marina en la Universidad de Pavía, quien introdujo el término bioética en el argot científico italiano a través de un artículo publicado en junio de 1973 en la revista Natura y que tituló «Rapporti uomo-Natura secondo le principali matefisiche orientali, loro implicazioni bioetiche ed ecologiche», según ha 
dearon sus orígenes, también en España han sido pioneros en la introducción y cultivo de esta disciplina los jesuitas a través de sus instituciones universitarias: nos referimos en concreto a la Cátedra de Teología Moral de la Facultad de Teología de la Universidad Pontificia de Comillas y al que hasta su muerte fue su titular, el P. Javier Gafo Fernández que, a su vez, era Director de la Cátedra y Máster de Bioética de la mencionada Universidad ${ }^{11}$.

\section{2) Dificultades de sistematización}

Sin embargo, aunque nos hallemos ante un neologismo generalmente admitido y continuamente utilizado por médicos, juristas, filósofos, periodistas y por la gran mayoría de las personas que probablemente jamás se encontrarán en toda su vida ante dilema alguno relacionado con la bioética, esta situación no resulta en modo alguno equivalente a la unanimidad en su definición y comprensión; antes al contrario, en lugar de eliminarse o allanarse, las divergencias acerca de su naturaleza, de sus ámbitos de aplicación, de su finalidad e incluso de su propio origen parece que aumenten a medida que crece el número de estudiosos que desde distintas perspectivas científicas se acercan a su tratamiento. Al término de su exposición sobre las dificultades con que tropiezan quienes intentan encontrar una «definición» adecuada de bioética, el profesor Russo sentencia, con toda razón: «Parafraseando una expresión de San Agustín, se podría decir que si nadie me pregunta qué es

puesto de relieve el profesor Russo. Puede verse, al respecto, G. Russo, Storia de la bioetica dalle origini ad oggi, en IDEM, Storia della bioetica. Le origini, il significato, le istituzio$n i$ (Roma 1995), 44-81. De la importancia que actualmente se da en Italia a los problemas que se plantean desde la bioética, así como a su naturaleza y contenido tanto material como formal, da sobrada cuenta la abundancia de títulos publicados en aquella nación sobre estas cuestiones y la gran acogida que tienen entre los lectores a juzgar por el espacio que estos temas ocupan en las estanterías de las librerías italianas.

${ }^{11}$ Cátedra que extiende su influencia más allá de las fronteras hispanas. También en otra Universidad jesuítica, la de Sophia, entre las más prestigiosas de Japón, se dejan sentir los ecos de esta institución española a través, por ejemplo, del jesuita y profesor en ambas Universidades, P. Juan Masiá Clavel que tanto en Madrid como en Tokio es profesor de Antropología Filosófica y Bioética. Son ya muy numerosas las tesis doctorales realizadas en ambas instituciones sobre cuestiones directamente relacionadas con la bioética. Por lo que se refiere al caso español, también cabe mencionar la línea de investigación que se sigue, y que ya ha dado sus primeros frutos literarios (Cf. I. MARTín SÁnchEZ [ed.], Bioética, Religión y Salud, Madrid 2005; y Bioética, Religión y Derecho [Actas del curso de verano de la Universidad Autónoma de Madrid celebrado en Miraflores de la Sierra del 14 al 16 de julio de 2005], Madrid 2005), por el equipo, dirigido por su catedrático titular, de la Cátedra de Derecho Eclesiástico del Estado de la Universidad Autónoma de Madrid. A partir del parámetro tan objetivo de la presencia de títulos en los estantes de las librerías, que hemos seguido en el caso de Italia, cabe concluir que el interés por estos problemas en España está a años luz de retraso respecto a otras naciones. Quizás sea consecuencia de esa tendencia tan española de creernos especialistas en todo sin saber de nada. 
la bioética, lo sé; pero en el momento que me preguntan cualquier cosa sobre ella, no lo sé» ${ }^{12}$.

La complejidad y dificultad que rodean a la mera fijación de su significado aumentan, si cabe, cuando nos acercamos al modo como las distintas tendencias explican o delimitan el propio contenido material de este término. Para unos, la bioética no va más allá de ser una rama o subespecie de la ética que versa, directamente, sobre el nacimiento, la salud y la muerte del ser humano; o bien, que se ocupa del fundamento y cobertura moral de los problemas jurídicos surgidos en torno a cuestiones como el aborto, la eutanasia, el encarnizamiento terapéutico, los trasplantes de órganos, la fecundación asistida, el tratamiento de embriones, la manipulación genética, etc. ${ }^{13}$

Un segundo grupo, por el contrario, estima que esta concepción restringe demasiado el verdadero contenido de la bioética y, siguiendo a Potter, optan por una comprensión de la bioética en la que se integran la médica (medical bioethics) junto con la ecológica (ecological bioethics) e incluso con la que ha venido a denominarse ética global (global bioethics) que, en si misma, trasciende al propio ser humano: «Una bioética global, como ciencia de la supervivencia, debe poder definir lo que es justo y lo que es erróneo en términos de conservación y protección de la biosfera» ${ }^{14}$.

El propio Reich, en la segunda edición revisada y ampliada de su Encyclopedia, ofrece una nueva definición más extensiva de bioética, considerándola ahora como «el estudio sistemático de las dimensiones morales -incluso la mentalidad moral, las decisiones, la conducta, las líneas de orientación, etc.-_de las ciencias de la vida y de la salud, a través de una variedad de metodologías éticas en un marco interdisciplinar» ${ }^{15}$.

La controversia en torno al contenido de la disciplina afecta también de forma relevante a la fijación del propio origen del término como, desde otra perspectiva, ya hemos apuntado anteriormente. Sin discutir el hecho de que sólo desde los años setenta se ha comenzado a reflexionar, directa y reflejamente, sobre estos problemas a partir de un neologismo; sin embargo, no falta quien se resiste a hacer coincidir el advenimiento de la bioética con el nacimiento de la palabra «bioética». Prefieren situar su inicio en la encrucijada histórica del pasmo producido entre el proceso de Nuremberg y la imagen pública de la irracionalidad de los crímenes nazis que, en el plano jurídico, derivó en

${ }^{12}$ Cf. G. Russo, Bioetica, en IDEM, Enciclopedia di bioetica e sessuologia (Turín 2004) 327-332, de manera especial la página 327.

${ }^{13}$ Cf. H. Kuhse y P. Singer, A Companion to Bioethics (Oxford 1998); E. LeCaldano, Bioetica. Le scelte morali (Roma-Bari 1999).

${ }^{14}$ V. R. PotTer, L'idea originaria di bioetica, en G. Russo (ed.), Storia de la bioetica..., cit., p. 327. De interés también las páginas 328-332.

${ }^{15}$ W. T. ReICH, Encyclopedia of Bioethics (Nueva York 1995) XXI. Puede verse también S. SPINSANTI, «Incontro con Warren Reich», L'Arco di Giano, n. 7, 1995, 219. En esta misma dirección se orienta Juan Masiá Clavel en la obra citada en la nota... 
la Declaración de Derechos del Hombre de 1948 y, en el ámbito filosófico, produjo la vuelta al iusnaturalismo de la década de los cincuenta ${ }^{16}$.

Otros, por el contrario, estiman que la bioética, tal y como hoy se plantea su estudio y contenidos, surge como consecuencia de la ruptura cultural que tiene lugar entre la década de los sesenta y los setenta y de su incidencia en el cambio de criterios y principios éticos y morales, así como de modelos y paradigmas políticos, operado a continuación en las sociedades occidentale ${ }^{17}$. Así pues, para los primeros, la bioética guarda una relación de continuidad con el pasado, con la ética tradicional, y en realidad no va más allá de ser un tipo de aplicación de los principios morales ya conocidos a unas circunstancias nuevas y cambiantes ${ }^{18}$. Los segundos, por el contrario, piensan que la bioética supone una auténtica ruptura con el pasado y, en consecuencia, la consideran una nueva ética de corte revolucionario y opuesto, en gran medida, a la tradición moral de Occidente ${ }^{19}$.

La comprensión efectiva del término bioética y de los contenidos materiales que en él encuentran cobertura también guarda, de hecho, una estrecha dependencia de la idea de ética que fundamente o dé cobertura a la propia reflexión bioética. Y ello al margen de que la bioética se considere, según hemos apuntado, como una subespecie del genérico ética o bien como una

16 «Cuando a partir de los años cincuenta de este siglo se hace patente en los ambientes jurídicos lo que comúnmente se ha denominado crisis del derecho, en realidad, a través de la misma, se está sometiendo a crítica no propiamente el derecho sino los ideales del individualismo jurídico; o lo que es lo mismo, según todos los indicios, esta crítica generalizada al derecho no es, en el fondo, otra cosa que una dura, aunque no siempre expresamente manifiesta, reacción contra el positivismo jurídico. Esta reacción contra el positivismo ha situado en este momento la cuestión del derecho en una dimensión propia que, a la vez que renuncia a cualquier atadura o dependencia respecto al idealismo jurídico neokantiano, también se aleja del formalismo lógico, donde la ley, en cuanto tal, adquiere una fuerza y un predominio absoluto en el tráfico de las relaciones jurídicas... por otra parte, intenta abrirse camino en la intrincada maraña del mundo del derecho un realismo jurídico nítida y claramente antipositivista que, en el fondo y llámesele como se quiera, es simplemente un redescubrimiento del derecho natural. Redescubrimiento que en ningún momento ha de suponer retorno o reviviscencia de anacrónicos e ilustrados tópicos del viejo iusnaturalismo racionalista» (A. CAlvo Espiga, «Acercamiento a la incidencia del derecho natural y de los derechos humanos en la elaboración del derecho», Scriptorium Victoriense 32, 1985, 286-287). También puede verse E. SGReCCIA, Manuale di bioetica, vol. I. Fondamenti ed etica biomedica (Milán 1999), 23-47.

${ }^{17}$ Cf. S. MAFFETONE, Il valore della vita. Un'interpretazione filosofica pluralista (Milán 1998), 170-173; M. MoRI, «La bioetica: che cos' è, quand' è nata e perché», Bioetica, n. 1, 1993, 115-143; de manera especial 133-135.

${ }^{18}$ Cf. F. Bellino, Bioetica e qualità della vita. Fondamenti (Nardò 1999), 21-39; K. DANner Clouser, Bioethics, en W. T. ReICH (ed.), Encyclopedia of Bioethics..., cit., vol. I, pp. 112-129.

${ }^{19}$ Cf. M. Mori, Conclusioni, en E. D' Orazio y M. Mori (ed.), «Quale base comune per la riflessione bioetica in Italia? Dibattito sul Manifesto di bioetica laica», Notizie di Politeia 12/41-42, 1996, 80-87; U. SCARPELLI, Bioteca laica (Milán 1998) 185-191. 
disciplina autónoma ${ }^{20}$. Aun así, al menos metodológicamente, las diversas y variadas corrientes que conforman el espectro de la bioética pueden reconducirse a dos grandes modelos teóricos o paradigmas que, como es lógico, se inspiran en y responden a dos concepciones generales del mundo y a dos sistemas filosóficos distintos: el primero procedería de una matriz de carácter y fundamento religiosos y el segundo respondería a un pensamiento de extracción y raíces laicas.

De forma eminente, aunque no exclusiva, el primer modelo se concretaría especialmente en los principios de la bioética católica en torno a la sacralidad de la vida o a la santidad de la vida, según se ha acuñado en ámbito anglosajón ${ }^{21}$. El segundo modelo está representado, sobre todo, por la bioética laica de la cualidad o calidad de la vida. ${ }^{22}$ Ciertamente, aunque no sean los únicos en sentido absoluto, estos dos modelos son sin ninguna duda los que, de hecho, han monopolizado, al menos en Occidente, la determinación del propio concepto de bioética, de sus límites y contenidos; y siguen siendo los marcos en que se sitúan actualmente los debates y discusiones sobre las cuestiones candentes en su ámbito ${ }^{23}$.

\footnotetext{
${ }^{20}$ Así se habla, entre los autores, de bioéticas de tendencia ontologista o bien de corte utilitarista, kantianas, subjetivistas, liberales radicales o hedonistas, sociobiologistas o personalistas, etc. Puede verse, al respecto, R. MoRDACCI, Una introduzione alle teorie morali. Confronto con la bioetica (Milán 2003); M. MORI, Bioetica. 10 temi per capire e discutere (Milán 2002): sobre esta cuestión concreta, las páginas 141-144.

${ }^{21}$ Algunos autores prefieren denominar a «su bioética» como bioética personalista en lugar de denominarla sin más como católica y se lamentan de que, con frecuencia, quienes no comparten o se oponen a los principios de los que ellos parten y defienden, al calificar de católicas sus posiciones, en realidad lo que buscan es «desacreditar al adversario»: «La bioetica personalista è stata abilmente etichettata come 'cattolica', per così ghettizzarla all'interno della Chiesa. Viene, infatti, facilitata la credibilità dell'affermazione che essa si fonda su concezioni e principi razionalmente indimostrabili, che solo chi crede in Dio e nella rivelazione cristiana può accettare. Si addebita pure ad essa di risovere i problemi con l'argomento di autorità, cioè in obbedienza all'autorità del Magistero ecclesiale» (L. Ciccone, Bioetica. Storia, principi, questioni, Milán 2003, 25). Quienes se han sentido aludidos por esta postura responden insistiendo en la equivocidad, amplitud y diversidad de la denominación personalista, al tiempo que recuerdan que «todo investigador es libre de elegir los términos que estima o retiene más apropiados al conjunto de su razonamiento y, además, no resulta incorrecto o desacreditador hablar de 'bioética católica'» (G. ForNERO, Bioetica cattolica..., cit., p. 23). Sin embargo, estos mismos autores no suelen reaccionar con la misma acribia metodológica, cuando desde posturas distintas a las suyas y ante las respuestas que se dan a determinados problemas, se les considera seguidores de una ética de muerte, más que de una moral de vida.

${ }^{22}$ Cf. E. Lecaldano, «Una morale libera da comandamenti dopo l'etica della sacralità della vita», Bioetica 1997/1, 81-88.

${ }^{23}$ «Legisladores, médicos y cualquier ciudadano deben reconocer que el verdadero problema radica en la alternativa de afirmar y tutelar la sacralidad de toda vida humana o de abrazarse, por el contrario, a una ética social para la que ciertos tipos o formas de vida humana son apreciables, mientras otros no lo son. Como nación, debemos elegir entre ética de la sacralidad de la vida y ética de la 'cualidad' de la vida» (R. REAGAN, «Abortion and the Conscience of the Nation», Human Life Review 9/2, 1983, 13-14).
} 
No faltan quienes, en desacuerdo con estos planteamientos polémicos y hasta hostiles sobre la naturaleza de la bioética, han propuesto, sin mucho éxito, una vía media a favor de una bioética sin adjetivos, insistiendo en que «la bioética no es ni religiosa, ni laica; es simplemente bioética» ${ }^{24}$.

\section{Para una razón jurídica del concepto de conciencia}

Tal como ha llegado a nuestro lenguaje, el término conciencia deriva su etimología del latín conscientia y del griego syneídesis, sustantivo equivalente a conciencia, o synoida, forma verbal que significa ser consciente o saber $^{25}$. El sustantivo syneídesis se encuentra por primera vez en DEMÓCRITO (Fragm. 297) y designa, según las circunstancias y el contexto en que aparece, tanto el conocimiento como la conciencia, e incluso la desazón de quien se ve acosado por los escrúpulos. En sus inicios, syneídesis, tuvo una significación más noética que moral y designaba, sobre todo, la capacidad personal de relacionarse consigo mismo, especialmente en lo que respecta a la consideración o percepción retrospectiva del propio pasado, circunstancia que acabó revistiendo al término conciencia del significado moral que ha predominado, ya a partir del siglo I a. C., en el lenguaje común ${ }^{26}$.

Diversidad significativa que también es una constante en las obras de la Patrística y de los escritores eclesiásticos de los orígenes, así como en las pri-

${ }^{24}$ R. LuCAs LuCAs, Bioetica per tutti (Cinisello Balsamo 2002) 6. La contestación a esta postura más aséptica o conciliadora, según se mire, ha venido, sobre todo, de los ambientes laicos: «Un cattolico e un laico rimangono un cattolico e un laico anche quando si dedicano a questioni come l'aborto o la determinazione del momento di morte prima di un trapianto. Certe diversità, anzi certi contrasti, limitati e attuiti nella vita quotidiana, nel diritto e nell'economia, da secoli di convivenza, sui nuovi problemi bioetici posti dallo sviluppo scientifico e tecnologico riacquistano feschezza e asprezza» (U. SCARPELLI, Bioetica laica..., cit., p. 19)

${ }^{25}$ Para todo este epígrafe puede verse A. CAlvo EsPIGA, «Conciencia y Estado de derecho», Laicidad y libertades. Escritos jurídicos 1, 2001, 17-45; de forma especial, las páginas $18-25$.

${ }^{26}$ «Esta evolución comienza con los 'siete sabios'... y el término menudea con este significado a partir del s. I a. C., sobre todo en los historiadores (Dión, Estrabón, Plutarco). Según que el hombre pueda o no justificar su obra ante esta instancia crítica que lleva en sí mismo, se habla de buena o recta (agathé u orthé) y mala (deiné y poneirá) conciencia. Además la buena conciencia es considerada, por regla general, como la que lleva a la paz, como la conciencia tranquila, mientras que la mala conciencia se hace notablemente desagradable, por el hecho de que intranquiliza al que la posee (cf. Eurípides, Or. 396, donde el matricida Orestes aduce como enfermedad que le aniquila la conciencia en cuanto conocimiento de las malas acciones). En la literatura griega las Erinnias son la personificación mitológica de esa mala conciencia que acosa al hombre» (H.-Chr. Hahn, Conciencia, en L. CoEnen, E. Beyreuther y H. BieTEnhard, Diccionario Teológico del Nuevo Testamento, vol. 1, Salamanca, 1980, 286). 
meras versiones o traducciones de los textos vétero y neotestamentarios donde syneídesis y conscientia son traducidas por términos o conceptos tan dispares como conocimiento en general, referido sobre todo a la ciencia profana, intuición, saber, sentido, opinión, forma de pensar, conciencia, testigo, norma de valores, orientación moral, consciencia de valores morales, deber interior, conocimiento del bien y del mal, etc.; sin olvidar que también, con frecuencia, el término conciencia viene utilizado en el sentido funcional de buena o mala conciencia o, lo que es lo mismo, en su dimensión moral ${ }^{27}$.

A la dificultad que ya de por sí supone la fijación del contenido de un concepto histórica y lingüísticamente tan complejo, se suma el hecho de que la reflexión occidental se halla condicionada y hasta determinada por el lastre ideológico que desde el tardío medievo arrastra este concepto a causa del retroceso de la concepción neotestamentaria de syneídesis en favor de una interpretación predominantemente moral y alegórica ${ }^{28}$, así como de la práctica identificación de la conciencia con su dimensión ascético-mística, en la que lo teológico-especulativo o filosófico-psicológico pasa a un irrelevante segundo plano en favor de su instrumentalización fáctica para la formación y progreso de la vida religiosa y espiritual, o dicho de otro modo, utilizándola como medio para aislar y evitar el pecado ${ }^{29}$.

Al margen, pues, de las distintas definiciones que se han elaborado del término conciencia, siempre dependiendo del ámbito metodológico desde el que se intente abordar su estudio, nosotros procuraremos operar, en principio, más con una descripción que con una definición, centrando nuestro interés sobre todo en los aspectos óntico-personales sin abandonar los que podríamos denominar como psico-morales ${ }^{30}$. En esta exposición, intentare-

${ }^{27}$ Para una información más completa no sólo de los aspectos filológicos sino también de los ideológicos, filosóficos y religiosos, así como de la problemática implicada en la utilización de estas expresiones por los autores referidos y por quienes posteriormente los han estudiado y traducido, puede verse J. STENZENBERGER, Über 'syneídesis' bei Klemens von Alexandrien, en VARIOS, Festgabe für Seppelt (Munich 1953) 27-53; IDEM, Conscientia bei Tertullianus, en VARIOS, Vitae et veritati. Festgabe für Karl Adam (Dusseldorf 1956) 28-43.

${ }^{28}$ Cf. C. SPICQ, Esquisse d'une histoire de l'exégèse latine au moyen âge (París 1944) 257-288.

${ }^{29}$ Hugo de San Víctor y Bernardo de Claraval dieron un gran impulso a esta línea de pensamiento, ejerciendo además una gran influencia entre los continuadores de ésta, que podríamos considerar, sacralización de la conciencia personal, tales como Pedro Celense, Ricardo de San Víctor, Tomás de Kempis y otros.

${ }^{30}$ El Diccionario de la Lengua Española editado por la Real Academia Española entiende, con un claro predominio, a nuestro entender, de su dimensión perceptivo-psico-estimativa, por conciencia la «propiedad del espíritu humano de reconocerse en sus atributos esenciales y en todas las modificaciones que en sí mismo experimenta». MARÍA MOLINER, en su Diccionario del uso del español, describe la conciencia, siempre con un predominio de lo dinámico-cognoscitivo, como el «conocimiento que el espíritu humano tiene de sí mismo» y también como la «facultad que hace posible ese conocimiento». También puede verse, al respecto, D. Llamazares Fernández, Derecho de la libertad de conciencia, vol. I. Libertad 
mos, pues, centrarnos en el análisis o descripción de la raíz o principio fundamental que determina o cualifica a la conciencia como realidad personal que trasciende no sólo los estados o situaciones subjetivas que invaden o por los que puede atravesar la persona sino, incluso, el medio o ambiente orgánico, físico e incluso social en que se origina.

A partir de los resultados ofrecidos por los abundantes intentos realizados desde la psicología y la metafísica, en orden a determinar o precisar el contenido estricto o los contenidos esenciales de la conciencia, puede plantearse el acercamiento a un cierto perfil definitorio de ésta. Si desde la psicología se pone énfasis en el drama interior de la persona atenazada por la inadecuada proporcionalidad entre los fines y objetivos ínsitos en su propio ser y los medios y posibilidades de que dispone para alcanzarlos, las teorías metafísicas sobre ella se han esforzado, al menos desde los supuestos de la filosofía de Descartes, por intentar liberar a la conciencia, elevándola al aséptico Olimpo de la razón, de todos los vínculos vitales que la unen e incluso identifican con cada sujeto personal y único. La trascendencia que, desde distintos supuestos y planteamientos, todas las teorías metafísicas reconocen a la conciencia con relación al medio físico y orgánico, en su más amplia y omnicomprensiva acepción en que ésta se inserta, muestra sin ningún género de duda que la conciencia, en su más profunda esencia, participa en o pertenece a un mundo que se sitúa más allá de la mera experiencia sensible... a un mundo individual y único entretejido de racionalidad en sus verdades y de personalismo en sus acciones.

Ahora bien, nunca la metafísica debe alejar al jurista de la prudencia. Identificar la conciencia con la razón o el espíritu, se escriba con mayúsculas o minúsculas, aboca inmediatamente a la desnaturalización de la conciencia y a su consiguiente desaparición. Radicada en la trascendentalidad y trascendencia de la racionalidad, la conciencia participa plenamente, me atrevería a decir que como dimensión fundamental de ésta, del mundo espacio-temporal concreto, en el que todo fluye sobrevolando la relatividad de lo

de conciencia y laicidad, Madrid 1997, 11; IDEM, Derecho Eclesiástico del Estado. Derecho de la libertad de conciencia, Madrid $1991^{2}$, p. 500. Hemos de llamar la atención sobre la constancia con que, al tratar de la conciencia, se invocan la dimensión espiritual, en su más amplia acepción, así como los valores, no los juicios concretos, morales de la persona, lo que lógicamente ha de abocarnos, desde la perspectiva jurídica que asumimos, a una estimación del topos conciencia más objetiva y totalizante de la persona, como ya apuntó el propio Tribunal Constitucional: «Junto al valor de la vida humana y sustancialmente relacionado con la dimensión moral de ésta, nuestra Constitución ha elevado también a valor jurídico fundamental la dignidad de la persona, que, sin perjuicio de los derechos que le son inherentes, se halla íntimamente vinculada con el libre desarrollo de la personalidad... Del sentido de estos preceptos puede deducirse que la dignidad es un valor espiritual y moral inherente a la persona, que se manifiesta singularmente en la autodeterminación consciente y responsable de la propia vida y que lleva consigo la pretensión al respecto por parte de los demás» (STC, 11-4-1985, F. J. 8). 
habitual ${ }^{31}$. Este doble anclaje de la conciencia en una necesaria duplicidad relacional, determinada por la concreción de la historia y la trascendencia de la razón o el espíritu, es el ámbito necesario donde ha de descubrirse y realizarse la verdad del hombre, conciliando e integrando la propia vida con la verdad personal, común a todo ser humano. Individualidad, libertad y la búsqueda de valores en el propio ser, debidamente relacionadas e integradas, conforman la esencia de la conciencia personal.

Probablemente, uno de los errores más graves del idealismo consistió en identificar o confundir la conciencia con el puro pensamiento o con la desnuda racionalidad, reconociendo, de forma exclusiva, su expresión más perfecta en el hecho del conocimiento objetivo al margen de cualquier influencia de la sensibilidad humana, tanto física como psicológica o afectiva. Según esta corriente filosófica, la conciencia habría de ser considerada, ante todo, como un ensimismamiento y una reflexión de la vida sobre ella misma, siempre, bien entendido, en el ámbito exclusivo de su esfera individual. Esta concepción, sin embargo, pasa por alto el hecho innegable de que la conciencia permanece la misma e idéntica a sí misma dentro de la más plural diversidad de sus manifestaciones. Cualquier circunstancia, acontecimiento o sentimiento, por inmenso e impactante que parezca, siempre resulta parcial y mínimo respecto a la totalidad del ser humano, porque siempre es el ser humano completo, en su totalidad e individualidad concreta y única quien se reconoce idéntico a, único y consciente de sí mismo.

Ser consciente o tener conciencia no es algo distinto a poseerse, a saberse, sentirse y percibirse uno y dueño de sí; o lo que es lo mismo, a controlar y garantizar la unidad interior y su expresión exterior, en dinamicidad o contemplación, de una individualidad esencialmente constituida en organicidad (materialidad-pluralidad-diversidad) y espiritualidad (unidad-sobrenaturali-

${ }^{31}$ Resulta ilustrativo, a este respecto, el célebre pasaje del Simposio en el que Diotima, explicando a Sócrates la naturaleza del eros, se refiere a la unidad-conciencia del hombre, aclarando y explicitando que la unidad humana no sólo acontece en el cuerpo, sino también en el alma, en el interior del hombre, desde el momento en que comportamientos, hábitos, opiniones deseos, placeres, dolores y miedos cambian continuamente en la misma e idéntica persona. Ni siquiera los conocimientos escapan a esta ley. Sólo el estudio y la reflexión, que generan recuerdos que ocupan el lugar de los desaparecidos, salvan la unidad de nuestro conocimiento de modo que siempre parezca el mismo: «... la naturaleza mortal busca, en la medida de sus posibilidades, de existir siempre y de ser inmortal... De hecho, también en el tiempo en que cada uno de los seres vivientes se dice que vive y que es el mismo (to auto), como por ejemplo de un hombre se dice que es el mismo desde que es niño hasta que es un anciano, y se dice que es el mismo aun cuando, en realidad, no mantenga en sí mismo las mismas cosas, sino que se renueva continuamente, e incluso pierde algunas cosas, en sus cabellos y en la carne y en los huesos y en la sangre y en todo lo que conforma su cuerpo... [Y, por lo que se refiere a los conocimientos] no puede decirse que sea el mismo, como acontece en la divinidad, sino que, en lugar de lo que desaparece o envejece, se coloca aquello que de mayor juventud es semejante a lo anterior» (Simposio 207 C - 208 B). 
dad-transcendencia). La conciencia, pues, no puede reducirse ni a puro conocimiento, ni puede identificarse con la causa de lo que somos, sino que, en cuanto reducto último de nuestra existencia, podría considerarse como la dimensión personal última por la que nosotros sabemos que somos y cómo somos.

Entenderemos, pues, por conciencia, siempre desde una perspectiva prevalentemente ontologista y operativa, por cuanto respecta al objetivo de esta reflexión, lo que resta de específica y fundamentalmente personal cuando el hombre se ve despojado de todo, es decir, el ámbito o realidad donde el hombre puede reconocerse como sí mismo y sentirse, respecto a sí mismo y en relación a los otros, como único y diverso a los demás. O dicho de otro modo, conciencia sería equivalente a persona en cuanto desnudo sujeto de relaciones intra e interpersonales y, en este sentido, expresaría o definiría a la persona en su más íntima esencia y, consecuentemente, en su más profunda debilidad. $\mathrm{Al}$ referirnos a la conciencia en su dimensión relacional intra e interpersonal asumimos una conceptualización abierta que trasciende y supera el ámbito de la simple e individualista privacidad.

Que la conciencia pueda ser definida como una relación íntima y privilegiada del hombre consigo mismo no es equivalente a su clausura en la trastienda de lo privado; antes al contrario, la conciencia, en cuanto fundamento último de la personalidad individual, ha de expresarse y manifestarse necesariamente en la actuación y proyección social del hombre. Más, la relación que en el foro de la conciencia establece el hombre consigo mismo ha sido, más allá de la influencia que hayan supuesto el humanismo o el iusnaturalismo iluminista, la causa última que ha llevado a plantearse a fin del siglo $\mathrm{XX}$ una imagen secularizada de la conciencia convertida, no sólo desde el derecho constitucional sino incluso desde la filosofía y la antropología, en principio trascendental y autónomo, creador de la libertad de pensamiento y de la libertad religiosa. Por otra parte, el hecho de que se reconozca a la conciencia como lugar en que adquiere toda su fuerza y potencialidad la exigencia y reivindicación de los derechos de la persona comporta e implica no sólo su nítida e inequívoca desprivatización, sino su necesaria «juridización» ${ }^{32}$.

\footnotetext{
${ }^{32}$ Esta necesaria relación de fundamentalidad entre conciencia y derechos conduce a la pregunta sobre quién o qué habrá de delimitar, definir o señalar las pautas y modos de relación, así como la jerarquía y circunstancias en que una y otros han de articularse. Es decir, cuando invocamos la virtualidad o fuerza jurídica de la conciencia, ¿estamos refiriéndonos a la manifestación de, o adecuación a, un orden moral objetivo; o, por el contrario, nos movemos en la diversidad de las decisiones subjetivas ancladas en principios trascendentes o trascendentales, o bien en opciones de anarquía ética? No es momento de entrar directamente en esta problemática, cuyo tratamiento excede los límites fijados a esta reflexión, puesto que el interrogante planteado exige el riesgo de una teoría general tanto de la conciencia como de la libertad de conciencia; pero tampoco cerramos esta senda a nuestra futura reflexión sobre esta temática, máxime cuando, según nuestra opinión, la respuesta a la pregunta formulada constituye el nudo gordiano, a través de la conciencia y de sus implicaciones jurídicas, del verdadero respeto a los derechos fundamentales de la persona y efectiva
} 


\section{Breve acercamiento a algunos planteamientos confesionales}

En relación con los problemas más graves e importantes que actualmente se plantea la bioética, al menos por lo que se refiere a aquellos que más directamente afectan a la vida del ser humano y a su conservación, todas las confesiones cristianas coinciden en situar y proponer a la persona humana como centro, fundamento, razón de ser última y, en consecuencia, límite de la experimentación científica en todo aquello que afecta a la persona en su esencia y dimensión de humanidad. De este modo, el respeto a la persona, y a su conciencia, tanto en sentido jurídico como ético o psicológico, así como la promoción de su desarrollo y perfeccionamiento se asumen, por parte de estas confesiones, como criterio definitivo de constraste moral a la hora de enjuiciar la licitud de acciones o decisiones vinculadas con el mundo de la medicina, la genética, la reproducción, la salud e incluso todo aquello que, relacionado con las ciencias de la naturaleza, afecte directamente al ser humano.

También las demás religiones monoteistas asumen idénticos principios sobre todo en aquellas cuestiones que ellas entienden directamente relacionadas con el ser humano y con su dimensión de criatura divina por excelencia. Es decir, no se trataría sino de respetar el plan de Dios que se concreta en el reconocimiento del valor absoluto de la persona. Del mismo modo que aceptan, y en tantas ocasiones impulsan, la investigación así como la creación y utilización de medios que favorezcan, protejan, amplíen y profundicen el bienestar de la persona humana, rechazan, por inmorales, todas y cada una de las intervenciones que, según ellas, trastocan o modifican el plan divino sobre los hombres: ni el aborto, ni la eufemísticamente denominada eutanasia, ni la manipulación genética, ni el ensañamiento pseudovitalista con enfermos sin remedio, ni aquellos tipos de fecundación artificial en que, según ellas, se altera sustancialmente el ritmo natural de la generación humana, etc. pueden esperar acogida en unos principios éticos que, aunque formalmente no tengan un primordial carácter religioso, se fundan en concepciones antropológicas y cosmológicas en que la centralidad de la persona y el plan de Dios han de situarse siempre por encima de cualquier veleidad y ansia desmedida de poder y dominio humano.

protección de su ejercicio. Para una aproximación a la aplicación de este concepto de conciencia a la problemática relacionada con el derecho a la salud puede verse el acertado planteamiento que realiza S. TARODO SORIA, Libertad de conciencia y derechos del usuario de servicios sanitarios (Bilbao 2005), 12-25, así como el clarificador y profundo estudio realizado por M. A. ASENSIO SÁNCHEZ, La patria potestad y la libertad de conciencia del menor. El interés del menor a la libre formación de su conciencia (Madrid 2006), 115-133, por cuanto respecta, en general, a la situación jurídica del menor. 


\section{1) El pionero magisterio de la Iglesia Católica}

$\mathrm{Si}$, como se ha expuesto anteriormente, se considerase la bioética como una especialidad dentro del género ética y se asumiera, como ya hemos señalado que defienden algunos, que aun cuando el término se acuñara a principios de los años setenta del siglo pasado, sin embargo, ya con anterioridad la preocupación por los problemas de carácter bioético estaba muy presente en la sensibilidad social, podríamos asegurar que el magisterio de la Iglesia Católica, sobre todo en y a partir del papa Pío XII, fue pionero en esta materia.

Indicio indiscutible y revelador de la preocupación e interés con que desde la ciencia y el pensamiento católicos se sigue todo lo relacionado con la bioética y sus planteamientos es la existencia de Cátedras o Institutos de Bioética en la mayoría de las Universidades Católicas y en casi todas las Facultades de Teología, dentro de los Departamentos de Ética o de Teología Moral: cada curso académico se cuentan por decenas los títulos de tesis doctorales o tesinas de licenciatura que tienen por objetos temas relacionados con la bioética. Los límites de este género académico nos impiden el análisis detallado de las abundantes (34 alocuciones, la última cinco días antes de su muerte y varios mensajes radiofónicos) y profundas enseñanzas de Pío XII sobre problemas y asuntos que hoy se consideran fundamentales y comunes en bioética, más allá, por supuesto, de las discrepancias científicas a la hora de determinar su origen, metodología e incluso el alcance de sus contenidos. Con no pocas reservas, por la dificultad de la misión, nos atrevemos a señalar, a modo orientativo, las siguientes intervenciones del Papa Pacelli:

- Alocución a los participantes en el Cuarto Congreso Internacional de Médicos Católicos [Roma, 29/09/1949] (Acta Apostolicae Sedis [AAS] 41, 1949, 557-561).

- Ídem a los participantes en el Congreso de la Unión Católica Italiana de Comadronas [Roma 29/10/1951] (AAS 43, 1951, 835-854).

- Ídem a los participantes en el Quinto Congreso Internacional sobre psicoterapia y psicología [Roma, 13/04/1953] (AAS, 45, 1953, 278286).

- Ídem a los asistentes al Primer Simposio Internacional de Genética Médica [Roma 07/07/1953] (AAS, cit., p. 596-607).

- Ídem a los asistentes al Vigésimosexto Congreso de la Sociedad Italiana de Urología [Roma 08/10/1953] (AAS, cit., p. 673-679).

— Ídem a los asistentes al Congreso Latino de Radiología y Electromagnetismo, así como al de Radiología Médica de la Asociación Italiana [Roma 04/04/1954] (AAS 46, 1954, 214-218).

— Idem a los Miembros de la Pontificia Academia de Ciencias [Roma 24/04/1955] (AAS 47, 1955, 394-401).

- Ídem a los participantes en el Congreso Mundial celebrado en Nápoles sobre la fecundidad y esterilidad humanas [Roma 19/05/1956] (AAS 48, 1956, 467-474). 
— Ídem a los asistentes al Cuarto Congreso de la Asociación Italiana de Quimioterapia [Roma 06/10/1956] (AAS, cit., p. 793-797).

- Ídem a los asistentes al Séptimo Congreso Internacional de la Sociedad Internacional de Hematología [Roma 12/09/1958] (AAS 50, 1958, p. 732-740).

El magisterio de la Iglesia continúa, bajo la huella de Pío XII, la elaboración y proposición de una amplia y abundante doctrina de hondas raíces bioéticas. No de otro modo pueden leerse, por ejemplo, los documentos del Concilio Vaticano II, de forma especial la Constitución Pastoral Gaudium et Spes, cuando exponen su concepción del hombre y de la familia (AAS 58, 1966, p. 1067-1074); la Encíclica Humanae Vitae, de 25 de julio de 1968 (AAS 60, 1968, 481-503); la Declaración De abortu procurato de la Congregación para la Doctrina de la Fe, de 18 de noviembre de 1974 (AAS 66, 1974, 730-747); la Declaración De quibusdam quaestionibus ad sexualem ethicam spectantibus, de 29 de diciembre de 1975 (AAS 68, 1976, 77-96); la Carta a los obispos sobre La sterilizzazione negli ospedali cattolici, de 13 de marzo de 1975; la Declaración de la Congregación de la Doctrina de la Fe De Euthanasia [Jura et bona], de 5 de mayo de 1980 (AAS 72, 1980, 542552); la Exhortación Apostólica Familiaris Consortio, de 22 de noviembre de 1981 (AAS 74, 1982, 81-191); la Instrucción De observantia erga vitam humanam nascentem deque procreationis dignitate tuenda [Donum Vitae], de 22 de febrero de $1987^{33}$ (AAS 80, 1988, 70-102). Finalmente, del largo pontificado de Juan Pablo II, cabe destacar las importantes referencias que el

${ }^{33}$ La conclusión de este documento reviste, a nuestro entender, un especial interés no sólo por lo que dice, sino, quizás y sobre todo, por los cauces de esbozada novedad metodológica que apunta: «[En este documento se intenta]... novam igitur adhortationem, sollicitudinis plenam, ad eos omnes dirigit qui, pro sua quisque parte atque officio, efficacem operam praestare possunt ut in familia atque in societate debita tirbuatur observantia vitae atque amori: ad eos scilicet, quibus munus incumbit conscientias et publicam opinionem formandi; ad eos qui scientiam scolunt et medicinam exercent; ad iuris peritos, et ad rei politicae addictos. Quibus omnibus ipsa exoptat, ut intellegant nullo modo componi posse agnitionem dignitatis personae humanae cum vitae et amoris contemptu, atque fidem in Deum vivum cum arroganti proposito de ortu ac sorte creaturae humanae ad arbitrium decernendi.

«Peculiari modo Congregatio pro Doctrina Fidei cum fiducia invitat atque instimulat theologos, ac nominatim moralis doctrinae cultores, ut quae de hac re a Magisterio Ecclesiae docentur, altius ea investigent ac magis magisque captui christifidelium accommodent, sub lumine sane doctrinae anthropologicae in re sexuali et matrimoniali, ac necessaria inter varias disciplinas relatione servata. Poterunt ita melius percipit huius doctrinae argumenta ac robur: Ecclesia Dei, cum defendit hominem contra suae ipsius potestatis abusum, simul eum commonefacit, quae sint verae suae nobilitatis rationes; tantum hoc modo futurae hominum communitati facultas praebetur vivendi et amandi in iis dignitatis ac libertatis condicionibus, quae a veritatis obsequio proficiscuntur. Definitae igitur agendi rationes, quae per hanc Instructionem impetiuntur, minime intendunt investigationum nisus cohibere, sed potius renovatum earum studium excitare, necessaria erga Ecclesiae doctrinam fidelitate servata» (p. 101) 
papa realiza a cuestiones directa o indirectamente relacionadas con la bioética en la Veritatis splendor, de 6 de agosto de 1993 (AAS 85, 1993, 11331228) y, sobre todo, la encíclica Evangelium vitae, de 25 de marzo de 1995 (AAS 87, 1995, 401-522), en la que, por primera vez se usa el término bioética en un documento magisterial pontificio y además se afrontan directamente los problemas más candentes de esta disciplina.

\section{2) Fundamentos 'bio-teológicos' de las religiones monoteístas}

Las tres grandes religiones monoteístas parten, en todo lo referido con la vida en general y la humana en particular, del axioma de la creación divina: todo lo que existe ha brotado de las manos de Dios y nada de lo llamado a existir es ajeno al designio de la voluntad divina, al margen y más allá de los matices con que en determinadas cuestiones se interprete el ex nihilo. Dios, pues, es fuente única y primordial de la vida y Él, por tanto, es reconocido como único dueño y señor de ella: el hombre es su agraciado depositario. La creencia en la resurrección y en el juicio divino con premio y castigo aparece necesariamente como colofón indiscutible de esta necesaria relación del hombre con su Creador.

Para la religión hebrea, el hombre es la criatura predilecta de Dios por haber sido creado por el mismo Dios a su imagen y semejanza: «El hombre es predilecto de Dios porque ha sido creado a su imagen; porque se le ha manifestado un amor especialísimo al haber sido creado a su imagen ${ }^{34}$. De este ser imagen de Dios derivan la dignidad humana, su misión en el mundo y la historia y el hecho de que para Dios todos los hombres sean iguales: «Dios creó un solo ser humano para enseñarnos que si uno destruye a una persona, la Escritura lo considera como si hubiese destruido el mundo entero; y si uno salva una vida, la Escritura lo considera como si hubiese salvado el mundo entero» ${ }^{35}$. La propia Mishnàh insiste en la radical y específica unicidad y singularidad del ser humano, fundadas y, al mismo tiempo, derivadas del propio acto creacional: «La grandeza del Santo, que sea por siempre bendito, se desvela de este modo: cuando un hombre acuña muchas monedas con un solo troquel [molde], todas ellas resultan exactamente iguales; por el contrario el Rey de reyes, el Santo, que sea por siempre bendito, ha hecho a cada hombre con el molde utilizado para el primero y, a pesar de ello, ninguno es igual a otro. Por tanto, todos y cada uno de los hombres pueden afirmar: el mundo ha sido creado para mí».

Esta semejanza del hombre con Dios le muestra, a su vez, cuál ha de ser la razón y sentido de su vida. El hombre debe tender a ser semejante a Dios en sus acciones, pero nunca debe pretender ser como Dios (Gen 3, 5), sino

${ }^{34}$ Mishnàh Abot III, 15 y Gen. 1, 27.

${ }^{35}$ Mishnàh Sanhedrín IV, 5. 
que el proceso de asimilación a su Dios se resume, para el hebreo, en el repetido precepto que figura en el Levítico: «Sed santos, porque Yo, el Señor, Dios vuestro, soy santo» (Lev 19, 2). El servicio debido a Dios debe animar y traspasar toda la existencia humana. Es más, el hecho de que en la Biblia no exista distinción alguna entre las prescripciones que se refieren a las relaciones interhumanas y las que afectan a las relaciones entre el hombre y Dios pone en evidencia sin ningún género de duda que ambas trayectorias de la relación humana derivan de la voluntad de Dios. En la Toràh, decisión moral y opción religiosa aparecen íntima e indisociablemente unidas. Se trata, en definitiva, de la realización de Dios en la experiencia humana. El ser humano, pues, se distingue de las demás criaturas porque, al haber sido creado a imagen de Dios, es capaz de elegir entre el bien y el mal, entre la rectitud y el pecado, entre obedecer y desobedecer: «Mira que pongo ante ti la vida y el bien, la muerte y el mal» (Dt 30,15).

También para la teología cristiana el Antiguo Testamento presenta al hombre como la obra más importante del $\mathrm{Creador}^{36}$. A causa de su semejanza divina el hombre se distingue esencialmente del resto de la creación, pero, a pesar de ello, no es nada por sí mismo ${ }^{37}$ y sólo es en la medida en que reconoce su dependencia de Dios ${ }^{38}$. Tanto la vida física del ser humano como su psique y afectividad residen indistintamente en el alma o en el espíritu, en la carne o en el corazón ${ }^{39}$, incluso la actividad intelectual y las decisiones de la voluntad vienen atribuidas de forma especial al corazón ${ }^{40}$.

Los Evangelios sinópticos parten de una imagen y concepción extremadamente claras y precisas del hombre: es el ápice de la creación, su perfecto cierre, en el que Dios manifiesta especialmente su amor y su cuidado y predilección $^{41}$; ha sido creado para dar gloria a Dios y producir frutos de salvación ${ }^{42}$.

${ }^{36}$ Cf. Gen $1,1-2,4 ; 2,4 b-7$ y Sal 8, entre las muchas citas que se podrían aportar.

${ }^{37} \mathrm{Cf}$. Is $2,22$.

${ }^{38}$ Cf. Gen 3, 8-11 y 4, 9-14.

${ }^{39}$ Cf. Jue 16, 5; I Sam 25, 37; Sal 21 [22], 27; etc.

${ }^{40}$ Cf. Ex 31, 6; I Sam 14, 7; etc.

${ }^{41}$ Cf. Mt 6, 26-30; 10, 29-31; etc.

42 «... en el pensamiento cristiano de todos los tiempos y de todos los lugares, el leit motiv del hombre como imagen de Dios, imagen de Cristo, es el planteamiento de fondo de una 'imitación', que es también una 'vida en Cristo en el Espíritu Santo', o sea, el camino que va de la imagen a la semejanza... [se trata de] la historia del amor loco de Dios quien cuando 'dice', 'hace' al hombre, revelando ya así al que vendrá como Palabra Encarnada, a cuya imagen el hombre descubrirá que ha sido creado. Decir el hombre es decir Cristo. Palabra pronunciada como amor y con amor, el hombre camina en la creación siguiendo las huellas de la relación que lo crea Imagen de la Relación y de la Comunión trinitaria. Decir el hombre es atreverse a decir la Trinidad... Por eso, la Revelación, Cristo como Persona Divinohumana, es sinónimo de historia de la salvación, puesto que cada vez que la imagen (el hombre) descubre su belleza y su origen se le quita el velo del ofuscamiento de Adán, pero sin agotar nunca el Misterio de su Imagen primordial. Cristo revela y a la vez oculta en la cruz la bondad de Dios, ese rostro inclinado sobre la criatura que lo podrá reflejar de nuevo, 
Según la antropología coránica el hombre ocupa un lugar privilegiado, muy por encima de todas las demás criaturas, en los planes de la creación divina, puesto que el hombre es el único representante de Dios sobre la tierra: los propios ángeles, por orden divina, están debajo del hombre. El Islam funda la dignidad del hombre no en el hecho de que el hombre haya sido creado a imagen y semejanza de Dios, puesto que Dios no puede ser semejante a nada ni a nadie, sino que aquella está directamente relacionada con la misión divina que el hombre debe llevar a cabo sobre la tierra, así como con la gracia que el hombre recibe de Dios para llevarla a buen término ${ }^{43}$.

\section{3) El trasunto práctico de los principios teológicos}

A partir de esta realidad fundamental se articulan las respuestas que las religiones monoteístas ofrecen ante los grandes retos o propuestas a que se enfrenta la bioética. Excedería los límites de nuestro propósito en esta sede intentar una siquiera pequeña muestra de la enseñanza de las distintas confesiones religiosas en torno a todos los problemas fundamentales de la bioética ${ }^{44}$. Y ello aunque lo abordáramos con la máxima brevedad. Vamos, pues,

recibiendo el Espíritu, o sea el amor, y así, amando con el mismo amor, podrá de nuevo reflejar el mismo esplendor, revelar a su vez la misma gloria... La creación, la salvación, la 'deificación' del hombre, se realiza 'por el Padre por medio del Hijo en el Espíritu Santo', según una de las fórmulas trinitarias más antiguas» (O. CLÉMENT, Introducción, en M. I. RUPNIK, Decir el hombre. Icono del Creador, revelación del amor, Madrid 2000, 5 y 6-7). Cf. Mt 5, 16; 7, 17-20; Lc 13, 6-9; 17, 7-11; etc.

${ }^{43} \mathrm{Cf}$. A. FAlATURI, Die Bedeutung des islamischen Menschenbildes für die Erziehung, en J. LÄHNEMANN (ed.), Erziehung zur Kulturbegegnung (Hamburgo 1986), 43-50; H. LuDIN-JANSEN, «Zur Frage vom Menschenbild im Koran», Temenos. Studies in comparative religion 16, 1980, 56-61; Манома (MuнаммаD), Le parole del Profeta, ed. de Abdullah al-Mamun alSuhrawardy (Roma 1997); T. NAGEL, Zum Menschenbild in modernen Islam, en 19. Deutscher Orientalistentag in Freiburg 1975 (Wiesbaden 1977), 559-566; A. M. DI NolA, Maometto. La saggezza dell'Islam (Roma 2001), 35-62; IDEM, L'Islam. Storia e segreti di una civiltà (Roma 2004), 65-166; A. SCHImmel, «Zur Anthropologie des Islam», Anthropologie religieuse 2, 1955, 140-154 [Supl.]; M. TworuschKA, Islam (Gotinga 1982), 43-51.

${ }_{44} \mathrm{Al}$ margen de su posibilidad de tratamiento, sobre todo por las razones aducidas, hemos de dejar constancia, por su actualidad e incidencia social, de la importante problemática derivada de la investigación sobre células-madre obtenidas de embriones humanos, de los casos planteados por la práctica de xenotrasplantes o trasplantes transgénicos, de los supuestos de venta voluntaria de órganos por parte del donante, de los interrogantes a los que en determinadas circunstancias extremas se enfrenta el médico aun cuando exista testamento vital previo, etc. Como recientemente confesaba un experimentado cirujano, «... alla fine... promisi a me stesso che da quel momento in poi, testamento biologico o meno, avrei approfondito con maggiore chiarezza, con ogni singolo paziente, tutti i rischi di un percorso clinico che a volte può celare insidie inaspettate... L'esistenza di direttive anticipate scritte dal paziente stesso costituiscono un supporto straordinario in momenti decisivi come quelli relativi a un'eventuale interruzione delle terapie. Tale strumento tuttavia non deve essere rigido e il medico deve mantenere la propria libertà di giudizio per valutare quando è il caso 
a mostrar, sin ánimo de exhaustividad como ya se ha señalado, la postura moral de estas grandes religiones sobre algunas de las cuestiones a que hoy se enfrenta la bioética.

\section{a) FECUNDACIÓN ARTIFICIAL ${ }^{45}$}

Sólo la inseminación artificial homóloga, es decir, la intracorpórea entre esposos es admitida como éticamente lícita por la moral católica y ello siempre que se utilice como ayuda a la procreación. A pesar de la diversidad de comunidades e Iglesias protestantes, cabe afirmar que la gran mayoría de los reformados aceptan los métodos artificiales de reproducción humana siempre que las células germinales sean propias de los miembros de la pareja (fecundación homóloga), rechazándose en general aquellos métodos que implican la fecundación heteróloga.

Al igual que en el caso de las anteriores, la moral hebrea sólo permite la utilización de técnicas reproductivas artificiales cuando el óvulo es fecundado con esperma del esposo (homóloga), rechazándose cualquier otro método en razón de los problemas que se plantearían tanto respecto a la unidad del matrimonio como respecto a la propia identidad y pertenencia familiar del hijo $^{46}$.

A semejanza de lo que ocurre con las Iglesias reformadas, también resulta difícil ofrecer una doctrina única y generalizada en el caso del Islam, dada su estructura social, política y religiosa, así como la autonomía de las distintas comunidades; sin embargo, se puede afirmar, sin riesgo de error, que la ética islámica sólo acepta la intervención artificial en la concepción cuando, para paliar la esterilidad de la pareja, se recurre a la fecundación homóloga, rechazando como ilícita la heteróloga por considerarla en realidad como un verdadero adulterio, si bien, como ya formuló hace años un ilustre canonista español, se trataría de un adulterio casto $^{47}$.

di proseguire le terapie e quando invece è più giusto fermarsi, evitando un accanimento che non rispetterebbe la dignità del paziente» (I. R. MARINO, Credere e curare, Turín 2005, 60 y 63). La cursiva es nuestra.

$45 \ll . .$. al contrario di molti anni fa quando ci si interrogava sulla possibilità di eliminare un embrione, ora si dibatte su quale sia il modo lecito per creare una nuova vita ricorrendo alla fecondazione medicalmente assistita» (I. R. MARINO, Credere..., cit., p. 45).

${ }^{46} \mathrm{Cf}$. R. DI SEGNI, Il punto di vista ebraico su aborto, contraccezione e fecondazione artificiale, en L. BIAGI y R. PEGORARO, Religioni e bioetica. Un confronto sugli inizi della vita (Padua 1997), 291-294.

${ }^{47}$ Cf. T. GARCía BARBERena, «Adulterio casto», Revista Española de Derecho Canónico 19, 1962, 72-81; A. GuEssous, La procreación artificial: un punto de vista islámico, en AA VV, Proyecto genoma humano: Etica (Bilbao 1991) 141-145; F. BEN HAMIDA, Islam y Bioética, en AA VV, La salud y los Derechos Humanos. Aspectos éticos y morales (Washington 1990) 74-76. 
Todas ellas rechazan como ilícito el recurso a la maternidad sustitutiva, con la única excepción de algunas escuelas jurídicas islámicas que la aceptan únicamente en el supuesto de que la madre portadora sea alguna de las esposas legítimas del marido. Por otra parte, dada la complejidad que presenta en la actualidad todo lo referido con las técnicas de reproducción asistida, quizás habría de tomarse en consideración, tanto desde el derecho como desde la ética, las opciones y perspectivas razonables que la ciencia propone ${ }^{48}$.

\section{b) $\mathrm{ABORTO}^{49}$}

Aun cuando las tres grandes religiones monoteístas reconocen a Dios como creador y señor de la vida, sin embargo difieren en su valoración ética del aborto en razón de la postura adoptada sobre el momento de la gestación en que se puede afirmar que existe verdadera y auténtica vida humana ${ }^{50}$.

\footnotetext{
48 «Proprio su questo argomento si troverebbe forse un accordo se si aprisse un dialogo costruttivo tra scienza e religione. Tutti, infatti, ammettono che in passato è stato fatto un errore nel creare decine di migliaia di embrioni umani che ora esistono e attendono solo di spegnersi nel freddo nei frigoriferi delle cliniche per l' infertilità. La loro fine è certa, ma è meglio lasciarli morire oppure utilizzare le loro preziose cellule per scopi di ricerca? Per chi è cattolico si tratta di vite e come tali non possono essere soppresse, ma può darsi che la scienza, ancora una volta, ci possa venire in aiuto. Si potrebbe forse individuare il momento in cui un embrione perde la capacità di molteplicare le sue cellule, cioè la possibilità riproduttiva, e non può più essere utilizzato per dare origine a una vita. A quel punto, con un meccanismo simile a quello previsto per la donazione degli organi di un paziente in morte cerebrale, gli embrioni potrebbero essere donati ai laboratori di ricerca.

«Si potrebbe pensare di elaborare, su basi scientifiche, la definizione di 'morte riproduttiva' cosí come è stato fatto con il concetto di 'morte cerebrale'...», aunque también se ha de tener siempre muy presente que «oggi nessuno è in grado di assicurare che la ricerca sulle terapie con le staminali estratte attraverso la distruzione di un embrione avrà l' impatto rivoluzionario auspicato. Per questo è necessario che anche gli uomini di scienza agiscano con prudenza: è inutile e immorale promettere ai cittadini certezze che, al momento, sono soltanto supposizioni» (I. R. MARINO, Credere..., cit., pp. 47-48).

${ }^{49}$ Se viene aceptando, tanto desde la ciencia médica como desde la ética y el derecho que la interrupción voluntaria del embarazo acaece en los siguientes supuestos: a) aborto terapéutico o realizado para salvaguardar la vida de la madre seriamente amenazada; b) aborto eugénico, denominado así porque tiene lugar en aquellos supuestos en que se prevé que el nuevo ser nacerá afectado por graves anomalías de carácter físico, psíquico o mental; c) aborto ético, practicado en aquellos supuestos en que el embarazo es consecuencia de la comisión de un delito, por ejemplo, una violación; y d) aborto psicosocial, denominado así por la variedad y amplitud de las razones y motivos que puede llegar a justificarlo legalmente (Cf. J. GAFo FERnándEZ, Bioética teológica, Madrid 2003, 181-184).

${ }^{50} \mathrm{Al}$ margen de esta cuestión, como recordaba recientemente un eminente cirujano, al plantear la objeción de conciencia por parte del médico a la práctica del aborto, no debe olvidarse nunca que el aborto es el desenlace de un fracaso: «L' aborto, da qualunque punto di vista lo si voglia guardare, è la storia di un fallimento e le donne che vi sono sottoposte, per scelta o per necessità, sono in grado di comprendere meglio di chiunque altro il motivo per cui un medico possa decidere di non praticarlo» (I. R. MARINO, Credere..., cit., p. 44).
} 


\section{La Iglesia católica ha considerado siempre el aborto como un delito espe-} cialmente malicioso $^{51}$. La afirmación del derecho a la vida del no-nacido, incluso en las situaciones más díficiles y dramáticas, es una constante en el magisterio reciente de la Iglesia católica ${ }^{52}$. También, y sobre todo por la rela-

${ }^{51}$ El canon 1398 del Código de Derecho Canónico establece la pena de excomunión latae sententiae para quien procura el aborto, si éste se produce. El Código de 1917, en el párrafo 1 del canon 2350, a semejanza del actualmente vigente, también establecía que «los que procuran el aborto, incluso la madre, incurren, si el aborto se verifica, en excomunión latae sententiae reservada al Ordinario...». Según doctrina de la Pontificia Comisión para la Interpretación Auténtica del Código de Derecho Canónico, el aborto no es sólo matar el fruto inmaduro del vientre, sino toda acción que de cualquier modo y en cualquier momento conduzca a su muerte. La pena afecta a todos los que intervienen en el aborto y no sólo a la madre que mata o hace matar a su hijo: «D. Utrum abortus, de quo in can. 1398, intelligatur tantum de eiectione fetus immaturi, an etiam de eiusdem fetus occisione quocumque modo et quocumque tempore a momento conceptionis procuretur. R. Negative ad primam partem; affirmative ad secundam» (AAS 80, 1988, 1818-1819), formalizando así un tipo delictivo mucho más amplio que el derivado de la norma codicial de 1917. En el Código PíoBenedictino se tipificaba el delito de aborto como la eyección violenta y, en consecuencia, provocada del vientre materno de un feto humano vivo que, por su insuficiente desarrollo, es decir, antes de los ciento ochenta días desde su concepción (por analogia con el canon $1115,2)$ no puede vivir separado de la madre. La doctrina canónica anterior a la constitución Apostolicae Sedis, de 12 de octubre de 1869, requería para que se consumase el delito de aborto que el feto estuviese animado, es decir, que estuviese dotado de alma humana. Según una opinión muy difundida entre los antiguos, el feto no está animado desde el momento de la fecundación, sino más tarde, cuando su cuerpo ha adquirido una cierta organización que solía fijarse en ochenta días para las mujeres y cuarenta para los varones. La Constitución mencionada zanjó la cuestión suprimiendo la distinción entre feto animado e inanimado. Así pues, para la mayor parte de la doctrina canónica no podría calificarse como aborto la craneotomía, la embriotomía y otras operaciones semejantes realizadas directamente con la intención de matar al feto, pues tales operaciones son distintas de la de abortar y habrían de ser calificadas, en principio, de homicidio, graduando su tipicidad según las circunstancias personales en que aquellas se realizaren. Además, dado que el delito exige intención dolosa, no cabía ni la figura del aborto indirecto ni del aborto preterintencional. A pesar, sin embargo, de la interpretación extensiva por la que se decanta la Pontificia Comisión de Intérpretes, a la hora de fijar la existencia del delito y la irrogación de la pena se han de tener presentes las excepciones previstas en el canon 1323 del vigente Código de Derecho Canónico.

52 «La sacralità della vita è uno dei capisaldi della religione cattolica e di molte altre religioni e filosofie. Per questo è naturale che la Chiesa si sia sempre mostrata molto attenta nell' affrontare le tematiche che riguardano l' origine e la fine della vita. L' attegiamento prudenziale secondo cui l' embrione debba essere trattato come persona umana, dato che nel momento in cui l' ovulo è fecondato si inaugura una nuova vita, risale già a una dichiarazione della Chiesa del 1974, ripresa poi in un' istruzione del 1987 firmata dall' allora cardinale Joseph Ratzinger, Donum vitae, seguita nel 1995 dall' enciclica di papa Giovanni Paolo II Evangelium Vitae.

«Sulla base di questi due documenti fondamentali, la posizione della Chiesa cattolica appare molto severa su tutto quello che riguarda la procreazione, comprese le tecniche di fecondazione assistita...» (I. R. MARINO, Credere..., cit., pp. 45-46). 
ción que pudiesen tener con las prácticas abortivas, la Iglesia se ha pronunciado en distintas ocasiones sobre la licitud moral de las técnicas de diagnóstico prenatal: se consideran lícitas cuando se realizan con absoluto respeto a la vida del feto y de la propia madre, evitando todo riesgo desproporcionado; y se valoran como totalmente ilícitas las que se realizan con finalidad abortiva.

Para los protestantes sólo puede calificarse como ético el aborto cuando es el único remedio necesario para salvar la vida de la madre. Siempre el derecho a la vida del no nacido prevalece sobre el derecho de la madre sobre su propio cuerpo. Las técnicas de diagnóstico prenatal son valoradas, en general, de forma negativa, sobre todo, al objeto de evitar posibles desviaciones eugenésicas ${ }^{53}$.

Para la moral judía el aborto sólo se admite en aquellos casos en que pueda correr peligro la salud de la madre. En estos supuestos, antes de proceder a la ejecución del aborto, se ha de contar con la opinión de una autoridad rabínica reconocida. En aquellas situaciones en que entran en conflicto la vida de la madre y la del feto, se opta por la vida de la madre con el único límite del momento del alumbramiento, momento en que la criatura se convierte en nefesh, es decir, en ser animado por la ruah Yahveh, instante en que ya no cabe la elección a favor de la madre ${ }^{54}$.

Influidos por las teorías sobre la animación a que hemos hecho referencia más arriba, los maestros del Islam han considerado siempre legal el aborto siempre que existiesen causas precisas y determinadas y se practicara dentro de los ciento veinte días después de la concepción. No faltan, sin embargo, juristas e intérpretes del Corán que rechazan y condenan el aborto en todas sus formas y condiciones, excepto cuando se halla realmente en peligro la vida de la madre ${ }^{55}$.

\section{c) EutANASia ${ }^{56}$}

Los pronunciamientos del magisterio de la Iglesia católica sobre los problemas en torno a la eutanasia son abundantísimos y están presentes en todos

\footnotetext{
${ }^{53} \mathrm{Cf}$. AA VV, La salud y los derechos humanos. Aspectos éticos y morales (Washington 1999), 319-322.

${ }^{54}$ Cf. R. DI SEgni, Il punto di vista ebaraico..., cit., p. 281-285.

${ }^{55}$ Cf. D. ATighetchi, Islam, Musulmani e Bioetica (Roma 2002), 69-75; B. F. MussALLAM, «Sexo y sociedad en el Islam», Revista Verde Islam, n. 8, 1998, 15-18.

${ }^{56} \mathrm{Al}$ margen de la diversidad de significaciones del término eutanasia, según el contexto y la intencionalidad en que se utilice, en esta exposición asumimos las dos acepciones del término más frecuentes y habituales en las cuestiones planteadas a la bioética. Tomamos la eutanasia, en un sentido amplio, como aquella acción u omisión que tiende a causar la muerte con la finalidad de eliminar el dolor: el sufrimiento convertiría a la vida, según la consideración social, en indigna de ser vivida, justificándose de este modo la provocación de la muerte. En sentido más estricto, entendemos por eutanasia cualquier intervención voluntaria encaminada a provocar la muerte de alguien que, por razones patológicas, está
} 
los ámbitos y niveles de la jerarquía eclesial. Para la doctrina y enseñanza católicas, la eutanasia es una gravísima violación de la ley de Dios, en cuanto que consiste, al margen de las circunstancias con que se pretenda revestir o disimular, en la eliminación deliberada, querida y buscada de una persona humana. Se considera, por tanto, la eutanasia como un crimen que ninguna ley humana puede legitimar o justificar.

Ahora bien, la moral católica sí reconoce el derecho de toda persona a morir con dignidad humana y cristiana; por ello, se estima moralmente lícita la renuncia a medios terapéuticos desproporcionados que únicamente conducen a la prolongación indebida de la agonía. Con todo, la Iglesia rechaza el uso de analgésicos hasta el extremo de anular la conciencia de la persona moribunda, en razón de que en este caso se priva al hombre de la posibilidad de, e incluso del derecho a, vivir la propia muerte, reduciéndolo a un estado de inconsciencia indigna del ser humano, pues, con frecuencia, con este proceder se busca, más que eliminar el posible sufrimiento al enfermo, evitar el malestar y embarazo de quienes se han de relacionar en momento tan crucial con el moribundo.

La vida humana, enseñan los protestantes, es don divino, obra de Dios que no sólo la crea, sino que la sustenta. También para ellos el mandamiento no matarás connota y presupone la absoluta inviolabilidad de la vida humana y la tajante prohibición de disponer de ella. En razón de ello, consideran la eutanasia activa como un acto condenable y rechazable en cuanto que supone la más vergonzosa degradación de la vida humana, además de abrir la posibilidad de situaciones aberrantes y manipuladoras de la persona ${ }^{57}$. No se oponen, sin embargo, a la no iniciación o a la supresión, según el caso, de medios médicos artificiales cuando ya no tienen por objeto la sanación del enfermo y se dirigen exclusivamente a prolongar, sin más, la vida/sufrimiento del enfermo.

Partiendo de la distinción entre la lícita acción de aliviar el dolor y no alargar la agonía y la inadmisible actuación que tiende directamente a acortar la vida para evitar el dolor y el sufrimiento, insisten, a la hora de valorar la licitud ética de un determinado comportamiento, en la importancia de la motivación de las acciones así como del fin pretendido. Por ello, por ejem-

próximo a la muerte, a fin de poner término a sus sufrimientos. En cualquiera de los dos sentidos, la muerte se considera siempre como un bien, como el único medio para liberarse de un sufrimiento intolerable o de una vida que no se considera digna de ser vivida. No entramos, en este lugar, ni en la mera descripción de las denominadas eugenésica, económica, criminal o experimental, por ser consideradas como simples homicidios o asesinatos en los ordenamientos democráticos.

${ }^{57}$ Probablemente no sea ajena a este radical rechazo de las prácticas eutanásicas por parte de las comunidades protestantes la experiencia vivida en Centroeuropa durante los años del nazismo con sus científicas, avanzadas y progresistas, en criterio de sus promotores, prácticas eutanásicas. 
plo, aceptan la licitud del uso en enfermos terminales de fármacos que alivien o mitiguen el dolor, aunque de su uso se derive indirectamente al acortamiento de la vida del paciente ${ }^{58}$. Al igual que otras confesiones religiosas, tambien los protestantes defienden el derecho a la utilización de todos los cuidados médicos integrales hasta el momento de la muerte, rechazando siempre el encarnizamiento terapéutico.

Para los moralistas y juristas islámicos, la eutanasia se presenta como contraria a la aceptación y superación humana del sufrimiento y, en consecuencia, si se practicara impediría obtener el perdón final y último de Dios, lo que la convierte en acto moralmente ilícito. Así pues, toda acción dirigida a poner fin a la vida humana, aunque se realice a petición de la persona, está totalmente prohibida y se considera como homicidio voluntario. El Islam no sólo rechaza la eutanasia activa directa, sino que también se opone radicalmente a la eutanasia pasiva directa, en lógica consecuencia con su condena general de cualquier interrupción voluntaria de la vida del enfermo. Sí que, por el contrario, se admite la licitud de aquellos tratamientos que tienden a hacer más llevadera la agonía y a aminorar sus dificultades, ansiedades y dolores, aunque ello implique el acortamiento de la vida del paciente. Y, del mismo modo, se acepta la licitud de la suspensión del tratamiento, bien de fármacos o de medios instrumentales artificiales, o su no iniciación cuando se tiene la certeza de que no existe esperanza alguna de curación, pues se considera que los tratamientos médicos sólo son obligatorios cuando ayudan positivamente a la curación del enfermo. A su vez, la ley islámica permite la no aplicación de tratamientos médicos o farmacológicos inútiles, así como su interrupción cuando sólo tienden a retrasar una muerte inevitable, siempre con el consentimiento del propio enfermo terminal o de sus familiares, según los casos. Sí que se urge la obligación de mantener las curas ordinarias de hidratación y nutrición ${ }^{59}$.

Para la moral hebrea la defensa de la vida, en cualquier situación, es un deber religioso directamente expresado en la Torá (Dt 30, 19); por ello, es un imperativo legal y moral prolongar la vida lo máximo que se pueda, debiéndose poner todos los medios posibles para salvar la vida de cualquier enfermo. De cualquier modo, ante situaciones límite, se estima que debe corresponder a personas ajenas a los directamente afectados la toma de decisiones a fin de evitar todo riesgo de subjetivismo y para poder decidir con objetividad e imparcialidad. En consecuencia, la ley judía tradicional rechaza y prohíbe toda acción dirigida a provocar o acelerar la muerte del paciente,

${ }^{58}$ Cf. P. TARQuis Alonso, Bases teológicas de la ética protestante, en J. GAFo FERnÁNDEZ (ed.), Bioética y religiones: el final de la vida (Madrid 2000), 60-64.

${ }^{59}$ Cf. D. ATIGHETChI, Islam, Musulmani e..., cit., p. 190-202; R. TATARY BAKRY, Islam, Bioética y final de la vida, en J. GAFO FERNÁNDEZ (ed.), Bioética y religiones..., cit., pp. 80-86. 
calificándola de asesinato, incluso la mitigación del dolor sólo se admite cuando no conlleve la provocación de la muerte ${ }^{60}$. Algunas autoridades o escuelas rabínicas estiman, aun contando con su valoración absolutamente positiva de la vida humana, que es lícito rechazar la prolongación de la vida por medios artificiales. Es importante señalar que cualquier decisión sobre el enfermo terminal exige la intervención de la Santa Fraternidad ${ }^{61}$ que, en caso de duda, ha de consultar a la autoridad rabínica correspondiente.

\section{d) El ENCARNIZAMIENTO TERAPÉUTICO (DISTANASIA)}

Constituye un tópico evidente el hecho de que la tecnología y el progreso científico actuales son capaces de prolongar artificialmente la vida de personas que, sin esperanza alguna de curación, no recuperarán jamás una condición aceptable de salud. Situación que irremediablemente enfrenta a médicos, familiares, moralistas y juristas ante el urgente dilema de la interrupción voluntaria de los tratamientos médicos ${ }^{62}$. Aunque la suspensión de todos aquellos actos que conforman el tratamiento médico conduce inevitablemente al fin de una existencia mantenida con vida artificialmente, por tratarse, en realidad, de la aceptación de un hecho natural, nos hallamos ante un supuesto completamente distinto al hecho de, por ejemplo, procurar directamente la muerte de una persona por medio de la administración de un determinado fármaco ${ }^{63}$.

${ }^{60}$ Cf. B. A. Garzón Serfaty, Judaismo y bioética, en J. Gafo Fernández (ed.), Bioética y religiones..., cit., pp. 115-122.

${ }^{61}$ Se trata de una institución de voluntariado compuesta por 18 miembros y que debe existir en cada comunidad judía. Su misión consiste en acompañar al enfermo en los últimos momentos de su vida, velando, además, porque se observen las prescripciones de la ley judía en las últimas fases del tratamiento médico. También entra en sus funciones la preocupación por la dignidad de las exequias tras la muerte, así como el acompañamiento y la atención a los familiares del difunto durante los días que dura el luto.

${ }^{62}$ En los Estados Unidos de América, por ejemplo, la interrupción de los tratamientos médicos, cuando no existe esperanza razonable de que el paciente pueda recuperar una condición aceptable de vida es una práctica habitual en los hospitales. Ahora bien, se trata de una posibilidad minuciosamente regulada por el ordenamiento y exquisitamente respetada por los profesionales de la sanidad. En la mayor parte de los casos, la decisión se adopta de común acuerdo entre médicos y familiares, salva siempre la situación que pueda derivarse de la existencia de testamento vital o biológico. Sin embargo, hemos de dejar constancia de que, a pesar de la existencia de tales prevenciones, no es infrecuente la existencia de conflicto en algunos casos.

${ }^{63}$ Hasta los años setenta, más o menos, se utilizaban todos los medios técnicos y mecánicos a disposición de los médicos para mantener con vida al paciente hasta que el corazón dejaba mecánicamente de latir, ejerciéndose sobre el enfermo un encarnizamiento terapéutico injusto e irrespetuoso con la dignidad humana. Las cosas comenzaron a cambiar en el año 1976 con el caso de Karen Quinlan, una mujer americana en estado vegetativo mantenida con vida gracias a un respirador automático. A petición de la familia, frente a la oposición 
La doctrina católica rechaza como no acorde con la dignidad humana la llamada obstinación terapéutica o, lo que es lo mismo, el empleo de medios extenuantes para el enfermo que, sin proporcionarle beneficio real alguno, sólo prolongan artificialmente su existencia. En caso, pues, de enfermedad terminal es totalmente lícito servirse únicamente de los medios normales y ordinarios que ofrece la medicina. Según la moral católica, el criterio que se ha de utilizar a la hora de decidirse por la continuidad en el mantenimiento de la vida de una persona no es otro que el de la distinción entre medios terapéuticos proporcionados y desproporcionados a la situación del enfermo: a los primeros no se debe renunciar, siendo lícita la renuncia a los segundos precisamente para no caer en el encarnizamiento terapéutico. Se suelen considerar desproporcionados aquellos medios y terapias en que las técnicas empleadas imponen al paciente sufrimientos y molestias superiores a los beneficios que puedan generar.

Los protestantes rechazan mayoritariamente el encarnizamiento terapéutico así como la prolongación artificial de la vida en circunstancias imposibles e inviables ${ }^{64}$.

También en el Islam se rechaza la distanasia, en razón de que el hecho de prolongar inútilmente las funciones fisiológicas vitales del enfermo va en contra del enfermo mismo y de su propia familia ${ }^{65}$.

La defensa de la vida hasta el último suspiro, radicada en el valor supremo e infinito de la vida humana para el judaismo, funda la prohibición de suspender los esfuerzos y medios dirigidos a prolongarla en cualquier circunstancia en que se encuentre el paciente. No obstante, la posición no es unitaria entre las autoridades rabínicas, pues mientras para unos la ley judía no permitiría ni la suspensión de tratamiento alguno ni la desconexión del enfermo terminal de los aparatos de los que depende, para otros sería totalmente legítima la eliminación de fármacos e instrumentos mecánicos que, de hecho, sólo sirven para prolongar el sufrimiento del paciente ${ }^{66}$.

de los médicos temerosos de poder ser perseguidos penalmente, la Corte Suprema de Nueva Jersey dio la razón a los familiares, precisando que si no existía una posibilidad razonable de que la paciente recuperase su integridad intelectiva debían serle retirados todas las máquinas y tratamientos de subsistencia y dejar que la mujer muriese en paz. Catorce años después, en 1990, el caso de Nancy Cruzan, en estado vegetativo, autónoma en la respiración, pero alimentada mediante sonda naso-gástrica, reabrió el debate de 1976. También en este caso se autorizó la suspensión del tratamiento y, como consecuencia, el Congreso se planteó la necesidad de reconocer como derecho de todo ciudadano la posibilidad de realizar el testamento vital.

${ }^{64}$ Cf. P. TARquis Alfonso, Bases teológicas..., cit., pp. 62-65.

${ }^{65}$ Cf. D. ATIGHETchi, Islam, Musulmani..., cit., 187-189; R. TATARY BAKRY, Islam, Bioética..., cit., pp. 83-86.

${ }^{66}$ Cf. B. A. GARzón Serfaty, Judaismo y bioética..., cit., pp. 121-124; I. JaKobowits, Ebraismo, en S. SPINSANTI (ed.), Bioetica e grandi religioni (Milán 1987) 29-33 y 47-50. 


\section{Ante la vida y la muerte: ¿obstinación o diálogo?}

La sacralidad de la vida humana y su consecuente indisponibilidad por parte de la voluntad individual es el principio que mejor y con más precisión especifica y define las características o propiedades de lo que podríamos calificar, en orden a facilitar la metodología de su conocimiento, como bioética(s) confesional(es), a diferencia de la(s) que podríamos denominar como bioética(s) laica(s) o no confesional(es), para las que el principio fundante y regulador sería, por el contrario, el de la «calidad/cualidad de la vida» (quality of Live): no es la vida, en cuanto tal o en cuanto manifestación necesaria de un valor superior de orden religioso o metafísico, la que tiene la primacía, sino la calidad de vida, el bien estar, sólo la que tiene apariencia de «ser digna de ser vivida ${ }^{67}$.

En un cierto sentido, podría decirse que ésta sería una ética de lo adjetivo: no es el sustantivo vida el que determina la eticidad de un determinado acto, sino el modo, la calificación, de esa vida lo que se convierte en fuente de eticidad. Los partidarios de esta bioética, siguiendo a Séneca ( «no es un bien el vivir, sino el vivir bien» ${ }^{68}$, defienden que «la moral moderna no es, genéricamente, la moral de la vida. Es la moral de la vida feliz... la vida, como tal, no es un valor; sólo una vida que pueda decirse humana es un auténtico valor ${ }^{69}$. La aceptación, por principio, de que la vida es un valor sujeto a la libre disposición del hombre o, por el contrario, la proclamación de que ningún ser humano puede decidir sobre la vida, considerada como realidad suprema por encima de voluntariosos deseos o de circunstanciales conmiseraciones, sigue distinguiendo, en su fundamento, las bioéticas religiosas de aquellas que, en principio, se acogen exclusivamente al valor funcional de la inmanencia.

\section{1) Las posturas y sus perfiles}

Desde una perspectiva pedagógica adulta, quizás el mejor modo de poner el primer broche a esta exposición sea ofrecer el testimonio de distin-

${ }^{67}$ Cf. G. Fornero, Bioetica cattolica..., cit., pp. 22-128 y 153-177; A. SocCI, Il genocidio censurato. Aborto: un miliardo di vittime innocenti (Casale Monferrato 2006), 9-25, 3843 y $153-173$.

68 «...non enim vivere bonum est, sed bene vivere» (L. A. SÉNECA, [Literae] Ad Lucilum, vol. I, libro 8, carta 70 [ed. Rizzoli], Milán 1999, p. 447). Y, como aconteció en el propio Séneca, la desembocadura lógica de este principio es, en situaciones límite, el suicidio: cf. IDEM, De ira, 3, 15. Al contrario de lo que ya ocurría en el Cristianismo contemporáneo de Séneca: cf. G. Lombardi, «L'Editto di Milano del 313 e la licità dello Stato», Studia et Documenta Historiae et Iuris 50, 1984, 26-28; C. MAZZuCCO, Il significato della «libertas» proclamata dai martiri della «Passio Perpetuae», en Forma Futuri. Studi in onore del card. M. Pellegrino (Turín 1975), 542-565.

${ }^{69}$ U. SCARPELLI, Bioetica laica (Milán 1998), 91 y 131. 
tas personas o instituciones sobre una de las cuestiones más candentes en los planteamientos actuales de la bioética que continuamente llama a la puerta de juristas, legisladores, moralistas, antropológos y filosófos: me refiero a la eutanasia. Pues bien, he aquí seis testimonios... que cada uno juzgue:

Pertenece el primero a la Congregación para la Doctrina de la fe, de la Iglesia Católica:

«Nada ni nadie puede autorizar la muerte de un ser humano inocente, ya se trate de un feto o un embrión, un niño o un adulto, un viejo o un enfermo incurable o agonizante. Nadie, por otra parte, puede exigir este gesto homicida por sí mismo o por medio de otra persona bajo la responsabilidad de quien lo pide, ni puede consentir en ello ni implícita ni explícitamente. Ninguna autoridad puede legítimamente imponerlo o permitirlo. Se trata de hecho de una violación de la ley divina, de una ofensa a la dignidad de la persona humana, de un crimen contra la vida, de un atentado contra la humanidad»(Declaración sobre la eutanasia, n. 1).

El segundo es del Cardenal Martini, Arzobispo de Milán, jubilado actualmente:

«Como monstruosa aparece la figura de un amor que mata, de una compasión que borra y aniquila a aquel cuyo dolor no puede soportar, de una filantropía que no sabe ni puede explicar si pretende liberar a otro de una vida convertida exclusivamente en una carga o por el contrario liberarse a sí misma de una presencia que aparece sólo como una carga» ( Omelia di Sant'Ambrogio», 1981, en D. TetTamanzi, Nuova bioetica cristiana, Cassale Monferrato, 2000, 544). Milán:

El tercero lo suscribe el Cardenal Tettamanzi, actual Arzobispo de

«Se trata [...] de asimilar por qué la eutanasia propiamente dicha se configura como un gesto monstruoso. El porqué está en el hecho de que la eutanasia contradice radicalmente el fundamental, intangible, irrenunciable valor de la vida humana como realidad 'sagrada'» (Nuova bioetica cristiana..., cit., p. 545).

El cuarto corresponde a uno de los varios Manifiestos sobre la eutanasia:

«Es cruel y bárbaro exigir que una persona sea mantenida viva contra su voluntad y que se le niega la suplicada liberación cuando su vida ha perdido toda dignidad, belleza, significado y perspectiva de futuro» (The Humanist, julio de 1974).

El quinto lo avala el conocido periodista Indro Montanelli:

«Considero que entre los derechos del hombre también, es más, sobre todo, ha de enumerarse el de poner fin a su vida cuando ésta se haya convertido para él en un calvario de sufrimiento sin esperanza y, dejándolo a merced de otros, le haya privado también de la posibilidad de defender el propio pudor y dignidad» (Corriere della Sera, 23-02-2000). 


\section{El sexto corresponde a Emanuele Severino:}

«Una sociedad que disponde de medios para que una mujer impida el nacimiento de otro ser debería, con mucha más razón, ofrecer los medios que permitan morir a quien, deseando la muerte, no puede autoproporcionársela» (Corriere della Sera, 20-09-1984).

Probablemente, como también se ha puesto suficientemente de relieve por quienes se dedican al estudio de esta problemática, quienes son seguidores de la teoría de la sacralidad de la vida como único fundamento válido y último de la bioética parten de la necesaria correlación descendente, en la que siempre la anterior determina a la siguiente, entre metafísica, antropología y ética ${ }^{70}$. Correlación establecida no en un sentido meramente estáticoontológico que exigiría la formulación conceptual-racional previa del hombre metafísico para desde esa percepción poder alcanzar al hombre ético, sino en una dimensión de prevalencia dinámico-hermenéutica en cuanto que la ética sólo se puede justificar debidamente y fundar racional-comprensivamente por medio de un discurso o elaboración totalizante, complexiva, sobre la persona humana capaz, en consecuencia, de explicar no sólo qué es el hombre, sino cuál es su lugar y función en el mundo y cuál es la causa, motivo y finalidad por la que está en este mundo ${ }^{71}$.

Es claro, pues, sobre todo si partimos del entronque metafísico de los principios o categorías filosóficas de base en que se inspiran, que, probable-

70 «Ogni etica è la conseguenza di una determinata concezione dell'uomo, ed ogni concezione dell'uomo è conseguenza di una determinata concezione della realtà; dell'essere nella sua totalità» (S. VANNi Rovighi, Elementi di filosofia, vol. 3, Brescia 1976, 216). Planteamiento claramente supuesto en la encíclica Fides et ratio de Juan Pablo II cuando defiende que «es necesaria una filosofía de fundamento auténticamente metafísico, capaz de trascender los datos empíricos para alcanzar, en su búsqueda de la verdad, lo absoluto, lo último, lo fundante. Se trata de una exigencia implícita tanto en el conocimiento de carácter sapiencial como en el de carácter analítico; en particular, es una exigencia propia del conocimiento del bien moral, cuyo fundamento último es el Bien sumo, Dios mismo. No quiero hablar aquí de la metafísica como si fuera una escuela específica o una corriente histórica particular. Sólo deseo afirmar que la realidad y la verdad trascienden lo fáctico y lo empírico, y reivindicar la capacidad que el hombre tiene de conocer esta dimensión trascendente y metafísica de manera verdadera y cierta, aunque imperfecta y analógica. En este sentido, la metafísica no se ha de considerar como alternativa a la antropología, ya que la metafísica permite precisamente dar un fundamento al concepto de dignidad de la persona por su condición espiritual. La persona, en particular, es el ámbito privilegiado para el encuentro con el ser y, por tanto, con la reflexión metafísica» (Fides et ratio, n. 83).

${ }^{71}$ «L'obiezione è questa: ma allora bisogna conoscere l'esistenza di Dio come fine ultimo per operare moralmente? Rispondo: non è necessario conoscere l'esistenza di Dio per operare moralmente, ma per giustificare filosoficamente (ossia razionalmente) la moralità. Il che vuol dire: non è detto che chi nega l'esistenza di Dio operi male; ma è certo che tutte le teorie che giusitificano il dovere di operare bene senza ricorrere a Dio finalizzatore sono errate, o almeno incomplete» (S. VANNI Rovighi, Elementi..., cit., p. 208) 
mente desde sus orígenes, ha existido y todavía hoy persiste una ruptura estructural, desde su mismo planteamiento teórico, entre la llamada bioética fuerte, de matriz católica, y la denominada bioética debil, de procedencia laica; es decir, entre una bioética metafísica, o estructuralmente abierta a la metafísica, y una bioética no-metafísica, o antimetafísica, que rechaza de plano cualquier referencia a la mera posibilidad de una construcción ontológica de la ética y toda alusión a la existencia de una verdad-metro-norma objetiva capaz de garantizar una regla cierta, sagrada e inviolable orientadora del juicio bioético.

\section{2) ¿Hacia una superación de las diferencias?}

Como era de esperar, ante tan extrema perspectiva no podían faltar las posturas conciliatorias contrarias a la idea de la existencia de una bioética de la cualidad/calidad de la vida radical y esquemáticamente «contrapuesta a una ética de la sacralidad de la vida, sin que se reconozca ciudadanía científica alguna a la infinidad de posturas y opciones intermedias entre estos dos paradigmas», haciendo, además, hincapie en la existencia, dentro del panorama cultural actual, de actitudes menos drásticas y conflictivas:

«La referida contraposición no corresponde a la realidad de las cosas, en cuanto que en ambos frentes el discurso con frecuencia está mucho más articulado y es más sutil — los mismos principios de sacralidad y de cualidad de la vida no definen necesariamente comportamientos radicalmente alternativos, sino que resultan en muchos casos integrables-y las posiciones resultan, en consecuencia, mucho más conciliadoras y dispuestas al compromiso» ${ }^{72}$.

Concordismo ético inmediatamente rechazado, sobre todo desde el lado de quienes mantienen posturas dentro de los principios éticos laicos:

«Se tiene... la sensación de que los dos frentes que se disputan el campo [de la bioética] hubiesen, por decirlo de algún modo, cristalizado sus posiciones, alcanzando un punto de incomunicabilidad substancial, empeñados [cerrados, comprometidos] además... en la discusión sobre el caso concreto y en la defensa a ultranza de las propias posiciones» ${ }^{73}$.

Sin embargo, como ha reconocido el propio Scarpelli, todavía queda la posibilidad de fructuosos encuentros en torno al caso concreto. Según el conocido estudioso, en torno a los casos concretos, sobre todo en aquellos en que se camina en el límite, «las distancias entre una ética religiosa y una ética laica aparecerán más cortas que en las proclamas de principio y, probable-

${ }^{72}$ G. PiAnA, «I limiti della prospettiva analitica in bioetica», Bioetica, n. 4, 2002, 805.

73 A. Rentería DíAZ, «Il principio di autonomia in Uberto Scarpelli», Bioetica, n. 4, 2003, 706. La cursiva es nuestra. 
mente, sobre muchos problemas se podrán hallar senderos comunes» ${ }^{74}$. Pues, en definitiva, todavía siguen lozanas e irresolutas dos preguntas fundamentales en la práctica de la medicina y en los juicios y linderos del moralista más allá de su adscripción ideológica:

- ¿Pueden la investigación médica y la tecnología de que disponemos ser puestas al servicio de quien ha decidido terminar con su propia vida o de quien opta, en principio, por acabar con la vida de alguien para, teóricamente, salvar a otro?

- ¿Qué limites hemos de asumir como individuos, miembros de una sociedad pluralista, a la hora de utilizar todos los medios e instrumentos que la ciencia pone a nuestra disposición y, en este mismo sentido, cuáles han de ser, por el contrario, los puntos de referencia para un creyente a la hora de valorar y enjuiciar problemas de tal complejidad?

No es facil conciliar íntegramente ambas visiones, la laica y la creyente, en la posible respuesta a preguntas de este género, pero ello ni significa ni implica que sea imposible la convergencia en un denominador común. Es evidente que quien vive desde la fe y cree en la vida eterna ha de tener una visión distinta y una actitud diferente ante esta clase de situaciones límite. Pero también es cierto que el respeto por la primacía de la vida y por la dignidad de la persona no es patrimonio exclusivo de los creyentes: el valor incomparable e in-apreciable de la persona humana es, sin duda alguna, patrimonio común de todos los que formamos parte de la sociedad o, al menos, debiera serlo más allá de cualquier fe o creencia. Ésta, y ninguna otra, ha de ser la referencia fundamental a la hora de estudiar y aplicar principios y normas que protejan verdaderamente la vida humana ante cualquier intento de eliminación, mercantilización o reducción a mero bien de consumo.

\section{3) Horizontes de entendimiento}

A pesar de las discrepancias y de las contradicciones apuntadas a lo largo de esta exposición y aun contando con que unas y otras puedan aparecer, con frecuencia, como opuestas hasta la imposibilidad de conciliación alguna, ello no significa de ningún modo que sea imposible el diálogo e incluso la sintonía, en muchos casos, entre los discrepantes, puesto que todos ellos recurren a valores fundamentales en toda solución/opinión sobre los casos o supuestos concretos:

«Las características, que nosotros consideramos revestidas de importancia moral en cada caso, son recibidas a través de valores que previa-

${ }^{74}$ U. SCARPELLI, Bioetica laica..., cit., pp. 27-28. 
mente ya habíamos aceptado en cuanto moralmente relevantes. Siempre tendremos necesidad de ciertas premisas de valor para llegar a conclusiones morales si queremos dar respuesta al cúmulo de circunstancias y problemas a que debemos enfrentarnos» ${ }^{75}$.

Siempre se debe tener presente en el filo de la reflexión, como enseñan los grandes maestros de la bioética laica y católica, que no pueden existir juicios de valor si no responden a determinados principios que, a su vez, estan determinados por entornos de referencia antropológicos y morales. Entornos que, en todos los casos y se opte por la opción de principio que se opte, condicionan las soluciones que se aporten a los casos concretos y que, a su vez, condicionan y fundamentan las diferencias entre los distintos modelos bioéticos:

«Las distintas valoraciones morales sobre las cuestiones específicas derivan del modelo ético de referencia, que siempre y necesariamente se halla presente en la reflexión moral, desde el momento en que la neutralidad en este campo no existe» ${ }^{76}$.

Aun cuando, dados los principios y las opciones de fondo de que se parte, pueda parecer imposible el encuentro entre la bioética personalista o católica o religiosa y la bioética laica, dado que una ética fundada en una antropología que defiende como principio supremo la sacralidad de la vida difícilmente se allanará a soluciones o componendas de cesiones a la debilidad, esto no tiene por qué significar la dejación y pasividad en la búsqueda, siempre en los límites de lo posible, de soluciones convergentes, en orden a suavizar las contradicciones más irreconciliables y las diatribas más lacerantes. Por ello, se sigue insistiendo por parte de quienes sienten profunda preocupación por la persona y sus derechos en que «desde el punto de vista práctico debe de ser máximo [y sin prejuicios castrantes] el esfuerzo en esta dirección. Pero tal búsqueda ha de ser hecha teniendo en cuenta las notables divergencias existentes en el plano teórico. El convencimiento de esta circunstancia aumenta (y no disminuye) la posibilidad de un diálogo sincero y franco entre las partes» ${ }^{77}$.

A pesar de que estructuralmente son distintas e irreconciliables en algunos puntos o aspectos importantes, la verdad es que bioética laica y bioética católica o religiosa están llamadas a entenderse, pues si necesariamente han de coexistir no les queda otra solución que dialogar y, en cierto sentido, inter-relacionarse si realmente se trata de llenar de auténtica humanidad las

p. 1399.

75 T. L. Beauchamp, Principialismo, en G. Russo (ed.), Enciclopedia di bioetica..., cit.,

${ }^{76}$ M. CAscone, Diakonia della vita. Manuale di bioetica (Roma 2004), 43.

${ }_{77}$ M. MORI, Per un chiarimento delle diverse prospettive etiche sottese alla bioetica (Milán 1990), 66. 
relaciones interpersonales ${ }^{78}$. Por otra parte, el ambiente multicultural y multiétnico de la mayor parte de las sociedades actuales hace más urgente la necesidad de un verdadero diálogo que no sea la mera y artificial yuxtaposición de monólogos individualistas y estériles, sino la búsqueda comprometida y apologéticamente desapasionada de entendimientos mínimos que posibiliten una convivencia plural en que las discrepancias y desavenencias no sean fruto de odios ideológicos, filosóficos o confesionales, sino consecuencia de la honestidad y sinceridad en la defensa y explicación de las propias convicciones.

\section{El ordenamiento jurídico desde la ética a la sociedad}

Es evidente que la bioética, tanto en lo que se refiere a los problemas que se plantea como a las respuestas que ofrece, se mueve entre dos coordenadas ineludibles: una personal, otra social. La bioética, en cualquiera de sus versiones u orígenes, tiende primaria y principalmente a facilitar medios y criterios de comportamiento y decisión para que las personas abocadas a situaciones límite en las que se pone en riesgo el derecho a la vida y la vida misma puedan decidir y actuar conforme a justicia, moralidad y libertad en el respeto de todos y cada uno de los derechos que se ponen en juego en estos supuestos. Ahora bien, no se debe perder de vista que, cuando se plantea cualquiera de las cuestiones relacionadas con la bioética, comenzamos a movernos en unos ámbitos en que las decisiones personales nunca son privadas/individualistas, sino que, en razón de los sujetos y derechos que se ven implicados y afectados, la proyección social y pública de estas decisiones es ineludible y en modo alguno se puede oscurecer o disminuir esta necesaria dimensión societaria, so pena de afectar a los derechos de la propia persona $\mathrm{y}$, en consecuencia, de rebajar y someter al ser humano a intereses que le son inferiores tanto jurídica como socialmente.

La dimensión e incidencia sociales de los problemas relacionados con la bioética provocan la necesidad de que el ordenamiento jurídico deba interesarse, siempre y exclusivamente desde una perspectiva socio-jurídica, por el

\footnotetext{
${ }^{78}$ Como se ha señalado acertadamente, a pesar de las concesiones que hace a algunos tópicos históricos, por un autor de mentalidad católica «...ci sono società meglio equipaggiate per vivere nel pluralismo ideologico ed etico; altre meno. Senza autolesionismo, possiamo affermare che il nostro mondo latino appartiene piuttosto a queste ultime. Siamo eredi delle crociate e delle guerre di religione, di reazione laiciste a tenaci concezioni teocratiche; ci è più familiare la prevaricazione nei confronti di chi dissente che il rispetto e il dialogo» (S. SPINSANTI, Etica biomedica, Cinisello Balsamo 1987, 19). Puede verse también A. SAntosuosso, Una chance per la bioetica e per il diritto, en E. D' ORAZIO y M. MORI (ed.), «Quale base comune per la riflessione bioetica in Italia? Dibattito sul Manifesto di bioetica laica», Notizie di Politeia 12/41-42, 1996, 56-61.
} 
establecimiento y desarrollo de instituciones jurídicas y estructuras legales que posibiliten, faciliten y garanticen la información y libertad personales ante cualquier decisión del género, tanto por lo que se refiera a la propia persona como a terceros. Por otra parte, difícilmente se podrán articular medidas adecuadas a estas novedosas situaciones si no se abandonan los viejos y, por tantos motivos, caducos esquemas jurídico-políticos del tipo de Estado que surge de la modernidad. La finalidad de la norma ha de tener en su horizonte a la persona y no directa y prevalentemente a cualidades o propiedades de ésta por muy importantes y fundamentales que puedan parecer ${ }^{79}$.

\section{1) La conciencia personal, sujeto y fuente de derecho}

La persona, pues, y su conciencia, por cuanto afecta y se relaciona con los problemas propios y característicos de la bioética, no deben seguir siendo consideradas por el ordenamiento como meros límites negativos de la norma, a través de un conjunto más o menos amplio y mejor o peor articulado de las objeciones de conciencia. Por el contrario, en estos supuestos, la conciencia ha de asumirse como fuente de derecho: la norma, en consecuencia, ha de plasmar la opción de la conciencia y no meramente permitir que, en determinadas circunstancias, la conciencia pueda situarse al margen de la norma.

También ha de tenerse en cuenta, como ya se ha señalado, la fuerte implicación del objeto de la bioética con las opciones y creencias religiosas, así como con usos y prácticas consuetudinarias y culturales. Además, no puede perderse de vista que las sociedades occidentales tienden a ser cada vez más multiétnicas, multirreligiosas y, a pesar de la discutida imprecisión del neologismo, multiculturales. Situación que, a todas luces, complica la

79 «...únicamente pretendemos plantear con la mayor claridad posible la necesidad y la urgencia social de un redimensionamiento personalista, es decir enraizado en la persona, de la relación que necesariamente ha de tener toda norma o institución jurídica con el hombre. O lo que es lo mismo: estimamos que el centro de cualquier reflexión o concreción normativa de las implicaciones jurídicas de la relacional existencia humana ha de ser siempre la dignidad del hombre. Dignidad que fundamentalmente es la consecuencia social y jurídica, a la vez, necesaria del componente transhistórico, espiritual o trascendente de toda persona y de la radical libertad substancialmente inherente a aquella realidad estructural personal y, a la vez, único medio operativo práctico capaz de realizar, en las coordenadas históricas en que el hombre vive, la verdad [y autenticidad] de su ser humano. Libertad que progresivamente se expresa, y a la vez se plenifica, en la relación existencial que en su desarrollo vital conforman la interioridad personal y su necesaria referencia a la historicidad de toda existencia» (A. CAlvo EsPIGA, «Acercamiento a la incidencia...», cit., pp. 319-320). Sobre esta centralidad y exclusividad de la persona como fundamento y razón del ordenamiento jurídico, también puede verse IDEM, Pautas para el análisis de un anacronismo jurídico: ¿ «Derechos humanos» en la Iglesia?, en Actas del Congreso de Teología de las Facultades de Teología de Vitoria y Deusto (Bilbao - Vitoria 1990), 371-373. 
posibilidad de dar respuestas jurídicas desde unos parámetros predominantemente racionalistas que asuman como razón estructurante de la sociedad una uniformidad institucional jerárquicamente ordenada al estilo kelseniano ${ }^{80}$. Se trata, sobre todo, de abandonar actitudes agresivas o defensivas, tantas veces enrocadas en falsas seguridades consecuencia de la absolutización de verdades parciales, para elaborar razonamientos y fijar los márgenes de una senda ética que, respetando radicalmente la libertad de las personas, pueda, en principio, ser aceptada por todos. La urgencia de los problemas y la perplejidad de las situaciones a que la ciencia nos aboca hacen cada día más acuciante el diálogo por la vida y menos comprensible el interés por alzar murallas de incomprensión o hundirse en trincheras ideológicas.

A pesar de su dificultad, más complicada en realidad de lo que a primera vista pudiera parecer, si se quiere dar respuestas válidas y socialmente eficaces en el ámbito de la bioética, no queda más remedio que abandonar los esquemas de la formalidad legal dominante en los ordenamientos democráticos contemporáneos y sustituirlos por la búsqueda de la justicia material, en el respeto y aceptación, como fuente normativa, de la conciencia personal. Como ya sugerimos hace años, probablemente nos hallemos ante la urgencia de retomar principios y metodología de los denominados ordenamientos de conciencia ${ }^{81}$.

${ }^{80}$ «Nada mejor que el éxito académico, dogmático y forense obtenido en la organización y jerarquización de las fuentes del derecho por la estructuración piramidal kelseniana para consagrar, bajo apariencia de libertad, la absoluta relativización y marginación de la persona frente a la estructura y, tras la garantía democrática de seguridad jurídica, de la libertad creativa frente a la repetitividad formal, de la espontaneidad social frente a la rigidez de la norma cuya referencia fundamental y justificativa es otra norma, no la persona» (A. CALvo EsPIGA, Conciencia..., cit., p. 39).

${ }^{81}$ «Así pues, el reconocimiento de las libertades más íntimas de la persona exige del Estado de derecho la progresiva integración de la norma jurídica en la esfera de la actividad social directamente relacionada con y derivada de la conciencia, en su más amplio sentido, del individuo. El ordenamiento estatal se encuentra abocado a regular determinados aspectos de la actividad social de la persona que derivan o se relacionan, de modo especial, con dimensiones extra o metajurídicas del ser humano. Ante esta exigencia, ¿qué capacidad de respuesta pueden tener sistemas jurídicos que no asumen la conciencia de la persona entre sus principios integradores o informadores? Reconocer relevancia a la conciencia personal y a sus implicaciones sociales, ¿no entraría en contradicción con el garantismo formalista y con la seguridad legal-material, propios de los sistemas jurídicos estatales? El Derecho Canónico, en cuanto ordenamiento confesional, puede constituir respuesta ejemplar o modélica a los interrogantes propuestos, ya que, debido a la naturaleza de las relaciones que regula, ha armonizado de tal modo norma jurídica e imperativo de conciencia que posibilita su progresiva integración y, poco a poco, evita o supera los riesgos de conflicto. Por tratarse de un ordenamiento confesional, la norma canónica tiende fundamentalmente a posibilitar la adecuación entre norma jurídica y conciencia, inclinándose siempre por la prevalencia de la conciencia sobre la norma, en caso de conflicto límite en la relación» (A. CALvo ESPIGA, «De nuevo sobre la naturaleza y lugar del Derecho Canónico: derecho confesional 'versus' ordenamiento estatal», Scriptorium Victoriense 44, 1997, 23-24). Para una visión 
La tarea no es fácil y es muy pesado el lastre social y jurídico que se arrastra en las modernas democracias en que formalismo y Estado de derecho han corrido parejos durante décadas y generaciones. Pero la dificultad no debe ser, en modo alguno, equivalente a inacción; al contrario, lo que hoy se exige del jurista es un esfuerzo mayor y una imaginación más despierta al servicio de la persona y de su conciencia tal como existen y se verifican en su situación ideológica, cultural, social y religiosa.

\section{2) Viejos esquemas ante nuevos problemas}

En aquellas sociedades en que las noticias se difundían al ritmo de las caballerías y donde las personas sólo salían de su aldea de origen o a causa de la pobreza, o porque contraían matrimonio o, temporalmente, por razones religiosas, caso de peregrinaciones o determinadas romerías, el principio formal de que la ley es igual para todos supuso una gran conquista donde la única gran diferencia entre las personas radicaba básicamente en el disfrute de importantes privilegios por quienes se acomodaban en las clases altas y en la privación de los derechos más elementales a la gran mayoría de personas que no pasaban de ser súbditos ${ }^{82}$. Sin embargo, la mayor parte de los grandes

ajustada y sintética de las líneas maestras que integran el conjunto sistemáticas de los grandes ordenamientos confesionales de matriz monoteista, puede verse S. FERRARI, El Espíritu de los derechos religiosos. Judaísmo, cristianismo e islam (Barcelona 2004), sobre todo las páginas 91-300.

82 «Au XVI ${ }^{\mathrm{e}}$ siècle, on s'achemine vers le domaine de la propriété privée. Il ne sera vraiment consacré qu' à l' époque révolutionnaire... Ceux qui, aux États généraux, prétendaient représenter le peuple, représentaient en fait la classe bourgeoise. Celle qui vend et qui achète. Dorénavant, vendre et acheter va vous donner le droit d' exister et d' être quelqu' un. C' est ce qui donne une valeur à la personne plus que d' être 'enfant de Dieu'. Au Moyen Âge, le fair d' être des créatures créait une égalité et une unité entre les personnes. Après, on est soit un propriétaire de biens, soit un misérable. Au Moyen Âge, le pauvre représente le Christ. L' expression 'pauvre mais honnête' employée aux XVIII ${ }^{\mathrm{e}}$ et XIX ${ }^{\mathrm{e}}$ siècles est significative: il y a présomption de malhonnêteté pour le pauvre... Au Moyen Âge, on lui faisait une place, même s' il était assis en bout de table. À partir du XVI ${ }^{\mathrm{e}}$ siècle, on a honte du miséreux et on l' exclut. Le fait de posséder de l' argent a créé des classes sociales et entraîné une fracture... Le spectacle d' une société dans laquelle l' argent n' a pas le premier rôle devrait être instructif pour nous: cela permettrait de rétablir des relations qui ne soient pas exclusivement fondées sur le maniement de l' argent» (R. PERnOud, Histoire et lumière, París 1998, 23 y 24-25). En este mismo sentido, aunque no realiza un análisis tan profundamente centrado en las actitudes personales, ideológicas y religiosas, puede verse O. BRUNNER, Sozialgeschichte Europas im Mittelalter (Gotinga 1978), 135-149 y 158-167. Y desde perspectivas más radicadas en el análisis y estudio de los hechos puede verse R. Delatouche, «La

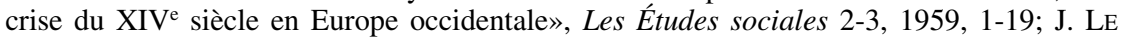
GoFF, La civilisation de l' Occident médiéval (París 1964); IDEM, «Le temps du travail dans la 'crise' du XIV è siècle: du temps médiéval au temps moderne», Le Moyen Âge 69, 1963, 597-613; S. Mochi ONORY, Fonti canonistiche dell’ idea moderna dello stato (Milán 1951). 
principios que han sustentado las viejas democracias se sienten hoy incapaces de dar respuestas jurídicas razonadas, razonables y aceptables a los problemas e interrogantes planteados por las nuevas sociedades conformadas en el fenómeno migratorio/inmigratorio; en el nacimiento de conglomerados sociales estables formados por personas de diferentes razas, idioma, cultura, religión, educación...

Además, al ya complejo problema de la globalización, que ha cambiado, en algunos casos sustancialmente, nuestras referencias ordinarias hasta el extremo de que cuando cada mañana se abre la ventana uno se topa, por ejemplo, con el desastre ecológico sucedido en las antípodas, en lugar de las flores y macetas de la vecina, se ha de sumar, todavía no está claro si por reacción o por estupidez, el renacimiento de particularismos nacionalistas que desvertebran y desarticulan sociedades ya maduras o en evidente proceso de consolidación. Situaciones que, a todas luces, dificultan e incluso imposibilitan soluciones jurídicas desde presupuestos sociales, ideológicos o políticos radicalmente distintos a aquellos que generaron los sistemas hasta ahora conocidos y todavía vigentes.

La centralidad y el respeto a la persona (a la propia persona y a la de los demás), asumido como criterio último de eticidad y, simultáneamente, como valor primario e incondicional de toda bioética a fin de evitar los inconvenientes de las filosofías morales de origen utilitarista, liberal o neoclásico, pueden constituir un buen y seguro inicio y fundamento para consolidar un método de camino común para las distintas opciones y alternativas que priman en la bioética contemporánea ${ }^{83}$. Así, por ejemplo, entre el neoutilitarismo liberal del derecho a morir, que se concreta, predominantemente, en la aceptación de la eutanasia y del denominado suicidio asistido y la utilización de terapias desproporcionadas con la única finalidad de «prolongar biológico-fisiológicamente la vida» cabe una especie de «tercera vía» en la que iniciar una andadura de acompañamiento por parte de las diversas éticas que, de hecho, subyacen a las distintas opciones bioéticas.

${ }^{83}$ En esta línea se mueve, por ejemplo, Massimo Reichlin, uno de los mayores exponentes en Italia de entre quienes intentan abrir vías de diálogo permanentes y aceptadas entre las distintas corrientes de la bioética: «Il riferimento alla persona umana come fonte di valore morale è comune a diverse teorie etiche contemporanee, anche se viene interpretato in maniera significativamente diversa nei diversi approcci: a volte, il valore della persona viene identificato con la considerazione imparziale delle sue preferenze e dei suoi interessi soggettivi, altre volte con il rispetto del suo diritto all'autodeterminazione, altre ancora con la promozione dei suoi beni fondamentali oggettivamente definiti. Mi sembra che, da un lato, le prospettive utilitariste e liberali non rendano ragione del valore intrinsecamente associato all'essere persona, un valore che è prioritario e indipendente rispetto a interessi e preferenze soggettive; dall'altro, che le prospettive fondate sulla legge naturale identifichino troppo rigidamente il rispetto per la persona con il rispetto per i suoi beni fondamentali, rischiando di ricadere in forme di naturalismo, sia pure attenuate» (M. REICHLIN, L'etica e la buona morte, Turín 2002, 181-182). 


\section{3) Persona, norma, conciencia}

El trasunto jurídico de los problemas a que se enfrenta la bioética contemporánea debe asentarse en otros principios y buscar nuevas fórmulas normativas. La conciencia de la persona, tal y como hemos intentado presentarla en estas páginas, puede ser, si se toma con seriedad y consecuencia su dimensión fundamental de fuente normativa y no sólo de límite u objeto, en el mejor caso, de las normas, la mejor opción para ir conformando espacios normativos que brinden cauces, medios y respuestas prácticas y concretas a los retos con que desde la bioética se siente interrogada la sociedad.

Con mayor frecuencia de lo que sería deseable en sociedades democráticas donde, en principio, se invoca a la persona, en su integridad ontológica y moral junto con los derechos que en ella se fundan y a ella protegen radicalmente, como fundamento social y político del conjunto de su sistema normativo, coexisten, más allá de toda lógica jurídica y social, proclamas y declaraciones sobre la urgencia y defensa de aquélla y de éste con actitudes de políticos y legisladores en que, al margen y por encima de cualquier diálogo o discusión ética o moral, promulgan normas sobre delicadísimas cuestiones directamente relacionadas con la vida y la muerte de seres humanos desde la más sutil ignorancia, incluso cínico desprecio, de la persona, de sus derechos, de sus creencias y de su ideología. Con la ya tan manida coartada de la ciencia, se cosifica, se margina, se instrumentaliza, se sacrifica a la persona en el ara de tópicos tan vacíos histórica y científicamente como humanamente peligrosos: progreso, bienestar, ciencia, avance, mejora, calidad de vida, oscurantismos de tiempos pasados... siguen siendo hoy, en época en que tantos divinizan ciencia y racionalidad, acríticos dogmas que esclavizan mentes y normas. Lo que realmente se consigue, por medio de estas actitudes y decisiones, es reducir a la persona a objeto de experimentación o de trueque, según los casos, a favor de proyectos e intereses que poco o nada tienen que ver con la persona.

La bioética, pues, debiera situarse, para ser radicalmente humana, en el vacío creado dentro de las relaciones interpersonales por la separación epistemológica entre ciencia y con-ciencia, a pesar de que la primera, de forma privilegiada a través de la técnica, sigue influyendo masivamente sobre las conciencias. Por otra parte, al aceptar, sin más, una ciencia ilimitada en cuanto a sus posibilidades de avance y superación, se oscurece progresivamente el sentido y necesidad de la conciencia en un doble sentido: en primer lugar porque, de hecho, se acaba identificando ciencia con técnica y ambas con ética; y, en segundo lugar, porque al no interrogarse, en razón de esa ausencia de límites, por el propio sentido y razón de la ciencia, la conciencia queda inconscientemente anegada e invadida en la acomodaticia técnica.

Entre los supuestos que más arriba hemos referido, el ejemplo de la reproducción asistida, caso típico dentro de los problemas a que, en la actualidad, se enfrenta la bioética, puede ayudar a explicitar y concretar lo dicho. Todo el proceso generativo, desde la concepción al parto y a la asunción del 
hijo, está orientado, marcado y determinado por la técnica. Y, de hecho, consciente o inconscientemente, así es percibido por quienes realizan esta experiencia. La pregunta surge con radicalidad no ya tanto desde el ámbito público de leyes y normas, sino desde la vivencia íntima, personal, única de quien o quienes asumen y se someten a una experiencia de esta clase. $\mathrm{O}$, dicho de otro modo, ¿puede responderse con honestidad, desde desnudos y asépticos principios generales de carácter jurídico o filosófico, al hecho incontestable de que una técnica anónima y puramente material se convierta en referente dialogal necesario de la persona en una de las decisiones más íntimas y comprometidas que puede adoptar un ser humano? ¿No debería la bioética, sobre todo en su dimensión de eqos, preguntarse por el propio sentido y razón de la ciencia, sobre todo en lo que afecta directamente a la persona?

Y si esto se hiciera con autenticidad científica, ¿no nos abocaría necesariamente, desde una perspectiva radicalmente personalista, a la conciencia como razón última y sentido de la relación ciencia-persona?

Nos planteábamos al principio de esta reflexión si no cabría hablar, dada la deriva por la que en tantas ocasiones se desliza la bioética, más de thánatos-ética que de bio-ética y quizás, si seguimos leyendo, pensando y preocupándonos de estos temas, debamos preguntarnos si la bioética tiende, de hecho, tal y como se plantea tantas veces a proteger y garantizar la vida o más bien busca legitimadoras coartadas para la muerte. Ėthos significa morada habitual, lugar en el que uno se siente al reparo y protegido, y bio-ética debiera ser, por tanto, el arte de vivir y la misión de profundizar en la seguridad de una vida protegida... quien tenga cabeza para pensar ;que piense! 


\title{
Derecho aplicable a los contratos celebrados a través de Internet*
}

\author{
Luís de Lima Pinheiro \\ Profesor de Derecho Internacional Privado \\ Universidad de Lisboa
}

\begin{abstract}
Resumen: Los contratos celebrados a través de Internet son con mucha frecuencia contratos internacionales, porque tienen contactos significativos con más de un Estado soberano. En este contexto, a la problemática general de los contratos internacionales se unen dificultades añadidas tales como la identificación y localización de sus cocontratantes. El presente artículo analizará la problemática general y concretará las nociones fundamentales sobre la determinación del Derecho aplicable a los contratos celebrados a través de Internet.
\end{abstract}

Palabras clave: Contratos internacionales, Internet, ley aplicable.

Abstract: Contracts celebrated through the Internet are frequently International Contracts, because they have a special contact with more than one Sovereign State. In this arena, in addition to the general problems posed by International Contracts, there are specific difficulties related to the identification and localization of the contracting parties. This article analyzes the general framework of this issue and studies the main principles of the determination of the Law applicable to Contracts celebrated through the Internet.

Key words: International Contracts, Internet, Law applicable.

Sumario: 1. Introducción. I. Derecho conflictual general. A) Régimen común. B) Régimen especial de los contratos de consumidores. C) Ảmbito del estatuto contractual. D) ¿Régimen especial del comercio electrónico intracomunitario? II. Derecho conflictual del arbitraje transnacional.

A) Aspectos generales. B) Litigios entre «empresarios».

\section{Introducción}

I. Internet es una red mundial de redes informáticas que comparten una tecnología de comunicación común. Constituye un medio de comunicación global que es accesible en casi todos los países del mundo. Este medio de comunicación es utilizado para la celebración de contratos ya a través de sitios de Internet (websites) interactivos, que permiten una contratación en línea, ya a través de mensajes de correo electrónico.

* Traducido por Antonia Durán Ayago. 
Los contratos celebrados a través de Internet son con mucha frecuencia contratos internacionales, porque tienen contactos significativos con más de un Estado soberano. Los contratos internacionales presentan dos problemas específicos: la determinación de los tribunales internacionalmente competentes y la elección del Derecho aplicable. Los tribunales del foro podrán conocer de los litigios derivados de estos contratos cuando fueren competentes según el Derecho de la Competencia Judicial Internacional. El Derecho material vigente del ordenamiento jurídico del foro será aplicable a estos contratos cuando el Derecho conflictual remita a este ordenamiento jurídico.

En todo caso, no basta el carácter global de Internet para conferir a un contrato celebrado a través de este medio de comunicación carácter internacional. Es necesario que el propio contrato sea internacional según el criterio de la internacionalidad relevante, en concreto que su ejecución implique una transferencia de valores a través de las fronteras o que ponga en juego intereses del comercio internacional ${ }^{1}$.

Es el caso de los contratos que son celebrados través de Internet entre partes con residencia o establecimiento efectivo en países diferentes o que deben ser ejecutados en un país diferente de aquél en el que las partes se encuentran.

II. Las ventajas del comercio electrónico son evidentes. Cualquier persona con un ordenador, un servicio de acceso a Internet y los programas adecuados puede realizar una actividad económica transnacional con costes mínimos. Cualquier adquirente de bienes o servicios tiene acceso a los sitios de proveedores de casi todo el mundo y puede, frecuentemente, realizar su transacción en línea. En muchas ocasiones, las órdenes para realizar el pago del precio se dan en línea y, en el caso de adquisición de programas de ordenador o de servicio prestado en línea, el proveedor también puede realizar su prestación a través de Internet.

Pero esta liberación de los condicionamientos espaciales también origina dificultades. Así, los intervinientes en Internet tienen más dificultades en la identificación y localización de sus cocontratantes porque los nombres de dominio utilizados en la red pueden no corresponder al nombre o denominación de la persona ni indicar su domicilio o sede. En muchos casos los proveedores de bienes o servicios utilizan nombres de dominio con sufijo genérico, por ejemplo «.com», que no tienen una connotación geográfica. Incluso los nombres de dominio con un sufijo (dominio de Internet de primer nivel) nacional (por ejemplo, «.pt») sólo indican que el nombre de dominio

${ }^{1}$ Ver Luís de Lima Pinheiro, Direito Comercial Internacional, Almedina, Coimbra, 2005, 67 y ss.; ver también Peter MANKOwSKI, «Das Internet im Internationalen Vertragsund Deliktsrecht», RabelsZ. 63 (1999) 203-294, 208 y ss., y Dieter MARTINY, «Vor Art. $27-$ Art. 30», in Münchener Kommentar zum Bürgerlichen Gesetzbuch, vol. X - EGBGB, 4. ${ }^{\text {a ed., }}$ Munique, 2006, Art. 28, n. ${ }^{\circ} 420$. 
fue registrado en la entidad acreditada en el país en cuestión (en Portugal, la Fundação para a Computação Científica Nacional).

La identificación de los proveedores de bienes y servicios es facilitada cuando su dominio de segundo nivel (por ejemplo, «google» en <www.google.pt $>$ ) corresponda necesariamente, por fuerza de la regulación de la entidad acreditada para su gestión de servicio de registro, al nombre o denominación de la persona.

Así, las reglas de registro de dominios pt (art. 2.3.2.2) establecen que:

- en el caso de personas colectivas, el nombre de dominio deberá coincidir con la firma o denominación que conste en la Cartão de Identificação de Pessoa Colectiva emitido por el Registro Nacional de Personas Colectivas o documento equivalente;

- en el caso de empresarios individuales, el nombre de dominio deberá coincidir íntegramente con la respectiva firma que conste en el documento acreditativo de la referida cualidad;

— en el caso de las profesiones liberales, el nombre de dominio deberá coincidir íntegramente con el respectivo nombre profesional que conste en el documento acreditativo de la referida cualidad;

- en el caso de los titulares de marcas registradas en registro nacional, comunitario o internacional, el nombre de dominio deberá corresponder a la marca nominativa o a los elementos nominativos de marca mixta registrada a favor del requirente de dominio, tal como consten en el respectivo título de registro nacional, comunitario o internacional desde que, en estos últimos casos, las marcas sean extensivas en Portugal.

Sería recomendable que reglas similares fueran adoptadas a nivel internacional.

III. En estudios anteriores me ocupé de la cuestión de la competencia internacional en materia de litigios relativos a Internet ${ }^{2}$ y de la determinación del Derecho aplicable a la responsabilidad extracontractual en Internet ${ }^{3}$. Pretendo ahora indagar en algunas nociones fundamentales sobre la determinación del Derecho aplicable a los contratos celebrados a través de Internet.

Internet es un medio de comunicación global que, en cuanto tal, requiere una regulación jurídica global de ciertos aspectos esenciales para la interacción social realizada en su ámbito.

2 «Competência internacional em matéria de litígios relativos à Internet», en Estudos em Homenagem ao Prof. Doutor Inocêncio Galvão Telles, vol. V, 695-712, Coimbra, 2003 (= Direito da Sociedade da Informação, vol. IV, 171-189, Coimbra, 2003).

3 «Direito aplicável à responsabilidade extracontratual na Internet», RFDUL 42/n. ${ }^{\circ} 2$ (2001) 825-834. 
Esta regulación puede hasta cierto punto ser llevada a cabo a través de fuentes espontáneas (costumbres y usos de comercio positivados) y por la actividad normativa de centros autónomos. Tenemos, entonces, una regulación de los contratos por el Derecho Transnacional, compuesto por reglas y principios que se forman independientemente de la acción de los órganos estatales o supraestatales ${ }^{4}$. Pero esta regulación transnacional de los contratos incide principalmente sobre los contratos comerciales internacionales, mientras que la mayor parte de los contratos celebrados a través de Internet son contratos con consumidores. Por otro lado, la existencia de costumbres en este ámbito aún es controvertida y los usos, que ciertamente se pueden formar rápidamente en este medio de comunicación, sólo vinculan a las partes mediante una incorporación en el contrato o mediante la positivación de una regla legal o consuetudinaria ${ }^{5}$. Hay que tener en cuenta, además, que la regulación por centros autónomos tiene necesariamente un significado limitado porque la gran mayoría de los usuarios de Internet no están representados en ninguna organización asociativa que establezca reglas sobre su relación en Internet ${ }^{6}$.

Se hace, pues, necesaria una regulación por instrumentos internacionales, más concretamente por tratados internacionales y actos de organizaciones intergubernamentales.

Algunas convenciones internacionales que unifican el Derecho material aplicable a determinados tipos de contrato internacional comprenden los contratos celebrados a través de Internet. Es el caso de la Convención de Viena sobre compraventa internacional de mercaderías en lo que respecta a la venta de mercaderías entre «empresarios». Esta convención aún no ha sido ratificada por el Estado portugués. Con carácter general, sin embargo, estas convenciones no regulan los problemas específicos de la contratación electrónica.

La regulación internacional, por lo que hace a las relaciones establecidas a través de Internet, apenas ha comenzado a dar sus primeros pasos, particularmente bajo el amparo de la Organización Mundial sobre la Propiedad Intelectual (OMPI) y la Comisión de Naciones Unidas para el Derecho Comercial Internacional (CNUDCI).

\footnotetext{
${ }^{4}$ Ver Lima Pinheiro (n. 1), 179 y ss.

${ }^{5}$ Ver también Elsa Dias Oliveira, A Protecção dos Consumidores nos Contratos Celebrados Através da Internet, Coimbra, 2002, 338 y ss., con más referencias, y Dário MourA VICENTE, Problemática Internacional da Sociedade da Informação, Coimbra, 2005, 136 y ss.

${ }^{6}$ Cuestión diferente es la de la delegación de competencias de regulación en instituciones privadas, tales como la Internet Corporation for Assigned Names and Numbers (ICANN) y la Fundação para a Computação Científica Nacional, por parte de Estados. Ver, en especial sobre la gestión del sistema de nombres de dominio, Markus KöHLER y Hans-Wolfgang ARNDT, Recht des Internet, $4 .^{\text {a }}$ ed., Heidelberga, 2003, 8 y ss., y Moura VicENTE (n. 5), 141 y ss.
} 
En el ámbito de la OMPI importa hacer referencia a la creación de un centro de arbitraje y mediación para la resolución de los litigios relativos a nombres de dominio y la adopción de dos convenios internacionales, denominados «Tratados sobre Internet» que buscan principalmente establecer una protección internacional de los derechos de autor (Tratado OMPI sobre los derechos de autor, Ginebra, 1996) y los derechos de los artistas intérpretes o ejecutantes y los derechos de los productores de fonogramas (Tratado OMPI sobre la interpretación y ejecución de los fonogramas, Ginebra, 1996) ajustados a la nueva realidad creada por Internet.

En lo que respecta a los contratos celebrados a través de Internet, importa sobre todo señalar la Convención de Naciones Unidas sobre la Utilización de las Comunicaciones Electrónicas en los Contratos Internacionales, adoptada por la Asamblea General en 2005, que contiene reglas importantes sobre el reconocimiento legal de las comunicaciones electrónicas, los requisitos de forma, el momento y el lugar de envío y de recepción de las comunicaciones electrónicas y la formación de los contratos electrónicos. Claro está que esta convención aún no está internacionalmente en vigor.

En este escenario, la misión de regular jurídicamente los contratos celebrados a través de Internet aún es desempeñada, esencialmente, por los ordenamientos jurídicos estatales. A pesar de los esfuerzos realizados en pos de una unificación internacional del Derecho de los Contratos internacionales en general ${ }^{7} \mathrm{y}$, en particular, del régimen aplicable al comercio electrónico (específicamente la Ley Modelo de la CNUDCI sobre el Comercio electrónico, 1996), los ordenamientos jurídicos estatales divergen en muchos aspectos en cuanto a la regulación jurídica de los contratos celebrados a través de Internet.

La determinación de la regulación jurídica de un contrato electrónico internacional presupone, de esta manera, la elección de un ordenamiento jurídico estatal (o de varios ordenamientos jurídicos estatales aplicables a diferentes aspectos del contrato). Esta elección se lleva a cabo por las normas de conflicto de Derecho Internacional Privado.

IV. En lo que respecta a la determinación del Derecho aplicable a los contratos internacionales, la tendencia dominante en los principales sistemas es establecer una diferenciación entre las relaciones interempresariales (business to business) y las relaciones con consumidores (business to consumers) y, eventualmente, otras categorías contractualmente más débiles ${ }^{8}$. Esta tendencia de diferenciación domina, en la Europa comunitaria, en el Convenio de Roma sobre ley aplicable a las obligaciones contractuales (1980) y, en los EE. UU., en el art. 1-301 del Uniform Commercial Code (2004).

\footnotetext{
${ }^{7}$ Ver Lima Pinheiro (n. 1), 82 y ss.

${ }^{8}$ Esta tendencia ya fue señalada hace más de veinte años, por Russell WEINTRAUB, «Functional developments in choice of law for contracts», RCADI 187 (1984), 239-305, 258.
} 
En las relaciones interempresariales - categoría que comprende todas las relaciones entre personas que realizan una actividad económica independiente-, el principio de la autonomía de la voluntad puede actuar en su más vasto alcance $\mathrm{y}$, por consiguiente, se admite la máxima libertad en la elección del Derecho aplicable a las relaciones entre empresarios (o, por lo menos, en la elección de un Derecho estatal).

A falta de elección, los principales sistemas nacionales han evolucionado en el sentido de evitar una preferencia absoluta, ya de la ley del proveedor, ya de la ley del adquirente, que sólo se puede justificar por la intención de beneficiar a una de las partes, y se han orientado a favor del criterio general de la conexión más estrecha que debe concretarse en función del conjunto de circunstancias que concurran en el caso concreto (art. 4 del Convenio de Roma sobre ley aplicable a las obligaciones contractuales [en adelante, $\mathrm{CR}$, art. $188 .^{\circ}$ del Second Restatement of Conflict of Laws y art. 9. ${ }^{\circ}$ de la Convención Interamericana sobre Derecho aplicable a los contratos internacionales).

En las relaciones con consumidores, el consumidor es habitualmente la parte económicamente más débil y negocialmente menos experimentada, lo que justifica un importante límite a la autonomía de la voluntad. Así, la elección de la ley aplicable al contrato no perjudica la aplicación de las normas imperativas protectoras del consumidor contenidas en la ley del país de su residencia habitual (art. 5.2 CR y el art. 1-301 del Uniform Commercial Code $)^{9}$.

Otra línea de diferenciación que es necesario tener en cuenta versa sobre la jurisdicción competente para conocer los litigios derivados del contrato. En el caso de que las partes estén vinculadas por un convenio arbitral válido, es necesario atender, para las relaciones comerciales internacionales, al Derecho conflictual especial del arbitraje internacional.

El presente estudio comenzará por el examen del Derecho conflictual general (I), en el que se suscitan las cuestiones más complejas en lo que se refiere a los contratos celebrados a través de Internet. En esta parte de nuestro estudio examinaremos el régimen común de determinación del Derecho aplicable a los contratos (A), el régimen especial aplicable a los contratos con consumidores (B), el ámbito del estatuto contractual (C) e indagaremos sobre la existencia de criterios especiales de determinación del Derecho aplicable con respecto al comercio electrónico intracomunitario (D). Finalizaremos con una breve referencia al Derecho conflictual especial del arbitraje transnacional (II).

${ }^{9}$ En concreto, el art. 1-301 (e) (1) del Uniform Comercial Code hace depender la validez de la elección de una conexión objetiva de la transacción con la ley escogida. Ver también art. 109.\% y b/2 del Uniform Computer Information Transactions Act, de 1999. 


\section{Derecho conflictual general}

\section{A) Régimen común}

Las reglas de conflicto generales aplicables a las obligaciones contractuales constan fundamentalmente en el Convenio de Roma sobre Ley aplicable a las obligaciones contractuales. Están en curso los trabajos con vistas a la revisión y transformación de este instrumento internacional en un reglamento comunitario que ya tomaron cuerpo en una Propuesta de Reglamento presentada por la Comisión Europea en diciembre de $2005^{10}$.

La autonomía de la voluntad en la determinación del Derecho aplicable a los contratos constituye hoy un principio de Derecho internacional privado común a la inmensa mayoría de los sistemas nacionales ${ }^{11}$. Este principio está consagrado en el apartado primero del art. $3 \mathrm{CR}$.

$\mathrm{El}$ art. $3 \mathrm{CR}$ no establece límites en cuanto a los ordenamientos jurídicos estatales que pueden ser elegidos para regular la relación contractual. En efecto, este precepto no subordina la elección a la existencia de un vínculo entre el contrato y la ley elegida ni a la demostración de un interés serio en la elección.

Pero el art. 3 CR no admite que las partes sustraigan el negocio a un ordenamiento jurídico o elijan normas no estatales. Esta exclusión, en cuanto a la elección de un Derecho no estatal, es criticable de iure condendo ${ }^{12} \mathrm{y}$ ha sido abandonada, al menos en parte, por la Propuesta de Reglamento (art. 3.2).

En los términos de la segunda parte del n. ${ }^{\circ} 1 \mathrm{del}$ art. $3 \mathrm{CR}$, el consentimiento de las partes en la designación del Derecho aplicable puede ser manifestado expresa o tácitamente. En cuanto a la designación tácita, este precepto exige que la elección resulte «de manera cierta de los términos del contrato o de las circunstancias del caso».

En lo que respecta a los contratos celebrados a través de Internet, será raro que las partes estipulen individualmente el Derecho aplicable, pero es mucho más frecuente que la cláusula de designación de la ley aplicable conste en un conjunto de cláusulas generales preelaboradas por el proveedor (entendido en sentido amplio, que comprende al licendiador) que se exhiben en su sitio de Internet. Normalmente, esta cláusula somete el contrato al Derecho de la sede o del establecimiento del proveedor.

En la contratación en línea suele suceder que en las páginas a que el adquirente accede para celebrar el contrato haya sólo un vínculo que remite a otra página en la que se contiene el clausulado general del proveedor. Otras

${ }^{10}$ COM (2005), 650 final.

${ }^{11}$ Ver, con más referencias y desarrollo, Lima PinHEIRo (n. 1), 99 y ss.

${ }^{12}$ Ver Lima Pinheiro (n. 1), 103 y ss. 
veces se abre sobre la ventana principal una ventana superpuesta o emegente (pop-up window) que necesariamente es vista por el adquirente, aunque la mayor parte de las cláusulas y, en concreto, la cláusula de elección del Derecho aplicable, sólo se hace visible cuando el usuario mueve el texto en esta ventana. En ambos casos, al adquirente normalmente se le pide que exprese su aceptación a través de un clic, hecho con el ratón del ordenador en un determinado campo o icono.

La ley aplicable a la formación y a la validez del consentimiento es — según el art. 3.4 CR - la propia ley elegida.

Normalmente una parte quedará vinculada por la estipulación individual que haya realizado con respecto al Derecho aplicable. Hay reglas más exigentes en cuanto a la integración en los contratos singulares de cláusulas contractuales generales, predispuestas por una de las partes, y que son propuestas a la adhesión de la otra parte.

A este respecto, debe también atenderse el n. ${ }^{\circ} 2$ del art. $8 \mathrm{CR}$ sobre la relevancia negocial de un comportamiento. Si la professio iuris constituye una cláusula general contractual, su inclusión en el contrato será apreciada, en primer lugar, por la ley elegida; si esta cuestión fuera respondida afirmativamente por esta ley, el declarante podrá aún invocar la ley de su residencia habitual para demostrar que no otorgó su consentimiento, si resulta de las circunstancias que no sería razonable que el valor dado al comportamiento de ese contratante fuere determinado por la ley elegida ${ }^{13}$.

Quiere esto decir que la vinculación del adquirente por la cláusula general de designación del Derecho aplicable depende no sólo del régimen aplicable a las cláusulas contractuales generales contenidas en la ley elegida, sino también, si resultara de las circunstancias que no fuera razonable que el valor dado a su comportamiento fuera determinado por la ley elegida, en función del régimen contenido en la ley de la residencia habitual.

Debe partirse del principio de que la vinculación de un consumidor final por una cláusula general de determinación del Derecho aplicable depende también de la ley de su residencia habitual, cuando la ley designada no le sea familiar. Lo que significa que los ciberconsumidores residentes habitualmente en Portugal se benefician en principio de la protección concedida por el régimen interno de las cláusulas contractuales generales ante clásulas generales de designación del Derecho aplicable contenidas en el sitio del proveedor.

${ }^{13}$ Cf. Christian Von BAR, Internationales Privatrecht, vol. II, Munique, 1991, 350 y ss.; Jürgen BASEDOW, «Gesetz zur Regelung des Rechts der Allgemeinen Geschäftsbedingungen (AGB-Gesetz)», in Münchener Kommentar zum Bürgerlichen Gesetzbuch, vol. I, 4. ${ }^{\text {a }}$ ed., Munique, 2001, § 12 AGBG n. ${ }^{\circ}$ 29; y MünchKomm./MARTINY (n. 1) Art. 31 n. ${ }^{\circ}$ 63. Ver, más extensamente, ANTÓNIO DE SousA, Conflito de Clausulados e Consenso nos Contratos Internacionais, Porto, 1999, 245 y ss. 
El régimen portugués de cláusulas contractuales generales determina expresamente su aplicación a todas las cláusulas generales independientemente de su forma de comunicación al público (art. 2 de la Ley de Cláusulas Contractuales Generales [en adelante, LCCG]). Este régimen excluye de los contratos singulares las cláusulas contractuales generales que ${ }^{14}$ :

— no hayan sido comunicadas en su integridad a los adherentes (arts. 5 y $8 / a)$;

- hayan sido comunicadas con violación del deber de información (arts. 6 y $8 / b$ );

- por el contexto en que surjan, por el epígrafe que las precede o por su presentación gráfica pasen desapercibidas a un contratante normal, colocado en una posición de contratante real (art. 8/c);

— estén insertas en «formularios» después de la firma de alguno de los contratantes (art. 8/d).

Este régimen es aplicable tanto en las relaciones con consumidores como en las relaciones entre empresarios. Podría cuestionarse si no justificaría una diferenciación, a semejanza de lo que ocurre con la ley alemana que sujeta la inclusión de las cláusulas generales en las relaciones entre empresarios exclusivamente a las reglas generales sobre declaraciones de voluntad y sobre la celebración de contratos ${ }^{15}$. En este orden de ideas, creo que en las relaciones entre empresarios se podría admitir que la inclusión de cláusulas generales resultase de una conducta concluyente tanto del lado del proponente como del lado del adherente, desde que éste tenga posibilidad de tener conocimiento de las cláusulas ${ }^{16}$.

En la contratación en línea, el adherente cuenta con todas las condiciones para tener conocimiento completo y efectivo del clausulado (art. 5.2 de la LCCG ${ }^{17}$. Es usual la inclusión de una cláusula de elección del Derecho

\footnotetext{
${ }^{14}$ Ver, más extensamente, António Menezes CoRdeiro, Tratado de Direito Civil Português, vol. I - Parte Geral, tomo I, 3. a ed., Coimbra, 2005, 618 y ss.

${ }^{15}$ Ver Karl LARENZ y Manfred Wolf, Allgemeiner Teil des Bürgerlichen Rechts, 9. a ed., Munique, 2004, 776 y ss.

${ }^{16} \mathrm{El}$ art. 5 de la Resolución del Instituto de Derecho Internacional sobre la autonomía de la voluntad de las partes en los contratos internacionales entre particulares, aprobada en la sesión de Basilea (1991), después de admitir, en su n. ${ }^{\circ} 1$ que la «ley aplicable puede ser designada por cláusulas contractuales generales siempre que las partes hayan consentido en ellas», añade, en su n. ${ }^{\circ} 2$, una regla material, según la cual este «consentimiento debe ser expresado por escrito, o de una manera conforme a los hábitos establecidos entre las partes, o según los usos profesionales de los que tengan conocimiento». Esta solución se inspira en la jurisprudencia del TJCE relativa a la cláusula de jurisdicción inserta en el formulario propuesto por una de las partes, cf. Erik JAYME, «L'autonomie de la volonté des parties dans les contrats internationaux entre personnes privées. Rapport définitif», Ann. Inst. dr. int. 64-I (1991), 62-76, 72 y ss.

${ }^{17}$ Cf. Basedow (n. 13) § 2 AGBG n. ${ }^{\circ} 19$.
} 
aplicable en el clausulado general del proveedor que contrata a través de Internet y, por consiguiente, no hay razón para que la cláusula pase desapercibida al adquirente, a menos que el epígrafe o la presentación gráfica de la cláusula puedan inducir al adquirente a error.

La exigencia de comunicación íntegra es satisfecha por la colocación del clausulado general en una ventana superpuesta o emergente, desde la que el clausulado sea fácilmente legible y/o pueda ser descargado en el ordenador del adherente y, si se desea, ser impreso ${ }^{18}$. Suscita más dudas el caso del clausulado que conste en otra página a la que se remite, a través de un hipervínculo, distinta de la página en que el adherente manifiesta su consentimiento $^{19}$. En mi opinión, la situación es en todo semejante a la que ocurre en el comercio jurídico tradicional cuando el contrato contiene una remisión al clausulado general que consta en un documento anexo ${ }^{20}$. Por eso, entiendo que será suficiente que el proponente indique claramente que contrata sobre la base de un clausulado general, que este clausulado es efectivamente accesible al adherente en la página a que remite el hipervínculo sin ninguna exigencia técnica adicional (de modo que pueda ser almacenado o impreso) y que el adherente lo acepte, expresa o tácitamente.

En lo que respecta al idioma, debe considerarse suficiente, en la contratación en línea, que el clausulado esté redactado en el mismo idioma que se utiliza en las páginas a las que el adquirente ha accedido para realizar la transacción. En efecto, el proveedor debe poder contar con el conocimiento por el adquirente del idioma utilizado en las páginas a las que accede para realizar la transacción, en concreto las que contienen el formulario de petición ${ }^{21}$.

Si la cláusula fuera de difícil comprensión o ambigua, el adquirente puede solicitar el esclarecimiento al proponente. En cualquier caso, si existe duda prevalece el sentido más favorable al adherente (art. 11.2 LCCG). En lo que toca a la cláusula de designación del Derecho aplicable, parece que en

${ }^{18} \mathrm{El}$ art. 31.1 del DL n. ${ }^{\circ} 7 / 2004$, de 7 de enero, determina que los términos contractuales y las cláusulas generales deben ser siempre comunicados de manera que permitan al destinatario almacenarlos y reproducirlos. Este precepto transpone el art. 10.3 de la Directiva 2000/31/CE del Parlamento y del Consejo, de 8 de junio de 2000, relativa a ciertos aspectos legales de los servicios de la sociedad de la información, en especial del comercio electrónico, en el mercado interno (Directiva sobre Comercio Eelectrónico).

${ }^{19}$ Ver MANKOWSKi (n. 1), 211 y ss.

${ }^{20} \mathrm{El}$ art. 5 bis de la Ley Modelo de la CNUDCI sobre el Comercio electrónico (adoptada en 1998) establece que «Information shall not be denied legal effect, validity or enforceability solely on the grounds that it is not contained in the data message purporting to give rise to such legal effect, but is merely referred to in that data message». El sentido de este precepto no es el de establecer un régimen especial para la incorporación por referencia en el comercio electrónico sino determinar la aplicación del régimen general a la contratación en línea.

${ }^{21}$ En este sentido, también BASEDOw (n. 13) § 2 AGBG n. 20. 
caso de duda sobre la ley designada deberá recurrirse a la conexión objetiva (ley aplicable a falta de elección).

La situación de desigualdad en la que normalmente se encuentra el consumidor lleva a aceptar generalmente la elección del Derecho del proveedor, Derecho que la mayoría de las veces desconoce y no tiene posibilidades de conocer con normal diligencia. La necesidad de protección del consumidor se contempla, a nivel conflictual, por el régimen especial contenido en el art. $5 \mathrm{CR}$. Este régimen, que se analiza en el apartado B, limita la eficacia de la elección del Derecho aplicable hecha por las partes.

En las relaciones entre empresarios no se justifica ninguna limitación a la eficacia de la elección del Derecho aplicable hecha por las partes.

De hecho, la Convención de Roma no es compatible con ningún control de contenido de la cláusula de elección del Derecho aplicable, aunque se trate de una cláusula general. Estuvo acertado el legislador portugués cuando en el DL n. ${ }^{\circ} 220 / 95$ suprimió la letra $h$ del art. 19 LCCG que prohibía, en consonancia con el cuadro negocial estándar, las cláusulas generales que remitiesen al Derecho extranjero, cuando los inconvenientes causados a una de las partes no fueren compensados por intereses serios y objetivos de la otra. Una aplicación analógica de la actual letra $g$ del art. 19 a las cláusulas de elección de ley sería contraria a la intención expresada por el legislador en el preámbulo del DL n. ${ }^{\circ} 220 / 95 \mathrm{y}$, en cualquier caso, incompatible con la $\mathrm{CR}^{22}$.

La elección del Derecho aplicable también puede resultar de una manifestación tácita de la voluntad, sea de ambas partes sea de una de ellas en el seguimiento de una declaración expresa de otra. A este respecto, los contratos celebrados a través de Internet no parecen suscitar problemas marcadamente específicos, aplicándose las consideraciones que han sido formuladas en relación con la generalidad de los contratos ${ }^{23}$.

La cláusula atributiva de competencia a los tribunales de un determinado Estado es un indicio importante, aunque no por sí concluyente, de la elección tácita del Derecho de ese Estado para regir el contrato. En el caso de que la cláusula de sumisión sea una cláusula contractual general, es de observar que sólo será relevante para la determinación de una elección tácita del Derecho aplicable la cláusula que fuere válidamente estipulada ${ }^{24}$.

A falta de elección válida por las partes del Derecho aplicable, este Derecho deberá ser determinado con base a un criterio objetivo. El n. ${ }^{\circ} 1$ del art. $4 \mathrm{CR}$ determina que el contrato será regulado por la ley del país con el que

${ }^{22}$ Cp. Menezes Cordeiro (n. 14), 636.

${ }^{23}$ Ver Lima Pinheiro (n. 1), 108 y ss. Ver también Mankowski (n. 1), 213.

${ }^{24}$ Ver, sobre los presupuestos y requisitos de los acuerdos de jurisdicción, LiMA PINHEIRo, Direito Internacional Privado, vol. III - Competência Internacional e Reconhecimento de Decisões Estrangeiras, Almedina, Coimbra, 2002, 131 y ss. y 211 y ss. 
presente un vínculo más estrecho. Se consagra así un criterio general de conexión, que debe ser concretado por el órgano de aplicación del Derecho mediante una valoración de un conjunto de circunstancias del caso concreto y con ponderación de todos los puntos de vista jurídicamente relevantes.

Este criterio general de vinculación más estrecha permite atender a los lazos de cualquier naturaleza, como el lugar de residencia, de la sede o del establecimiento de las partes, o del lugar de ejecución del contrato, o del idioma del contrato, la referencia de las disposiciones de un determinado ordenamiento jurídico o el empleo de términos y expresiones característicos de este ordenamiento jurídico (que con todo no permitan inferir una designación tácita) o el nexo funcional que el contrato establezca con otro contrato regido por cierto Derecho ${ }^{25}$.

La principal dificultad que puede surgir con los contratos celebrados a través de Internet es la que se refiere a la determinación del lugar de residencia, sede de administración o establecimiento de las partes.

Se alega que las sociedades que actúan a través de Internet pueden no tener una administración central en un establecimiento principal. Aunque el problema no consiste propiamente en la falta de residencia, de administración central o de establecimiento.

Una sociedad no deja de tener administración central por el hecho de que las deliberaciones de los administradores sean tomadas a través de los modernos medios de comunicación sin su presencia física en el mismo local. Lo que de ello puede resultar es la dificultad de determinar la sede de administración. Pero esto es un problema creado por los modernos medios de comunicación que no es específico de los contratos celebrados a través de Internet. Es posible obviar esta dificultad por medio de la presunción de que la sede de la administración coincide con la sede estatutaria ${ }^{26}$.

La persona que desarrolla una actividad económica a través de Internet tiene normalmente uno o varios centros de actividad. Según el considerando $19 .^{\circ}$ de la Directiva sobre Comercio Electrónico ${ }^{27}$, el local de establecimiento de una sociedad prestadora de servicios a través de un sitio en Internet no es el local donde se encuentra la tecnología de apoyo a ese sitio o el local desde donde éste sea accesible, sino el local en que esa sociedad desarrolla una actividad económica. Esto vale para las normas contenidas en la Directiva $^{28}$. Resta saber si la circunstancia de que este centro no se manifieste externamente obsta a su reconducción al concepto de establecimiento relevante según la CR.

\footnotetext{
${ }^{25}$ Ver, más extensamente, Lima Pinheiro (n. 1), 112 y ss.

${ }^{26}$ Ver Lima PinheIro, Direito Internacional Privado, vol. II - Direito de Conflitos. Parte Especial, 2. ${ }^{\text {a }}$ ed., Almedina, Coimbra, 2002, 97 y ss.

${ }^{27}$ Supra n. 18.

${ }^{28}$ Ver también la definición de establecimiento contenida en el art. 4.h de la Convención de Naciones Unidas sobre el uso de comunicaciones electrónicas en los contratos internacionales (2005) y el art. 6.4 de la misma Convención.
} 
La determinación del concepto de establecimiento relevante para la CR constituye un problema de interpretación de la norma convencional que debe ser resuelto a la luz de su finalidad. El art. 4.2 CR tiene por objetivo indicar el lazo que, en caso de duda, prevalece en la determinación de la conexión más estrecha. Este lazo debe ser fácilmente recognoscible por la contraparte del prestador profesional. A esta luz, parece claro que sólo importa como establecimiento o centro de actividad el lugar en que realiza una actividad negocial externa ${ }^{29}$.

Cierto es que en los contratos celebrados a través de Internet es más frecuente la imposibilidad o gran onerosidad de determinar la residencia, sede o establecimiento de la otra parte.

El proveedor puede defenderse ante este riesgo mediante la solicitud, hecha a la otra parte, de la indicación de su residencia, sede o establecimiento. El adquirente que indica la residencia, sede o establecimiento en un determinado país no puede más tarde invocar la falsedad o inexactitud de los elementos suministrados ${ }^{30}$.

El adquirente cuenta con menos defensa, razón por la que los proveedores deben ser legalmente obligados a indicar, en la página principal o en otra página a la que los clientes tengan que acceder para realizar el negocio, su residencia, sede de administración o establecimiento.

La Directiva sobre Comercio Electrónico apunta en esta dirección al obligar a los Estados miembros a garantizar el acceso a la dirección geográfica en que el proveedor se encuentra establecido (art. 5.1). Esta norma debe ser aplicada a los prestadores establecidos en el territorio de los Estados miembros (art. 3.1). En la transposición de este precepto, el DL n. ${ }^{\circ} 7 / 2004$, de 7 de enero, obliga a los prestadores de servicios de la sociedad de la información a proporcionar esta información en línea (art. 10.1.b).

A falta de indicación de la residencia, sede de administración o establecimiento, debe presumirse que ésta corresponde a cualquier indicación geo-

${ }^{29}$ En el mismo sentido, MünchKomm./Martiny (n. 1) Art. 28 n. ${ }^{\circ} 50$. El concepto de establecimiento relevante, en materia de competencia internacional, para el art. 5.5 del Convenio de Bruselas sobre competencia judicial y ejecución de decisiones en materia civil y mercantil, ya fue objeto de interpretación autónoma por el TJCE. Por establecimiento (secundario) se entiende aquí «un centro de operaciones que se manifiesta externamente de modo duradero como prolongación de una empresa matriz, provisto de una dirección y materialmente equipado de modo que pueda negociar con terceros...» - ver TCE 6/10/1976, en el caso De Bloos (CTCE [1976] 605), y 22/11/1978, en el caso Somafer (CTCE [1978] 2183). Este «centro de operaciones» se encuentra subordinado al control y la dirección del «establecimiento principal», pero tiene autonomía para la gestión de negocios corrientes, ver también an. Huet en el caso Somafer y an. Bischoff, Gothot/Holleaux y Geimer en el caso De Bloos. Más extensamente, ver Lima Pinheiro (n. 24), 90 y ss.

${ }^{30}$ En el mismo sentido, en relación con la competencia, George DELTA e Jeffrey MATSUURA, Law of the Internet, Nova Iorque, 2004, § 3.03 A. 
gráfica contenida en el nombre de dominio. Así, por ejemplo, puede presumirse que un proveedor que dispone de un nombre de dominio o dirección de correo electrónico con un sufijo «.pt» está localizado en Portugal ${ }^{31}$.

En caso de divergencia entre la residencia, sede de administración o establecimiento, indicada por el proveedor o presumida en los términos anteriormente expuestos, y su localización real, la confianza depositada por el adquirente en la información que le fue prestada debe ser tutelada y, por consiguiente, el proveedor no puede invocar su localización real. Pero como el proveedor tiene el deber de prestar una información veraz, el adquirente puede demostrar que la localización real del proveedor no corresponde a la indicada y prevalerse de esta localización ${ }^{32}$.

Si la localización del establecimiento no fuera cognoscible por el adquirente, es legítimo presumir que el establecimiento relevante se sitúa en la residencia o sede del proveedor ${ }^{33}$.

Estos criterios carecen de utilidad cuando el proveedor no indique su localización y ésta no se pueda presumir según el nombre de dominio (por ejemplo, cuando son utilizados nombres de tipo genérico como «.com», «.org» $\mathrm{y}$ «.edu»).

En este caso habrá de establecer la conexión más estrecha basándose en otros vínculos que liguen el contrato con un determinado país, tales como la residencia, sede o establecimiento del adquirente, o idioma del sitio, elementos contenidos en el sitio que permitan establecer su orientación a un mercado nacional determinado, o lugar de entrega del bien o de la prestación del servicio, o lugar de pago y la moneda de pago. Claro está que el lugar de ejecución de una prestación no es relevante cuando la prestación sea cumplida en línea.

En los términos del apartado segundo del art. $4 \mathrm{CR}$, «se presume» que el contrato presenta una conexión más estrecha con el país de la residencia habitual o de la sede de la administración central del prestador de la prestación característica. Si el contrato fue celebrado en el ejercicio de una actividad económica o profesional del prestador de la prestación característica es relevante el país donde está situado su establecimiento principal o, si en los

\footnotetext{
${ }^{31}$ En el mismo sentido, Elsa Dias OliveIRA, «Contratos celebrados através da Internet», en Estudos de Direito Comercial Internacional, vol. I, org. por Lima PINHEIRO, 219-237, Coimbra, 2004, 225. Cp. art. 6.5 del Convenio de Naciones Unidas sobre el uso de las comunicaciones electrónicas en contratos internacionales.

${ }^{32}$ En el mismo sentido, Mankowski (n. 1), 223, y Alfonso Calvo Caravaca y Javier CARrascosa GonzÁLEZ, Conflictos de leyes y conflictos de jurisdicción en Internet, Madrid, 2001, 65. Del mismo parecer, el art. 6.1 del Convenio de Naciones Unidas sobre el uso de las comunicaciones electrónicas en contratos internacionales.

${ }^{33}$ En sentido convergente, MANKOWSKI (n. 1), 230. Ver también, en cuanto a las personas singulares, el art. 6.3 del Convenio de Naciones Unidas sobre el uso de las comunicaciones electrónicas en contratos internacionales.
} 
términos del contrato la prestación debe ser realizada por otro establecimiento, la situación de este establecimiento.

Esta «presunción» debe ser entendida como una directriz interpretativa que actúa en los casos en que la determinación de la conexión más estrecha suscite dudas. Esta directriz es también aplicable a los contratos celebrados a través de Internet ${ }^{34}$.

El apartado quinto del art. 4 permite relegar esta «presunción» «siempre que resulte del conjunto de circunstancias que el contrato presenta una conexión más estrecha con otro país». Aunque no sea una hipótesis de fácil verificación, no hay que excluir absolutamente que una convergencia en la indicación geográfica en el nombre de dominio del proveedor con una orientación de su contenido a un determinado mercado, inferida del idioma utilizado, moneda de pago exigida u otros elementos, pueda justificar la relegación de la «presunción» a favor de la ley del proveedor ${ }^{35}$.

En los contratos que se refieren al intercambio de bienes y servicios por dinero, la prestación característica es la que consiste en la entrega de la cosa, en la cesión del uso o en la prestación del servicio. Quiere esto decir, por ejemplo, que el deudor de la prestación característica es, en el contrato de venta, el vendedor, en el contrato de licencia, el licenciador, y en el contrato de prestación de servicio, el prestador del servicio ${ }^{36}$.

En el contrato de licencia la prestación que individualiza el contrato es la cesión de uso del derecho de propiedad intelectual. Por consiguiente, es ésta la prestación característica, aunque el licenciado se obligue, además de la prestación pecuniaria, a formas de utilización del derecho ${ }^{37}$. Frecuentemente, sin embargo, el contrato presenta una conexión más estrecha con el país de protección de la propiedad intelectual, caso en que no es relevante la «presunción» a favor de la ley del licenciador ${ }^{38}$.

En los contratos de prestación de servicios en línea, la prestación característica es también la del prestador del servicio ${ }^{39}$. Por ejemplo, en el contrato de suministro de acceso a Internet la prestación característica es la que realiza el proveedor de acceso.

Si no fuera cognoscible ni el establecimiento del proveedor ni su residencia o sede, la presunción debe ser descartada en los términos del art. $4.5^{40}$.

\footnotetext{
${ }^{34}$ Cf. MünchKomm./Martiny (n. 1), Art. 28 n. ${ }^{\circ} 417$.

${ }^{35}$ Como sugieren José Fernández Rozas y Sixto SÁnchez Lorenzo, Derecho Internacional Privado, 3. ${ }^{\text {a }}$ ed., Madrid, 2004, 478.

${ }^{36}$ En cuanto a otros tipos contractuales, ver Lima Pinheiro (n. 1), 117 y ss.

37 Cf. Martin Hiestand, «Lizenzvertrag», in Internationales Vertragsrecht, org. por Christoph Reithmann e Dieter MARTINY, Colonia, 2004, n. ${ }^{\circ}$ 1737. Ver también James FAWCETT y Paul Torremans, Intelectual Property and Private International Law, Oxford, 1998, 573 y ss. Cp. Moura Vicente (n. 5), 234 y 248.

38 Ver Lima Pinheiro (n. 26), 288 y ss.

${ }^{39}$ Cf. MünchKomm./MarTiny (n. 1), Art. 28 n. ${ }^{\circ} 422$ y ss.

${ }^{40}$ En sentido convergente, Calvo Caravaca/CARrascosa González (n. 32), 62.
} 
De lo anteriormente expuesto se deduce que la determinación de la ley objetivamente competente también es posible en los contratos celebrados a través de Internet, pero puede suscitar inusitadas dificultades. De ahí que sea especialmente recomendable la elección por las partes del Derecho aplicable a estos contratos.

\section{B) Régimen especial de los contratos con consumidores}

Vimos en la Introducción que en las relaciones de empresarios con consumidores hay razones que justifican un desvío del régimen general con vistas a la protección de los consumidores. El art. 5 CR contiene reglas especiales sobre ciertos contratos «celebrados por consumidores» que establecen justamente esta protección ${ }^{41}$.

Se entiende por «contratos celebrados por consumidores» aquellos que tienen por objeto el suministro de bienes muebles corporales o de servicios a una persona para una finalidad que se pueda considerar ajena a su actividad profesional, así como los contratos destinados a la financiación de tal suministro. Esta definición corresponde al art. 13 Convenio de Bruselas relativo a la competencia judicial y la ejecución de decisiones en materia civil y comercial, y debe ser interpretada a la luz de la finalidad de protección de la parte más débil ${ }^{42}$.

Tienen por objeto la adquisición de bienes corporales los contratos onerosos de transmisión, como la venta, locación-venta y locación financiera.

El concepto de adquisición de servicios debe ser entendido en sentido amplio $^{43}$, comprendiendo las actividades no subordinadas de cualquier naturaleza, incluyendo la actividad realizada en interés de otro.

Una primera cuestión que se suscita es saber si ciertos bienes adquiridos en línea, como ficheros de texto, obras de música o vídeo y programas de ordenador, se pueden considerar como bienes corporales a efectos de esta disposición. Parece que el ejemplar de una obra adquirido en línea puede ser considerado como un bien corporal. Pero no hay suministro de un bien corporal en la licencia de programa de ordenador cuyo objeto es un derecho de propiedad intelectual. Debe, sin embargo, admitirse la aplicación analógica

${ }^{41}$ Ver Lima Pinheiro, «Direito aplicável aos contratos com consumidores», ROA 61 (2001) 155-170 (= in Estudos do Instituto de Direito do Consumo, vol. I, 93-106, Coimbra, 2002) y (n. 26), 198 y ss.

42 Cf. Mario Giuliano e Paul Lagarde, «Rapport concernant la convention sur la loi applicable aux obligations contractuelles», JOCE C 282, 31/10, 1980, 23. Sobre la interpretación del art. 13. ${ }^{\circ}$ del Convenio de Bruselas, ver Lima Pinheiro (n. 24), 105 y ss.

${ }^{43}$ Cf. MünchKomm./Martiny (n. 1), Art. 29 n. ${ }^{\circ}$ 17, y Paul LAGARDE, «Le nouveau droit international privé des contrats après l'entrée en vigueur de la Convention de Rome du 19 juin 1980», R. crit. 80 (1991), 287-340, 314. 
de las reglas especiales del art. 5 a casos en que se verifica la misma necesidad de protección ${ }^{44}$.

El apartado segundo del art. 5 establece un límite al principio de autonomía de la voluntad en la elección del Derecho aplicable al contrato. En efecto, este precepto determina que la elección por las partes de la ley aplicable no puede tener como consecuencia privar al consumidor de la protección que le garantizan las disposiciones imperativas de la ley del país en que tenga su residencia habitual.

Esta disposición se sostiene sobre una idea de alternatividad: aplicar las disposiciones imperativas de la ley de la residencia habitual que sean más favorables al consumidor que las reglas de la ley elegida. También puede decirse que la ley de la residencia habitual garantiza un estándar mínimo de protección.

A falta de elección por las partes de ley aplicable, el apartado tercero del art. 5 consagra un desvío de la cláusula general de la conexión más estrecha. Esta cláusula general conduce frecuentemente a la aplicación de la ley del país en que el proveedor de bienes o servicios tiene su establecimiento, en virtud de la «presunción» establecida por el apartado segundo del art. 4. Según el apartado tercero del art. 5, el contrato se regulará por la ley del país en que el consumidor tenga su residencia habitual.

Estas reglas especiales sólo se aplican si se verifican ciertas conexiones con el Estado de residencia habitual ${ }^{45}$.

Primero, que la celebración del contrato ha sido precedida en el país de residencia habitual del consumidor de una propuesta que le fue especialmente dirigida o de anuncio publicitario.

Para que exista una propuesta dirigida al consumidor, en el sentido de este precepto, basta con que el consumidor sea invitado a presentar una propuesta (invitación a contratar) ${ }^{46}$. Es suficiente, por ejemplo, que el proveedor haya enviado un catálogo al consumidor o le haya invitado a visitar su establecimiento. Así, los mensajes publicitarios enviados por correo electrónico a los consumidores pueden normalmente ser calificados como «propuestas dirigidas especialmente al consumidor» en el sentido del CR.

El sentido de la Convención se satisface, por otro lado, con un anuncio publicitario hecho en el país de la residencia habitual del consumidor. El anuncio publicitario debe estar dirigido al país de residencia habitual, pero no tiene que ser específicamente dirigido a ese país. Por eso, se considera

\footnotetext{
${ }^{44}$ En sentido convergente, MünchKomm./Martiny (n. 1), Art. 29 n. ${ }^{\circ}$ 14, y CAlvo CARAvaCA/CARrascosa GonZÁlez (n. 32), 93 y ss. y 95.

${ }^{45}$ Para un análisis y crítica ver EugÉNIA GALVÃo Teles, A protecção do consumidor nos contratos internacionais (diss. mestrado policopiada), 1997, 368 y ss. o 396 y ss. Ver también Id., «A lei aplicável aos contratos de consumo no 'labirinto comunitário', in Est. Inocêncio Galvão Telles, vol. I, 683-751, Coimbra, 2002, 696 y ss.

${ }^{46}$ Cf. MünchKomm./Martiny (n. 1), Art. 29 n. 34.
} 
que está dirigido al país de la residencia habitual cualquier anuncio realizado en un medio de comunicación que sea susceptible de alcanzar todos los países (como, por ejemplo, la transmisión televisiva por satélite e Internet) y que no excluya efectivamente la celebración de contratos con consumidores del país en cuestión ${ }^{47}$.

Se exige además que el consumidor haya ejecutado en el país de su residencia habitual los actos necesarios para la celebración del contrato ${ }^{48}$. Por actos necesarios se entiende aquí, por ejemplo, la firma de los documentos que hayan sido presentados al consumidor o el envío de su encargo al proveedor. En el caso de los contratos celebrados a través de Internet, debe entenderse que el consumidor realizó los actos necesarios en el país de su residencia habitual cuando para tal efecto accedió a la página del proveedor en este país ${ }^{49}$.

El proveedor que ofrece sus productos en Internet puede limitar el suministro a consumidores residentes habitualmente en un determinado país o países. En este caso, la confianza del proveedor en la información aportada por el consumidor debe estar tutelada y, por consiguiente, el consumidor que indique una residencia habitual falsa no se puede beneficiar de la protección concedida por el art. $5 \mathrm{CR}^{50}$.

El régimen especial de los contratos con consumidores también se aplica si la otra parte o el respectivo representante ha recibido el pedido del consumidor en el país de la residencia habitual de éste ${ }^{51}$. Están comprendidas en esta hipótesis las situaciones en que el consumidor se dirige a un estableci-

${ }^{47}$ Cf. Mankowski (n. 1), 234 y ss.; Abbo JunkeR, «Internationales Vertragsrecht im Internet», RIW 45 (1999), 809-818, 815 y ss.; Lima PinheIro (n. 41), 162; MünchKomm./ MARTiny (n. 1), Art. 29 n. ${ }^{\circ} 36$; Bernd Von HofFMAnN y Karsten Thorn, Internationales Privatrecht, 8. ${ }^{a}$ ed., Munique, 2005, 454. En sentido convergente, Gabrielle KAUFMANN-KoHLER, «Internet: mondialisation de la communication - mondialisation de la résolution des litiges?», in Internet. Which Court Decides? Which Law Applies, org. por Katharina BoElEWoelKi y Catherine Kessedjian, 89-142, A Haia, Londres y Boston, 1998, 138 y ss.; Dicey and Morris on the Conflict of Laws, 13. ${ }^{\mathrm{a}}$ ed. por Lawrence Collins (ed. gral), Adrian Briggs, Jonathan Hill, J. McCleAn y C. MorSE, Londres, 2000, 1288 y ss.; y, entre nosotros, Elsa Dias Oliveira (n. 5), 224 y ss., y (n. 31), 229, y Eugénia Galvão Teles (n. 45 [2002]), 697, n. 41. Ver también MARQUES DOS SANTOS, «Direito aplicável aos contratos celebrados através da Internet e tribunal competente» (2003), in Estudos de Direito Internacional Privado e de Direito Público, 159-225, Coimbra, 2004, 182 y ss.

${ }^{48}$ Ver también el art. 20. ${ }^{\circ}$ del DL n. ${ }^{\circ} 359 / 91$, de 21/9, sobre los contratos de crédito al consumo.

${ }^{49}$ Cf. Dicey and Morris (n. 47), 1289, y Calvo Caravaca/CARrascosa González (n. 32), 97. Ver además Mankowski (n. 1), 250 y ss.; Elsa Dias Oliveira (n. 5), 235 y ss.; MaRQUES DOS SANTOS (n. 47), 183 y ss.

${ }^{50}$ Ver MANKOWSKI (n. 1), 248 y ss.

${ }^{51}$ Sobre este concepto de «pedido» ver EugÉnia Galvão Teles (n. 45 [2002]), 698. 
miento de una sociedad «extranjera» o a un puesto de ventas de esta sociedad en una feria o exposición el país de su residencia habitual, aunque la sociedad no haya hecho publicidad en este país ${ }^{52}$. Además, la interpretación de este precepto debe ser autónoma respecto de los sistemas de los Estados contratantes.

El envío del pedido a través de Internet suscita algunas cuestiones.

Este pedido debe considerarse recibido por el proveedor en el momento en que, habiendo sido introducido en la red, puede ser conocido por el proveedor ${ }^{53}$.

Más problemática es la determinación del lugar en que se considera recibido el pedido. Podría pensarse en el lugar donde se sitúa el equipo de recepción del proveedor ${ }^{54}$. Sin embargo, parece que, a la luz de un criterio teleológico, se debe considerar como lugar de recepción todo aquél en que, ante el consumidor, aparenta estar situado el equipo de recepción del proveedor. En efecto, el consumidor debe poder contar con la recepción del pedido en el lugar en que aparentemente el proveedor puede tener conocimiento de él; el consumidor no puede contar con el lugar en que el proveedor casualmente se encuentre cuando accede a la red ni con el lugar en que por forma no recognoscible por el consumidor se sitúa el equipo de recepción del proveedor. Así, por ejemplo, el pedido debe considerarse recibido en el país de residencia habitual del consumidor cuando éste contrata en línea en un sitio que contiene en su nombre de dominio una indicación geográfica que apunta hacia este país o envía el pedido por correo electrónico a una dirección que contiene la misma indicación geográfica ${ }^{55}$.

Por ejemplo, un consumidor residente habitualmente en Portugal que contrata en línea en un sitio con el nombre «.pt» o envía el pedido por correo electrónico a una dirección con la terminación «.pt».

La entidad que proporciona al proveedor el acceso a la red, así como las entidades que exploten servidores intermedios que intervengan en el estable-

${ }^{52}$ Cf. Giuliano/Lagarde (n. 42), 24.

${ }^{53}$ Cf. Mankowski (n. 1), 253. Como la interpretación es autónoma, no son relevantes las disposiciones contenidas a este respecto en los sistemas nacionales. En el sistema portugués, el art. 6.1 del DL n. ${ }^{\circ} 290-\mathrm{D} / 99$, de 2 de agosto, determina que el documento electrónico comunicado por un medio de telecomunicación se considera recibido por el destinatario si fuera transmitido a la dirección de correo electrónico definido por acuerdo de las partes y en éste fuera recibido. Ver art. 15 de Ley Modelo de la CNUDCI sobre Comercio electrónico (1996) y art. 10 Convenio de Naciones Unidas sobre el uso de las comunicaciones electrónicas en contratos internacionales. Según este último precepto, una comunicación electrónica se considera recibida en el lugar en que su destinatario tenga su establecimiento efectivo.

${ }^{54}$ En este sentido, MünchKomm./MarTiny (n. 1), Art. 29 n. ${ }^{\circ} 40$.

${ }^{55}$ En este sentido, MANKOWSKI (n. 1), 253 y ss. En sentido convergente ver, entre nosotros, Elsa Dias Oliveira (n. 5), 242 y ss. y Marques dos Santos (n. 47), 184. Cp. art. 6.5 del Convenio de Naciones Unidas sobre el uso de las comunicaciones electrónicas en contratos internacionales. 
cimiento de la comunicación con el consumidor, no pueden a este efecto ser consideradas representantes del proveedor ${ }^{56}$, a menos que actúen en nombre de éste.

La tercera hipótesis en que se aplica el régimen especial de los contratos con consumidores se verifica cuando el contrato consiste en una venta de mercadería y el consumidor se desplaza del país de su residencia habitual a otro país y en él hace su pedido, siempre que el viaje haya sido organizado por el vendedor con el objetivo de incitar al consumidor a celebrar la compra. Esta hipótesis no es frecuente en el caso de los contratos celebrados a través de Internet.

El régimen especial de los apartados segundo y tercero del art. 5 no es aplicable al contrato de transporte ni al contrato de prestación de servicio, cuando el servicio debido al consumidor deba ser prestado exclusivamente en un país diferente de aquél en que el consumidor tenga su residencia habitual (art. 5.4). Pero sí se aplicará al contrato que establezca, por un precio global, prestaciones combinadas de transporte y de alojamiento (contrato de viaje) (art. 5.5).

El apartado cuarto del art. 5 suscita la cuestión de saber si un servicio prestado en línea debe ser considerado como prestado fuera del país de la residencia habitual del consumidor. En caso afirmativo, el art. 5 no se aplicaría a estos contratos de prestación de servicios.

Sucede, sin embargo, que la ratio de esta exclusión sólo comprende los casos en que el consumidor se desplaza a otro Estado y en él se beneficia de una prestación de servicio. En estos casos, el consumidor no puede razonablemente contar con la aplicación de la ley de su Estado de origen dado que el contrato presenta vínculos más estrechos con el Estado en que la otra parte está establecida y presta el servicio ${ }^{57}$. La situación es diferente cuando un proveedor se obliga a una prestación de servicio que no es ejecutada en un lugar determinado, sino en línea, ante un consumidor que se debe beneficiar del servicio en el país de su residencia habitual. No se entrevé ninguna razón para privar al consumidor de la protección concedida por el art. $5^{58}$.

Así, por ejemplo, queda comprendido en el régimen del art. 5 el contrato de suministro de acceso a Internet celebrado con un consumidor ${ }^{59}$.

\footnotetext{
${ }^{56}$ Ver también Kurt SiEHR, «Telemarketing und Internationales Recht des Verbraucherschutzes», in Jahrbuch des Schweizerischen Konsumentenrechts. JKR 1998, 151-201, 163 y ss.

${ }^{57}$ Cf. Giuliano/Lagarde (n. 42), 24 y ss.

${ }^{58}$ En el mismo sentido, MAnKowski (n. 1), 254 y ss.; M. FAllon e J. MeEuSEN, «Le commerce électronique, la directive 2000/31/CE et le droit international privé», R. crit. 91 (2002), 435-490, 456; Marques dos Santos (n. 47), 186 y ss.; MünchKomm./Martiny (n. 1), Art. 29 n. 28.

${ }^{59}$ Cf. MünchKomm./Martiny (n. 1), Art. 29 n. ${ }^{\circ} 18$.
} 
En cuanto a los contratos celebrados a través de Internet, el art. 5 presenta aún el problema de determinación del lugar de la residencia habitual del consumidor. El proveedor o prestador de servicio puede resolver el problema solicitando al consumidor esta información. También en este caso se debe entender que el consumidor no puede invocar un lugar de residencia habitual diferente de aquel que indicó al celebrar el negocio.

Según un parecer minoritario, el consumidor en el comercio electrónico no debería beneficiarse de la protección concedida por la CR (salvo en situaciones cualificadas en que el proveedor le envíe una propuesta o anuncio publicitario por medio del correo electrónico) ${ }^{60}$.

En este sentido se argumenta, en primer lugar, que el proveedor quedaría sujeto al riesgo de la aplicación de las normas imperativas de todos los países en que tiene acceso a Internet, o que tendría un efecto disuasorio del comercio electrónico, en especial en lo que respecta a las pequeñas y medianas empresas. Sin embargo, tal efecto disuasorio no es del todo reconocible: el riesgo de aplicación de las normas imperativas de casi todos los países del mundo no obstó al desarrollo exponencial del comercio electrónico, porque las ventajas de éste superan ampliamente las desventajas resultantes de ese riesgo ${ }^{61}$.

En la medida en que el proveedor se beneficia de las ventajas de un medio de comunicación global, que es accesible a los consumidores de casi todos los países del mundo, y a coste muy bajo, es justo que también soporte los riesgos y las desventajas inherentes ${ }^{62}$.

El riesgo de aplicación de las normas imperativas de múltiples países no es, de hecho, privativo de Internet. Hace mucho que ocurre con los contratos con consumidores celebrados a raíz de anuncios publicitarios hechos por publicaciones periódicas de distribución internacional, radiodifusión internacional, transmisiones televisivas por satélite o por redes internacionales. También existe en diversas hipótesis de responsabilidad extracontractual, en concreto, ofensas al buen nombre y a la reputación perpetradas a través de esos medios de comunicación y la responsabilidad del productor que exporta a una multiplicidad de países. Este riesgo nunca ha tenido un impacto visi-

\footnotetext{
${ }^{60}$ Ver referencias en MANKowski (n. 1), 235 y ss. y, también, Katharina Boele-WoelKi, «Internet und IPR: Wo geht jemand ins Netz?», in Völkerrecht und Internationales Privatrecht in einem sich globalisierenden internationalen System - Auswirkungen der Entstaatlichung transnationaler Rechtsbeziehungen (Berichte der Deutschen Gesellschaft für Völkerrecht, vol. 39), 307-351, 330 y ss.; entre nosotros, MOURA ViCENTE (n. 5), 253 y ss. SieHR (n. 56), 160 y ss. comenzó defendiendo esta postura, pero la modificó en una obra posterior; ver Internationales Privatrecht, Heidelberga, 2001, 149.

${ }^{61}$ Ya señalado por MANKOWSKI (n. 1), 235.

${ }^{62}$ Ver MANKOWSKI (n. 1), 236 y ss.; SONNENBERGER, «Das Internationale Privatrecht im dritten Jahrtausend - Rüblick und Ausblick», ZvglRWiss 100 (2001), 107-136, 130 y ss.; SIEHR (n. 60), 149.
} 
ble sobre la oferta transnacional de bienes y servicios: los proveedores se orientan por los estándares normativos internacionalmente dominantes y es raro que los consumidores ejerzan judicialmente pretensiones derivadas de los contratos con ellos celebrados. El riesgo de una acción judicial fundada en normas imperativas que se aparten de los estándares internacionalmente dominantes es reducido y, en todo caso, es sobradamente compensado por las ventajas de un mercado global.

En segundo lugar, alégase que el art. $5 \mathrm{CR}$ presupone un «consumidor pasivo», que es captado por una actividad del proveedor realizada en el país de su residencia habitual, mientras que en el comercio electrónico el proveedor se limita a colocar su sitio en una red informática, pudiendo el consumidor buscar el sitio del proveedor y establecer el contacto.

En rigor, sin embargo, el precepto convencional no exige la «pasividad del consumidor», sino que el consumidor reciba una propuesta en el país de su residencia habitual o pueda ser captado por un anuncio publicitario hecho en este país y que actúe negocialmente en este país (podríamos hablar de un consumidor «sedentario»). Para acceder a la publicidad hecha en cualquier medio de comunicación el consumidor tiene normalmente que realizar alguna actividad, por ejemplo, comprar una publicación periódica que contiene el anuncio o poner el televisor y sintonizar el canal televisivo que emite el anuncio y, en caso de que quiera concretar el negocio, tiene que contactar con el proveedor ${ }^{63}$. La relevancia social y jurídica de la publicidad hecha en un sitio de Internet también es la misma que la realizada en otros medios: se trata de una actividad de promoción de un producto que constituye, como mínimo, una invitación a contratar dirigida a personas indeterminadas. La situación del consumidor en el comercio electrónico es, pues, enteramente comparable a la del consumidor tradicional.

Aunque en el comercio electrónico el consumidor es captado por una forma más intensa y envolvente y, en la hipótesis normal en que se realiza la contratación en línea, corre el riesgo de decisiones negociales menos reflexivas e informadas ${ }^{64}$. Si alguna diferencia de tratamiento estuviera justificada, lo estaría en el sentido de una mayor protección del consumidor cibernauta y no en el sentido contrario.

Se sostiene que la publicidad hecha a través de Internet está tendencialmente limitada a determinados espacios geográficos, en concreto en virtud del idioma utilizado o en los avisos (disclaimers) contenidos en las páginas que la contienen. Por ejemplo, un sitio redactado en lengua alemana no estaría dirigido a los países en que esta lengua no es hablada.

${ }^{63}$ Como justamente señala MANKowsKi (n. 1), 240 y ss.

${ }^{64}$ Ver también Kaufmann-Kohler (n. 47), 138 y ss. y Marques dos Santos (n. 47), 182. 
La verdad, sin embargo, es que no sólo la mayoría de los sitios están redactados en lengua inglesa, que es mundialmente conocida, como también en otras lenguas más localizadas que son conocidas por muchos consumidores fuera del país de origen. El proveedor que, por ejemplo, mantiene un sitio en lengua alemana, no puede ignorar que este sitio puede ser comprendido por todos los hablantes de la lengua alemana, y más específicamente, por las comunidades alemanas residentes en los Estados Unidos, en Brasil o en Portugal. Pero no se ve por qué razón los consumidores hablantes de lengua alemana, residentes en estos países, que acceden a un sitio en lengua alemana han de ser privados de la protección concedida por la CR a los consumidores.

Por otro lado, constituye un venire contra factum proprium que un proveedor que acepta contratar con un consumidor residente en un determinado país venga a invocar que su página contiene un aviso según el cual no está dirigida a este país ${ }^{65}$.

A favor de la aplicación del régimen del art. 5 CR, los ciberconsumidores pueden invocar dos razones imperativas.

En primer lugar, la tesis contraria llevaría a privar de toda la protección conflictual a un sector cada vez más amplio de consumidores, conduciendo a una diferencia de trato entre los ciberconsumidores y los restantes consumidores claramente contraria al principio de igualdad. Así lo entiende el legislador comunitario que, al adoptar la Directiva sobre Comercio electrónico, presupone que los ciberconsumidores gozan de la protección de las normas de su residencia habitual en los mismos términos que los restantes consumidores (ver, en concreto, Considerando n. ${ }^{\circ} 55$ y art. 1.3).

En segundo lugar, el legislador comunitario consolidó en el Reglamento n. ${ }^{\circ} 44 / 2001$, de 22/12/2000, relativo a la competencia judicial, al reconocimiento y a la ejecución de resoluciones judiciales en materia civil y mercantil, el régimen especial de protección de los consumidores en materia de competencia internacional que es aplicable cuando el contrato sea celebrado con una persona que dirige su actividad, por cualquier medio, al Estado miembro del domicilio del consumidor o a varios Estados, incluyendo ese Estado miembro, y dicho contrato estuviera comprendido en el marco de tales actividades (art. 15.1.c).

A la luz de la Exposición de Motivos de la propuesta modificada de la Declaración conjunta del Consejo y de la Comisión sobre los arts. $15 .^{\circ}$ y $73 .{ }^{\circ}$, esta formulación está orientada a comprender los contratos celebrados a través de Internet siempre que el sitio del proveedor «invite a la celebración de contratos a distancia y que se haya celebrado efectivamente un contrato a distancia, por cualquier medio» ${ }^{66}$.

${ }^{65}$ En el mismo sentido, MANKOWSKI (n. 1), 245.

${ }^{66}$ Ver Lima Pinheiro (n. 24), 109 y ss. 
Uno de los dos trazos fundamentales de este régimen de protección del consumidor consiste en la facultad atribuida al consumidor de interponer una acción en el lugar de su domicilio (art. 16.1). Esta regla de competencia internacional está naturalmente concatenada con las reglas de conflicto que salvaguardan la aplicación de las normas imperativas protectoras del consumidor contenidas en la ley del país de su residencia habitual en el caso de elección de otra ley y que mandan aplicar la ley de su residencia habitual a falta de elección de ley.

La tesis en cuestión conduciría a una inexplicable falta de armonía entre el régimen comunitario de competencia internacional y el Derecho aplicable, y obligaría al tribunal del domicilio del consumidor a aplicar exclusivamente la ley del proveedor siempre que esta ley hubiese sido objeto de una cláusula de elección del Derecho aplicable o que el país del proveedor presentase una conexión más estrecha (posiblemente «presumida») con el contrato.

No sorprende, por eso, que el sentir de la doctrina dominante haya sido consagrado por la Propuesta de Reglamento sobre la Ley aplicable a las obligaciones contractuales que, en su art. 5.2.2, determina la aplicación del régimen especial de los contratos con consumidores cuando el contrato haya sido celebrado con una persona que, por cualquier medio, dirige su actividad económica o profesional al Estado miembro en que el consumidor tiene su residencia habitual o a varios Estados incluyendo este Estado miembro y el contrato quede comprendido en el ámbito de esta actividad. Se deduce de la Exposición de motivos que esta formulación trata justamente de alinear el art. 5 de la Propuesta de Reglamento con el art. 15 del Reglamento 44/2001.

Esta Exposición de Motivos esclarece que el sitio del proveedor no tiene que ser interactivo; es suficiente que el sitio invite al consumidor a celebrar un contrato a distancia, por ejemplo, a través de telefax. No se verifica este presupuesto cuando el sitio ofrece información a los potenciales consumidores en todo el mundo pero remite a la celebración del contrato a un concesionario o agente local ${ }^{67}$.

Este precepto de la Propuesta de Reglamento no exige que el consumidor haya ejecutado en el país de su residencia habitual todos los actos necesarios para la celebración del contrato, por entenderse que esta exigencia es superflua en lo que respecta a los contratos celebrados a través de Internet ${ }^{68}$.

Cabe aún hacer referencia a una orientación intermedia, según la cual el consumidor «sólo» es privado de la protección concedida por el CR cuando el sitio del proveedor es «pasivo» o no está dirigido al país de la residencia habitual del consumidor a la luz de los anuncios en él contenidos, del idio-

676 y ss.

${ }^{68}$ Cf. Exposición de Motivos, 7. 
ma utilizado, de la moneda de pago exigida y de otros contenidos de información publicitaria ${ }^{69}$.

La distinción entre sitios «pasivos»y sitios «activos» surge en la jurisprudencia de los tribunales de los Estados Unidos con respecto a la competencia «interestatal», es decir, la competencia de los tribunales de cada Estado federado con respecto a las relaciones que presentan contactos con otros Estados de la Unión. Tiene interés examinar esta jurisprudencia para averiguar hasta qué punto conduce a criterios útiles para el desenvolvimiento de las soluciones en nuestro ordenamiento jurídico.

En el sistema de los Estados Unidos la competencia in personam puede ser «general» o «específica». La distinción se traza según que el elemento de conexión que fundamenta la competencia dependa o no de la naturaleza del litigio (sea o no «específico»). Para establecer la competencia «específica» es necesario determinar si los lazos con el Estado del foro son «relativos» al litigio y, en caso afirmativo, si son constitucionalmente suficientes ${ }^{70}$. Para esta última cuestión, la jurisprudencia del Tribunal Supremo aplica un «test de contactos mínimos», que atiende, entre otros aspectos, al «aprovechamiento intencional» (purposeful availment) de los «beneficios y protección» del Estado del foro. La jurisprudencia del Supremo Tribunal presenta, a este respecto, diversas oscilaciones y suscita muchas dudas. No obstante, esta jurisprudencia revela dos ideas dominantes: no basta una «actividad unilateral» de la otra parte en el Estado del foro, fuera de control del demandado, y la competencia del Estado del foro debe ser previsible para el demandado en razón de su conducta o de su conexión con este Estado ${ }^{71}$. En cuanto a la competencia «general» se fundamenta en la presencia del demandado en el Estado del foro, el consentimiento del demandado, domicilio o residencia habitual del demandado, en la necesidad y en los contactos que, a pesar de no ser «relativos» al litigio, sean «continuados y sistemáticos» con el Estado del foro ${ }^{72}$.

En este contexto surgió, en la jurisprudencia de los tribunales de primera instancia, si bien con un número reducido de decisiones de segunda instancia, una orientación que distingue entre sitios meramente «pasivos» y sitios «activos» ${ }^{73}$. Se considera «pasivo» el sitio que se limita a suministrar información y «activo» el sitio que «solicita la contratación» (solicite business) en línea ${ }^{74}$. La contratación a través de un sitio «activo» fundamenta la com-

${ }^{69}$ Ver Calvo Caravaca/Carrascosa González (n. 32), 96 y ss. En sentido parecido, pero atendiendo al grado de «pasividad» del consumidor, FALlon/MEEuSEN (n. 58), 447 y ss.

${ }^{70}$ Ver Eugene Scoles, Peter HAY, Patrick Borchers y Symeon Symeonides, Conflict of

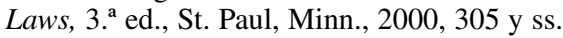

${ }^{71}$ Ver SCOLES/HAY/BORCHERS/SyMEONIDES (n. 70), 309 y ss.

72 Ver Scoles/Hay/Borchers/SymeOnides (n. 70), 336 y ss.

${ }^{73}$ Ver Delta/Matsuura (n. 30) $\$ 3.03$ B y C.

${ }^{74}$ Ver Delta/Matsuura (n. 30) $§ 3.03$ E. 
petencia del Estado desde el que el usuario tiene acceso ${ }^{75}$; el mero acceso a un sitio "pasivo» en el Estado del foro no es suficiente para fundamentar la competencia.

Otras decisiones, sin embargo, han adoptado otro parecer; además de eso, se admite una categoría intermedia, de sitios que permiten al usuario intercambiar información con el ordenador de almacenamiento, sin «solicitar la contratación» en línea, como por ejemplo cuando el sitio permite el envío de un correo electrónico, la solicitud de contacto telefónico, la solicitud de información adicional en línea o el contacto con un operador en línea. En estos casos, la resolución del problema de competencia sería dudosa y se tendría que basar en otros criterios. Algunos autores sugieren que, en estos casos, se podría aplicar analógicamente el criterio del «flujo de comercio» (stream of commerce), según el cual no basta la colocación en el mercado interestatal de un producto, y es necesario demostrar que el demandado ha dirigido intencionalmente su actividad al Estado del foro. La doctrina más representativa en materia de Conflict of Laws ha señalado que la utilidad de esta distinción tiende a desvanecerse una vez que casi todas las web comerciales tienen actualmente algún componente «activo» ${ }^{76}$.

En cuanto el Derecho aplicable a los contratos con consumidores, no existe una regla vigente uniforme en los Estados de la Unión como la del art. 5.2 CR. No obstante, muchos Estados tienen leyes protectoras de consumidores (o de ciertas categorías de consumidores) que no permiten la derogación de las normas imperativas protectoras de los consumidores en ellos domiciliados ${ }^{77}$. La tendencia de evolución es favorable a un régimen de protección próximo al contenido en la CR, como da cuenta el art. 1-301 (e)(2) de la nueva versión de la Uniform Commercial Code (2003); según esta disposición, la elección del Derecho aplicable no puede privar al consumidor de la protección que le sea concedida por las reglas imperativas del Estado de su residencia o, si se trata de un venta de mercancías en que el consumidor «celebre el contrato» y reciba la mercancía en un Estado que no es el de su residencia, por las reglas imperativas de este Estado ${ }^{78}$. De la doctrina consul-

${ }^{75}$ Mas cp. James Donohue, «Personal Jurisdiction», in Internet Law and Practice, vol. I, 2004, § 9:17.

${ }^{76}$ Cf. Scoles/Hay/Borchers/SymeOnides (n. 70), 313 n. 22.

${ }^{77}$ Por ejemplo, en materia de contrato de seguro, ver ScOLES/HAY/BorCHERS/SYMEONIDES (n. 70), 967 y ss.

${ }^{78}$ Es el texto de la siguiente disposición: «Application of the law of the State or country determined pursuant to subsection (c) or (d) may not deprive the consumer of the protection of any rule of law governing a matter within the scope of this section, which both is protective of consumers and may not be varied by agreement: (A) of the State or country in which the consumer principally resides, unless subparagraph (B) applies; or (B) if the transaction is a sale of goods, of the State or country in which the consumer both makes the contract and takes delivery of those goods, if such State or country is not the State or country in which the consumer principally resides». 
tada ninguno se pronuncia en el sentido de una exclusión del ciberconsumidor de esta protección.

También la Ley Modelo adoptada en los Estados Unidos, por la National Conference of Commissioners on Uniform State Laws (Uniform Computer Information Transactions Act, de 1999) sigue hasta cierto punto estas soluciones. En efecto, la Ley Modelo determina que en los contratos con consumidores la elección de la ley aplicable no perjudica a las normas imperativas de la ley objetivamente competente (art. 109.a). La ley objetivamente competente es, en cuanto a los contratos con consumidores que se obliguen a la entrega de una copia en soporte corpóreo, la del Estado en que la copia es o debería haber sido entregada al consumidor (art. 109.b.2). Los restantes contratos son sometidos, a falta de elección, a la ley de conexión más significativa o, tratándose de contratos de suministro de acceso o que tengan por objeto la entrega electrónica de una copia, la ley del establecimiento del licenciador.

De este breve excurso sobre el sistema de los Estados Unidos, destaca que la diferenciación del régimen aplicable a los contratos con consumidores según que el sitio del proveedor sea «activo» o «pasivo» surgió en el contexto de criterios de competencia interestatal de contenido flexible y poco determinado y que no puede ser transpuesta para los cuadros definidos por el Derecho vigente en la Europa comunitaria, sea en materia de competencia internacional, sea en materia de determinación del Derecho aplicable. En especial, esta distinción es incompatible con una correcta interpretación del art. 5 CR, como lo es, aparentemente, con el Derecho conflictual vigente en muchos Estados de los Estados Unidos de América.

En lo relativo a la competencia, existe una amplia convergencia en esta materia entre las tendencias dominantes en la jurisprudencia de los tribunales estadounidenses y el Derecho Comunitario europeo. Estas tendencias apenas divergen en relación con los sitios que, aunque contengan una invitación a contratar a distancia, no permiten la contratación en línea ni son dirigidos intencionalmente al país de residencia habitual del consumidor. Ante la generalizada tendencia de los sitios de los proveedores en el sentido de permitir la contratación en línea, esta diferencia pierde gran parte de su significado práctico.

En lo que se refiere al Derecho aplicable, las soluciones acogidas tanto por la Propuesta de Reglamento comunitario como en la Uniform Commercial Code son preferibles. El consumidor que contrata a distancia a raíz de una propuesta o de una invitación a contratar hecha en un sitio de Internet debe gozar de la protección de las normas imperativas del país de su residencia habitual, salvo si el proveedor hubiere excluido la contratación con consumidores residentes en este país y el consumidor hubiera dado una falsa información sobre la localización de su residencia habitual. Como resulta de lo anteriormente expuesto, no se puede sostener en puridad que un proveedor que ofrece sus bienes o servicios en Internet y que acepta contratar con consumidores de determinado país no dirige su actividad a este país. 
En esta materia, hay aún que señalar la existencia de diversos regímenes que son susceptibles de superposición a la ley competente. Puede tratarse, en concreto, de regímenes contenidos en el Derecho Comunitario o en las leyes internas que transponen Directivas comunitarias (art. $20 \mathrm{CR}$ ) o normas «autolimitadas» de fuente interna que no se basan en actos comunitarios (art. 7.2 CR) ${ }^{79}$.

Me referiré a la Ley de Cláusulas Contractuales Generales, al régimen de los contratos a distancia con consumidores y al régimen de contratos a distancia entre prestadores de servicios financieros y los consumidores.

En lo que se refiere a la prohibición de ciertas cláusulas contractuales generales en los contratos celebrados con consumidores finales, hay que tener en cuenta lo dispuesto en el art. 23 LCGC, en la redacción dada por el DL n. ${ }^{\circ}$ 249/99, de 7 de julio.

El n. ${ }^{\circ} 1$ de este artículo determina la aplicabilidad de las normas contenidas en los arts. 20 y siguientes de este diploma, independientemente de la ley que las partes hayan escogido para regir el contrato, siempre que éste presente una conexión estrecha con el territorio portugués.

En los términos del n. ${ }^{\circ} 2$, «en caso de que el contrato presentara una conexión estrecha con el territorio de otro Estado miembro de la Comunidad Europea se aplicarán las disposiciones correspondientes de ese país en la medida en que éstas determinen su aplicación».

Según el preámbulo del DL n. ${ }^{\circ}$ 249/99, el objetivo básico de este diploma fue adaptar la LCCG a lo dispuesto en la Directiva 93/13/CEE relativa a las cláusulas abusivas en los contratos celebrados con los consumidores. Con la nueva redacción dada al art. 23 LCCG, la legislación nacional procuró transponer lo dispuesto en el art. 6.2 de la Directiva: «Los Estados miembros tomarán las medidas necesarias para que el consumidor no sea privado de la protección concedida por la presente Directiva por el hecho de haber sido elegido el derecho de un Estado tercero como derecho aplicable al contrato, siempre que el contrato presente una relación estrecha con el territorio de los Estados miembros».

Según la mejor interpretación ${ }^{80}$, este precepto sólo se aplica a los contratos que, a falta de elección, se regirían por el Derecho de un Estado miembro. Una vez que la norma de conflicto sobre contratos celebrados por consumidores (art. 5 CR) ya asegura, en ciertos casos, la protección de las normas imperativas de la ley del país de la residencia habitual del consumidor, el art. 6.2 de la Directiva gana sentido cuando el consumidor no goza de la protección conferida por el art. 5.2 CR, por no verificarse los presupuestos

${ }^{79}$ Sobre el concepto de norma «autolimitada» y el art. 7.2 CR ver LiMA PINHEIRO, Direito Internacional Privado, vol. I - Introdução e Direito de Conflitos. Parte Geral, Almedina, Coimbra, 2001, 193 y ss.

${ }^{80}$ Ver Lima Pinheiro (n. 26), 223 y ss. 
de aplicación definidos en sus núms. 1, 2, 4 y 5, y el Derecho de un Estado miembro es competente por el art. $4 \mathrm{CR}^{81}$.

Sin embargo, la intención del legislador del DL n. ${ }^{\circ} 249 / 99$, aunque posiblemente basada en una interpretación incorrecta del art. 6.2 de la Directiva, apunta claramente en el sentido de sobreponerse a las normas contendidas en los arts. 20 y siguientes LCCG y a las disposiciones correspondientes de los otros Estados comunitarios, bien a la ley del tercer Estado designada por las partes bien a la ley objetivamente competente.

Así, el régimen portugués de cláusulas contractuales generales en las relaciones con los consumidores es aplicable no sólo a los contratos celebrados a través de Internet con ciberconsumidores residentes habitualmente en Portugal o en los que las partes hayan elegido la ley portuguesa (art. 5.2 CR), sino también a los que tengan una conexión estrecha con el territorio portugués ${ }^{82}$, cuando sean más favorables al consumidor que las normas de la ley competente.

El régimen de los contratos a distancia con los consumidores fue introducido por el DL n. ${ }^{\circ}$ 143/2001, de 26 de abril, que transpuso la Directiva 97/7/CE del Parlamento Europeo y del Consejo relativa a la protección de los consumidores en materia de contratos a distancia. Este régimen, que es aplicable a los contratos celebrados a través de Internet (ver definición del contrato a distancia contenida en el art. 2.a), con exclusión de los servicios financieros (art. 3.1), impone al prestador del servicio deberes de información previa y de confirmación de informaciones a través de soporte duradero y confiere al consumidor un derecho de rescisión.

El art. 12.2 de esta Directiva establece que «los Estados miembros deben tomar las medidas necesarias para que el consumidor no sea privado de la protección conferida por la presente Directiva por el hecho de haber sido elegido el Derecho de un tercer país como derecho aplicable al contrato, cuando el contrato presente una relación estrecha con el territorio de uno o más Estados miembros». Se trata de una disposición semejante a la contenida en el art. 6.2 de la Directiva sobre cláusulas abusivas y debe ser interpretada en el mismo sentido. El DL n. ${ }^{\circ}$ 143/2001, sin embargo, no contiene ninguna norma de conflicto. Se trata de una transposición imperfecta, que no respeta lo dispuesto en el art. 12.2 de la Directiva. En todo caso, parece que las normas contenidas en este diploma que transponen la Directiva deben tener el

${ }^{81}$ Cf., en relación con la Directiva sobre Cláusulas Abusivas, Erik JAYME y Christian KOHLER, «L'interaction des règles de conflit contenues dans le droit dérivé de la Communauté européenne et des conventions de Bruxelles et de Roma», R. crit. 84 (1995), 1-40, 20 y ss.

${ }^{82}$ Sobre la concreción de conexión estrecha, cp. EugÉNIA Galvão Teles (n. 45 [1997]) 235 y ss. y (n. 45 [2002]), 711 y ss. y ElSA OLIVEIRA (n. 5), 264 y ss. Ver también, en sentido diferente, Moura Vicente (n. 5), 254. 
ámbito de aplicación en el espacio que resulta del art. 12.2 de esta Directiva, en los términos expuestos.

Por consiguiente, las normas internas que transponen la Directiva sobre contratos a distancia son aplicables a los consumidores residentes habitualmente en Portugal, siempre que se verifiquen los presupuestos del $n .^{\circ} 2$ del art. $5 \mathrm{CR}$; en los restantes casos, estas normas serán aplicables cuando el contrato presente la conexión más estrecha con Portugal según el art. 4 CR.

La Directiva 2002/65/CE relativa a la comercialización a distancia de servicios financieros prestados a consumidores aún no ha sido transpuesta al ordenamiento jurídico portugués, pero ya están en curso los trabajos con vistas a ello. Esta Directiva, que también es aplicable a los contratos celebrados a través de Internet, impone al prestador del servicio deberes de información, deberes de información previa y la comunicación en soporte duradero de los términos del contrato y de las informaciones previas; confiere además al consumidor un derecho de rescisión.

En este sentido, la Directiva exige que el consumidor sea informado antes de la celebración del contrato de cualquier cláusula contractual relativa a la legislación aplicable al contrato (art. 3.1.3.f). Esta información debe ser comunicada en papel o en otro soporte duradero (art. 5.1), lo que incluye disquetes, CD-ROM, DVD y disco duro, pero no en sitios de Internet, salvo que permitan al consumidor almacenar la información de un modo que, en el futuro, le permita un acceso fácil a ella y la reproducción inalterada de las informaciones almacenadas (Considerando n. 20 y art. 2.f). Esta Directiva contiene en el art. 12.2 una norma de conflicto idéntica a la contenida en la Directiva sobre Contratos a distancia y que debe ser interpretada del mismo modo.

\section{C) Ámbito del estatuto contractual}

La ley designada en los términos de los arts. 3, 4 y 5.3 CR regula ${ }^{83}$ :

— la formación y la validez del contrato (art. 8.1);

— su interpretación (art. 10.1.a);

- el cumplimiento de las obligaciones que genere (art. 10.1.b);

- los límites de los poderes atribuidos al tribunal por la respectiva ley del proceso, las consecuencias del incumplimiento total o parcial de esas obligaciones, incluyendo la evaluación del daño en la medida en que fuere indemnizable (art. 10.1.c);

- las diversas causas de extinción de las obligaciones, así como la prescripción y la caducidad fundadas en la expiración de un plazo (art. 10.1.d);

${ }^{83}$ Ver, más extensamente, Lima Pinheiro (n. 26), 209 y ss. 
- las consecuencias de la nulidad del contrato (art. 10.1.e);

- las presunciones legales y el reparto de la carga de la prueba (art. 14).

Para saber si la oferta de productos y servicios hecha en un sitio de Internet sirve como propuesta contractual o sólo como invitación a contratar ha de consultarse la ley que sería designada por las normas de conflicto del Convenio en el caso de que el contrato hubiese sido válidamente celebrado. La misma ley es aplicable a la responsabilidad precontractual con tal de que esta presuponga, ante la ley o leyes potencialmente aplicables, la existencia de una relación jurídica entre las partes ${ }^{84}$.

El art. 11 de la Convención de Naciones Unidas sobre el uso de comunicaciones electrónicas en los contratos internacionales establece, en sintonía con el art. 14.2 de la Convención de Viena sobre la compraventa internacional de mercaderías ${ }^{85}$, que una propuesta hecha a personas indeterminadas a través de una comunicación electrónica debe ser considerada una invitación a contratar, a menos que indique claramente la intención del proponente de vincularse en caso de aceptación.

Diferente es la solución del DL n. ${ }^{\circ} 7 / 2004$, de 7 de enero, que, en la línea de entendimiento generalmente seguida entre nosotros, establece que la oferta de productos o servicios en línea representa una propuesta contractual cuando contiene todos los elementos necesarios para que el contrato quede concluido con la simple aceptación del destinatario (art. 32.1). Este precepto será aplicable cuando la ley portuguesa estuviera llamada a regular el contrato y, en las relaciones con consumidores residentes habitualmente en Portugal cuando, habiendo sido elegida otra ley, la ley portuguesa sea más favorable al consumidor que la ley elegida (supra B). Resulta más dudoso que este precepto pueda ser aplicado a título de ley del establecimiento del prestador del servicio ${ }^{86}$.

\section{D) ¿Régimen especial del comercio electrónico intracomunitario?}

La Directiva sobre Comercio Electrónico ${ }^{87}$, así como las leyes nacionales que la transpusieron, vinieron a suscitar una amplia controversia sobre su incidencia en la determinación del Derecho aplicable a los contratos comprendidos en su ámbito de aplicación.

${ }^{84}$ Ver Lima Pinheiro (n. 26), 154 y ss.

${ }^{85}$ Ver Lima Pinheiro (n. 1), 269 y ss.

${ }^{86}$ Ver Lima Pinheiro, «O Direito de Conflitos e as liberdades comunitárias de estabelecimento e de prestação de serviços», en Seminário Internacional sobre a Comunitarização do Direito Internacional Privado, 79-109, Coimbra, 2005 (= en Estudos em Memória do Professor Doutor António Marques dos Santos, vol. I, 273-303, Almedina, Coimbra, 2005), 106 y ss.

${ }^{87}$ Supra n. 18. 
La Directiva es aplicable a toda prestación de servicio que, mediante remuneración, es realizada a distancia, a solicitud individual de un destinatario por vía electrónica, a través de instrumentos electrónicos de procesamiento (incluida la compresión digital) y de almacenamiento de datos que es enteramente trasmitido, enviado y recibido a través de radio, medios ópticos u otros medios electromagnéticos ${ }^{88}$.

Esto comprende muchos contratos de prestación de servicio en línea que son frecuentemente celebrados a través de Internet, tales como, por ejemplo, contratos de suministro de acceso a Internet y contrato de acceso a las bases de datos informáticas.

El n. ${ }^{\circ} 4$ del art. 1 de esta Directiva determina que «la presente Directiva no establece normas adicionales de Derecho internacional privado».

Sin embargo, el art. 3.1 establece que «Todo Estado miembro velará por que los servicios de la sociedad de la información facilitados por un prestador de servicios establecido en su territorio respeten las disposiciones nacionales aplicables en dicho Estado miembro que formen parte del ámbito coordinado».

También el considerando $22 .^{\circ}$ afirma que los servicios «deben estar sujetos, en principio, a la legislación del Estado miembro en que el prestador de servicios se encuentre establecido». origen».

De ahí que se afirme que la Directiva consagra el «principio del país de

No habría contradicción entre los arts. 3 y 1.4 si el ámbito coordinado se limitase al Derecho económico, en concreto al régimen de acceso y ejercicio de actividad. En efecto, la aplicación de las normas de Derecho económico no depende de las normas de Derecho internacional privado. El «principio del país de origen» serviría sólo para la aplicación de las normas de Derecho público de la economía con incidencia sobre la libertad de prestación de servicios $^{89}$.

La Directiva, sin embargo, no sigue este criterio de forma coherente.

Primero, al definir el «ámbito coordinado», la Directiva utiliza una formulación excesivamente amplia, ya que incluye «las exigencias que el prestador de servicios tiene que observar» «incluyendo las aplicables (...) a los contratos, o las referentes a la responsabilidad del prestador de servicios».

${ }^{88}$ Art. 1.\%/2 de la Directiva 98/34/CE, de 22/6/1998, en la redacción dada por la Dir. 98/48/CE, de 20/7/1998, aplicable ex vi art. 2.\%a de la Directiva sobre Comércio Electrónico. Sobre este ámbito material de aplicación ver Alexandre DiAs PEREIRA, «A protecção do consumidor no quadro da Directiva sobre o Comércio Electrónico», en Estudos de Direito do Consumidor (2/2000), org. por António PinTo MonTEIRO, 43-140, Coimbra, 55 y ss.

${ }^{89}$ En este sentido, ver Calvo Caravaca/CARrascosa GonZález (n. 32), 34 y ss. 
Segundo, el alcance de los núms. 1 y 2 del art. 3 es restringido por su n. ${ }^{\circ}$ 3 , que excluye de su aplicación un conjunto de dominios referidos en el anexo, incluyendo los derechos de propiedad intelectual, la «libertad de las partes de elegir la ley aplicable a su contrato», las «obligaciones contractuales relativas a contratos celebrados por los consumidores» y la «validez formal de los contratos que creen o transfieran derechos sobre bienes inmuebles, siempre que esos contratos estén sujetos a requisitos de forma obligatorios en virtud de la legislación del Estado miembro en el que esté situada la propiedad inmobiliaria».

Esta enumeración es incoherente por varias razones.

Desde luego, la libertad de elección del Derecho aplicable al contrato no es un «dominio», sino una norma de conflicto. Si la Directiva no contiene normas de Derecho internacional privado no afecta a las reglas de conflicto en materia de obligaciones contractuales y, por consiguiente, la referencia a esta norma de conflicto debe despreciarse. Si, por el contrario, la Directiva pretendiese establecer una norma de conflicto («principio del país de origen») en materia de obligaciones contractuales, salvo las relativas a los contratos celebrados por los consumidores, esta referencia no se entendería.

La referencia a las obligaciones contractuales relativas a los contratos celebrados por los consumidores, sugiriendo una diferencia de tratamiento relativa a las restantes obligaciones contractuales, entra en contradicción con lo dispuesto en el art. 1.4, ya que la ley aplicable a la generalidad de los contratos se determina por las normas de Derecho internacional privado.

No menos incoherente es la referencia a la «validez formal de los contratos que creen o transfieran derechos en materia de propiedad inmobiliaria». La ley aplicable a la validez formal de los contratos se determina por las normas de Derecho internacional privado, tengan o no por objeto bienes inmuebles ${ }^{90}$. Sería un hecho impensable que la validez formal de un contrato celebrado por un prestador de servicios estuviera sometida a la ley del Estado en que él se encuentra establecido, independientemente de la ley aplicable al fondo del contrato y de la ley del lugar de celebración. Así, el art. 3.1 no es aplicable a la validez formal de ningún contrato, lo que hace su referencia inútil.

Finalmente, no se excluye la responsabilidad civil del prestador del servicio, lo que entra en contradicción con el art. 1.4, ya que la ley aplicable a la responsabilidad civil se determina por las normas de Derecho internacional privado ${ }^{91}$.

Verdaderamente, la Directiva es contradictoria, revelando falta de claridad en la delimitación entre el régimen de las libertades comunitarias y el

\footnotetext{
${ }^{90}$ Ver art. $9 .^{\circ} \mathrm{CR}$.

${ }^{91}$ Ver art. 45..$^{\circ}$ del Código Civil.
} 
Derecho conflictual privado y, más en general, una cierta alineación de nociones y principios básicos del Derecho internacional privado.

La explicación de estas contradicciones reside, según la información que tengo, en la circunstancia de que el art. 1.4 fue introducido en el último momento de las negociaciones que antecedieron a la adopción de la Directiva por el Consejo, como condición fundamental para su aprobación, sin haber tenido tiempo para corregir el anexo. Con la introducción del art. 1.4 el legislador comunitario quiso apartar cualquier derogación del Derecho conflictual general (y en particular las normas de la Convención de Roma sobre la ley aplicable a las obligaciones contractuales y de los futuros reglamentos comunitarios) por el principio del país de origen ${ }^{92}$.

A esta luz, parece claro que las contradicciones antes referidas deben ser resueltas con primacía del art. 1.4, que este precepto es básico para la interpretación y para la transposición de la Directiva, y que las exclusiones equívocas que constan en el anexo no deben ser transpuestas.

La regla general consagrada en el n..$^{\circ} 1$ del art. 4 sale al encuentro de lo que vengo defendiendo desde $2001^{93}$, según lo cual la libertad de prestación de servicios no condiciona, en principio, el Derecho conflictual privado. Como intenté demostrar en otro lugar, la libre circulación de servicios no implica la competencia del Derecho del Estado de origen para regir el contrato o la responsabilidad extracontractual ${ }^{94}$. El principio del país de origen sirve principalmente para las normas de Derecho público de la economía con incidencia sobre la libertad de prestación de servicios ${ }^{95}$.

${ }^{2}$ Ver Lima Pinheiro (n. 87), 104, y Vincent Heuzé, «De la compétence de la loi du pays d'origine en matière contractuelle ou l'anti-droit europeen», in Mélanges Paul Lagarde, 393-415, París, 2005, 406, n. 41.

${ }^{93}$ Ver Lima Pinheiro (n. 3), 834; Id., «Federalismo e Direito Internacional Privado algumas reflexões sobre a comunitarização do Direito Internacional Privado», Cadernos de Direito Privado (2003/2) 3-19, 15 y ss.; Id. (n. 87), 93 y ss.

${ }_{94}$ Ver, además de las obras citadas en la nota anterior, Michael WiLDERSPIN e Xavier LEWIS, «Les relations entre le droit communautaire et les règles de conflits de lois des États membres», $R$. crit. 91 (2002), 1-37 y 289-313, 302 y ss. y MARques dos SAnTos (n. 47), 211 y ss. Ver también la doctrina citada por FALlON/MEEUSEN (n. 58), 480 n. 99.

${ }^{95}$ Cf. Calvo Caravaca/Carrascosa González (n. 32), 34 y ss.; Lima Pinheiro (n. 87),

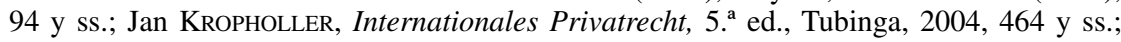
Heuzé (n. 93) maxime 412 y 414, que con alguna exageración califica la transposición del principio del país de origen para el Derecho privado como «impostura jurídica». Cp., en el sentido de aplicación del principio del país de origen en materias de Derecho privado comprendidas por el «ámbito coordinado», Emmanuel CRABIT, «La directive sur le commerce électronique. Le projet 'Mediterranée'», R. Droit de l'Union Européenne (4/2000) 749-833 (administrador principal en la Dirección General de Mercado Interior de la Comisión Europea, que viene a defender una interpretación de la Directiva que corresponde al proyecto elaborado por esta Dirección General que fue recusado por el legislador comunitario a través de la inclusión del art. 1.4 en la versión final); doctrina citada por FALLON/MeEusen (n. 58), 
En el plano de la política jurídica, los defensores de la extensión del principio del país de origen al Derecho privado argumentan que este principio facilita la actividad transnacional de los prestadores de servicios, por cuanto disminuye sus costes de transacción derivados de la obtención de informaciones sobre las leyes de los países de destino y los dispensa de que acomoden sus actividades a los regímenes posiblemente más rigurosos en ellos vigentes.

Pero de ahí no resulta cualquier valor añadido por el desarrollo del comercio internacional en general, y del comercio internacional electrónico en particular, ya que todas las ventajas que los prestadores de servicios obtienen con la aplicación de su ley conllevan correlativas desventajas para los destinatarios de las prestaciones de servicios.

En primer lugar, la aplicación de la ley del prestador del servicio aumenta globalmente los costes de la transacción de comercio internacional, ya que muchos prestadores transnacionales de servicios realizan transacciones en masa a determinados países, siendo el coste de obtención de la información sobre las leyes de estos países amortizado por una multiplicidad de transacciones, en cuanto que la gran mayoría de los destinatarios de los servicios realiza sólo adquisiciones esporádicas a proveedores extranjeros ${ }^{96}$. Los costes de la transacción en que hayan incurrido los destinatarios del servicio con la obtención de información sobre las leyes de los países de origen son por este motivo individualmente más onerosos y globalmente más elevados.

En segundo lugar, la aplicación de la ley del prestador de servicios, no sólo priva al destinatario de la protección concedida por su ley, lo que es obvio, sino que también favorece a los prestadores que están establecidos en Estados miembros con un régimen jurídico más «liberal» en relación con los prestadores que están establecidos en Estados miembros con leyes más rigurosas. Esto estimula a los prestadores de servicios a buscar los países con un menor nivel de protección de los destinatarios y presiona a los restantes

481 n. 100; Moura VICENTE, «Comércio electrónico e responsabilidade empresarial», in Direito Internacional Privado. Ensaios, vol. I, 193-239, Coimbra, 2002, 218 y ss. y (n. 5), 213 y ss. FALLON/MEEUSEN defienden una solución intermedia ([n. 58] 484 y ss.): en el Estado de origen el principio del país de origen determina, a falta de elección por las partes, la ley aplicable a los aspectos del contrato que quedan comprendidos en el ámbito coordinado; en el Estado de acogida se aplican las reglas generales de conflicto, limitándose la Directiva a vedar las reglas de Derecho material que constituyan una restricción a la circulación de servicios. También Peter Mankowski, «Herkunftslandprinzip und deutsches Umsetzungsgesetz zur e-commerce-Richtlinie», IPRax 22 (2002), 257-266, que excluye el Derecho conflictual de contratos del ámbito de aplicación del principio del país de origen, y

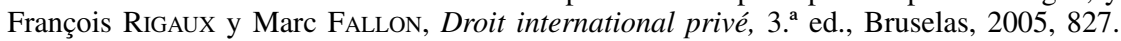
Además la Directiva no parece impedir absolutamente la aplicación de las normas de Derecho económico del país en que el servicio sea prestado (cf. arts. $1 . \% / 3$ y 3.\%/4).

96 Ver Heuzé (n. 93), 397 y ss. 
países a desregular los contratos de prestación de servicios, dando lugar a una verdadera race to the bottom ${ }^{97}$.

Subyacente a la defensa del principio del país de origen en materia de Derecho privado sólo puede estar, en consecuencia, el deseo de privilegiar los intereses de los proveedores frente a los intereses de los adquirentes. Naturalmente, la tentación de defender soluciones de este tipo es grande en los países que son predominantemente exportadores de bienes y servicios, pero es una tentación a la que se debe resistir. Por un lado, porque la economía mundial evoluciona rápidamente y es muy probable que diversos países que hoy son predominantemente exportadores mañana sean predominantemente importadores (una evolución rápida en este sentido se espera especialmente en el comercio electrónico). Por otro lado, y ésta es la consideración principal, el Derecho Internacional Privado debe aspirar a proporcionar soluciones justas que, en concreto, se plasman en una composición equilibrada de los intereses de las partes; no debe perseguir políticas de favorecimiento de las partes «nacionales» frente a las partes «extranjeras».

Las soluciones hoy consagradas en los principales sistemas nacionales en cuanto a la determinación del Derecho aplicable a los contratos son el producto de una evolución secular que plasma una justa composición de intereses. De acuerdo con estas soluciones, en las relaciones entre empresarios el contrato debe ser regulado por la ley elegida por las partes, y a falta de elección, por la ley del país que presenta una conexión más estrecha con el contrato.

Señálese, además, que en los Estados Unidos, en el antes referido Uniform Computer Information Transactions Act se siguen en principio las mismas soluciones. En efecto, el art. 109 de esta Ley Modelo establece como regla general subsidiaria la competencia de la ley del Estado que presenta la conexión más significativa con la transacción (b/3). Sólo se hace una concesión a favor de la competencia subsidiaria de la ley del establecimiento del prestador del servicio con respecto a los contratos de suministro de acceso y a los contratos que tengan por objeto la entrega electrónica de una copia $(\mathrm{b} / 1)$.

Los grupos de presión que defienden los intereses de los proveedores en la Comisión de la Comunidad Europea han hecho esfuerzos para que se abandone el criterio de la conexión más estrecha a favor de la ley del establecimiento del proveedor: esto sucede no sólo con la tentativa de introducir el principio del país de origen en la Directiva relativa a los servicios en el mercado interior y en la Directiva sobre Comercio Electrónico sino también en el Proyecto de Reglamento sobre la ley aplicable a las obligaciones contractuales (art. 4).

${ }^{97}$ Ver Heuzé (n. 93), 400 y ss. 
Claro que el Derecho vigente ya permite la aplicación del Derecho del país del establecimiento del proveedor cuando fuere éste el país con el que el contrato presenta la vinculación más estrecha; además, el Derecho vigente «presume», en caso de duda, que el contrato presenta los vínculos más estrechos con este país. Lo que los defensores de la extensión del principio del país de origen al Derecho privado pretenden es que se aplique la ley del país del proveedor a los contratos que indubitadamente presentan una conexión más estrecha con otro país, por ejemplo con el país del adquirente.

Veamos un ejemplo: un proveedor polaco, que dispone de un sitio redactado en lengua alemana, celebra en línea con una empresa alemana un contrato de venta de una mercancía que debe ser entregada en Alemania. Según el art. 4.1 y 5 CR este contrato presenta la conexión más estrecha con Alemania y, por consiguiente, es competente la ley alemana. La tesis del principio del país de origen conduciría, en vez de eso, a la aplicación de la ley polaca.

Es cierto que estas hipótesis son menos frecuentes en los casos de prestación de servicios en línea. Pero no son inconcebibles: supóngase un caso de un proveedor de acceso que, a pesar de utilizar un nombre «.pt» y ofrecer sus servicios en un sitio redactado en portugués, está establecido en España. ¿Sería justo aplicar al contrato la ley española?

Por mi parte entiendo que las soluciones vigentes son adecuadas al comercio intracomunitario, y que no se justifica ningún desvío a favor del principio del país de origen.

No es otra la opinión que ha prevalecido en la doctrina más autorizada, como da cuenta la Posición del Grupo Europeo de Derecho Internacional Privado sobre el Proyecto de Directiva relativa a los servicios en el mercado interior (noviembre de 2004) y el Desarrollo de esta Posición (Diciembre de 2004) $)^{98}$. La misma opinión acaba de triunfar en el Parlamento europeo con respecto a esta Directiva: según las últimas noticias, ha sido eliminado del texto de la Directiva sobre servicios en el mercado interior aprobado por el Parlamento Europeo, en febrero de 2006, el principio del país de origen, por lo menos en lo que se refiere al Derecho privado. La libertad de prestación de servicios sólo obliga al Estado miembro de acogida a permitir el libre acceso a la actividad de un servicio y el ejercicio de esta actividad en su territorio.

La interpretación de la Directiva sobre Comercio electrónico atrás expuesta no deja de ser cualificada por tres órdenes de consideraciones.

En primer lugar, no se excluye que el art. 3 de la Directiva sea interpretado en el sentido de apartar la aplicación de las normas de Derecho material de la ley competente en la medida en que estas reglas constituyan «restric-

${ }^{98}$ En <http://www.drt.ucl.ac.be/gedip/gedip_documents.html>. 
ciones» injustificadas a la libertad de prestación de servicios ${ }^{99}$. A favor de esta interpretación puede invocarse el Considerando n..$^{\circ} 23$ de la Directiva sobre Comercio Electrónico, según el cual, en las versiones francesa, inglesa y alemana, «lo dispuesto en la legislación aplicable a través de las normas de conflicto del Derecho Internacional Privado no debe restringir la libertad de prestar servicios de la sociedad de la información en los términos previstos en la presente Directiva ${ }^{100}$. Pero esto sólo puede suceder muy excepcionalmente, visto que la aplicación de las normas de Derecho privado no conduce, en principio, a una restricción de la libertad de prestación de servicios $^{101}$.

Segundo, puede cuestionarse si el art. 3.1 no fundamenta una conexión especial frente a las reglas jurídico-privadas contenidas en la Directiva, de forma que cada Estado deba determinar la aplicación de sus normas de transposición de la Directiva a las prestaciones de servicios por prestadores establecidos en su territorio ${ }^{102}$. En mi opinión no es posible dar una respuesta genérica a esta cuestión.

En relación con el régimen aplicable a los contratos celebrados a través de Internet, la Directiva sólo contiene algunas reglas fragmentarias sobre la admisibilidad de los contratos celebrados por medios electrónicos, deberes de información y órdenes de encargo. La conexión «ley del país del establecimiento del prestador del servicio» no es adecuada a estas reglas.

Tampoco se encuentra en la Directiva un régimen aplicable a la responsabilidad extracontractual, sino, tan solamente, algunas reglas fragmentarias sobre la responsabilidad de los prestadores intermediarios de servicios. Es previsible que las normas que transpongan la Directiva al ordenamiento jurídico de un Estado miembro, sobre la responsabilidad de los prestadores intermediarios de servicios establecidos en su territorio, se superpongan a la ley competente ${ }^{103}$.

Finalmente, la Directiva contiene algunas disposiciones específicas sobre las normas de protección de consumidores ${ }^{104}$.

El n. ${ }^{\circ} 3$ del art. 1 determina que la Directiva no perjudica el nivel de protección de los intereses de los consumidores, «tal como consta en los actos

${ }^{99}$ Como sugiere Wilderspin/Lewis (n. 95), 302 y ss., y MArques dos SAntos (n. 47), 211 y ss., invocando, a este respecto, el «principio de reconocimiento mutuo». Ver también Sonnenberger (n. 62), 126 y ss., y MünchKomm./Martiny (n. 1) Art. 34 Anh. III n. 25 y ss., 36 y 39.

${ }^{100}$ En la versión portuguesa se lee que lo «dispuesto en la legislación aplicable a raíz de las normas de conflicto del Derecho Internacional Privado no restringe la libertad de prestar servicios» (s.n.), pero se trata claramente de un lapsus de traducción.

${ }^{101}$ Ver Lima Pinheiro (n. 87), 95 y ss.

102 Ver también Fallon/Meeusen (n. 58), 489 y ss.

${ }^{103}$ En este sentido, Lima Pinheiro (n. 3), 834.

104 Ver también Dias Pereira (n. 89), 102 y ss. 
comunitarios y en la legislación nacional de aplicación de éstos, en la medida en que no restrinjan la libertad de prestación de servicios de la sociedad de la información». Como ya se señaló, el n. ${ }^{\circ} 3$ del art. 3 determina la no aplicación de los núms. 1 y 2 a «las obligaciones contractuales relativas a los contratos celebrados por los consumidores». Esta exclusión, aunque de dudosa utilidad ante lo dispuesto en el art. 1.4, deja claro que la Directiva no perjudica la aplicación de las normas jurídico-privadas de protección de los consumidores, independientemente de que se traten o no de normas de aplicación de actos comunitarios.

El legislador comunitario vuelve a referirse a las «medidas de defensa de los consumidores» en el n. ${ }^{\circ} 4 \mathrm{del}$ art. 3 , admitiendo que un Estado miembro adopte medidas que en derogación del $n .^{\circ} 2$ restrinjan la libre circulación de servicios, desde que, habiendo solicitado al Estado miembro en que el prestador del servicio está establecido su adopción, éste no haya tomado medidas adecuadas, después de la notificación a este Estado miembro y a la Comisión. Las medidas deben ser proporcionales al objetivo de defensa de los consumidores (art. 3.4.a.III). Como el n. ${ }^{\circ} 2$ no se aplica a las normas jurídico-privadas de protección de los consumidores, el n ${ }^{\circ} 4$ sólo puede tener en cuenta el Derecho público de protección del consumidor. Esta disposición muestra que el principio del país de origen se aplica al Derecho público de protección del consumidor que tenga incidencia en la libre prestación de servicios, pero con importantes limitaciones.

Las leyes de transposición de la Directiva dan cuenta de las dificultades encontradas por los Estados miembros en la conciliación de las disposiciones contradictorias en ella contenidas. Estas leyes, en concreto, no dan una respuesta clara e inequívoca a la cuestión de la relevancia del principio del país de origen para la determinación del Derecho aplicable a los contratos y a la responsabilidad extracontractual.

Ninguna de las leyes consultadas establece claramente la regla del país de origen para la determinación del Derecho aplicable al contrato. La ley alemana y española parecen desechar claramente esta solución, pero sin que su contenido sea suficientemente inequívoco para evitar dudas de interpretación.

En efecto, la ley alemana (Teledienstegesetz, de 1997, modificada en 2001), al mismo tiempo que establece que «los proveedores de servicios establecidos en Alemania y sus teleservicios están sujetos a los requisitos y a las exigencias del Derecho alemán» (art. 4.1), determina que «la ley no crea reglas en el campo del Derecho internacional privado...» (art. 2.6). La doctrina está mucho más dividida, aunque la mayoría de los autores más representativos niega que la ley se aparte de las reglas generales de Derecho Internacional Privado a favor de la ley del país de origen ${ }^{105}$.

${ }^{105}$ Cf., en concreto, Sonnenberger (n. 62), 126 y ss.; MünchKomm./Martiny (n. 1), Art. 34 Anh. III n. ${ }^{\circ}$ 37; Kropholler (n. 96), 465. Ver también la crítica de Thomas PfEIFFER, «Welches Recht gilt für elektronische Geschäfte?», JuS (4/2004) 282-285. Cp. en el sentido 
La ley española (Ley 34/2002, de 11 de julio), por su parte, determina su aplicación a los prestadores de servicios de la sociedad de la información establecidos en España y a los servicios por ellos prestados, así como la sujeción de estos prestadores a las demás disposiciones del ordenamiento jurídico español que les sean de aplicación, en función de la actividad que desempeñen (art. 2.1 y 4). Establece también que la determinación de la ley aplicable a los contratos electrónicos se hará sobre la base de las normas de Derecho internacional privado, «debiendo tomarse en consideración lo establecido en los artículos 2 y 3 de esta Ley» (art. 26). CALvo CARAVACA/ CARRACOSA GonZÁlez son de la opinión de que ni en la Directiva ni en la ley española de transposición de ésta se contienen normas de Derecho internacional privado ${ }^{106}$.

Las leyes francesa, italiana y de Reino Unido realizan una transposición más imperfecta en este punto, ya que no transponen el art. 1.4 de la Directiva. En todo caso, estas leyes admiten una interpretación ya en el sentido de que el principio del país de origen sólo vale para las normas de Derecho económico, ya en su extensión al Derecho privado de los contratos y de la responsabilidad extracontractual.

Así, la ley francesa (Loi pour la confiance dans l'économie numérique, de 2004) somete el comercio electrónico a la ley del Estado miembro en cuyo territorio esté establecida la persona que lo ejerce, «bajo reserva de la intención común de esta persona y de aquella a la que son destinados los bienes o servicios» (art. 17.1 en relación con el art. 14.1). La ley italiana (Decreto Legislativo italiano n. ${ }^{\circ} 70$, de 9 de abril de 2003) determina la aplicación de las disposiciones nacionales al ámbito coordinado y las normas de esta ley a los servicios suministrados por un prestador establecido en territorio italiano e incluye en el ámbito coordinado las «disposiciones que el prestador del servicio debe satisfacer» con respecto a los contratos y a la responsabilidad extracontractual (art. 3.1 en relación con el art. 2.1.h). La ley del Reino Unido (Electronic Commerce [EC Directive] Regulations 2002) establece que las «exigencias» (aparentemente establecidas por la ley del Reino Unido) que caen dentro del ámbito coordinado (o que incluye las «exigencias» en materia de contratos y de responsabilidad del prestador de servicios) son aplicables a los prestadores de servicios establecidos en el Reino Unido (art. 4.1 en relación con el art. 2.1.b).

de la irrelevancia del art. 2./VI TDG y, como tal, de la relevancia del principio del país de origen como regla de conflicto de Derecho internacional privado, Gerhard Kegel e Klaus SCHURIG, Internationales Privatrecht, 9. ${ }^{a}$ ed., Munique, 2004, 682, pero en sentido crítico en relación con la responsabilidad extracontractual; MANKOWSKI (n. 1), 258, sólo en relación con el Derecho de competencia y con algunas áreas de responsabilidad extracontractual.

${ }^{106}$ Derecho Internacional Privado, vol. II, 6. ${ }^{a}$ ed., Madrid, 2005, 541. 
Lo mismo se puede decir, entre nosotros, del DL n. $.^{\circ} 7 / 2004$, de 7 de enero, como procuré demostrar en un estudio anterior ${ }^{107}$.

En caso de duda, debe preferirse una interpretación conforme a la Directiva $\mathrm{y}$, por consiguiente, todas las leyes deben ser interpretadas, a la luz del art. 1.4 de la Directiva, en el sentido de no introducir ningún apartamiento respecto del Derecho conflictual general en materia de contratos y de responsabilidad extracontractual.

Por último, es necesario señalar que una interpretación de cualquiera de estas leyes en el sentido de consagrar el principio del país de origen en materia de ley aplicable a los contratos sería incompatible con el CR. Lo dispuesto en el Convenio prevalecería sobre las normas internas en cuanto fuente jerárquicamente superior. El art. $20 \mathrm{CR}$, que concede primacía a las disposiciones establecidas en las legislaciones nacionales armonizadas en ejecución de actos comunitarios, no sería aplicable, dado que se trataría de normas internas que van mas allá de lo establecido por la Directiva ${ }^{108}$.

Lo mismo hay que decir respecto de la Propuesta de Reglamento sobre ley aplicable a las obligaciones contractuales, ya que el Reglamento prevalecerá en el ordenamiento interno sobre las leyes ordinarias y que la Directiva sobre Comercio Electrónico no consta en la lista de los actos comunitarios que, por contener normas de conflicto sobre obligaciones contractuales, ven su aplicación reservada (art. 22.a y Anexo 1).

\section{Derecho conflictual del arbitraje transnacional}

\section{A) Aspectos generales}

Un estudio sobre el Derecho aplicable a los contratos celebrados a través de Internet no puede ignorar que los litigios que derivan de estos contratos son, en principio, arbitrables y que en el arbitraje transnacional en sentido estricto se aplican criterios especiales de determinación del Derecho aplicable al fondo de la controversia.

El arbitraje transnacional en sentido estricto -que la Ley 31/86, de 29 de agosto (Ley del Arbitraje voluntario, LAV) designa como «arbitraje internacional» (art. 32) - es el que pone en juego intereses del comercio internacional. Se trata del arbitraje que tiene por objeto controversias derivadas de las relaciones entre empresarios o entes equiparados que presentan contactos relevantes con más de un Estado soberano.

${ }^{107}$ Lima Pinheiro (n. 87), 107 y ss.

108 Ver también Wilderspin/Lewis (n. 95), 310 y ss., Lima Pinheiro (n. 87), 109 y MünchKomm./MARTiNY (n. 1), Art. 34 Anh. III n. 55 y ss. 
De ello resulta que existe un Derecho conflictual especial del arbitraje transnacional que se aplica a las relaciones entre «empresarios», mientras que al arbitraje transnacional que tiene por objeto relaciones con consumidores finales se aplica, en principio, el Derecho conflictual general ${ }^{109}$, estudiado en la Parte I.

Claro que los tribunales de arbitraje transnacional no están sometidos a un particular sistema nacional de Derecho Internacional Privado ${ }^{110}$, y, por consiguiente, cuando se ocupen de litigios derivados de contratos con consumidores, los árbitros deberán atender a los principios del Derecho conflictual comunes a los Estados que tienen un contacto relevante con el contrato. A falta de principios comunes, los árbitros deben aplicar el Derecho conflictual del Estado que presenta una conexión más significativa con el contrato.

En otro lugar ya realicé un estudio sistemático del arbitraje voluntario y, en concreto, de los presupuestos y requisitos de validez del acuerdo de arbitraje $^{111}$. De este estudio resulta que en los contratos celebrados a través de Internet es posible la inclusión de una cláusula compromisoria y que ésta puede acordarse a través de un clic en un icono o en un campo contenido en el sitio del proveedor que expresa la aceptación de una cláusula visible en la misma página, en una página superpuesta o en una página a la que remite un hipervínculo contenida en la página a que el adquirente accede para realizar la transacción ${ }^{112}$.

Hay, en todo caso, que tener en cuenta las exigencias generales hechas por el régimen de las cláusulas contractuales generales que fueran aplicables, y que han sido analizadas anteriormente en relación con la cláusula de elección del Derecho aplicable (I. A.). En las relaciones con consumidores, la inclusión de un acuerdo de arbitraje en un clausulado general del proveedor no es tan usual como la inclusión de una cláusula de designación del Derecho aplicable. De ahí que sea más fácilmente concebible que las cláusulas compromisorias pasen desapercibidas a los consumidores cuando no se llame su atención sobre estas cláusulas en las páginas a que necesariamente acceden para realizar la transacción. Esto puede tener como consecuencia la exclusión de la cláusula general compromisoria del contrato singular (art. 8 de la Ley de Cláusulas Contractuales Generales). Además de eso, la Directiva sobre cláusulas abusivas y la LCCG portuguesa contienen exigencias específicas con respecto a las cláusulas compromisorias.

${ }^{109}$ Cf. Isabel de Magalhães Collaço, «L'arbitrage international dans la récente loi portugaise sur l'arbitrage volontaire», in Droit international et droit communautaire, 55-66, Actes du colloque. Paris 5 et 6 avril 1990 (Fundação Calouste Gulbenkian, Centro Cultural Português), París, 1991, 60 in fine y ss.; Lima PinHeIro, Arbitragem Transnacional. A Determinação do Estatuto da Arbitragem, Almedina, Coimbra, 2005, 258.

${ }^{110}$ Ver Lima Pinheiro (n. 110), 29 y ss. y 234 y ss., con más referencias.

${ }^{111}$ Ver Lima Pinheiro (n. 110), 91 y ss. y 200 y ss.

112 Ver Lima Pinheiro (n. 110), 93 y ss. Ver también Moura Vicente (n. 5), 357 y ss. 
La $L C C G$ prohíbe, en las relaciones con consumidores finales, las cláusulas contractuales generales que «prevean modalidades de arbitraje que no aseguren las garantías de procedimiento establecidas en la ley» (art. 21.h en la redacción dada por el DL n. $\left.{ }^{\circ} 220 / 95\right)$. No es enteramente claro a qué arbitrajes se refiere el legislador. El anexo referido en el art. 3.3 de la Directiva sobre cláusulas abusivas, que el legislador portugués transpuso, se refiere a «una jurisdicción de arbitraje no comprendida por las disposiciones legales».

Parece razonablemente seguro que no se extrae de ello límites acerca de la arbitrabilidad en materia de litigios derivados de contratos de consumidores. Es igualmente cierto que del Reglamento comunitario relativo a la competencia judicial, al reconocimiento y a la ejecución de decisiones en materia civil y mercantil (Reglamento 44/2001, de 22 de diciembre de 2000) no se puede extraer ninguna consecuencia sobre la eficacia de los acuerdos de arbitraje celebrados con consumidores, ya que el arbitraje se encuentra genéricamente excluido del ámbito de aplicación de este Reglamento (art. 1.2.d $)^{113}$.

Pero además de eso, el art. 19.g del régimen de cláusulas contractuales generales prohíbe, en consonancia con el cuadro negocial estándar, las cláusulas contractuales generales que «establezcan un foro competente que suponga graves inconvenientes para una de las partes, sin que los intereses de la otra lo justifiquen». RAÚL VENTURA defiende la extensión de este precepto a los acuerdos de arbitraje ${ }^{114}$. Concuerdo con esta posición, aunque debo subrayar que sólo en situaciones verdaderamente excepcionales esto se pueda verificar.

En regla, un acuerdo de arbitraje estipulado, por los modos usuales, en un contrato celebrado en línea entre «empresarios» es válido y eficaz. Cabe ahora hacer una breve referencia a los criterios especiales de determinación del Derecho aplicable a estos contratos en el contexto del arbitraje transnacional.

\section{B) Litigios entre «empresarios»}

La determinación del Derecho aplicable al caso sometido a arbitraje de litigios entre «empresarios» se regula principalmente por las reglas y princi-

${ }^{113}$ Ver Lima Pinheiro (n. 24), 64 y ss., con más referencias. Cp. Moura Vicente, «Resolução extrajudicial de conflitos de consumo com carácter transfronteiriço», in Direito Internacional Privado. Ensaios, vol. I, 393-414, 2002, 396 y ss.; Id., «Resolução extrajudicial de conflitos no sector bancário», Revista da Banca 55 (2003), 57-84 (número distribuído em Junho de 2004), 67 y ss.

${ }^{114}$ Cf. Raúl ventURA, «Convenção de arbitragem e cláusulas gerais», ROA 46 (1986), 548, 44. Ver también Menezes Cordeiro (n. 14), 636. 
pios propios del Derecho Transnacional del Arbitraje ${ }^{115}$. Las soluciones consagradas por los principales sistemas nacionales interaccionan con estas reglas y principios autónomos y sólo pueden ser debidamente comprendidas a su luz.

Las soluciones de Derecho Transnacional del Arbitraje resultan principalmente de la práctica de los tribunales arbitrales, que dan cuerpo a ciertos principios que integran hoy la consciencia jurídica del medio arbitral, y de los reglamentos de centros institucionalizados de arbitraje, que emplean criterios de determinación de Derecho aplicable diferentes de los generalmente seguidos por los tribunales estatales y consagrados en los sistemas nacionales de Derecho conflictual.

Así, el principio de autonomía de la voluntad permite, en el marco de este Derecho Transnacional, que las partes remitan a cualquier Derecho estatal, al Derecho internacional público, a la lex mercatoria, a los «principios generales» $\mathrm{o}$ a la equidad ${ }^{116}$. En la práctica de los tribunales arbitrales es relativamente frecuente el recurso a los principios generales del Derecho, a «los principios comunes» a los sistemas nacionales, a los usos del comercio internacional y a modelos de regulación, tales como los Principios UNIDROIT de los contratos comerciales internacionales.

Esto quiere decir que un contrato celebrado a través de Internet entre «empresarios», y que incluya un acuerdo de arbitraje apropiado, puede ser sustraído por las partes a cualquier Derecho estatal. Ésta puede ser una solución conveniente cuando ninguna de las partes se quiera someter al Derecho de la otra, en especial cuando se haya hecho una referencia a un complejo normativo que regule sistemáticamente el contrato, como es el caso de los Principios UNIDROIT.

Claro que esto se refiere sólo al régimen aplicable al contrato y no excluye que los árbitros deban aplicar ciertas normas y principios fundamentales comunes a los Estados a título de orden público transnacional y deban atender a ciertas directrices estatales sobre la aplicación de normas imperativas emanadas de los Estados que tienen una conexión significativa con el arbitraje o que constituyan posibles foros de ejecución de la decisión arbitral ${ }^{117}$, así como a ciertas directrices supraestatales emanadas de organizaciones internacionales ${ }^{118}$.

115 Esta postura, ya por mí defendida en Contrato de Empreendimento Comum (Joint Venture) em Direito Internacional Privado, 1998, 630 y ss., fue acogida por la STJ de 11/10/2005, proc. 05A2507 [in <http://www.dgsi.pt/jstj.nsf>]. Ver, con más detenimiento, Lima Pinheiro (n. 110), 234 y ss.

${ }^{116}$ Cf. el art. 17.\%/3 del Reglamento del Arbitraje CCI; el art. 28.\% del Reglamento de Arbitraje Internacional AAA; y el art. 22.\%/3 del Reglamento LCIA que permiten la elección de «reglas de Derecho». Esta orientación, ya por mí defendida en Contrato de Empreendimento Comum... (n. 116), 1020 y ss., fue seguida por la STJ de 11/10/2005.

117 Ver Lima Pinheiro (n. 110), 263 y ss. y 535 y ss.

118 Ver Lima Pinheiro (n. 110), 571 y ss. 
A falta de elección por las partes, no hay reglas claramente establecidas sobre la determinación del Derecho aplicable. La tendencia más significativa que se ha manifestado en la jurisprudencia arbitral y en los reglamentos de centros de arbitraje adopta el criterio de las reglas de Derecho más apropiadas al litigio ${ }^{119}$.

El criterio de las reglas del Derecho más apropiadas al litigio es un criterio muy flexible, que permite a los árbitros tener en cuenta el conjunto de circunstancias del caso concreto y atender a todos los puntos de vista jurídicamente relevantes. La idea de apropiación permite una ponderación de intereses y una consideración de contenido específico de las cuestiones jurídicas a resolver ${ }^{120}$.

En la determinación del Derecho aplicable los árbitros deben atender a los lazos que la relación controvertida establezca con los diferentes países. Pero también puede tener en consideración el contenido material de los respectivos Derechos. Las reglas de Derecho más apropiadas pueden ser tanto estatales como extraestatales. Los árbitros deben atender a la costumbre y a los usos del comercio internacional, así como a eventuales reglas formuladas por organizaciones sectoriales para regular las relaciones económicas entre sus miembros y, subsidiariamente, pueden recurrir a los principios generales del Derecho y a los «principios comunes» de los sistemas en presencia.

Así, en la elección de las reglas más apropiadas a un litigio derivado de un contrato celebrado a través de Internet, los árbitros podrán aplicar las reglas que según una evaluación objetiva sean más ajustadas al comercio electrónico, en concreto el régimen de comercio electrónico más moderno y equilibrado que esté en vigor en uno de los países en contacto con el contrato. Pero los árbitros podrán igualmente aplicar reglas extraestatales, en concreto hacer una referencia directa a las normas de las Convenciones internacionales o a los usos y costumbres del comercio electrónico.

En la determinación del Derecho aplicable, los tribunales arbitrales no pueden regirse sólo por reglas y principios autónomos. Deben tener en cuenta las directrices sobre la determinación del Derecho aplicable emanadas de los Estados que presentan lazos especialmente significativos con el arbitraje

${ }^{119}$ Así, el Reglamento de Arbitraje CCI establece que el árbitro aplicará las reglas de Derecho que considere apropiadas (art. 17.\%1); el Reglamento de Arbitraje Internacional AAA determina que el tribunal arbitral aplicará la(s) ley(s) o las reglas de Derecho que juzgue apropiadas (art. 28.\%1) y el Reglamento de Arbitraje OMPI contiene un precepto idéntico (art. 59.\%); el Reglamento LCIA manda aplicar la(s) ley(s) o reglas de Derecho que considere adecuadas (art. 22.\%/3); en fin, el Reglamento de Arbitraje CAC determina la aplicación del Derecho más apropiado al litigio.

${ }^{120}$ IsABel De Magalhães Collaço (n. 110), 64 y ss., cita, en este contexto, al art. 27.\%/2 del Regulamento CAC ( «A falta de elección, los árbitros aplicarán el derecho más apropiado al litigio, teniendo en cuenta en concreto la localización de los intereses en juego y la naturaleza espífica de las cuestiones jurídicas a resolver»). 
o del Estado en que previsiblemente la decisión, en caso de necesidad, deba ser ejecutada ${ }^{121}$.

La gran mayoría de las legislaciones recientes sigue una vía de encuadramiento del arbitraje transnacional, adoptando regímenes especiales de Derecho conflictual que revelan una gran apertura a las soluciones adoptadas por la jurisprudencia arbitral y por los reglamentos de los centros de arbitraje ${ }^{122}$.

El Derecho portugués comparte esta tendencia, ya que dispone de un régimen especial de determinación del Derecho aplicable al arbitraje internacional (art. $33 \mathrm{LAV}$ ), entendido como aquel que, teniendo lugar en territorio portugués (art. 37. ${ }^{\circ}$ ), «pone en juego intereses del comercio internacional» (art. 32) (supra A).

El Derecho portugués permite, sin restricción, la elección por las partes del Derecho aplicable (art. 33.1 LAV) ${ }^{123}$. Esto sirve plenamente para la elección de un Derecho estatal, Derecho internacional público o de una particular Convención internacional de Derecho material unificado. En todos estos casos la elección recae sobre Derecho objetivo.

En lo que respecta a la elección de la lex mercatoria la cuestión a resolver es si el Derecho portugués vigente — en lo que se refiere a la elección de un «Derecho»- no debe ser interpretado en un sentido más restrictivo que el Derecho Transnacional de Arbitraje.

Así, hácese valer que las partes podrán remitir a las reglas y principios jurídicos de la lex mercatoria que efectivamente estén en vigor. Pero no se podrá aceptar que sirva como designación de un Derecho, en el sentido del art. $33 \mathrm{LAV}$, una elección de la lex Mercatoria que no se traduzca más que, ante la naturaleza de la relación controvertida y las características del sector del comercio internacional en cuestión, en el recurso a los principios autónomamente considerados o a los modelos de regulación ${ }^{124}$.

${ }^{121}$ Ver Lima Pinheiro (n. 110), 535 y ss. y 609 y ss.

${ }^{122}$ Es lo que se verifica con lo dispuesto en los arts. $1492 .^{\circ}$ y ss. NCPC fr.; en el art. $33 .^{\circ}$ LAV; en los arts. $176 .^{\circ}$ y ss. de la Ley federal suiza de Derecho Internacional Privado; en el art. 1054..$^{\circ}$ del CPC holandés; en los arts. $832 .^{\circ}$ y ss. CPC it. (en la redacción dada en 1994); en el art. 46..$^{\circ}$ de la Ley «inglesa» de arbitraje de 1996; en el art. 2..$^{\circ}$ de la Ley brasileña de arbitraje y en el art. 1051..$^{\circ} \mathrm{ZPO}$ en la redacción dada por la Ley alemana de 22/12/97. Recuérdese que cerca de 45 jurisdicciones han adoptado leyes de arbitraje inspiradas en la Ley Modelo de la CNUDCI sobre Arbitraje comercial internacional, incluyendo Alemania, Australia, Canadá, Escocia, algunos Estados de Estados Unidos (California, Connecticut, Illinois, Oregon y Texas), Federación Rusa, Grecia, Hong-Kong, India, Irlanda, Macao y Japón; cf. <http://www.uncitral.org/en-index.htm>.

${ }^{123}$ Cf. RLx 24/1/1995 (CJ [1995-I] 98).

${ }^{124}$ Cf. Isabel de Magalhães Collaço [loc. cit.]. En el mismo sentido, Lima Pinheiro (n. 116), 1034 y ss. En sentido próximo, Maria Helena BRITo, Direito do Comércio Internacional (Relatório), Coimbra, 2004, 123, entendiendo, sin embargo, que la elección de la lex mercatoria, por ser necesariamente una elección parcial, no elimina la necesidad de determinar el ordenamiento jurídico competente. En el sentido de la limitación de la elección de un Derecho estatal, se pronuncia Moura ViCEnTE (n. 5), 97 y ss. y 369. 
Sin embargo, si los árbitros, con base en la designación hecha por las partes, resolvieran el caso según los principios y modelos de regulación, no parece que haya fundamento para la anulación de la decisión ${ }^{125}$.

A falta de elección, el art. 33.2 LAV remite al Derecho más apropiado al litigio. La interpretación de este precepto debe hacerse en el contexto propio del arbitraje transnacional y atendiendo al significado que, en ese contexto, puede atribuirse a la expresión «Derecho más apropiado al litigio» y a expresiones similares.

En primer lugar, estas expresiones dejan claro que el tribunal arbitral puede proceder a la elección del Derecho aplicable por voie directe, es decir, sin tener que basarse en ningún sistema positivo de Derecho conflictual ${ }^{126}$. El recurso a un particular sistema de Derecho conflictual, la aplicación simultánea de las normas de conflicto de todos los sistemas que tienen una conexión significativa con el arbitraje o a los «principios conflictuales generales» es meramente facultativo.

En segundo lugar, la remisión al Derecho más apropiado al litigio es una cláusula general de remisión que deja al tribunal arbitral un vasto margen de apreciación. El tribunal arbitral puede atender a cualquier elemento que considere relevante para establecer la remisión. A diferencia de lo que ocurre con una cláusula general de conexión más estrecha, el órgano de aplicación no está vinculado a otorgar mayor importancia a los lazos objetivos de «localización», ni ha de apartar la posibilidad de que la elección del Derecho aplicable sea hecha en función de su adecuación material al caso, en los términos que atrás fueron expuestos.

Ante el sistema portugués, las reglas objetivas de la lex mercatoria pueden ser aplicadas como Derecho más apropiado al litigio. También parece admisible la aplicación de las reglas de Derecho Internacional Público general o convencional. Los árbitros ya no pueden decidir exclusivamente con base en los principios generales del Derecho, «principios comunes» a los sistemas nacionales aisladamente considerados, o modelos de regulación (como los Principios UNIDROIT), pues están obligados a juzgar según el Derecho constituido, a menos que las partes lo autoricen a juzgar según la equidad (art. 22 LAV).

125 Ver Lima Pinheiro (n. 110), 166 y ss. y 268 y ss.

${ }^{126}$ Cf. Isabel de Magalhães Collaço (n. 110), 64. Ver también la Exposición de Motivos de la propuesta de Ley no $34 /$ IV [supracit.], n. ${ }^{\circ}$ 7. Cp. FERrer CorreIA, «O Direito Aplicável pelo Árbitro Internacional ao Fundo da Causa», BFDC 77 (2001) 1-11, 9 y ss., que defiende, aparentemente de iure constituto, que los árbitros deben aplicar la norma de conflicto de la ley que tenga una conexión más estrecha con el caso; Moura ViCENTE, Da arbitragem comercial internacional. Direito aplicável ao mérito da causa, Coimbra, 1990, 240 y ss.; Id. (n. 5), 369 y ss. 
En consecuencia, a falta de regla extraestatal aplicable al caso, los árbitros, si no estuvieren autorizados a juzgar según la equidad, deben recurrir al Derecho estatal o supraestatal.

Aunque el Derecho designado por las partes o, en su omisión, escogido por los árbitros, sea un Derecho estatal, constituye regla consagrada por la unificación internacional del Derecho del Arbitraje transnacional, por las normativas de centros de arbitraje y por la jurisprudencia arbitral que el tribunal arbitral, en materia contractual, deberá siempre tomar en consideración las disposiciones del contrato y los usos del comercio ${ }^{127}$. Quiere esto decir que los usos del comercio y, en concreto, aquellos que se hayan formado en el comercio electrónico, se consideran incorporados en los contratos celebrados a través de Internet, independientemente de la estipulación de las partes y de la relevancia que les atribuya la lex contractus, pero teniendo como límite sus normas imperativas.

${ }^{127}$ Ver, más extensamente, Lima Pinheiro (n. 1), 217 y ss. 


\section{NOTAS \\ Y JURISPRUDENCIA}




\section{๑) Universidad de Deusto - ISSN 0423-4847}




\title{
Recorrido por la jurisprudencia sobre los denominados «Alardes»: una fiesta plagada de conflictos
}

\author{
María Burzaco Samper \\ Profesora de Derecho Administrativo \\ Universidad Pontificia Comillas
}

Resumen: La celebración en diversas localidades vascas de los denominados «Alardes» ha sido fuente de constantes conflictos judiciales desde los años noventa. Sin negar la dimensión sociológica que tales controversias presentan, debe reconocerse que, desde una perspectiva estrictamente jurídica, los procesos judiciales han dado lugar a una jurisprudencia de indudable interés que, por otro lado, ha venido marcada por una evolución significativa en su fundamentación. Este trabajo se ocupa de realizar ese recorrido desde las primeras sentencias, centradas en la vulneración del principio de igualdad, hasta la línea trazada por la STS de 2 de junio de 2003 que, en cuanto consideró el Alarde como manifestación del derecho de reunión, marcó un punto de inflexión en la resolución de estos conflictos recurrentes.

Palabras clave: derecho de reunión, espectáculos públicos, principio de igualdad, participación democrática, proceso contencioso-administrativo.

Abstract: The celebration of the so called «Alardes» in diverse Basque localities has been the starting point of constant judicial conflicts since the 90's. Without denying the sociological dimension of such controversies, it must be recognized that, from a strictly legal perspective, the judicial processes have motivated a jurisprudence of doubtless interest that, on the other hand, manifests a significant evolution on its basis. This work covers all this progression from the very first sentences, which somehow put at risk the equality principle, to the new stage marked by the STS of the $2^{\text {nd }}$ of June of 2003 which, as far as it considered the Alarde as a manifestation of the meeting right, marked a point of inflexion in the resolution of these recurrent conflicts.

Key words: meeting right, public spectacles, principle of equality, democratic participation, contentious-administrative process.

Sumario: I. Apuntes Preliminares. - II. Las primeras Sentencias: Alarde y Principio de igualdad. A) Las distintas concepciones sobre el Alarde: Alarde Tradicional frente a Alarde Igualitario; B) La posición de las Corporaciones Locales en la celebración de los Alardes: variaciones y estrategias; C) Mención específica a ciertas cuestiones procesales. III. El Alarde como ejercicio del Derecho de reunión. A) Los hechos que dieron lugar a un nuevo recurso contencioso-administrativo; B) Naturaleza del Alarde; C) Sobre el objeto del proceso; D) La postura discrepante del Tribunal Supremo; 1. Alarde y Derecho de reunión; 2. En cuanto a la 
actuación policial; E) Síntesis de la doctrina del Tribunal Constitucional sobre el Derecho de reunión; F) Nuestra crítica a la STS de 2 de junio de 2003. - IV. La respuesta judicial al último conflicto: Sentencia del tribunal Superior de Justicia del País Vasco de 21 de junio de 2005. A) Objeto del proceso; B) Legitimación activa y art. 122.1 LJCA; C) Los argumentos de la Asociación recurrente y la respuesta judicial a éstos. V. Consideraciones Finales.

\section{Apuntes preliminares}

Los conflictos suscitados en torno al «Alarde tradicional» (en adelante, AT) y al «Alarde igualitario» (en adelante, AI) se han convertido en una cuestión de puntual aparición en la agenda judicial desde los años noventa.

Independientemente del alcance que desde los medios informativos se ha dado a las controversias y disputas entre los grupos implicados, lo cierto es que en el plano jurídico han originado un buen número de resoluciones judiciales en las que se evidencia que estamos ante un problema jurídicamente complejo que entremezcla extremos de muy diversa índole. Por otro lado, la propia actitud que, tras las primeras Sentencias, adoptaron tanto las instituciones públicas - Corporaciones municipales de las localidades vascas de Hondarribia e Irún-, como los promotores de los distintos Alardes ha coadyuvado a alterar el signo de tales conflictos dando pie a una jurisprudencia de indudable interés.

Con carácter previo debe explicarse que el Alarde constituye una manifestación popular de tipo festivo que posee, además, una nota de conmemoración de ciertos acontecimientos históricos ${ }^{1}$ en el que residen aspectos de distinto carácter: festivos, cívicos, sociales y religiosos. Esta circunstancia ha planteado, paralelamente, una dificultad de primer orden en cuanto a la naturaleza del propio acto y el régimen jurídico al que está sometido. Un extremo de consecuencias relevantes en lo atinente no sólo a la normativa aplicable, sino también a los aspectos y cauces procesales a través de los que los referidos conflictos debían canalizarse.

De todo ello es buena prueba el análisis de la ya prolija jurisprudencia en torno a esta figura, cuestión que centra este estudio.

${ }^{1}$ Las disputas se han producido en dos localidades vascas, Hondarribia e Irún, en las que se conmemoran sendos hechos de armas. Concretamente en la primera de ellas, los acaecidos el 7 de septiembre de 1638 para el levantamiento del sitio a que les sometieron las tropas francesas. Por su parte, en Irún, se rememora la batalla de Peña de Aldabe, ganada por las milicias forales en 1552. 


\section{Las primeras Sentencias: Alarde y Principio de igualdad}

\section{A) Las distintas Concepciones sobre el Alarde: Alarde Tradicional frente a Alarde Igualitario}

Los conflictos sobre los Alardes tienen su origen en el distinto entendimiento que los ha inspirado: los promotores del AT esgrimen un supuesto purismo que se materializaría en la escenificación fiel de los hechos históricos conmemorados y que explicaría una neta distinción en el protagonismo asignado a hombres y mujeres, generalmente con la postergación de éstas a un papel secundario. Por el contrario, el llamado AI posee un carácter reivindicativo por el que se propugna la participación indistinta de hombres y mujeres en cualesquiera de los roles que tienen entrada en el Alarde.

Partiendo de esta diversidad de concepciones, los primeros procesos judiciales tuvieron su origen en resoluciones municipales denegatorias de peticiones de participación en régimen de igualdad en los Alardes correspondientes. Ha de tenerse en cuenta que en aquel momento los respectivos Ayuntamientos eran los organizadores de tales eventos que, además, contaban con Ordenanzas que vinculaban a sus órganos (más específicamente al Alcalde) a la Junta del Alarde y lo regulaban en diversos aspectos. Planteados los pertinentes recursos contencioso-administrativos contra las denegaciones de participación igualitaria, las sentencias que los resolvieron entendieron que la actuación municipal incurría en vulneración del principio de igualdad constitucionalmente reconocido (art. $14 \mathrm{CE}$ ), con base en los siguientes fundamentos:

Es un hecho irrefutable que el grado de participación de hombres y mujeres en los actos de los Alardes no es en modo alguno equiparable. Sin embargo, esta circunstancia por sí sola no contraviene el principio de igualdad. Dilucidar esta cuestión nuclear pasaba por perfilar la naturaleza del Alarde y los derechos o intereses que afectaban a los interesados. Los partidarios del AT defendían que esta celebración consiste en una mera reproducción y puesta en escena de los correspondientes acontecimientos que se conmemoran, de suerte que el distinto papel desempeñado por hombres y mujeres no es sino el reflejo fiel del suceso histórico.

Este argumento se rechaza con base tanto en argumentos históricos ${ }^{2}$ como en la propia dicción literal del término rememorar que, conforme

${ }^{2}$ En relación con el Alarde de San Marcial de Irún, la STSJPV de 17 de enero de 1998 en sus FJ $6 .^{\circ}$ y $7 .^{\circ}$ hace un extenso análisis de los hechos históricos que aquél conmemora y que fueron objeto de una también amplia prueba pericial, concluyendo que el Alarde posee «caracteres rememorativos seguramente ciertos», aunque presenta igualmente «una significación social, festiva y participativa insoslayable». STSJPV (Sala de lo Contencioso-Administrativo; Sección 1.a) núm. 16/1998, de 17 de enero de 1998; recurso núm. 774/1997. Referencia El Derecho Editores (en adelante, EDE) 1998/24109. 
determina la STS de 19 de septiembre de $2002^{3}$, «alude al simple recuerdo de un hecho pasado, cualquiera que sea la manera elegida para su evocación» y que, en suma, «puede efectuarse mediante una escenificación o también a través de actuaciones de naturaleza diferente, como puede ser una celebración festiva en la que intervengan los actuales miembros del pueblo o la colectividad a que se refiere el hecho histórico» (FJ 4. ${ }^{\circ}, a$ y $b$ ).

Esta misma sentencia resalta que "podría resultar comprensible una exclusión femenina, si el único propósito es ofrecer en la actualidad una imagen plástica del suceso histórico que reproduzca con total exactitud cuál fue su realidad material». «Sin embargo, en las celebraciones festivas de carácter popular, cuando son organizadas en el marco de actividades de una Administración Pública y con sujeción a la regulación reglamentaria que por ella haya sido establecida, la exclusión femenina resulta injustificada, pues equivaldría a admitir que en razón del sexo se pueden establecer diferentes grados de participación ciudadana en esa clase de acontecimientos. El riguroso canon de legitimidad que ha de ser aplicado a las diferenciaciones por razón de sexo, aplicado al presente caso, significa que la exclusión de mujeres en el Alarde de San Marcial, para ser considerada justificada, exigiría inexcusablemente que el Alarde (...) fuera sólo una representación histórica, y que estuviera acreditado que la costumbre de su celebración reflejó en todo momento el inequívoco propósito popular de escenificar con absoluta fidelidad el acontecimiento que se quiere recordar» (FJ $4 .^{\circ}, c, d$ y $\left.e\right]$

A estos argumentos cabe añadir el contenido en el FJ 5..$^{\circ}$ de la STS de 13 de septiembre de $2002^{4}$ donde, de manera contundente, se afirma:

«...corresponde a dicha Administración, como Poder Público, promover las condiciones que hagan real la igualdad, remover los obstáculos que la impidan o dificulten, y facilitar la participación de todos los ciudadanos en la vida política, económica, cultural y social, a tenor de los arts. 1.1 y 9.2 de la Constitución, de modo que, sea cual sea la naturaleza del evento, ostenta éste, sin duda, una dimensión popular que se desarrolla en el municipio, sin que las instituciones públicas de éste puedan inhibirse como si de algo absolutamente ajeno se tratara o como si de desarrollara poco menos que en la estratosfera, lo que bien puede quedar reforzado cuando derechos fundamentales y principios o valores superiores andan en juego (...)».

${ }^{3}$ STS (Sala 3. a.; Sección 7. a), de 19 de septiembre de 2002; recurso núm. 2241/1998. EDE $2002 / 39444$.

${ }^{4}$ STS (Sala 3. a; Sección 7. a) de 13 de septiembre de 2002; recurso núm. 2239/1998. EDE $2002 / 35060$. 
B) La posición de las Corporaciones Locales en la celebración de los Alardes: variaciones y estrategias

Hemos indicado con anterioridad que las controversias se suscitaron inicialmente en momentos en los que las Corporaciones municipales tenían una posición activa en la celebración de los correspondientes Alardes desde un doble plano: por una parte, como organizadores de los actos festivos que, en mayor o menor proporción, eran también sufragados con fondos públicos; $y$, por otro lado, mediante el ejercicio de su potestad reglamentaria dictando, a través de Ordenanzas, normas reguladoras de diversos aspectos concernientes al propio Alarde.

En ese sentido, hubo algunos intentos de desmarcar las controversias de la actuación municipal que, sistemáticamente, fracasaron en la instancia judicial. Especialmente significativo es el caso resuelto por STSPV de 17 de enero de 1998, en el que la Alcaldía de Irún alega la inadmisibilidad del recurso aduciendo que el Ayuntamiento se ciñó a comunicar un acto de la Junta del Alarde, argumento que mereció la siguiente respuesta:

«(...) el Alcalde de Irún preside la Junta del Alarde, mas con carácter fundamental es el órgano unipersonal que preside, dirige el gobierno y la administración municipal y representa a la Corporación Local que ordena el Alarde por medio del ejercicio de competencias normativas y de ejecución amplísimas - artículo 21.1 Ley de Bases de Régimen Local 7/1985, de 2 de abril-. Desde ambas perspectivas las atribuciones que le adornan resultan de la máxima relevancia a la hora de posibilitar la intervención de personas o grupos en el acto público conmemorativo de que se trata y de sintetizar la posición del poder público local al respecto, y ante la solicitud de las administradas podía haber adoptado distintas opciones, ninguna de las cuales tachables de incompetencia o abuso de sus facultades, capacidades y atribuciones. Podrá decirse acaso que, por su sola autoridad no estaba facultada la Alcaldía para derogar preceptos de una Ordenanza hipotéticamente opuestos a la pretensión, ni para interpretar y aplicar sin preceptivas consultas la misma de manera satisfactoria para el ejercicio del derecho. Pero ese mismo fenómeno se concita con carácter muy frecuente respecto de la actividad normal de ejecución y aplicación de las disposiciones de carácter reglamentario por parte de cuantos órganos de la Administración están llamados a hacerlo, y no por ello se puede desconocer la afección de sus resoluciones denegatorias a los mencionados derechos fundamentales.

De otra parte, el esquema de organización competencial de la Administración local lleva a que órganos inferiores o distintos al Pleno o al Alcalde sólo pongan fin con sus actos a la vía administrativa cuando actúan por delegación o lo establezca una disposición legal, —artículo 52 Ley de Bases de Régimen Local de 2 de abril de 1985-, y no consta así que la Junta del Alarde cuente con atribuciones activas o directamente ejecutivas ni que pueda poner fin a la vía administrativa (por más que se le atribuya una facultad de revisión o examen de decisiones y de solventar 
dudas que lo es, por hipótesis respecto de la interpretación y aplicación que hacen otros órganos), mientras que materias con un sentido análogo, como la formación de nuevas compañías, quedan a la aprobación del Ayuntamiento, que resuelve "a la vista del informe que al respecto emita la Junta Municipal del Alarde» —artículo 15-. De ahí deducimos que ningún otro órgano municipal distinto de la Alcaldía o del Pleno podría haber sido estrictamente competente para dictar un pronunciamiento último sobre la cuestión sometida a debate, y no es preciso extenderse demasiado sobre la amplitud competencial de los Alcaldes, tanto por enunciación expresa como por la cláusula de cierre del artículo 21.m LBRL, STS de 10 de noviembre de 1992 o de 27 de febrero de 1997.

Lo que singulariza entonces la afección del ejercicio del derecho fundamental invocado por parte de la Resolución o acto recurrido en este proceso, que requiere el citado artículo $6 \mathrm{LPJDF}$, es que «a limine» y sin siquiera otros trámites, iniciativas, razonamientos o exposición de obstáculos procedimentales que pudieran embargar su actuación, la Alcaldía, tomando y asumiendo implícitamente el contenido de una previa interpretación de la Ordenanza respecto de la exclusiva participación de los varones, responde de manera tal que el ejercicio del derecho fundamental queda frustrado o rechazado, en lo que es un acto de aplicación implícita pero concluyente y eficaz del criterio, normativo o interpretativo, contrario a la participación de las mujeres en dicha manifestación popular. Y esa resulta ser la voluntad de la Administración demandada, manifestada a través de quien la dirige y ejerce representación de la misma, que se combate en el presente recurso» (FJ 3. ${ }^{\circ}$ ).

Las resoluciones judiciales a las que hemos hecho referencia, determinaron un «cambio de estrategia» a partir del cual las Corporaciones municipales pasaron a ocupar un segundo plano en la celebración de los Alardes, limitándose al ejercicio de la potestad autorizatoria contemplada en la normativa sectorial sobre espectáculos públicos. Así las cosas, y no siendo ya el Ayuntamiento correspondiente el dinamizador de los mismos sino fundaciones y asociaciones de naturaleza estrictamente privada, las eventuales solicitudes de participación igualitaria perdieron su original sentido.

Los conflictos continuaron con puntual periodicidad, pero su construcción jurídica difería necesariamente de la mantenida en los primeros tiempos, variando asimismo el objeto de los procesos judiciales. Este hecho queda subrayado en la STSJPV de 7 de octubre de $1999^{5}$ en la que, ante la alegación de inadmisibilidad por litispendencia ${ }^{6}$, el órgano jurisdiccional recuerda que en el caso aludido, la pretensión se centraba en «el reconoci-

${ }^{5}$ STSJPV (Sala de lo Contencioso-Administrativo; Sección 1. ${ }^{\text {a }}$ ) núm. 739/1999, de 7 de octubre de 1999; recurso núm. 4434/1998. EDE 1999/33704.

${ }^{6}$ Ésta se producía en relación con el recurso de casación contra STSJPV de 16 de enero de 1998, finalmente resuelto por la STS de 13 de septiembre de 2002, ambas comentadas en el epígrafe anterior. 
miento de la una situación jurídica relativa a la participación igualitaria de varones y mujeres en el Alarde», mientras que en el supuesto al que se enfrentan «la razón petitoria del recurso se refiere a obligaciones de las Entidades Locales respecto de la organización de tal acontecimiento (...), y subsidiariamente, a la autorización de su celebración con arreglo a las previsiones de la Ley vasca reguladora de los espectáculos públicos, y puede afirmarse que ni desde el primero de los prismas existe una coincidencia de objetos entre ambos procesos ni la causa de pedir es la misma» (FJ 2.. ${ }^{7}$. Como puede advertirse, estamos ante un tipo de pretensión muy distinta a la de los primeros recursos: aquí, las recurrentes elevan una petición al Ayuntamiento (concretamente al de Hondarribia) para que éste organizara el Alarde o, subsidiariamente, autorizase su organización a la Asociación actora. Denegada la solicitud, se formula recurso ante la Sala que realiza una interesante precisión señalando que cabe hablar de «organización» de los Alardes en un doble sentido (FJ 3. ${ }^{\circ}$ ):

a) Como «entramado de festividades patronales (...) que, con muy alta probabilidad, son aprobadas, programadas y, total o parcialmente, financiadas desde el ámbito municipal». Desde esta perspectiva, el Alarde es público y por tanto, las actividades desarrolladas en torno a él, no quedan sometidas a previa intervención administrativa autorizatoria. «Ahora bien, el carácter implícito de esa autorización no podrá excluir, sino que presupondrá en todo caso, el sometimiento del acto a los estándares de seguridad y «minimun» ético-jurídico que se especifican en el artículo 18 de dicho texto legal [refiriéndose a la legislación autonómica sectorial de espectáculos públicos], y que comprenden la exclusión de toda conculcación de los derechos fundamentales de las personas». Dicho carácter público impregna todo lo que tenga que ver con el Alarde que, por lo demás, y con base en determinadas Ordenanzas, se vincula a la Administración municipal tanto en el pla-

\footnotetext{
${ }^{7}$ Este mismo FJ 2. ${ }^{\circ}$ prosigue diciendo: «Presupuesto que lo que delimita objetivamente la pretensión ejercitada no son los motivos impugnatorios o alegatorios empleados por la parte, sino el fundamento de lo que se pide, que se identifica, al menos en una pretensión de reconocimiento de situación jurídica individualizada, con la razón jurídica especifica en que se funda y que se sintetiza en la cuestión suscitada por el recurso, en uno y otro proceso es diverso no sólo el pedimento y objeto procesal de que se reconozca una situación jurídica individualizada en un caso y se asuma una obligación legal en otro por vía de petición, o se autorice el ejercicio de un derecho, sino también (...), el fundamento de significación jurídica de que la pretensión recibe su causa y del que deriva el postulado de congruencia de que el órgano jurisdiccional haya de pronunciarse, "sobre la misma causa que se alegó para deducir las pretensiones”. - SSTS de 5 de octubre de 1995, o 26 de julio de 1996-. Así, la causa de pedir, que es un elemento de la pretensión, es ahora y entonces diferente, puesto que la razón objetiva de pretender es, o bien el derecho a al igualdad, o bien, la posición de la Entidad Local en el entramado legal acerca de los bienes culturales o, en origen, el derecho de la parte actora a ser autorizada para la celebración de un espectáculo público».
} 
no funcional (mediante el otorgamiento de facultades decisorias al Ayuntamiento que se erige así en fiscalizador de las actividades organizativas), como en el orgánico (incorporando la Alcaldía a la Junta del Alarde). Es precisamente «esa vinculación especial con un Poder público democrático y sometido a la Constitución y las leyes, lo que determina el contenido de esa fiscalización y su orientación hacia la aplicación del postulado fundamental que obliga a aquel a promover condiciones de igualdad y, "a facilitar la participación de todos los ciudadanos en la vida política, económica, cultural y social" —artículo $9.2 \mathrm{CE}$ - , como vinculación decisivamente más fuerte que aquella otra que la Administración demandada esgrime acerca de la salvaguarda de sus formas y signos tradicionales, por importantes que éstos resulten».

b) La organización puede entenderse también como asunción de todas las tareas de ejecución que el Alarde comporte (diseño de las compañías, selección de participantes, puesta en escena, regulación de indumentarias, actuaciones, etc.), lo cual, sin duda, no constituye una obligación municipal «ex lege». La Sala recuerda que el art. 25 LBRL describe ámbitos competenciales locales, siendo el art. 26 del mismo cuerpo legal el que contiene el listado de servicios de prestación obligatoria por parte de los Municipios (lo que implica, correlativamente, el derecho de los vecinos a exigir dicha prestación). De cualquier modo, ni de esta normativa general, ni de la sectorial en su caso aplicable $^{8}$, se colige la existencia de una obligación exigible al Municipio en cuanto a la organización directa del Alarde.

\section{C) Mención específica a ciertas cuestiones procesales}

Algunos de los recursos interpuestos evidenciaron las implicaciones procesales derivadas de la dificultad de perfilar la naturaleza jurídica de los Alardes.

La mayoría de los procesos mencionados se sustanciaron conforme a la antigua Ley 62/ 1978, de 26 de diciembre de Protección Jurisdiccional de los Derechos Fundamentales de la Persona ${ }^{9}$. Sin embargo, la desvinculación de las Corporaciones públicas respecto a estos eventos y el hecho de que, a la vista de los altercados de orden público producidos en varias convocatorias, los distintos promotores de éstos procedieran a comunicarlos a la autoridad

${ }^{8}$ Se alude específicamente a la Ley de Patrimonio Cultural Vasco (Ley 7/1990, de 3 de julio) que atribuye a los entes locales la «misión de realzar y dar a conocer el valor cultural de los bienes integrantes del patrimonio histórico del pueblo vasco que radiquen en su término municipal».

${ }^{9}$ Derogada parcialmente por la Disposición derogatoria 2. ${ }^{a}$ LJCA, norma que actualmente regula este procedimiento como uno de los especiales en el Capítulo Primero, del Título V. 
autonómica competente, dio lugar a variaciones importantes en los procesos judiciales. Es elocuente, a estos efectos, la STSJPV de 7 de septiembre de $2000^{10}$ en la que, resolviendo el recurso contencioso interpuesto por los partidarios del AT contra una Resolución del Director de Seguridad Ciudadana del Departamento de Interior del Gobierno Vasco ${ }^{11}$, la Sala declara la inadmisibilidad del recurso por la inadecuación del procedimiento (arts. 88.1.b) y 68.1.a) LJCA), en cuanto entiende que el Alarde no implica ejercicio de derecho fundamental alguno (cuestión que abordaremos más detalladamente en el epígrafe III), y por tanto, el cauce procesal empleado resultaba de todo punto improcedente ${ }^{12}$.

Por otro lado, la confusión entre «compañías» de desfile, asociaciones y/o fundaciones promotoras del Alarde, y por qué no decirlo, el empleo de tendenciosos subterfugios por parte de los grupos implicados, se ha vuelto en contra de los propios recurrentes en ciertas ocasiones. Así ocurrió en el caso resuelto por STSJPV de 14 de diciembre de $2001^{13}$ que apreció la inadmisibilidad del recurso por falta de legitimación activa de la recurrente. En este caso, una de las Asociaciones defensoras del AI (parte en buen número de los procesos a los que estamos aludiendo), formuló recurso contencioso sin que quedara constancia en autos de la relación existente entre ella y la Compañía bajo cuyo nombre desfilaba el AI, y sin que hubiera referencia alguna en el expediente administrativo a su presencia como parte interesada. Este hecho llevó indefectiblemente a que el Tribunal apreciara la falta de legitimación activa al no manifestarse en el recurso que se hubiera violado derecho fundamental ni interés legítimo alguno - propio o de sus asociados-, ni acreditarse, en este último caso, la habilitación para defender derechos o intereses legítimos colectivos (art. 19.1 $a$ y $b$ LJ).

\section{El Alarde como ejercicio del derecho de reunión}

\section{A) Los hechos que dieron lugar a un nuevo recurso contencioso-adminis- trativo}

Los sucesos acontecidos el 8 septiembre 1998 en Hondarribia dieron pie a un nuevo procedimiento jurisdiccional que, finalmente, supuso un giro

\footnotetext{
${ }^{10}$ STSJPV (Sala de lo Contencioso-Administrativo; Sección 1. ${ }^{a}$ ) núm. 458/2000; recurso núm. 1622/00.

${ }^{11}$ Dicha Resolución establecía la posición de las compañías en el desfile del Alarde «sin solución de continuidad», acordando que los defensores del AT lo hicieran inmediatamente después que los del AI.

${ }^{12}$ Se alude al procedimiento especial para la protección de los derechos fundamentales de la persona, y en concreto el establecido en el art. 122 LJCA, relativo al derecho de reunión.

${ }^{13}$ STSJPV (Sala de lo Contencioso-Administrativo; Sección 3. a), núm. 1209/2001, de 14 de diciembre de 2001; recurso núm. 2115/99. EDE 2001/76063.
} 
relevante en la doctrina jurisprudencial sobre los Alardes. Los incidentes se produjeron cuando la Compañía defensora del AI trató de incorporarse al AT provocándose a partir de aquel momento forcejeos, insultos y, a la postre, la intervención de la policía autonómica vasca que, formando un cordón, imposibilitó la participación de la primera en los actos. Estos hechos llevaron a la interposición ante el TSJPV de un recurso contencioso-administrativo que fue resuelto por sentencia de 11 de febrero de $2000^{14}$. Resolución judicial que, al margen de su posterior anulación por STS de 2 de junio de 2003, presenta argumentos jurídicos notablemente trabados dando solución a cuestiones jurídicas de considerable complejidad. De ello nos ocuparemos a continuación.

\section{B) Naturaleza del Alarde}

Planteada esta cuestión de un modo indirecto, la Sala niega de manera tajante que estemos ante el ejercicio de derechos fundamentales, remitiéndose a los fundamentos jurídicos de la STJPV de 7 de octubre de 1999 que, en lo referido a la cuestión sustantiva, había realizado dos precisiones de importancia:

a) De un lado, el Alarde no tiene ligazón posible con el derecho a la libertad religiosa consagrado en el art. $16 \mathrm{CE}$ y regulado por LO 7/1980, de 5 de julio: siendo «rasgo general de impregnación religiosa de origen de un sinfin de celebraciones y festividades locales de nuestra geografía, ninguno ofrece tal acontecimiento de entre los caracteres de un acto de manifestación o adoración religiosa, sino que antes bien, tanto por su fisonomía externa —desfile de numerosos vecinos con indumentarias, armas y demás parafernalias militares de época-, como por la completa ausencia de toda simbología o iconografía religiosa explícita y visible, sus ministros de culto, ceremonias y ritos, constituye exaltación netamente cívica y participativa, de valores identitarios, hechos históricos de armas, tradiciones, culturas o modos de ser colectivos» (FJ 4..$^{\circ}$ ).

b) Asimismo, «menos aún puede aceptarse si cabe que esa representación o puesta en escena de la marcha de un antiguo ejercito se inscriba en el ejercicio del derecho político de reunión y manifestación de la Ley Orgánica 9/1.983, de 15 de julio, que (...) nunca podrá esgrimirse desde la perspectiva en que se hace, como si su entrada en escena dependiese del mayor o menor grado de alteración del orden público y de eventual intervención de la fuerza pública que se presu-

${ }^{14}$ STSJPV (Sala de lo Contencioso-Administrativo; Sección 1. ${ }^{\text {) }}$ núm. 94/2000, de 11 de febrero de 2000; recurso núm. 4359/1998. EDE 2000/5030. 
miese como derivación de un acto, y no en cambio del contenido de éste. La jurisprudencia del Tribunal Constitucional ha puesto de relieve que la finalidad de ese derecho fundamental de reunión pacífica y sin armas es la exposición de ideas - de ahí su enlace con la libertad de expresión-, y la defensa de intereses o la publicidad de problemas y reivindicaciones, a través de una agrupación o asociación transitoria de personas, y nada de esto se compadece mínimamente con la invocación de tal Derecho de Reunión para todo otro fin legitimo — cultural, religioso, festivo, etc.-, que suponga la medial concurrencia concertada de un numeroso grupo de personas en lugares de tránsito público (...). Específicamente la STC 85/1988, 28 abril (...) diferencia entre el requisito de finalidad lícita y la concreta finalidad de la reunión - elemento externo al puro contenido del Derecho de Reunión-, que funciona como condición legitimadora, "pero no como contenido del mismo en el sentido de que cualquier actividad lícita pueda ser realizada por el cauce del derecho de reunión al margen del régimen legal y reglamentario al cual esté sometida, pues ello entraña una inaceptable desnaturalización del derecho en la que se invierten los términos que lo relacionan con su finalidad», y aclara que, «con independencia del derecho a reunirse que tengan las personas que pretenden alcanzar una finalidad lícita determinada, la actividad a realizar para satisfacerla no queda, por ello, exenta de cumplir las condiciones de legalidad que les imponga el ordenamiento jurídico, y no entenderlo así conduciría a la conclusión absurda de que el Derecho de Reunión suprime las potestades administrativas de intervención en las actividades privadas con sólo que un número suficiente de personas decidan realizarlas»-F.J. 3-. Podrá objetar válidamente la Administración demandada que tal iniciativa no le es propia sino de una entidad privada defensora del «Alarde tradicional» integrada por los mandos de éste, pero tal circunstancia nunca le exonerará del cumplimiento de sus propios deberes constitucionales y legales como Administración local».

\section{C) Sobre el objeto del proceso}

Otra de las dificultades que se planteó en el presente caso fue el sometimiento a revisión jurisdiccional de una actuación policial verificada «de facto», esto es, sin procedimentalización y elemento formal previo. Tras citar la doctrina sentada en STC 160/1991, 18 julio $^{15}$, la Sala distingue dos supuestos:

${ }^{15}$ STC (Sala 2. a) 160/1991, de 18 de julio; recurso núm. 831/1988. BOE 190/1991, de 9 de agosto. 
«la del acto "de urgencia” manifestado por la fuerza, en que decisión y ejecución se confunden. Y la del acto administrativo con decisión previa y separada, producida mediante forma no escrita adecuada al normal ejercicio jerárquico de la competencia _orden verbal interna (...)_ pero de carácter implícito y sólo manifiesto a través de actos de los Agentes de la Administración».

Pues bien, a efectos del enjuiciamiento de la legalidad de la actuación impugnada, el Tribunal entiende que, si bien y tal y como se ha constatado con anterioridad, no estamos ante el ejercicio del derecho de reunión, sin embargo, se da la «necesaria traslación a este supuesto de las doctrinas que han tomado cuerpo en torno al art. 21 CE». Así las cosas, «el límite al ejercicio del derecho de reunión (...) se materializa en que la autoridad policial pueda adoptar, no sólo las medidas pertinentes para posibilitar el ejercicio en libertad del derecho de los manifestantes, o la protección de derechos y bienes de titularidad de terceros, sino que queda legitimada, "en orden a alcanzar tales objetivos, a modificar las condiciones del ejercicio del derecho de reunión e incluso prohibirlo, siempre que concurran los motivos que la CE exige, y previa la realización del oportuno juicio de proporcionalidad" (FJ 2. ${ }^{\circ}$, STC 66/1995, 8 mayo)». Aplicando estas ideas al supuesto enjuiciado, la Sala declara:

El Alarde se configura como «ejercicio de una facultad de participación cívica en la que está comprometida, por lo menos en su aspecto reaccional frente a las actitudes y comportamientos lesivos, el principio de igualdad y el derecho a no sufrir discriminaciones específicas del artículo 14 CE, en relación con el artículo 9.3, ya sea por razón de sexo, o ya se considere trasmutado por derivación este concepto en una discriminación por la mera condición social minoritaria de los partidarios activos de la participación femenina en los Alardes, con pleno respaldo jurisdiccional». Por otro lado, y considerando que «la ponderación de intereses a la que se ve obligada la fuerza policial es análoga a la que ante el Derecho de Reunión se le plantearía, debiendo arbitrar proporcionalmente entre participación igualitaria y seguridad de personas y bienes»; teniendo en cuenta asimismo que la Asociación recurrente había comunicado con la suficiente antelación a la policía autonómica su intención de celebrar el acto conmemorativo, solicitando además la adopción de las medidas de seguridad necesarias para los participantes, «se pone de manifiesto que las medidas finalmente adoptadas sobre el terreno, (...) sólo condujeron tendencial y objetivamente a excluir la participación de uno de los grupos, sobre la base exclusiva de consideraciones técnicas, puntuales e inmediatas de seguridad pública y del más pronto restablecimiento del orden externo en riesgo de alteración», con "completo desentendimiento hacia las demandas anticipadas de seguridad y protección que dicho colectivo social dirigía fundadamente y cuya implementación posibilitaba, al menos, el diseño de medidas y dispositivos restrictivos preestablecidos que armonizasen hasta donde fuese posible todas las facultades legitimas en presencia» (FJ 5. ${ }^{\circ}$ ). 
Desde todas estas consideraciones, la Sala entiende que la actuación policial incurrió en «una constitucionalmente ilegítima incidencia sobre el principio de no discriminación», procediendo así a la estimación del recurso.

\section{D) La postura discrepante del TS}

La sentencia que acabamos de exponer fue objeto de recurso de casación interpuesto por el Gobierno Vasco; casación que fue estimada por la citada STS de 2 de junio de 2003 al discrepar en los dos aspectos fundamentales del contenido de aquélla:

\section{Alarde y DeRecho de ReUnión}

En lo concerniente a la naturaleza del Alarde, la resolución judicial da un giro decisivo en cuanto reconduce aquél al ejercicio del derecho fundamental de reunión en los siguientes términos:

«Por lo que se refiere al título jurídico en virtud del cual se celebró el Alarde de 1998, es nuestro parecer que se trata del derecho de reunión y manifestación reconocido por el artículo 21 de la Constitución. Derecho que asistía tanto a quienes promovieron su ejercicio desde la "A. F. H" [AT] como a quienes lo hicieron desde la "C. J." [AI]. A esa conclusión llegamos, no sólo porque unos y otros se acogieron a las normas que lo regulan y porque la demanda de la Asociación "J.M." se construye sobre él, sino porque la realidad de los hechos así lo pone de manifiesto. Grupos distintos de personas se reunieron pacíficamente y sin armas, pues las que portaban únicamente tenían el sentido de completar el atuendo y de servir para salvas, con el propósito de manifestar públicamente las ideas que les animan entre las que se incluyen, junto a la conmemoración de un acontecimiento histórico y la renovación del voto a la Virgen de Guadalupe, las que se refieren al acto mismo del Alarde, pues sobre esa celebración de carácter cívico y religioso se mantienen dos concepciones diferentes en torno a la participación de la mujer. (...)

Se dan, pues, los elementos que según la jurisprudencia constitucional identifican el derecho de reunión. Así, dice la Sentencia del Tribunal Constitucional 42/2000: "Cuando se ejercita en lugares de tránsito público es una manifestación colectiva de la libertad de expresión ejercitada a través de una asociación transitoria de personas que opera a modo de técnica instrumental puesta al servicio del intercambio o exposición de ideas, de la defensa de intereses o de la publicidad de problemas o reivindicaciones, constituyendo, por tanto, un cauce relevante del principio democrático participativo, cuyos elementos configuradores son el subjetivo -agrupación de personas-, el temporal —duración transitoria-, el finalista -licitud de la finalidad - y el real u objetivo - lugar de celebración-(SSTC 55/1988, 28 abril, FJ 2. ${ }^{\circ}$-Ref. EDE 1988/371-y 66/1995, 8 mayo, FJ 3. ${ }^{\circ}$-Ref. EDE 1995/2054-)”. 
Desde luego, en los actos de Hondarribia se aprecia un claro propósito participativo pero eso (...) es algo que caracteriza el ejercicio típico del derecho de reunión y manifestación y no lo transforma en la innominada facultad de participación cívica que aprecia la sentencia de instancia (...). Así, pues, estamos ante el ejercicio de este derecho fundamental y el mismo asiste tanto a quienes pretenden ejercerlo para celebrar el Alarde de un modo como a los que creen que debe realizarse de otro distinto. También cabe decir que, existiendo distintas concepciones sobre la manera en que debe llevarse a cabo tal manifestación, no puede aceptarse que exista el derecho de quienes lo conciben de una forma determinada a integrarse con quienes lo entienden de otra diferente cuando no haya acuerdo sobre esa integración» (FJ 6. $\left.{ }^{\circ}\right)$.

Esta STS de 2 de junio de 2003 tuvo efecto lógico e inmediato en posteriores SSTSJPV. Así, la STSJPV de 24 de octubre de 2003 en la que, con mención expresa al cambio de criterio operado, se señala que «las consecuencias relevantes de la anterior doctrina (...) son tres:

En primer lugar, que el desarrollo del Alarde constituye ejercicio del derecho de reunión [para las dos partes que pretenden participar en el mismo bajo su distinta y particular concepción].

En segundo lugar, que siendo ejercicio del derecho de reunión por quienes conciben dicho acto de forma radicalmente incompatible, no cabe reconocer el derecho de uno de ellos a integrarse en el otro si no hay acuerdo sobre dicha integración, sin que jueguen en ello consideraciones de igualdad relevantes desde el momento en el que no intervienen en su organización las corporaciones públicas.

Finalmente, que ante la probable alteración del orden público y de la paz ciudadana que el intento de fusión de ambos grupos puede producir corresponde a la Administración el ejercicio de las potestades que tienen conferidas por la LO 9/1983 de 15 de julio para modalizar el ejercicio del derecho alterando las circunstancias de tiempo o lugar en lo mínimo indispensable para conjurar dichos peligros y para satisfacer en su mayor grado el derecho de manifestación de cada uno de los grupos, y finalmente durante el desarrollo de los actos, el ejercicio de sus potestades de policía en orden al mantenimiento del orden y la paz social» (FJ 3. $\left.{ }^{\circ}\right)$.

\section{EN CUANTO A LA ACTUACIÓN POLICIAL}

Por lo que atañe a la actuación policial que la STSPV consideró discriminatoria, el TS disiente igualmente por entender que ésta no sólo no se desentendió de la solicitud de protección efectuada por el AI, sino que su intervención evitó conductas y sucesos más graves, fue adecuada y proporcionada y tendió a garantizar el ejercicio del derecho fundamental concernido sin pretender la discriminación ni producirla efectivamente (FJ $\left.6 .^{\circ}\right)$. 


\section{E) Síntesis de la doctrina del Tribunal Constitucional sobre el Derecho de Reunión}

Según se ha manifestado en los argumentos, tanto la sentencia recurrida en casación, como la STS que la anula, se remiten a doctrina del TC en apoyo de sus tesis. En la medida en que ambas son abiertamente contradictorias, creemos que es conveniente tratar de sintetizar, de un modo ordenado, los pronunciamientos que sobre el derecho de reunión en lugares de tránsito público ha realizado el $\mathrm{TC}^{16}$ :

a) El derecho de reunión es «una manifestación colectiva de la libertad de expresión ejercitada a través de una asociación transitoria de personas, que opera a modo de técnica instrumental puesta al servicio del intercambio o exposición de ideas, la defensa de intereses o la publicidad de problemas y reivindicaciones». Un derecho que es «individual en cuanto a sus titulares y colectivo en su ejercicio» y que históricamente surge como derecho autónomo intermedio entre los de libre expresión y asociación con los que sigue manteniendo «íntima conexión doctrinal» tal y como se refleja en su propia conceptuación.

b) Cuatro son los elementos que configuran este derecho:

1) Subjetivo: Agrupación de personas caracterizada de modo esencial por ser una «concurrencia concertada» en la que se da cierto grado de vinculación de cada uno de los participantes con los demás. Desde esta consideración, no constituye elemento subjetivo la mera aglomeración o confluencia casual de personas en un determinado espacio físico puesto que es preciso que exista «concierto mutuo para concurrir, el saberse participantes en una reunión».

2) Objetivo: Lugar de celebración ${ }^{17}$.

3) Temporal: Duración transitoria.

4) Finalista: En este punto debe distinguirse entre fin como elemento interno y parte del contenido esencial del derecho y la finalidad de la reunión como elemento externo. Así las cosas, la licitud de esta última «funciona como condición legitimadora del ejercicio del derecho», mas no como contenido de éste, de lo que se concluye que no cabe canalizar por vía del derecho de reunión cualquier actividad lícita so pena de desnaturalizar el derecho a través de una

\footnotetext{
${ }^{16}$ Sin ánimo agotador, cabe citar como sentencias más relevantes, las que siguen: STC (Sala 1.a) 85/1988, de 28 de abril de 1988; recurso núm. 942/1987; BOE 128/1988, de 28 de mayo de 1988. STC (Sala 2. ${ }^{\text {a) }}$ 66/1995, de 8 de mayo de 1995; recurso núm. 1693/1992; BOE 140/1995, de 13 junio 1995.

${ }^{17}$ Debe tenerse en cuenta que, aunque el objeto de este estudio obliga a circunscribir el derecho de reunión al producido en lugares de tránsito público, en realidad cabe hablar de dos clases de reuniones atendiendo al lugar en el que se celebran, siendo distinto el régimen de intervención administrativa aplicable en uno y otro caso.
} 
inversión de los términos relativos a su finalidad. En síntesis: «es la licitud del fin la que legitima la reunión y no el derecho de reunión con fin lícito el que legaliza, por su sola invocación, la actividad a través de la cual se cumple dicho fin».

c) Los elementos subjetivo y objetivo del derecho de reunión hacen que éste adquiera una dimensión de singular relieve como «cauce del principio democrático participativo» en un Estado social y democrático de Derecho. Desde este punto de vista, el derecho del art. $21 \mathrm{CE}$ es «para muchos grupos sociales (...) uno de los pocos medios de los que disponen para poder expresar públicamente sus ideas y reivindicaciones».

d) Como cualquier otro derecho, el de reunión no es un derecho ilimitado o absoluto y exige conciliar su ejercicio con la protección de derechos y bienes de terceras personas. Esta circunstancia explica la previsión de un régimen de intervención administrativa que, en cualquier caso, no tiene carácter autorizatorio. En este sentido, la obligación de comunicación previa a la autoridad gubernativa no implica el deber de obtener autorización, por cuanto el ejercicio del derecho «se impone por su eficacia inmediata y directa sin que pueda conceptuarse como un derecho de configuración legal» ${ }^{18}$.

e) De igual modo, la potestad administrativa que permite a la autoridad gubernativa el establecimiento de modificaciones y, en su caso, la prohibición de ejercicio del derecho, «no es reconducible a ningún género de manifestación de autotutela», puesto que cualquier actuación administrativa en esa dirección es revisable jurisdiccionalmente con una inmediatez que encuentra reflejo tanto en el plazo del que dispone el órgano administrativo para dictar resolución, como en «el mecanismo especialmente acelerado de control judicial de la misma».

f) El límite del derecho de reunión conforme al art. 21.2 CE exige que cualquier modificación o prohibición de éste se apoye en «razones fundadas de alteración del orden público», expresión que merece, a su vez, ciertas precisiones:

- La existencia de «razones fundadas» impide que sea suficiente «la mera sospecha o la posibilidad de que ésta produzca esa altera-

${ }^{18}$ En Derecho Administrativo esta figura suele conocerse como «comunicación previa con reserva de oposición», que SANTAMARÍA PASTOR caracteriza como «modalidad aligerada de la técnica autorizatoria», consistente en que se otorga a la Administración la potestad de comprobar la legalidad de los términos de la comunicación y su ajuste a los intereses públicos, pudiendo formular en su caso un mandato prohibitivo o condiciones para su realización, de suerte que, transcurrido el plazo sin respuesta administrativa, el particular puede emprender la actividad proyectada. SANTAMARÍA PAStor, Juan Alfonso, Principios de Dere-

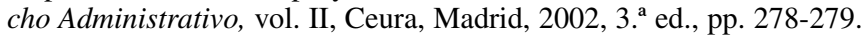


ción», sino que exige que la autoridad gubernativa cuente con «datos objetivos suficientes, derivados de las circunstancias de hecho concurrentes en cada caso, a partir de los que cualquier persona en una situación normal pueda llegar racionalmente a la conclusión, a través de un proceso lógico basado en criterios de experiencia, que la concentración producirá con toda certeza el referido desorden público». En cualquier caso, una interpretación sistemática del precepto constitucional lleva a que las eventuales dudas sobre la producción de estos efectos deban ser resueltas mediante la necesaria aplicación del principio «favor libertatis».

- De la locución «razones fundadas», derivan tres consecuencias relevantes: a) la resolución gubernativa deberá estar motivada; b) el que deban ser fundadas exige que se aporten las razones que han llevado a la conclusión de que, si se celebra la reunión en los términos en los que está prevista, se producirá la alteración del orden público proscrita; y, c) de igual modo, debe justificarse la imposibilidad de adoptar las medidas preventivas necesarias para conjurar esos peligros y permitir el efectivo ejercicio del derecho fundamental.

— El orden público al que se refiere el art. 21.2 CE no remite a un concepto genérico de orden público, sino «al orden público con peligro para personas o bienes», de suerte que la «situación de peligro» se incorpora a la noción no como elemento adjetivo o externo, sino como su elemento sustantivo y definidor que, en cuanto tal, debe ser analizado «en el contexto del precepto constitucional del que forma parte, es decir, como límite del derecho fundamental de reunión en lugares de tránsito público». Desde esta premisa, el orden público «se refiere a una situación de hecho, el mantenimiento del orden en sentido material en lugares de tránsito público, no al orden como sinónimo de respeto a los principios y valores jurídicos y metajurídicos que están en la base de la convivencia social y son fundamento del orden social, económico y político». De ahí la imposibilidad de que los poderes públicos apliquen criterios de oportunidad política o juicios basados en el sistema de valores que fundan el orden social en un momento histórico determinado lo que, a la postre, impide cualquier discriminación motivada en el contenido de los mensajes que los promotores pretendan transmitir y siempre que aquéllos no contravengan la legalidad.

— La afectación del orden público debe ser con peligro para las personas y bienes, "entendiendo por tal desorden material el que impide el normal desarrollo de la convivencia ciudadana en aspectos que afectan a la integridad física o moral de personas o a la integridad de bienes públicos o privados». De este modo, no cabe 
la limitación del derecho basada en cualquier tipo de alteración del normal funcionamiento de la vida colectiva, sino sólo aquella que implique un desorden externo con riesgo para la integridad de las personas y bienes. Dicho esto, debe también precisarse que «ese peligro no es sinónimo de utilización de la violencia» por parte de quienes participan en las concentraciones, ya que en este caso, no cabría otra solución que la prohibición de la convocatoria correspondiente, «puesto que se trataría de una acción ajena o no integrada en el referido derecho».

- El art. 21.2 CE «no delimita el contenido del derecho de reunión, sino que establece un límite a su ejercicio», y otorga a los poderes públicos una facultad (la de modificación o, en su caso, prohibición) que en su ejercicio debe estar guiada por el principio de proporcionalidad. Teniendo en cuenta que ese límite del 21.2 CE debe tener un contenido concreto, «deberá concluirse que en su ámbito se incluyen los peligros para personas o bienes derivados de las acciones violentas que puedan derivarse de la celebración pacífica de la concentración, ya sea porque la misma cree situaciones que provoquen directamente esos peligros, ya porque imposibilite la realización de actividades tendentes a evitar o a paliar los citados peligros» ${ }^{19}$.

g) Por lo que respecta a la concreta facultad de prohibición del ejercicio del derecho de reunión, se subraya la necesidad de que medida tan drástica esté sometida a un juicio de proporcionalidad de suerte que sólo será constitucionalmente legítima en caso de que no existan otros medios de preservar el orden público. Dicho juicio de proporcionalidad deberá reunir tres requisitos o condiciones: 1) aptitud de la medida para alcanzar el objetivo propuesto (salvaguarda del orden público sin peligro para personas y bienes); 2) necesidad de la medida, entendida como inexistencia de medida alternativa más moderada para el logro del objetivo con igual eficacia; 3 ) proporción en sentido estricto, esto es, adecuación y equilibrio «por derivarse de ella más beneficios o ventajas para el interés general que perjuicios sobre otros bienes o valores en conflicto».

${ }^{19} \mathrm{El}$ entrecomillado corresponde al FJ 3. ${ }^{\circ}$ de la STC 66/1995 de 8 de mayo (cit.), que contó con un Voto particular formulado por el Magistrado GonZÁlEz CAMPOS quien, en relación con el párrafo trascrito, subraya que la sentencia debería haber concretado más uno y otro supuesto «pues es evidente que no conduce al mismo resultado que el peligro para las personas y bienes derivado de la previsible alteración del orden público sea entendido como un peligro directo o sólo indirecto». Desde esta posición, el Magistrado entiende que incluir los riesgos para las personas y bienes que puedan producirse de un modo indirecto o eventual implica «una discutible ampliación del límite establecido en el art. 21.2 CE» que, aun aceptada, requiere una mayor exigencia a la autoridad gubernativa sobre la justificación de la imposibilidad de adoptar medidas preventivas. 
h) La facultad de modificación permite a la autoridad gubernativa la alteración de fecha, lugar o duración de la reunión a celebrar. No obstante, esta facultad no es enteramente discrecional, sino que viene condicionada por la programación dada por los promotores. Particularmente importante es el elemento objetivo (lugar de celebración) del derecho de reunión ya que su elección por parte de los promotores «está íntimamente relacionado con el objetivo de publicidad de las opiniones y reivindicaciones» de aquellos hasta el punto de que «en ciertos tipos de concentraciones el lugar de celebración es para los organizadores la condición necesaria para poder ejercer su derecho de reunión en lugares de tránsito público, puesto que del espacio físico en el que se desenvuelve la reunión depende que el mensaje que se quiere transmitir llegue directamente a sus destinatarios principales».

\section{F) Nuestra crítica a la STS de 2 de junio de 2003}

A nuestro entender, y sin negar validez a la argumentación de la STS, el entronque de los Alardes en el derecho de reunión resulta forzado. En primer lugar, el que «unos y otros» se acogieran a las normas que regulan el mencionado derecho o el que la demanda se construyera sobre él no es un dato suficientemente decisivo. Hemos tenido ocasión de comprobar que los procesos originados por los Alardes están plagados de ardides de todo tipo, mediante los cuales las partes tratan de eludir doctrina jurisprudencial según convenga a sus intereses. De igual modo, se acogen a cauces procesales que no siempre resultan los idóneos, tal y como se ha constatado en alguna de las sentencias a las que hemos aludido y que declaran la inadmisibilidad de ciertos recursos.

Tampoco estamos de acuerdo en que, desde un punto de vista de derecho sustantivo, los actos comprendidos en los Alardes puedan considerarse como ejercicio del derecho de reunión, aunque debemos convenir que en el AI se da una nota reivindicativa que puede inducir a equívocos. No puede ponerse en duda que estamos ante dos concepciones distintas de una fiesta; igualmente incuestionable es que el devenir de los acontecimientos prueba que ambas concepciones son irreconciliables y que las Administraciones públicas concernidas se han mostrado incapaces de acercar posturas. Ahora bien, cuestión distinta es que el dislate producido por todos esos factores encuentre una solución de conveniencia que, de algún modo, implique el entendimiento extensivo de un derecho fundamental con el fin de poder hacer aplicable el régimen jurídico de éste, tratando de conseguir así un eventual «efecto pacificador».

Se dice por parte del TS que «grupos distintos de personas se reunieron pacíficamente y sin armas, pues las que portaban únicamente tenían el sentido de completar el atuendo y de servir para salvas, con el propósito de manifestar públicamente las ideas que les animan entre las que se incluyen, 
junto a la conmemoración de un acontecimiento histórico y la renovación del voto a la Virgen de Guadalupe, las que se refieren al acto mismo del Alarde, pues sobre esa celebración de carácter cívico y religioso se mantienen dos concepciones diferentes en torno a la participación de la mujer». Esta visión de la realidad permite al TS derivar que confluyen los cuatro elementos que configuran el derecho de reunión y que han quedado expuestos en líneas precedentes. Una conclusión, a nuestro entender, más que cuestionable:

a) En cuanto al elemento subjetivo, parece claro que estamos ante una agrupación de personas, «pacífica y sin armas». La mera alusión a que las que portaban formaban parte del atuendo no deja de parecernos chocante y, en todo caso, es un dato cuya aparente irrelevancia puede ser engañosa (volveremos sobre ello al hablar del elemento finalista). Sin embargo, la cuestión no es tanto que se dé una agrupación de personas como el que haya «concurrencia concertada», esto es, el que los participantes se sepan en una reunión. ¿Los participantes en el Alarde «se saben» en una reunión o, por el contrario, en una fiesta popular? Ciertamente los acontecimientos que se han ido produciendo en estos años pueden haber alterado la percepción, la propia toma de conciencia de los integrantes de los distintos Alardes sobre el significado del acto en el que participan, ideologizándolo total o parcialmente y sumando componentes de «libertad de expresión» inexistentes en tiempos anteriores. Por otro lado, también debe admitirse que, sobre todo en el AI, se da un importante ingrediente reivindicativo en cuanto a la igualdad de derechos de la mujer que, además, encuentra ligazón con ciertas asociaciones y grupos formalmente constituidos. Dichos factores tal vez permitan deducir que se cumple un elemento subjetivo que, de cualquier modo, no termina de encajar plenamente en cuanto nos resulta dudoso que todos los vecinos participantes de los eventos acudan entendiendo que éstos van más allá de un mero festejo local.

b) El elemento objetivo consistente en el lugar de reunión puede parecer absolutamente evidente, pero de igual manera, presenta algunas dificultades. Una reunión en lugares de tránsito público no elige cualquier tipo de ubicación en la medida en que el emplazamiento se enlaza con el mensaje y/o con la difusión que se quiere dar a éste. No obstante, el hecho de que el Alarde transcurra por los «centros neurálgicos» de una determinado término municipal no tiene una significación especial o, si se prefiere, diferencial. Todas las fiestas locales en cuyo programa se incluyen paseos de comparsas, grupos vecinales o «procesiones» de cualquier tipo transitan por los principales lugares del Municipio. Es más, cualquier actividad programada en fiestas se lleva a cabo, casi por definición, en el núcleo principal de un pueblo, no extramuros de él. 
c) El elemento temporal — duración transitoria — no plantea en principio problemas, ni siquiera por su carácter periódico. Puede decirse que no son las más frecuentes, pero debemos admitir que determinadas manifestaciones se producen invariablemente en determinada fecha cada año y todos los años. En cualquier caso, el ingrediente temporal es, desde nuestro punto de vista, el menos revelador y en el supuesto que nos ocupa cabe considerarlo coincidente con la temporalidad propia de toda fiesta popular que, de la misma manera, se celebra también en unas fechas predeterminadas y con carácter transitorio.

d) La divergencia principal se produce, sin duda, en el elemento finalista que, a nuestro juicio, no fue debidamente considerado en la STS. Señalábamos antes que la doctrina del TC distingue entre fin como componente interno y parte del contenido esencial del derecho de reunión y finalidad lícita de éste, que actúa externamente y como condición legitimadora de su ejercicio.

Por aportar todos los detalles, diremos que esta distinción se efectuó en STC 85/1988, de 28 de abril (cit.), en la que se resolvió un recurso de amparo interpuesto en relación con una resolución de la Delegación del Gobierno de Asturias que denegaba la solicitud para la celebración de cuestaciones públicas. En la sentencia se afirmaba que las cuestaciones públicas no constituyen ejercicio del derecho de reunión por no concurrir en ellas ni el elemento subjetivo de «concurrencia concertada», ni el finalista, realizando en este punto la distinción a la que nos venimos refiriendo; asimismo se recuerda que las cuestaciones están reguladas en disposiciones específicas que prevén, a su vez, un concreto régimen de intervención administrativa distinto necesariamente del propio de un derecho fundamental como el de reunión.

Pues bien, el TS «despacha» el análisis de este extremo indicando que «es clara la diferencia entre el Alarde y otras agrupaciones transitorias de personas que no son expresión del derecho de reunión como las que pretenden cuestaciones mediante mesas petitorias que menciona la Sala de instancia». Este argumento, tomado en sus propios términos, no puede compartirse por cuanto la Sala de lo Contencioso Administrativo del TSJPV (Sala de instancia) en ningún momento asimiló el Alarde a las cuestaciones públicas, limitándose a traer doctrina constitucional al supuesto enjuiciado y aportando, sin más pretensiones, los datos relativos a la STC en la que se basaba. La Sala, en jurisprudencia reiterada, ha entendido que el Alarde constituye en esencia un espectáculo público en el que confluyen aspectos muy variados - festivos, religiosos, históricos, de participación cívica...- y que, en atención a esta naturaleza, se rige por la normativa sectorial aplicable a estos eventos. Por lo demás, el empleo de este argumento podría igualmente jugar en contra de la STS, en la medida en que ésta se apoya en la STC 42/2000, de 14 de febrero, por la que se estima un recurso de amparo contra ciertas resoluciones administrativas que imponían multas por interrupción del tráfico al participante en una manifestación de trabajadores debidamente comunicada; supuesto que tampoco es asimilable en modo alguno al de los Alardes. 
La STS que ahora comentamos no entra, en realidad, en el análisis de los elementos conformadores del derecho de reunión, sino que, por lo que se desprende de la lectura de los Fundamentos Jurídicos, los entiende concurrentes sin mayor precisión por apreciarse un «claro propósito participativo (...), algo que caracteriza el ejercicio típico de reunión y manifestación y no lo transforma en innominada facultad de participación cívica que aprecia la sentencia de instancia».

Que el derecho de reunión posee un carácter de cauce democrático participativo es, desde luego, irrebatible y así ha sido subrayado por el TC. Sin embargo, no toda expresión de participación ciudadana constituye derecho de reunión so pena, como decíamos, de desnaturalización del derecho, extendiendo su ámbito más allá de lo admisible. Cualquier finalidad lícita no desemboca en elemento finalista del derecho de reunión, sino que actúa con externidad a él. En este sentido, creemos que el TS confunde el aspecto participativo que existe en los Alardes otorgándole una vertiente que no posee, por más que, en efecto, los conflictos tengan su origen en dos concepciones distintas de ellos. En tal sentido, no estamos de acuerdo en que nos hallemos ante «distintas concepciones sobre la manera en que debe llevarse a cabo tal manifestación», considerando a priori que el Alarde es manifestación por su rasgo de participación.

Los mismos detalles externos de los participantes, con atuendos de época, compañías en un desfile de corte histórico-militar (que crípticamente sirven al TS para concluir que es una reunión «pacífica») dan muestra de que los intervinientes son, antes de nada, vecinos en una fiesta y no integrantes de una manifestación.

Por lo demás, no encontramos el sentido que se quiere dar a la expresión «innominada facultad de participación cívica», locución que sirve de crítica a la STSJPV. La participación, ligada comúnmente a la cláusula de Estado Democrático, aparece «nominada» en el texto constitucional sólo en ciertos casos y, por lo que respecta al art. 9.2 CE, con total amplitud incluyendo la de «todos los ciudadanos en la vida política, económica, cultural y social».

\section{La respuesta judicial al último conflicto: sentencia del Tribunal Superior de Justicia del País Vasco de 21 de junio de 2005}

\section{A) Objeto del proceso}

Se impugna en el presente caso la Resolución del Director de Seguridad Ciudadana del Departamento de Interior del Gobierno Vasco de 10 de junio de 2005, por la que se dispone sobre horarios e itinerarios de los Alardes de San Marcial de Irún, modificando parcialmente los correspondientes tanto al AT (recurrente en el proceso) como al AI.

Ha de ponerse de manifiesto que los promotores del AT solicitaron del Ayuntamiento de Irún la autorización para su desfile al amparo de la Ley del 
Parlamento Vasco 4/1995, de 10 de noviembre, de Espectáculos públicos; autorización que fue otorgada por Resolución del indicado Ayuntamiento de 17 de febrero de 2005 y debidamente comunicada por éste a la autoridad autonómica. Por el contrario, el AI comunicó al gobierno autonómico el plan de su convocatoria en cumplimiento del régimen jurídico aplicable al ejercicio del derecho de reunión y que, como es sabido, implica el ejercicio de ciertas potestades públicas de intervención.

Respecto a las distintas vías empleadas - cuestión que, como se verá, suscitó cierta dificultad procesal-, sólo cabe pensar que estamos ante un nuevo intento «tramposo» de eludir la legalidad que, conforme a la STS de 2 de junio de 2003, es aplicable a los Alardes. Al margen de la crítica que esta sentencia pueda merecer, lo cierto es que sienta una doctrina clara sobre la naturaleza de esta celebración y en tal medida, resulta cuando menos sorprendente que el AT haga oídos sordos a dicho pronunciamiento canalizando una solicitud de autorización al amparo de la normativa sectorial de espectáculos públicos ${ }^{20}$.

Más insólita resulta aún la postura del Ayuntamiento de Irún que, en respuesta a la comunicación de manifestación efectuada por la autoridad autonómica competente, informa de la autorización para la celebración del Alarde de San Marcial, sus horarios y emplazamientos aludiendo a «que el Tribunal Superior de Justicia del País Vasco mediante la correspondiente sentencia ya ha fallado que la conmemoración del Alarde no tiene amparo en el derecho de reunión o manifestación», que en todo caso tal conmemoración está sujeta a la regulación sobre espectáculos públicos, terminando su informe del siguiente modo: «... parece que el acto comunicado es expresión de la celebración de un acto de Alarde que parte, como premisa falsa, de la cobertura por el derecho de manifestación o reunión según se ha dicho antes».

${ }^{20}$ A nuestro juicio el carácter tendencioso de la petición de autorización municipal queda en evidencia en las propias alegaciones del AT al formular el recurso y que el FJ $1 .^{\circ}$ STSJPV de 21 de junio de 2005 sintetiza del siguiente modo: «(...) b) La resolución recurrida afecta ilícitamente a la determinación sobre el orden público llevada a cabo por la autorización administrativa municipal concedida a favor de la Asociación recurrente. La celebración de la manifestación comunicada el 8 de junio de 2005 por la "Asociación A. P. A. A." [AI] para su celebración el mismo día 30 de junio de 2005, responde a una concepción del Acto del Alarde de San Marcial opuesta al sostenido por la ahora recurrente y se presenta con un carácter reivindicativo y reaccional respecto del mismo. Por lo que al coincidir parcialmente en horarios y recorridos, incide gravemente en el orden público previamente establecido por la resolución municipal dictada al amparo de la Ley del Parlamento Vasco 4/1995, de 10 de noviembre, de espectáculos públicos» (la negrita es nuestra).

Lo que parece deducirse de esta alegación es que la petición de autorización municipal por parte de los promotores del AT trató de «preconstituir orden público», si es que cabe tal expresión. 
El contenido del informe municipal sólo puede producir perplejidad y, desde luego, no puede tener su justificación en un eventual desconocimiento de la doctrina del TS sentada dos años antes. Antes bien, estamos ante una omisión consciente y puede decirse que hasta recalcitrante en su empeño de dar cobertura jurídica a una de las partes implicadas. Una actitud que, a nuestro juicio, no es admisible en una Administración Pública que, conforme al art. 103.1 CE, debe servir con objetividad los intereses generales y actuar con sometimiento pleno a la ley y al Derecho.

\section{B) Legitimación Activa y art. 122.1 LJCA.}

La Administración demandada opone la inadmisibilidad del recurso por falta de legitimación activa de la recurrente (art. 69.b) in fine LJCA), por entender que estando ante un procedimiento especial de protección de derechos fundamentales de la persona, procede aplicar el art. 122.1 LJCA, conforme al cual sólo los «promotores» están legitimados para la interposición del recurso ${ }^{21}$.

Dicha alegación se funda en que la petición original de la Asociación recurrente, lejos de enmarcarse en el ejercicio del derecho de reunión, encuentra el título jurídico que le sirve de fundamento en la autorización municipal para celebrar un espectáculo público, invocando asimismo la interpretación dada por el mismo Tribunal en Auto de 13 de septiembre de 2002.

Por lo que atañe a este último argumento, la Sala recuerda las diferencias entre el caso que dio lugar al precitado Auto y el que ahora se resuelve. En efecto, en aquel proceso jurisdiccional, el TSJPV vino a negar legitimación activa a la Delegación del Gobierno en la Comunidad Autónoma Vasca para recurrir la inactividad del Gobierno Vasco al no prohibir una manifestación a celebrar en Bilbao con el fin de «protestar contra las actuaciones realizadas por el Juzgado núm. 5 de la Audiencia Nacional y por el Congreso de los Diputados». Ante la petición de una medida cautelar de suspensión de la manifestación con base en el supuesto interés legítimo de «salvaguardar el cumplimiento de las resoluciones judiciales», la Sala apreció la falta de legitimación activa de la Delegación del Gobierno «a partir de una doble denotación jurídico-procesal» a la que se remite en el presente caso:

— «El art. 11.1 de la Ley Orgánica 9/1983, de 15 de julio, Reguladora del derecho de reunión, en relación con el art. 122.1 de la Ley Juris-

${ }^{21}$ La dicción literal del artículo establece: «En el caso de prohibición o propuesta de modificación de reuniones previstas en la Ley Orgánica Reguladora del Derecho de Reunión que no sean aceptadas por los promotores, éstos podrán interponer recurso contencioso-administrativo ante el tribunal competente (...) dentro de las 48 horas siguientes a la notificación de la prohibición o modificación». 
diccional 29/1998, atribuye la legitimación para solicitar el control jurisdiccional de la actuación administrativa en el ámbito de dicho procedimiento jurisdiccional especial a los organizadores o promotores de la manifestación afectada; y, exclusivamente, frente a la decisión gubernativa de prohibición o de propuesta de modificación en la forma de ejercicio de derecho fundamental. Por lo que,

- la determinación del título jurídico (derecho o interés legítimo en relación con la prohibición o la propuesta de modificación de la reunión o manifestación, sobre el que la parte recurrente funda la legitimación para el ejercicio de las pretensiones procesales, define un requisito indispensable para la válida constitución de la relación jurídico procesal» $\left(\mathrm{FJ} 2 .^{\circ}\right)$.

En segundo lugar, en cuanto al título jurídico que sirve de base a la pretensión y su eventual discordancia con la vía procesal seguida, el Tribunal estima que, en aplicación de la doctrina jurisprudencial establecida en la STS de 2 de junio de 2003, el Alarde es asimilable al ejercicio del derecho reconocido en el art. $21 \mathrm{CE}$. Y hace notar que la Resolución administrativa impugnada es resultado de la acumulación y resolución en un mismo procedimiento administrativo (art. 73 LRJAP $^{22}$ ) de dos intervenciones administrativas: la primera, incoada a instancia del AI; la segunda, seguida de oficio tras la comunicación municipal del otorgamiento de la autorización al AT.

Así las cosas, «la autoridad gubernativa ha tenido en todo momento a ambas asociaciones organizadoras de cada una de las distintas formas de Alarde (...) como promotoras de unos actos a desarrollar en lugares de tránsito público del término municipal de Irún», siendo obligado «reconocer la evidencia del título jurídico (interés legítimo como sujeto pasivo de la situación de gravamen creada unilateralmente por la resolución de la autoridad gubernativa) que dota de legitimación activa a la recurrente $(\ldots) »\left(\mathrm{FJ} \mathrm{2.} .^{\circ}\right)$.

C) Los argumentos de la Asociación recurrente y la respuesta judicial a éstos

La parte actora sostiene su pretensión anulatoria en tres motivos de impugnación, uno de los cuales ha sido ya comentado en líneas precedentes (véase nota al pie núm. 20).

${ }^{22}$ Según este artículo «el órgano administrativo que inicie o tramite un procedimiento, cualquiera que haya sido la forma de su iniciación, podrá disponer su acumulación a otros con los que guarde identidad sustancial o íntima conexión», sin que quepa recurso alguno contra el acuerdo de acumulación. 
Se arguye en primer término, que la resolución recurrida ha sido dictada sin audiencia previa a la Asociación promotora del AT, trámite que, sin embargo, y como subraya la sentencia, no está previsto en el procedimiento especial establecido en la LODR, razón por la cual se rechaza el argumento.

Debe señalarse que, considerando que la resolución administrativa no resulta de un procedimiento administrativo común, la inexistencia de un trámite de audiencia legalmente establecido no determina una menor garantía para los ciudadanos ${ }^{23}$ (cuestión que podría calificarse de alarmante estando en presencia de un derecho fundamental): la LODR dedica cuatro artículos (del 8 al 11) a las «reuniones en lugares de tránsito público y manifestaciones», preceptos que se ciñen a la obligación de comunicación a la autoridad gubernativa su contenido, la notificación por parte de ésta al Ayuntamiento en que la reunión haya de celebrarse para que informe sobre las circunstancias del recorrido propuesto ${ }^{24}$, las causas que permiten la introducción de modificaciones (o en su caso, prohibición) por parte de la instancia pública competente y, finalmente, el cauce jurisdiccional y plazos de acceso a éste para recurrir dicha resolución modificativa o prohibitiva de la reunión comunicada $^{25}$.

Dicho esto, la garantía del derecho no se halla tanto en el propio procedimiento administrativo - sumamente lacónico - como en la apertura inmediata de la vía judicial; hecho este «que disipa cualquier situación de indefensión material» (FJ 3..$^{\circ}$.

La misma suerte que la anterior alegación corre la denuncia de que la resolución administrativa incurre en desviación de poder. Alegación, en todo caso, deficientemente formulada, en cuanto sólo se predica de parte de la resolución (la relativa a tiempos del recorrido) y no de la que afecta al AI.

${ }^{23}$ La propia CE, en su art. 105.3, no contempla el trámite de audiencia como elemento insoslayable de todo procedimiento administrativo. En este sentido establece que la ley regulará «el procedimiento a través del cual deben producirse los actos administrativos, garantizando, cuando proceda, la audiencia del interesado».

${ }^{24}$ Esta previsión del art. 9.2 fue incorporada por LO 9/1999, de 21 de abril (BOE 96/1999, de 22 de abril) de modificación de la LO 9/1983, para «hacer posible que los municipios afectados por el ejercicio de los derechos de reunión y manifestación estén informados y hagan patente su opinión ante la autoridad gubernativa, sin que ello suponga la modificación de las condiciones y plazos para el ejercicio de dichos derechos, de acuerdo con el principio de garantizar a estas entidades locales su derecho a participar en todos aquellos asuntos que afecten a su ámbito de interés, aun cuando sí se acomoda al nuevo trámite el plazo de que dispone la autoridad gubernativa para prohibir o proponer modificaciones» (Exposición de Motivos LO 9/1999).

${ }^{25}$ Esta regulación está en plena consonancia con el art. 21.2 CE, en virtud del cual, «En los casos de reuniones en lugares de tránsito público y manifestaciones se dará comunicación previa a la autoridad, que sólo podrá prohibirlas cuando existan razones fundadas de alteración del orden público, con peligro para personas o bienes». 
Entiende la actora (AT) que la intervención gubernativa subvierte los límites del art. 10 LO 9/1983, por cuanto en lugar de estar basada en «razones fundadas de que puedan producirse alteraciones de orden público con peligro para personas y bienes», lo hace dando prioridad a la reivindicación de una política de igualdad.

Con el fin de comprender mejor el sentido del argumento, conviene hacer mención al caso resuelto por STSJPV de 24 de octubre de $2003^{26}$. Se impugnaba igualmente una Resolución del Director de Seguridad Ciudadana del Departamento de Interior del Gobierno Vasco en la que, a diferencia del supuesto que nos ocupa ahora, se determinó que en el Alarde de Hondarribia la AT desfilara «sin solución de continuidad, inmediatamente posterior a la C. J. [AI]». En el examen del fondo del asunto, el Tribunal estimó disconforme a derecho el acto recurrido al apreciar que se producía una vulneración del derecho de reunión de la recurrente que no podía «verse forzada contra su voluntad a desfilar junto a quienes conciben el Alarde en términos que, por las razones que sólo a ellos incumben, no están dispuestos a aceptar». Y prosigue con la siguiente consideración en la que, sin duda, encuentra su apoyo la alegación de la que estamos hablando:

«Es contraria a derecho además, porque desde la necesaria congruencia entre lo resuelto y la finalidad perseguida de garantizar la seguridad, no guarda la debida adecuación, pues la proximidad de ambos grupos sin solución de continuidad favorece el enfrentamiento según enseña una larga experiencia, por lo que en términos de pura razonabilidad no es admisible y evidencia que en realidad la Administración, cierto que inducida a ello por la doctrina de esta Sala, pretende más bien satisfacer un supuesto derecho a la igualdad de quienes quieren participar en el Alarde con una doble función de las mujeres que no aceptan los convocantes, incurriendo por ello en desviación de poder».

En síntesis: teniendo en cuenta que la posibilidad de prohibición o modificación del ejercicio del derecho de reunión únicamente cabe por remisión a las razones de seguridad contenidas en los arts. 21.2 CE y 10 LODR, la búsqueda de finalidades distintas (satisfacción del derecho a la igualdad) mediante esta potestad administrativa de intervención incurre en un vicio — la desviación de poder- determinante de la anulación del acto (art. 63.1 LRJAP).

A vista de este pronunciamiento, el intento de lograr un fallo en el mismo sentido y sustentado en igual argumentación era lógico, teniendo en cuenta, además, los términos del FJ 5. ${ }^{\circ}$ de la Resolución de 10 de junio de 2005, aquí recurrida:

${ }^{26}$ STSJPV (Sala de lo Contencioso-administrativo; Sección 2. a), núm. 783/2003, de 24 de octubre de 2003; recurso núm. 2266/2000; EDJ 2003/156188. 
«Clarificada la naturaleza jurídica del acto comunicado por parte del Tribunal Supremo, como expresión del ejercicio de un derecho fundamental, ha de tenerse en cuenta en segundo lugar que los valores que propugna la citada manifestación "Alarde Igualitario" se encuentran en sintonía con los que predica tanto el estatuto de Autonomía en su art. 9, apartado 2 , como los contenidos en la recientemente aprobada ley 4/2005 para la igualdad de mujeres y hombres. Principios que informan el sentido de los actos de las instituciones públicas vascas, siendo por ello obligación de los poderes públicos, y por lo tanto el objeto de esta Resolución no sólo no poner obstáculos a esta comunicación de manifestación, sino la de tratar de remover aquellos otros que pudieran darse. Poniendo, en su caso, los medios adecuados para su realización efectiva, garantizando y priorizando sobre cualquier otro acto similar la pretensión formulada por los comunicantes de realizar una manifestación para "reclamar la verdadera y efectiva igualdad entre hombres y mujeres en el principal rito de afirmación colectiva de Irún".

Por ello, se hace necesario, además de regular los términos en los que debe celebrarse la manifestación objeto de esta Resolución, hacer llegar a los organizadores del acto denominado "Alarde Tradicional" estas circunstancias, para que adapten sus actos programados en función de las incidencias y repercusiones que la concurrencia de ambos pudiera tener».

No obstante, lo cierto es que la Resolución impugnada motiva la introducción de modificaciones en razones de seguridad que encuentran apoyo en un informe policial. De él se desprende que la coincidencia parcial de espacios y tiempos entre ambas convocatorias puede ocasionar «graves incidencias de orden público» con riesgo para personas y bienes, y más atendiendo al considerable número de personas que los actos congregan. Motivos que encuentran reflejo en el FJ 6..$^{\circ}$ de la Resolución:

«... considerando los antecedentes de años anteriores, la polémica, los incidentes ocurridos y el carácter masivo de la participación en los diversos actos, se hace preciso disponer lo necesario para garantizar que la celebración de los mismos resulte compatible con las exigencias de la convivencia democrática y el orden pacífico ciudadano, minimizando el riesgo para los participantes, tanto del acto "Alarde Tradicional" como de la manifestación comunicada como "Alarde igualitario", salvaguardando la efectiva protección de las libertades y del derecho de reunión y manifestación».

La STSJPV, recordando que el Alarde ha sido fuente permanente de altercados, tiene como «notorio» que es precisamente el abundante despliegue policial el que ha neutralizado los riesgos verificados en ediciones anteriores, evitando alteraciones de orden público que, por lo demás, son nuevamente previsibles.

Por lo referido a la invocación que la resolución impugnada realiza al art. 9.2 CE y la eventual desviación de poder que ésta pudiere contener, se señala que ésta «queda limitada a motivar, a mayor abundamiento una opción 
que, nuclearmente, se funda en la más efectiva preservación del ejercicio del derecho de reunión por ambas Asociaciones promotoras. Por lo que cabe entender que la invocación de la licitud de los objetivos de reclamación de una determinada forma de participación cívica de las mujeres en los actos del Alarde se efectúa a los solos efectos de priorizar el ejercicio de las competencias gubernativas en materia de reunión y manifestación respecto de las competencias municipales en materia de autorización de espectáculos públicos».

Entendemos que del contenido de la Resolución impugnada se sigue que, efectivamente, son razones de orden público las que motivan la modificación parcial de trayectos y horarios efectuada por la autoridad gubernativa. Sin embargo, y aunque compartimos la interpretación de que el argumento «pro igualdad» lo es «a mayor abundamiento», no es tan evidente que la pretensión de «priorizar» se refiera a dar preponderancia a las competencias gubernativas en materia de derecho de reunión sobre las municipales en el ámbito sectorial de espectáculos públicos. Desde nuestro punto de vista, ni la dicción literal del FJ 5. ${ }^{\circ}$ de la Resolución, ni el mismo contexto en el que se hace la afirmación, permiten concluir en esa línea; mas al contrario, parece indicarse que ante actos de un mismo carácter debe prevalecer aquél en el que se propugne la igual participación entre hombres y mujeres ${ }^{27}$ y dicha finalidad, aunque encomiable y legítima, se desmarca de los rigurosos límites a los que se somete la intervención administrativa en este derecho fundamental.

${ }^{27}$ Así parece colegirse de la mención a la Ley del Parlamento Vasco 4/2005, de 18 de febrero (BOPV núm. 42, de 2 de marzo de 2005) para la Igualdad de Mujeres y Hombres. Aunque no se alude explícitamente a artículo alguno, no podemos obviar la intención subyacente en el art. 25 de dicha Ley cuando, bajo el rótulo «Actividades culturales» establece:

«1. Las administraciones públicas vascas, en el ámbito de sus competencias, han de adoptar las medidas necesarias para evitar cualquier discriminación por razón de sexo y para promover un acceso y participación equilibrada de mujeres y hombres en todas las actividades culturales que se desarrollen en el ámbito de la Comunidad Autónoma de Euskadi.

Se prohíbe la organización y realización de actividades culturales en espacios públicos en las que no se permita o se obstaculice la participación de las mujeres en condiciones de igualdad con los hombres.

2. Las administraciones públicas vascas no podrán conceder ningún tipo de ayuda ni sus representantes podrán participar en calidad de tales en ninguna actividad cultural, incluidas las festivas, las artísticas, las deportivas y las realizadas en el ámbito de la normalización lingüística del euskera, que sea discriminatoria por razón de sexo. (...)».

No obstante, y considerando el enlace del Alarde con el derecho de reunión, debe entenderse de aplicación el art. 3.2 («Igualdad de oportunidades») de la misma Ley, según el cual: «Los poderes públicos vascos deben adoptar las medidas oportunas para garantizar el ejercicio efectivo por parte de mujeres y hombres, en condiciones de igualdad, de los derechos políticos, civiles, económicos, sociales y culturales y del resto de derechos fundamentales que puedan ser reconocidos en las normas (...)». 


\section{Consideraciones finales}

El recorrido por la jurisprudencia sobre los Alardes evidencia que ésta se encuentra cargada de aristas, diversidad de planos jurídicos y subterfugios de todo tipo que, de algún modo, han sobredimensionado el conflicto.

La mejor muestra de ello es posiblemente la STS de 2 de junio de 2003 que, considerando el Alarde como expresión del derecho de reunión, termina por dar una solución que, opinamos, es poco convincente y jurídicamente cuestionable. En todo caso, y habida cuenta que a partir del mencionado fallo, es la doctrina que debe aplicarse, lo previsible es que los conflictos que puedan seguir produciéndose se ciñan al control de las resoluciones administrativas que, en uso de las facultades contenidas en la LODR, procedan a la modificación de los términos de las distintas convocatorias.

No podemos concluir esta reflexión sino trasladando nuestra opinión de que, siendo legítimas las distintas concepciones existentes sobre el Alarde, lo auténticamente lamentable es la manifiesta y reiterada incapacidad de los colectivos involucrados y de las propias instancias públicas para lograr que una celebración festiva discurra por los cauces pacíficos exigibles y sin necesidad de las intervenciones gubernativas, policiales y judiciales hasta ahora siempre presentes.

Tal vez esta tónica haya empezado a romperse el presente año, primera ocasión en que las partes implicadas en el Alarde de San Marcial de Irún han decidido aceptar los términos de la Resolución de la Dirección de Seguridad Ciudadana del Gobierno Vasco y no acudir a la vía judicial. 


\title{
Fibromialgia y/o Síndrome de la Fatiga Crónica. Una propuesta para la aproximación a su doble dimensión jurídica y médica ${ }^{1}$
}

\author{
Javier León Iglesias \\ Abogado
}

Licenciado en Derecho por la Universidad de Deusto

Doctor en Medicina por la Universidad del País Vasco

\begin{abstract}
Resumen: En los últimos años hemos venido presenciando grandes cambios en relación con las enfermedades crónicas, tanto cuantitativa -incremento significativo de afectados_- como cualitativamente — distintas formas de enfermar-. Surgen así las realidades clínicas derivadas de la Fibromialgia - FM- y/o Síndrome de la Fatiga Crónica - SFC - .

Con unas particularidades clínicas similares —dolor músculo-esquelético difuso crónico y fatiga severa-, cuentan con una elevada epidemiología y una dificultad para su objetivación, pues las pruebas diagnósticas suelen arrojar resultados de práctica normalidad, lo cual engendra serios problemas para su consideración como entidades socio-laborales, conforme a la definición legal de Incapacidad Permanente.

Previo estudio de 77 expedientes de invalidez en los que figuraban estos diagnósticos, nos encontramos con personas que desempeñaban, en su mayoría, profesiones de contenido físico, y que padecían un mayor número de entidades artrósicas, herniarias y ansioso-depresivas respecto al colectivo general de sujetos con estos procesos patológicos.

Resulta aún muy discutida, en el ámbito clínico y jurídico, la influencia que tienen en la FM y/o SFC las alteraciones psicológicas, no así su importante coste farmacológico - la polimedicación observada representa 1.634,19 euros por persona y año-- y prestacional —un 14,66\% del conjunto de pensiones de Incapacidad Permanente en los grados de Absoluta y Total que abona el INSS-.
\end{abstract}

Palabras clave: Fibromialgia, fatiga crónica, incapacidad laboral.

Abstract: During recent years we have been able to observe significant changes in the field of chronic diseases, both in form (different ways to acquire the illness) and factor (significant increase in the number of affected subjects). As such, new clinical realities taking after Fibromyalgia -FM- and Chronic Fatigue Syndrome - CFS—, are happening.

${ }^{1}$ A los Profesores Ricardo Franco y Fernando Manrique. El primero de ellos me acercó al apasionante mundo de la ciencia médica, mientras que debo al segundo mi formación como jurista. Ambos me enseñaron que la persona que desempeña cualquier tipo de modalidad profesional es precisamente, y antes que cualquier otra cosa, eso: persona. 
With similar clinical specificities - chronic diffuse muscle-skeleton pain, and severe fatigue-, that account for a high epidemiologic base, and pose serious difficulties as to their objectification, since diagnosis tests will normally throw up results of practical normality, it represents a serious problem as to their being considered socio-labour entities, in accordance with the legal definition of Permanent Disability.

Following a study of 77 disability dossiers, where these diagnosis were to be found, we encountered subjects who were in the majority of cases engaged in physical related professions, and who were subject to a higher number or arthrosis, hernia, and anxious-depressive states than those affecting the broader population with similar patogenous processes.

It is still highly debated within the legal and medical arena, the influence FM and CFS may have in a psychological disorder, even though its high pharmacological cost is a proven fact -observed polymedication represents 1.634,19 euros per head/year - as it also is benefit wise -accounting for up to 14,66\% of the global figure of Absolute and Total Permanent Disability Pensions, being handed over by the INSS-.

Key words: Fibromyalgia, Chronic Fatigue, Work disability.

En los albores del siglo XXI, el Derecho tiene la misión de dar respuesta, ahora más que nunca, a una nueva, a la vez de compleja, dinámica social, uno de cuyos principales paradigmas — un logro de la Medicina - es que contamos con una esperanza de vida más larga; si bien la otra cara de la moneda la encontramos en el panorama epidemiológico actual sobre enfermos crónicos y su correlato necesario en el ámbito de las incapacidades laborales. No en vano, los datos de la encuesta sobre discapacidades, deficiencias y estado de Salud (EDDES) recogidos por el Instituto Nacional de Estadística (INE) ${ }^{1}$, revelan que en torno a 19 millones de españoles padecen procesos patológicos crónicos, de los cuales tan sólo el 20,7\% permanecen en activo laboral.

Los cambios sociales que estamos presenciando en los últimos años afectan, incluso, a las formas de enfermar. Sirva como ejemplo ${ }^{2}$ la epidemia ocurrida a mediados de la década de los ochenta en el sector de operadores de teléfono y teclados - Telecom Australia - en la que, sin motivo aparente, un buen número de personas presentaban una serie de menoscabos dolorosos, ocasionados - se pensaba entonces - por esfuerzos repetitivos, lo que motivó múltiples reclamaciones indemnizatorias, procedimientos judiciales en definitiva, por esta pérdida de la capacidad laboral.

Hoy sabemos que este acontecimiento, que trajo de cabeza a los operadores médico-legales de aquel país, pudo atribuirse a las entidades clínicas que ahora nos ocupan: la Fibromialgia —en adelante FM - y/o Síndrome de la Fatiga Crónica - SFC-.

Fue Hench quien en 1975 incorporó el vocablo FM, si bien habríamos de esperar hasta 1990 para que el American College of Rheumatology ${ }^{3}$ fijara los 
criterios para su clasificación, cuyo eje fundamental lo representan los 18 puntos - tender points - distribuidos en la anatomía corporal del sujeto evaluado - se reproducen en la Tabla número 1 -, de los cuales al menos 11 deben ser sumamente dolorosos a la palpación por el facultativo. En consecuencia, podemos definir la $\mathrm{FM}^{4,5}$ como un trastorno caracterizado por la aparición de dolor músculo-esquelético difuso crónico que, a menudo, se acompaña de un cortejo sintomático de, entre otros, rigidez matutina, sueño no reparador, fatiga y debilidad, cefaleas, colon irritable, fenómeno de Raynaud, síndrome seco y trastornos emocionales. Aunque sus mecanismos de producción son hoy por hoy desconocidos, el mayor consenso doctrinal ${ }^{6}$ viene a considerar que lo que en realidad ocurre es que se pone de manifiesto una disfunción en los mecanismos de la modulación y de la percepción del dolor en proporciones superiores a lo que se considera como clínicamente normal, habiéndose comprobado, a su vez, un trastorno neurológico caracterizado por el incremento de los tonos simpáticos y descenso de los parasimpáticos ${ }^{7}$.

Desde su reconocimiento por la Organización Mundial de la Salud, OMS, en 1992, y su consiguiente tipificación en el manual de clasificación internacional de enfermedades (ICD 10) con el código M79-0, su prevalencia ha ido aumentando progresivamente. En nuestro país, el trabajo publicado por la Sociedad Española de Reumatología ${ }^{8}$ habla en favor de un nivel aproximado de afectación del 2,37\% en personas mayores de 20 años - con una relación mujer-varón de $21-1-$, por lo que se estima que alrededor de 700.000 españoles cumplen con los criterios de la FM.

Una clínica muy similar a la del SFC — por lo que en este trabajo abordamos conjuntamente ambas realidades clínicas-, cuyos criterios —esta vez diagnósticos- - se fijan en $1994^{9}$ - Tabla número 2- Nos encontramos, pues, ante una entidad clínica a la que algunos trabajos ${ }^{10}$ atribuyen una epidemiología de un 2,6\% de la población general, y que se caracteriza por fatiga severa incapacitante en combinación con otros síntomas: trastornos en la concentración y en la memoria breve, alteraciones del sueño y dolor músculo-esquelético.

Sentados estos presupuestos, el lector posiblemente se preguntará qué papel juega el Derecho y, más concretamente, el Derecho de la Seguridad Social como disciplina autónoma ${ }^{11}$, en el ámbito de estas patologías. La respuesta - descrita en la literatura médica cuando se apunta a la, también, alta incidencia en el ámbito laboral, habida cuenta de que los sujetos afectados forman parte, en su mayoría, de la población activa ${ }^{12,13}$ - viene de la mano de la propia práctica jurídica, cuando los operadores intervinientes en este tipo de procesos se cuestionan la conveniencia o no de las incapacidades laborales.

Y centrado en estos términos el debate, proponemos un sistema de investigación en consonancia con una de las principales funciones del Derecho, que es la de ajustarse a las demandas sociales de cada momento. Parece cla- 
ro, en este sentido, que, si atendiéramos exclusivamente a los posicionamientos jurisprudenciales sobre la materia, estaríamos obviando no solamente los resultados de las investigaciones clínicas — con el quantum estadístico obtenido sobre los datos que se infieren de la entrevista clínica, exploración física o la terapéutica-, sino que también la opinión, igualmente cualificada, que tienen los facultativos sobre el eventual reconocimiento de la prestación de Incapacidad Permanente a personas afectadas de FM y/o SFC.

El punto de partida necesario de esta dinámica de trabajo debe ser, por ende, el análisis del panorama normativo y jurisprudencial de la pensión de referencia en nuestro país. Así las cosas, conforme al artículo 136.1 del Real Decreto Legislativo 1/1994 de 20 de junio, por el que se aprueba el Texto Refundido de la Ley General de la Seguridad Social -LGSS—, en la modalidad contributiva, es Incapacidad permanente la situación del trabajador que, después de haber estado sometido al tratamiento prescrito y de haber sido dado de alta médicamente, presenta reducciones anatómicas o funcionales graves, susceptibles de determinación objetiva y previsiblemente definitivas, que disminuyan o anulen su capacidad laboral (...). El primer pasaje de la definición legal que genera controversia en el ámbito de los síndromes que nos ocupan es el que apunta a que las lesiones han de ser determinadas objetivamente, pues un nuevo elemento de identificación entre la FM y el SFC es el que trae causa en la práctica normalidad de las pruebas analíticas y complementarias de diagnóstico, que es menester realizar para acreditar que los síntomas existen y son tan severos como la persona afectada apunta en la anamnesis - entrevista clínica- No se ponen de acuerdo las publicaciones jurídicas de los últimos años sobre el verdadero alcance que debe conferirse a esta determinación objetiva, pues, aun cuando algunos $^{14}$ informan de que para comprobar las reducciones anatómicas o funcionales deben practicarse pruebas médicas fiables — resonancia magnética, radiografías...-, otros, por el contrario ${ }^{15}$, utilizan la disyuntiva determinación objetiva o diagnóstico del proceso patológico presente y comprobado, es decir, podría encajar en la acción protectora del precepto la confirmación médica del padecimiento, aunque las pruebas clínicas no arrojen datos patológicos —en este sentido, también, las sentencias del Juzgado de lo Social n. ${ }^{\circ} 32$ de Barcelona de 4-2-02, y del Juzgado de lo Social n. ${ }^{\circ} 3$ de Álava de 8-10-02-.

Nuestra Sala de lo Social del Tribunal Superior de Justicia del País Vasco acoge esta última doctrina — sentencia de 18 de marzo de 2003 —, añadiendo que las alteraciones sensoriales — de las que el dolor es la más habitual- son deficiencias a tener en cuenta, según lo dispuesto en el artículo 136.2 de la LGSS. Ahora bien, dudamos de la aplicación del precepto invocado, habida cuenta de que define el alcance prestacional de la Invalidez, pero en su modalidad no contributiva. De cualquier forma, este órgano judicial no siempre ha mantenido el mismo criterio. Recordemos, en este sentido, aquellas sentencias que informaban de que en la FM no constaba patolo- 
gía orgánica, concreta y determinada que la justificara, por lo que no encajaba dentro de los supuestos objetivables a que se refiere el artículo 136.1 de la LGSS —resoluciones judiciales de 11-2-03, recurso n. ${ }^{\circ} 23 / 03$, y de 29-4-03, Recurso n. ${ }^{\circ}$ 691/03, entre otras-.

Por su parte, no siempre es precisa el alta médica para acceder a la Incapacidad Permanente, según la literalidad del artículo - tras haber permanecido el beneficiario en Incapacidad Temporal durante un período de 12 meses, prorrogables por 6 más, y, llegando, en supuestos de demora de la calificación de Invalidez, hasta un máximo de 30, todo ello según lo dispuesto en los artículos 128 y 131 Bis $2 .^{\circ}$, párrafo $2 .^{\circ}$ de la LGSS-, por cuanto que además de la situación de no alta restringida al acceso a la Incapacidad Permanente en el grado de Absoluta - de la que luego trataremos-o Gran Invalidez, conforme se dispone en el artículo 138.3 de la LGSS, y la de asimilación a trabajadores por cuenta ajena; nos encontramos con una de las cuestiones más complejas del sistema de Seguridad Social: las situaciones asimiladas al alta. Entre los supuestos previstos legalmente, provocan un especial debate en los procesos de Seguridad Social aquellos casos en los que el presunto beneficiario de invalidez pretende acceder a la pensión permaneciendo como demandante de empleo, una vez agotada la prestación contributiva o asistencial, amparándose, en efecto, en el artículo 36, párrafo 1. , del Real Decreto 84/1996 de 26 de enero, pues por circunstancias vitales diversas - que habrán de analizarse detenidamente en el marco de una interpretación no formalista y humanizadora, v.g. sentencias del Tribunal Supremo de 12-7-1988, 13-9-1988 y 26-1-1998, entre otras- puede haber dejado de sellar su cartilla durante un período de tiempo determinado.

A modo de Derecho comparado, en EE.UU. ${ }^{16}$ se define esta modalidad prestacional como «la incapacidad para llevar a cabo cualquier tipo de actividad remunerada, en sus tareas fundamentales, a causa de un impedimento físico o mental demostrable por médicos e informes médicos durante un período ininterrumpido de, al menos, doce meses», si bien su alcance se encuentra condicionado por la Disability evaluation under social security, una lista cerrada de patologías susceptibles de Invalidez, similar a la puerta que deja abierta el artículo 137.3 de la LGSS para el desarrollo reglamentario por el Gobierno, previo informe del Consejo General del INSS, de una similar enumeración legal.

Concluye este artículo 136.1 de la LGSS indicando la necesaria acreditación de una disminución o anulación de la capacidad laboral del sujeto evaluado, lo cual, en realidad, se constituye como marco para la posterior clasificación de los grados de Incapacidad Permanente, en función de la aptitud profesional residual en cada caso. Nosotros nos ocupamos de los grados de Absoluta y Total, únicos acotados en la investigación.

Así, la Incapacidad Permanente Absoluta - IPA — del artículo 137.1.c de la LGSS, definida en el artículo 137.5 de la misma normativa sustantiva, es la situación que inhabilita por completo al trabajador para toda profesión 
u oficio, y a la que se asigna legalmente el $100 \%$ de la base reguladora. De una primera lectura podría parece ${ }^{17}$ que difícilmente se encontrarán supuestos que encajen plenamente con este descriptor, de no ser por las previsiones del artículo 141.2 de la LGSS que permiten la compatibilidad de la pensión con el ejercicio de actividades acordes con el estado del inválido, y que no representen un cambio en su capacidad de trabajo a efectos de revisión. Son además indicativas de que en esta materia no se van a crear precedentes jurisprudenciales aquellas resoluciones judiciales que vienen a indicar que la misma enfermedad afecta en mayor o menor grado a una persona, mientras que en otra escasamente afecta a su capacidad -Auto del Tribunal Supremo de 9-7-92, recurso 2144/91-, lo cual no impide la existencia de una doctrina de general aplicación sobre este grado de acción protectora de la IPA, como la que diferencia toda posibilidad física para realizar cualquier quehacer laboral, de aquella otra situación de quien, aún con aptitudes para alguna actividad, no la pueda consumar con cierta eficacia - sentencia de la Sala de lo Social del Tribunal Superior de Justicia de Navarra de 15-12-97-, aunque siempre en consideración a las limitaciones que concurren de manera individualizada en el expediente que ha de juzgarse, más que en los padecimientos en sí mismos - sentencia de la Sala de lo Social del Tribunal Superior de Justicia de La Rioja de 2-2-99, entre otras-.

Por su parte, el artículo 137.1.b de la LGSS en relación con el 137.4 delimita la acción protectora de la Incapacidad Permanente Total - IPT-, disponiendo la inhabilidad del trabajador para la realización de todas o de las fundamentales tareas de su profesión habitual, siempre que pueda dedicarse a otra distinta. Su correlato económico se traduce en un 55\% de la base reguladora, o en un $75 \%$ si, entre otros requisitos, el beneficiario cuenta con 55 o más años. Para analizar la profesión habitual a la que el trabajador dedicaba su actividad fundamental previamente al inicio de la incapacidad, obligada es la valoración - siguiendo las Fundamentaciones del Tribunal Supremo, v.g. 21-11-96, Recurso 465/96- de todas las circunstancias de la actividad de trabajo, incluida la incompatibilidad con un ambiente determinado, si bien esta solución puede chocar con la pacífica - ahora sí- doctrina jurisprudencial en el sentido de que no cabe equiparar el concepto jurídico de profesión habitual con el de categoría, y menos aún con el de que trae causa en el puesto de trabajo, pues la pérdida de este último no siempre implicará que el sujeto no pueda seguir desempeñando su profesión en otro centro de trabajo o, incluso, con encuadramiento en otro régimen de la Seguridad Social.

En los casos de FM y/o SFC nos encontramos, además, con una dificultad adicional. Recordemos que el colectivo afectado lo conforman fundamentalmente mujeres, relegadas hasta ahora, en muchos casos, a las funciones de ama de casa y, a pesar de que se han dado ya los primeros pasos para la valoración económica de la producción doméstica, atribuyéndole de lege ferenda ${ }^{18}$, entre otras, la categoría laboral del trabajador autónomo, confor- 
me a lo dispuesto en la disposición adicional primera de la Ley 24/1997, de 15 de julio, de Consolidación y Racionalización del Sistema de Seguridad Social, lo cierto es que en la actualidad no se les atribuye una concreta dimensión jurídico-laboral y, por tanto, no están protegidas por la prestación permanente analizada en su nivel contributivo.

Todo cuanto acaba de indicarse se sustancia por los cauces procedimentales, primero de la vía administrativa —en la que intervienen los Equipos de Valoración de Incapacidades, adscritos a las diferentes Direcciones Provinciales del Instituto Nacional de la Seguridad Social, cuya constitución y competencias aparecen reguladas en el Real Decreto 1300/1995 de 21 de julio y, para su aplicación y desarrollo, en la Orden de 18 de enero de 1996-, y, una vez concluida ésta, - normalmente con resolución denegatoria en los supuestos de FM y/o SFC - se seguirán los trámites de la vía judicial previstos legalmente en el texto refundido de la Ley de Procedimiento Laboral (Real Decreto Legislativo 2/1995 de 7 de abril) y la Ley de Enjuiciamiento Civil con carácter supletorio. Por ello, en lo sucesivo se citarán siempre Sentencias Judiciales — de Juzgados de lo Social (SJS) y de las Salas de lo Social de los Tribunales Superiores de Justicia (STSJ) - correspondientes a los expedientes de las personas que formaron parte de nuestra muestra.

Pero ¿cómo encajar la FM y/o SFC en estos presupuestos jurídicos, si los médicos a los que corresponde, en primera instancia, la valoración del cuadro no se ponen de acuerdo sobre la conveniencia o no de la incapacitación de estas personas? Basta, en este sentido, con comprobar que mientras White ${ }^{19}$ critica la actitud de aquellos sectores clínicos que argumentan que la única razón por la que este síndrome - FM - existe es por contar con un sistema de pensiones un tanto generoso que está preparado para ser «desplumado» por unos individuos que reivindican estar demasiado enfermos para trabajar otros, por el contrario ${ }^{20}$, justifican los efectos contraproducentes de, incluso, la Incapacidad Temporal en estos pacientes, en el convencimiento de que serán más conscientes del dolor como consecuencia de la inactividad, se sentirán aislados, el descenso en su productividad les llevará a una pérdida de la autoestima, tendrán problemas económicos, perdiendo, además, su estabilidad laboral, estarán atemorizados por el momento en el que, en su caso, hayan de reincorporarse al trabajo, sin olvidar, tampoco, los problemas familiares provocados por todo cuanto antecede.

Partiendo de esta variada gama de opiniones, en nuestro trabajo nos planteábamos, a modo de objetivos, de una parte, conocer las, en su caso, especiales características que presentan aquellos afectados de FM y/o SFC que inician - $\mathrm{O}$ se les instruye - un proceso de Incapacidad Permanente, respecto a quienes no lo hacen, por ejemplo en cuanto a comorbilidad, tratamientos... ; y, de otra parte, intentábamos llegar a un consenso entre la clase médica y jurídica sobre la dinámica médico-legal que debía seguirse en lo sucesivo, en consideración a los contenidos de las referencias médico-cien- 
tíficas y las sentencias judiciales, valoradas de forma cualitativa-descriptiva y analítica. No obstante lo anterior, consideramos, también, que se hacía preciso aplicar la estadística, siquiera como instrumento coadyuvante, a los expedientes de Incapacidad Permanente en los que figuraban los diagnósticos de FM y/o SFC, y que se instruyeron por quien suscribe desde el 23 de febrero de 1999 hasta el 31 de julio de 2004 -muestra de 77 expedientes tramitados en distintas provincias españolas-. Solamente desde esta última perspectiva metodológica, estábamos en disposición de aproximarnos a los criterios que pudieron influir en el sentido de la resolución de los casos - estimatoria o desestimatoria-, como son el sexo del juzgador, el contenido de la profesión habitual o los meses consumidos previamente de la prestación de Incapacidad Temporal.

Finalmente, un estudio de estas características precisaba de un cómputo, siquiera aproximado - pues no debe pasarse por alto que contamos con limitaciones metodológicas ${ }^{21}$ - tanto del coste farmacológico medio que provocan los sujetos analizados, como de los montantes económicos que representan los pensionistas que padecen estas realidades clínicas respecto al total de incapacitados permanentes, únicamente en los grados — recordemos- de total y absoluta, para lo que nos apoyamos en los datos facilitados por la entidad gestora Instituto Nacional de la Seguridad Social.

Los resultados pusieron de manifiesto que nos encontramos fundamentalmente con mujeres — como era de prever $(90,90 \%)$ - , con una media de edad de 48,35 años, residentes en un entorno en su mayoría urbano - industrial o sector servicios $(94,80 \%)$ - y que, finalmente, desarrollaban profesiones de contenido eminentemente físico $(59,74 \%)$, aunque son, paradójicamente, las de tipo sedentario y/o intelectual en las que los datos estadísticos nos muestran una cierta tendencia a la estimación, aunque sin contraste - esta particularidad estadística obedecía a la muestra utilizada, un tanto escasa, así como a la categorización que fue diseñada al efecto-.

Esta dicotomía profesional - física frente a sedentaria - y su incidencia en la incapacitación de los afectados de FM y/o SFC se confirman plenamente en las sentencias analizadas, pues, aun cuando para algunos Juzgadores $a$ quo en el dolor fibromiálgico severo y rebelde al tratamiento está contraindicada la realización de esfuerzos, manejo de pesos, posturas prolongadas, también de bipedestación, y movilidad continua de las articulaciones, agravando todos estos parámetros la sintomatología - SJS n. ${ }^{\circ} 1$ de Vizcaya de 22-11-00, SJS n. 3 de Vizcaya de 24-5-01, SJS n. ${ }^{\circ} 2$ de Palencia de 15-10-03, SJS n. ${ }^{\circ} 3$ de Guipúzcoa de 13-2-04-, pues es el dolor el que limita la movilidad al margen del estado físico de las articulaciones - SSTSJ del País Vasco de 30-11-01, recurso n. ${ }^{\circ}$ 2110/2001, SJS n. ${ }^{\circ} 3$ de Vizcaya de 22-10-02, lo cual resulta predicable del SFC, sobre el cual se postula la evitación de actividades de esfuerzo físico (en atención a la fatiga crónica objetivada a través de la febrícula y astenia) - SJS n. ${ }^{\circ} 8$ de Vizcaya de 26-11-01—; para otros, por el contrario, deben prevalecer, no sólo los resultados de las prue- 
bas radiográficas que, en efecto, no objetivan signos que justifiquen el cuadro doloroso y la limitación funcional referida por los pacientes - SJS n. ${ }^{\circ} 3$ de Vizcaya 29-1-01 - , sino que también el estado de la movilidad de las articulaciones - SSTSJ del País Vasco de 14-5-02, recurso n. ${ }^{\circ}$ 902/2002-. Repárese en que lo que en realidad se discute es cuál es el dato exploratorio que debe considerarse a los efectos de la calificación de la Incapacidad Permanente: limitaciones de movilidad articular o restricciones dolorosas de la movilidad.

Por contra, en los trabajos clínicos se llega a un cierto consenso a la hora de considerar estos factores de sobrecarga mecánica de los músculos ${ }^{22}$ y de realización de esfuerzos propios de las profesiones de contenido eminentemente físico, especialmente repetitivos ${ }^{23}$, como agravantes de las manifestaciones álgicas que, por ende, deben reducirse en el puesto de trabajo; no siendo ésta una idea nueva, desde el momento en que ya en una publicación editada en $1929^{24}$ se trataba la incidencia que en la, entonces, Fibrositis tenía la exposición al esfuerzo, lo cual se ejemplificaba con los mineros que presentaban dolor en la región dorsal y hombros como consecuencia del empleo del pico en posición forzada, y ello sin perjuicio de que se abogaba, también, por promover desde el principio los movimientos y ejercicios activos para evitar la rigidez.

Ahora bien, a pesar de la mayor tendencia a la estimación observada, también encontramos controversia en las sentencias en torno a la contraindicación o no de permanecer en posiciones sedentes constantes, características de las profesiones de tipo administrativo. La solución positiva la encontramos en aquellos fundamentos jurídicos que inciden en que los dolores generalizados, particularmente intensos en columna cervical, lumbar y en extremidades superiores, impiden la adopción de posturas sedentes - SSTSJ de Madrid de 15-10-02, recurso n. . 307/2002-; frente a aquellos otros en los que se sostiene que el dolor aparecería al cabo de un lapso temporal importante en este tipo de posiciones, pues hasta ese momento la capacidad es ordinaria - SJS n. ${ }^{\circ} 8$ de Vizcaya de 23-9-02-.

Por su parte, los promedios estadísticos nos mostraban una permanencia en Incapacidad Temporal previa al procedimiento de Invalidez de 15,05 meses - con tendencia a la estimación a mayor lapso temporal transcurrido-, de lo que deducimos un primer elemento de diferenciación entre nuestra muestra y el colectivo general de pacientes, que acreditaban 9,01 meses consumiendo este tipo de prestación ${ }^{25}$.

En cuanto a los antecedentes personales, llamaba nuestra atención la alta prevalencia de apendicectomías hallada en estas personas -22,07\%—, lo cual confirmaba nuestra hipótesis inicial de una mayor presencia de este tipo de intervenciones quirúrgicas respecto a la población general, como ya se informaba, por otra parte, a inicios del siglo pasado ${ }^{24}$, es decir, un punto sensible a nivel de los músculos oblicuos derechos acompañado de dispepsia vaga podía ser y, a veces, era confundido con la apendicitis, y lo que resulta 
más preocupante, que aquel proceso sería culpable, en algunos casos, de operaciones para la extirpación del apéndice por el cirujano, quien luego habría de apelar a su imaginación para descubrir la concreta lesión hallada.

Continuamos analizando los datos que se extraían de la anamnesis -entrevista clínica médico-paciente-, entre los que destacan como más significativos la historia patobiográfica de acontecimientos vitales adversos -69,76\% - , la disminución o pérdida de la apetencia sexual -81,81\% —, a menudo relacionada con el cansancio, los trastornos psicológicos y la medicación; y, finalmente, las disfunciones cognitivas -en las que se observa una cierta tendencia a la estimación de los supuestos en los que aparecen- descritas por la literatura médica para estos procesos: disfunciones en la atención y concentración, trastornos en la memoria a corto plazo y disfasia nominativa, esta última entendida como la dificultad para adjudicar el fonema correspondiente a la designación de objetos y personas (v.g. cosa, casa...).

Cuestión más compleja es la de la comorbilidad — concurrencia de otras patologías - sobre todo, la psiquiátrica. Así pues, comprobamos que en comparación con otros trabajos que atendían metodológicamente a pacientes con FM y/o SFC en general, nuestros potenciales beneficiarios de Incapacidad Permanente contaban con un mayor número de procesos artrósicos -74,02\%-, herniarios - 45,45\% - y ansioso-depresivos - 66,23\%-. En los dos primeros se observaba, sorprendentemente, una cierta tendencia a la desestimación, mientras que los casos que prosperaban más habitualmente —normalmente en el orden jurisdiccional social, como se indicó más atrás, eran aquellos en que la FM y/o SFC aparecían asociadas a cualquier tipo de psicopatología, o bien en estado puro (en el cuadro clínico solamente figuraban estos síndromes).

Y hablamos de dificultad en lo concerniente a la comorbilidad psiquiátrica, por cuanto que nos adentramos en uno de los mayores debates - en el sector médico y jurídico- sobre estos síndromes: ¿es antes el huevo o la gallina?, es decir, ¿la clínica de la FM y/o SFC provoca las alteraciones psicológicas, o éstas influyeron decisivamente en el diagnóstico?

No debe pasarse por alto, en este sentido, que ya en el siglo XIX Charcot incluyó como una más a la Histeria — que debe su nombre a los Griegos, porque atribuían al útero (Hysterá en griego) la causa de sus trastornosdentro del catálogo de enfermedades, y que los que a día de hoy analizan su influencia en la $\mathrm{FM}^{26}$, sin perder de vista en ningún momento que las algias están presentes, aducen que la Histeria recurre en ocasiones al padecimiento corporal desplazándose allí el centro de su atención y de su sufrimiento, pues el dolor psíquico hace desaparecer la palabra y el pensamiento, transmutándose por fin, en dolor físico; es decir, siguiendo las aportaciones psicosomáticas de Pierre Marty, un complejo proceso a través del cual estos pacientes tratan de resolver a través del cuerpo algo que no pueden manejar de otra forma. 
De cualquier forma, las conclusiones que se alcanzan difieren bastante entre sí. Mientras Rotés ${ }^{27}$ — uno de los padres de los reumatólogos de nuestro país- y Nielson et $\mathrm{al}^{28}$ piensan que los trastornos psicológicos y los funcionales forman parte del círculo de la Fibromialgia, desde el momento en que la depresión desmotiva al enfermo con lo que aumenta su dolor crónico; y, de igual forma, la sensibilización central, al provocarle más dolor, le hunde a nivel psicológico; otros ${ }^{29}$, en cambio, no perciben esta recíproca causalidad con tanta nitidez, pues advierten que la presencia de una psicopatología relevante en un paciente con este diagnóstico no implica que ambas condiciones no pueden coexistir paralelamente sin ninguna influencia entre ellas; dándose, además, la circunstancia ${ }^{30}$ de que la inespecificidad de algunos de los síntomas - sueño no reparador, dificultad en la memoria y en la concentración, mialgias, fatiga...- aparecen también en la depresión, y sugiriéndose ${ }^{23}$, incluso, que la FM —aplicable también al SFCconstituiría una «enfermedad de moda», que enmascararía, bien un trastorno de somatización como consecuencia de la dificultad de afrontamiento de los problemas cotidianos, o bien una forma de vida con ansiedad o depresión.

La clase judicial no es ajena a esta polémica, desde el momento en que elucubra en el sentido de que está aún por determinar por la ciencia médica si la FM si es consecuencia de padecimientos psíquicos, o a la inversa, los padecimientos psíquicos son efecto secundario de la propia referencia álgica -SJS n. ${ }^{\circ} 7$ de Vizcaya de 13-1-03-. Ahora bien, hay quien se posiciona directamente en la primera de las alternativas expuestas - las referencias álgicas referidas por los pacientes están relacionadas con el subjetivismo y sus problemas psíquicos, SJS n. ${ }^{\circ} 5$ Vizcaya de 15-10-01 y 30-11-01, respectivamente-, aludiéndose, incluso, en algunos supuestos, a que el diagnóstico de neurosis histérica influiría sobre la percepción del dolor - SJS n. 7 de Vizcaya de 18-2-03, SSTSJ del País Vasco de 5-3-04, recurso n. ${ }^{\circ}$ 3005/2003-.

De todas formas, observamos una favorable acogida de las pretensiones de la prestación analizada — no en todos los casos, conforme a los datos estadísticos-, cuando concurre en comorbilidad el psicodiagnóstico de trastorno depresivo mayor, lo que evidencia la existencia de un menoscabo psiquiátrico severo y un superior deterioro de las facultades cognoscitivas - SJS n. ${ }^{\circ}$ 9 de Vizcaya de 28-2-02, SJS n. ${ }^{\circ} 4$ de Vizcaya de 25-9-02-. Se llega a asociar con esta consideración nosológica psíquica la clínica de severa pérdida de memoria, atención y concentración, propia de la FM y/o SFC, según hemos explicado anteriormente, lo cual, nos parece, en principio, un contrasentido - SJS n. ${ }^{\circ} 7$ de Vizcaya de 4-2-04-.

Tampoco parece que estén en lo cierto aquellos magistrados que, en aplicación de una doctrina uniforme, señalan que en cuanto a las más numerosas sentencias que aprecian situación de Invalidez lo hacen, por lo general, en supuestos en que la FM aparece en calidad de enfermedad concomitante 
o asociada a otras patologías, normalmente de índole depresiva - SJS n. 2 de Vigo de 9-7-03 y SJS n. ${ }^{\circ} 3$ de Guipúzcoa de 26-11-03-, pues la estadística revela, también, una mayor tendencia estimatoria cuando nos encontramos ante una FM y/o SFC puros.

Nos ocupamos ahora de la exploración física, a través de la cual se determinó en nuestra serie una media de 16,23 puntos sensibles de los reproducidos en la Tabla número 1 que, nuevamente, llama nuestra atención, y que provocan una cierta tendencia a la desestimación de la pensión cuanto mayor es su número; lo cual pondría, en definitiva, de manifiesto la controversia al menos en el ámbito judicial — de su utilidad clasificatoria; y ello a pesar de lo que se aduce en contrario en algunas resoluciones judiciales: la jurisprudencia y la doctrina médica son unánimes a la hora de determinar que la FM adquiere la categoría de enfermedad grave e invalidante cuando supera los 18 puntos dolorosos - SJS n. ${ }^{\circ} 2$ de Vigo de 9-7-03, SSTSJ de Cantabria de 24-6-04, recurso n. ${ }^{\circ}$ 112/04-.

Constituyen, también, datos exploratorios relevantes las restricciones dolorosas de la movilidad $-82,85 \%$ - las contracturas musculares $-70,76 \%$ - o la disminución de la fuerza segmentaria - 63,63\%—.

Su importancia a los efectos prestacionales que nos ocupan, se confirma desde el momento en que, ciertamente, no $\operatorname{contamos}^{8}$ con ningún signo o prueba de laboratorio que coadyuve en el diagnóstico, lo que hace que la FM - y por extrapolación, el SFC - entren a formar parte de esa categoría de los síndromes funcionales-somáticos que se estructuran más por los síntomas que por las pruebas complementarias. No es — asegura Rivera ${ }^{32}$ - como una gripe en la que los signos son tan precisos que sólo existen dos posibilidades, la tienes o no la tienes.

Por ello, los magistrados echan de menos una valoración pormenorizada de los efectos funcionales de estos síndromes. La proyección incapacitante de dicho padecimiento, se indica, requiere una particular rigurosidad en la prueba - SJS n. ${ }^{\circ} 5$ de Zaragoza de 14-3-02, SSTSJ de Cataluña de 17-1-03, recurso n. $.^{\circ} 2672 / 2002$, entre otras-.

Nuestra muestra, por otra parte, se encontraba en su mayoría polimedicada $-74,02 \%$ - dato este que, en comparación con los resultados que se deducen de la investigación liderada por Wolfe ${ }^{33}$, sugiere un nuevo elemento diferenciador entre nuestra serie que postula la prestación de Incapacidad Permanente, y el grupo general de pacientes de FM y/o SFC en el que no concurría esta multifarmacología. Además, el coste farmacéutico que representaban las personas a las que se les habían pautado amitriptilina, paracetamol, antiinflamatorios no esteroideos, tramadol y opioides ascendía a $1.634,19$ euros por persona y año.

Finalmente nos encontramos con una estimación del $44,15 \%$ de los expedientes que se instruyeron durante el período de referencia, de los cuales el 73,52\% correspondían al grado de Incapacidad Permanente Total y el 26,47\% al de Absoluta, dato curioso en relación con la estadística general de 
pensionistas, en la que no se observaba una diferencia de esta magnitud y que interpretamos, de acuerdo con la polémica expuesta sobre estos procesos patológicos, en el sentido de que se percibe una cierta cautela de los órganos judiciales a la hora de la calificación de estos supuestos y, por ende, en los casos en que se reconoce la pensión, se hace, por lo general, en el marco del menor grado de acción protectora que representa la Incapacidad Permanente Total.

Los datos estadísticos, en esta ocasión, nos muestran una mayor tendencia a la estimación cuando la sentencia es dictada por una magistrada de lo Social, quizá en atención a un rol de protección por razón de género, teniendo en cuenta la mayoría aplastante de mujeres como «sujetos pasivos» de las entidades clínicas que nos ocupan; si bien, cuando se formalizaba recurso de suplicación ante las salas de lo Social de los Tribunales Superiores de Justicia, se observaba una cierta tendencia a la revocación cuando concurría una FM y/o SFC puros frente a si se acreditaba comorbilidad con otras patologías orgánicas o psiquiátricas, o, incluso, cuando el proceso patológico determinante del fallo fue la psicopatología - a lo sumo revocaciones parciales-.

$\mathrm{Si}$ a todo cuanto hemos expuesto se añade la alta epidemiología de Incapacidad Permanente Absoluta y Total por FM y/o SFC — una vez extrapolamos nuestros datos a las estadísticas generales de pensionistas españoles-, es decir, estas personas percibirían un $14,66 \%$ de todas las pensiones de este tipo que abona el INSS, con su correlato económico del 22,30\% de las partidas que destina esta entidad gestora para estos grados prestacionales, llegamos a la conclusión de que era necesario plantear un trabajo de estas características.

Hemos apostado por una nueva forma de hacer investigación, cuyos rigores metodológicos, muy probablemente, no alcancen a los ya existentes, aunque lo cierto es que una vez finalizado este trabajo multisdisciplinar, estamos en disposición de afirmar que existen dos disciplinas que no están tan distanciadas como podría parecer a primera vista: la jurídica y la médica. 


\section{Tabla número 1 \\ Criterios clasificatorios de la Fibromialgia ${ }^{3}$}

\section{Para proceder a la clasificación, es preciso que concurran en el paciente de forma simultánea, los dos siguientes criterios (ACR):}

1. Historia de dolor generalizado durante al menos tres meses:

- En el lado izquierdo del cuerpo.

- En el lado derecho del cuerpo.

- Encima de la cintura.

- Debajo de la cintura.

- Dolor de esqueleto axial (columna cervical, cara anterior del tórax, columna dorsal o lumbar).

2. Dolor en al menos 11 de los 18 puntos sensibles a la palpación digital (fuerza de $4 \mathrm{~kg}$ ). Puntos positivos son los que el paciente presenta como dolorosos a la palpación, pues una molestia no se considera como dolor. Las principales localizaciones son las siguientes:

- Occipucio bilateral, en inserción de los músculos suboccipitales.

- Cervical bajo: bilateral, en la cara anterior del espacio intertransverso de C5-C7.

- Trapecio: bilateral, en el punto medio de su borde superior.

- Supraespinoso: bilateral, en su origen sobre la espina de la escápula cercana a su borde medial.

- Segunda costilla: bilateral, a nivel de la 2. ${ }^{a}$ unión costocondral, lateral a la articulación de ambas superficies.

— Epicóndilo lateral: bilateral, a $2 \mathrm{~cm}$ distal del epicóndilo.

- Glúteo: bilateral, en el cuadrante supero-externo de las nalgas en el pliegue anterior del músculo.

- Trocánter mayor: bilateral, posterior a la prominencia del trocánter.

- Rodilla: bilateral, en el paquete de grasa medial proximal a la interlínea articular. 


\section{Tabla número 2 Criterios diagnósticos del Síndrome de la Fatiga Crónica9}

1. Fatiga crónica persistente (seis meses mínimo), o intermitente, inexplicada, que se presenta de nuevo con inicio definido y que no es resultado de esfuerzos recientes; no mejora claramente con el descanso; ocasiona una reducción considerable de los niveles previos de actividad cotidiana del paciente.

2. Exclusión de otras enfermedades potencialmente causantes de fatiga crónica.

De forma concurrente, deben estar presentes cuatro o más signos o síntomas de los que se relacionan, todos ellos persistentes durante seis meses o más y posteriores a la presentación de la fatiga:

1. Trastornos de concentración o memoria recientes.

2. Odinofagia.

3. Adenopatías cervicales o axilares dolorosas.

4. Mialgias.

5. Poliartralgias sin signos inflamatorios.

6. Cefalea de inicio reciente o de características diferentes de la habitual.

7. Sueño no reparador.

8. Malestar postesfuerzo de duración superior a veinticuatro h. 


\section{Referencias bibliográficas*}

1. El paciente en España. Madrid: Fundación Farmaindustria; 2004. p. 557.

2. McKinley W, Cram J, Margoles M et al. Innovations in Soft-Tissue Jurisprudence. Trial Diplomacy Journal 1992; 15: 199-208.

3. Wolfe F, Smythe HA, Yunus MB et al. The American College of Rheumatology 1990 Criteria for the Classification of Fibromyalgia. Report of the Multicenter Criteria Commitee. Athritis and Rheumatism 1990; 33 (2): 160-172.

4. Carceller JM, Fidalgo MI. Tratamiento de la Fibromialgia desde la clínica del dolor. Dolor 1998; 13: 116-122.

5. Rodríguez R, Lindman R, Mulero J et al. Fibromialgia. Actualización y nuevas perspectivas. Madrid: ICN Huber; 1994.

6. Mulero J, Andreu JL, Sanz J. Fisiopatología de la Fibromialgia. Dolor 1998; 13: 110-115.

7. Cohen H, Neumann L, Shore M el al. Autonomic Dysfunction in Patients With Fibromyalgia: Application of Power Spectral Analysis of Heart Rate Variability. Seminars in Arthritis and Rheumatism 2000; 29 (4): 217-227.

8. Prevalencia e impacto de las enfermedades reumáticas en la población adulta española. Estudio EPISER 2000. Madrid: SER, MSD, Ministerio de Sanidad y Consumo; 2001. pp. 77-91.

9. Fukuda K, Strauss SE, Hickie I. et al. The Chronic Fatigue Syndrome: A Comprehensive Approach to Its Definition and Study. Ann Intern Med 1994; 121: 953-959.

10. Wessely S, Chalder T, Hirsch S et al. The Prevalence and Morbidity of Chronic Fatigue and Chronic Fatigue Syndrome: A Prospective Primary Care Study. American Journal of Public Health 1997; 87 (9): 1449-1455.

11. Manrique F. Manual de Derecho de la Seguridad Social. Bilbao: Universidad de Deusto, Departamento de Publicaciones; 1984.

12. Soriano E, Gelado MJ, Girona MR. Fibromialgia: un diagnóstico cenicienta. Atención primaria 2000; 26 (6): 415-418.

13. Belmonte MA. Dolor musculoesquelético generalizado no articular, Fibromialgia y síndromes afines. Jano 1990; 904: 88-94.

14. García JM. Mecánica procesal de las Incapacidades Laborales. Valencia: Ediciones Tro; 1999.

15. Álvarez M, De Val AL. Manual de Derecho de la Protección Social. Murcia: Ediciones Laborum; 2003.

* En este trabajo se ha seguido el sistema de citación bibliográfica de Vancouver. 
16. Starlanyl DJ, Copeland ME. Fibromyalgia and chronic myofascial pain syndrome. Vermont: New Harbinger Publications, Inc.; 1995. pp. 333344.

17. Blanco JM, Dueñas LJ, López M et al. Las Incapacidades Laborales. Un punto de vista práctico. Valladolid: Lex Nova; 2002.

18. Alonso E, Serrano M, Tomás G. El trabajo del ama/amo de casa. Un estudio jurídico y su consideración ética. Vitoria-Gasteiz: Diputación Foral de Vizcaya, Gabinete del Diputado General; 2003. pp. 15-149.

19. White KP. Fibromyalgia: The Answer Is Blowin' in the Wind. The Journal of Rheumatology 2004; 31 (4): 636-639.

20. Bernier R. Fibromyalgia. Collége des Médecins du Québec 1996.

21. Galindo C. Fibromialgia. Dolor 2004; 19: 171-187.

22. Alonso JL, Álvarez B, Alegre J. Fibromialgia. Seminarios de la Fundación Española de Reumatología 2000; 1-4: 199-211.

23. Zubieta AJ, Aragón A, Cantalejo M. La Fibromialgia: una enfermedad del pasado, actual y con futuro. Rheuma 2003; 6: 9-22.

24. Thomson FG, Gordon RG. Las enfermedades reumáticas crónicas, diagnóstico y tratamiento. Barcelona: Manuel Marin - editor; 1929. pp.18-28.

25. Albornoz J, Povedano J, Quijada J et al. Características clínicas y sociolaborales de la Fibromialgia en España: Descripción de 193 pacientes. Rev Esp Reumatol 1997; 24: 38-44.

26. Muro J. Fibromialgia: Un misterio doloroso. Reflexiones en clave «F» 2003; 1: 14-18.

27. Rotés-Querol J. La Fibromialgia en el año 2002. Rev Esp Reumatol 2003; 30 (4): 145-149.

28. Nielson WR, Harth M. Fibromyalgia: Beyond the Rhetoric. The Journal of Rheumatology 2004; 31 (4): 631.

29. Yunus MB. Psychological aspects of Fibromyalgia syndrome: a component of the dysfunctional spectrum syndrome. Baillière's Clinical Rheumatology 1994; 8 (4): 811-837.

30. Komaroff AL. The Biology of Chronic Fatigue Syndrome. The American Journal of Medicine 2000; 108: 169-171.

31. Leza JC. Fibromialgia: Un reto también para la neurociencia. Rev Neurol 2003; 36 (12): 1165-1175.

32. Rivera J. Controversias en el diagnóstico de Fibromialgia. Rev Esp Reumatol 2004; 31 (9): 501-506.

33. Wolfe F, Anderson J, Harkness D et al. A prospective, longitudinal, multicenter study of service utilization and costs in Fibromyalgia. Arthritis \& Rheumatism 1997; 40 (9): 1560-1570. 


\section{๑) Universidad de Deusto - ISSN 0423-4847}




\section{CONGRESOS}




\section{๑) Universidad de Deusto - ISSN 0423-4847}




\title{
Transporte marítimo de mercancías de corta distancia y responsabilidad del transportista. Una aproximación jurídico- internacional en el contexto de su promoción en el ámbito comunitario
}

\author{
Carlos Llorente Gómez de Segura \\ Abogado y \\ Profesor Asociado doctor de Derecho Internacional Privado \\ Universidad Carlos III de Madrid
}

\begin{abstract}
Resumen: La política europea de transporte quiere promocionar el transporte marítimo de corta distancia (TMCD) para revitalizar un sector en declive y convertirlo en alternativa al transporte terrestre de mercancías en determinadas circunstancias. No se trata de una labor a corto plazo ni fácil, en la que, además, se plantean incertidumbres de alcance jurídico-privado derivadas tanto de la complejidad estructural que caracteriza a las operaciones de transporte con TMCD (superposición de contratos) como de la diversidad de regímenes susceptibles de aplicación en cada caso a dichas operaciones. La superación de estas incertidumbres se conseguirá, por un lado, familiarizando a los operadores de transporte implicados en actividades de transporte con TMCD con preceptos como el artículo $2 \mathrm{CMR}$, regulador de un tipo de transporte superpuesto carretera-mar (ro-ro) especialmente idóneo para el desarrollo de dichas operaciones; $y$, de otro lado, con un mejor conocimiento de los puntos de encuentro y de divergencia entre las regulaciones aplicables al fenómeno de la responsabilidad del transportista en los sectores terrestre y marítimo. Este artículo pretende analizar en sus líneas generales el régimen del artículo 2 CMR y comparar los modelos terrestre y marítimo de responsabilidad del transportista.
\end{abstract}

Palabras clave: Transporte marítimo de corta distancia, Responsabilidad del transportista, Artículo $2 \mathrm{CMR}$, Regímenes de responsabilidad por carretera y mar: comparación.

Abstract: The EU transport policy is trying to promote short sea shipping (SSS) in order to bring it up to a modern shape and as an alternative to the carriage of goods by road under certain circumstances. It is neither a short-term task nor an easy one and, additionally, it brings about some legal uncertainties which derive from the structural complexity of the transport operations which include SSS (contract overlapping), as well as from the divergent legal regimes applicable in each case to those operations. In order to overcome those uncertainties, transport operators dealing with SSS should, on the one hand, get acquainted with rules such as the one contained in article 2 CMR, which covers an special kind of roadsea combined transport (ro-ro) that fits ideally in regular operations with SSS. And, on the other hand, they should get a better knowledge of the similarities and differences between the road and sea liability regimes. With this article we will try both to describe the basic meaning of article 2 CMR and to compare those two liability regimes. 
Key words: Short-Sea Shipping, Carrier's Liability, Article 2 CMR, Comparison of Road and Sea Liability Regimes.

Sumario: I. Presentación. - II. Las implicaciones jurídico-privadas de las operaciones de transporte con TMCD en el plano de la responsabilidad de los operadores de transporte: marco general. - III. Transporte superpuesto: la responsabilidad del transportista en el artículo 2 CMR. IV. La responsabilidad del transportista en el transporte internacional por carretera y por mar: análisis comparativo de ambos regímenes: 1. Carácter del régimen de responsabilidad. 2. Periodo de responsabilidad. 3. Fundamento de la responsabilidad. 4. Supuestos principales de responsabilidad. 5. Limitación de la deuda indemnizatoria. 6. Pérdida del beneficio de la limitación de la deuda indemnizatoria. 7. Aplicación del régimen de responsabilidad a las diversas acciones. 8. Protestas. 9. Prescripción. 10. Conclusiones.

\section{Presentación ${ }^{1}$}

El transporte marítimo de corta distancia (TMCD) está de moda. Y lo está gracias a la política comunitaria de transporte, que desde 1995 está promocionando activamente esta modalidad de transporte con el objetivo —entre otros, pero señaladamente- de aliviar la congestión del tráfico terrestre de mercancías (sobre todo por carretera) que afecta a nuestro continente, a través de la apertura de «autopistas del mar» que permitan una integración plurimodal de las operaciones de transporte, facilitando el transporte «puerta a puerta» ${ }^{2}$.

La promoción del TMCD en el nivel comunitario, dentro de este contexto, se ha centrado fundamentalmente en la superación de los distintos obstáculos — técnicos, administrativos, logísticos y económicos-que impiden su

${ }^{1}$ Este trabajo está basado en la ponencia que presentó su autor en la Jornada sobre la Seguridad Jurídica de la Mercancía en el TMCD, que se celebró en Castellón el 7 de junio de 2006 y fue organizada por la Fundación Instituto Portuario de Estudios y Cooperación de la Comunidad Valenciana (FEPORTS) y por la Asociación Española de Promoción del Transporte Marítimo de Corta Distancia (SPC-SPAIN), organismos a los que desde estas páginas deseo reiterar mi agradecimiento por su invitación y mis votos por la promoción de esta modalidad de transporte.

${ }^{2}$ Una forma rápida y concisa de conocer la evolución de los esfuerzos comunitarios en esta materia es consultar la «Comunicación de la Comisión al Consejo, al Parlamento Europeo, al Comité Económico y Social Europeo y al Comité de las Regiones, sobre el transporte marítimo de corta distancia», Bruselas, 2.7.2004, COM (2004), 453 final. En esta Comunicación hay abundantes referencias a otros textos y documentos que pueden situar al lector interesado en el buen camino de la comprensión del alcance y objetivos de la política comunitaria en esta materia. 
adecuado desarrollo y, si bien se están produciendo ya algunos resultados significativos, se trata de un ejercicio a largo plazo, como reconoce la propia Comisión.

Ahora bien, como parte de esa labor de fomento, no se ha previsto directamente el análisis de las implicaciones jurídico-privadas del TMCD, pero parece razonable pensar que si se pretende impulsar una determinada modalidad de transporte como alternativa (o complemento) a otras, habrá que dedicar cierta atención a esas cuestiones, para poner de manifiesto el marco de derechos y obligaciones en el que se van a mover los distintos agentes que operan en este sector. A este objetivo responden principalmente las reflexiones que siguen.

\section{Las implicaciones jurídico-privadas de las operaciones de transporte con TMCD en el plano de la responsabilidad de los operadores de transporte: marco general}

Un transporte marítimo de corta distancia, en sentido estricto ${ }^{3}$, no plantea particulares problemas de configuración jurídico-privada. No va a ser éste, por tanto, el objeto de nuestro análisis. Pero sí los puede plantear, en vía de hipótesis, la ejecución de operaciones de transporte (internacional) de mercancías por carretera en las que se recurra al TMCD durante una parte de su ejecución ${ }^{4}$. De hecho, ésta es una de las finalidades que sustentan la promoción del TMCD en el ámbito comunitario: conseguir que una parte del trayecto total, susceptible de realización íntegra por carretera, se ejecute por $\operatorname{mar}^{5}$.

\footnotetext{
${ }^{3}$ Es decir, como transporte exclusivamente marítimo e independiente de otras fases previas o posteriores a la marítima, que se efectúa entre dos puertos situados en zonas geográficas próximas o cercanas. Como tal, desde una perspectiva jurídico-contractual, el TMCD se estructuraría a través de un contrato de transporte de mercancías por mar sujeto a la correspondiente legislación interna o internacional, según fuese el caso.

${ }^{4}$ En este trabajo, a partir de ahora, nos referiremos a este supuesto como «operaciones de transporte con TMCD».

${ }^{5}$ Pongamos un ejemplo que, como suele decirse con razón, vale más que mil palabras. Imagínese que una mercancía debe ser trasladada desde un punto en el interior de España hasta un destino en el interior de Italia. En vía de principio, una opción razonable es la de transportar dicha mercancía desde su origen hasta su destino completamente por carretera. Pero otra opción puede ser la de trasladar la mercancía por carretera desde el interior de España hasta un puerto de nuestra costa mediterránea (p. ej., Barcelona), embarcar la mercancía (incluso sin descargarla, embarcar también el camión) en un buque con destino a un puerto italiano (corta distancia) (p. ej., Génova) y una vez allí proceder al transporte de la mercancía, otra vez por carretera, hasta el destino interior italiano. Algunas de las ventajas de esta segunda opción son, a juicio de los expertos, que el transporte total resulta más barato, es más benévolo ambientalmente, y descongestiona las carreteras.
} 
Pues bien, en este contexto, para fundar y medir la responsabilidad de los porteadores que intervienen en una operación de transporte con TMCD hay que realizar un doble ejercicio previo:

1) Averiguar dónde se sitúan dichos operadores en la estructura contractual en la que se inserta la fase de TMCD; e

2) Identificar la regulación aplicable a dicha estructura y, en particular, a cada una de las relaciones que la componen (y, por ende, a la determinación de la responsabilidad de los operadores que forman parte de ellas).

Con respecto a la primera cuestión habría que decir que si bien las operaciones de transporte con TMCD, en vía de hipótesis, no tienen por qué responder a un mismo modelo estructural, las tendencias marcadas por el tráfico a este respecto ponen de manifiesto la existencia de patrones más o menos homogéneos — homogeneidad que no es sinónimo de simplicidad- que se repiten en la configuración contractual de las operaciones de transporte con TMCD, destacando, por encima de otros, el del denominado transporte «superpuesto» carretera-mar (Ro-Ro), es decir, aquél en el que si bien las mercancías se trasladan sustancialmente por carretera ${ }^{6}$, en una fase determinada del traslado (habitualmente una fase intermedia) el vehículo de carretera, junto con la mercancía (sin ruptura de carga), son embarcados en un buque (ferry) especialmente preparado para realizar este tipo de desplazamientos ${ }^{7}$. Por regla general, en este tipo de estructuras hay una superposición

${ }^{6}$ La combinación carretera-mar es la más frecuente, pero también cabrían, en este contexto, otras combinaciones multimodales junto con la fase marítima. Sobre estas cuestiones y el transporte multimodal en general, véase el trabajo de C. LLORENTE GómEZ DE SEGURA, «El contrato de transporte multimodal internacional de mercancías», en A. L. CALVO CARAvaCA y L. FernándeZ de la Gándara (Dirs.) y P. Blanco-Morales Limones (Coord.), Contratos internacionales, Madrid 1997, pp. 583 ss., en especial p. 588.

${ }^{7}$ Una alternativa al transporte ro-ro, también operativa en este ámbito, es que la combinación tierra-mar se produzca no por la carga del vehículo terrestre, junto con su mercancía, sobre el buque, sino por el uso de contenedores u otros medios de consolidación de cargas, que se transportan primero por vía terrestre, se descargan luego del vehículo terrestre para ser cargados en el buque hasta su destino, donde se vuelven a repartir por vía terrestre, en su caso. Sobre los problemas jurídicos derivados del transporte por contenedores, particularmente en el sector marítimo, véase AA.VV., Containerisation. Some implications of through transport from the banker's point of view, London, October 1966; K. GRÖNFORS, «Container transport and The Hague Rules», J.Bus.L. (1967) 298; W. D. ANGus, «Legal implications of the 'container revolution' in international carriage of goods» (1968) McGill L.J. 395-429; A. ARGYRIADIS, «Rechtsfragen des Übersee-Container-Verkehrs», RabelsZ (1969), 235; F. BERLINGIERI JR., «Probleme giuridici del trasporto in containers», Dir.Mar. (1971), 146; M.E. DEORCHIS, «The container and the package limitation. The search for predictability», 5 J.Mar.L. \& Com. 251-279 (1974); F. BIANCA, «Osservazioni sulla responsabilitá del vettore nel trasporto marítimo mediante containers», Dir. Trasp. (1991), 547. 
de contratos en la que, por un lado, el operador de transporte principal (agencia de transporte, transitario o el propio transportista por carretera) organiza (contrata) todo el transporte frente a su cliente (asumiendo la responsabilidad derivada del traslado completo) y, por otro lado, otro porteador se encarga de la ejecución parcial del transporte por mar por indicación del (y frente al) operador principal y sin vinculación contractual alguna con el cliente ${ }^{8}$.

El segundo ejercicio se plantea porque las operaciones con TMCD, también en vía de hipótesis, son habitualmente (en particular en el contexto comunitario) operaciones de carácter internacional, es decir, presentan algún elemento de extranjería en su estructura ${ }^{9}$; caracterización esta que obliga a tener que decidir, entre otras cuestiones, cuál es el Derecho aplicable a una o varias de las relaciones que componen la estructura contractual en la que se inserta el $\mathrm{TMCD}^{10}$. En un buen número de casos, la regulación aplicable a la operación de transporte con TMCD podrá ser reconducida a alguno de los instrumentos del Derecho uniforme del transporte (terrestre y marítimo) que están en vigor, señaladamente el $\mathrm{CMR}^{11}$ (a través, sobre todo, de su ar-

\footnotetext{
${ }^{8}$ A este tipo de estructuras con superposición de contratos se la suele denominar con el nombre de «transporte unitario»o «transporte con subtransporte». Sobre ésta y otras modalidades de transporte con pluralidad de porteadores, véase C. LLORENTE GómEZ DE SEGURA, «Régimen jurídico del transporte cumulativo de mercancías en el Derecho español. Una nueva aproximación», Diario La Ley, 6 y 7 de enero de 2003, núms. 5690 y 5691.

${ }^{9}$ A. L. Calvo Caravaca y J. Carrascosa GonzÁlez, Derecho internacional privado, I, 7. a edición, Granada 2006, pp. 13 ss. No siempre habrán de ser operaciones internacionales, no obstante. Imagínese el supuesto de un transporte de mercancías por carretera entre Bilbao y Palma de Mallorca, en el que el camión con su carga viaja por vía marítima desde el puerto de Barcelona hasta un puerto sito en las Islas Baleares. En estos casos, el recurso al DIPr., como sector del ordenamiento jurídico regulador de las situaciones privadas internacionales, será innecesario. Y habrá que buscar la regulación aplicable en la normativa interna.

${ }^{10}$ Téngase en cuenta que, en ocasiones, la internacionalidad de la operación de transporte en la que se inserta el TMCD (y el eventual recurso al DIPr.) no vendrá dada por el carácter transfronterizo del traslado - origen y destino situados en dos Estados distintos (aunque será lo habitual) — sino que también se producirá en aquellos supuestos de transportes internos efectuados por transportistas establecidos en un Estado distinto de aquél en el que se lleva a cabo el transporte (es el caso del cabotaje comunitario, p. ej.). En general, sobre esta situación, y sus implicaciones de DIPr., véase C. LlORENTE GÓMEZ DE SEGURA, «Integración europea y unificación de la reglamentación del contrato de transporte de mercancías por carretera: Algunos datos y reflexiones, en F. MARTínez SANZ (Dir.) y M. ${ }^{a}$ Victoria Petit LAVAL (Coord.), I Congreso internacional de transporte: los retos del transporte en el siglo XXI, I, Valencia 2005, pp. 847 ss.

${ }^{11}$ CMR = Convenio de Ginebra, de 19 de mayo de 1956, relativo al contrato de transporte internacional de mercancías por carretera (BOE núm. 109, de 7 de mayo de 1974; corrección de errores en BOE de 15 de junio de 1995), modificado por el Protocolo de 5 de julio de 1978 (BOE núm. 303, de 18 de diciembre de 1982). Sobre este Convenio, véanse, entre los trabajos de orden general, J. BASEDOw, «CMR», en Münchener Kommentar zum Handelsgesetzbuch, Bd. 7, Viertes Buch, Handelsgeschäfte (\$\$ 407-457) Transportrecht, München 1997, pp. 857 ss.; M. A. CLARKE, International carriage of goods by road: CMR, 3rd. ed., London 1997; H. GLÖCKNER, Leitfaden zur CMR, 7 Auf., Berlin 1991; K. F. HAAK, The
} 
tículo 2, al que dedicaremos, por su importancia en esta materia, un apartado posterior) y las RHV (LTM) ${ }^{12}$. Pero no siempre será asi ${ }^{13}$. Y, en todo caso,

liability of the carrier under the CMR, The Hague 1986 (trad. por J. WADE); H. WIDMANN, Übereinkommen über den Beförderungsvertrag im internationalen Straßengüterverkehr (CMR), Luchterhand, Neuwied/Kriftel/Berlin 1993.; C. LlORENTE GÓMEZ DE SEGURA, «El contrato de transporte internacional de mercancías por carretera», en A. L. CALVO CARAVACA y L. Fernández de la Gándara (Dirs.) y P. BlanCo-Morales Limones (Coord.), Contratos internacionales, Madrid 1997, pp. 467 ss.; ID., «Contratos internacionales de transporte por carretera, ferrocarril, marítimo y multimodal», en A. L. CALVO CARAVACA Y J. CARRASCOSA GonZÁLEZ (Dirs.), Curso de contratación internacional, Madrid 2003, pp. 363-379; R. LöEWE, «Commentary on the Convention of 19 may 1956 on the contract for the international carriage of goods by road», ETL (1976) 311; F. MARTÍNEZ SANZ, La responsabilidad del porteador en el transporte internacional de mercancías por carretera (CMR), Granada 2002; A. MESSENT y D. GLASS, Hill \& Messent CMR: Contracts for the international carriage of goods by road, 3rd ed., London 2000; A. PESCE, Il contratto di trasporto internazionale di merci su strada, Padova 1984; F. J. SÁNChEZ-GAMBORINO, El contrato de transporte internacional. CMR, Madrid 1996; J. THEUNIS (Gen. ed.), International Carriage of Goods by Road (CMR) London 1987; y K.H. THÜME (Hrsg.), Kommentar zur CMR: Übereinkommen über den Beförderungsvertrag im internationalen Straßengüterverkehr, Heidelberg 1995. En particular, R. ZüCHNER, «Zum Frachtvertrag nach der CMR», VersR (1964), 223; J. WILLENBERG, «Der internationale Strassengüterverkehr nach dem inkrafttreten der CMR. Eine übersicht über die ersten Entscheidungen», NJW (1968), 1020 ; J. VREBOS, «Convention relative au transport international de marchandises par route (CMR)», ETL (1966), 678; R. ZüCHNER, «Der Haftungsregelung der CMR für den grenzüberschreiten Strassengüterverkehr», Der Betrieb (1965), 59.

${ }^{12} \mathrm{RHV}=$ Convenio de Bruselas de 25 de agosto de 1924, para la unificación de ciertas reglas en materia de conocimientos de embarque (Gaceta de Madrid núm. 212, de 31 de julio de 1930) (Reglas de La Haya), modificado por los Protocolos de 23 de febrero de 1968 (Reglas de Visby) y de 21 de diciembre de 1979 (BOE de 11 de febrero de 1984); LTM = Ley de 22 de diciembre de 1949, de transporte marítimo de mercancías en régimen de conocimiento de embarque (BOE núm. 358, de 24 de diciembre de 1949). Sobre la compleja y debatida convivencia entre estos dos grupos normativos (RHV y LTM) en nuestro ordenamiento jurídico, véase J. M. ${ }^{a}$ RuIz Soroa, S. Zabaleta SARAsúa y M. González RodríGUEZ, Manual de Derecho del Transporte Marítimo, Vitoria-Gasteiz, 1997, 2. ${ }^{\text {a }}$ edición, pp. 371 ss. En general, sobre el régimen de las RHV (LTM), AA.VV., The Hague-Visby Rules and the Carriage of Goods by Sea Act, London 1977; A. Diamond, «The Hague-Visby Rules», (1978) 2 LMCLQ 225-266; F. SÁNCHEZ CALERO, El contrato de transporte marítimo de mercancías. Las Reglas de La Haya-Visby, Elcano 2000 (con anterioridad, del mismo autor, El contrato de transporte marítimo de mercancías, Roma-Madrid 1957). Igualmente, M. A. Clarke, Aspects of the Hague Rules, The Hague 1976.

${ }^{13}$ Cuando la correspondiente cuestión litigiosa derivada de la operación de transporte en la que se inserta el TMCD no pueda ser resuelta con el recurso a uno de los instrumentos de Derecho uniforme del transporte, por caer fuera de su ámbito de aplicación o por no estar regulada en dicho instrumento (laguna), la determinación del Derecho aplicable a dicha cuestión, en nuestro ordenamiento, habrá de ser realizada acudiendo al Convenio de Roma de 19 de junio, sobre la ley aplicable a las obligaciones contractuales (BOE núm. 171, de 19 de julio de 1993; corrección de errores en BOE núm. 189, de 9 de agosto de 1993). Sobre este Convenio, en particular, véase C. Llorente GómEZ DE SEGURA, «El contrato de transporte y el Convenio de Roma sobre la ley aplicable a las obligaciones contractuales», en A. L. Calvo Caravaca y J. CARRascosa GonzÁlez, Estudios sobre contratación internacional, Madrid 2006, pp. 337 ss. 
puede suceder que el contrato principal tenga carácter internacional, pero no lo tengan, por el contrario, las relaciones internas de la operación.

A la luz de estas reflexiones previas, y dado el carácter abierto y multiforme de esta cuestión, creemos necesario centrar el objeto de nuestro análisis en las siguientes cuestiones:

1) Determinación del régimen de responsabilidad aplicable al transporte superpuesto carretera-mar, particularmente en el caso regulado por el artículo $2 \mathrm{CMR}$, por ser paradigmático y de frecuente aplicación en las operaciones de transporte europeas con TMCD.

2) Comparación del régimen de responsabilidad del empresario de transporte (porteador) en los transportes internacionales por carretera y marítimo, con la finalidad de poner de manifiesto las similitudes y diferencias existentes entre ambos regímenes. De este modo, sobre todo a la luz de sus diferencias, podrán advertirse las incertidumbres jurídico-privadas que pueden plantear las operaciones de transporte con TMCD. Y, visto desde una perspectiva positiva, podremos destacar, igualmente, los puntos de conexión (que son bastantes y significativos) entre los regímenes de responsabilidad de ambos modos de transporte.

\section{Transporte superpuesto: la responsabilidad del transportista en el artículo 2 CMR}

El artículo 2 CMR centra su atención en aquellos contratos de transporte internacional de mercancías por carretera, sometidos a dicho Convenio ${ }^{14}$

${ }^{14}$ El CMR es un Convenio de aplicación obligatoria, lo cual significa que su aplicación dependerá exclusivamente de que se den, en cada caso, las circunstancias previstas en su Capítulo I (en particular, su artículo 1), que es el que define, precisamente, el ámbito de aplicación del Convenio. No hay margen, por tanto, para la autonomía de la voluntad en este ámbito, como, en ciertas ocasiones y en algún ordenamiento en particular (nos referimos a Italia), se ha pretendido justificar por su doctrina y tribunales (véase, p. ej., sobre la excepción «italiana», G. VALAPERTA, «La CMR è facoltativa?», Trasporti 1976 [10], 100; S. CARBONE, «Il diritto uniforme in tema di trasporti ed il suo ambito di applicazione nell'ordinamento italiano: casi e materiali», Dir.Mar. [1978], 369; M. GRIGOLI, «Sull'applicabilità della Convenzione di Ginevra del 1956 relativa al trasporto internazionale di merci su strada», Giust. civ. [1981], 296; E. FADDA, «Presupposti per l'applicazione della CMR. Finalmente la giurisprudenza cambia orientamento», Dir.Mar. [1982], 415 [nota a App. Firenze 2 febbraio 1981]; ID., «Ancora sui presupposti per l'applicazione della CMR», Dir.Mar. [1984], 554; M. FRIGO, «La pretesa derogabilità della CMR e i caratteri del diritto uniforme», Riv. dir. int. priv. proc. [1983], 94; M. MARESCA, «Ambito di applicazione della Convenzione di Ginevra sul trasporto di merci su strada del 1956 e ruolo della volontà delle parti», ETL [1983], 70; G. SILINGARDI, «La CMR: da normativa uniforme di applicazione necessaria a disciplina patizzia», Diritto del commercio internazionale [1987], 613). En suma, las partes de un con- 
conforme a su artículo $1.1^{15}$, en los que «el vehículo que contiene la mercancía sea transportado por mar (...) en una parte de su recorrido sin ruptura de carga».

Se trata, por lo tanto, de transportes superpuestos ${ }^{16}$ (en este caso, carretera-mar) ${ }^{17}$.

El artículo 2 CMR, como pone de manifiesto su inclusión en el Capítulo I del CMR (junto con el artículo 1), tiene como misión delimitar el ámbito de aplicación de dicho Convenio ${ }^{18}$ con respecto a este tipo de transportes

trato de transporte internacional de mercancías por carretera que caiga bajo el ámbito de aplicación definido por el artículo 1 CMR no pueden válidamente excluir la aplicación de este Convenio a su contrato, sin que quepa concluir lo contrario de la exigencia prevista en el artículo 6.1(k) CMR, que obliga a las partes del contrato a incluir en el documento de transporte (carta de porte) una cláusula de las llamadas «paramount», por la que se indica que el contrato de transporte formalizado en dicho documento está sometido, a pesar de cualquier cláusula contraria, al régimen establecido en el CMR (sobre este tipo de cláusulas, J. J. Álvarez RuBio, Las cláusulas paramount: autonomía de la voluntad y selección del derecho aplicable en el transporte marítimo internacional, Madrid 1997; E. SElvig, «The paramount clause», 10 Am. J. Comp. L. 205-226 [1961]; en general, sobre esta cuestión y otros problemas conexos, E. Castellanos Ruiz, Autonomía de la voluntad y Derecho uniforme en el transporte internacional, Granada 1999). Aquella exigencia, cuya vulneración acarreará una determinada imputación de responsabilidad al porteador (artículo 7.3 CMR), opera, por tanto, en un plano distinto al de otras «cláusulas paramount», cuya existencia sí constituye un verdadero presupuesto de aplicabilidad de la normativa uniforme, como sucede, por ejemplo, en el ámbito marítimo (véase, en este sentido, el artículo 10, letra [c] RHV).

${ }^{15}$ De acuerdo con este precepto, el CMR «se aplicará a todo contrato de transporte de mercancías por carretera realizado a título oneroso por medio de vehículos, siempre que el lugar de la toma de carga de la mercancía y el lugar previsto para la entrega, indicados en el contrato, estén situados en dos países diferentes, uno de los cuales al menos sea un país contratante, independientemente del domicilio y nacionalidad de las partes del contrato». Sobre este precepto, A. PESCE, «Chapter 1. The Contract and Carriage under the CMR (Arts. 1, 41)», en J. THEUnIS (Ed.), International Carriage of Goods by Road, London 1987, pp. 1 ss.

${ }^{16}$ En general, R. ZüCHNER, «Zur Rechstnatur der Beförderungsvertrages beim Huckepackverkehr», VersR (1966), 100; P. BRUNAT: «Le régime juridique des transports internationux route/mer», $B T$ (1976), 227; R. H. WIJFFELS, «Transports par car-ferries (note sous Comm. Paris, 14 mars 1973)», BT (1974), 271.

${ }^{17} \mathrm{El}$ art. 2 CMR fue introducido en el Convenio de Ginebra a instancias del Reino Unido (Clarke, Carriage of goods by road... cit., § 3.1.2.2.1) para que, de este modo, los numerosos transportes internacionales por carretera que partiesen de -o llegasen a- dicho país (habiendo de utilizar necesariamente la vía marítima) pudieran quedar sujetos también al CMR. De ahí que esté integrado, junto con el art. 1, en el Capítulo 1. ${ }^{\circ}$ del CMR ( «Ámbito de aplicación»). Igualmente, A. E. DonALD, «CMR-An outline and its history», [1995] 4 $L M C L Q 420-429$ y «CMR: an outline and its history-Goods to and from the continent», ETL (1976), 166; D. J. HILL, «Combined transport to Europe», [1975] 3 LMCLQ 303-307; «Carriage of goods by road to the continent», ETL (1976), 182.

${ }^{18}$ A. Chao, «Le champ d'application de la CMR», BT (1986), 733; M. A. Clarke, «Scope of CMR. Shell Chemicals v. P. \& O. Roadways» (Case and Comment)», [1993] 2 LMCLQ 156-158 = [1993] 1 Lloyd's Rep. 114. 
superpuestos, particularmente en lo que se refiere al problema de la responsabilidad del transportista de mercancías por carretera.

Y lo hace a través de tres reglas recogidas en su apartado 1: una regla general (inciso primero); una excepción (inciso segundo), y, finalmente, una cláusula de cierre (inciso tercero).

La regla general establece que, en los casos de transportes superpuestos previstos en su artículo 2, el CMR «se aplicará al conjunto del transporte», no obstante su naturaleza plurimodal. Según esta regla, por lo tanto, a esos transportes superpuestos les serán de aplicación todas las normas contenidas en el CMR, incluidas las relativas a la responsabilidad del transportista de carretera (Capítulo IV), si bien — hay que insistir- no sólo éstas ${ }^{19}$.

La excepción, por su parte, establece que, en las condiciones y circunstancias previstas en el precepto (que analizaremos inmediatamente), las normas por las que se regule la responsabilidad del transportista por carretera serán aquellas que resulten de aplicación al tramo marítimo. Por lo tanto, en esta hipótesis, el transportista por carretera verá su régimen de responsabilidad (por pérdida, avería o retraso) sometido no a las normas del Capítulo IV del CMR (artículos 17-29) sino, eventualmente, a otro conjunto normativo, en concreto, en nuestro caso (por tratarse de un TMCD), el que resulte de aplicación al segmento marítimo. En suma, el objetivo del artículo 2 CMR es conseguir que, en determinadas circunstancias, la responsabilidad del transportista por carretera cuyo vehículo sea trasladado - junto con su carga (es decir, sin ruptura de carga) - por otro modo de desplazamiento distinto durante una parte del recorrido total contemplado en el contrato, sea medida no según las normas de responsabilidad previstas en dicho Convenio, sino conforme a las normas propias del modo de transporte - distinto de la carretera- en el que pueda localizarse el origen del hecho desencadenador de dicha responsabilidad (sistema de responsabilidad tipo «network»o «red»). De este modo, no sólo se respetará la aplicación de la reglamentación jurídica directamente vinculada a la causación del daño, sino que, además, se conseguirá equiparar el sistema de responsabilidad al que quedará sometido el transportista por carretera (responsable principal ante el acreedor del transporte: artículo $3 \mathrm{CMR}$ ) con el del porteador del modo distinto a la carretera (porteador marítimo) que haya causado el incumplimiento (facilitándose, de esta manera, el ejercicio de la acción de regreso por parte del primer operador frente a este último).

${ }^{19}$ Las normas de Derecho aplicable que se recogen en el CMR abarcan un contenido que suele ser el usual en otros instrumentos de Derecho uniforme del transporte y que, básicamente, se centran en la regulación de dos grandes ámbitos de problemas: por un lado, los derivados de la documentación del contrato y, por otro, los relativos a la responsabilidad del transportista. Pero estas normas se complementan, a su vez, con otras relativas al contenido del contrato (derecho y obligaciones de las partes), al ejercicio de reclamaciones (en un ámbito precontencioso) y a los problemas derivados del transporte sucesivo. 
Finalmente, la cláusula de cierre establece que si, en el supuesto anterior, no existiesen disposiciones normativas aplicables al tramo marítimo, «la responsabilidad del transportista de carretera será determinada por el presente Convenio». Se vuelve, de este modo, a la aplicación de las reglas sobre responsabilidad recogidas en el Capítulo IV del CMR (se «cierra» así el sistema).

La excepción del inciso segundo del artículo 2.1 CMR, que es la que concede verdadera virtualidad a dicho precepto, como hemos avanzado, establece varios requisitos para su aplicación, cuya oscuridad y complejidad en ciertos extremos han sido objeto de crítica ${ }^{20}$. Intentaremos, a continuación, ofrecer una síntesis clarificadora de su significado.

Los requisitos son los siguientes:

1) La pérdida, avería o retraso en la entrega de la mercancía deberán haber sobrevenido durante el transporte no realizado por carretera (en nuestro caso, el marítimo).

2) La pérdida, avería o retraso en la entrega de la mercancía no habrán debido ser causados por algún acto u omisión del transportista por carretera, sino por un hecho que no ha podido producirse más que durante y por razón del transporte no realizado por carretera (en nuestro caso, el marítimo).

La prueba de estos requisitos (origen y causa marítimos) corresponderá a quien alegue la excepción del artículo 2.1 CMR (habitualmente, será el transportista por carretera).

${ }^{20}$ Sobre este controvertido precepto, R. RoDIÈRE, «Les transports combinés route/autre mode de locomotion. Contribution à l'étude de l'article 2 de la CMR», BT (1973), 458; J. THEUNIS, «The liability of a carrier by road in roll on-roll off traffic», en J. THEUNIS (Gen. Ed.), International Carriage of Goods by Road (CMR), London 1987, pags. 235 ss.; J. RAMBERG, «Deviation fron the legal regime of the CMR (Art. 2)», en J. THEunIS (Gen. ed.), International Carriage of Goods by Road (CMR), London 1987, pags. 19 ss.; PUTZEYs, J., «Le droit superposé ou les paradoxes de l'article 2 CMR», ETL (1990), 107; ID., «L'article 2 de la CMR, une autre interpretation», BT (1991), 87; J. TheunIS, «Die Haftung des Straßenfrachtführers bei der Ro-Ro Beförderung», TranspR (1990), 263; M. BoMBEECK, Ph. HAMER Y B. VerhaEgEN, «La responsabilité du transporteur routier dans le transport par car-ferries. L'article 2 de la Convention relative au contrat de transport international de marchandises par route (CMR)», ETL (1990), 110; A. vAN BEELEN, «De aansprakelijheid van de wegvervoerder bij stapelvervoer conform art. 2 CMR», ETL (1991), 743. Igualmente, R. ACHARD, Nota sobre el «Anna Oden», BT (1986), 689; ID., «Transport en pontée. Paramount clause et l'article $2 \S 1$ de la CMR. A propos de l'arrêt de Cassation Anna Oden», DMF (1989), 219; W. CZAPSKI, «Responsabilité contractuelle lors des transports internationaux routiers entre le continent européen et la Grande Bretagne (à travers la Manche)», I.R.U. (document interne), Genève 1984. Del mismo autor: «Responsabilité contractuelle lors du transport de véhicles routiers par car-ferries», I.R.U. (document interne), Genève 1986»; «Responsabilité du transporteur routier lors du transroulage et du ferroutage», ETL (1990), 172; «El transporte marítimo de camiones, remolques y semirremolques a corta distancia: aspectos jurídicos», $R G D$ (1992), 4303. También puede consultarse el trabajo de P. G. FITZPATRICK, «Combined transport and CMR Convention», J. Bus. L. 311-319 (1968). 
Una vez probados estos requisitos, como dijimos, «la responsabilidad del transportista por carretera no será determinada por (el CMR), sino de la forma en que se determinaría la responsabilidad del transportista que no efectuó el transporte por carretera».

Ahora bien, para identificar el régimen que resultaría de aplicación a la responsabilidad del transportista marítimo, el artículo 2.1 CMR plantea la necesidad de realizar un doble ejercicio:

1) Hay que situarse en la hipótesis de que «se hubiera establecido un contrato de transporte entre el remitente (del contrato de transporte sometido al CMR) y ese otro transportista que no efectuó el transporte por carretera, para el exclusivo transporte de esa mercancía» (el llamado «contrato hipotético»).

2) Hay que identificar cuáles habrían sido «las disposiciones legales vigentes aplicables al transporte de mercancías por ese modo distinto de la carretera». O, dicho de otro modo, las disposiciones aplicables al «contrato hipotético». Probablemente, esta identificación es la que mayores problemas ha planteado con ocasión de la aplicación e interpretación del artículo 2.1 CMR, como por otro lado ya anticipa la cláusula de cierre del inciso final del precepto («si tales disposiciones no existen»), pues no siempre los elementos de hecho de la situación encajan en el ámbito de las normas hipotéticamente susceptibles de aplicación en cada caso.

Cuatro ideas más antes de cerrar este apartado:

1) La responsabilidad del transportista de carretera por la pérdida, avería o retraso causados durante el transporte por mar, en el marco del artículo $2 \mathrm{CMR}$, se funda en el artículo $3 \mathrm{CMR}$, que establece el principio general de responsabilidad del transportista (de carretera) por sus auxiliares $^{21}$, entre los que se encuentra, en nuestro caso, el transportista que lleva a cabo el tramo marítimo. Ahora bien, ese principio general tiene un límite, el de que los auxiliares hayan actuado «en el ejercicio de sus funciones». Fuera de este límite, por lo tanto, al transportista por carretera no se le podrá hacer responsable por los actos $\mathrm{u}$ omisiones ilícitos del transportista marítimo.

2) Según el artículo 2.2 CMR, si el transportista de carretera y el transportista marítimo que interviene en el TMCD fuesen «una misma per-

${ }^{21}$ En general, F. JoRDANO FRAGA, La responsabilidad del deudor por los auxiliares que utiliza en el cumplimiento, Madrid 1994; y P. ZELAYA: La responsabilidad civil del empresario por los daños causados por sus dependientes. Naturaleza y requisitos, Aranzadi, Pamplona 1995. Véanse, igualmente, los trabajos de O. TORRALBA, «La responsabilidad de los auxiliares en el cumplimiento de las obligaciones», $A D C$ (1971), 1143, y A. CRISTÓBAL, «La responsabilidad del deudor por sus auxiliares», $A D C$ (1989), 5. 
sona, su responsabilidad se determinará igualmente por el apartado anterior, como si ambas funciones hubiesen sido efectuadas por dos personas distintas». Este es un precepto de especial relevancia para las empresas de transporte que decidan realizar transportes internacionales de carretera con recurso al TMCD empleando vehículos y buques integrados ambos en su organización empresarial.

3) Aunque pueda resultar obvio, hay que recordar que el artículo $2 \mathrm{CMR}$ es un precepto que regula la responsabilidad del transportista (internacional) de mercancías por carretera, pero no la responsabilidad del transportista (marítimo) que ha colaborado en la ejecución del transporte superpuesto. La responsabilidad de éste se regirá por las normas aplicables al contrato que le une con el transportista de carretera, quien, por regla general, será quien ejercite la correspondiente acción de responsabilidad contra él (habitualmente, en vía de regreso).

4) $\mathrm{Si}$ el reclamante quisiera (y pudiera) dirigirse directamente contra el transportista marítimo para exigirle responsabilidad por vía extracontractual, podría entrar en juego el artículo 28.2 CMR, según el cual «cuando, por pérdida, avería o retraso, se reclame en juicio responsabilidad extracontractual a personas de las que responde el transportista según el artículo 3, estas personas pueden prevalerse de las disposiciones de este Convenio que excluyan la responsabilidad del transportista o que determinen o limiten las indemnizaciones debidas». En nuestra interpretación de este precepto en su aplicación a supuestos de TMCD cubiertos por el artículo 2 CMR, por tanto, cabría entender que si el reclamante se dirige extracontractualmente contra el transportista marítimo que interviene en el TMCD, éste podrá ampararse en el artículo 2 CMR, es decir, podrá invocar, en su protección, la aplicación de las normas reguladoras de la responsabilidad aplicables al transporte marítimo (p. ej., RHV), siempre que se den los requisitos y condiciones previstas en aquel precepto.

\section{La responsabilidad del transportista en el transporte internacional por carretera y por mar: análisis comparativo de ambos regímenes}

La oportunidad de realizar, en el contexto de este trabajo, un análisis comparativo de la responsabilidad del transportista en el transporte internacional por carretera y por mar se destaca tras las reflexiones que hemos dedicado al artículo 2 CMR, modelo estructural prototípico de las operaciones de transporte con TMCD, en el que se combinan (o solapan) los regímenes de responsabilidad de ambos modos de transporte. El análisis es particularmente relevante para el transportista por carretera que, eventualmente, puede verse sometido al régimen de responsabilidad propio de otro modo de transporte (el marítimo). 
Por razones obvias, este análisis comparativo deberá ser necesariamente breve y se centrará en las principales cuestiones que afectan a todo régimen de responsabilidad del transportista.

La comparación se establecerá entre el sistema previsto en el $\mathrm{CMR}^{22}$ y el recogido en las RHV-LTM (y, eventualmente, para el sector marítimo, en las $\mathrm{RH}^{23}$ y en la PALGNM) ${ }^{24}$.

${ }^{22}$ Téngase en cuenta, por otro lado, que el CMR es el modelo que se está siguiendo actualmente en nuestro país por la Comisión de reforma de nuestra legislación del transporte terrestre, por lo que las referencias al CMR en este trabajo no se sustentan sólo en su proyección exclusivamente internacional. Sobre la corriente, generalizada en Europa, de extender la regulación del CMR al tráfico interno, véase, en general, C. LLORENTE GómEz DE SEGURA, «La incidencia del CMR en la armonización de la regulación del contrato de transporte en los Estados miembros de la Comunidad Europea», en A. L. Calvo Caravaca y S. Areal Ludeña (Dir.), Cuestiones actuales del Derecho mercantil internacional, Madrid 2005, pp. 745 ss. En particular, J. PutZEYs, «The Belgian "Midway" for Applicability of CMR to Inland Road Transport: Palliative or Final Solution», en K. F. HAAK y E. C. SwART (Eds.) Road Carrier's Liability in Europe, Part 2, The Hague 1995; G. Petersson y J. WeTTER, «The integration of the CMR rules in Swedish domestic road transportation regulations», [1978] 4 LMCLQ 567. Para la situación en Dinamarca, véase, U. ANDERSEN, «The Applicability of CMR in National Transport Law», en K. F. HAAK y E. C. SwART (Eds.), Road carrier's liability in Europe, 2, The Hague 1995; J. L. SARAGOÇA, «El contrato de transporte en Portugal: la aplicación de la Convención internacional CMR a los servicios interiores como fórmula para actualizar su régimen jurídico», $R G D$ (1992), 4331. ID., «Application of the CMR Convention on contracts for the carriage of goods by road in Portugal», en K. F. HAAK y E. C. SwART (Eds.), Road carrier's liability in Europe, 2, The Hague 1995 (= «La aplicación de la Convención CMR a los contratos de transporte nacional de mercancías por carretera en Portugal», RGD (1995), 10223); F. J. SÁnCHEZ-GAmborino, «Portugal avanza hacia la modernización de su derecho sobre el contrato de transporte, en línea a la Convención CMR», $R G D$ (1995), 2341; M. CLARKE, "Contracts for the Carriage of Goods by Road: Cabotage in the United Kingdom», J.B.L. (1998), 591-595; F. BERNARDEAU, «La CMR en tant que régle des transports intérieurs», ETL (1998), 793. La última reforma alemana (HGB) en materia de transporte, también ha seguido un camino similar: por todos, C. Llorente GómEZ DE SEGURA, «La nueva regulación del contrato de transporte en Alemania. Transportsrechtsreformgesetz (TRG)», RDM (1999), 1601.

${ }^{23} \mathrm{RH}=$ Reglas de Hamburgo = Convenio de Hamburgo de 31 de marzo de 1978, sobre el transporte marítimo de mercancías (no vigente en España). La bibliografía sobre las RH es muy abundante, sobre todo en la doctrina extranjera. Entre otros, F. BERLINGIERI JR., «La nuova Convenzione sul trasporto di merci per mare», Dir. Mar. (1978), 185; K. GRÖNFORS, «Die Hamonisieriung des Transportrechts und die Hamburger Regeln», RabelsZ (1978), 696; S. MANKABADY (Ed.), The Hamburg Rules on the carriage of goods by sea, Leyden-Boston 1978; AA.VV., The Hamburg Rules, London 1978; R. RoDIÈRE, «La responsabilité du transporteur maritime suivant les Règles de Hambourg (le point de vue d'un juriste latin)», DMF (1978), 451; J. C. Sweeney, «Les Règles de Hambourg. Point de vue d'un juriste anglo-saxon», DMF (1979), 323; C. LEGENDRE, «La Convention des Nations Unies sur le transport de marchandises par mer», DMF (1978), 387; J. C. Moore, «The Hamburg Rules», 10 J.Mar.L. \& Com. 1-11 (1978-1979); M. ALTER, «La Convention sur les transports de marchandises par mer (Règles de Hambourg)», JDI (Clunet) (1979), 793; G. AUCHTER, «La Convention des Nations-Unies sur le transport de marchandises par mer de 1978 (Règles de 


\section{Carácter del régimen de responsabilidad}

En el transporte por carretera, esta cuestión está regulada en el artículo 41 CMR, que acoge el régimen más estricto de todos los instrumentos de Derecho uniforme del transporte, al establecer que «toda estipulación que,

Hambourg, 1978)», ETL (1979) 3, 215; W. TETLEY, «The Hamburg Rules: A commentary», (1979) 1 LMCLQ 1-20; C. DouAY, «La Convention des Nations Uníes sur le transport de marchandises pare mer (Régles de Hambourg)», BTICF-ZIE (1979), 17; W. E. AsTLE, The Hamburg Rules, London 1981; F. SÁNCHEZ CAlERo, Las Reglas de Hamburgo sobre el contrato de transporte marítimo de mercancías. Una valoración crítica, Barcelona 1981; J. A. GómEZ SEGADE, «El transporte marítimo de mercancías: de las Reglas de La Haya a las Reglas de Hamburgo», RDM (1980), 221; R. MATILlA, «Reglas de Hamburgo. Principios fundamentales», RGLJ (1981), 281; AA.VV., «Le Regole di Hamburgo», Dir. Mar. (1983), 172, 501 y 734; V. MENGANO, Le Regole di Hamburgo e la responsabilitá del vettore, Napoli 1983; J. M. AlCÁNTARA, «Las Reglas de Hamburgo ante su inminente entrada en vigor. Una valoración actualizada», Der. Neg. (1990-1991), 398; R. A. GoNZÁLEZ LEBRERO, «Las Reglas de Hamburgo», Tapia (1991), núm. 6, pp. 73 ss.; C.F. LüDdEKE y A. Johnson, A guide to the Hamburg Rules. From Hague to Hamburg via Visby. An industry report, London 1991; A. EmParanza Sobejano, «El transporte marítimo bajo conocimiento de embarque: Su régimen jurídico internacional tras la entrada en vigor de las Reglas de Hamburgo», en J. M. ${ }^{\text {a }}$ DE EIZAGUiRRE (Coord.), El Derecho del transporte marítimo internacional, San Sebastián 1994, pp. 41-77; R. ILlESCAS ORTIZ, «Las Reglas de Hamburgo (Convenio de las Naciones Unidas sobre el transporte marítimo de mercancías, 1978), en AA.VV., Derecho uniforme del transporte internacional, Madrid 1998, pp. 67 ss. El sistema de las RH difiere sustancialmente del previsto en las RHV. Para un análisis comparativo entre unas y otras, véase G. F. CHANDLER III, «A comparison of Cogsa, the Hague/Visby Rules and the Hamburg Rules», 15 J.Mar.L. \& Com. 233-291 (1984). Con una misma perspectiva, B.W. YANCEY, «The carriage of goods: Hague, Cogsa, Visby and Hamburg», 57 Tul.L.Rev. 1238-1259 (1983); P. BonASSIES, «La responsabilitè du transporteur maritime dans les Règles de la Haye et dans les Règles de Hambourg», Dir.Mar. (1989), 949. En un estadio previo, F. BERLINGIERI Jr., «La Convenzione di Bruxelles del 25 agosto 1924 sulla polizza di carico ed il progetto Uncitral di convenzione sul trasporto di merci per mare: un raffronto critico», Dir. Mar. (1977), 557. Igualmente, J. M. ${ }^{a}$ GondRA, «El proyecto de reforma del Convenio de Bruselas de 25 de agosto de 1924, sobre transportes marítimos en régimen de conocimiento», RDM (1965), 313.

${ }^{24}$ PALGNM = Propuesta de Anteproyecto de Ley General de la Navegación Marítima (Ministerio de Justicia, Madrid 2004). Las menciones en este trabajo al régimen previsto en estos dos textos normativos (RH y PALGNM) se justifican en una personal apuesta de futuro. La PALGNM puede llegar a ser la próxima regulación del transporte marítimo en nuestro país, la cual se inspira señaladamente, por otro lado, en las RH en materia de responsabilidad (véanse las páginas 14 y 51 de su «Memoria»), y propone además la ratificación de dicho Convenio por parte del Estado español («Memoria», página 81). No hay aún, entre nosotros, demasiadas referencias bibliográficas sobre la PALGNM, por lo que debemos remitirnos a los trabajos que sobre esta materia verán la luz en un futuro próximo y que formaron parte de la XIV Jornada sobre Derecho Marítimo en San Sebastián, celebrada el pasado 18 de mayo de 2006, organizada por la Escuela de Administración Marítima del Gobierno Vasco, con la colaboración del Departamento de Derecho de la Empresa de la Universidad del País Vasco (UPV-EHU). 
directa o indirectamente, derogue el presente Convenio, será considerada nula y sin efecto» ${ }^{25}$.

Por lo tanto, fuera de las posibilidades de pacto divergente que el propio CMR admita (p. ej., artículo 24), el régimen de responsabilidad del transportista es plenamente imperativo.

En todo caso, la nulidad a la que se refiere el artículo 41 CMR será de carácter parcial (en sus palabras: «no lleva aparejada la de las demás estipulaciones del contrato de transporte»).

En el sector marítimo, por su parte, el régimen de responsabilidad del transportista en régimen de conocimiento de embarque también tiene carácter imperativo, pero con carácter mínimo, es decir, el régimen legal de responsabilidad es inderogable para las partes, salvo que los pactos divergentes beneficien al derechohabiente. Si los pactos fuesen nulos, también aquí la nulidad será parcial.

Esta posición se desprende de los artículos 1(b), 3.8, 5 y 7 RHV $(2,4,10$, 13 y 17 LTM). Y también es la que recogen los artículos 2.3 y $23 \mathrm{RH}$ y el artículo 329 PALGNM.

\section{Periodo de responsabilidad}

Con esta expresión se describe el periodo de tiempo durante el cual el transportista responderá por el incumplimiento del contrato, si la pérdida, avería o retraso han sido causados por un hecho que sea reconducible a dicho periodo.

Generalmente, el periodo de responsabilidad del transportista comienza desde que se hace cargo de la mercancía en su origen hasta que la entrega (real o ficticiamente) en su destino. Y así lo establece inequívocamente el artículo 17.1 CMR para el transporte por carretera.

En el transporte marítimo, conceptualmente hablando, el periodo de responsabilidad también se define y delimita en unos mismos términos. La diferencia que se plantea en este sector es que no hay ningún precepto en las RHV (LTM) similar al artículo 17.1 CMR.

Lo que sí hay, pero no es lo mismo, es un precepto que delimita la extensión temporal del régimen imperativo de responsabilidad establecido por el Convenio (artículos 1.e RHV y 1 LTM), que como sabemos, acoge la regla llamada «tackle to tackle» (si bien con algunas complicaciones interpretativas añadidas por la redacción de la LTM). Es decir, el transportista marítimo es responsable desde que se hace cargo de la mercancía en origen hasta que la entrega en destino, pero su responsabilidad por las fases no marítimas del

${ }^{25}$ M. ZAAP, «Vertraglich begründete Überprüfungspflichten und Art. 41 CMR», TranspR (1991), 371. 
traslado se regirá no por las RHV (LTM) sino por las normas que resulten de aplicación a esas otras fases ${ }^{26}$.

Las RH (artículo 4) ${ }^{27}$ y la PALGNM (artículo 331) pretenden eliminar esta tradicional disfunción marítima reconduciendo el tratamiento normativo del periodo de responsabilidad del transportista marítimo a un sistema como el previsto en el CMR (si bien con algunas particularidades portuarias, que tendrán en cuenta la eventual intervención forzosa de autoridades o terceros en las fases previa y posterior al trayecto marítimo).

\section{Fundamento de la responsabilidad}

En esta materia, los sistemas terrestre (carretera) y marítimo se inspiran en un mismo modelo, el de presunción de responsabilidad (o de culpa): es decir, probado un incumplimiento contractual originado en el periodo de responsabilidad, se presume la responsabilidad del transportista, quien, para liberarse de dicha imputación de responsabilidad, deberá demostrar que el incumplimiento ha sido causado por uno de los hechos exoneradores previstos en la ley.

Éste es el sistema establecido en los artículos 17 y 18 CMR y, con cierta oscuridad y complejidad, en el artículo 4 RHV, apartados 1, 2 y 4 (artículos 6, 7 y 8 LTM). También lo acogen, por su parte, el anexo II y artículo 5 RH y el artículo 333 PALGNM.

Las divergencias entre ambos sistemas surgen con la formulación de las causas de exoneración.

En el CMR, acogiendo un sistema más elaborado, el transportista dispone de unas causas de exoneración generales y otras especiales.

Las causas generales de exoneración (artículo 17.2) son las siguientes: (a) la culpa del derechohabiente; (b) una instrucción de éste no derivada de una acción culposa del transportista; (c) el vicio propio de la mercancía; y (d) las circunstancias que el transportista no pudo evitar y cuyas consecuencias no pudo impedir ${ }^{28}$. La prueba de estas causas corresponde al transportista (artículo 18.1).

Las causas especiales de exoneración, por su parte, están recogidas en el artículo 17.4 y gozan de un régimen de prueba más beneficioso para el transportista que el del artículo 18.1 (artículo 18.2-5), por tratarse de riesgos específicos del transporte.

${ }^{26}$ D. Morán Bovio, Extremos del periodo de aplicación mínimo en la $C B-P V$, Madrid 1998. Del mismo autor, «Mercancías en la fase portuaria: problemas y soluciones», en Estudios Duque, II, Valladolid, pp. 1473 ss.

${ }^{27}$ D. Moran Bovio, «Los límites del periodo de la responsabilidad del porteador en las Reglas de Hamburgo», en Estudios Menéndez, III, Madrid 1995, pp. 3947 ss.

${ }^{28}$ C. M. CAshmore, «Circumstances which the carrier could not avoid», J. Bus. L. 344-345 (1983). 
Por su parte, en el sistema marítimo vigente, las causas de exoneración se recogen en un largo - y confuso- listado, deudor del casuismo anglosajón característico de este modo de trasporte (4.2 RHV, 8 LTM). Se trata, en cualquier caso, de causas que pueden reconducirse, de un modo u otro, a las categorías generales o especiales del transporte por carretera. Más concisas (pero abiertas) se manifiestan en este ámbito, sin embargo, las RH cuando aluden, como circunstancia exoneradora general, a la necesidad de que el porteador marítimo pruebe que sus empleados o agentes adoptaron todas las medidas que razonablemente podían exigirse para evitar el hecho y sus consecuencias $^{29}$.

Otras cuestiones particulares que cabría destacar en este ámbito:

1) Así como los defectos técnicos de los vehículos de transporte por carretera no se pueden aducir como causa de exoneración (artículo $17.3 \mathrm{CMR})^{30}$, en el ámbito marítimo el transportista no será responsable de los daños derivados de la falta de navegabilidad del buque, a no ser que haya concurrido negligencia por su parte en este ámbito (artículos 4.1 RHV y 8 LTM) ${ }^{31}$.

2) No hay en el sector terrestre una posibilidad de exoneración como la que presentan las llamadas «faltas náuticas» en el transporte marítimo (artículos 4.2.a RHV y 8 LTM, párrafo tercero, letra $a$ ), particularidad marítima que, no obstante, desaparece en el sistema de las RH y de la PALGNM.

3) El incendio recibe un tratamiento específico en el transporte marítimo, del que no goza en el transporte por carretera ${ }^{32}$. En aquél, se presume su carácter fortuito y se pone sobre el demandante la carga de probar la negligencia del transportista en su causación o en la adopción de medidas para su extinción o atenuación (artículos 4.2.b RHV y 8.b LTM; también acogen esta peculiaridad marítima los artículos 5.3 RH y 333.2 PALGNM).

4) Los sistemas terrestre y marítimo coinciden en conceder un tratamiento particular al transporte de animales vivos, si bien las RHV (artículo 1c) (artículo 2 LTM) lo hacen para excluirlo del concepto de «mercancías» y, consiguientemente, para dejarlo fuera del ámbito de

${ }^{29}$ Un análisis comparativo en esta materia entre los principales textos internacionales marítimos puede encontrarse en R. HERBER, «The basis of liability of the carrier under the international conventions of carriage of goods by sea», Dir. Mar (1990), 493.

${ }^{30}$ K. H. Thume, «Die Haftung des CMR-Frachtführers für Fahrzeügmängel», RIW (1994), 357. En otro contexto, D. GLASS, «CMR and hired trailers.- A tilt too far?», [1981] 3 LMCLQ 384-388

${ }^{31}$ Sobre esta cuestión, por todos, J. C. SÁEnz García de Albizu, La innavegabilidad del buque en el transporte marítimo, Madrid 1992.

32 J. C. SÁenz García De Albizu, «La evolución de la excepción de incendio como causa de exoneración de la responsabilidad del porteador marítimo», ADM (1990), 165. 
aplicación de sus normas ${ }^{33}$, mientras que el CMR (artículo 17.4.f) lo considera un supuesto de riesgo específico del transporte y lo incluye entre los supuestos de prueba privilegiada (artículo 18.2), si bien con algunos matices (artículo 18.5). El futuro de la regulación marítima a este respecto, no obstante, aproximará el régimen marítimo al terrestre (artículos 5.5 RH y 334 PALGNM).

5) El tratamiento de la responsabilidad del transportista en los supuestos de desviación del vehículo (buque) de su ruta encuentra un acomodo clásico en el sector marítimo (artículos 4.2 .1 y $4.4^{\circ} \mathrm{RHV}, 8.1$ y 9 LTM, 5.6 RH y 288 PALGNM) ${ }^{34}$, pero no así en el ámbito del CMR, que no regula esta cuestión.

\section{Supuestos principales de responsabilidad}

La caracterización de los principales supuestos de responsabilidad del transportista es prácticamente universal en el sector del transporte (con independencia del modo). Habitualmente, el transportista responderá por la «pérdida», «avería» o «retraso» en la entrega de la mercancía.

De estos supuestos, el retraso es el que presenta algún interés desde la perspectiva de nuestro análisis ${ }^{35}$, pues así como en el ámbito del transporte por carretera, la correspondiente reglamentación le otorga un tratamiento específico, definiéndolo (artículo $19 \mathrm{CMR}$ ) y, en su caso, presumiendo la pérdida de la mercancía en caso de retrasos significativos (artículo 20 $\mathrm{CMR})^{36}$, la legislación marítima (RHV) ha prescindido de regularlo como supuesto de responsabilidad, sin perjuicio de la interpretación que a este respecto se ha propuesto del artículo 6 LTM, en cuya virtud cabría entender que el retraso también está previsto como supuesto de responsabilidad del transportista marítimo, si bien sujeto a posibles pactos exoneradores de responsabilidad, que, en este supuesto, no estarían prohibidos ${ }^{37}$. Este silencio (o indefinición) de la legislación marítima desaparece en las RH (artículo 5.2) y en el artículo 332 PALGNM, que dan un paso en el reconocimiento expreso del retraso como supuesto general de responsabilidad general del transportista marítimo.

${ }^{33}$ J.L. GoÑ ETCHEVERS, «El transporte de animales vivos», en AA.VV., Seminario sobre la responsabilidad del transportador de mercancías por agua (Buenos Aires), Milano 1983, pp. 77 ss.

${ }^{34}$ Por todos, J. C. SÁEnz García de Albizu, El desvío de ruta en el transporte marítimo, Vitoria 1995.

${ }^{35}$ K. GRÖNFORS, «The concept of delay in transportation law», ETL (1974), 400.

${ }^{36}$ K. H. Thume, «Die Haftung des CMR-Frachtführers für Verspätungschaden», RIW (1992), 966; A. C. HARDinghaM, «The delay provisions of CMR», [1979] 2 LMCLQ 193-198.

${ }^{37}$ En general, J. C. SÁEnz García de Albizu, «La responsabilidad del porteador por retraso en el transporte marítimo», Estudios Broseta, III, Valencia 1995, pp. 3355 ss. 


\section{Limitación de la deuda indemnizatoria}

Los transportes por carretera y marítimo comparten una misma posición de principio en materia de limitación de la deuda indemnizatoria del transportista responsable por pérdida y averías ${ }^{38}$. En ambos casos, está limitación se calcula sobre dos planos. Primero, sobre el valor de las mercancías perdidas o averiadas (daños directos). Y, en segundo lugar, sobre los importes monetarios máximos establecidos por la ley.

Con respecto al primer plano (valor de las mercancías), sin embargo, hay una divergencia significativa entre los dos modos de transporte considerados y es que, así como en el transporte por carretera el valor a tener en cuenta es de las mercancías en origen (artículo 23.1 CMR), en el transporte marítimo (artículos 4.5.b RHV y 11.b LTM) se trata del valor de las mercancías en destino, posición que comparte el artículo 335 PALGNM (las RH no dicen nada al respecto). El CMR y las RHV-LTM, por su parte, coinciden a la hora de proporcionar criterios orientadores para el cálculo de dicho valor (como, p. ej., la cotización bursátil de las mercancías, su precio corriente en el mercado, su valor usual), aspecto este que, sin embargo, no ha sido objeto de atención por la PALGNM (tampoco por las RH).

Por lo que respecta a los límites cuantitativos legales, por otro lado, las diferencias entre el modo terrestre (carretera) y el modo marítimo se proyectan en dos ámbitos: uno, el método de cálculo; y otro, el número de unidades de cuenta que se establecen como límite.

En el sector de la carretera, los límites legales de indemnización se calculan sobre la base de los kilogramos de peso bruto de la mercancía que faltare (artículo 23.3 CMR) o que se hubiere averiado (artículo 25.2 CMR). En el sector marítimo, también se utiliza este criterio del peso bruto de la mercancía perdida o averiada (artículos 4.5.a RHV y 11.a LTM; igualmente, artículos 6.1.a RH y 335 PALGNM), pero, alternativamente, puede emplearse el criterio del bulto o unidad del cargamento (véanse los preceptos recién mencionados), pudiendo elegir el reclamante la cantidad más elevada que resulte de la aplicación de ambos criterios. Hay, por otro lado, una especialidad marítima adicional en este terreno y es la que introduce la conocida "container clause», para los supuestos de bultos o unidades de cargamento agrupa-

${ }^{38}$ En general, entre nosotros, en el sector del transporte por mar, véase el trabajo de J. L. RUEDA MARTínEZ, «La limitación de la responsabilidad del porteador en el transporte marítimo de mercancías», ADM (1990), 19. Para el sistema del CMR en esta materia, H. GLÖCKNER, «Limits to liability and liability insurance of carriers under articles 3 and 23 to 29 of the CMR», en J. TheunIS (Gen. Ed.), International Carriage of Goods by Road (CMR), London 1987, pags. 97 ss. Del mismo autor, «Die Haftungbeschränkungen und die Versicherung nach den Art. 3, 23-29 CMR», TranspR (1988), 327. Igualmente, J. KNORRE, «Zur Haftung des Frachtführers nach Art. 23 u. 25 CMR», TranspR (1985), 241. 
dos en contenedores (artículos 4.5.b RHV, 11.c LTM, 6.2.a RH y 335.2 PALGNM) ${ }^{39}$.

También son distintos, como adelantamos, el número de unidades de cuenta (derechos especiales de giro o DEG) ${ }^{40}$ que se aplican en el transporte por carretera y en el transporte marítimo para calcular el límite máximo de indemnización. Mientras en el primero son 8,33 DEG, en el segundo son 666,67 DEG por bulto o unidad del cargamento o 2 DEG por kilogramo de peso bruto perdido o averiado (estas cantidades se modifican en las RH y en la PALGNM, que pasan a ser 835 DEG y 2,5 DEG respectivamente).

No es sustancialmente divergente, por su parte, el tratamiento que se le da en el transporte por carretera y el transporte marítimo a la cuestión de la posible modificación convencional de los límites indemnizatorios, pues en ambos casos se admiten pactos modificativos de las partes. Las diferencias, si se puede hablar de diferencias, estriban en los procedimientos habilitados en uno u otro caso para proceder a la referida modificación convencional de los límites de indemnización.

En el CMR hay dos procedimientos o sistemas perfectamente delimitados a este respecto: uno, la llamada «declaración de valor» (artículo 24 CMR); y otro, la llamada «declaración de interés especial en la entrega» (artículo 26 CMR). Fuera de ellos, no podrán ser reclamadas indemnizaciones de sumas superiores a las legalmente establecidas (artículos 23.6 y 41.1 CMR). Ambas declaraciones deberán fijarse en la carta de porte contra el

${ }^{39}$ Véase, entre otros, J. L. DE GuRSE, «The 'container clause' in article 4(5) of the 1968 Protocol to the Hague Rules», 2 J.Mar. L. \& Com. 131-146 (1970); T. BISSELL, «The operational realities of containerisation and their effect on the 'package' limitation and the 'ondeck' prohibition: Review and suggestions», 45 Tul.L.Rev 902-924 (1971); D. ZschOche, «Die Per-Package-Limitation beim transport in Containern», NJW (1978) 2421; T. J. ARMSTRONG, «Packaging trends and implications in the container revolution», 12 J. Mar. L. \& Com. 427-465 (1981); L. B. ALEXANDER, «Containerization, the per package limitation and the concept of 'fair opportunity' (Comment)» 11 Mar.Law 123-140 (1986); G. M. BoI, «Applicazione del limite del debito del vettore ai containers», Dir.Mar. (1986), 574; ID., «Sull'applicabilità ai containers del limite del debito del vettore» (nota), Dir.Mar. (1986), 1067; ID., «Trasporto a mezzo contenitori e responsabilità del vettore marittimo: i primi orientamento della giurisprudenza italiana» (nota), Dir.Mar. (1989), 1074; ID., «Il trasporto marittimo a mezzo contenitori: la giurisprudenza italiana di fronte al dato normativo», Dir.Mar. (1994), 734; AA.VV., Il trasporto a mezzo contenitori: disciplina legale delle responsabilità, profili assicurativi e gestione delle liti, Seminario organizado por el Centro Ligure per la Produttività, bajo el patrocinio de la Camera di Commercio de Genova, 13-14 de octubre de 1994.

${ }^{40}$ Con alcance crítico, A. TовоLEwsKi, «The special drawing right in liability conventions: an acceptable solution?», RDU/ULR (1978), II, 13; J. RAMBERG, «Monetary limits: CMR or national law», ponencia presentada en The European Inland Road Transport Law Conference (Eurotral'94), Erasmus Universiteit, Rotterdam, 24-25 de noviembre de 1994 y publicada en K. F. HAAK y E. C. SWART, Road carrier's liability in Europe, 2, Stichting Vervoeradres, The Hague 1995. 
pago de un sobreporte. La primera tiene como objeto declarar un valor de la mercancía superior a los 8,33 DEG por kilogramo de peso bruto, sustituyendo el montante declarado al legal. Y la segunda permitirá reclamar una indemnización igual al perjuicio suplementario que consiga probarse, además de la que, en su caso, corresponda en función de la aplicación de los límites legal o declarado del valor de la mercancía.

En el ámbito marítimo, por su parte, es admitida también la «declaración de valor» (artículos 4.5. a y h RHV y 11.a y f LTM; véase, igualmente, el artículo 335.1 PALGNM). Y si bien no se contempla un procedimiento específico como el de la «declaración de especial interés en la entrega», no puede decirse que la normativa marítima aplicable sea restrictiva en este particular, como demuestran las posibilidades que abren los artículos 4.5.g y 5 RHV, primer inciso (11.g y 13 LTM) (véanse, igualmente, los artículos 6.4 y 23.2 RH y, en general, 329 PALGNM).

Finalmente, por lo que respecta a los límites indemnizatorios en los casos de retraso en la entrega de las mercancías, el CMR (artículo 23.5) los cifra en una suma que no excederá el precio del transporte, siempre que se pruebe que el retraso causó un perjuicio. No hay, por razones que advertimos anteriormente, un tratamiento específico de esta cuestión en el régimen de las RHV (LTM), pero sí en las RH (artículo 6.1.b) y en la PALGNM (artículo 336.1), que establecen un límite de dos veces y medio el flete pagadero por las mercancías afectadas por el retraso, límite que podrá ser modificado convencionalmente (artículos 6.4 RH y 329 PALGNM). En la futura regulación marítima, por otro lado, se recoge, además, una regla específica aplicable a los supuestos de concurrencia de indemnizaciones por avería y retraso (artículos 6.1.c RH y 336.3 PALGNM), que es inexistente en el CMR y en las RHV (LTM).

\section{Pérdida del beneficio de la limitación de la deuda indemnizatoria}

La pérdida del beneficio de la limitación de la deuda indemnizatoria en determinadas circunstancias está recogida en todos los instrumentos del Derecho uniforme del transporte, incluidos los relativos al transporte por carretera y al transporte marítimo. Es el caso del artículo $29 \mathrm{CMR}^{41}$ y de los

${ }^{41}$ O. TumA, «Art. 29 CMR. Bestandsaufnahme und Ausblick», ETL (1993), 649; ID., "Variations on the theme: "wilful misconduct" and "Große Fahrlässigkeit"», ponencia presentada en «The European Inland Road transport Law Conference (Eurotral'94)», Erasmus Universiteit, Rotterdam, 24-25 de noviembre de 1994 y publicada en K. F. HAAK y E. C. SwART, Road carrier's liability in Europe, 2, Stichting Vervoeradres, The Hague 1995. Igualmente, A. CHAO, «Dol, fraude ou infidelité et faute lourde du voiturier. Incidences sur la responsabilité, la réparation due et la recevabilité de l'action», BT (1990), 315; P. LuTZ, «Die Rechtsprechung der französischen Cour de Cassation zum Begriff des großen Verschulders des Frachtführers nach Artikel 29 CMR», TranspR (1989), 155. 
artículos 4.5.e y 4bis.4 RHV (11.e y 10.4 LTM), que acogen un régimen que es aplicable tanto a la responsabilidad del transportista como a la de sus auxiliares dependientes o independientes.

Las divergencias más significativas entre los sistemas propios de la carretera y del sector marítimo en esta materia residen en cómo se formulan normativamente las circunstancias en las que procede la pérdida del citado beneficio. Así, en el CMR, la pérdida se producirá cuando el daño haya sido causado por dolo o culpa equiparable al dolo por la ley del foro ${ }^{42}$. Mientras que en el sector marítimo se requiere que el daño sea el resultado de un acto o de una omisión del transportista, que se produce o con intención de provocarlo o temerariamente y con conocimiento de que probablemente del hecho se deducirá un daño.

\section{Aplicación del régimen de responsabilidad a las diversas acciones}

Para blindar el régimen de responsabilidad contractual previsto en sus normas, frente al posible ejercicio de acciones extracontractuales ${ }^{43}$, los instrumentos del Derecho uniforme del transporte por carretera y marítimo acogen una regla según la cual, en caso de reclamación aquiliana contra el transportista o sus auxiliares, éstos podrán ampararse en las disposiciones del correspondiente Convenio que establezcan exoneraciones o limitaciones de responsabilidad.

${ }^{42}$ P. IVALDI, «Wilful misconduct e colpa grave fra diritto internazionale e diritto interno», Riv.Dir.Int.Priv.Proc. (1989), 617. Entre nosotros, F. J. SÁNCHEZ-GAMBORINO, «La llamada culpa equiparable al dolo y sus consecuencias en el contrato de transporte», RDM (1995), 723.

${ }^{43}$ El problema de la concurrencia de acciones contractuales y extracontractuales en una misma situación ilícita ha suscitado una notable discusión doctrinal. En general, M. YZQUIERDO: «La zona fronteriza entre la responsabilidad contractual y la aquiliana. Razones para una moderada unificación», $R C D I$ (1991), 443. En el sector específico del transporte (sobre todo marítimo), F. SolveNI, «Responsabilitá contrattuale ed extraconttratuale del trasporto marittimo di cose», Dir.Mar. (1960), 400; ID., «Sul concorso della responsabilitá conttratuale ed extraconttratuale nel trasporto marittimo di cose», Dir.Mar. (1969), 271; M. FALLON, «Le concours des actions en responsabilité: tâtonnements et certitudes de la Cour de Cassation de Belgique (Cass. 7. 12. 1973)», ETL (1974), 534; M. LÓPEZ DE GoNZALO, «Orientamenti della giurisprudenza in tema di concorso di responsabilitá contrattuale ed extraconttratuale nel trasporto marittimo di cose», Dir.Mar. (1984), 846; ID., «Il concorso di responsabilità conttratuale ed extraconttratuale nella Hague-Visby Rules e nelle altre convenzioni di diritto uniformi di trasporto», Dir.Mar. (1986), 611; C. MEDINA, «Ancora sul concorso o meno di responsabilità conttratuale e extraconttratuale del vettore aereo $\mathrm{o}$ sulla decadenza di responsabilità», Dir.Mar. (1989), 1138. 
En este sentido se pronuncian los artículos $28 \mathrm{CMR}^{44}$ y 4 bis RHV (10 bis LTM) (también los artículos 7 RH y 337 PALGNM) ${ }^{45}$.

El único matiz diferenciador, si bien relevante, sobre este particular es que en el sector del transporte marítimo (RHV-LTM) la protección que dispensa esta regla uniforme no se extiende a los auxiliares independientes del transportista marítimo («contratistas por cuenta propia»), sino sólo a los auxiliares dependientes. La protección de aquéllos, en su caso, podrá articularse a través de la inserción en el documento de transporte de la llamada «cláusula himalaya», de frecuente pero debatida utilización en el tráfico ${ }^{46}$. Esta posición está llamada a cambiar en las RH y la PALGNM, que propugnan un régimen semejante al CMR.

\section{Protestas}

La facultad que tiene el destinatario de la mercancía para realizar protestas sobre su estado o situación en el momento de su entrega es muy relevante a los efectos de reforzar su posición de ataque de cara a una eventual reclamación. No es de extrañar, por tanto, que todos los instrumentos de Derecho uniforme del transporte aborden esta cuestión con la debida atención y que

${ }^{44}$ O. Tuma, «Zur Frage der Möglichkeit der Geltendmachung deliktischer Ansprüche wegen Güterschäden gegen im internationalen Straßengüterverkehr tätige Frachtführer unter besonderer Berücksichtigung der Stellung der Person des Anspruchstellers als Vetragspartner bzw. als außervertraglicher Dritter zum in Anspruch Genommenen sowie zur Frage, ob deliktische Ansprüche nicht am Frachtvertrag Beteilgter durch vertragliche Bestimmungen eingeschränkt werden konnen-CMR Art. 28, 32», ETL (1983), 3.

${ }^{45}$ En general, en el sector marítimo, J. M. RuIz SoROA, «Aplicación del régimen jurídico propio de las acciones de responsabilidad por averías o pérdidas en el cargamento o daños al pasajero», III Jornadas de Derecho marítimo de San Sebastián, San SebastiánDonostia 1996, pp. 89 ss. Igualmente, G. RigHETTI, «Responsabilitá conttratuale e responsabilitá extraconttratuale del vettore marítimo e del noleggiante», Dir.Mar. (1961), 569; K. GRÖNFORS, «Non-contractual claims under the Hamburg Rules», en S. MANKABADY (Ed.), The Hamburg Rules on the carriage of goods by sea, Leyden-Boston 1978, pp. 187 ss.; F. M. B. REYNOLDS, «The significance of tort claims in respect of carriage by sea», (1986) 1 LMCLQ 97-111.

${ }^{46}$ Sobre esta cláusula y otros aspectos próximos, J. B. DoAK, «Liabilities of stevedores, terminal operators and other handlers of cargo», 45 Tul.L.Rev. $752-769$ (1971); S. CigoJ, «Legal relations of stevedores in comparative law», (1975) 3 LMCLQ 296-302; W. TETLEY, «The Himalaya clause. Heresy or genius», 9 J.Mar.L.Com. 111-130 (1977-1978); D. G. PowLES, «The Himalaya Clause», (1979) 3 LMCLQ 331-346; J. ZAwITOSKI, «Limitation of liability for stevedores and terminal operators under the carrier's bill of lading and Cogsa», 16 J. Mar. L. \& Com. 337-363 (1985); C. D. HOOPER, «Legal relationships: terminal owners, operators and users», 64 Tul.L.Rev. 595-609 (1989); AA.VV., «Symposium on terminal operations and multimodalism», Admiralty Law Institute, Tulane Law School, 64 Tul. L. Rev. 281-629 (1989); S. Hilton, «The Himalaya Clause in South Africa. The Sanko Vega (Case and Comment)», (1992) 3 LMCLQ 317-322; N. GASKELL, «Shipowner liability for cargo damage caused by stevedores. The Coral (Case and Comment)», (1993) 2 LMCLQ 170-177. 
lo hagan, en cierto modo, de una manera semejante en todos ellos, si bien no se caracterizan, en su mayoría, por su simplicidad y sistematicidad.

Así, por un lado, tanto el CMR (artículo 30) ${ }^{47}$ como las RHV (artículo 3.6; también, artículo 22 LTM) ofrecen al destinatario dos procedimientos de protesta: uno, las reservas (CMR) o avisos (RHV-LTM); y, otro, la inspección conjunta o verificación contradictoria de la mercancía. En un mismo sentido se pronuncian los artículos 19 RH y 340 PALGNM.

Tratándose del segundo de los procedimientos, el CMR establece que «la prueba contraria al resultado de esta verificación no será admisible más que si se trata de pérdidas o averías ocultas y siempre que el destinatario haya dirigido reservas escritas al transportista en el plazo de siete días, descontados domingos y festivos, desde esta verificación» (artículo 30.2). La normativa marítima se limita a establecer que «las reservas por escrito son inútiles si el estado de la mercancía ha sido comprobado contradictoriamente en el momento de la recepción» (artículos 3.6 RHV, párrafo segundo y 22 LTM, párrafo tercero).

En el caso de reservas o avisos, por su parte, se exige, en primer lugar, que se hagan por escrito (artículo 3.6 RHV, primer párrafo y artículo 22 LTM, primer párrafo), si bien en el CMR (artículo 30.1), este requisito sólo se establece expresamente para los casos de pérdidas o averías ocultas. Y, en segundo lugar, deben ser hechas dentro del plazo establecido, que en caso de pérdidas o averías aparentes será el mismo momento de entrega de las mercancías (posición compartida por el CMR y las RHV-LTM, no así por las RH o la PALGNM, que lo extienden hasta el día laborable siguiente a la entrega); y en el caso de pérdidas o averías no aparentes (u ocultas) será de siete días desde la fecha de entrega, en el CMR, o de los tres días laborables siguientes a la entrega, en el caso de las RHV-LTM (éste es también el plazo acogido por la PALGNM, pero no por las RH, que lo fijan en 15 días).

Pero, quizás, lo más relevante del régimen de las protestas (en particular, de los avisos o reservas) sea la determinación de sus consecuencias o, para ser más precisos, de las consecuencias derivadas de la omisión de reservas o de su realización fuera de plazo. En este aspecto, el transporte por carretera y el transporte marítimo siguen una misma regla: a falta de reservas válidamente realizadas, se presumirá (iuris tantum) la recepción de las mercancías por el transportista en el modo descrito en la carta de porte. Esta consecuencia, por su parte, alcanza también a los supuestos en que no se hubiere procedido a la correspondiente inspección conjunta o verificación contradictoria.

${ }^{47}$ R. LOEwE, «The CMR provisions concerning claims and actions», en J. THEUNIS (Gen. ed.), International Carriage of Goods by Road (CMR), London 1987, pags. 145 ss. Igualmente, del mismo autor, «Die Bestimmungen der CMR über Reklamationen und Klagen», TranspR (1988), 309. 
En el caso de que el supuesto de responsabilidad considerado sea el retraso, una vez más tan sólo el CMR alude al régimen de protestas. Y lo hace en su artículo 30.3 cuando señala que «el retraso en la entrega no dará lugar a indemnización más que en el caso de que se haya dirigido reserva por escrito al transportista dentro del plazo de veintiún días desde la puesta de la mercancía a disposición del destinatario». Una previsión semejante no aparece en el sistema de las RHV-LTM, por razones conocidas, pero sí en las RH (artículo 19.5), aunque no en la PALGNM. Las RH exigen dar aviso por escrito dentro de un plazo de 60 días desde que las mercancías debieron ser entregadas y, en caso contrario, establecen también la preclusión del derecho a la indemnización de daños y perjuicios.

Finalmente, coinciden CMR (artículo 30.5) y las RHV-LTM (artículos 3.6, párrafo cuarto, y 22, párrafo quinto, respectivamente; igualmente, véase el artículo $19.4 \mathrm{RH}$ ) en establecer una regla en cuya virtud se exige a las partes que se den recíprocamente toda clase de facilidades para la inspección de la mercancía y para la realización de las constataciones y verificaciones necesarias. Este régimen no aparece en la PALGNM.

\section{Prescripción}

En esta materia, el CMR (artículo 32.1, primer párrafo) establece unos plazos de prescripción de las acciones derivadas del contrato de transporte que son, en concreto, de un año (plazo general) o de tres años, este último previsto especialmente para los supuestos de acciones basadas en el artículo 29 CMR (existencia de dolo o culpa equiparable al dolo). La regulación del CMR en esta materia se completa con la determinación del comienzo del plazo de prescripción (artículo 32.1, segundo párrafo), con unas polémicas reglas relativas a la interrupción y suspensión de la prescripción (artículo 32.2 y 3 ) $^{48}$ y, finalmente, con la indicación de los efectos derivados de la prescripción (artículo 32.4). También, el CMR regula, si bien en otra sede, la prescripción de las acciones de repetición en los casos de transportes sucesivos aunque con una remisión al régimen general del artículo 32 (artículo 39.4) ${ }^{49}$.

${ }^{48}$ R. DE WIT, «La formulation de réserves et la suspension de la prescription sous l'empire de la C.M.R. Note sous Comm. Bruxelles 2 avril 1990», ETL (1991), 547; D. DE BEULE, «L'article 32.2 CMR», ETL (1988), 654; C. M. CASHMORE, «CMR limitation period; suspension of period by virtue of written claim», J. Bus. L. 172-173 (1985); R. DE ÁNGEL YAGÜEZ, «Interrupción y suspensión de la prescripción. Convenio de Ginebra sobre transportes por carretera», La Ley (1987-4), 213; J. KNORRE, «Die Person des Reklamierenden im Sinne des Art. 32 Abs. 2 CMR», TranspR (1989), 308.

${ }^{49}$ En general, sobre el régimen de la prescripción en el CMR, véase J. WETTER, «The time bar regulations in the CMR convention», [1979] 4 LMCLQ 504-509; A. C. HARDINGHAM, «Aspects of the limitation of actions under CMR», [1979] 3 LMCLQ 362-367; A. EMPARANZA SOBEJANO, «La prescripción de las acciones en el Convenio relativo al contrato de transporte internacional de mercancías por carretera (CMR)», RGD (1992), 11713; A. L. 
En el ámbito de las RHV (LTM), por su parte, esta cuestión está regulada en su artículo 3.6, párrafo cuarto (artículo 22 LTM, párrafo cuarto), donde se afirma que «el porteador y el buque quedarán descargados de cualquier responsabilidad relacionada con las mercancías a menos que se entable la acción correspondiente dentro de un año, a contar desde la entrega de las mismas, o desde la fecha en que hubieren debido entregarse». Se coincide, por tanto, con el plazo general del CMR (un año), pero ahí se detienen los parecidos. Así, la determinación del dies a quo en el régimen marítimo es menos precisa que en el CMR. Y, por otro lado, y mucho más relevante, el plazo de las RHV-LTM, según postura unánime, no es de prescripción, sino de caducidad, aunque las RHV-LTM permiten la prórroga de dicho plazo mediante acuerdo concertado entre las partes con posterioridad al hecho que dio lugar a la correspondiente acción.

La regulación de esta materia en las RH está recogida en su artículo 20. Y también en el artículo 341 de la PALGNM (o en su artículo 330.4, para la acción de repetición en los supuestos de concurrencia de porteadores contractual y efectivo). Tanto en uno como en otro instrumento, el plazo de prescripción, que será tal (y no de caducidad), es de dos años.

\section{Conclusiones}

La política comunitaria en el sector del transporte ha hecho una apuesta innegable por el TMCD. Por un lado, para revitalizar un sector en claro declive. Y, por otro, para impulsar su inserción en el marco de operaciones de transporte multimodal más eficientes, rápidas, seguras y respetuosas con el medio ambiente. Nos parece una política muy sensata.

Desde un punto de vista jurídico-contractual, las operaciones de transporte con TMCD plantean, sin duda, ciertas incertidumbres, en parte porque no hay un modelo estructural único que configure jurídicamente a dichas operaciones; y, también, por la inevitable superposición contractual y de regímenes, más o menos divergentes entre sí, que caracteriza a este tipo de operaciones. Pero esta apreciación, llamémosla negativa, no debe impedirnos apreciar los aspectos positivos del actual estatus jurídico aplicable a las operaciones de transporte con TMCD. Es cierto que no contamos con un régimen uniforme aplicable a los distintos modos de transporte ${ }^{50}$, situación

Monge GiL, «Transporte internacional de mercancías. Prescripción (Comentario a la sentencia del Tribunal Supremo de 24 de febrero de 1995)», CCJC (1995), 767, ref. 1036; A. PÉREZ Moriones, «La regulación de la prescripción de las acciones en el Convenio de Ginebra de 19 de mayo de 1956, relativo al contrato de transporte internacional de mercancías por carretera», $R d P$ (1999), 203.

${ }^{50}$ S. ZAMORA, «Carrier liability for damages or loss to cargo in international transport», 23 Am. J. Comp. L. 391 (1975). Y aun así, siempre tendríamos el problema de la divergente aplicación nacional del correspondiente régimen uniforme. Como botón de muestra, CH. DE BATTISTA, «Carriage conventions and their interpretation in English Courts», J. Bus. L. 130-142 (1997); D. J. HILL, «The interpretation of CMR in the English courts», [1977] 2 LMCLQ 212-217. 
que algunos calificarán de utópica. Y que ni siquiera se ha conseguido alcanzar un consenso sobre una regulación uniforme del transporte multimodal. Pero debemos recordar que, al menos en el contexto comunitario o europeo, contamos con un precepto, el artículo $2 \mathrm{CMR}$, que, no obstante sus dificultades interpretativas y de aplicación, contempla, precisamente, un modelo de estructuración del transporte que responde fielmente a las exigencias que plantean las operaciones de transporte con TMCD o, por ser más precisos, de un buen número de dichas operaciones. Cabría recomendar, sin duda, una reforma de dicho precepto, para clarificar su aplicación y alcance, en los términos sugeridos por la doctrina que lo ha criticado. Pero el precepto está ahí y puede dar un juego adecuado en el contexto de la utilización del TMCD en operaciones de transporte multimodales. Y, por otro lado, también están ahí el CMR y las RHV (LTM) como instrumentos reguladores de las diferentes fases, etapas o relaciones implicadas en las operaciones de transporte con TMCD, para proporcionar la suficiente confianza a los operadores que intervienen en este sector. Una confianza que proviene de la solera de dos cuerpos normativos que, sin perjuicio de sus defectos (mayores o menores, según el caso) han sido objeto de una aplicación solvente y regular por parte de los operadores jurídicos a lo largo del tiempo. Probablemente, la labor pendiente sea la de proporcionar a los operadores del transporte por carretera la suficiente información acerca del alcance de la regulación marítima vigente (RHV), labor esta que, dicho sea de paso, vendría facilitada por una eventual entrada en vigor entre nosotros y los países de nuestro entorno de las $\mathrm{RH}$, que responden a un modelo de regulación del contrato de transporte más próximo al CMR que a las RHV. Pero esto, pensarán algunos, también puede ser una utopía ${ }^{51}$.

\footnotetext{
${ }^{51}$ Para una valoración de las RH, desde distintas aproximaciones, pueden consultarse los trabajos de K. GRÖNFORS, «The Hamburg Rules. A failure or success?», J.Bus.L (1978), 334; S. KATZ, «New momentum towards entry into force of the Hamburg Rules», ETL (1989), 297; C. K. NubupKo, «La Convention des Nations Unies sur le transport international de merchandises par mer dix ans après», DMF (1989), 539; L. DelwaIDE, «The Hamburg Rules: a choice for the EEC?», Dir.Mar. (1994), 74; B. MAKINS, «The Hamburg Rules: A casualty?», Dir. Mar. (1943), 637. Véase, igualmente, desde otra perspectiva, D. MoRÁN Bovio, «Primeras sentencias en aplicación de las Reglas de Hamburgo», RGD 627 (1996), 13303.
} 


\section{๑) Universidad de Deusto - ISSN 0423-4847}




\title{
Repercusiones del hecho del consumo en las vicisitudes del Derecho Social $^{*}$
}

\author{
Manuel M. ${ }^{\text {a }}$ Zorrilla Ruiz \\ Catedrático Emérito de la Universidad de Deusto \\ Ex-Presidente del Tribunal Superior de Justicia del País Vasco \\ Presidente de la Asociación de Jueces y Magistrados Jubilados de España
}

\begin{abstract}
Resumen: Las peripecias del hecho del consumo se relacionan con los cambios sucesivos del Derecho Social. El Estado de Bienestar favoreció el hecho del consumo, a causa de las circunstancias peculiares de la era de la prosperidad. La moda de la productividad aceleró el hecho del consumo y la inconsciente cooperación de los trabajadores a la obtención de la plusvalía que los empleadores lograban. La crisis económica - interminable y complicada - impuso soluciones cualitativas para reordenar el Derecho Social, salvaguardar el empleo escaso y mitigar la propensión al hecho del consumo. La globalización ha impulsado el hecho del consumo y sentado las bases del tratamiento neoliberal del Derecho Social, beneficiando al capital en detrimento de los trabajadores dependientes.
\end{abstract}

Palabras clave: adquisiciones cualitativas, disolución del conflicto industrial, globalización, hecho del consumo, relaciones de trabajo.

Abstract: The events of the fact of consumption are related with the succesive changes of the Social Law. The Welfare State favoured the fact of consumption, duty to the circumstances of the age of the prosperity. The fashion of the productivity increased the fact of consumption and the inconscious cooperation given by the workers to the gain in value in profite of the employers. The economic crisis, complex and limitless, imposed qualitative solutions to put in order the Social Law, protect the slight employment and moderate the propension to the fact of consumption. The globalization has impelled the fact of consumption and has put the basis of the neoliberal treatment for the Social Law, in profite of the capital, but being in detriment of the dependent workers.

Key words: qualitative advantages, dissolution of the industrial conflict, globalization, fact of consumption, labour relations.

Sumario: I. Evolución y proyección general del hecho del consumo. - II. Devaluación del hecho del trabajo y exaltación del hecho del consumo. - III. Reacción anticonsumista de orden cualitativo. - IV. Dispersión histórica del hecho del consumo y de las relaciones de trabajo. V. Suerte del hecho del consumo tras la instalación del estado social y

* Ponencia presentada por el autor en el Congreso Internacional sobre Derecho de Consumo, celebrado en la Universidad de Deusto (Bilbao), los días 26 a 28 de junio de 2006. 
democrático de derecho. - VI. Impacto de la productividad industrial en el hecho del consumo. - VII. Correlaciones de la plusvalía y el hecho del consumo. - VIII. Destino del hecho del consumo ante el advenimiento de la crisis económica. - IX. Interconexiones del hecho del consumo, las mudanzas de las relaciones de trabajo y el fenómeno de la economía general. - X. ¿Hacia la privatización neoliberal del régimen jurídico de las relaciones de trabajo? - XI. Espectro consumista de los programas globalizadores. - XII. Función de las relaciones colectivas de trabajo en el hecho del consumo de los bienes y servicios esenciales de la comunidad. - XIII. Reflexión final.

\section{Evocación y proyección general del hecho del consumo}

El hecho del consumo es el resultado de la distribución y puesta en el mercado de libre competencia, y de la obtención de bienes materiales y/o prestaciones de servicios a través de un título jurídicamente válido para integrarlos en el patrimonio de los adquirentes. A las transformaciones físicas de los factores productivos consistentes - por orden de complejidad - en materias primas, bienes de producción, en su acepción más amplia, y bienes de consumo incorporados a partir del ciclo que los origina, siguen su distribución y oferta en circunstancias de lugar y de tiempo que, sin cambios de sustancia o accidente, pretenden extraer un lucro económico de su reparto y enajenación. Beneficio que, tratándose de servicios en sentido estricto, asocia ese lucro a una transformación cualitativa que no muda su identidad originaria.

El hecho del consumo —que inicialmente designa la superación de las formas primarias de la economía de sobrevivencia - termina acampando bajo la dominación que el ejercicio de la libertad de empresa impone en aquellos episodios que abordan las reivindicaciones colectivas - cuando reclaman el cumplimiento de las funciones sociales de dicha libertad-o practican un ecumenismo consumista que, impregnado de intenciones de signo variable, sugiere un cambio sustancial del curso de los acontecimientos.

Tardó algún tiempo en abrirse paso la idea de que incluso las aseveraciones de la filosofía perenne no desautorizaban un marco de laicismo económico en el que había lugar para una perspectiva secular de las operaciones típicas del hecho del consumo. Algo que, atisbado en principio como una exhibición de atrevimiento y avalado después por interpretaciones respetables, terminó confirmándose por vía de deducciones convincentes. Si se cita este ejemplo, no es por su especialidad anecdótica y sí para apuntar la variedad de las conexiones que un lúcido examen del hecho del consumo contribuye a descubrir y/o aclarar.

Las doctrinas jurídico-políticas surgidas al calor de la era de los descubrimientos despertaron la preocupación por un neoconsumismo en que la 
relación de servicios del trabajo dependiente subyacía al grosor de otras consideraciones de base que procedía hacer a la sazón. La tesis calvinista de que el éxito de las operaciones lucrativas respaldaba la bondad moral de los triunfadores económicos y anunciaba su salvación eterna, muestra - con cinismo subliminal e insuperable- los estímulos de una concepción abusiva del consumo y practica una aberrante exaltación de quienes profesionalmente se entregaban a satisfacer sus exigencias. Las reglas colegidas de esta ideología no sólo abarcaban a quienes, mediante la producción, predisponían al consumo, sino también a cuantos soportaban una situación de dependencia de mercado que, a la larga, definiría a la nueva clase — la de los trabajadores por cuenta ajena- como el primero y más sacrificado de los grupos parciales de la futura sociedad pluralista.

\section{Devaluación del hecho del trabajo y exaltación del hecho del consumo}

El designio de convertir la sociedad en un campo sin fronteras para las avideces consumistas - subrayando sus excelencias, naturales o artificiosas, y velando la fealdad de su rostro diabólico - ha pospuesto los escasos valores morales del fenómeno y suscitado reflexiones que, pocas veces, elogian su prevalecimiento $\mathrm{y}$, más frecuentemente, le censuran o enumeran sus tachas. El hecho del consumo ha provocado una subestimación del hecho del trabajo que, como factor productivo, incrementa el valor de los bienes y servicios dados al mercado y brindados a los consumidores por los que aprovechan la plusvalía emanada de sus transformaciones. Se fuerza - hoy más que nunca y menos que en un futuro de cierta temibilidad - la tarea de edificar un universo gobernado por una idea intelectual y moralmente detestable. La de que, ante lo perentorio de enriquecerse mediante las operaciones de consumo subsiguientes a las de producción y puesta en el mercado, los pobres — desheredados e indefinidamente débiles - están llamados a protagonizar unos capítulos históricos en los que pierden siempre las batallas libradas en pro de su liberación. Bien, porque, en los vergonzosos escenarios donde luce y escandaliza su pobreza, poco importa su suerte, si la capacidad de consumir no cuenta y, en su lugar, menudean los auxilios humanitarios que son la coartada de la negativa a liberarlos. Bien, porque ciertos cambios de las relaciones de trabajo merman las exigencias de consumo que aquejan a quienes más necesitan de su satisfacción.

Cuando se invocan o cuestionan la moralidad y la modernidad de la globalización - multiplicadores galopantes de un hecho del consumo que, además de desbordar las previsiones razonables, superan las conjeturas más fantásticas- se endurecen los rasgos del rostro diabólico que caracteriza a su finalidad de alienación. Para que el consumo sobreviva en el universo achicado o tierra plana que funda su fenomenología, se fabrican ciertas reglas de juego. Se sostiene que la utilidad o beneficio industrial que reporta al oferen- 
te de bienes y/o servicios su puesta en el mercado no debe sufrir el castigo de la parte de los costes de producción que, según las pautas del Estado social y democrático de Derecho, convienen a unas condiciones equitativas de trabajo y, en concreto, a la suficiencia remuneratoria de los trabajadores dependientes. La cosmoeminencia de la dignidad de la persona individual deja de ser, para las especulaciones consumistas, un objetivo respetable y se convierte en la más seria de las objeciones implícitas en los valores de una libertad inviolable e inteligentemente comprendida.

De ahí, los propósitos - tenaces y maléficos- de atentar contra esa dignidad por medio de mecanismos reductores. Consiste uno de ellos en aprovechar las condiciones de competencia fomentadas por una globalización que borra la compartimentación de los mercados, estableciendo, entre ellos, un sistema osmótico de interpenetración que elimina las barreras obstructivas de las aproximaciones geográficas. Otro arbitrio vigoriza estas posibilidades, contrariando las acciones sindicales y minando la fuerza de los poderes que las determinan. Remedios que suprimen, ya que no todos, buena parte de los obstáculos surgidos a la edificación de un universo consumista que tiende a crecer indefinidamente.

Según las líneas de fuerza del principio de irreversibilidad, que gratificaba los esfuerzos hechos para hacer irrevocables las adquisiciones sociales más imperecederas y costosas, el hecho del consumo reflejaba los aspectos siguientes. Las conquistas se obtenían sin contraprestaciones de los empleadores, porque era ése el imperativo de un poder sindical que las arrancaba en pago de una deuda histórica de largo recorrido. Los empresarios se entregaban a las tareas de acondicionamiento del mercado para mantener unos niveles de consumo - garantizadores de un beneficio económico estimulante y continuado, no desalentador y disperso- que, de otro modo, quedarían perjudicados por las concesiones de una negociación colectiva en que, al contrario de los temas de la contratación individual, el poder sindical - legislador ejerciente de su especial autonomía - dictaba condiciones que integraban el ordenamiento jurídico extraestatal del Derecho Social.

\section{Reacción anticonsumista de orden cualitativo}

Cuando -intuidas las ilusiones que iban más lejos del mero consumismo- cobraron cuerpo las aspiraciones cualitativas de los trabajadores y se expandieron las doctrinas favorables a su función activa en el gobierno de la empresa, los conflictos se trasladaron, por mor de justificados fundamentos, a los centros de trabajo en que sus divergencias se acusaban de modo más álgido. Había que atacar, en primer término, las técnicas de productividad que, lejos de ser comunes a todos los procesos, mostraban variedades - precisas y sutiles- que sustentaban los alicientes de un hecho del consumo tocado por dificultades adquisitivas de bulto. Era preciso evitar que los obje- 
tivos consumistas se explotasen para robustecer los poderes de organización de los empleadores que - obcecados en multiplicar los productos codiciados por los consumidores - restringían excesivamente, cuando no anulaban, el contenido esencial o núcleo invulnerable de los derechos constitucionales de unos trabajadores que devenían ciudadanos de segunda zona en el lugar de empleo. Era forzoso impedir que la obsesión competitiva - dirigida a exasperar la cautividad consumista - no mudase las obligaciones de medios o de simple actividad, a que se contraían las prestaciones profesionales de los trabajadores, en obligaciones de fines o de resultado, que imponían ritmos intensos y genéricos de actividad. Ritmos por encima de los que - como convenía a la naturaleza de las relaciones individuales de empleo- debían atenerse a la cualidad habitual del trabajo y a la noticia que - con los métodos de verificación a su alcance- tuviese el empleador de la aptitud profesional de cada trabajador y de las restricciones que le aquejasen en su caso.

Las dificultades para competir y facilitar a los consumidores unos ritmos de producción económicamente accesibles provenían del encarecimiento de los factores productivos - las materias energéticas o sus sustitutivos de obtención técnicamente costosa- y aconsejaban soluciones flexibles acompañadas de sacrificios compartidos. De ellas formaba parte la puesta en suspenso de la irreversibilidad de las adquisiciones sociales — abandonando la máxima siempre más, nunca bastante... que había forjado este principio- - y la socialización de los beneficios industriales mediante inversiones que asignaban a los instrumentos y medios productivos el ejercicio de una función social. Ésta consistiría en mantener activos los ciclos de producción que, al precio de esfuerzos desusados e imaginativos, debían subsistir en beneficio general del empleo y de la cobertura de un consumo que, de no ser así, quedaría dañado en perjuicio de la tutela de cada interés particular y de las expectativas de los intereses generales.

Antes de producirse la invasión de la fenomenología globalizadora, estas opciones suavizaban las cargas de los empleadores que afectaban - porque les era gratificante y útil - una parte de su patrimonio a operaciones de reestructuración y otros objetivos salvíficos, evitando la evaporación de los mercados en que navegaban los activistas del consumo. La territorialización de los conflictos industriales fijaba los términos de la confrontación y confirmaba las servidumbres geofísicas que perpetuaban la condena a enfrentarse y entenderse, para normalizar, con fortuna variable, los roces del sistema de relaciones industriales.

Los eventos de la globalización equivalen al salto cualitativo de concienciación de los experimentos hechos en el espacio de esas relaciones. Se intenta sobreexcitar un consumo - de cuya intensidad y extensión no se desiste- elevado a distintivo indeleble de una sociedad que tampoco renuncia a erigirse en su protagonista estelar y eminente. Nadie ponía en cuestión, al día de ayer, la supervivencia y el vigor iusnaturalista del principio de irreversibilidad de las adquisiciones sociales que, ante la crueldad de las agresiones 
causantes de su ruina, hoy no enmascara su desmoronamiento y su declive. Puede hablarse de una regla de inexorable defensa del consumo a cargo del factor capital que, si se jacta de algo, es de dar —orquestada por la propaganda- la impresión de que, bajo la apariencia evolutiva de que todo cambia aceleradamente, las cosas tienden rabiosamente a no dejar de seguir siendo ellas mismas, lo que, en clave inmovilista, habían sido hasta entonces para su provecho.

La libertad de establecimiento empresarial — que internacionaliza, las bases físicas de la acción productiva - y la libre circulación de capitales - que, valiéndose de esta circunstancia, invade los ámbitos del consumo existente o inaugura otros nuevos- desmantelan las barreras geográficas que acotaban la estanqueidad del clásico conflicto industrial. Permitían emprender acciones útiles para templar las tensiones exageradas del conflicto y devolverle la tensión propia de su subsistencia y eficacia sociales. Los sindicatos gozaban de una fuerza específica - apta para situarlos, como efectivos poderes de hecho, en el marco de las decisiones relativas a los destinos de la sociedad pluralista - que se difundía al ámbito físico de la soberanía estatal. El Estado - alternando las posturas de control y de apoyocumplía los deberes de moral política que simbolizaba su acogida. Pertenecían a un sistema de fuerzas que, gracias a las operaciones de integración y de conflicto, dictaban — pues tal era la realidad subyacente a la negociación colectiva- condiciones generales que se retransmitían a los contratos individuales de trabajo inscritos en cada unidad negociadora o ámbito funcional. Reglas vinculantes para los empleadores, que, al acatarlas, tenían que prever - con visión profética del cúmulo de riesgos industriales que les abrumaban- la reacción diferida y esperada de los consumidores frente a ofertas cuyos precios incluían el coste económico de aquellas concesiones sociales.

\section{Dispersión histórica del hecho del consumo y de las relaciones de tra- bajo}

Una de las victorias de la globalización ha consistido en disolver el conflicto industrial mediante un distanciamiento geográfico de sus protagonistas que conmueve la firme instalación de los agentes sociales del mundo del trabajo en el área territorial del Estado soberano moderno. Lo peculiar del ejercicio de la libertad sindical colectiva era la dedicación de unos sujetos de base institucional - los sindicatos reconocidos por imperio del Derecho de Gentes y asentados en la geografía del Estado que acataba sus funciones históricas y, con salvedades, no obstaba a sus iniciativas - a consolidar las adquisiciones exigidas por la promoción - cuantitativa, en principio, y cualitativa después - de los intereses de la clase trabajadora. Una tutela que, a causa de la perseverancia de su avance, rompe el primitivo marco del interés profesional y amplifica sus modestos objetivos de origen. Esta tarea com- 
prendía el análisis de los círculos de consumo que se localizaban y calificaban mediante operaciones de diagnóstico. Había que predecir, con márgenes mínimos de error, la magnitud de los beneficios industriales que los empleadores deseaban obtener - previa una referencia estadística veraz respecto al hecho del consumo - y cuya exacta evaluación formaba parte - usando de un concepto muy caro al Derecho común de las obligaciones- de la presuposición o base del negocio en las convenciones colectivas de trabajo. El poder sindical - enseñoreado de sus vicisitudes hasta que el cambio y los signos de los tiempos le desplazaron de sus posiciones dominantes- disponía de las referencias ofrecidas por el vasto espectro consumista para seleccionar las reivindicaciones que, en función de esos datos y otros concomitantes, debía ejercitar.

El Estado de Derecho liberal burgués — que asumió las victorias de la revolución industrial e institucionalizó su caja de sorpresas - aceptaba el hecho del consumo como una realidad social inseparable de la Política Legislativa del liberalismo. A buen seguro que - de no haber figurado, inicial e inequívocamente, en el elenco de los objetivos predilectos de esa ciencia de la legislación - el hecho del consumo no habría tardado en irrumpir en la escena social y en plantear los problemas relativos al espíritu y finalidad de las leyes que eventualmente le hubiesen ignorado, haciéndose pionero de una interpretación evolutiva que adelantaba su estreno técnico-jurídico. El Estado demoliberal concibió, sin hartura de imaginación, el hecho del consumo como una contingencia conexa con la suerte - afortunada o decadente- de los procesos productivos que se legitimaban, ante el Derecho objetivo, por atribuir la titularidad y el ejercicio de los derechos subjetivos constitucionales de propiedad privada y de libertad de transacciones comerciales e industriales. Derechos que, aunque básicos en la realidad sociopolítica de entonces, no disfrutaban de unas acciones de apoyo ajenas a los postulados de la filosofía vetoliberal.

Un examen de los diversos sectores económicos — maduros o incipientes- permitiría divisar los campos en que las exigencias consumistas comulgaban con la simplicidad de la estructura social de que eran parte sus sujetos activos, a cuyos intereses proveía un Derecho de satisfacción de necesidades compartidas de antiguo. Se diferenciaban de aquellos otros en que - atisbándose un Derecho de invención de necesidades rastreadas nebulosamente, coincidentes con las demandas concupiscibles del bienestar individual, precisadas de esclarecimiento y de una sistematización elementalanticipaban la popularidad y el crédito sociales que, como fenómeno multidireccional, el hecho del consumo estaba en vías de adquirir.

El carácter y las perspectivas del hecho del consumo incidían, con sensibilidad variable, en la suerte de las relaciones de trabajo que, a falta de respaldo institucional, gozaban del apoyo de las acciones sindicales - ayunas de la necesaria estrategia y hostiles a los poderes de Derecho ya constituidos- y de las reacciones, ocasionales y modestas, de los sectores de una opinión pública mejor o peor ilustrada sobre la magnitud de sus eventos. 
Los regímenes autoritarios de Occidente imprimieron a la producción y al consumo un sello de exaltación patriótica que, sin merma de su repercusión en las relaciones de trabajo, ocultaba un ajuste político de cuentas. La dación de bienes al mercado - sugerente de cautelosas actitudes ante el hecho del consumo o determinante de su capacidad de excitación- escondía, invocando el hecho productivo, designios temibles para el futuro de la familia humana. La producción — que desencadenaba y alentaba el consumo- se concebía como una unidad nacional al servicio de la patria e influía, por partida doble, en la perversión del régimen de las relaciones de trabajo. A la figura bicípite del empobrecido contrato de trabajo, sucedió una estructura tricípite que se justificaba por el interés nacional del sistema autoritario en servir a la patria con los hechos del consumo activados por la intensificación productiva de sus actividades. Cada relación individual de trabajo, así forzada, no nacía del acuerdo de voluntades entre las partes que aparentemente ejercitaban las libertades contractuales. Procedía de un imperativo superior - semejante a la función de la ley como fuente de las obligaciones y a la contradicción en los términos del concepto de contrato forzoso- que, arrinconando la autonomía de los intervenientes, asociaba ese vínculo al deber de acatar el mensaje irrenunciable de la voluntad del Derecho y el Estado. El empresario - responsable ante el Estado del éxito consumista de la producción y convertido en sujeto de un ejercicio privado de funciones públicas - auxiliaba a un consumo de finalidades tenebrosas, que abarcaba dispositivos y operaciones belicistas en pugna con los rasgos constructivos de la economía. El ciudadano - consciente de su fidelidad a los requerimientos patrióticos del hecho del consumo - se insertaba en el proceso por obra y gracia de su obligación de lealtad para con el Estado. Las interacciones de la autonomía de la voluntad individual no contaban con ninguno de los espacios habitables que exigía su naturaleza jurídica.

No se alteraba menos el régimen de las relaciones colectivas. La confrontación de la lucha de clases confería a las acciones sindicales la defensa de intereses desnudos — que, a veces, se elevaban a la categoría de derecho subjetivos- llamados a incidir en las operaciones del hecho del consumo afectadas por esa protección primaria. Dicho antagonismo fue abolido - aunque subyacía conforme a la indisponible naturaleza de las cosas- desde que la filosofía del sistema autoritario mudó los términos de la correlación. Las pretensiones colectivas de los trabajadores se asociaron artificiosamente a las de los empleadores, con los que formaron una sedicente comunidad de intereses compartidos. Quería evitarse que el hecho del consumo - consecuente con el de una producción selectivamente orientada — sufriera situaciones de degradación que, a causa de las acciones colectivas de los trabajadores, inquietasen la continuidad del engendro jurídico-político que se proyectaba. Cerradas las opciones del sindicalismo de reivindicación y abiertas las del sindicalismo patriótico, los productores, alienados por el ímpetu de la propaganda, se incorporaban a ese novedoso propósito. Su 
adhesión al talante nacional se compensaba con condiciones de trabajo que - amén de responder a la grandeza de las ilusiones asumidas - les trasladaban a un sugestivo mercado de consumo y les facilitaba los medios para adquirir los bienes y/o servicios que en él se les ofrecían.

Había una extensa parcela de producción y consumo, en la que - como variante de la actitud genérica que declaraba abolido el conflicto- se sucedían operaciones políticas de intencionalidad unívoca y gran envergadura. La difusión de esta quimérica construcción comunitaria hizo del empresario - responsable ante el Estado de la cantidad, calidad y continuidad de la producción- el agente eficaz que, dejando de enfrentarse a la clase social enajenada por las promesas revolucionarias de su fulminación, pasó a ser - amén de otras incitaciones que se le trasladaban- el promotor de unos hábitos y necesidades consumistas que, olvidando sus antagonismos, los componentes de la comunidad asimilaron con presteza. La doctrina del espacio económico quiso hacer una síntesis —encaminada a demostrar la verosimilitud del fenómeno e imponer el consabido acto de fe- de las aspiraciones de expansión territorial y de la difusión del hecho del consumo. Todo ello sucedió en provecho exclusivo de los productores nacionales y a costa del bienestar social y económico de los Estados transfronterizos soberanos, que soportaron las devastadoras guerras de agresión encaminadas a consumar un atentado inolvidable contra el Derecho de Gentes de su tiempo.

\section{Suerte del hecho del consumo tras la instalación del estado social y democrático de derecho}

Interesa lo suyo vigilar el curso del hecho del consumo desde que, con discutibles criterios de moralidad, las potencias victoriosas de la $2{ }^{a}{ }^{\mathrm{a}}$ Guerra Mundial redistribuyeron las zonas de influencia en que - para la desventura o el prestigio de sus respectivas elecciones- se adoptaron y pusieron a prueba los modelos económicos que unas y otras habían preferido.

Las parcelas de la cultura occidental pasan a conocer una evolución del hecho del consumo que engrandece los rasgos del Derecho encargado de su regulación. No se oculta el cuerpo de las aportaciones del flamante Derecho Social, proveniente de un iusnaturalismo existencial que, atestado de luces, irrumpe en la vida y la esperanza de los seres humanos. Se advierten, como temas sensibles de conciliación y de progreso, la renuncia sindical a la revolución y la penetración del sindicato en el espacio físico de la soberanía del Estado social y democrático de Derecho, cuyas reglas de juego se ofrece a respetar y con cuyos objetivos sociales está dispuesto a comulgar sinceramente. Emerge una negociación colectiva que, para graduar sus posibilidades y sus fines, parte de la averiguación imprescindible sobre las relaciones entre la prosperidad capitalista y el hecho del consumo. Se entiende preci- 
pitadamente que — gracias a la acción de unos sindicatos más partidarios de gestionar convencionalmente las mejoras sociales que de acudir a los cauces conflictivos de reivindicación - se ha tocado techo en la defensa de los intereses de unos trabajadores que, menospreciando la ocasión puesta a su alcance, malinterpretan la grandeza de la peripecia histórica que les ha correspondido vivir. Se resisten numantinamente - al igual que los sindicatos que, tras contribuir a esa mejora de su condición, hacen alto, algo así como marcando el paso - a reconocer que la senda de la revolución no ha agotado su curso y sigue abierta a un porvenir cualitativo en que se hagan realidad las promesas de compartir el ejercicio de los poderes de organización y dirección de las especialidades productivas.

El capital aprovecha el espejismo de falsa plenitud —surgida al calor de las grandiosas conquistas sindicales- para introducir magnitudes notables en pro del hecho del consumo y difundir la tesis de que, gracias a la influencia de este dato, la sociedad próspera ha puesto fin a la confrontación interclasista e implantado una estructura arreglada a los signos de los tiempos. Véase cómo y hasta dónde lo pretende el cuerpo de doctrina económicosocial forjado con ese motivo.

La disponibilidad de las riquezas naturales — autorizada por el sistema internacionalizado de colonización o cuasicolonización que precedió al ejercicio del derecho de autodeterminación de los pueblos - confiere a los procesos productivos un ingrediente de prosperidad que multiplica los estados de cosas en pro del hecho del consumo. El traslado de las invenciones tecnológicas del curso de la guerra a la economía de la paz induce a la apertura de procesos productivos inéditos y a probar la eficacia de descubrimientos que, con aires de reto, complican los hábitos — simplistas y clásicos- de unos consumidores perplejos ante tales sorpresas. Las experiencias de interrelación y sondeo de mercados, que facilitan los antecedentes bélicos, fomentan la multinacionalidad de las empresas y preconizan el triunfo reservado al hecho del consumo en la era de la globalización. Los recursos de la propaganda - que los regímenes autoritarios aplicaron tozudamente a la política - recalcan la utilidad del momento para aprender a dominar las relaciones económicas y no dilapidar las oportunidades en que el auge y la moderna traza del hecho del consumo se van a concretar.

Estas circunstancias y alguna que otra más discreta explican que el hecho del consumo - equitativamente adscrito, en la parte que le toca, a la causa de las conquistas de la justicia social — no sólo cubra las necesidades debidas a unas carencias antecedentes y notorias. Da también paso al disfrute de bienes cuyo provecho se desconocía o cuyas apetencias - artificiosas, muchas de ellas - derivan del manejo de mecanismos de adoctrinamiento e inducción, que, sin declarar probada la necesidad objeto de satisfacción, la diseñan a su capricho y conveniencia.

La ausencia de sensibilidad moral y de inquietud -individuales y colectivas- sobre muchas de las conquistas cualitativas pendientes de desarro- 
llarse y alcanzar el buen fin, conduce a una transformación de la estructura social, fruto de las motivaciones que el hecho del consumo aviva y de las devociones que suscita. El éxito de las reivindicaciones sociales demuestra que se han liquidado las álgidas contradicciones de la lucha de clases y se han civilizado las confrontaciones exasperadas - esto es, no distendidas ni normalizadas - del conflicto industrial. Los sindicatos de Occidente secundan la hoja de ruta de los Estados sociales y democráticos de Derecho y, a cambio de la adopción de las Políticas Sociales que éstos hacen suyas, desisten de la trasnochada obsesión de exterminarlos por la vía revolucionaria de la utopía marxista. La composición dualista de la sociedad - espejo del enfrentamiento irreductible de las clases sociales y de la inviabilidad de su armisticio- se sustituye por una figura estratificada o superposición de plantas sociales, cuyos pobladores comparten una posición que, al diluir sus diferencias, concentra sus afinidades. Las clases sociales pasan a ser las secciones horizontales de una pirámide que acoge a quienes - con independencia de las fuentes de obtención de sus rentas- gozan de la misma aptitud adquisitiva para consumir. La inclinación plausible a una sana proletarización de la clase burguesa degenera en un frenético aburguesamiento de la clase trabajadora, ávida de cambiar, no sin sonrojo, su derecho de primogenitura social por un plato de lentejas.

Los regímenes autoritarios del Occidente europeo invocaron, a título particular, el entusiasmo patriótico común para declarar - contra la Historia - abolida una lucha de clases que querían sumir en el olvido. La refacción democrática de las relaciones sociales —obra del Estado social y democrático de Derecho- se comprime y reduce a sólo una parte de la totalidadad, novedosa y optimista, que sus descubridores predijeron. La proliferación del entusiasmo consumista desconflictiviza las relaciones de trabajo, porque el hecho del consumo - que intensifica y engrosa el bienestar - supone un acicate más inmediato y acuciante que el hecho de la transformación social cualitativa, hipotecado por su lejano y poco accesible porvenir, por la dureza del sacrificio anejo a sus premisas intelectuales y morales, y por la incertidumbre de su consolidación definitiva. Estas motivaciones - resumidas en el surrealismo del miedo a ganar - acompañan al rumbo economicista de unos sindicatos que no aciertan a resumir y ordenar lo que el ejercicio de las libertades sindicales tiene de acción cooperativa y de reacción contestataria. Entienden que el peso específico de su renuncia a la revolución les dispensa, por el momento, de otras cargas y les permite suspender sus compromisos cualitativos frente a la clase trabajadora, a la que, así las cosas, desamparan y rinden un flaco servicio. La exaltación del hecho del consumo juega - junto a sus excelencias secundarias-el papel, menos elogiable y airoso, de congelar la sensibilidad sindical indispensable para cumplir, sin cortapisas, un programa de justicia cabal del régimen de las relaciones industriales.

Otros fueron la concepción y el destino del hecho del consumo en los países ex-socialistas atrapados en la órbita de sujeción — más bien que de 
influencia- soviética. Las operaciones de la revolución pendiente se dieron por conclusas desde el momento en que, sin consultar sus pareceres, el acuerdo de las potencias vencedoras les sumergió en el caudal de una revolución anterior - ya consumada - que, una vez digeridos, les convirtió en dependencias de almacenamiento y exportación del pensamiento marxista. Lo que no siempre hicieron con absoluta sumisión y buen obedecer. La lucha de clases no se entendió abolida, sino que se dijo superada merced a una planificación irreversible que se preciaba de haber puesto fuera de juego los presupuestos conflictivos de las tradicionales relaciones de trabajo. El hecho del consumo perdió su importancia en las economías de ese signo y padeció una crítica cerril que - pese a las claudicaciones de un marxismo progresivamente anfibológico - fustigaba las adicciones de los ciudadanos - fueran o no trabajadores dependientes - de Occidente, desordenadamente entregados a la fruición de consumir con la vehemencia del transparente objeto de un deseo. La lucha de clases se entendió superada, sin visos de renacimiento, porque, aunque luego las cosas ocurrieron de modo distinto, los diarios sucesos de la economía y la política seguían entendiéndose - machaconamente- como sendos capítulos del fin de la Historia que nunca se produjo.

De ahí, la promesa de una sociedad idílica, purgada de los antagonismos que aquella lucha fomentaba, y sustraída a las actitudes de emulación y envidia que engendraban las desigualdades. Ello derivaría de una previsión metodológica a la que se atribuía la eficacia de un automatismo milagroso, y no - como sostuvieron los regímenes autoritarios de corte fascista- de sus imposiciones dogmáticas. El hecho del consumo era la cobertura - controlada y dosificada por el Estado- de las exigencias de los necesitados — que no tenían que ser forzosamente los más desposeídos o carentes de bienesa expensas del esfuerzo de quienes, sacrificando la deseable conmutatividad, estuvieran en condiciones aptas para satisfacerlos. Gratificar a cada uno conforme a sus necesidades y recabar de cada uno según sus posibilidades, sin fricciones político-sociales, confrontaciones álgidas o ajustes de cuentas. Todo un programa de retorno a la inocencia original y de placidez de las relaciones humanas. La identificación del ciudadano con el trabajador y la eliminación de las relaciones de trabajo por cuenta ajena, redujeron el hecho del consumo a un aspecto más de la reprobación del caduco proyecto revolucionario, castigado - con un fracaso cáustico - por la inercia sancionadora de las cosas y la enseñanza de los tiempos que lo aniquilaron.

\section{Impacto de la productividad industrial en el hecho del consumo}

El hecho del consumo y su repercusión en el régimen de las relaciones de trabajo sufren - tras las reflexiones anteriores - el impacto de la productividad y la adhesión a una moda surgida del endurecimiento de la competencia. Esta agresividad nace, a su vez, de la pérdida del control económico 
sobre las riquezas de los países del Tercer Mundo que han tomado —rabiosamente- la salida en la carrera de sus respectivos procesos de descolonización. La marginación del mercado amenaza a los ciclos productivos y a los empleadores que, inhábiles para calificar y asumir unos retos de magnitud desconcertante, descuidan o no aciertan a diseñar las previsiones tecnológicas que, según lo específico de cada variedad o unidad industrial, corrijan las deficiencias advertidas y contengan su acción competitiva en un círculo del que, en otro caso, se ven inapelablemente expulsados. Es natural e inaplazable que - abaratando el precio de los bienes y/o servicios que hay en el mercado y atrayendo las preferencias de los consumidores conscientes de esta coyuntura - se conserven los beneficios industriales y, como cumple a la satisfacción del contenido esencial de la libertad de iniciativa económica, se aumente sensatamente su cuantía. Cuando, sin elevar el número de unidades de producto, el precio de los bienes y/o servicios se reduce para evitar su acumulación y acelerar el hecho del consumo, los oferentes terminan huyendo del mercado de libre competencia. El estudio de sus perspectivas y posibilidades económicas preconiza un futuro consistente en arrostrar - dejando atras toda esperanza - un endeudamiento galopante y, a la postre, causante de su ruina. Si el precio reducido se multiplica por un número de unidades de producto superior al que se generaba antes de aplicarse las transformaciones tecnológicas, se obtienen utilidades mayores que las derivadas de las operaciones aritméticas hechas conforme a los datos de origen, cuya conservación disuade de la voluntad de competir a cuantos empresarios no sean portadores de un virus de autodestrucción económica. No cabe operar con un número menor de unidades, cuyos precios superan a los que atraen las preferencias de los consumidores, porque es ésta la receta infalible para que el desahucio del mercado sobrevenga más tarde o más temprano.

La reordenación del hecho del consumo - alertada por el señuelo de la productividad - trata de defender, contra viento y marea, la avidez con que, ante la reedificación incompleta de las relaciones sociales, el capital había promovido - gracias a la coyuntura de prosperidad económica y a la acción obcecada de la propaganda - una comunidad de consumidores que, de buenas a primeras, se ve amenazada de desintegración. La solución consiste en que, además de atacar el mal surgido, el talante consumista de los trabajadores se eleve a la segunda potencia y se apliquen - con beneficiosa apariencia- a las relaciones de trabajo algunas de las novedades aportadas por los éxitos de la productividad.

La refacción del hecho del consumo transfigura las relaciones de trabajo, al desvirtuarse la deuda de actividad de los trabajadores dependientes - constitutiva de una obligación de medios que se entiende cumplida con el agotamiento de las conductas de atención y cuidado inherentes a la diligencia exigible- y hacerse de ella una obligación de fines o de resultado. Su ejecución deja de limitarse a desplegar la actividad profesional —remunerada a tiempo- durante la preceptiva jornada, con la solicitud y asiduidad típi- 
cas de aquella diligencia. También incluye la retribución del rendimiento -indispensable para el abaratamiento de los precios y el incremento de la oferta cursada a los consumidores- que se cifra en sumas de dinero cuyo importe depende de la evaluación de la eficiencia que las fórmulas de racionalización productiva asignan a cada puesto o grupo de trabajo. Aparecen los incentivos - cualitativamente diferenciados del salario a tiempo- que ponderan el número de unidades de bienes o la cantidad de los servicios obtenidos al aplicar los módulos racionalizadores. Para facilitar, acudiendo a un giro complaciente, el cumplimiento de la obligación de fines imbricada en el tejido de las relaciones de trabajo, hay que sobrepasar los límites de la diligencia naturalmente impuesta por la obligación de medios del trabajador. Este se expone a ritmos de actividad inmisericordes que, ante el arrebato lucrativo de la competencia, rebasan las dosis de atención y cuidado que, hasta entonces, definían pacíficamente la verdadera naturaleza jurídica del deber profesional de trabajar.

Las apetencias de bienestar material y las adicciones consumistas que engendran las técnicas de racionalización productiva — controladas a medias por la entrada y la contestación del sindicato en el lugar de empleo- excitan la cautividad de los trabajadores respecto al hecho del consumo. Le satisfacen dominados por unos mecanismos que les enajenan y confiscan la dignidad necesaria para expresar, sin cortapisas, la plenitud de la personalidad explícita en el hecho del trabajo creador. Amén de los conflictos interpersonales que provocan, los usos innovados hacen de los trabajadores cautivos unos conspicuos cómplices de la explotación que experimentan y unos pacientes ignorantes de la plusvalía que se les arranca. Tal es el saldo de los episodios de sumisa capitulación ante unas pautas racionalizadoras que, a tenor de la productividad inventada para competir, dictan este modo de participar en los ciclos de producción, aunque también obligan a otro estilo — más eficaz, sin duda — de acción sindical y mudan de lugar los horizontes de localización y desencadenamiento del conflicto. La teoría de la lucha continua delimita los campos y apunta las estrategias defensivas que procede emplear para contener esos avances y mantener a los trabajadores informados sobre el peligro de su disvalor.

La endemia consumista -irreversible como tal - ya no reside tanto en lo alarmante del fenómeno que trasluce, cuanto en las consecuencias catequéticas de su invasión en la metodología del trabajo. Constituye el sucedáneo o la contrafigura esperpéntica de los ideales cualitativos - a saber, la tutela de los derechos constitucionales de los trabajadores en el lugar de empleo y de su advenimiento a la dirección y gobierno de la empresa- que seguían siendo los ideales retadores en el universo de las relaciones de trabajo, aunque sus pobladores — secuestrados por la impenitente adicción al consumo - habían errado de raíz al no elegir la dirección acertada. Sin sensibilizarse a estos inconvenientes de grueso calibre, el Estado social y democrático de Derecho puso todas sus complacencias en la visión — tan ingenua 
como históricamente alicorta- de un futuro socialmente justo y perdurable por tiempo indefinido. Le faltaron intuición y arrestos para adoptar una Política Social transformadora que, ante una crisis intranquilizadora y perceptible, diera luz verde a los avances cualitativos y rehabilitase la dignidad hurtada al hecho del consumo. El duelo entre la productividad y la participación estaba entonces a punto de empezar.

No sin tropiezos y demoras, se operaba un cambio en la estructura y dimensiones del sindicalismo tradicional, que — para defender los intereses colectivos de los trabajadores frente a la enajenación consumista y la perversión del hecho del consumo exaltada por la productividad - soportaban algunas correcciones. Una de ellas, rehacía la morfología sindical e ideaba las variantes aptas para frecuentar, fuera ya de los grandes espacios sociales, las guerras de guerrillas que iban a librarse en los campos de batalla del lugar de empleo. Otra inventó la teoría de la lucha sindical continua y del conflicto permanente, que decía no a las contraprestaciones de la tregua productivista, defendía la ininterrupción y la agresividad de las contiendas sindicales, y desautorizaba los compromisos contraídos en nombre del deber de paz.

\section{Correlaciones de la plusvalía y el hecho del consumo}

Todas estas reacciones obedecen al agravio de la plusvalía que dimana de aplicar las reglas y agotar los experimentos de la racionalización productiva. La conexión del hecho del consumo con la conmutatividad necesaria y deseable en las relaciones individuales de trabajo, exhuma una plusvalía patente en las innovaciones que aparejan los objetivos de la productividad y el ejercicio de un derecho de resistencia sindical frente a sus agresiones. La plusvalía denota la ruptura — más o menos velada - de la equivalencia objetiva de las prestaciones de los contratos de trabajo en los procesos productivos que preceden a la dación de bienes y al hecho del consumo de los mercados de libre competencia. Se sostenía que, en el contexto del Estado demoliberal, la plusvalía - tal y como enseñaba su candidez diabólica - compensaba los riesgos queridos y corridos por los empresarios que - con ánimo de lucro y asumiendo las probabilidades, ordinarias o extraordinarias, de no lograr las ventajas patrimoniales anejas a sus iniciativas - retenían anticipadamente, como parte de los beneficios previstos, algo que, en justicia material y en equidad, les era indebido. Confiscaban lo que, desde esa perspectiva, suponía la adhesión de la personalidad y la creatividad del trabajador a los actos transformadores en que participaba. Imperaba la idea de que aquél —cautivo de las técnicas de productividad y privado de transmitir a los bienes y/o servicios consumibles su impronta personal- se relacionaba con el resultado final de su trabajo como con un objeto - extraño e irreconocible - que, desencantándole, malograba su perfección individual. 
La concepción rudimentaria, pero certeramente definida, de la plusvalía subrayaba la confiscación o requisa - obra de los propietarios de los instrumentos y medios de producción - de la energía, manual por lo común, y, menos frecuentemente, intelectual que los trabajadores transmitían a los demás factores del ciclo productivo. La situación de dependencia exigía acomodar su esfuerzo y sus capacidades a las directrices de organización que, para consumar los cambios necesarios, adoptaban los titulares de la libertad de empresa. Estas transformaciones provocaban la conversión del producto en un cuerpo cierto o determinaban el aderezo del servicio, seguidos de la distribución en que consistían la dación al mercado y el ofrecimiento a los sujetos activos del hecho del consumo. De ahí, los incrementos o dosis de valor añadido al coste de las materias primas o, más exactamente, de los bienes de producción a los que se aplicaban la fuerza de trabajo y los avances de la tecnología. De este incremento - incluido en el coste del bien de consumo - se adueñaba el capital, remunerando a los trabajadores dependientes con salarios de menor cuantía que la que, según los criterios de conmutatividad o equivalencia objetiva de las prestaciones, requerían la cantidad y calidad de su cooperación.

Aunque la plusvalía se alimenta de aportaciones tecnológicas que agrandan su potencial maléfico, no ha prevalecido — quién sabe por qué motivaciones o acicates - una crítica demasiado escandalizada de los males explícitos en sus evidencias. La desnaturalización del hecho del consumo - que encarna y origina - la convierte en algo que, ofuscándoles, cautiva a los perceptores de rentas de trabajo, más como fuente de un bienestar por el que acaban pagando un alto precio, que como ayuda al crecimiento de la dignidad personal que se ve reflejada en el espejo de la obra bien hecha, deleitosamente cultivada y amorosamente concluida.

\section{Destino del hecho del consumo ante el advenimiento de la crisis económica}

La crisis económica forzó el hallazgo o invención -fruto de una especie de fuerza mayor universal - de un Derecho Social caracterizado por la quiebra del principio de irregresividad de las adquisiciones sociales y por la asignación de nuevas funciones sociales a la libertad de iniciativa empresarial en los mercados de libre concurrencia. No abordó los problemas de la conexión del hecho del consumo con las reivindicaciones defensivas del —en su acepción más laxa y divulgada por la jerga de los sindicatos-acervo de derechos adquiridos de los trabajadores, cuyas excursiones consumistas -fogosamente espoleadas por la concupiscencia de una sociedad próspera - no se apagaron, de súbito, con el advenimiento de la crisis, sino que pasaron de un estado de normalidad, sin prevenciones, a un desazonado estado de alarma. 
La verdad histórica daba cuenta y razón de una monetización de la negociación colectiva, cuya rotulación ilustraba, de paso, sobre las depresiones semánticas de algunas zonas del lenguaje del Derecho de las relaciones de trabajo. Habían corrido parejas las conquistas debidas al asentamiento del Estado social y democrático de Derecho - como la excelencia de la negociación colectiva, en vez de la endemoniada conflictividad que la precedía- y a la renuncia de los sindicatos a la revolución en los espacios económicos de la cultura occidental y de la ambientación social anglosajona. Los trabajadores compartían la condición de destinatarios del nuevo Derecho Social y la de demandantes de bienes y servicios que - ahora ligados a la promoción del bienestar - se les habían rehusado, de raíz, en su anterior estado de indigencia. Al revalerse de las normas que les rescatan de ese empobrecimiento, emplazan en un plano cuantitativo - conexo con las evidencias del hecho del consumo - el óptimo de las mejoras deseables y, dentro de ése, gobiernan la parcela de las reclamaciones económicas que fundan sus designios de prosperidad. Hasta que la explosión de la crisis plantea un dilema irreductible, la negociación colectiva -monetizada en demasía - convive con los avances cualitativos que, a impulso de los clamores sindicales de la participación frente a la insistencia de la racionalización productiva, sostienen los objetivos sociales de liberación. Unas expectativas que la virulencia y la contumacia de la crisis - como suceso inesperado, como compañera de viaje de las andanzas económicas, como hecho históricamente irrefutable y como realidad devastadora del Derecho Social - fueron, al cabo de un tiempo transcurrido demasiado pronto, devaluando y dejando fuera de combate.

\section{Interconexiones del hecho del consumo, las mudanzas de las relacio- nes de trabajo y el fenómeno de la economía general}

La velocidad adquisitiva de la penetración de los trabajadores en el orbe consumista desencadena unos efectos que completan la tutela de intereses desprotegidos hasta entonces, que se suman a la causa de los demás consumidores y que — ante la ampliación de esa comunidad incidental — resuenan en el panorama de la economía general.

Los organismos internacionales competentes en materia económica recuerdan - con la vehemencia del que, so pena de condenación eterna, reitera las máximas de un dogma de fe-que el poder adquisitivo de las rentas de trabajo, comprensivas de las retribuciones salariales y los emolumentos de los empleados públicos, no se mejora incrementando intempestivamente las sumas de dinero en que consisten. Ahí residen el error capital de la monetización de la negociación colectiva y el falso prestigio de los postulados sindicales que han circulado de su mano. La espiral de inflación - a que esas alzas dan lugar- destruye las ventajas que sus perceptores reivindican en 
clave social y recorta el poder adquisitivo de las unidades monetarias que ingresan. Se ha de prever - austera y escrupulosamente - un crecimiento de dimensiones racionales que, situando en su justo medio la subjetividad de las reivindicaciones consumistas y la objetividad del hecho del consumo, evite que la capacidad de adquisición dependa de una voluptuosidad antisocial, cuando lo suyo es erigirse en un elemento selectivo para cada economía individual o familiar. De ahí, la siguiente consideración.

Los sindicatos - cuyos estados mayores no han ignorado el rigor técnico de esta recomendación machacona - la impugnan sosteniendo que, lejos de enunciar una pauta estabilizadora y conveniente para la buena marcha de la economía general, responde a la terca obsesión capitalista de asegurar la continuidad del beneficio, mediante la plusvalía que se arranca y que, a toda costa, quiere perpetuarse. Las evidencias de la crisis económica obligaron a aceptar la verdad y la necesidad de aplicar una regla que los sindicatos no atacaban a causa de su heterodoxia, sino del ademán testimonial que, para disentir de esas propuestas, les imponían su miedo al descrédito y la carga de sus compromisos históricos. Vigente el Derecho Social de la prosperidad, servía de poco apelar al principio restrictivo de la moderación salarial en pro de la economía general. Las victorias sindicales — que combatían ese dogma con su voluntarismo de poderes de hecho y no con la sensatez de una negociación reflexiva - siguieron sosteniendo la tesis de la iliquidez y duración indefinida de la deuda histórica que constituía, desde sus orígenes, una de las reivindicaciones del Estado de Bienestar. De ahí, la protección - tenaz y emocional- del interés consumista de los trabajadores, que, salvo contadas excepciones, convivía con los consejos de prudencialismo económico impartidos para paliar sus insolencias e impedir, a la luz de una flexibilidad fiel a sí misma y no atestada de malos ejemplos, la degradación de las relaciones de trabajo.

El hecho de la globalización -abierto a múltiples insinuaciones y vertientes - ha encontrado la clave de sus desafíos en el fenómeno del achicamiento del mundo. Su concepto - indeterminado en lo jurídico, lo social, lo económico y aun en las zonas del hecho religioso- despierta, en lo especulativo, criterios apasionados y dispares. Da lugar, en lo que toca a las acciones, a iniciativas y experiencias que, fascinadas por el asombro y la curiosidad, reaniman, sin cesar, las tentaciones de revisar el discurso - cuyos interrogantes se debaten- sobre el fenómeno proteico que la globalización ha resultado ser y sigue siendo.

\section{X. ¿Hacia la privatización neoliberal del régimen jurídico de las relacio- nes de trabajo?}

Vistas las colisiones y ambigüedades de diagnóstico que originan las divergencias en torno a su etiología general, sus especies, sus disparida- 
des y las apuestas sobre su subsistencia, se han mezclado — sin sistema y sin pausa- las cuestiones relativas a la naturaleza y el rumbo de la crisis económica, a la suerte asignada al hecho del consumo por cuantos lo anhelan y promueven, $\mathrm{y}$ al aprovechamiento de ambas circunstancias — subjetiva la una y objetiva la otra - para advenir a unas conclusiones de síntesis.

En vez de un uso provechoso y sujeto a efectivos controles, la opción acogida bajo el rótulo de flexibilidad degeneró en el ejercicio abusivo de las funciones sociales que se le atribuían y se esperaban de su puesta en escena. No palió los excesos del hecho del consumo y conjugó estos propósitos -que, pese a sus apariencias antagónicas, servían a las motivaciones de su causa - con un fin de fiesta desolador y pesimista, semejante al fin de la Historia que la dogmática marxista predijo como el signo fatal de un futuro inmovilizado y sin retorno. Así empieza la devastación o voladura controla$d a$ de unas relaciones de trabajo que - pese a su adelgazamiento y menoscabo- conviven, descabezados sus protagonistas, con la cultura del hecho del consumo auspiciado por la obnubilación del capital. Soslayando, no sin dificultades, las cargas de la proximidad geográfica y las confrontaciones sindicales, el capital quiere librarse del agobio causado por las fricciones de un conflicto que, sin visos de recuperación, tiende a disolverse. ¿Cómo es el vacío que entonces se vislumbra?

La incoación de la crisis económica repercutiría en todos los aspectos de las relaciones individuales y colectivas de trabajo, comenzando por la desmonetización de las ventajas que potenciaban el consumo y que, sumadas a otras adquisiciones sindicales, secundaban la línea trazada por el principio de irregresividad de las adquisiciones sociales. La monetización —que, en la era de la prosperidad, abrió un período rotundamente amnésico para proveer a otras necesidades que se le pospusieron - mantuvo la predilección de los trabajadores por el hecho del consumo en un plano tan eminente como irrenunciable, aunque la conciencia sindical — deudora de tantas obligaciones históricas - no se lograba desprender de unas pretensiones cualitativas en pro de las que era inexcusable continuar luchando. La imagen del hecho del consumo en el marco del Derecho Social, cambió a causa de las tentativas de sortear los escollos de la crisis y evitar la dislocación del viejo mundo - $\tan$ ajetreadamente poblado y construido - de las relaciones individuales y colectivas de trabajo.

La respuesta a las conveniencias o demandas de los consumidores de bienes y servicios requería conservar un poder adquisitivo mermado por el grosor de las circunstancias convergentes en la emergencia de la crisis económica. La perspectiva de estar condenados a entenderse - coaceptada por los sindicatos y los empresarios ante el dilema de un menoscabo incorregible de las actividades productivas o el recurso a quién sabe qué arbitrios salvíficos - promueve una pedagogía reductora. Se intenta retirar al hecho del consumo el carácter de aspiración obsesiva y primordial, para que, tras este 
sacrificio, sus rebajas se compensen con ventajas cualitativas y se resarzan los perjuicios colectivos que ha irrogado el nuevo estado de cosas. La renuncia sindical a la revolución exigía que las comunidades modernas - sitas en los círculos de la economía de mercado- adoptasen un modelo de relaciones de trabajo acorde con las señales de prosperidad que alumbraban el nacimiento del Derecho objetivo innovado por el Estado social y democrático de Derecho. La propulsión optimista del hecho del consumo era el detonante del cambio estructural de la sociedad y el freno al flujo de unos propósitos cualitativos que, a pesar de sus evocaciones platónicas, se demoraban con pésima conciencia. Ocurrida la crisis económica, que arruina los ingredientes prósperos de la anterior etapa, el Estado social y democrático de Derecho capitula y asiente a salidas que, entre otras, incluyen una de máximo calado, a saber, la renuncia sindical al principio de irregresividad que hasta entonces se estimaba intangible. Esta abdicación — aneja a la entronización de la flexibilidad laboral-significa que la tutela de los intereses de los trabajadores no va a depender - preponderante y afanosamente- de las ventajas dinerarias que multiplican las experiencias del hecho del consumo e invitan a gustar de sus modalidades veleidosas. Ante la utilidad y la necesidad urgente de ciertos elementos no consumistas de satisfacción, se acometen esfuerzos didácticos para difundir su conocimiento y promover su arraigo.

Conviene realzar los aspectos que - como ejemplo de adoctrinamiento moral, social y económico- importan estas novedades. Se alega, en primer término, la relatividad del derecho a un crecimiento sistemático - frecuentemente inmoderado- de las ventajas y utilidades constitutivas del hecho del consumo. En segundo lugar, una parte de los beneficios empresariales — destinados a cumplir una función social— se aplican a las operaciones de reconversión industrial — cuya especificación no es del caso- que, velando por la continuidad y el regular funcionamiento de los procesos productivos, conservan, aunque desmejoradas, las oportunidades de empleo y no destruyen, aunque sí desangelan, la devoción de los asalariados para con el hecho del consumo. Por fin, las utilidades del hecho del consumo de los trabajadores - mermado por las causas críticas que lo determinan - se complementan con el beneficio de las normas colectivas que, gracias al dinamismo de la autonomía sindical, satisfacen intereses cubiertos por una tutela actualizada y vigorosa. Los acuerdos sobre una política de rentas calman la intransigencia del frenesí monetizante que aquejaba a los sindicatos intervenientes en la negociación. Otro tanto sucede con el tratamiento de la deuda de seguridad en el trabajo, comprensiva de los deberes de atención y cuidado que - conforme a la concepción normativa de la culpabilidad - individualizan la diligencia necesaria para preservar el contenido esencial o núcleo invulnerable de los derechos a la integridad física y a la protección de la salud. Cabe citar, en fin, la constitución de las representaciones colectivas en los lugares de empleo —donde, renovándose para evitar la alternativa de morir, la 
estrategia sindical ha enclavado la explosión y la remisión de los conflictos- y la fijación de las garantías que, para ejercer con inmediación sus funciones, se adjudican a los representantes sindicales.

Como no puede menos de ocurrir, las relaciones de trabajo reservan al hecho del consumo las ventajas de un espacio habitable dotado de oportunidades económicas o monetizantes, pero también se abren a un marco amplificado, en el que el economicismo de la actividad profesional pierde algo de su peso específico. Se integra y armoniza inteligentemente con adquisiciones - no menos sustanciales - que, poniendo el hecho del consumo en su lugar, exhuman aspectos notables que, haciendo de la necesidad virtud, reciben el auxilio de las nuevas especies de tutela.

Este programa - conciliador y reflexivo- se vio frustrado, demasiado pronto, por la dificultad de gestionar — coadministrándolas con prudencia y conocimiento de causa - las manifestaciones de la noción de flexibilidad individual o colectiva, cuyos experimentos invitaban a compartir, honesta y atinadamente, responsabilidades de hondura. La innovación no funcionó con la severidad cartesiana que, según el optimismo de sus definidores, profetizaba el éxito del proyectado ensayo. Han abundado las aplicaciones abusivas de la idea de flexibilidad y han escaseado las oportunidades de localizar y corregir, eficaz y ejemplarmente, los numerosos excesos perpetrados al amparo de su elasticidad términológica.

Los sindicatos — apresados por la tela de araña que, restándoles movilidad, congelaba sus iniciativas - descubrieron y denunciaron tardíamente la ausencia de juego limpio — en el que su candidez había confiado - sobre el tratamiento de la crisis económica. Combatieron, sin habilidad y sin fortuna, la imposición de soluciones que, para paliar esos efectos negativos, desgastaban -más allá de lo razonable y equitativamente lícito- los derechos individuales y colectivos de los trabajadores. En el embrollo de luces y de sombras que cegaban el paso a una claridad cegadora y decisiva, el tiempo transcurrió en daño de cuantos - a medida que las inagotables e incontrolables ocurrencias del capital deformaban, hasta la extenuación, el concepto jurídico indeterminado de flexibilidad - se encontraron cada vez más inermes para arrostrar sus desafíos y corregir sus yerros.

Se afianzó así — ganando la partida — el estado de cosas influyente en la privatización neoliberal del Derecho de las relaciones de trabajo. Se simplificaron la fenomenología y el peso específico que el hecho del consumo había conquistado en una parcela social solicitada por tendencias que animaban lo racional y lo concupiscible de sus expresiones. Dirigida la una a conservar los hábitos del hecho del consumo, que se empequeñecían, y orientada la otra a salvar, cuando menos, la mala conciencia del olvido que, en perjuicio de ciertas asignaturas pendientes, estaba a punto de desvanecerse. 


\section{Espectro consumista de los programas globalizadores}

Otros son el mensaje del renacimiento consumista, patente en cuantos episodios avisan de la continuidad y el pluralismo de la globalización, y las derivaciones imprevistas que —-según los accidentes de las personas, del tiempo y del lugar- surgen de modo asistemático, pero visible y penetrante. Pueden ser proporcionadas o asimétricas, confusas o intelectualizadas, las contingencias que - revelando las invasiones torrenciales del hecho del consumo - se divisan desde las atalayas globalizadoras. El embeleso del hecho del consumo no puede minimizarse, frente a su indudable e indeleble magnetismo, y exige reconstituir — con una imaginación asediada por los temores de fugacidad o frágil acogida - los alicientes de su fisonomía y el rendimiento de los modelos adoptados. Ello requiere disipar los reparos técnicos y sociológicos -que se le oponen en dosis muy copiosas- y otros, de varia etiología, que, so pretexto de enderezar los rumbos del hecho del consumo, circulan sin consistencia lógica ni poder persuasivo. Aun admitiendo que el hecho del consumo es una constante de la vida actual de relación, no remite el afán de denunciar la concupiscencia económica de cuantos - para lograr la utilidad óptima de sus operaciones- exprimen sus réditos con ardor usurario.

También hay que escrutar — dedicándoles un minucioso examen — ciertas operaciones globalizadoras de que las normas de orden público -imperativas y/o prohibitivas - deben ocuparse, atendiendo a su metodología y sus condiciones de efectividad. La difusión y popularidad de esas opciones se sujetan jurídicamente, pese a quien pese, a los controles que, no sin engorro, compete aún ejercer al antes poderoso y omniprovidente Estado social y democrático de Derecho.

La debilitación sindical, genéricamente entendida, forma parte del programa globalizador. Una estrategia productiva que, obnubilada por la protección de su interés, desprecia las restricciones emanadas del sector social del ordenamiento jurídico o las elude zafiamente, exige - algo así como regresando a la época de la colonia- supeditar, colocándole bajo la espesura de la bota opresora, el poder sindical al poder empresarial. Una audacia notable - que se ensaya de entrada — es disponer, como fórmula de organización saludable, el alejamiento físico que - según el adagio que reza dos no se enfrentan, si uno no quiere la confrontación... - liquide los antagonismos, verificables y cercanos, de dos poderes descomunicados que se sustraen a las tensiones de su proximidad conflictiva. Los empresarios frecuentan la variante de reconversión industrial derivada de la libertad de establecimiento, dispersando - gradualmente o de súbito - los lugares de empleo y seleccionando, si preexisten, o eligiendo, si son de nueva planta, ámbitos territoriales más cómodos para el asentamiento de los procesos productivos y la apertura de los mercados de trabajo. He ahí los espacios en que, a causa de sus diversidades, los oferentes de empleo mediatizan absolutamente las demandas de trabajo, y donde las acciones y reacciones sindicales no se 
intentaron nunca o — huérfanas de popularidad y de arraigo- malviven una desgraciada existencia.

Es éste el diagnóstico veraz, no disfrazado ni encubierto, de la situación que caracteriza a una de las experiencias globalizadoras más generalizadas y frecuentes. Se atisba una disipación o predisolución del conflicto industrial — su certificado de defunción se está expidiendo- que facilita las condiciones óptimas para que, aliviados de su gravosa conflictividad, los hechos productivos garanticen márgenes de beneficio cuyas cifras — calculadas al céntimo, tras la exoneración de aquellas cargas - los hacen compatibles con la presentación de un abanico nuevo de ofertas seductoras para el consumidor.

Las comunidades industriales de origen —en que, por tradición e inevitabilidad histórica, el antagonismo clasista había ganado carta de naturale$\mathrm{za}$ - sufren la evasión migratoria de los capitales que, al restringir las ofertas de empleo y perjudicar la creación de riqueza susceptible de adquisición en ese medio, coloca a las demandas de trabajo en un estado de indigencia que empeora la estrella del hecho del consumo. Se esfuma la base de las contradicciones que, inherentes a la dureza del conflicto, constituían la herramienta indispensable para dignificar las condiciones de trabajo y conseguir ventajas que - aunque taradas por las terapias desmonetizantes de la crisis económica- favorecían el hecho del consumo.

Dos aspectos de la reestructuración contribuyen a que el crecimiento de los beneficios industriales coexista con condiciones propicias a la extensión del hecho del consumo. Es uno la sustitución de mano de obra por tecnología que aminora o suprime los ingredientes indeseables de conflictividad. El otro consiste en la desconcentración productiva que no coloca en el mercado el definitivo bien de producción - resultante de un proceso unitario, indivisible y concentrado- y se vale de formas de interposición contractual entre los empresarios que aportan los elementos confluentes en los bienes íntegros o cuerpos ciertos ofrecidos a los consumidores. No faltan ofertas peculiares que, ante las ventajas económicas de estos procesos de fraccionamiento o dispersión, multiplican los alicientes del hecho del consumo e invitan a desarrollar sus experiencias.

Los hábitos migratorios de los empleadores prosperan a medida que se adueñan de espacios geográficos donde las libertades sindicales fueron siempre algo ignoto y de ejercicio impredecible. Han mediado, unas veces, prejuicios históricos y circunstancias culturales que ni de lejos reparaban en ellas, situándolas al margen de cualquier previsión sobre las actividades productivas. Se ha incoado, en otras ocasiones, un entrenamiento - harto tímido- que poco o nada ha conseguido sin el apoyo de instancias extrasindicales que rivalizan con el poder político y añaden un desaconsejable plus de riesgo social. Los empresarios - aprovechando la oportunidad en pro de la libertad de establecimiento y de la irrestricta circulación de capitalesdominan el hecho del consumo, contemplan sus episodios de aceptación social y sopesan las utilidades que reporta para graduar su magnitud. 
La hegemonía del mercado y el dictado de las condiciones de consumo en los países de origen - donde impera una libertad económica consolidada - se consiguen a costa del desgaste de los poderes sindicales. La fijación de las condiciones básicas de las relaciones de trabajo se sustraen a las estipulaciones de la negociación colectiva y se transfieren al campo de la contratación individual, en que el poder contractual del empleador inutiliza el cuanto de tutela que unos sindicatos erosionados e inseguros no garantizan ni procuran. Abundan los supuestos de conflicto impropio entre trabajadores que, con explicable desazón, ignoran las condiciones de reclutamiento de sus pares, o, con justificada frustración, saben de las ventajas que, a título personal, han obtenido mediante una contratación descolectivizada en el plano de los intereses que abarca y aborda. Los intereses de categoría se difuminan y suplantan por la pulverización de intereses que, según la imagen hobbesiana del instinto de conservación, demuestra que cada trabajador se convierte en un lobo para quienes le son afines en el ejercicio de la actividad profesional que comparten.

Adiós, pues, a las protestas y aclamaciones de solidaridad. El proceso de estimación de la influencia de los salarios en los costes de producción racionaliza la distribución de los bienes y/o servicios dables al mercado, mide los beneficiosos estímulos de su ingreso en él y marca unas pautas del hecho del consumo que, al hacer apetecible la demanda, aceleran también su absorción.

Las acciones sindicales se ciñen a cometidos de gestión y otros de discreta entidad. El nuevo rumbo de los acontecimientos frena la intensidad de la fuerza social que, aun en trance de crisis, caracterizaba a la negociación colectiva - principal fuente del ordenamiento extraestatal - y establecía condiciones, colectivas también, que - como fuentes integradoras o completivas - se propagaban a las relaciones individuales de trabajo en el ámbito funcional asignado. Los empleadores daban los pasos precisos para que, salvados esos inconvenientes, el hecho del consumo, lejos de degradarse, se contuviese en unos niveles compensatorios y aceptables. Lo negativo de la situación se acentúa con el demérito sindical que, arrastrado por su economicismo insaciable, el capital ojea de continuo, para acabar con el estorbo de las viejas garantías - desterradas del nuevo mundo que se globaliza- $\mathrm{y}$ escribir, cuanto antes, la página obituaria del Derecho Social. A cambio del refuerzo y el estímulo del hecho del consumo, arden —en la pira funeraria de las reivindicaciones sociales- las más caras de las adquisiciones que la crisis económica empezó aligerando - decíase que temporal y moderadamente- y que la furia de la mundialización se apresta hoy a fulminar sin tregua ni misericordia.

La obsesión del capital era multiplicar el consumo —usando, entre otras muchas, de estas vías - y la de los consumidores en activo, olvidar, sin distinción de estratos sociales, unos imperativos de solidaridad que, pese a todo, renacen y se reconocen allí donde — con insistencia prodigiosa- sur- 
gen consignas dotadas de una sana capacidad de renacimiento y puesta al día. Las más abnegadas y admirables enseñan a reemplazar las avideces consumistas por la devoción que reclaman las perspectivas de un interés general fundado en los retos de la coexistencia, en el sentido idílico de la colaboración y en los alicientes de la participación. Ni más ni menos que la sustitución del bien común aristotélico-tomista por su defensa en clave de modernidad y moralidad seculares.

\section{Función de las relaciones colectivas de trabajo en el hecho del con- sumo de los bienes y servicios esenciales de la comunidad}

Los conocidos con el nombre de servicios esenciales de la comunidad constituyen bienes y/o servicios cuya susceptibilidad de disfrute confiere un carácter especial al hecho del consumo que implica su naturaleza y sus funciones. Satisfacen las necesidades que, de individuales y simplistas, pasan a compartirse por los integrantes de una colectividad o mera coincidencia de personas físicas en un espacio geográfico concreto. Están ahí por circunstancias que, aunque extrañas a la voluntad de coincidencia, crean un sentimiento de comunidad y un proyecto de constituirla en condiciones de solidaridad bastantes para avalar la ilusión depositada puestas en un modo digno y justo de sobrevivir. El imperativo de no disociarse - porque cunde la convicción de que el espíritu de solidaridad o el instinto de conservación han vencido al arrinconamiento de una vida insular - obliga a aceptar la necesidad del hecho del consumo y a ordenar esa práctica.

El hecho del consumo de bienes y servicios esenciales se justifica porque, a falta de ellos, la comunidad - recién erigida — se disloca y adviene a un estado regresivo de disolución. Retoma el carácter inorgánico de colectividad, como si nunca hubiese existido la conversión emanada del pacto social que le dio vida en momentos difíciles de enclavar históricamente. De ahí, la consolidación de un interés general - del que es parte la continuidad del ciclo de satisfacción de los bienes y servicios esenciales- que merece consideración.

Las relaciones colectivas de trabajo pueden, ante el control costoso de su normalidad, superar el nivel habitual de sus tensiones - inherente a la estructura clásica de los conflictos industriales - y afluir a estados de enrarecimiento que interrumpen el funcionamiento regular de los servicios esenciales. El perjuicio que causa tal evento tiene que limitarse —-según la regla de oro cuyo cumplimiento es imposible de garantizar - a la normalidad de la presión que conviene a las relaciones de trabajo afectadas, pero no puede castigar, contra todo Derecho, la generalidad de la vida en común, recayendo sobre personas y grupos que no han contraído, en la esfera del conflicto, responsabilidad alguna.

Incumbe al poder público —urgido a remover los obstáculos opuestos a la subsistencia de la igualdad y la libertad que cimentan la comunidad y su 
futuro- suplir las deficiencias que impiden el hecho del consumo de los bienes y servicios esenciales, mientras no se restaure el estado de cosas que asegure su prestación por los agentes — públicos o privados- encargados de su entrega al mercado y consiguiente oferta. Operación que constituye misión imposible ante la emocionalidad que, acompañando a las situaciones de conflicto, sabotea la racionalización de unas acciones sistemáticamente desproporcionadas.

\section{Reflexión final}

La colocación sistemática de todo o parte del Derecho Social en la vastedad dogmática e histórica del Derecho del consumo ha respondido a una concepción omnicomprensiva que resta al hecho del trabajo parte de su animación y dinamismo. Aun a riesgo de un cambio de método, parece acorde con el antropocentrismo recurrente del Derecho Social abordar la materia propuesta desde una perspectiva que, para evocar las funciones sociales del hecho del consumo, propone la siguiente consideración.

Hay una oleada de protagonistas del drama del trabajo que, ante las páginas en blanco del libro que acoja el testimonio de sus experiencias, van a escribir derecho — con los renglones torcidos de la flaqueza humana- la historia de su redención. Recordarán — como verdad de base- que su dignidad personal les pone por encima de las personas, que les oprimieron, y de las cosas que, deseando y debiendo consumirse, les fueron negadas. Estos éxitos - más o menos efímeros - no prevalecerán sobre el aprecio de una condición erguida y animosa que, frente al hecho del consumo, reclama el ejercicio de las funciones sociales que éste debe cumplir y que se esperan de sus óptimas oportunidades.

\section{Bibliografía de orientación}

ANDRIEUX, A y LIGNON, J. ¿Existe conciencia de la clase obrera?, traducción española de A. MARCos. Madrid: Ed. ZYX, 1967.

BARTOCCI, E. Sindacato, classe, società. Padua: Ed. CEDAM, 1975.

CACHON, L. Flexibilidad y mercado de trabajo, traducción española de $\mathrm{CH}$. Marestaing. Madrid: Ed. Centro de Publicaciones del Ministerio DE Trabajo y Seguridad Social, 1987.

COOPER, C. M. Economía, tecnología y empleo, traducción española de F. FZ. Madrid: Ed. Centro de Publicaciones del Ministerio de Trabajo y SEGURIDAd Social, 1987.

De LA VILla, L. E. Materiales para el estudio del sindicato. Madrid: InstiTUTO DE Estudios Sociales, 1979. 
DuFTY, N. F. Cambios en las relaciones entre empresarios y trabajadores en el ámbito de la empresa, traducción española de R. SERRATACO. Madrid: Instituto de Estudios Laborales y de Seguridad Social, 1967.

Galbraith, K. L'ere de l'opulence. París: Ed. Calmann-Levy, 1961.

Gorz, A. Strategie ouvriere et neocapitalisme. París: Ed. Du SEuIL, 1964.

Halbwachs, M. Las clases sociales, traducción española de M. Aub. México-Buenos Aires: Ed. Fondo DE Cultura EconómiCA, 1964.

Lengelle, M. La consommation. París: Ed. Presses Universitaires de FRANCE, 1965.

Martín Valverde, A. et al. Derecho del Trabajo. Madrid: Ed. Tecnos, 2004.

Meynaud, J. L'evaluation et le role des besoins des biens de consommation dans les divers regimes economiques. París: Ed. C.N.R.S., 1963; Les consommateurs et le pouvoir. Lausanne: Ed. MoRNEX, 1964.

MitTElstADT, A. et al. Mercado de trabajo y crisis económica. Madrid: Ed. Servicio de Publicaciones del Ministerio de Trabajo y Seguridad SOCIAL, 1985.

Montoya, A. Derecho del Trabajo. Madrid: Ed. Tecnos, 2005.

PaCKARD, V. L'art du gaspillage. París: Ed. Calmann-LeVy, 1962.

Quin, C. Les consommateurs. París: Ed. Du SEuIL, 1965.

SAGARDoy, J. A. Relaciones de trabajo y estructuras políticas. Madrid: Ed. Instituto de Estudios Laborales y de la SEGURIDAD Social, 1984.

SENDON, M. et al. Sistemas de relaciones laborales y solución de conflictos colectivos en Occidente. Bilbao: Ed. CONSEJO DE RELACIONES LABORALES DE EUZKADI, 1984.

TAWNEY, R. H. La sociedad adquisitiva, traducción española de M. de FERDINANDY. Madrid: Ed. AlianZa Editorial, 1972.

TOURAINE, A. La coscienza operaia, traducción italiana de G. MANFREDI. Milán: Ed. FRANCo ANGELI, 1975.

Ureta, J. C. y Garnica, G., Capitalismo inteligente. Madrid: Ed. Espasa CALPE, 1990.

ZorRILlA, M. M. «Formación del ordenamiento extraestatal en las relaciones de trabajo», Estudios de Deusto, v. 33, pp. 230-266; «Evolución y desfiguraciones del conflicto industrial», Estudios jurídicos en memoria de JOSÉ M. ${ }^{a}$ LIDÓN. Bilbao: Ed. UnIVERSIDAD DE Deusto, 2002, pp. 1359-1375; «Modernidad y moralidad de la mundialización», Estudios de Deusto, v. 50/2, pp. 181-196; «Garantías precisas para el mantenimiento de los servicios esenciales de la comunidad», Revista de la Facultad de Derecho de la Universidad Complutense de Madrid, n. ${ }^{\circ} 17$ (Monográfico), pp. 226-230. 


\section{๑) Universidad de Deusto - ISSN 0423-4847}




\section{Revista Estudios de Deusto}

\section{Normas de publicación}

1. Contenido. La Revista de Estudios de Deusto publica, con carácter semestral (junio y diciembre), trabajos de investigación sobre Derecho y Ciencia Política.

2. Envío de originales. Los originales han de ser inéditos, escritos en lengua castellana, en Microsoft Word o formato compatible. Se entregarán en papel (en el Decanato de Derecho a la atención del Director de la Revista) y, también, en soporte electrónico (disquete, CD-ROM o correo electrónico a la dirección: estudiosdeusto@der.deusto.es).

3. Formato. En primera página se incluirá el título, nombre del autor, filiación académica, direcciones de correo ordinario y electrónico y teléfono de contacto. La segunda página recogerá dos resúmenes, en castellano e inglés, de unas 120 palabras cada uno y las palabras clave del trabajo (entre 3 y 5 palabras) tanto en castellano como en inglés.

4. Normas de edición. Las normas de edición son las habitualmente utilizadas en publicaciones científicas, tal como se recoge en las «Normas básicas para la presentación de trabajos escritos» de la Facultad de Derecho de la Universidad de Deusto.

5. Proceso de publicación. El Director de la Revista, con la participación del Consejo de Redacción y el asesoramiento del Consejo Asesor, decidirá la publicación de los trabajos basándose en una evaluación externa, anónima e independiente. Los trabajos serán publicados como «Estudios» o como «Notas» según su naturaleza y extensión ( \pm 20 páginas escritas a espacio y medio, en letra Times New Roman y tamaño 12). Los autores de los trabajos podrán realizar la corrección de pruebas de imprenta y, si en el plazo de una semana natural no se recibe su corrección, se entenderá que el autor está conforme con la impresión recibida.

6. Copy Right. Los autores de los trabajos inéditos publicados en la Revista Estudios de Deusto podrán reproducirlos en otro lugar con la debida anotación de su publicación original en Estudios de Deusto. 


\section{Estudios de Deusto}

Universidad de Deusto 